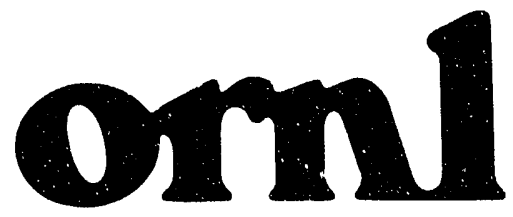

OAK RIDGE

NATIONAL

LABORATORY

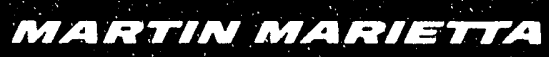

(Edition 13 of ORNL-5198)

ORNL-6743

(Edition 13 of ORNL-5198)

\title{
Transportation Energy Data Book: Edition
}

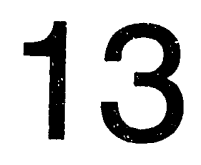

Stacy C. Davis Sonja G. Strang
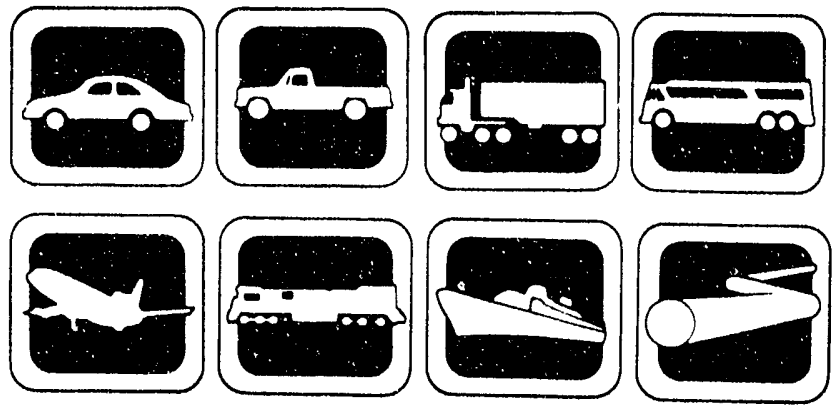

MARTIN MARIETTA ENERGY SYSTEMS, INC.

FOR THE UNITED STATES

DEPARTMENT OF ENERGY 


\section{FREQUENTLY USED TABLES}

New Car Fuel Economy for Selected Countries . . . . . . . . . . . . . . 1-13

Transportation Energy Use by Mode and Fuel Type . . . . . . . . . . 2-14

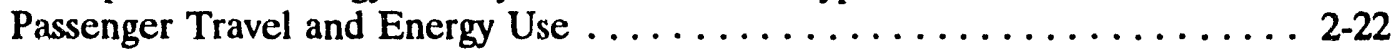

Energy Intensities of Passenger Modes . . . . . . . . . . . . . . 2-24

Energy Intensities of Freight Modes . . . . . . . . . . . . . 2-27

Vehicle Miles of Travel by Vehicle Type $\ldots \ldots \ldots \ldots \ldots \ldots \ldots \ldots$ 3-6

Autos and Trucks in Use . . . . . . . . . . . . . . . . . . . 3-9

Annual Automobile Miles by Age $\ldots \ldots \ldots \ldots \ldots \ldots \ldots \ldots \ldots . \ldots \ldots$ 3-24

Truck Size Class Definitions and Fuel Economy . . . . . . . . . . . 3-43

CAFE Standards . . . . . . . . . . . . . . . . . . . . . . 3-55

Gas Guzzler Tax Schedule . . . . . . . . . . . . . . . . . . 3-59

Fuel Economy as a Function of Speed ............... 3-60

Vehicle Emission Standards ...................... 3-66

Transportation's Contribution to Emissions . . . . . . . . . . . . . 3-69

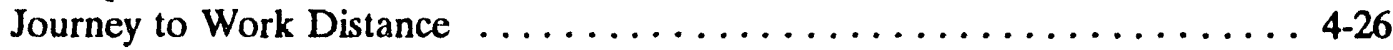

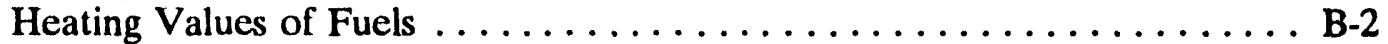

Energy Unit Conversions $\ldots \ldots \ldots \ldots \ldots \ldots \ldots \ldots \ldots \ldots$ B-4

GNP Implicit Price Deflator $\ldots \ldots \ldots \ldots \ldots \ldots \ldots \ldots \ldots \ldots \ldots$ B-14

\section{COMMON CONVERSIONS}

$\begin{array}{lll}1 \text { Quad } & =84,997.9 \text { Gigawatthours } \\ & =0.4724 \text { million barrels per day of oil (mbpd), or } \\ & =8 \text { billion gallons of gasoline } \\ 1 \text { Gigawatthour } & =1.1765 \times 10^{-5} \text { Quads } & \\ 1 \text { Mbpd } & =2.117 \text { Quads per year } \\ 1 \text { Barrel } & =42 \text { gallons } \\ 1 \text { Btu } & =1055 \mathrm{Joules} \\ 1 \text { Gallon of Gasoline } & =125,000 \mathrm{Btu} \text { (gross) }=115,400 \mathrm{Btu} \text { (net) } \\ 1 \text { Gallon of Methanol } & =64,600 \mathrm{Btu} \text { (gross) }=56,560 \mathrm{Btu} \text { (net) } \\ 1 \text { Gallon of Diesel } & =138,700 \mathrm{Btu} \text { (gross) }=128,700 \mathrm{Btu} \text { (net) } \\ 1 \text { Gallon of Gasoline } & =6.2 \text { pounds } & \\ 1 \text { U.S. Gallon } & =0.8321 \text { Imperial Gallons }=3.785 \mathrm{Liters} \\ 1 \text { Liter } & =61.026 \mathrm{Cubic} \text { inches } \\ \text { Inertia Weight } & =\text { Curb Weight }+300 \text { Pounds } \\ 1 \text { Mph } & =1.609 \mathrm{Kph} & \\ 1 \text { Horsepower } & =0.7457 \text { Kilowatts } \\ 1 \text { Mile } & =1.609 \text { Kilometers }\end{array}$

${ }^{2}$ Electricity generation and distribution have been taken into account. Without electricity generation and distribution, 1 gigawatthour $=0.3412 \times 10^{-5}$ Quads, 1 Quad $=293,083.2$ gigawatthours. 
Center for Transportation Analysis

Energy Division

\title{
TRANSPORTATION ENERGY DATA BOOK: \\ EDITION 13
}

\author{
Stacy C. Davis \\ Sonja G. Strang
}

March 1993

Prepared for

Office of Transportation Technologies

U.S. Department of Energy

Prepared by

OAK RIDGE NATIONAL LABORATORY

Oak Ridge, Tennessee 37831 managed by

MARTIN MARIETTA ENERGY SYSTEMS, INC. for the

U.S. DEPARTMENT OF ENERGY under Contract No. DE-AC05-84OR21400 
This report has been reproduced directly from the best available copy.

Avallable to DOE and DOE contractors from the Otfice of Scientific and Technical Information, P.O. Box 62, Oak Ridge, TN 37831; prices available from (615) 576-8401, FTS 626-8401.

Available to the public from the National Technical Information Service, U.S. Department of Commerce, 5285 Port Royal Rd., Springfield, VA 22161.

This report was prepared as an account of work sponsored by an agency of the United States Government. Nelther the United States Government nor any agency thereof, nor any of their employees, makes any warranty, express or implied, or assumes any legal liability or responsibility for the accuracy, completeness, or usefulness of any information, apparatus, product, or process disclosed, or represents that its use would not infringe privately owned rights. Reference herein to any specific commercial product, process, or service by trade name, trademark, manufacturer, or otherwise, does not necessarily coristitute or imply its endorsement, recommendation, or favoring by the United States Government or any agency thereof. The views and opinions of authors expressed herein do not necessarily state or reflect those of the United States Government or any agency thereof. 
Users of the Transportation Energy Data Book are encouraged to comment on errors, omissions, emphases, and organization of this report to one of the persons listed below.

\author{
Stacy C. Davis \\ Oak Ridge National Laboratory \\ P. O. Box 2008 \\ Bldg. 5500A, MS 6366 \\ Oak Ridge, Tennessee 37831-6366 \\ Telephone: (615) 574-5957 \\ FAX (615) 574-3851
}

Philip D. Patterson

Office of Transportation Technologies

Department of Energy, CE-30

Forrestal Building, Room 6B-094

1000 Independence Avenue, S.W.

Washington, D.C. 20585

Telephone: (202) 586-9121

FAX (202) 586-1637 


\section{TABLE OF CONTENTS}

List of Figures $\ldots \ldots \ldots \ldots \ldots \ldots \ldots \ldots \ldots \ldots \ldots \ldots \ldots \ldots \ldots \ldots$

Foreword $\ldots \ldots \ldots \ldots \ldots \ldots \ldots \ldots \ldots \ldots \ldots \ldots \ldots \ldots \ldots \ldots \ldots \ldots \ldots$ xvii

Acknowledgments $\ldots \ldots \ldots \ldots \ldots \ldots \ldots \ldots \ldots \ldots \ldots \ldots \ldots \ldots \ldots \ldots \ldots$

Abstract $\ldots \ldots \ldots \ldots \ldots \ldots \ldots \ldots \ldots \ldots \ldots \ldots \ldots \ldots \ldots \ldots \ldots$

Statistical Summary $\ldots \ldots \ldots \ldots \ldots \ldots \ldots \ldots \ldots \ldots \ldots \ldots \ldots \ldots \ldots$ xiii

Introduction $\ldots \ldots \ldots \ldots \ldots \ldots \ldots \ldots \ldots \ldots \ldots \ldots \ldots \ldots \ldots \ldots \ldots$

Chapter 1. International Transportation Statistics $\ldots \ldots \ldots \ldots \ldots \ldots \ldots \ldots \ldots$

Table 1.1. Automobile Registrations for Selected Countries, 1950-90 . . . . . 1-3

Table 1.2. Truck and Bus Registrations for Selected Countries, 1950-90 . . . . 1-4

Table 1.3. Vehicles per Capita for Selected Countries, 1950-90 . . . . . . . 1-6

Table 1.4. Gasoline Prices for Selected Countries, 1978-91 . . . . . . . . . . 1-9

Table 1.5. Diesel Fuel Prices for Selected Countries, 1978-91 . . . . . . . . . 1-11

Table 1.6. New Gasoline Car Fuel Economy for Selected

Countries, $1973-89 \ldots \ldots \ldots \ldots \ldots \ldots \ldots \ldots \ldots \ldots \ldots$. . . . . . . . . .

Table 1.7. Fuel Economy of the Gasoline Automobile Population for

Selected Countries, $1970-89 \ldots \ldots \ldots \ldots \ldots \ldots \ldots \ldots \ldots \ldots$. . . . . . . . .

Table 1.8. Annual Miles Driven per Vehicle for Selected

Countries, $1984-90 \ldots \ldots \ldots \ldots \ldots \ldots \ldots \ldots \ldots$. . . . . . . . . . . . . . . . .

Table 1.9. Inland Surface Transport of Goods for Selected Countries, 1985 . . 1-18

Table 1.10. Annual Vehicle Miles Traveled by Personal Vehicles for

Selected Countries, 1970-89 . . . . . . . . . . . . . . . . . 1-19

Table 1.11. Passenger Travel by Personal Vehicles for Selected

Countries, $1970-89 \ldots \ldots \ldots \ldots \ldots \ldots \ldots \ldots \ldots \ldots \ldots$ 1-20

Table 1.12. Energy Use by Personal Vehicles for Selected

Countries, $1970-89 \ldots \ldots \ldots \ldots \ldots \ldots \ldots \ldots \ldots \ldots \ldots$ 1-21

Table 1.13. Passenger Travel by Bus for Selected Countries, 1970-89 . . . . . . 1-22

Table 1.14. Energy Use by Bus for Selected Countries, 1970-89 . . . . . . . . . 1-23

Table 1.15. Passenger Travel by Rail for Selected Countries, 1970-89 . . . . . . . 1-24

Table 1.16. Energy Use by Rail for Selected Countries, 1970-89 . . . . . . . . . 1-25 
Chapter 2 Transportation Energy Characteristics $\ldots \ldots \ldots \ldots \ldots \ldots \ldots \ldots \ldots$ 2-1

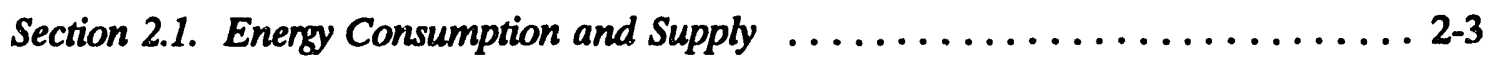

Table 2.1. Refinery Yield of Petroleum Products from a Barrel of Crude Oil, 1978-91 ............................... 2-4

Table 2.2. United States Petroleum Production and Consumption, 1970-91 . . 2 2-5

Table 2.3. Consumption of Petroleum by End-Use Sector, 1973-91 . . . . . . 2-7

Table 2.4. Distribution of Energy Consumption by Source,1981 and

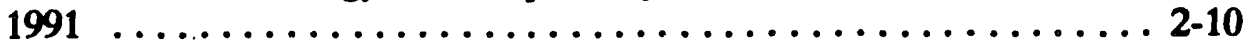

Table 2.5. Electric Utility Energy. Input by Source, $1973-1991 \ldots \ldots \ldots \ldots$. . 2-11

Table 2.6. Consumption of Total Energy by End-Use Sector, 1970-91 . . . . 2 2-13

Table 2.7. Domestic Consumption of Transportation Energy by Mode and Fuel Type, $1990 \ldots \ldots \ldots \ldots \ldots \ldots \ldots \ldots \ldots \ldots \ldots$. 2-14

Table 2.8. Distribution of Domestic Consumption of Transportation Energy

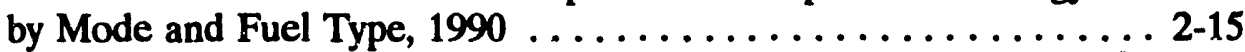

Table 2.9. Transportation Energy Use by Mode, $1990 \ldots \ldots \ldots \ldots \ldots \ldots$ 2-17

Table 2.10. Transportation Energy Consumption by Mode, $1970-90 \ldots \ldots \ldots$ 2-18

Table 2.11. Highway Usage of Gasoline and Special Fuels, 1973-90 . . . . . . 2-20

Section 2.2. Energy Efficiency and Intensity $\ldots \ldots \ldots \ldots \ldots \ldots \ldots \ldots \ldots \ldots \ldots \ldots \ldots \ldots$

Table 2.12. Passenger Travel and Energy Use in the United States, 1990 . . . . 2-22

Table 2.13. Energy Intensities of Passenger Modes, 1970-90 . . . . . . . . . . . . 2-24

Table 2.14. Intercity Freight Movement and Energy Use in the United

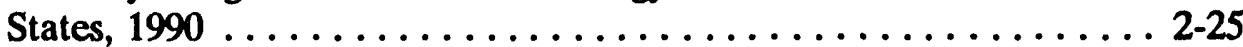

Table 2.15. Energy Intensities of Freight Modes, 1970-90 . . . . . . . . . . 2-27

Section 2.3. Economics ........................... 2-28

Table 2.16. Retail Prices for Motor Fuel, 1978-91 ............... 2-29

Table 2.17. Prices for Selected Transportation Fuels, $1978-91 \ldots \ldots \ldots \ldots$ 2-30

Table 2.18. Prices for a Barrel of Crude Oil and a Gallon of Gasoline, 1976-91 . 2-32

Table 2.19. Gross National Product (GNP) as Related to Transportation 1970-91 ....................... 2-34

Table 2.20. Personal Consumption Expenditures (PCE) as Related to

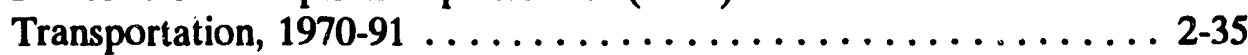

Table 2.21. Statistical Indices as Related to Transportation, $1970-91 \ldots \ldots \ldots$ 2-36

Table 2.22. Average Price of a New Car, $1970-91 \ldots \ldots \ldots \ldots \ldots \ldots \ldots .2 .39$

Table 2.23. Automobile Operating Costs, $1975-91 \ldots \ldots \ldots \ldots \ldots \ldots \ldots$ 2-40 


\section{TABLE OF CONTENTS \\ (continued)}

Chapter 3. Highway Mode $\ldots \ldots \ldots \ldots \ldots \ldots \ldots \ldots \ldots \ldots \ldots \ldots \ldots \ldots \ldots$ 3-1

Section 3.1 Highway Vehicle Characteristics .................. 3-3

Table 3.1. Highway Energy Use by Mode, $1970-90 \ldots \ldots \ldots \ldots . . \ldots$. . . . . 3-4

Table 3.2. Highway Vehicle Miles Traveled by Mode, $1979-90$. . . . . . . . . 3-6

Table 3.3. Vehicle Stock and New Sales in United States, 1990 Calendar Year . . . . . . . . . . . . . . . . . . . . . 3-8

Table 3.4. Automobiles and Trucks in Use, 1979-1991 . . . . . . . . . . 3-9

Table 3.5. Average Age of Automobiles and Trucks in Use, 1970-1991 . . . . . 3-10

Table 3.6. Scrappage and Survival Rates for Automobiles, All Trucks, and Light Trucks . .................... 3-12

Table 3.7. Scrappage and Survival Rates for Automobiles ........... . 3-14

Table 3.8 Scrappage and Survival Rates for All Trucks . . . . . . . . . . 3-16

Section 3.2 Automobiles $\ldots \ldots \ldots \ldots \ldots \ldots \ldots \ldots \ldots \ldots \ldots \ldots \ldots \ldots$ 3-18

Table 3.9 New Retail Automobile Sales in the United States, 1970-91 . . . . . 3-19

Table 3.10. Automobiles in Use by Age, 1970 and $1991 \ldots \ldots \ldots$. . . . . . . 3-20

Table 3.11. Automobiles in Operation and Vehicle Travel by

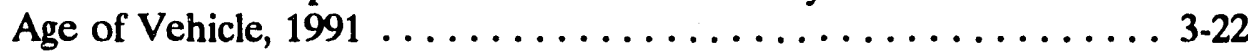

Table 3.12. Summary Statistics for Passenger Cars, 1970-90 . . . . . . . . . 3-23

Table 3.13. Average Annual Miles Per Automobile by Automobile Age . . . . . . 3-24

Table 3.14. Average Material Consumption for a Domestic Automobile, 1978, 1984, and $1992 \ldots \ldots \ldots \ldots \ldots \ldots \ldots \ldots \ldots \ldots \ldots \ldots$. . . . . . . . . . . .

Table 3.15. Sales-Weighted Engine Size of Domestic and Import Automobiles by Size Class, Sales Periods 1976-1992 . . . . . . . . . . . . . 3-26

Table 3.16. Sales-Weighted Curb Weight of Domestic and Import Automobiles by Size Class, Sales Periods 1976-1992 . . . . . . . . . . . . . . . 3-27

Table 3.17. Sales-Weighted Interior Space of Domestic and Import Automobiles by Size Class, Sales Periods 1976-1992 . . . . . . . . . . . . . . 3-28

Table 3.18. Period Sales, Market Shares, and Sales-Weighted Fuel Economies of New Domestic and Import Automobiles, Selected Sales Periods 1976-1992 ......................... 3-30 


\section{TABLE OF CONTENTS (continued)}

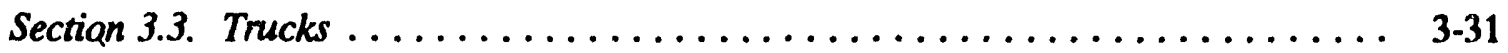

Table 3.19. New Retail Sales of Light Trucks in the United States, 1970-91 . . . 3-32

Table 3.20. New Retail Domestic Truck Sales by Gross Vehicle Weight, 1970-91 .................................. 3-34

Table 3.21. Trucks in Use by Age, 1970 and $1991 \ldots \ldots \ldots \ldots \ldots \ldots \ldots$ 3-35

Table 3.22. Trucks in Operation and Vehicle Travel by Age of Vehicle, 1991 . . . 3-36

Table 3.23. Period Sales, Market Shares, and Sales-Weighted Fuel Economies of New Domestic and Import Light Trucks, Selected Sales Periods 1976-92 ............................. 3-37

Table 3.24. Summary Statistics for Two-Axle, Four-Tire Trucks, 1970-90 . . . . 3-38

Table 3.25. Summary Statistics for Other Single-Unit Trucks, $1970-90 \ldots \ldots \ldots$ 3-40

Table 3.26. Summary Statistics for Combination Trucks, $1970-90 \ldots \ldots \ldots \ldots$. $\ldots$.42

Table 3.27. Truck Fuel Economy by Size Class, 1977, 1982, and 1987 . . . . . . 3 3-43

Table 3.28. Percentage of Trucks by Size Class, 1977, 1982, and $1987 \ldots \ldots$. . . 3-43

Section 3.4. Buses .................................... 3-44

Table 3.29. Buses in Operation by Type, $1970-90 \ldots \ldots \ldots \ldots$. . . . . . . . . . 3-45

Table 3.30. Passenger and Vehicle Travel by Bus Type, 1970-90 . . . . . . . . . 3-46

Table 3.31. Average Annual Miles per Bus By Type, 1970-90 . . . . . . . . . . . 3-47

Table 3.32. Energy Consumption and Energy Intensities by Type of Bus,

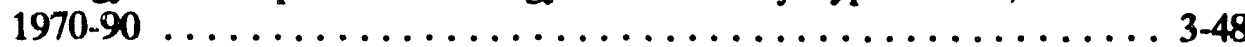

Section 3.5. Fleets ............................... 3-49

Table 3.33. Distribution of New Domestic Fleet Automobile Registrations by Size Class, $1975-91 \ldots \ldots \ldots \ldots \ldots \ldots \ldots \ldots \ldots \ldots . \ldots \ldots$ 3-50

Table 3.34. Automobile Fleets by Use, $1970-91 \ldots \ldots \ldots \ldots \ldots \ldots \ldots \ldots$ 3-51

Table 3.35. Federal Government Vehicles by Agency, Fiscal Year 1988 . . . . . 3-53

Section 3.6. Federal Standards and Motor Vehicle Fuel Economy ............ 3-54

Table 3.36. Corporate Average Fuel Economy (CAFE) Standards Versus SalesWeighted Fuel Economy Estimates for Automobiles and Light Trucks, 1978-92 .......................... 3-55

Table 3.37. Corporate Average Fuel Economy (CAFE) Fines Collected, $1983-91$. . . . . . . . . . . . . . . . . . . . . . . . . 3-57

Table 3.38. Tax Receipts from the Sale of Gas Guzzlers, 1980-91 . . . . . . . . 3-57 


\section{TABLE OF CONTENTS \\ (continued)}

Table 3.39. The Gas Guzzler Tax on New Cars ................ 3-59

Table 3.40. Fuel Economy by Speed, 1973 and $1984 \ldots \ldots \ldots \ldots \ldots \ldots \ldots$. . . . . . . . . .

Table 3.41. Average Urban and Rural Interstate Speeds, $1970-90 \ldots \ldots \ldots \ldots$ 3-62

Section 3.7. Vehicle Emissions $\ldots \ldots \ldots \ldots \ldots \ldots \ldots \ldots \ldots \ldots \ldots \ldots \ldots . \ldots \ldots$

Table 3.42. Federal Emission Control Requirements for Automobiles and Light Trucks, $1976-94 \ldots \ldots \ldots \ldots \ldots \ldots \ldots \ldots \ldots \ldots$ 3.66

Table 3.43. Federal Emission Control Requirements for Heavy-Duty

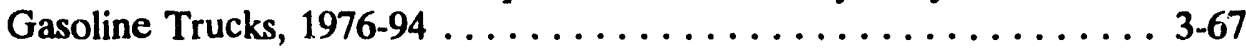

Table 3.44. Federal Emission Control Requirements for Heavy-Duty Diesel Trucks, $1976-94 \ldots \ldots \ldots \ldots \ldots \ldots \ldots \ldots \ldots \ldots$. 3-68

Table 3.45. Transportation's Contribution to U.S. Emissions, 1978-90 . . . . . . 3-69

Table 3.46. Exhaust Emission Standards for Clean-Fuel Vehicles in the California Pilot Test Program ................... 3-70

Table 3.47. California Air Resources Board Standards .............. 3-71

Table 3.48. Possible Fuel/Vehicles for Clean-Fuel Vehicles .......... 3-72

Table 3.49. Contribution of Transportation Fuel Use to Total Carbon Emission for Selected Countries ..................... 3-73

Section 3.8. High-Occupancy Vehicle Lanes ................... 3-74

Table 3.50. Miles of High-Occupancy Vehicle Lanes, $1969-90 \ldots \ldots \ldots \ldots$ 3-75

Chapter 4. Personal Travel Statistics $\ldots \ldots \ldots \ldots \ldots \ldots \ldots \ldots \ldots \ldots \ldots \ldots$ 41

Table 4.1. Population and Vehicle Profile, $1950-90 \ldots \ldots \ldots \ldots \ldots \ldots .44$

Table 4.2. Financial Profile of the Population, $1970-89 \ldots \ldots \ldots \ldots \ldots \ldots$. . . . . . .

Table 4.3. Average Annual Expenditures of Households by Income, 1990 . . . 4 4-7

Table 4.4. Demographic Characteristics of Auto/Truck/Recreational Vehicle (RV) and Air Travelers, $1988-90 \ldots \ldots \ldots \ldots \ldots \ldots$ 4.8

Table 4.5. Distribution of Trips for All Modes by Trip Purpose and Round-Trip Distance, 1974, 1983, and 1990 . . . . . . . . . . . . 4-9

Table 4.6. Mode of Travel by Trip Purpose, $1990 \ldots \ldots \ldots \ldots \ldots \ldots \ldots$. . . . . . . . .

Table 4.7. Means of Transportation to Work for the United States: 1980 and

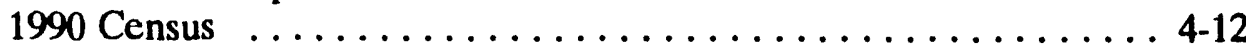

Table 4.8. Summary Statistics on Demographic Characteristics and Total Travel, $1969,1977,1983$, and 1990 Series of the NPTS . . . . . . . 4-13 


\section{TABLE OF CONTENTS \\ (continued)}

Page

Table 4.9. Number of Households by Vehicles Available, 1969, 1977, 1983, and 1990 Series of the NPIS .................. 4-15

Table 4.10. Average Annual VMT, Vehicle Trips and Trip Length per Household for Selected Trip Purposes, 1969, 1977, 1983, and 1990 Series of the NPTS . ........................ 4-17

Table 4.11. Average Vehicle Occupancy for Selected Trip Purposes, 1969, 1977, 1983, and 1990 Series of the NPTS ................ 4-19

Table 4.12. Distribution of Journey-to-Work Trips by Usual Mode, 1969, 1977, 1983, and 1990 Series of the NPTS . . . . . . . . . . .

Table 4.13. Commuting Patterns of Journey-to-Work Trips by Mode 1969, 1977, 1983, and 1990 Series of the NPTS ............... 4-22

Table 4.14. Distribution of Journey-to-Work Trips by Household Income and Mode, 1990 . . . ......................... 4-24

Table 4.15. Distribution of Journey-to-Work Trips by Worker Age and Mode, $1990 \ldots \ldots \ldots \ldots \ldots \ldots \ldots \ldots \ldots \ldots \ldots \ldots$. 4-25

Table 4.16. Distribution of Journey-to-Work Trips by Trip Distance and Mode, 1990 ........................... 4-26

Table 4.17. Distribution of Vehicles by Age, 1969, 1977, 1983, and 1990 Series of the NPTS ......................... 4-27

Table 4.18. Average Annual Miles per Vehicle by Number of Vehicles Available, $1969,1977,1983$, and 1990 Series of the NPTS . ......... 4-29

Table 4.19. Average Annual Miles per Vehicle by Number of Adults in Household, 1977, 1983, and 1990 Series of the NPTS . . . . . . . 4-30

Table 4.20. Distribution of Annual Miles by Driver Age and Sex, 1969, 1977, 1983, and 1990 Series of the NPTS ................ 4-31

Table 4.21. Average Annual Miles per Vehicle by Household Vehicle Ownership, 1990 .......................... 4-32

Chapter 5. Alternative Fuels Statistics

Table 5.1. On-Road Fuel/Energy Economy Summary for the AMFA Federal Vehicles, FY 1991 ......................... 5-5

Table 5.2. Number of Alternative Refuel Sites by State and Fuel Type, 1992 . . 5-6

Table 5.3. Advanced Battery Technology Goals of the U.S. Advanced Battery Consortium ......................... 5-13

Table 5.4. Basic Chemistry of Various Transportation Fuels .......... 5-14

Table 5.5. Reid Vapor Pressure of Various Alcohol/Ether/Gasoline Blends . . . 5-15 Table 5.6. U.S. Production of Methanol and Ethanol, 1978-1991 ........ 5-16

Table 5.7. State Tax Exemptions for Gasohol, September 1992 . . . . . . . . 5-17

Table 5.8. Gasohol Consumption by Reporting States, $1980-91 \ldots \ldots \ldots \ldots$ 5-18 


\section{TABLE OF CONTENTS \\ (continued)}

Chapter 6. Nonhighway Modes $\ldots \ldots \ldots \ldots \ldots \ldots \ldots \ldots \ldots \ldots \ldots \ldots, 6,1$

Table 6.1. Nonhighway Energy Use by Mode, $1970-90 \ldots \ldots \ldots \ldots \ldots .6 .2$

Section 6.1. Air ................................. 6.4

Table 6.2. Summary Statistics for Domestic and International Certificated Route Air Carriers (Combined Totals), 1970-90 . . . . . . . . 6 6-7

Table 6.3. Traffic Data for Large Certificated Route Air Carriers by Carrier Group, Scheduled and Nonscheduled Services, 1982 and $1991 \ldots$. . 6-10

Table 6.4. Summary Statistics for General Aviation, $1970-90 \ldots \ldots \ldots \ldots \ldots$ 6-11

Section 6.2. Water $\ldots \ldots \ldots \ldots \ldots \ldots \ldots \ldots \ldots \ldots \ldots \ldots \ldots \ldots \ldots, 6,13$

Table 6.5. Tonnage Statistics for Domestic and International Waterborne Commerce, $1970-89$... . . . . . . . . . . . . . . . . . . . 6 6-15

Table 6.6. Summary Statistics for Domestic Waterborne Commerce, 1970-89 . . 6-16

Table 6.7. Breakdown of Domestic Marine Cargo by Commodity Class, 1989 .. 6-18

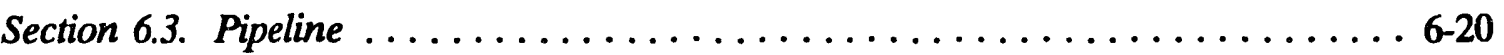

Table 6.8. Pipeline Shipments of Energy, $1972-90 \ldots \ldots \ldots \ldots \ldots \ldots \ldots$ 6-21

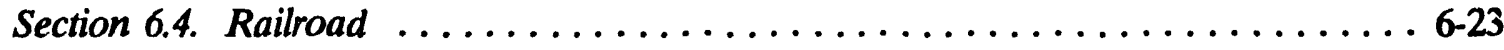

Table 6.9. Class I Railroad Freight Systems in the United States Ranked by Revenue Ton-Miles, $1990 \ldots \ldots \ldots \ldots \ldots \ldots \ldots \ldots$. . . . . . . . . . . .

Table 6.10. Summary Statistics for Class I Freight Railroads, 1970-90 . . . . . 6-26

Table 6.11. Railroad Revenue Carloadings by Commodity Group,

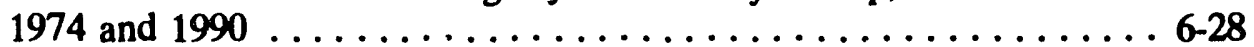

Table 6.12. Summary Statistics for the National Railroad Passenger Corporation

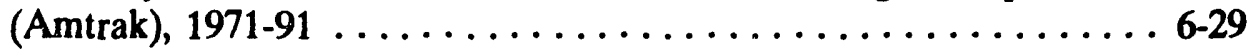

Table 6.13. Summary Statistics for Rail Transit Operations, $1970-90 \ldots \ldots \ldots$. 6-31

Appendix A. Sources $\ldots \ldots \ldots \ldots \ldots \ldots \ldots \ldots \ldots \ldots \ldots \ldots \ldots \ldots \ldots$ A-1

Appendix B. Conversions $\ldots \ldots \ldots \ldots \ldots \ldots \ldots \ldots \ldots \ldots \ldots \ldots \ldots \ldots \ldots \ldots \ldots \ldots$ B-1

Glossary $\ldots \ldots \ldots \ldots \ldots \ldots \ldots \ldots \ldots \ldots \ldots \ldots \ldots \ldots \ldots \ldots \ldots \ldots$, G-1

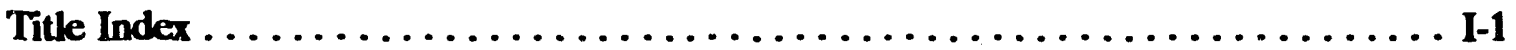




\section{LIST OF FIGURES}

Chapter 1. International Transportation Statistics $\ldots \ldots \ldots \ldots \ldots \ldots \ldots \ldots \ldots . . .1$

Figure 1.1. United States Automobile, and Truck and Bus Registrations as a Percent of World Registrations, 1960-90 .......... 1-5

Figure 1.2. Automobiles per Capita for Selected Countries, 1950-90 . . . . . 1-7

Figure 1.3. Trucks and Buses per Capita for Selected Countries, 1950-90 . . 1-8

Figure 1.4. Gasoline Prices for Selected Countries, 1980 and 1990 . . . . . 1-10

Figure 1.5. Diesel Fuel Prices for Selected Countries, 1980 and 1990 . . . . . 1-12

Figure 1.6. New Gasoline Car Fuel Economy for Selected Countries, 1973-89 . . . . . . . . . . . . . . . . . . . . . . . . . . . 1-14

Figure 1.7. Fuel Economy of the Gasoline Automobile Population for Selected Countries, 1970-89 . . . . . . . . . . . . . . 1-16

Figure 1.8. Inland Surface Transport of Goods for Selected Countries, 1985 1-18

Chapter 2. Transportation Energy Characteristics $\ldots \ldots \ldots \ldots \ldots \ldots \ldots \ldots \ldots$

Section 2.1. Energy Consumption and Supply $\ldots \ldots \ldots \ldots \ldots \ldots \ldots \ldots \ldots$

Figure 2.1. Refinery Yield of Petroleum Products from a Barrel of Crude Oil, 1978 and $1991 \ldots \ldots \ldots \ldots \ldots \ldots \ldots \ldots \ldots \ldots \ldots \ldots . \ldots \ldots$

Figure 2.2. Transportation Petroleum Consumption as a Percentage of Total United States Crude Oil Production, 1973-91 . . . . . . 2-6

Figure 2.3. United States Petroleum Production and Consumption, $1970-91 \ldots \ldots \ldots \ldots \ldots \ldots \ldots \ldots . . \ldots \ldots$

Figure 2.4. Petroleum Use by End-Use Sector, 1973-91 . . . . . . . . . 2-9

Figure 2.5. Distribution of Energy Consumption by Sector, $1991 \ldots \ldots$. . . 2-10

Figure 2.6. Electric Utility Energy Input by Source, 1973-91 . . . . . . . . . 2-12

Figure 2.7. Distribution of Transportation Energy Use by Fuel Type, 1990 . . 2-16

Figure 2.8. Distribution of Transportation Energy Use by Mode, $1990 \ldots$. . . 2-16

Figure 2.9. Transportation Energy Consumption by Mode, 1970-90 . . . . . 2-19

Section 2.2. Energy Efficiency and Intensity ................. 2-21

Figure 2.10. Passenger Energy Intensities by Type of Carrier, $1990 \ldots \ldots$. . . 2-23

Figure 2.11. Intercity Freight Energy Intensities by Type of Carrier, $1990 \ldots$ 2-26 


\section{LIST OF FIGURES \\ (continued)}

\section{Page}

Section 2.3. Economics ........................... 2-28

Figure 2.12. Price Indices for Selected Transportation Fuels, 1978-91 . . . 2-31

Figure 2.13. Crude Oil and Gasoline Price Indices, 1976-91 . . . . . . . . . 2-33

Figure 2.14. Consumer Price Indices, 1970-91 . . . . . . . . . . . . . . . 2-37

Figure 2.15. Average Price of New Cars, 1970-91 . . . . . . . . . . . . . . 2-39

Figure 2.16. Automobile Operating Costs, 1975-91 . . . . . . . . . . . . . . 2-41

Chapter 3. Highway Mode $\ldots \ldots \ldots \ldots \ldots \ldots \ldots \ldots \ldots \ldots \ldots \ldots \ldots \ldots \ldots$. $\ldots \ldots \ldots$

Section 3.1. Highway Vehicle Characteristics $\ldots \ldots \ldots \ldots \ldots \ldots \ldots \ldots \ldots$

Figure 3.1. Percentages of Highway Energy Use by Mode, 1970-90 . . . . . 3-5

Figure 3.2. Annual Growth Rates of Highway Vehicle Miles Traveled by Mode, 1970-90 and 1982-90 . . . . . . . . . . . . . . . . . . 3-7

Figure 3.3. Average Age of Automobiles and Trucks in Use, 1970-91 . . . . 3-11

Figure 3.4. Survival Probabilities of Automobiles, All Trucks and Light Trucks . . . . . . . . . . . . . . . 3-13

Figure 3.5. Survival Probabilities of Automobiles . . . . . . . . . 3-15

Figure 3.6. Survival Probabilities of All Trucks $\ldots \ldots \ldots \ldots \ldots \ldots \ldots \ldots$ 3-17

Section 3.2. Automobiles ......................... 3-18

Figure 3.7. Automobiles in Use by Age, 1970 and $1991 \ldots . . \ldots \ldots$. . . 3-21

Figure 3.8. Engine Size, Curb Weight, and Interior Space of Domestic and Import Automobiles by Size Class, $1976-92$. . . . . . . . . . . 3-29

Section 3.3. Trucks $\ldots \ldots \ldots \ldots \ldots \ldots \ldots \ldots \ldots \ldots \ldots \ldots \ldots \ldots \ldots \ldots$ 3-28

Figure 3.9. Import, Diesel, and Four-Wheel Drive Shares of Light Truck Sales, 1970-91 . . . . . . . . . . . . . . . . 3 3-33

Figure 3.10. Summary Statistics by Type of Truck, 1990 . . . . . . . . . . . . 3-39

Figure 3.11. Annual Growth Rates for Truck Statistics by Type of Truck, $1970-90 \ldots \ldots \ldots \ldots \ldots \ldots \ldots \ldots \ldots \ldots$. . . . . . . . . . . . . .

Section 3.5. Fleets ........................... 3-50

Figure 3.12. Distribution of Automobile Fleets by Ust, $1991 \ldots \ldots \ldots$. . . . 3-52 
LIST OF FIGURES

(continued)

Page

Section 3.6. Federal Standards and Motor Vehicle Fuel Economy . . . . . . . . . 3-54

Figure 3.13. Corporate Average Fuel Economy Standards and

Sales-Weighted Fuel Economy Estimates for

Automobiles and Light Trucks, 1978-92 . . . . . . . . . 3-56

Figure 3.14. CAFE Fines and Gas Guzzler Tax Revenues, 1980-91 . . . . . 3 3-58

Figure 3.15. Fuel Economy by Speed, 1973 and $1984 \ldots \ldots$. . . . . . . . . 3-61

Figure 3.16. Average Interstate Speeds, $1970-90 \ldots \ldots \ldots \ldots \ldots$. . . . . . . . . . . .

Figure 3.17. Urban Driving Cycle .................... 3-63

Figure 3.18. Highway Driving Cycle $\ldots \ldots \ldots \ldots \ldots \ldots \ldots \ldots \ldots \ldots$ 3-63

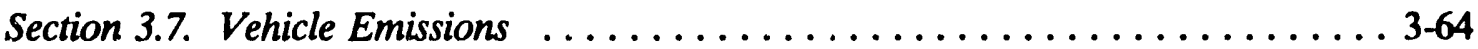

Figure 3.19. Torque and Speed Cycles for Transient Emissions Testing of a Typical Heavy-Duty Diesel Engine . . . . . . . . 3-65

Section 3.8. High-Occupancy Vehicle Lanes . . . . . . . . . . . . . . 3-74

Figure 3.20. Miles of High-Occupancy Vehicle Lanes, 1969-90 . . . . . . . . 3-76

Figure 3.21. U.S. Urban Areas Where HOV Facilities Were in Operation or Development as of $1990 \ldots \ldots \ldots \ldots \ldots \ldots \ldots \ldots$. . . . . . . . . . . .

Chapter 4. Personal Travel Statistics $\ldots \ldots \ldots \ldots \ldots \ldots \ldots \ldots \ldots \ldots \ldots \ldots \ldots \ldots$

Figure 4.1. Population and Vehicle Profile, $1970-90 \ldots \ldots \ldots \ldots \ldots \ldots$. . . . . .

Figure 4.2. Financial Profile, $1970-89 \ldots \ldots \ldots \ldots \ldots \ldots \ldots \ldots$. . . . . . . . . .

Figure 4.3. Average Distance of Trips by Trip Purpose, 1974, 1983, and $1990 \ldots \ldots \ldots \ldots \ldots \ldots \ldots \ldots \ldots \ldots \ldots \ldots$. . . . . . . . . . . . . . . .

Figure 4.4. Mode of Travel by Trip Purpose, 1990 . . . . . . . . . . . . 4-11

Figure 4.5. Percent Change in Numbers of Individuals, Households, Drivers, Workers, and Vehicles, 1969, 1983, and 1990 Series of NPTS . . 4-14

Figure 4.6. Number and Percentage of Households by Number of Vehicles Available, 1969, 1977, 1983, and 1990 Series of NPTS . . . . 4-16

Figure 4.7. Household Vehicle Travel for Selected Trip Purposes, $1969,1977,1983$, and 1990 Series of the NPTS . . . . . . 4-18

Figure 4.8. Average Vehicle Occupancy ................. 4-20

Figure 4.9. Distribution of Journey-to-Work Trips by Usual Mode . . . . . . 4-21

Figure 4.10. Average Commute Trip Distance for Selected Modes . . . . . . . . 4-23 


\section{IIST OF FIGURES \\ (continued)}

Page

Figure 4.11. Distribution of Automobiles by Vehicle Age, 1977, 1983, and 1990 Series of the NPTS . . . . . . . . . . . . 4 428

Figure 4.12. Distribution of Household-Based Trucks by Vehicle Age, 1977, 1983, and 1990 Series of the NPTS . . . . . . . . . 4-28

Figure 4.13. Average Annual Miles per Vehicle by Number of Vehicles Available, 1969, 1977, 1983, and 1990 Series of the NPTS . . . 4-29

Figure 4.14. Average Annual Miles per Vehicle by Number of Adults in Household, 1977, 1983, and 1990 Series of the NPTS . . . . . 4 430

Chapter 5. Alternative Fuek Statistics . . . . . . . . . . . . . . . . . 5-1

Figure 5.1. Number of Alternative Refuel Sites by State $\ldots \ldots \ldots \ldots \ldots$ 5-7

Figure 5.2. Compressed Natural Gas Refueling Sites in the United States . . 5-8

Figure 5.3. A Map Example of Compressed Natural Gas Refueling Sites for the State of Indiana . . . . . . . . . . . . . . . . . 5-9

Figure 5.4. A Map Example of Methanol and Ethanol Refueling Sites for the State of California .................... 5-10

Figure 5.5. Target Acquisition of Alternative Fuel Vehicles for Federal Fleets ....................... 5-11

Figure 5.6. FY 1993 Agency Requests for Alternative Fuel Vehicles . . . . . 5-11

Figure 5.7. Gasohol Consumption of Selected States, 1980-91 . . . . . . . 5-19

Chapter 6. Nonhighway Modes $\ldots \ldots \ldots \ldots \ldots \ldots \ldots \ldots \ldots \ldots \ldots \ldots \ldots$ 6.

Figure 6.1. Percentages of Nonhighway Energy Use by Mode,

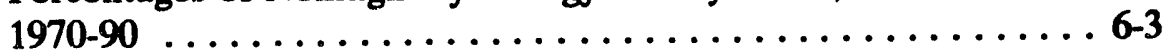

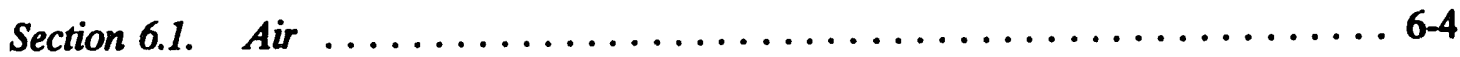

Figure 6.2. Passenger-Miles, Cargo Ton-Miles, and Energy Use for Certificated Route Air Carriers, 1970-90 . . . . . . . . . 6 6-8

Figure 6.3. Average Trip Length and Load Factor for Certificated Route Air Carriers, 1970-90 . . . . . . . . . . . . . . . 6-9

Figure 6.4. Passenger-Miles and Energy Use in General Aviation, 1970-90 


\section{LST OF FIGURES}

(continued)

Section 6.2. Water ............................. 6-13

Figure 6.5. Ton-Miles, Average Length of Haul, and Energy Use for Domestic Waterborne Commerce, 1970-89 . . . . . . . . . . 6-17

Figure 6.6. Breakdown of Domestic Marine Cargo by Commodity Class, $1989 . \ldots \ldots \ldots \ldots \ldots \ldots \ldots \ldots \ldots \ldots \ldots \ldots$. . . . . . . . . . .

Section 6.3. Pipeline $\ldots \ldots \ldots \ldots \ldots \ldots \ldots \ldots \ldots \ldots \ldots \ldots \ldots \ldots \ldots .6 .6 \ldots$

Figure 6.7. Natural Gas and Petroleum Shipped by Pipeline, 1972-90 . . . . 6 6-22

Section 6.4. Railroad $\ldots \ldots \ldots \ldots \ldots \ldots \ldots \ldots \ldots \ldots \ldots \ldots \ldots \ldots . \ldots \ldots \ldots$

Figure 6.8. Revenue Tons, Revenue Ton-Miles, Energy Intensity, and Energy Use for Class I Freight Railroads, 1970-90 6-27

Figuie 6.9. Energy Use and Passenger-Miles for Amtrak and Rail Transit, 1970-91 6-30 


\section{FOREWORD}

Even the birth of a baby boy did not slow Stacy Davis down in her pursuit of producing this year's Transportation Energy Data Book. She and her team at ORNL have made additions in this edition which make it more useful than ever.

To give the reader an appreciation of the scope of this document, consider the following diverse data facts:

- $\quad$ The United States share of world automobile registrations and world truck registrations is about 32 percent (Figure 1.1), down from much higher values 40 years ago.

- Between 1980 and 1990, the real price of gasoline dropped in all the selected, developed countries, except for Canada (Figure 1.4).

- The average price of a new imported car did not equal the price of a new domestic car until 1982. In 1991, the new import average price was nearly $\$ 2000$ more than that for the average domestic car (Table 2.22).

- Gasoline and oil costs as a percent of total operating costs for automobiles are only about 15 percent (Table 2.23).

- The R. L. Polk estimate of the number of vehicles in use for a calendar year is preferable to the Federal Highway Administration estimate of registered vehicles for purposes of comparing to fuel use or miles driven per vehicle (Table 3.4). 
- In 1970, 8.2 percent of the autos in use were over 10 years old. By 1991, this figure rose to 25.9 percent (Table 3.10).

- The percentage of conventional steel in the average weight of a new auto dropped from 53.8 in 1978 to 44.0 in 1992 (Table 3.14).

- The percentage of trucks in operation that are in class 1 (under 6000 pounds gross vehicle weight) rose from 66.0 in 1977 to 85.4 in 1987 (Table 3.28).

- The miles of High-Occupancy Vehicle (HOV) lanes grew to 339 in 1990 (Table 3.52).

- Average vehicle occupancy dropped from 1.9 in 1977 to 1.6 in 1990 (Table 4.11).

- The average distance for commuting trips rose from 9.2 miles in 1977 to 10.6 miles in 1990 (Table 4.13).

- The gross and net heating values for transportation fuels are shown in Table B.1.

I hope you find this data book to be useful. Let me know if you have suggestions for data that should be added.

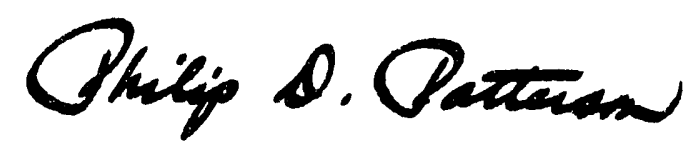




\section{ACKNOWLEDGEMENTS}

We wish to express our gratitude to the many individuals who assisted in the preparation of this document. First, we would like to thank Philip D. Patterson and the staff of the Office of Transportation Technologies for their continued support of the Transportation Energy Data Book. This document also benefits from the criticism and careful review of Phil Patterson of the U.S. Department of Energy, John Maples, consultant, and Patricia Hu, David Greene, Bruce Peterson, Frank Southworth, Jerry Hadder, Scott Stevens, Shih-Miao Chin, and Shaw-Pin Miaou of Oak Ridge National Laboratory (ORNL). We would also like to thank the Federal Highway Administration (FHWA), for allowing the publication of the 1990 Nationwide Personal Transportation Study (NPTS) data. The tables, text, and figures from the NPTS were done for the FHWA by Patricia Hu, ORNL, and Jennifer Young, University of Tennessee.

In addition, we would like to acknowledge the contributions of Sherry Campbell of the Health, Safety, Environment, and Accountability Division for the preparation of the title index. Finally, we are indebted to Maggie Bruer for her skills in assisting with the preparation of the manuscript. 


\begin{abstract}
The Transportation Energy Data Book: Edition 13 is a statistical compendium prepared and published by Oak Ridge National Laboratory (ORNL) under contract with the Office of Transportation Technologies in the Department of Energy (DOE). Designed for use as a desk-top reference, the data book represents an assembly and display of statistics and information that characterize transportation activity, and presents data on other factors that influence transportation energy use. The purpose of this document is to present relevant statistical data in the form of tables and graphs. Each of the major transportation modes - highway, air, water, rail, pipeline - is treated in separate chapters or sections. Chapter 1 compares U.S. transportation data with data from seven other countries. Aggregate energy use and energy supply data for all modes are presented in Chapter 2. The highway mode, which accounts for over three-fourths of total transportation energy consumption, is dealt with in Chapter 3. Topics in this chapter include automobiles, trucks, buses, fleet automobiles, federal standards, fuel economies, and vehicle emission data. Household travel behavior characteristics are displayed in Chapter 4. Chapter 5 contains information on alternative fuels and alternatively-fueled vehicles. The last chapter, Chapter 6, covers each of the nonhighway modes: air, water, pipeline, and rail, respectively.
\end{abstract}



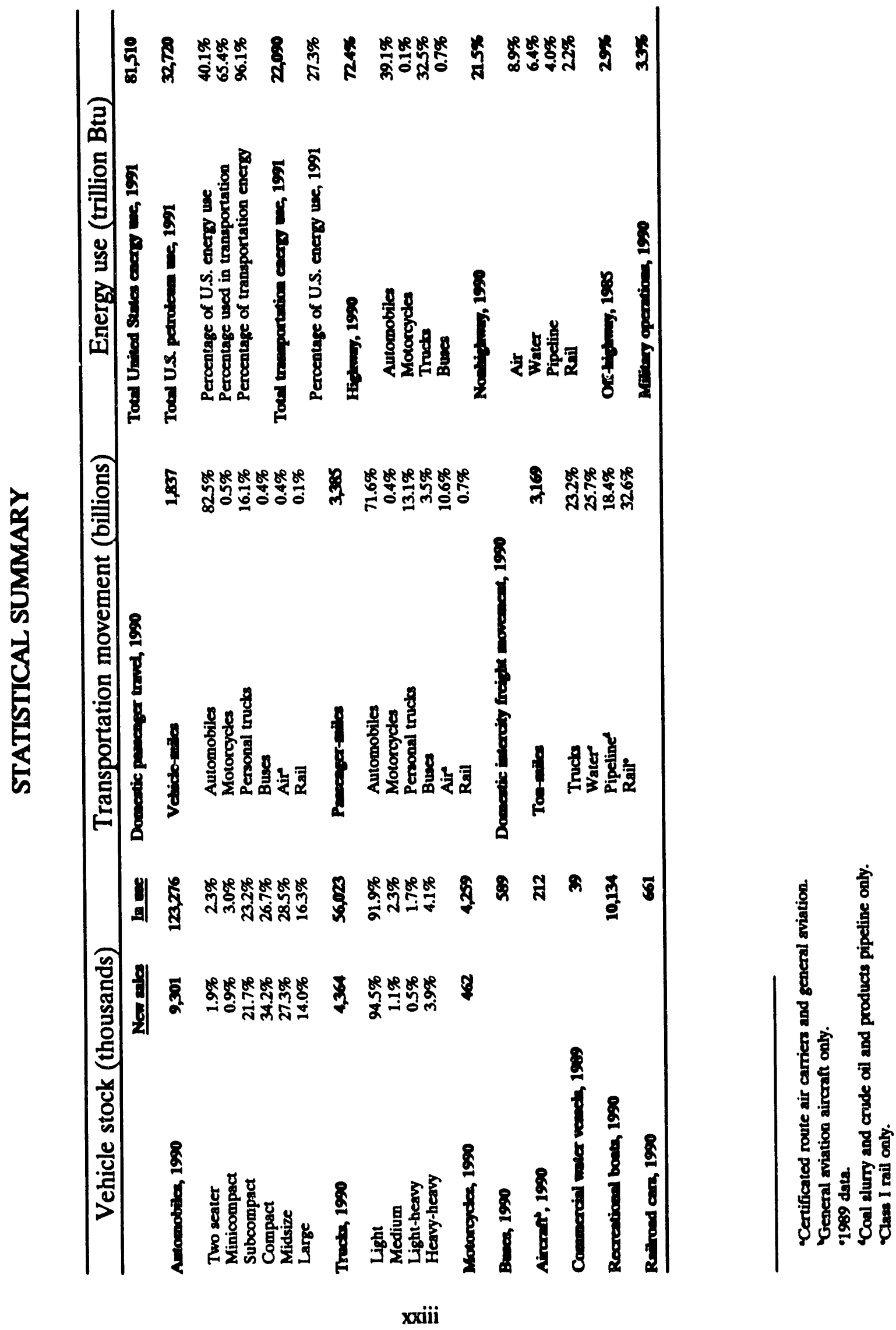


\section{INTRODUCTION}

In January 1976, the Transportation Energy Conservation (TEC) Division of the Energy Research and Development Administration contracted with Oak Ridge National Laboratory (ORNL) to prepare a Transportation Energy Data Conservation Data Book to be used by TEC staff in their evaluation of current and proposed conservation strategies. The major purposes of the data book were to draw together, under one cover, transportation data from diverse sources, to resolve data conflicts and inconsistencies, and to produce a comprehensive document. The first edition of the TEC Data Book was published in October 1976. With the passage of the Department of Energy (DOE) Organization Act, the work being conducted by the former Transportation Energy Conservation Division fell under the purview of the DOE's Office of Transportation Programs (now the Office of Transportation Technologies). DOE, through the Office of Transportation Technologies, has supported the compilation of Editions 3 through 13.

Policymakers and analysts need to be well-informed about activity in the transportation sector. The organization and scope of the data book reflect the need for different kinds of information. For this reason, Edition 13 updates much of the same type of data that is found in previous editions. 
Chapter 1 contains information which compares U.S. transportation data with data from seven selected countries in Asia, Europe, and North America. The U.S. data in this chapter are presented for comparison with other international data only and, therefore, should not match domestic data found in other chapters of the book. Chapter 2, Transportation Energy Characteristics, presents aggregate energy use data for each of the major transportation modes (i.e., highway, air, water, pipeline, and rail), as well as related statistics on the price and supply of transportation fuels. Chapter 3 covers detailed statistics on three major highway modes: automobiles, trucks, and buses. Also contained in this chapter is information on federal standards and fuel economies of highway vehicles, and vehicle emission data. Household travel behavior characteristics are displayed in Chapter 4. Chapter 5 presents data on alternative fuels and alternatively-fueled vehicles. Chapter 6 consists of data for the nonhighway modes: air, water, pipeline, and rail. Sources used represent the latest available data.

In any attempt to compile a comprehensive set of statistics on transportation activity, numerous instances of inadequacies and inaccuracies in the basic data are encountered. Where such problems occur, estimates are developed by ORNL. To minimize the misuse of these statistics, an appendix (Appendix A) is included in this edition to document the estimation procedures. The attempt is to provide sufficient information for the conscientious user to evaluate the estimates and to form his or her own opinions as to their utility. Clearly, the 
accuracy of the estimates cannot exceed the accuracy of the primary data, an accuracy which in most instances is unknown. In cases where data accuracy is known or substantial errors are strongly suspected in the data, the reader is alerted. In all cases it should be recognized that the estimates are not precise.

The majority of the statistics contained in the data book are taken directly from published sources, although these data may be reformatted for presentation by ORNL. Consequently, neither ORNL nor DOE can endorse the validity of these data.

Edition 13 of the Transportation Energy Data Book includes over 200 pages of tables and figures. To facilitate use of this information, several aids in format and presentation techniques are included. Statistical highlights from the data book precede this introduction, and a synopsis of chapter contents is provided at the beginning of each chapter. Some of the average rates of change in the data book are calculated using 1982 as a base year. This is because an oil embargo was affecting the economy in 1982, and the year was chosen as a year of economic recession. 


\section{CHAPTER 1 \\ INTERNATIONAL TRANSPORTATION STATISTICS}

This chapter includes statistics related to the transportation sector of eight selected countries. Countries were included based on data availability, geographical distribution, and transportation fuel use as a percentage of total refined petroleum consumptic $n$. The statistics presented for the United States in this chapter are from international sources and are only for use in international comparisons. The numbers may differ slightly from data presented in other chapters of the book.

In $1950,76 \%$ of the world's automobiles were registered in the United States; by 1990 , that percentage had dropped to $32.3 \%$ (Table 1.1). The U.S. had a lower annual growth rate in automobile registrations from 1950 to 1990 than any of the other listed countries except Sweden, for which data are not available for the years 1950 to 1970. The U.S. also accounts for $32.7 \%$ of the world's truck and bus registrations. Japan has experienced the largest growth in truck and bus registrations since 1950, 12.9\% annually (Table 1.2).

The U.S. had the highest number of automobiles per capita in 1990 (0.574), with Italy following second (0.478). Japan has had the lowest number of automobiles per capita of any of the listed countries. However, Japan, whose truck and bus registration growth was noted earlier, closely follows the U.S. in the number of trucks and buses per capita, 0.175 and 0.180 , respectively (Table 1.3 ).

The data on gasoline prices indicate that Italy has had the highest gasoline prices since 1982, while the U.S. has had the lowest of the listed countries (Table 1.4). Italy's high gasoline prices in 1990 were mainly due to the gasoline tax (Figure 1.4). In 1990 over $50 \%$ of the diesel price could be attributed to tax in four countries - Italy, France, the United Kingdom, and West Germany (Figure 1.5). 
Data from the Lawrence Berkeley Latoratory (LBL) are contained in Tables 1.6, 1.7 and 1.10-1.16. These data are generated by LBL using various country sources: Japan - Japan Institute for Energy Economics and Ministry of Transport;

France - $\quad$ Agence Francaice pour la Matrise d'Energie, now Agence d'Environment et Matrise de L'Energie;

Italy - Data provided by Agip Petroli, 1990 (private communication) and Italstat, National Accounts of Transportation;

Sweden - Transport Raadet (Transportation Council), National Board of Industry, Energy Board, and Ministry of Communications and Transport;

UK - Digest of Traasport Statistics, Energy Technology Support Unit, D. Martin (private comununication);

Germany - "Vehker in Zahlen" ("Transportation in Figures," published by the Ministry of Tránsport) ccmpiled by Deutsches Institut fuer Wirtschaft, Berlin;

US - Data from various tables and editions of the Transportation Energy Data Book, Oak Ridge National Laboratory.

Details on the methodology for compiling these data can be found in "Energy Efficiency and Human Activity," by Lee Schipper, Steve Myers, et. al., Cambridge University Press, Cambridge, MA, 1992, and the "Proceedings of the ACEEE Conference on Automobiles and the Greenhouse Effect." 


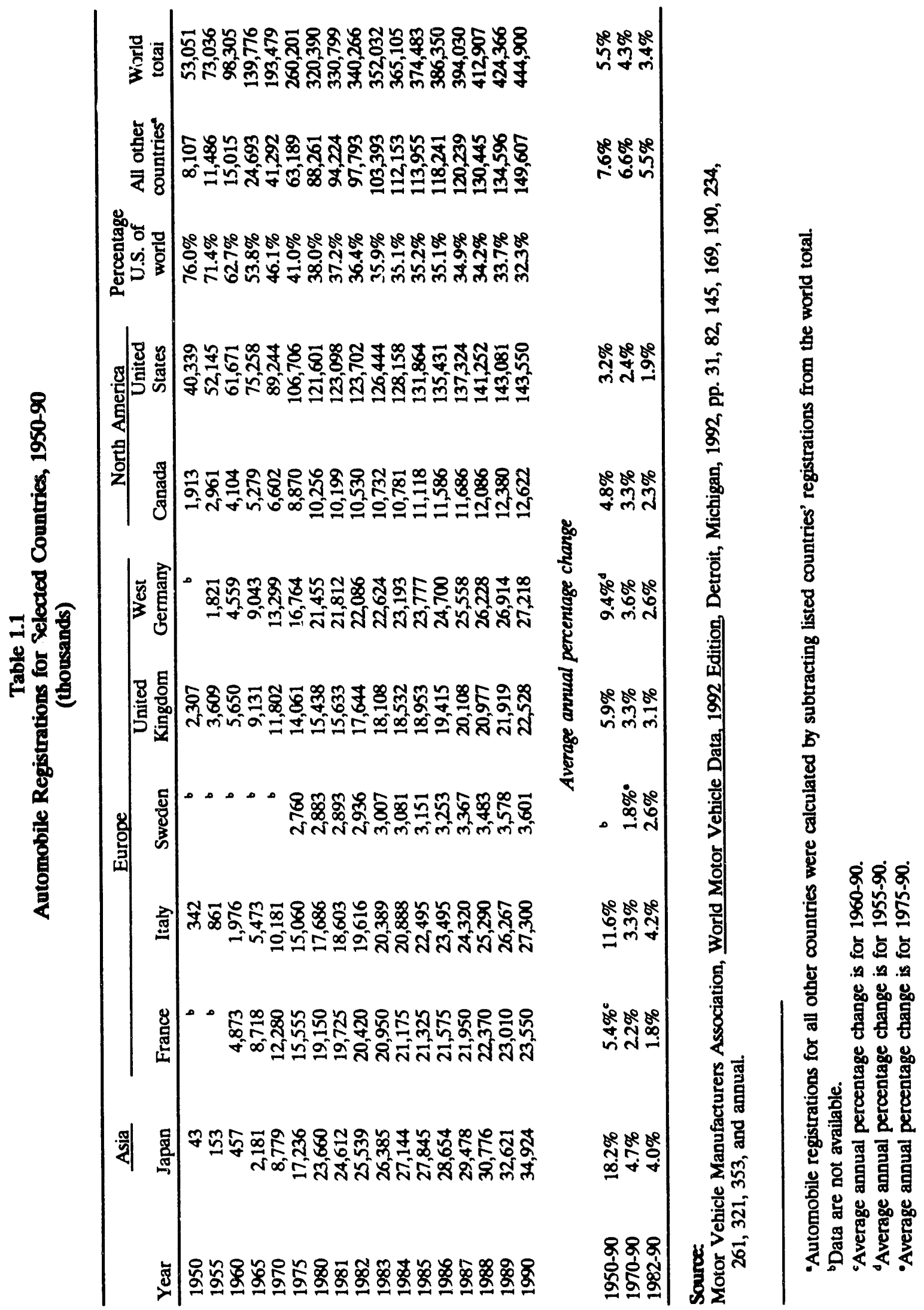




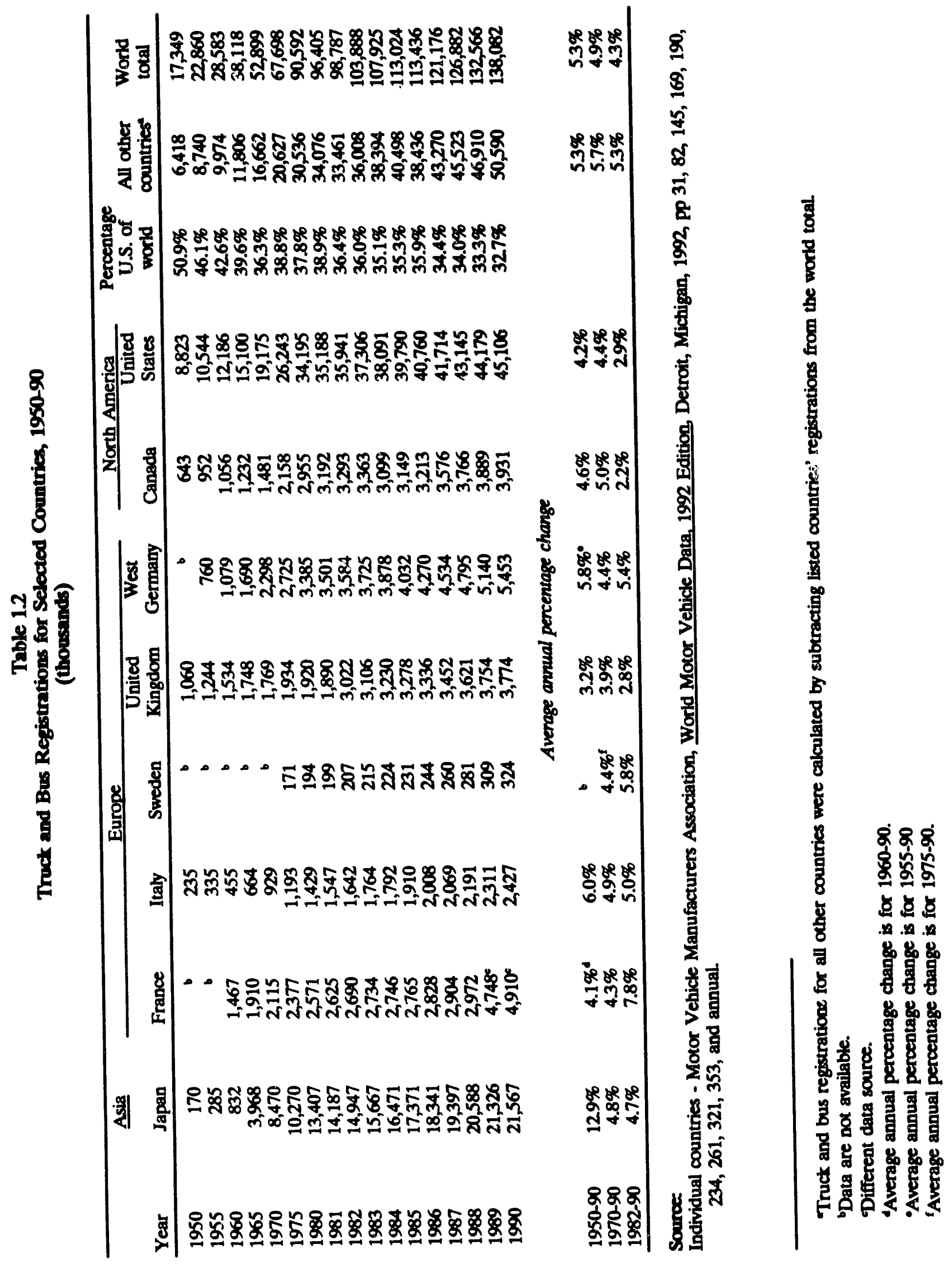




$$
\text { 准 }
$$




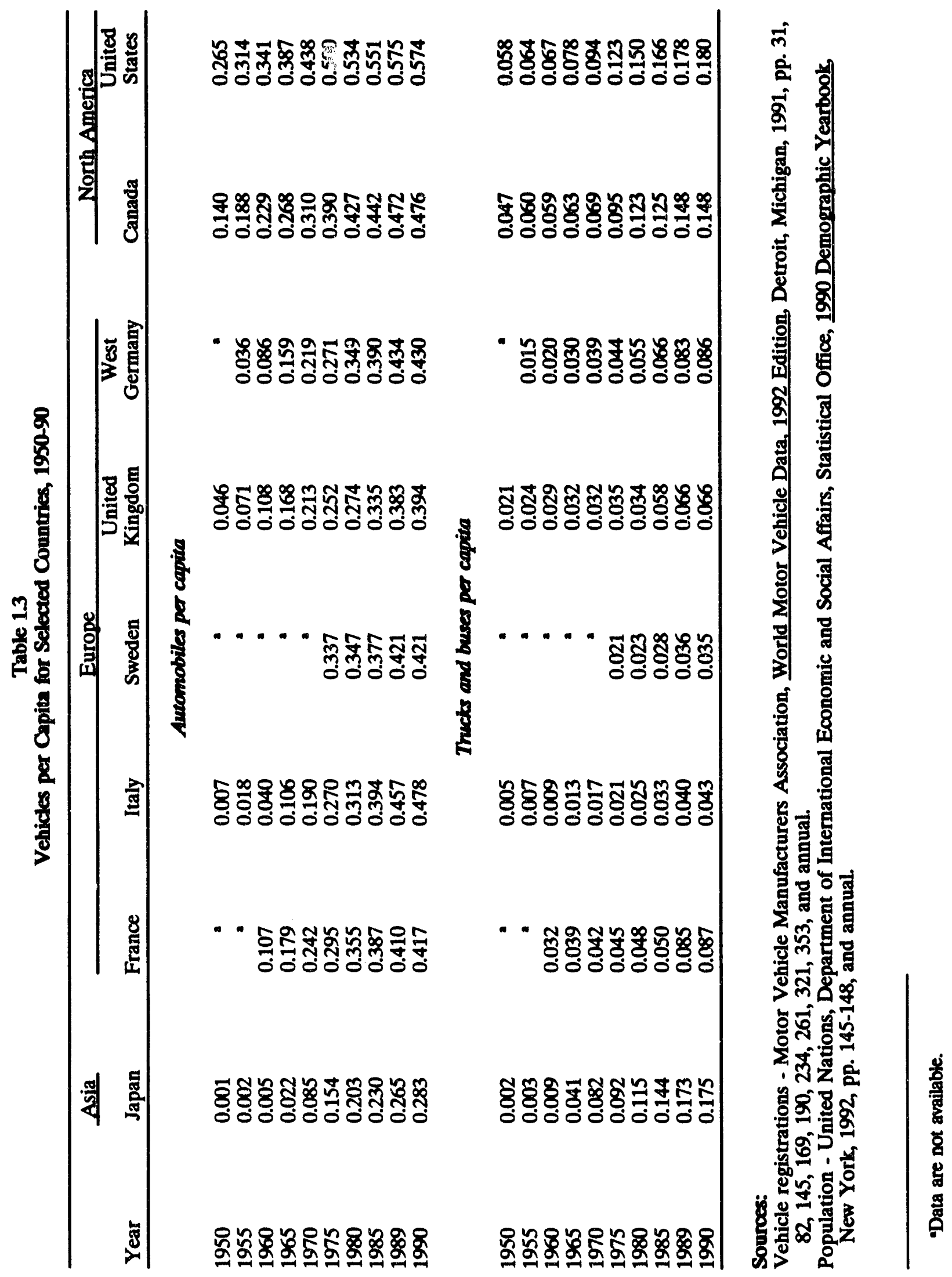




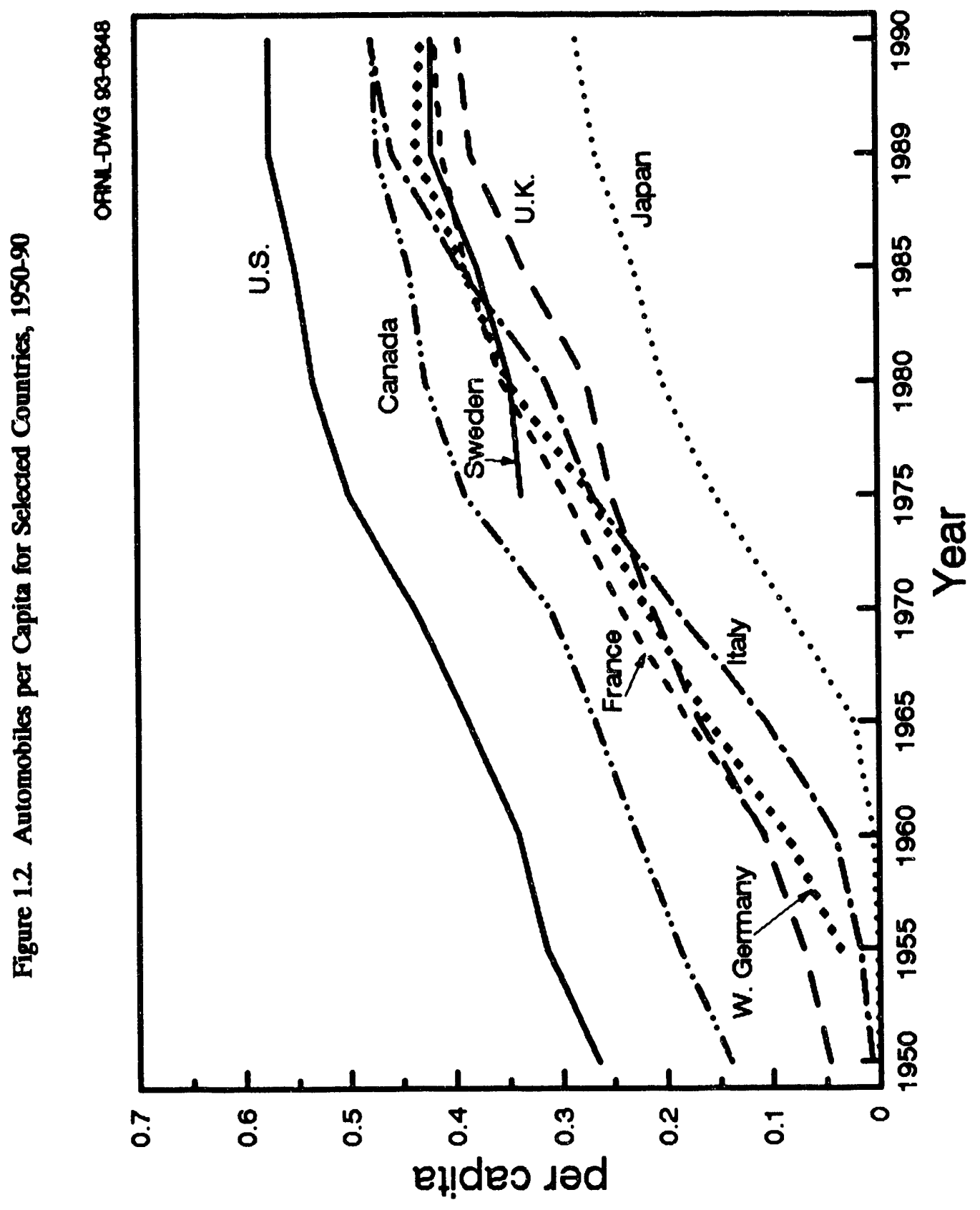

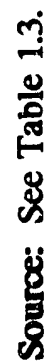




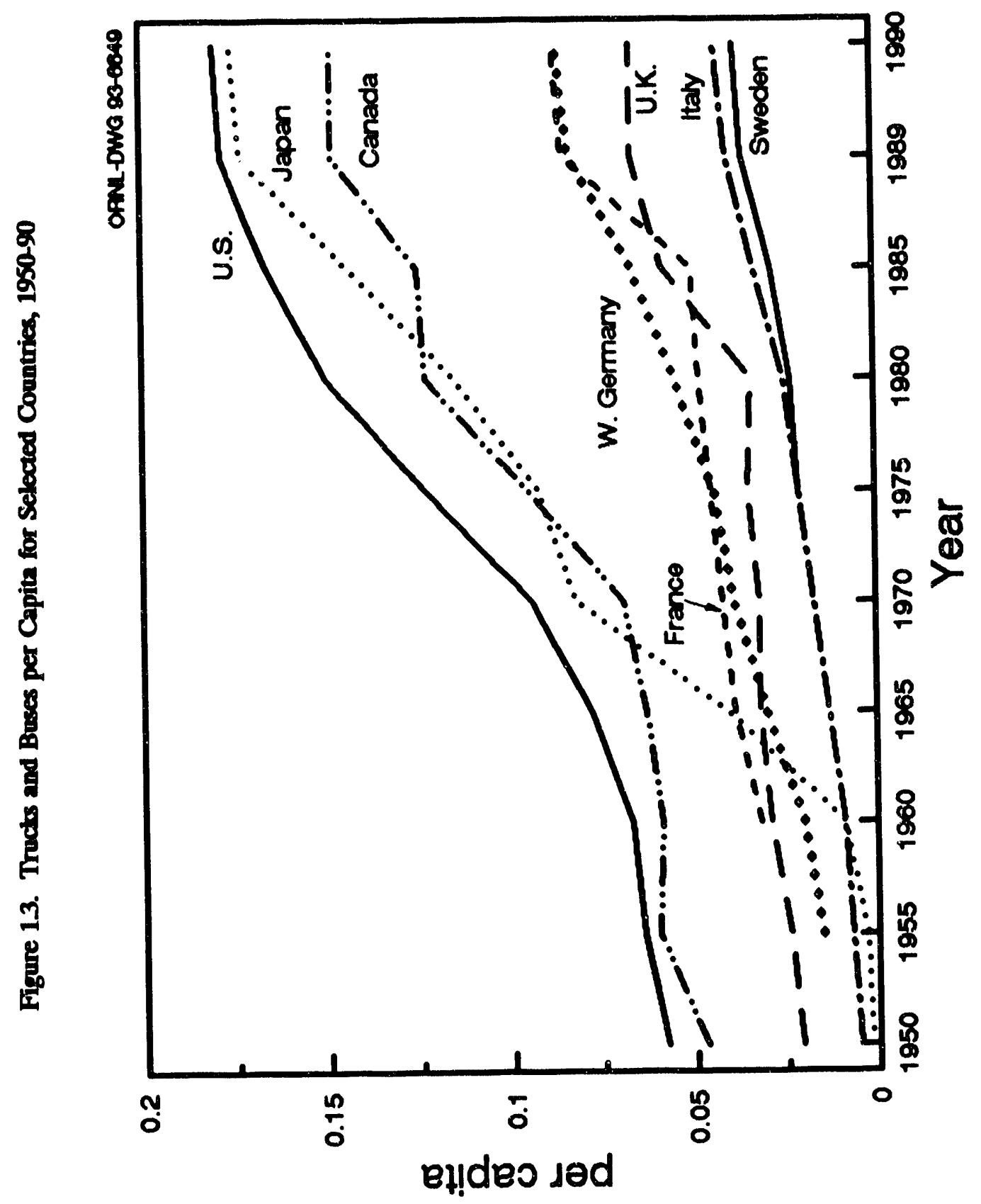

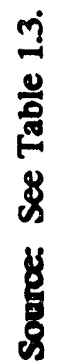


$1-9$

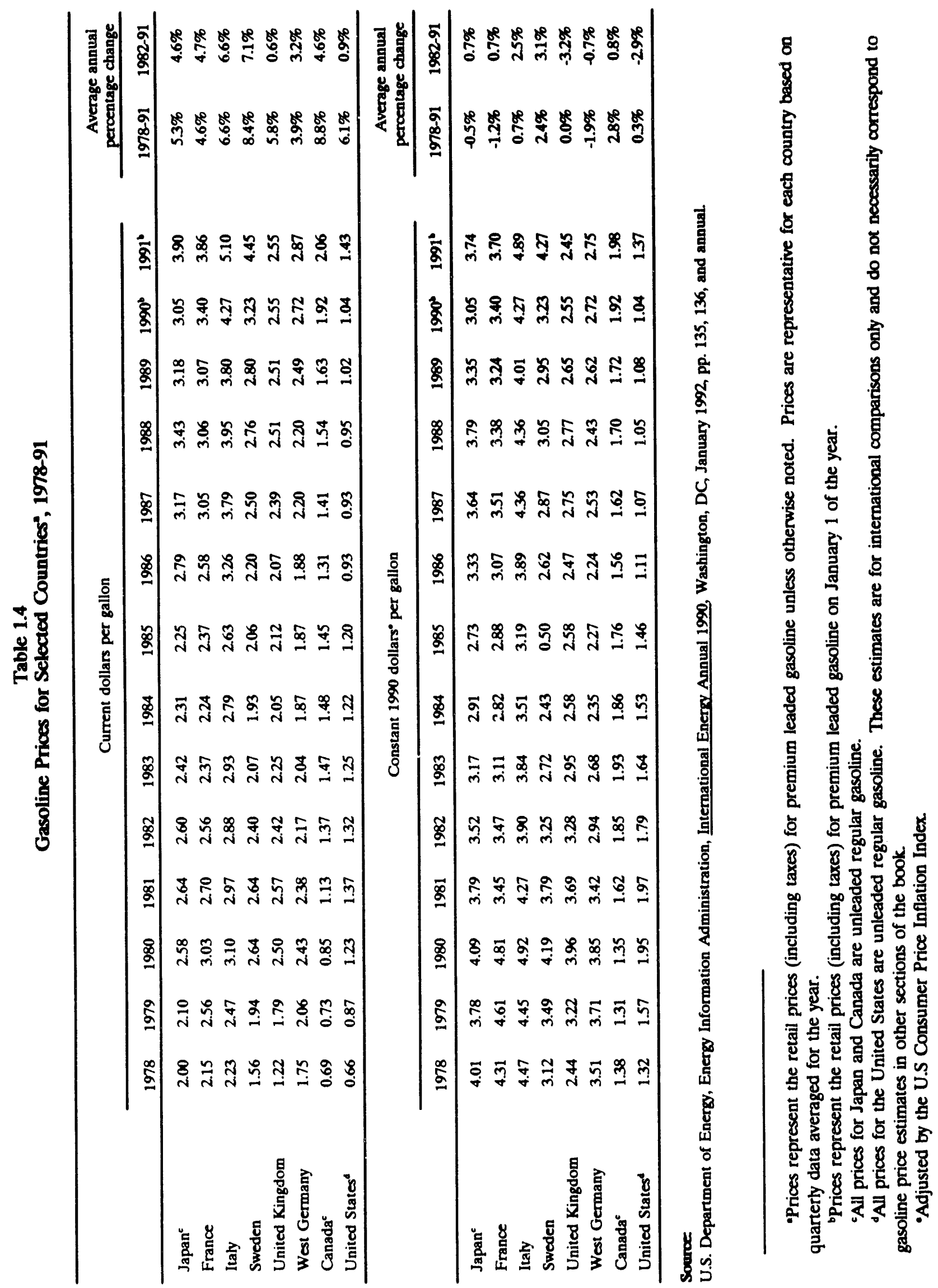




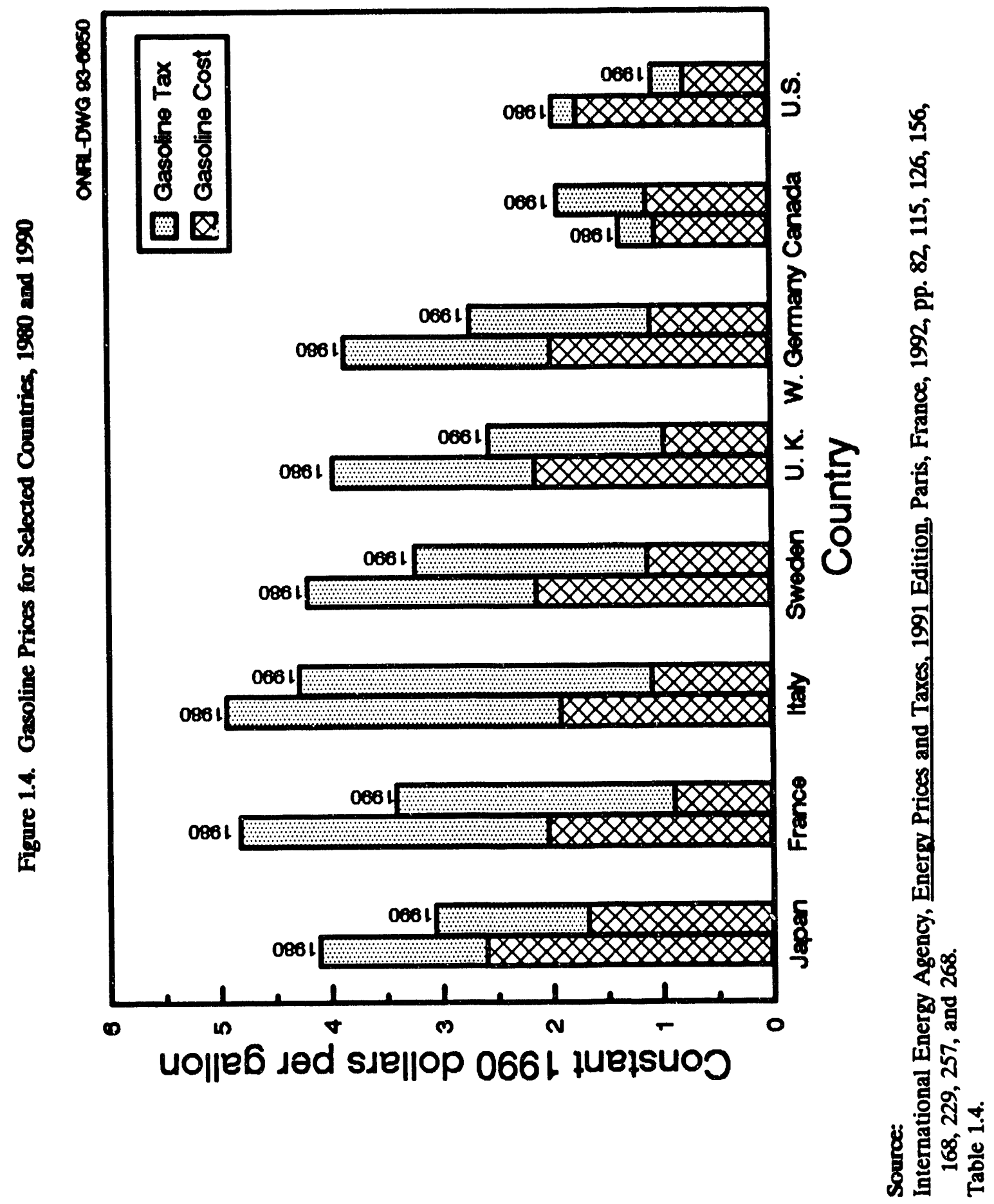


1-11

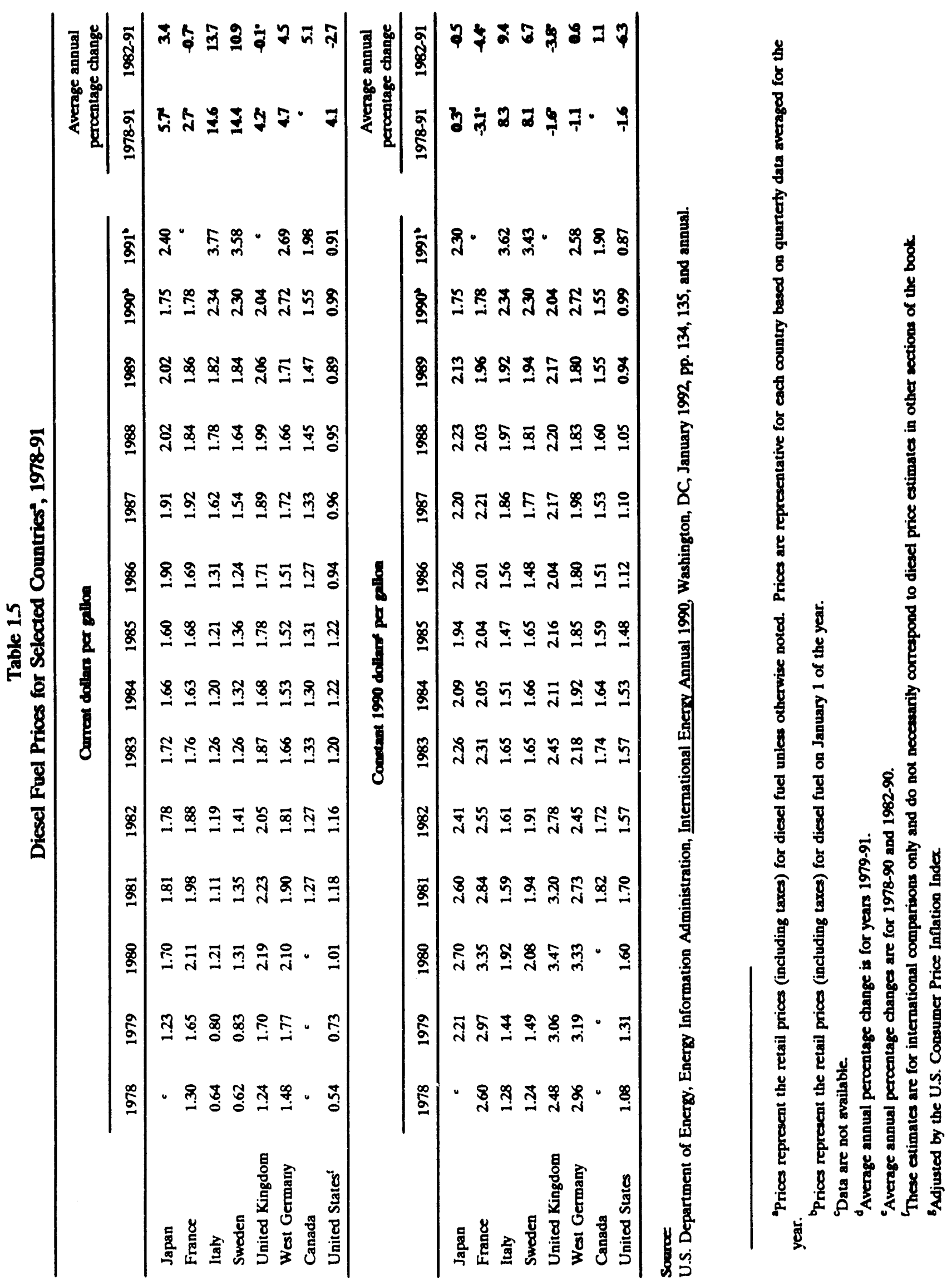



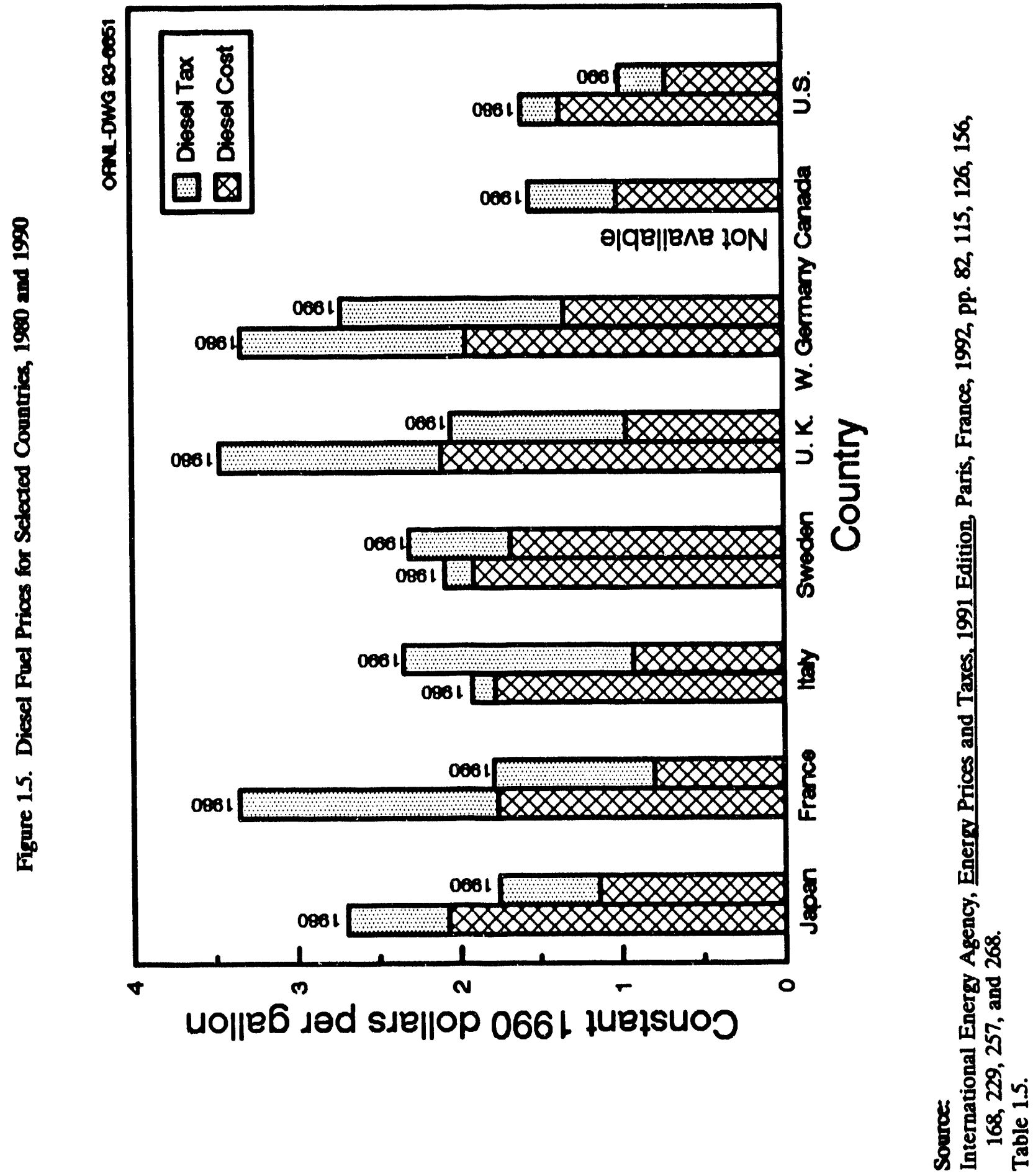
According to the best available data, new cars in France have the highest fuel economy of the listed countries. Caution should be used, however, when comparing fuel economy data between countries because each country may use different methods of calculating new car fuel economy. The data, therefore, may not be directly comparable.

Table 1.6

New Gasoline Car Fuel Economy for Selocted Countries, $1973-89$ (miles per gallon)

\begin{tabular}{|c|c|c|c|c|c|c|}
\hline Year & Japan & France & Italy & Sweden & Germany & United States \\
\hline 1973 & 22.7 & : & $\bullet$ & $\bullet$ & 23.0 & 13.1 \\
\hline 1974 & 22.1 & - & $:$ & * & : & 13.8 \\
\hline 1975 & 21.3 & 27.7 & 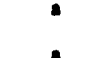 & 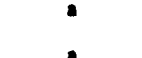 & 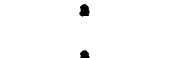 & 15.4 \\
\hline 1976 & 22.7 & 28.2 & ' & $\bullet$ & : & 16.8 \\
\hline 1977 & 25.1 & 28.5 & $\bullet$ & $\bullet$ & $\bullet$ & 17.8 \\
\hline 1978 & 27.0 & 28.7 & 8 & 25.4 & 24.1 & 18.7 \\
\hline 1979 & 27.4 & 29.1 & 2 & 25.7 & 24.6 & 18.8 \\
\hline 1980 & 27.4 & 30.4 & 28.4 & 26.3 & 26.2 & 22.6 \\
\hline 1981 & 29.1 & 31.9 & 28.8 & 27.2 & & 24.2 \\
\hline 1982 & 30.8 & 33.1 & 29.6 & 27.5 & $\bullet$ & 24.8 \\
\hline 1983 & 30.3 & 33.7 & 31.9 & 27.5 & 29.2 & 24.7 \\
\hline 1984 & 30.3 & 34.5 & 32.9 & 27.8 & 30.3 & 24.7 \\
\hline 1985 & 29.3 & 35.1 & 32.9 & 27.8 & 31.1 & 25.1 \\
\hline 1986 & 28.4 & 35.3 & 33.8 & 28.2 & 31.5 & 25.8 \\
\hline 1987 & 27.9 & 35.7 & 34.3 & 28.8 & 30.7 & 26.0 \\
\hline 1988 & 27.4 & 36.1 & 34.3 & 28.5 & 29.9 & 25.9 \\
\hline 1989 & & 36.3 & & 28.5 & & 25.6 \\
\hline \multicolumn{7}{|c|}{ Average annual percentage change } \\
\hline $1973-89$ & $1.3 \%^{b}$ & $2.0 \% \%^{c}$ & $2.4 \%^{d}$ & $1.1 \%{ }^{\circ}$ & $1.8 \%^{\prime}$ & $4.3 \%$ \\
\hline $1982-89$ & $-1.9 \%^{b}$ & $1.3 \%$ & $2.5 \% \mathrm{~d}$ & $0.5 \%$ & $0.5 \%^{\prime}$ & $0.5 \%$ \\
\hline
\end{tabular}

Sources:

International Energy Studies, Energy Analysis Program, Lawtence Berkeley Laboratory, Berkeley, CA, 1991. Data were compiled from country sources, such as oil companies, energy economics institutes, and government ministries.

-Data are not available.

'Average annual percentage changes are for years $1973-88$ and 1982-88.

'Average annual percentage change is for years 1975-89.

Average annual percentage changes are for years 1980-88 and 1982-88.

'Average annual percentage change is for years 1978-89.

'Average annual percentage changes are for years 1973-88 and 1983-88. 


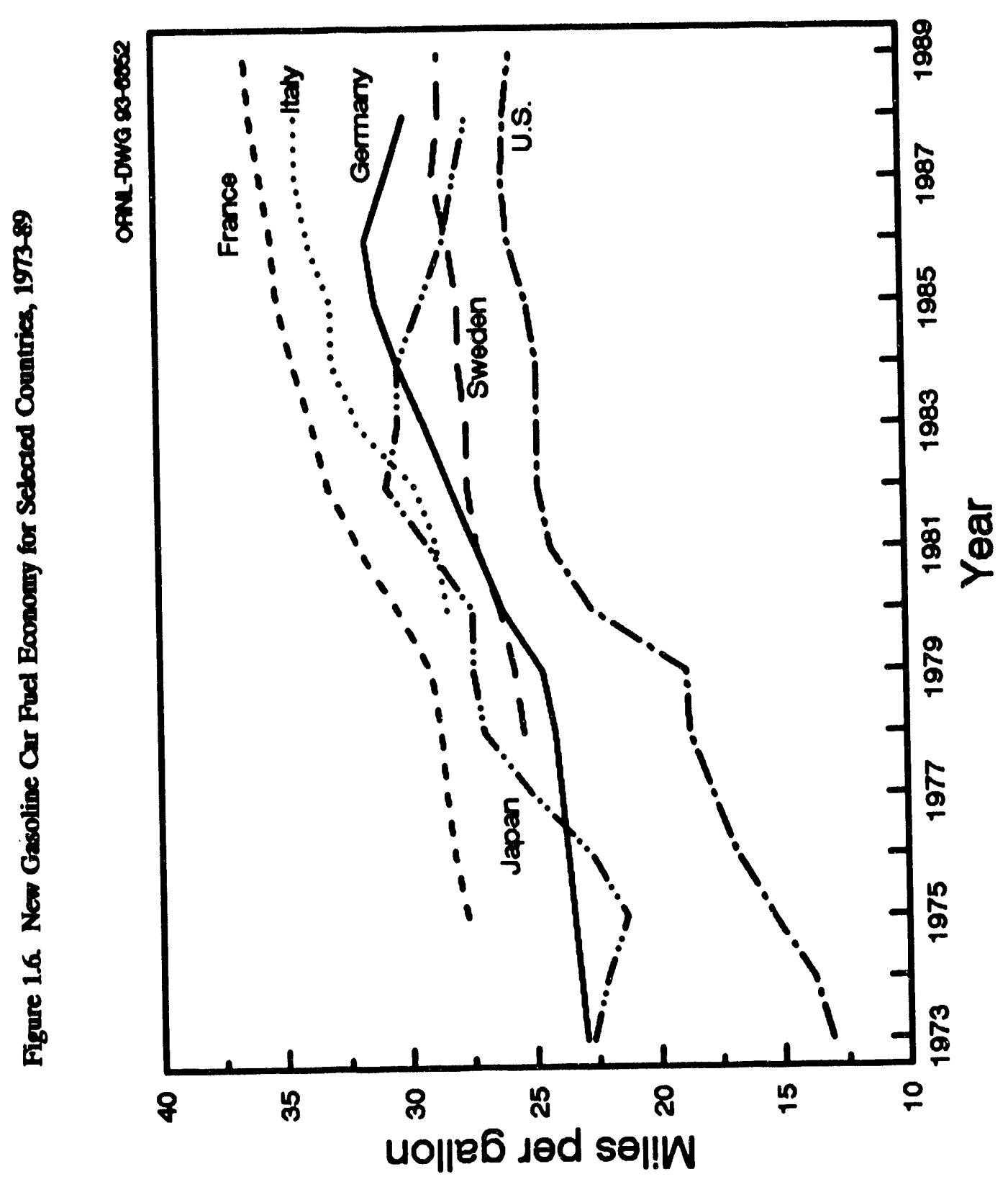

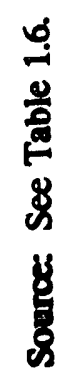


Because each country may use different methods of calculating fuel economies, caution should be used when comparing fuel economy data between countries. The data for the United States were generated specifically for international comparisons and should be used only for that purpose; they are not consistent with other domestic fuel economy figures.

Table 1.7

Puel Boonomy of the Gasoline Automobile Population for Selected Countries, $1970-89$ (miles per gillon)

\begin{tabular}{|c|c|c|c|c|c|c|c|}
\hline Year & Japan & France & Italy & Sweden & $\begin{array}{c}\text { United } \\
\text { Kingdom }\end{array}$ & Germany & $\begin{array}{l}\text { United } \\
\text { States }\end{array}$ \\
\hline 1970 & 21.4 & 27.8 & 2 & 22.9 & 23.5 & 23.1 & 13.3 \\
\hline 1971 & 19.6 & 27.8 & : & $\because$ & 23.4 & 22.0 & 13.2 \\
\hline 1972 & 21.4 & 27.8 & 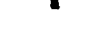 & 22.4 & 22.0 & 21.5 & 13.2 \\
\hline 1973 & 21.4 & 28.0 & 27.8 & 22.2 & 21.8 & 22.0 & 13.1 \\
\hline 1974 & 21.4 & 27.6 & & & 21.8 & 22.1 & 13.1 \\
\hline 1975 & 21.4 & 27.3 & ' & 22.3 & 22.6 & 22.0 & 13.3 \\
\hline 1976 & 21.4 & 26.4 & 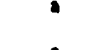 & 22.1 & 22.7 & 21.9 & 13.3 \\
\hline 1977 & 21.4 & 26.5 & 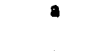 & & 22.5 & 21.7 & 13.5 \\
\hline 1978 & 19.6 & 26.1 & $\bullet$ & 21.7 & 22.1 & 21.5 & 13.7 \\
\hline 1979 & 19.6 & 26.4 & 27.9 & : & 21.6 & 21.8 & 14.0 \\
\hline 1980 & 19.6 & 27.7 & 27.9 & 21.7 & 22.7 & 21.6 & 15.0 \\
\hline 1981 & 19.6 & 28.1 & 28.1 & 21.8 & 23.6 & 21.7 & 15.4 \\
\hline 1982 & 21.4 & 26.9 & 28.1 & 21.8 & 23.8 & 21.7 & 16.0 \\
\hline 1983 & 21.4 & 26.8 & 28.4 & 21.9 & 23.8 & 21.7 & 16.4 \\
\hline 1984 & 21.4 & 27.0 & 28.9 & 21.9 & 23.8 & 21.7 & 16.9 \\
\hline 1985 & 21.4 & 27.0 & 29.1 & 22.1 & 24.2 & 21.7 & 17.2 \\
\hline 1986 & 21.4 & 26.9 & 29.6 & 22.5 & 24.2 & 21.7 & 17.2 \\
\hline 1987 & 21.4 & 27.0 & 30.0 & 23.0 & 24.5 & 21.9 & 17.6 \\
\hline 1988 & 21.4 & 26.7 & 30.3 & 23.2 & 24.2 & 22.1 & 18.5 \\
\hline 1989 & & 27.0 & 30.7 & 23.2 & 25.5 & 22.5 & 19.0 \\
\hline \multicolumn{8}{|c|}{ Average annual percentage change } \\
\hline $1970-89$ & $0.0 \%^{b}$ & $-0.2 \%$ & $0.6 \%{ }^{c}$ & $0.1 \%$ & $0.4 \%$ & $-0.1 \%$ & $1.9 \%$ \\
\hline $1982-89$ & $0.0 \%{ }^{b}$ & $0.1 \%$ & $1.3 \%$ & $0.9 \%$ & $1.0 \%$ & $0.5 \%$ & $2.5 \%$ \\
\hline
\end{tabular}

Sources:

International Energy Studies, Energy Analysis Program, Lawrence Berkeley Laboratory, Berkeley, CA, 1991. Data were compiled from country sources, such as oil companies, energy economics institutes, and government ministries.

'Data are not available.

${ }^{b}$ Average annual percentage changes are for years 1970-88 and 1982-88.

'Average annual percentage change is for years 1973-89. 


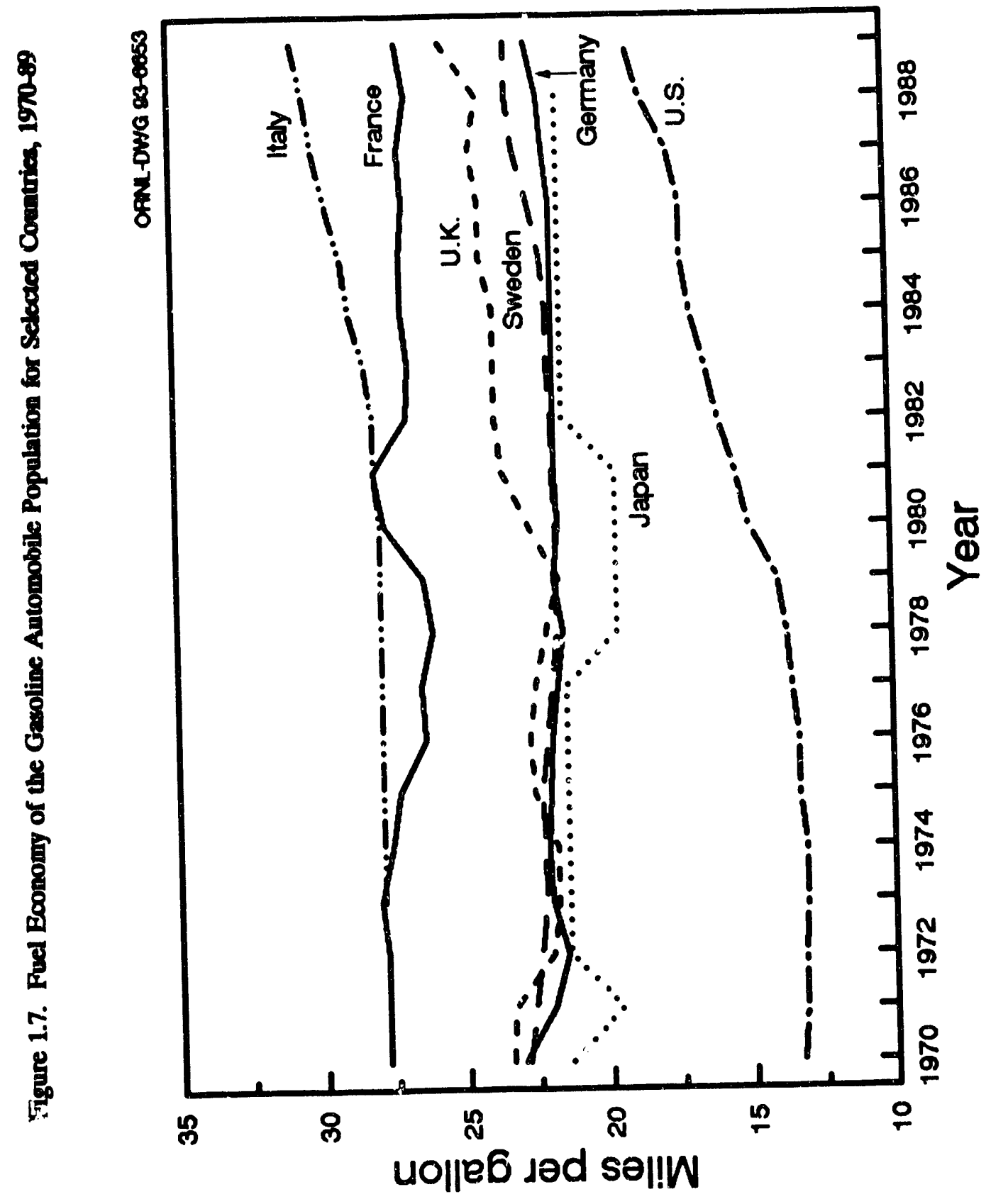

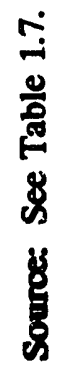


Table 1.8

Annual Miles Driven per Vehicle for Selected Countries, 1984-90

(miles)

\begin{tabular}{|c|c|c|c|c|c|c|c|}
\hline & 1984 & 1985 & 1986 & 1987 & 1988 & 1989 & 1990 \\
\hline \multicolumn{8}{|l|}{ Asia: } \\
\hline \multicolumn{8}{|l|}{ Japan } \\
\hline Cars & 6,486 & 6,503 & 6,519 & 6,274 & 6,124 & 6,074 & $:$ \\
\hline Trucks & 7,485 & 7,438 & 7,483 & 6,786 & 6,913 & 6,920 & $\bullet$ \\
\hline Buses & 17,052 & 17,070 & 17,250 & 17,299 & 17,310 & 16,120 & - \\
\hline \multicolumn{8}{|l|}{ Europe: } \\
\hline \multicolumn{8}{|l|}{$\overline{\text { France }}$} \\
\hline Cars & 7,643 & 7,768 & 8,078 & 8,451 & 8,389 & 8,451 & 8,451 \\
\hline Trucks & 12,428 & 12,428 & 12,428 & 12,428 & 13,049 & 13,671 & 13,671 \\
\hline Buses & 29,827 & 29,827 & 29,827 & 29,827 & 29,827 & 31,070 & 31,070 \\
\hline \multicolumn{8}{|l|}{ Italy } \\
\hline Cars & 6,152 & 6,152 & 6,152 & 6,214 & 6,338 & a & " \\
\hline Trucks & 19,596 & 13,453 & 13,566 & 13,648 & 13,647 & 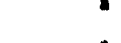 & " \\
\hline Buses & 31,960 & 32,822 & 34,616 & 35,636 & 36,787 & " & - \\
\hline \multicolumn{8}{|l|}{ Sweden } \\
\hline Cars & 7,457 & 7,457 & 7,457 & 7,768 & 7,768 & 7,457 & 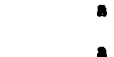 \\
\hline Trucks & & & 27,342 & 27,963 & 27,963 & & 』 \\
\hline Buses & 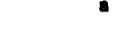 & • & & & & * & - \\
\hline \multicolumn{8}{|c|}{ United Kingdom } \\
\hline Cars & 8,078 & 8,700 & 8,700 & 9,197 & 9,102 & 9,496 & 10,377 \\
\hline Trucks & 30,449 & 30,449 & 31,691 & 35,54 & 29,963 & 13,752 & 35,349 \\
\hline Buses & 28,584 & 26,720 & 27,963 & 2299 & 16,947 & 19,529 & 23,439 \\
\hline \multicolumn{8}{|c|}{ West Germc.ny } \\
\hline Cars & 8,700 & 8,451 & 8,700 & 8,886 & 9,072 & 9,010 & 9,010 \\
\hline Trucks & 17,337 & 17,710 & 18,083 & 18,145 & 18,207 & 18,642 & 19,139 \\
\hline Busas & 32,375 & 33,121 & 33,369 & 34,488 & 35,047 & 35,420 & 36,041 \\
\hline \multicolumn{8}{|c|}{ North Alinerica: } \\
\hline \multicolumn{8}{|l|}{ Canada } \\
\hline Cars & 10,119 & 10,092 & 10,267 & 10,715 & 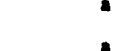 & 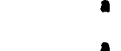 & 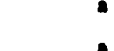 \\
\hline Trucks & & & & & 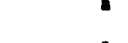 & 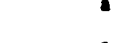 & ^ \\
\hline Buses & " & " & • & - & " & a & - \\
\hline \multicolumn{8}{|c|}{ United States } \\
\hline Cars & 9,785 & 9,558 & 9,606 & 9,882 & 10,117 & 10,380 & 10,556 \\
\hline Trucks & 11,873 & 12,745 & 12,955 & 13,421 & 13,654 & 13,899 & 13,868 \\
\hline Buses & 11,532 & 8,215 & 8,536 & 8,844 & 8,875 & 9,094 & 9,136 \\
\hline
\end{tabular}

Sources:

International Road Foundation, World Road Statistics 1986-90, Washington, DC, 1991, pp. 76, 78, $80,82,86$, and 88 .

1990 U.S. data - U.S. Department of Transportation, Federal Highway Administration, Highway Statistics 1990, Washington, DC, 1991, Table VM-1, p. 192.

'Data are not available. 
Table 1.9

Inland Surface Transport of Goods for Selocted Countries, 1985 (million ton-miles)

\begin{tabular}{lrrr}
\hline & Road & Water & Rail \\
\hline Asia: & & & \\
Japan & 127,992 & 127,915 & 13,623 \\
Europe: & & & \\
\hline France & 69,608 & 5,221 & 33,561 \\
Italy & 89,576 & 125 & 11,718 \\
Sweden & 13,162 & 5,594 & 10,930 \\
United Kingdom & 63,455 & 25,917 & 9,509 \\
West Germany & 83,343 & 29,956 & 39,776 \\
North America: & & & \\
\hline United States & 609,691 & 382,223 & 894,960 \\
\hline
\end{tabular}

Source:

International Road Foundation, World Road Statistics 1985-89,

Washington, DC, 1990 , pp. 79, 81, 83, 87, and 89.

Figure 1.8. Inland Surface Traneport of Goods for Selected Countries, 1985

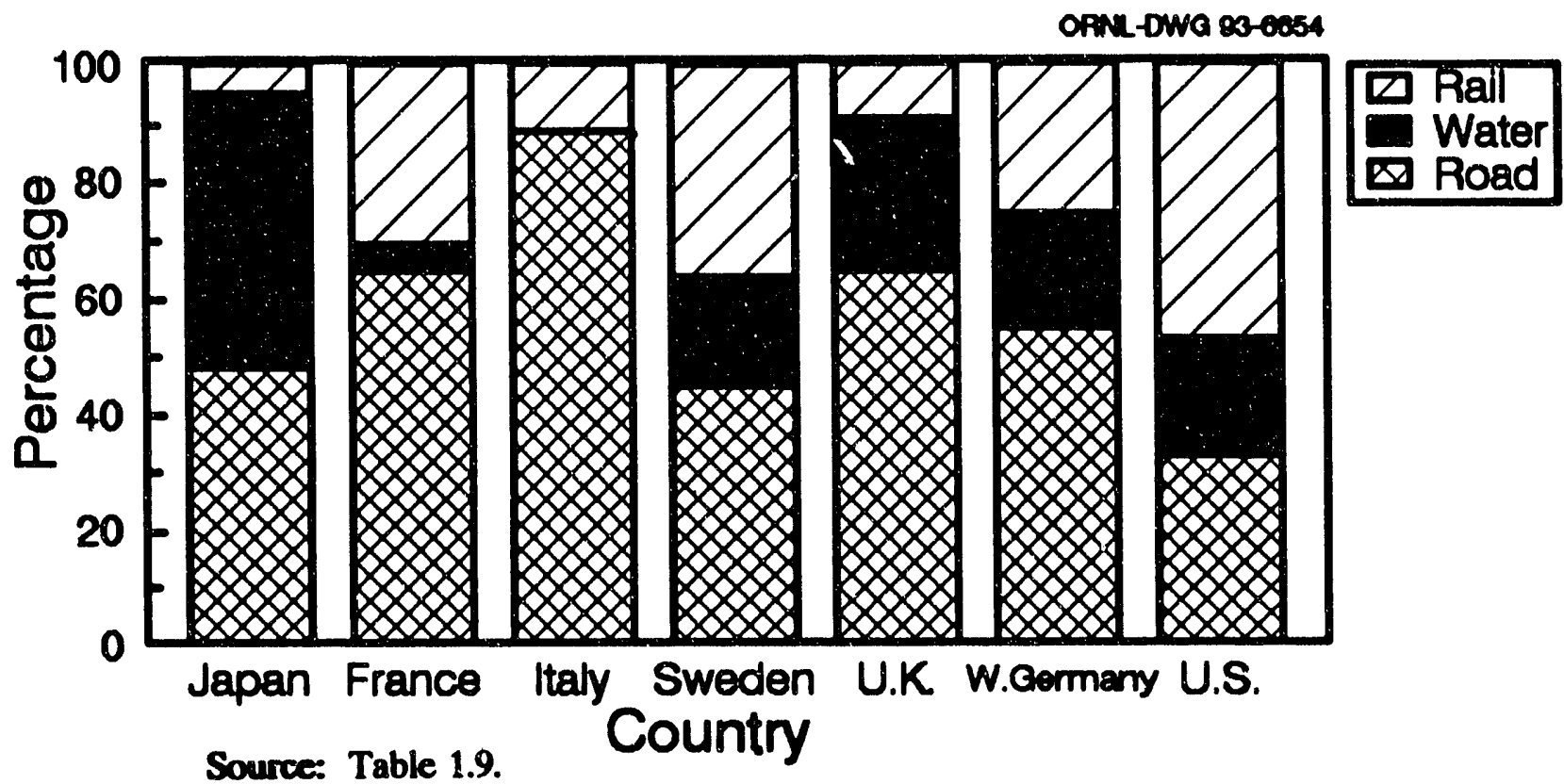


Table 1.10

Annual Vehicle Miles Traveled by Personal Vehicles for Selected Countries, $1970.89^{\circ}$

\begin{tabular}{rrrrrrrrr}
\hline Year & Japan & France & Italy & Sweden & $\begin{array}{r}\text { United } \\
\text { Kingdom }\end{array}$ & Germany & $\begin{array}{r}\text { United } \\
\text { States }\end{array}$ \\
\hline 1970 & 9,387 & 8,357 & 7,344 & 9,016 & 13,658 & 8,903 & 11,097 \\
1972 & 7,941 & 8,358 & 6,187 & 9,084 & 13,988 & 8,519 & 11,527 \\
1973 & 7,789 & 8,913 & 6,403 & 9,072 & 13,884 & 8,336 & 11,383 \\
1975 & 6,687 & 8,148 & 6,115 & 8,867 & 13,411 & 8,454 & 10,669 \\
1976 & 6,610 & 8,080 & 5,925 & 8,939 & 13,779 & 8,321 & 10,841 \\
1977 & 6,848 & 8,012 & 5,780 & 8,960 & 14,040 & 8,187 & 10,965 \\
1978 & 6,755 & 7,981 & 6,089 & 9,221 & 14,635 & 8,127 & 11,037 \\
1979 & 6,762 & 7,852 & 6,429 & 8,908 & 14,052 & 7,972 & 10,590 \\
1980 & 6,720 & 8,037 & 6,377 & 8,887 & 14,537 & 7,917 & 10,529 \\
1981 & 6,688 & 8,191 & 6,366 & 8,806 & 14,668 & 7,354 & 10,543 \\
1982 & 6,773 & 7,796 & 6,430 & 8,855 & 14,837 & 7,538 & 10,737 \\
1983 & 6,728 & 7,790 & 6,326 & 8,830 & 17,051 & 7,645 & 10,838 \\
1984 & 6,758 & 7,926 & 6,401 & 8,902 & 15,186 & 7,685 & 10,897 \\
1985 & 6,948 & 7,883 & 7,029 & 8,776 & 15,192 & 7,486 & 10,923 \\
1986 & 7,003 & 8,105 & 7,186 & 9,079 & 15,540 & 7,710 & 11,034 \\
1987 & 7,254 & 8,191 & 7,392 & 9,249 & 16,301 & 7,895 & 11,282 \\
1988 & 7,392 & 8,321 & 7,584 & 9,224 & 15,991 & 8,049 & 11,698 \\
1989 & c & 8,444 & 7,745 & 9,230 & 17,099 & 7,998 & 11,970 \\
$1970-89$ & $-1.3 \%$ d & $0.1 \%$ & $0.3 \%$ & $0.1 \%$ & $1.2 \%$ & $-0.6 \%$ & $0.4 \%$ \\
$1982-89$ & $1.5 \%$ d & $1.1 \%$ & $2.7 \%$ & $0.6 \%$ & $2.0 \%$ & $0.8 \%$ & $1.6 \%$ \\
\hline
\end{tabular}

Sources:

Lee Schipper, Steve Myers, et. al., "Energy Efficiency and Human Activity," Cambridge University Press, Cambridge, MA, 1992, and the "Proceedings of the ACEEE Conference on Automobiles and the Greenhouse Effect."

Includes privately owned automobiles and light trucks.

'Data for 1971 and 1974 are not available.

'Data are not available.

${ }^{d}$ Average annual percentage changes are for $1970-88$ and $1982-88$. 
Table 1.11

Passenger Travel by Personal. Vehicles for Selocted Conntrich, 1970-89

(billion passenger-miles)

\begin{tabular}{|c|c|c|c|c|c|c|c|}
\hline Year & Japan & France & Italy & Sweden & $\begin{array}{r}\text { United } \\
\text { Kingdom }\end{array}$ & Germany & $\begin{array}{r}\text { United } \\
\text { States } \\
\end{array}$ \\
\hline 1970 & 183 & 188 & - & 34 & 179 & 216 & 2,109 \\
\hline 1972 & 210 & 209 & 158 & 37 & 198 & 232 & 2,289 \\
\hline 1973 & 204 & 235 & 170 & 38 & 208 & 240 & 2,323 \\
\hline 1975 & 213 & 231 & 186 & 40 & 199 & 249 & 2,249 \\
\hline 1976 & 225 & 237 & 194 & 41 & 209 & 256 & 2,327 \\
\hline 1977 & 224 & 246 & 205 & 42 & 217 & 265 & 2,377 \\
\hline 1978 & 247 & 256 & 220 & 42 & 230 & 275 & 2,454 \\
\hline 1979 & 265 & 263 & 227 & 42 & 230 & 285 & 2,383 \\
\hline 1980 & 265 & 279 & 233 & 41 & 243 & 288 & 2,352 \\
\hline 1981 & 272 & 289 & 241 & 41 & 247 & 272 & 2,359 \\
\hline 1982 & 288 & 289 & 243 & 42 & 252 & 281 & 2,399 \\
\hline 1983 & 302 & 295 & 248 & 42 & 254 & 289 & 2,447 \\
\hline 1984 & 306 & 304 & 254 & 44 & 267 & 295 & 2,508 \\
\hline 1985 & 325 & 305 & 260 & 45 & 271 & 294 & 2,563 \\
\hline 1986 & 334 & 319 & 267 & 47 & 286 & 311 & 2,624 \\
\hline 1987 & 380 & 329 & 275 & 49 & 307 & 325 & 2,718 \\
\hline 1988 & 417 & 342 & 283 & 51 & 319 & 340 & 2,839 \\
\hline 1989 & 454 & 356 & c & 54 & 343 & 348 & 2,920 \\
\hline \multicolumn{8}{|c|}{ Average annual percentage change } \\
\hline $1970-89$ & $4.9 \%$ & $3.4 \%$ & $3.7 \%^{d}$ & $2.5 \%$ & $3.5 \%$ & $2.5 \%$ & $1.7 \%$ \\
\hline $1982-89$ & $6.7 \%$ & $3.0 \%$ & $2.6 \%$ & $3.7 \%$ & $4.5 \%$ & $3.1 \%$ & $2.8 \%$ \\
\hline
\end{tabular}

Sources:
Lee Schipper, Steve Myers, et. al., "Energy Efficiency and Human Activity," Cambridge University
Press, Cambridge, MA, 1992, and the "Proceedings of the ACEEE Conference on Automobiles and the Greenhouse Effect."

Includes privately owned automobiles and light trucks.

'Data for 1971 and 1974 are not available.

'Data are not available.

${ }^{\circ}$ Average annual percentage changes are for $1972-88$ and $1982-88$. 
Table 1.12

Energy Use by Personal Vehicles for Selocted Countrics, 1970-89' (trillion Btu)

\begin{tabular}{|c|c|c|c|c|c|c|c|}
\hline Year & Japan & France & Italy & Sweden & $\begin{array}{r}\text { United } \\
\text { Kingdom }\end{array}$ & Germany & $\begin{array}{r}\text { United } \\
\text { States }\end{array}$ \\
\hline 1970 & 488 & 431 & c & 104 & 510 & 631 & 9,263 \\
\hline 1972 & 602 & 480 & - & 112 & 612 & 744 & 10,551 \\
\hline .1973 & 687 & 534 & 379 & 117 & 652 & 755 & 10,999 \\
\hline 1975 & 759 & 540 & c & 125 & 621 & 805 & 10,867 \\
\hline 1976 & 797 & 573 & c & 130 & 648 & 842 & 11,479 \\
\hline 1977 & 834 & 593 & c & c & 666 & 885 & 11,742 \\
\hline 1978 & 918 & 627 & c & 135 & 707 & 939 & 12,119 \\
\hline 1979 & 958 & 636 & 473 & c & 720 & 965 & 11,685 \\
\hline 1980 & 968 & 648 & 493 & 133 & 733 & 997 & 10,972 \\
\hline 1981 & 985 & 673 & 512 & 133 & 719 & 940 & 10,891 \\
\hline 1982 & 1,023 & 690 & 536 & 134 & 740 & 975 & 10,811 \\
\hline 1983 & 1,087 & 705 & 538 & 135 & 752 & 1,009 & 10,926 \\
\hline 1984 & 1,098 & 718 & 550 & 140 & 793 & 1,037 & 11,008 \\
\hline 1985 & 1,134 & 715 & 574 & 140 & 801 & 1,031 & 11,183 \\
\hline 1986 & 1,179 & 754 & 594 & 146 & 845 & 1,099 & 11,562 \\
\hline 1987 & 1,218 & 773 & 620 & 151 & 896 & 1,152 & 11,711 \\
\hline 1988 & 1,284 & 799 & 654 & 154 & 944 & 1,205 & 11,902 \\
\hline 1989 & 1,414 & 811 & c & 159 & 997 & 1,214 & 12,046 \\
\hline \multicolumn{8}{|c|}{ Average annual percentage change } \\
\hline $1970-89$ & $5.8 \%$ & $3.4 \%$ & $3.7 \%^{d}$ & $2.3 \%$ & $3.6 \%$ & $3.5 \%$ & $1.4 \%$ \\
\hline $1982-89$ & $4.7 \%$ & $2.3 \%$ & $3.4 \%{ }^{d}$ & $2.5 \%$ & $4.4 \%$ & $3.2 \%$ & $1.6 \%$ \\
\hline
\end{tabular}

Sources:

Lee Schipper, Steve Myers, et. al., "Energy Efficiency and Human Activity," Cambridge University Press, Cambridge, MA, 1992, and the "Proceedings of the ACEEE Conference on Automobiles and the Greenhouse Effect."

'Includes privately owned automobiles and light trucks.

bData for 1971 and 1974 are not available.

'Data are not available.

${ }^{d}$ Average annual percentage changes are for $1973-88$ and 1982-88. 
Table 1.13

Pasenger Treved by Bus for Selocted Countries, $1970-89$

(billion pescenger-miles)

\begin{tabular}{|c|c|c|c|c|c|c|c|}
\hline Year & Japan & France & Italy & Sweden & $\begin{array}{r}\text { United } \\
\text { Kingdom } \\
\end{array}$ & Germany & $\begin{array}{c}\text { United } \\
\text { States } \\
\end{array}$ \\
\hline 1970 & 64 & 16 & b & 3 & 33 & 30 & 85 \\
\hline 1972 & 67 & 18 & 30 & 4 & 31 & 33 & 88 \\
\hline 1973 & 69 & 19 & 31 & 4 & 33 & 34 & 90 \\
\hline 1975 & 68 & 21 & 33 & 4 & 34 & 36 & 93 \\
\hline 1976 & 61 & 22 & 36 & 4 & 33 & 36 & 101 \\
\hline 1977 & 65 & 23 & 37 & 4 & 31 & 38 & 104 \\
\hline 1978 & 66 & 24 & 37 & 4 & 31 & 38 & 105 \\
\hline 1979 & 67 & 24 & 39 & 4 & 30 & 40 & 107 \\
\hline 1980 & 68 & 24 & 40 & 5 & 28 & 40 & 106 \\
\hline 1981 & 67 & 24 & 40 & 5 & 26 & 41 & 107 \\
\hline 1982 & 65 & 24 & 42 & 5 & 25 & 41 & 107 \\
\hline 1983 & 64 & 24 & 41 & 5 & 26 & 40 & 108 \\
\hline 1984 & 64 & 25 & 40 & 6 & 26 & 38 & 116 \\
\hline 1985 & 65 & 23 & 45 & 6 & 26 & 33 & 113 \\
\hline 1986 & 63 & 24 & 46 & 6 & 25 & 33 & 118 \\
\hline 1987 & 64 & 26 & 48 & 6 & 25 & 33 & 121 \\
\hline 1988 & 66 & 26 & 50 & 6 & 25 & 33 & 127 \\
\hline 1989 & 68 & 24 & $b$ & 6 & 25 & 33 & 125 \\
\hline \multicolumn{8}{|c|}{ Average annual percentage change } \\
\hline $1970-89$ & $0.3 \%$ & $2.2 \%$ & $3.2 \%^{c}$ & $3.7 \%$ & $-1.5 \%$ & $0.5 \%$ & $2.1 \%$ \\
\hline $1982-89$ & $0.6 \%$ & $0.0 \%$ & $2.9 \%^{\mathrm{c}}$ & $2.6 \%$ & $0.0 \%$ & $-3.1 \%$ & $2.2 \%$ \\
\hline
\end{tabular}

Sources:

Lee Schipper, Steve Myers, et. al., "Energy Efficiency and Human Activity," Cambridge University Press, Cambridge, MA, 1992, and the "Proceedings of the ACEEE Conference on Automobiles and the Greenhouse Effect."

'Data for 1971 and 1974 are not available.

'Data are not available.

'Average annual percentage changes are for 1972-88 and 1982-88. 
Table 1.14

Bnergy Use by Bus for Selocted Countries, $1970-89$

(trillion Btu)

\begin{tabular}{|c|c|c|c|c|c|c|c|}
\hline Year & Japan & France & Italy & Sweden & $\begin{array}{c}\text { United } \\
\text { Kingdom }\end{array}$ & Germany & $\begin{array}{l}\text { United } \\
\text { States }\end{array}$ \\
\hline 1970 & 47 & 14 & - & 5 & 37 & 24 & 109 \\
\hline 1972 & 54 & 16 & $b$ & 6 & 35 & 27 & 106 \\
\hline 1973 & 59 & 17 & 22 & 6 & 35 & 28 & 109 \\
\hline 1975 & 56 & 20 & $b$ & 7 & 32 & 30 & 119 \\
\hline 1976 & 56 & 21 & $b$ & 7 & 32 & 31 & 129 \\
\hline 1977 & 56 & 22 & $b$ & b & 32 & 33 & 132 \\
\hline 1978 & 55 & 23 & $b$ & 7 & 32 & 34 & 135 \\
\hline 1979 & 55 & 24 & 32 & $b$ & 32 & 35 & 137 \\
\hline 1980 & 53 & 25 & 32 & 6 & 32 & 36 & 138 \\
\hline 1981 & 53 & 26 & 32 & 7 & 31 & 37 & 143 \\
\hline 1982 & 53 & 27 & 36 & 7 & 32 & 37 & 146 \\
\hline 1983 & 54 & 27 & 38 & 8 & 34 & 38 & 145 \\
\hline 1984 & 52 & 27 & 43 & 8 & 41 & 38 & 154 \\
\hline 1985 & 52 & 27 & 47 & 8 & 43 & 38 & 161 \\
\hline 1986 & 53 & 28 & 51 & 9 & 44 & 38 & 154 \\
\hline 1987 & 54 & 28 & 57 & 9 & 44 & 39 & 157 \\
\hline 1988 & 55 & 27 & 60 & 9 & 44 & 39 & 159 \\
\hline 1989 & 59 & 29 & $b$ & 9 & 44 & 39 & 163 \\
\hline \multicolumn{8}{|c|}{ Average annual percentage change } \\
\hline $1970-89$ & $1.2 \%$ & $3.9 \%$ & $8.9 \%^{c}$ & $3.1 \%$ & $0.9 \%$ & $2.6 \%$ & $2.1 \%$ \\
\hline $1982-89$ & $1.5 \%$ & $1.0 \%$ & $15.0 \%^{c}$ & $3.7 \%$ & $4.7 \%$ & $0.8 \%$ & $1.6 \%$ \\
\hline
\end{tabular}

Sources:

Lee Schipper, Steve Myers, et. al., "Energy Efficiency and Human Activity," Cambridge University Press, Cambridge, MA, 1992, and the "Proceedings of the ACEEE Conference on Automobiles and the Greenhouse Effect."

'Data for 1971 and 1974 are not available.

'Data are not available.

${ }^{c}$ Average annual percentage changes are for $1973-88$ and $1982-88$. 
Table 1.15

Paseenger Travel by Rail for Selocted Countries, 1970-89

(billion passenger-miles)

\begin{tabular}{|c|c|c|c|c|c|c|c|}
\hline Year & Japan & France & Italy & Sweden & $\begin{array}{r}\text { United } \\
\text { Kingdom }\end{array}$ & Germany & $\begin{array}{r}\text { United } \\
\text { States }\end{array}$ \\
\hline 1970 & 178 & 29 & 21 & 3 & 22 & 30 & 23 \\
\hline 1972 & 185 & 31 & 23 & 3 & 21 & 31 & 21 \\
\hline 1973 & 193 & 32 & 24 & 3 & 22 & 31 & 21 \\
\hline 1975 & 200 & 35 & 24 & 4 & 22 & 30 & 20 \\
\hline 1976 & 197 & 36 & 26 & 4 & 20 & 29 & 20 \\
\hline 1977 & 193 & 36 & 26 & 4 & 21 & 29 & 20 \\
\hline 1978 & 192 & 38 & 26 & 4 & 21 & 29 & 21 \\
\hline 1979 & 193 & 38 & 26 & 4 & 22 & 30 & 22 \\
\hline 1980 & 194 & 38 & 27 & 4 & 21 & 31 & 22 \\
\hline 1981 & 195 & 39 & 27 & 4 & 21 & 31 & 21 \\
\hline 1982 & 195 & 40 & 26 & 4 & 19 & 30 & 21 \\
\hline 1983 & 198 & 41 & 26 & 4 & 21 & 29 & 21 \\
\hline 1984 & 200 & 43 & 26 & 4 & 22 & 30 & 21 \\
\hline 1985 & 204 & 44 & 25 & 4 & 22 & 32 & 22 \\
\hline 1986 & 207 & 43 & 27 & 4 & 23 & 31 & 23 \\
\hline 1987 & 213 & 43 & 27 & 4 & 24 & 30 & 24 \\
\hline 1988 & 223 & 45 & 29 & 4 & 25 & 31 & 24 \\
\hline 1989 & 228 & 46 & $b$ & 4 & 24 & 31 & 25 \\
\hline \multicolumn{8}{|c|}{ Average annual percentage change } \\
\hline $1970-89$ & $1.3 \%$ & $2.5 \%$ & $1.8 \%$ & $1.5 \%$ & $0.5 \%$ & $0.2 \%$ & $0.4 \%$ \\
\hline $1982-89$ & $2.3 \%$ & $2.0 \%$ & $1.8 \%^{c}$ & $0.0 \%$ & $3.4 \%$ & $0.5 \%$ & $2.5 \%$ \\
\hline
\end{tabular}

Sources:

Lee Schipper, Steve Myers, et. al., "Energy Efficiency and Human Activity," Cambridge University Press, Cambridge, MA, 1992, and the "Proceedings of the ACEEE Conference on Automobiles and the Greenhouse Effect."

'Data for 1971 and 1974 are not available.

'Data are not available.

'Average annual percentage changes are for $1970-88$ and 1982-88. 
Table.1.16

Energy Use by Rail for Selocted Countriex, $1970-89^{\circ}$

(trillios Btu)

\begin{tabular}{|c|c|c|c|c|c|c|c|}
\hline Year & Japan & France & Italy & Sweden & $\begin{array}{r}\text { United } \\
\text { Kingdom } \\
\end{array}$ & Germany & $\begin{array}{r}\text { United } \\
\text { States } \\
\end{array}$ \\
\hline 1970 & 54 & 21 & $b$ & 4 & 33 & 30 & 61 \\
\hline 1972 & 56 & 19 & 18 & 4 & 33 & 29 & 59 \\
\hline 1973 & 58 & 18 & 17 & 4 & 33 & 29 & 58 \\
\hline 1975 & 58 & 20 & 16 & 5 & 33 & 26 & 62 \\
\hline 1976 & 60 & 20 & 17 & 5 & 32 & 25 & 62 \\
\hline 1977 & 60 & 21 & 16 & $b$ & 35 & 22 & 59 \\
\hline 1978 & 60 & 21 & 17 & 5 & 34 & 25 & 55 \\
\hline 1979 & 61 & 21 & 18 & b & 34 & 27 & 65 \\
\hline 1980 & 60 & 21 & 16 & 5 & 35 & 28 & 63 \\
\hline 1981 & 60 & 21 & 17 & 5 & 34 & 28 & 54 \\
\hline 1982 & 61 & 22 & 17 & 5 & 31 & 27 & 56 \\
\hline 1983 & 62 & 23 & 17 & 5 & 33 & 26 & 60 \\
\hline 1984 & 60 & 23 & 18 & 5 & 32 & 26 & 69 \\
\hline 1985 & 61 & 23 & 18 & 6 & 34 & 27 & 70 \\
\hline 1986 & 61 & 22 & 19 & 5 & 32 & 27 & 72 \\
\hline 1987 & 64 & 23 & 19 & 5 & 31 & 27 & 76 \\
\hline 1988 & 67 & 23 & 19 & 6 & 31 & 27 & 78 \\
\hline 1989 & 70 & 23 & b & 5 & $b$ & 28 & 81 \\
\hline \multicolumn{8}{|c|}{ Average annual percentage change } \\
\hline $1970-89$ & $1.4 \%$ & $0.5 \%$ & $0.3 \%$ & $1.2 \%$ & $-0.3 \% d$ & $-0.4 \%$ & $1.5 \%$ \\
\hline $1982-89$ & $2.0 \%$ & $0.6 \%$ & $1.9 \%^{c}$ & $0.0 \%$ & $0.0 \%{ }^{d}$ & $0.5 \%$ & $5.4 \%$ \\
\hline
\end{tabular}

Sources:

Lee Schipper, Steve Myers, et. al., "Energy Efficiency and Human Activity," Cambridge University Press, Cambridge, MA, 1992, and the "Proceedings of the ACEEE Conference on Automobiles and the Greenhouse Effect."

'Data for 1971 and 1974 are not available.

bata are not available.

'Average annual percentage changes are for $1972-88$ and $1982-88$.

AAverage annual percentage changes are for years 1970-88 and 1982-88. 


\section{CHAPTER 2 TRANSPORTATION ENERGY CHARACTERISTICS}

The U.S. was responsible for more than one-quarter of the world's petroleum consumption in 1990. Domestic crude oil production, which had been declining every year from 1985 to 1990 rose by 0.02 million barrels per day in 1991 . While domestic crude oil production has declined $17.8 \%$ from 1985 to 1991 , the amount of crude oil imported has increased $49.5 \%$ in that time period to meet the domestic demand. Imports in 1991 accounted for $45.5 \%$ of U.S. petroleum consumption, down from a high of $47.2 \%$ in 1990 (Table 2.2).

Most of the petroleum consumed in the U.S. was in the transportation sector, $65.4 \%$ (Table 2.3), accounting for $27.3 \%$ of total energy use in 1991 (Table 2.6). While the transportation section depended primarily on petroleum, the residential and commercial sector depended heavily on electricity (Table 2.4).

The fuels used in the transportation sector include gasoline, distillate fuel oil (diesel fuel), jet fuel, residual fuel oil, natural gas, and electricity. Gasoline, however, accounted for the majority of transportation energy consumption in 1990 (60.4\%) (Figure 2.7). Of total transportation energy use in $1990,72.4 \%$ was consumed by the highway mode while the nonhighway mode (which includes water, air, pipeline, and rail transportation) accounted for $21.5 \%$. The remaining $6.1 \%$ of transportation energy use was consumed by the off-highway mode and military activities (Table 2.9).

The average price for all types of gasoline jumped 10 cents from 1989 to 1990 (in constant 1990 cents). Unleaded regular gasoline prices (in constant 1990 cents) experienced an average decline of 5\% annually from 1982 to 1991 (Table 2.16). The refiner sales prices for other transportation fuels such as propane, aviation gasoline and jet fuel also increased from 1989 to 1990 and declined in 1991 (Table 2.17). Many of these fuel price fluctuations are due to the $\$ 22.24$ price for a barrel of crude oil in 1990 (a $\$ 3.30$ increase from 1989 in constant 1990 dollars) and the 1991 price of $\$ 18.30$ per barrel in constant 1990 dollars (Table 2.18). 
Transportation's share of the gross national product (GNP) fell below $17 \%$ in 1991. GNP has been growing at an average rate of $3.0 \%$ from 1982 to 1991 , while transportation outlays have grown an average of $1.9 \%$ annually (Table 2.19 ). Transportation personal consumption expenditures (PCE) for 1991 were at approximately the same level as 1989, while total PCE have grown. Transportation PCE was approximately $11.3 \%$ of total PCE in 1991, the lowest in the twenty-year series (Table 2.20).

Although consumers in 1990 spent almost four times more for a used car than they would have in 1970, the used car Consumer Price Index (CPI) has declined slightly from a high of 3.859 in 1989 (Table 2.21). The average price of a new domestic car in constant 1990 dollars declined again in 1991 to $\$ 256$ less than the high in 1989. Import car prices also decreased slightly from 1990 to 1991 . The average price of a domestic car was approximately $\$ 2,000$ less than an import car in 1991 (Table 2.22). The cost of operating a car rose to 41.85 cents per mile in 1991. Gas and oil, once as much as one-quarter of the total cost to operate a car, accounted for only $15.4 \%$ of the total cost in 1991, which was up from $13.2 \%$ in 1990 (Table 2.23). 
Section 2.1.

Energy Consumption and Supply 
Table 21

Refincry Yield of Petrokeum Products from a Barrel of Crude Oil, 1978-91" (percentage)

\begin{tabular}{cccccc}
\hline Year & $\begin{array}{c}\text { Motor } \\
\text { Gasoline }\end{array}$ & $\begin{array}{c}\text { Distillate } \\
\text { fuel oil }\end{array}$ & $\begin{array}{c}\text { Jet } \\
\text { fuel }\end{array}$ & $\begin{array}{c}\text { Liquefied } \\
\text { petroleum gas }\end{array}$ & Other $^{b}$ \\
\hline 1978 & 44.1 & 21.4 & 6.6 & 2.3 & 29.6 \\
1979 & 43.0 & 21.5 & 6.9 & 2.3 & 30.3 \\
1980 & 44.5 & 19.7 & 7.4 & 2.4 & 30.0 \\
1981 & 44.8 & 20.5 & 7.6 & 2.4 & 28.7 \\
1982 & 46.4 & 21.5 & 8.1 & 2.2 & 26.2 \\
1983 & 47.6 & 20.5 & 8.5 & 2.7 & 24.8 \\
1984 & 46.7 & 21.5 & 9.1 & 2.9 & 24.2 \\
1985 & 45.6 & 21.6 & 9.6 & 3.1 & 24.6 \\
1986 & 45.7 & 21.2 & 9.8 & 3.2 & 24.8 \\
1987 & 46.4 & 20.5 & 10.0 & 3.4 & 24.5 \\
1988 & 46.0 & 20.8 & 10.0 & 3.6 & 24.4 \\
1989 & 45.7 & 20.8 & 10.1 & 4.0 & 24.2 \\
1990 & 45.6 & 20.9 & 10.7 & 3.6 & 24.1 \\
1991 & 45.7 & 21.3 & 10.3 & 3.8 & 24.1 \\
\hline
\end{tabular}

Source:

Department of Energy, Energy Information Administration, Petroleum Supply Annual 1991 , Vol. 1, June 1992, Table 19, p. 52, and annual.

Figure 21. Refinery Yiedd of Petraleum Products from a Barred of Crude On, 1978 and 1991

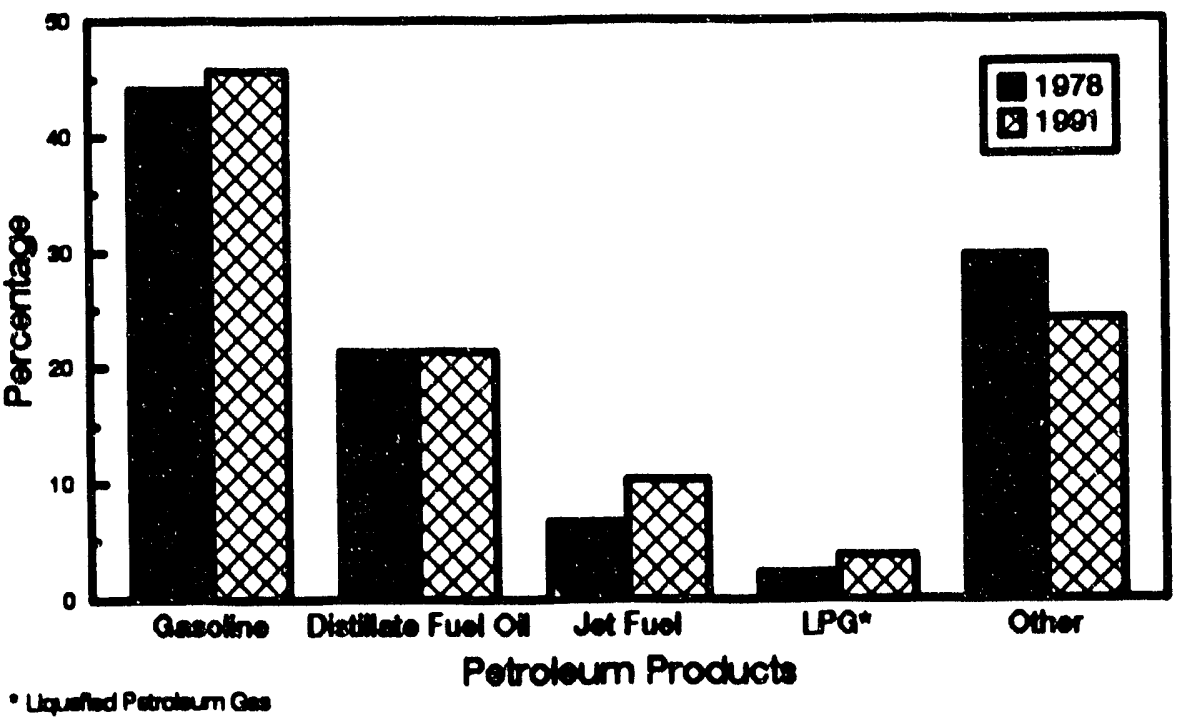

Source: See Table 2.1.

-Products sum greater than $100 \%$ due to processing gain. The processing gain for years 1978 to 1980 is assumed to be $4 \%$.

Includes aviation gasoline, kerosene, naphtha and other oils for petrochemical feedstock use, special naphthas, lubricants, waxes, petroleum coke, asphalt and road oil, still gas, and miscellaneous products. 


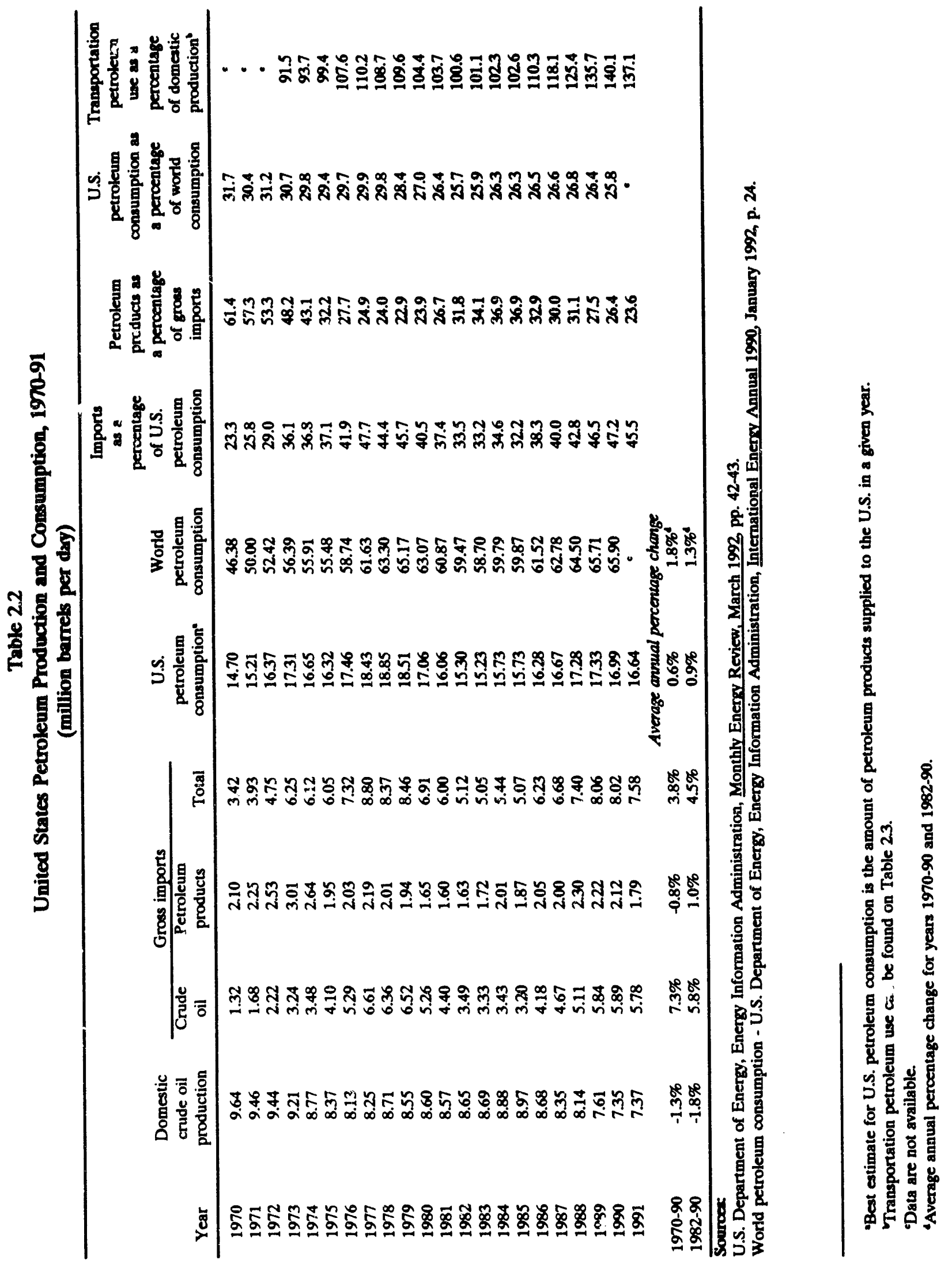




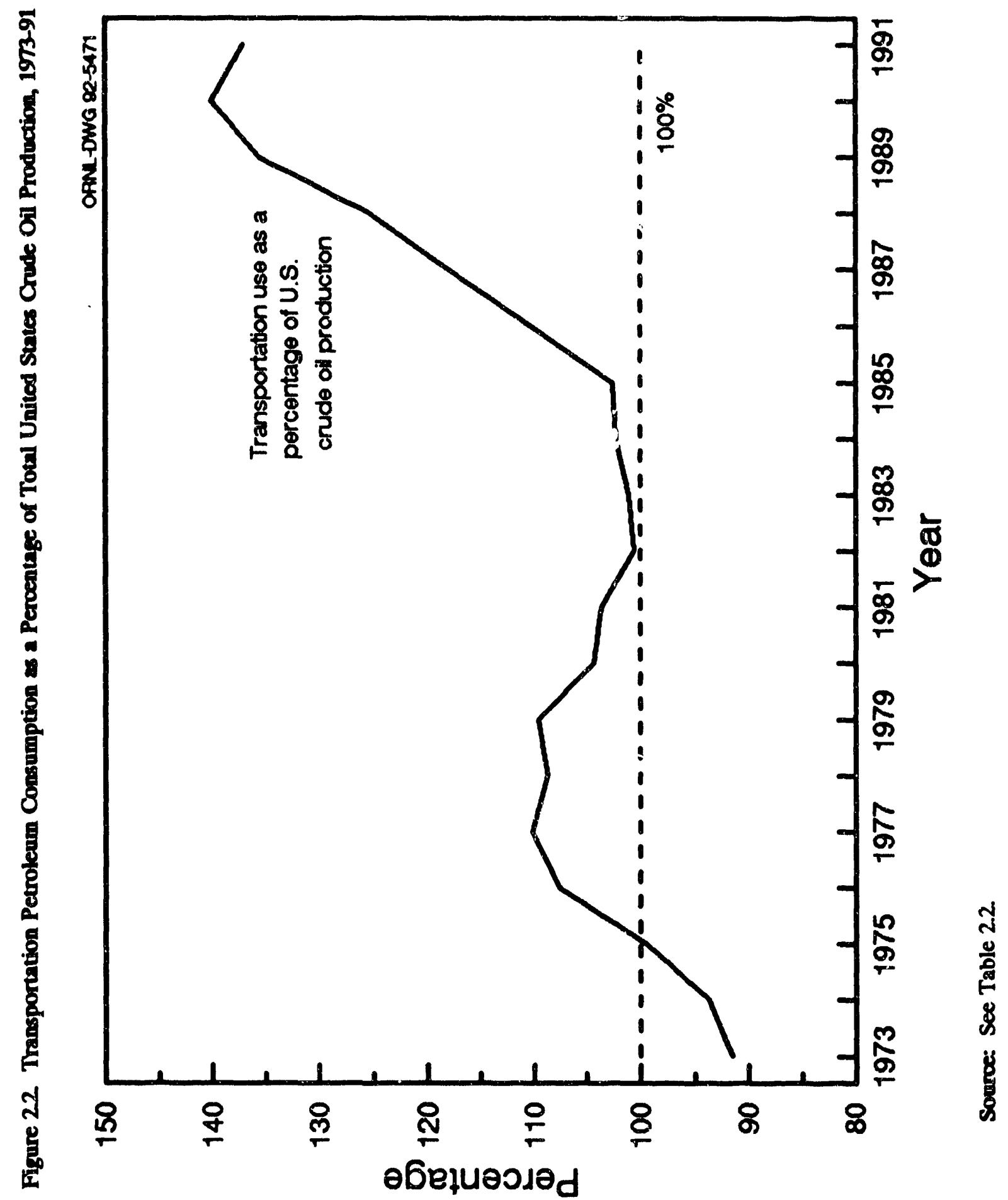


Over $65 \%$ of the petroleum consumed in the U.S. in 1991 was used by the transportation sector. Although, transportation's share of petroleum use has increased since 1989, the total petroleum declined slightly between 1989 and 1991.

Table 23

Consumption of Petroleum by End-Use Sector, 1973-91

(quadrillion Btu)

\begin{tabular}{cccccccc}
\hline Year & Transportation & $\begin{array}{c}\text { Percentage } \\
\text { transportation } \\
\text { of total }\end{array}$ & $\begin{array}{c}\text { Residential } \\
\text { and } \\
\text { commercial }\end{array}$ & Industrial & $\begin{array}{c}\text { Electric } \\
\text { utilities }\end{array}$ & Total & $\begin{array}{c}\text { Total in } \\
\text { million barrels } \\
\text { per day }\end{array}$ \\
\hline 1973 & 17.83 & $51.2 \%$ & 4.39 & 9.10 & 3.52 & 34.84 & 16.46 \\
1974 & 17.40 & $52.0 \%$ & 4.00 & 8.69 & 3.37 & 33.46 & 15.81 \\
1975 & 17.61 & $53.8 \%$ & 3.81 & 8.15 & 3.17 & 32.74 & 15.47 \\
1976 & 18.51 & $52.6 \%$ & 4.18 & 9.01 & 3.48 & 35.18 & 16.62 \\
1977 & 19.24 & $51.8 \%$ & 4.21 & 9.77 & 3.90 & 37.12 & 17.53 \\
1978 & 20.04 & $52.8 \%$ & 4.07 & 9.87 & 3.99 & 37.97 & 17.94 \\
1979 & 19.83 & $53.4 \%$ & 3.45 & 10.57 & 3.28 & 37.13 & 17.54 \\
1980 & 19.01 & $55.6 \%$ & 3.04 & 9.53 & 2.63 & 34.21 & 16.16 \\
1981 & 18.81 & $58.9 \%$ & 2.63 & 8.29 & 2.20 & 31.93 & 15.08 \\
1982 & 18.42 & $60.9 \%$ & 2.45 & 7.79 & 1.57 & 30.23 & 14.28 \\
1983 & 18.59 & $61.9 \%$ & 2.50 & 7.42 & 1.54 & 30.05 & 14.19 \\
1984 & 19.22 & $61.9 \%$ & 2.54 & 8.01 & 1.29 & 31.06 & 14.67 \\
1985 & 19.50 & $63.1 \%$ & 2.52 & 7.81 & 1.09 & 30.92 & 14.61 \\
1986 & 20.27 & $63.0 \%$ & 2.56 & 7.92 & 1.45 & 32.20 & 15.21 \\
1987 & 20.87 & $63.5 \%$ & 2.59 & 8.15 & 1.26 & 32.87 & 15.53 \\
1988 & 21.62 & $62.2 \%$ & 2.61 & 8.43 & 1.56 & 34.22 & 16.16 \\
1989 & 21.86 & $63.9 \%$ & 2.54 & 8.13 & 1.69 & 34.22 & 16.16 \\
1990 & 21.80 & $65.0 \%$ & 2.18 & 8.31 & 1.25 & 33.54 & 15.84 \\
1991 & 21.41 & $65.4 \%$ & 2.17 & 7.96 & 1.18 & 32.72 & 15.46 \\
& & & & & & & \\
$1973-91$ & $1.0 \%$ & \multicolumn{7}{c}{ Average annual percentage change } & & $-3.8 \%$ & $-0.7 \%$ & $-5.9 \%$ & $-0.3 \%$ & \\
$1982-91$ & $1.7 \%$ & $-1.3 \%$ & $0.2 \%$ & $-3.1 \%$ & $0.9 \%$ & \\
\hline
\end{tabular}

Source:

U.S. Department of Energy, Energy Information Administration, Monthly Energy Review, March 1992, pp. 27, 29, 31, 33.

Calculated from Total column. One million barrels per day of petroleum equals 2.117 quadrillion Btu per year. 


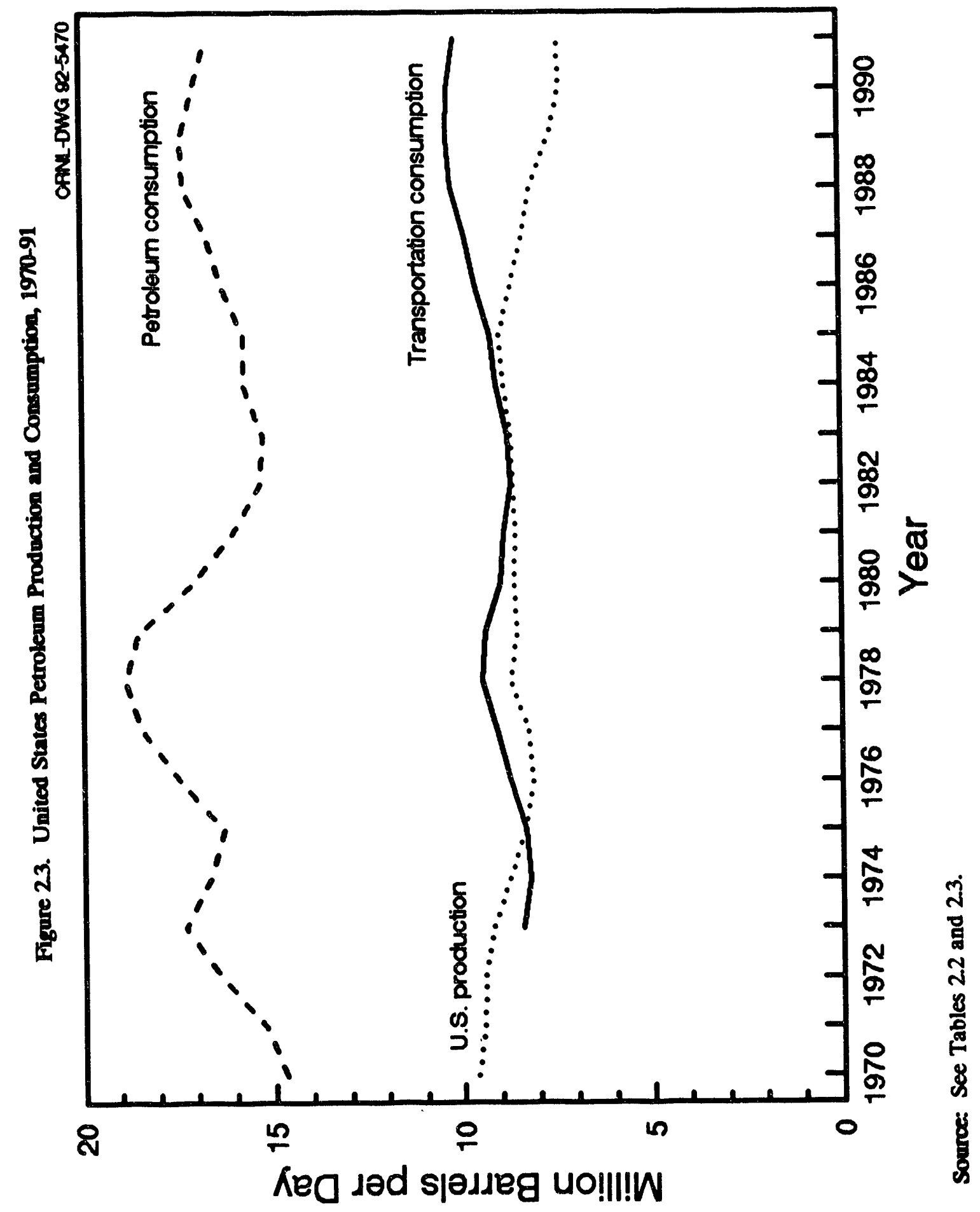




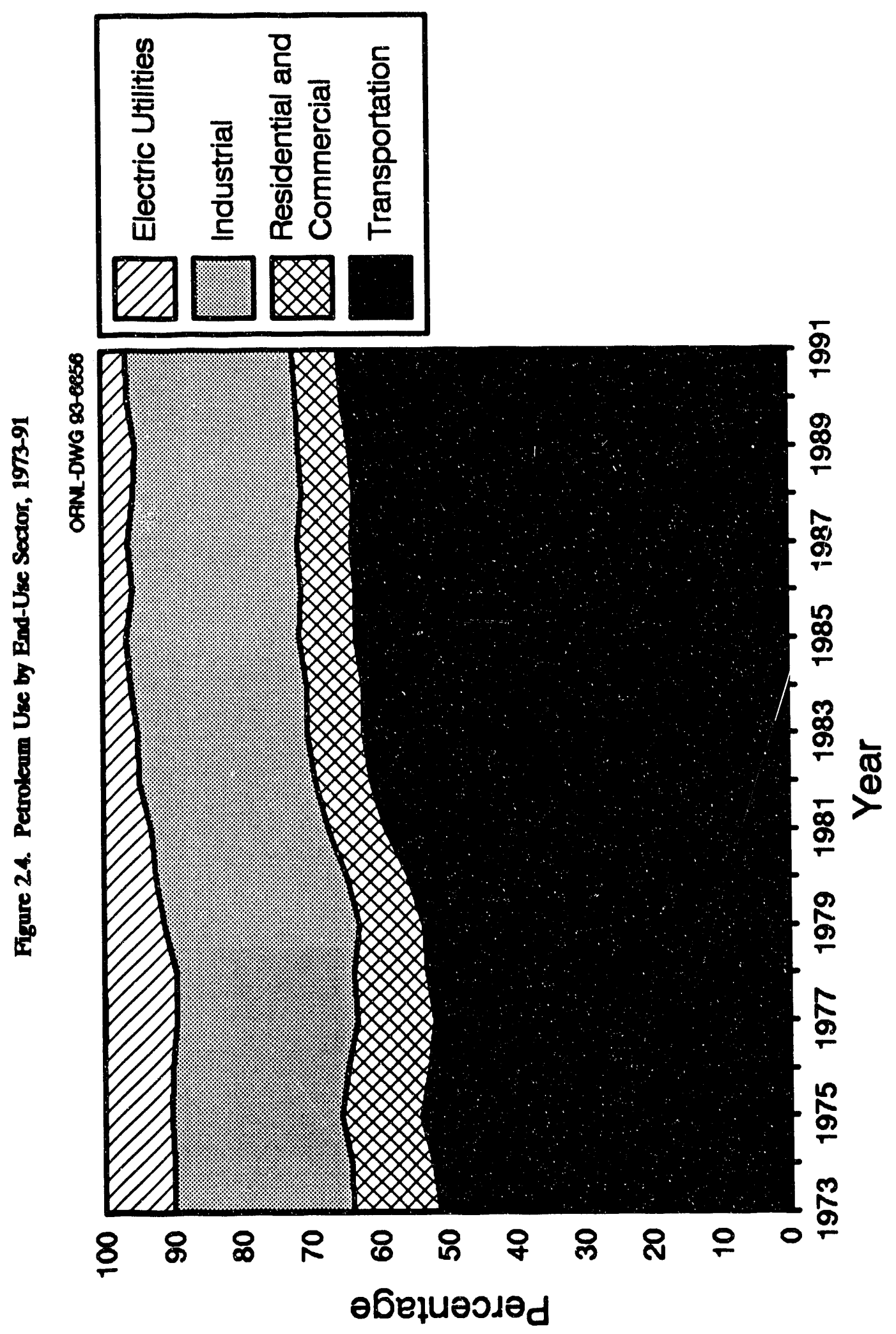

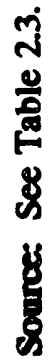


Table 24

Distribution of Energy Consumption by Source, 1981 and 1991 (percentage)

\begin{tabular}{|c|c|c|c|c|c|c|c|c|}
\hline \multirow[b]{2}{*}{ Energy source } & \multicolumn{2}{|c|}{ Transportation } & \multicolumn{2}{|c|}{$\begin{array}{l}\text { Residential and } \\
\text { Commercial } \\
\end{array}$} & \multicolumn{2}{|c|}{ Industrial } & \multicolumn{2}{|c|}{$\begin{array}{l}\text { Electric } \\
\text { Utilities } \\
\end{array}$} \\
\hline & 1981 & 1991 & 1981 & 1991 & 1981 & 1991 & 1981 & 1991 \\
\hline Petroleum & 96.4 & 96.1 & 10.4 & 7.3 & 28.3 & 26.8 & 8.9 & 3.9 \\
\hline Natural gas" & 3.4 & 3.7 & 28.7 & 25.7 & 28.2 & 29.9 & 15.2 & 9.6 \\
\hline Coal & 0.0 & 0.0 & 0.7 & 0.5 & 10.8 & 8.8 & 50.8 & 53.7 \\
\hline Hydroelectric & 0.0 & 0.0 & 0.0 & 0.0 & 0.1 & 0.1 & 12.6 & 10.2 \\
\hline Nuclear & 0.0 & 0.0 & 0.0 & 0.0 & 0.0 & 0.0 & 11.2 & 21.9 \\
\hline Electricityb & 0.2 & 0.2 & 60.2 & 66.5 & 32.6 & 34.4 & 0.0 & 0.0 \\
\hline Other & 0.0 & 0.0 & 0.0 & 0.0 & 0.0 & 0.0 & 0.5 & 0.6 \\
\hline & 100.0 & 100.0 & 100.0 & 100.0 & 100.0 & 100.0 & 100.0 & 100.0 \\
\hline
\end{tabular}

\section{Source:}

U.S. Department of Energy, Energy Information Administration, Monthly Energy Review, March 1992, Washington, DC, pp. 27, 29, 31, 33.

Figure 2.5. Distribution of Energy Consumption by Sector, 1991

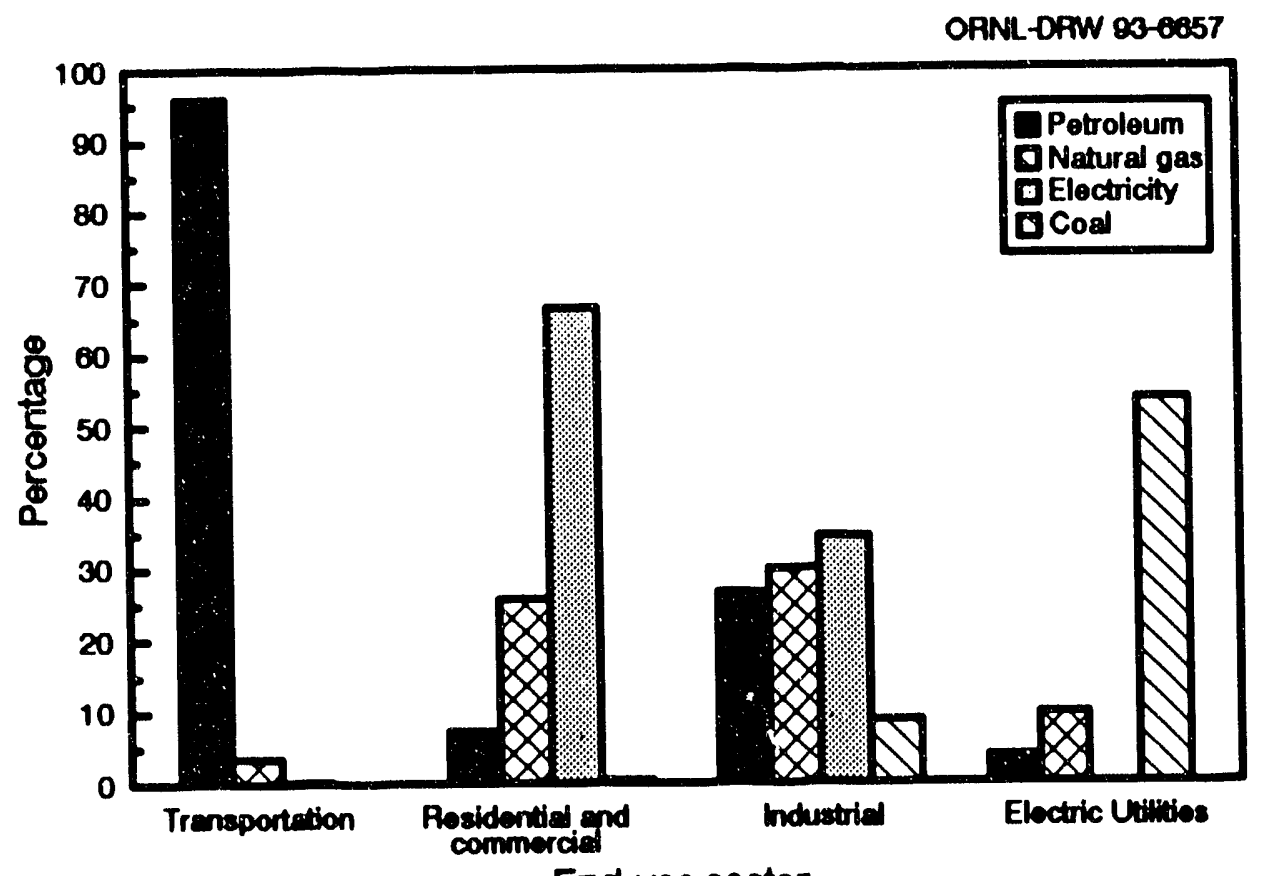

Source: See Table 2.4 . End-use sector

'Includes supplemental gaseous fuels. Transportation sector includes pipeline fuel only.

'Includes electrical system energy losses.

'Energy generated from geothermal, wood, waste, wind, photovoltaic, and solar thermal energy sources. 
From 1973 to 1991 electricity generation has depended less on natural gas, petroleum, and hydroelectric power and has depended more on coal, nuclear generated electric power, and other sources. Although nuclear generated electric power grew tremendously from 1973 to 1991, coal continued to be the predominant source for electricity generation - 54\% in 1991 .

Table 25

Electric Utility Energy Input by Source, 1973-91 (quadrillion Btu)

\begin{tabular}{cccccccc}
\hline Year & Coal & $\begin{array}{c}\text { Natural } \\
\text { gas }\end{array}$ & Petroleum & $\begin{array}{c}\text { Hydro- } \\
\text { electric } \\
\text { power }\end{array}$ & $\begin{array}{c}\text { Nuclear } \\
\text { electric } \\
\text { power }\end{array}$ & Other & Total \\
\hline 1973 & 8.66 & 3.75 & 3.52 & 2.98 & 0.91 & 0.05 & 19.85 \\
1974 & 8.53 & 3.52 & 3.37 & 3.28 & 1.27 & 0.06 & 20.02 \\
1975 & 8.79 & 3.24 & 3.17 & 3.19 & 1.90 & 0.07 & 20.35 \\
1976 & 9.72 & 3.15 & 3.48 & 3.03 & 2.11 & 0.08 & 21.57 \\
1977 & 10.26 & 3.28 & 3.90 & 2.48 & 2.70 & 0.08 & 22.71 \\
1978 & 10.24 & 3.30 & 3.99 & 3.11 & 3.02 & 0.07 & 23.72 \\
1979 & 11.26 & 3.61 & 3.28 & 3.11 & 2.78 & 0.10 & 24.13 \\
1980 & 12.12 & 3.81 & 2.63 & 3.09 & 2.74 & 0.11 & 24.51 \\
1981 & 12.58 & 3.77 & 2.20 & 3.07 & 3.01 & 0.13 & 24.76 \\
1982 & 12.58 & 3.34 & 1.57 & 3.54 & 3.13 & 0.11 & 24.27 \\
1983 & 13.21 & 3.00 & 1.54 & 3.87 & 3.20 & 0.13 & 24.96 \\
1984 & 14.00 & 3.22 & 1.27 & 3.73 & 3.55 & 0.17 & 25.98 \\
1985 & 14.54 & 3.16 & 1.09 & 3.33 & 4.15 & 0.21 & 26.48 \\
1986 & 14.44 & 2.69 & 1.45 & 3.35 & 4.47 & 0.23 & 26.64 \\
1987 & 15.17 & 2.94 & 1.26 & 3.04 & 4.91 & 0.24 & 27.56 \\
1988 & 15.85 & 2.71 & 1.56 & 2.61 & 5.66 & 0.24 & 28.63 \\
1989 & 15.99 & 2.88 & 1.69 & 2.85 & 5.68 & 0.22 & 29.30 \\
1990 & 16.19 & 2.88 & 1.25 & 2.91 & 6.16 & 0.20 & 29.60 \\
1991 & 16.07 & 2.88 & 1.18 & 3.05 & 6.54 & 0.19 & 29.90 \\
& & & & & & & \\
$1973-91$ & $3.5 \%$ & $-1.5 \%$ & $-5.9 \%$ & $0.1 \%$ & $11.6 \%$ & $7.7 \%$ & $2.3 \%$ \\
$1982-91$ & $2.8 \%$ & $-1.6 \%$ & $-3.1 \%$ & $-1.6 \%$ & $8.5 \%$ & $6.3 \%$ & $2.3 \%$ \\
\hline & & & & & & &
\end{tabular}

Source:

U.S. Department of Energy, Energy Information Administration, Monthly Energy Review, March 1992 p. 33.

'Other consists of electricity generated for distribution from wood, waste, geothermal, wind, photovoltaic, and solar thermal energy. 


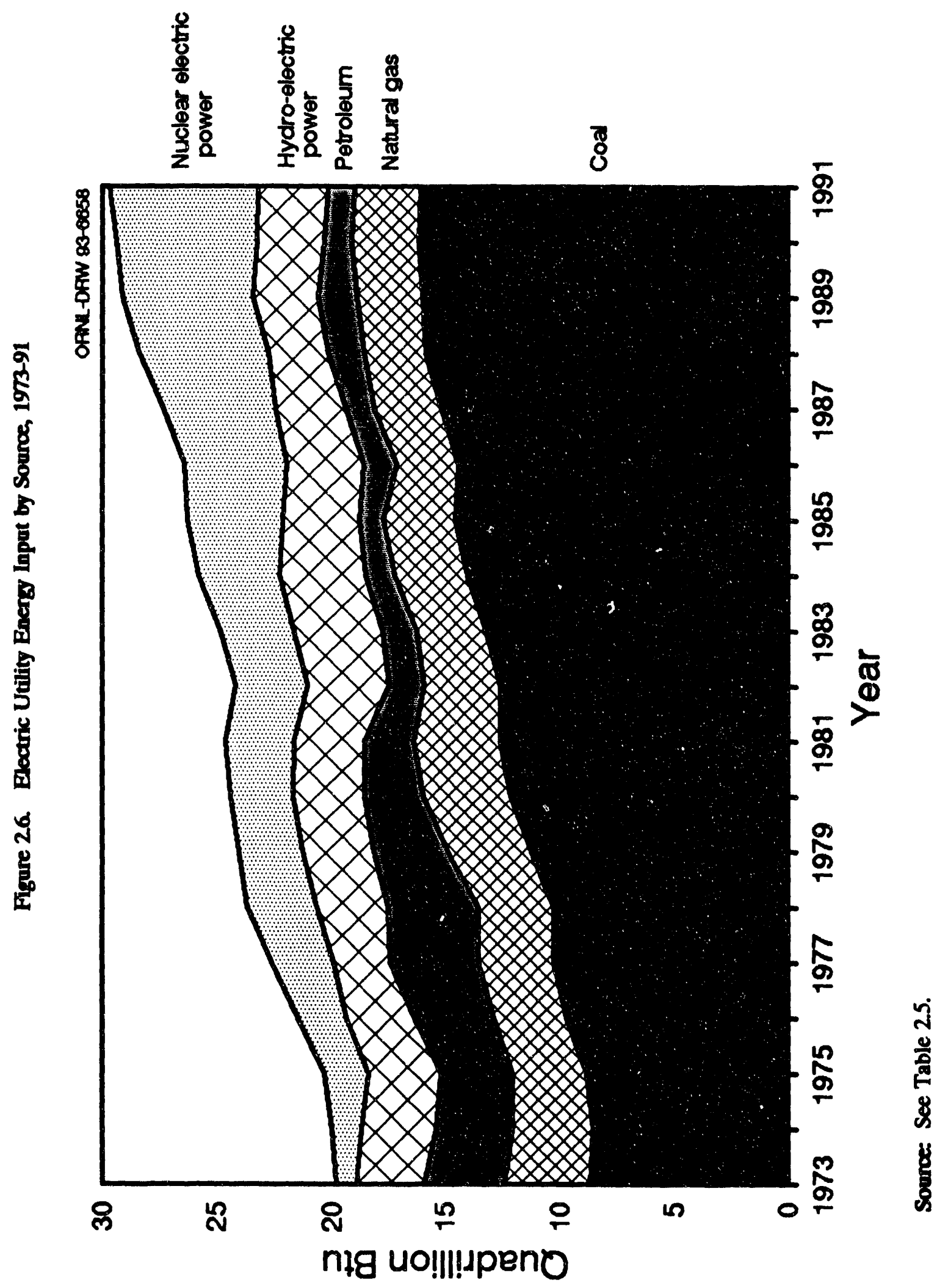


The transportation sector has accounted for over $27 \%$ of total energy use since 1985. Total energy use is up to 81.51 quads in 1991, after a slight decline in 1990.

Table 26

Consumption of Total Energy by Bnd-Une Sector, 1970-91" (quadrillion Btu)

\begin{tabular}{|c|c|c|c|c|c|}
\hline Year & Transportation & $\begin{array}{c}\text { Percentage } \\
\text { transportation } \\
\text { of total }\end{array}$ & $\begin{array}{c}\text { Residential } \\
\text { and } \\
\text { Commercial }\end{array}$ & Industrial & Total \\
\hline 1970 & 16.07 & $24.2 \%$ & 21.71 & 28.65 & 66.43 \\
\hline 1971 & 16.70 & $24.6 \%$ & 22.59 & 28.59 & 67.88 \\
\hline 1972 & 17.70 & $24.8 \%$ & 23.69 & 29.88 & 71.27 \\
\hline 1973 & 18.61 & $25.1 \%$ & 24.14 & 31.53 & 74.28 \\
\hline 1974 & 18.12 & $25.0 \%$ & 23.72 & 30.70 & 72.54 \\
\hline 1975 & 18.24 & $25.9 \%$ & 23.90 & 28.40 & 70.54 \\
\hline 1976 & 19.10 & $25.7 \%$ & 25.02 & 30.23 & 74.36 \\
\hline 1977 & 19.82 & $26.0 \%$ & 25.39 & 31.08 & 76.29 \\
\hline 1978 & 20.61 & $26.4 \%$ & 26.09 & 31.39 & 78.09 \\
\hline 1979 & 20.47 & $25.9 \%$ & 25.81 & 32.62 & 78.90 \\
\hline 1980 & 19.70 & $25.9 \%$ & 25.65 & 30.61 & 75.96 \\
\hline 1981 & 19.51 & $26.4 \%$ & 25.24 & 29.24 & 73.99 \\
\hline 1982 & 19.07 & $26.9 \%$ & 25.63 & 26.14 & 70.85 \\
\hline 1983 & 19.13 & $27.1 \%$ & 25.63 & 25.76 & 70.52 \\
\hline 1984 & 19.80 & $26.7 \%$ & 26.45 & 27.85 & 74.10 \\
\hline 1985 & 20.07 & $27.1 \%$ & 26.68 & 27.20 & 73.95 \\
\hline 1986 & 20.81 & $28.0 \%$ & 26.81 & 26.61 & 74.24 \\
\hline 1987 & 21.44 & $27.9 \%$ & 27.60 & 27.81 & 76.85 \\
\hline 1988 & 22.30 & $27.8 \%$ & 28.92 & 28.98 & 80.20 \\
\hline 1989 & 22.55 & $27.7 \%$ & 29.41 & 29.38 & 81.35 \\
\hline 1990 & 22.53 & $27.7 \%$ & 28.86 & 29.90 & 81.29 \\
\hline 1991 & 22.29 & $27.3 \%$ & 29.56 & 29.66 & 81.51 \\
\hline \multicolumn{6}{|c|}{ Average annual percentage change } \\
\hline $1970-91$ & $1.6 \%$ & & $1.5 \%$ & $0.2 \%$ & $1.0 \%$ \\
\hline 1982-91 & $1.7 \%$ & & $1.6 \%$ & $1.4 \%$ & $1.6 \%$ \\
\hline
\end{tabular}

Source:

U.S. Department of Energy, Energy Information Administration, Monthly Energy Review, March 1992, Washington, DC, Table 2.2, p. 25.

'Electrical energy losses have been distributed among the sectors. 
Table 27

Domestic Consumption of Transportation Energy by Mode and Fuel Type, 1990

(trillion Btu)

\begin{tabular}{|c|c|c|c|c|c|c|c|}
\hline & Gasoline & $\begin{array}{l}\text { Diesel } \\
\text { fuel }\end{array}$ & $\begin{array}{c}\text { Liquefied } \\
\text { petroleum gas }\end{array}$ & Jet fuel & $\begin{array}{l}\text { Residual } \\
\text { fuel oil }\end{array}$ & $\begin{array}{c}\text { Natural } \\
\text { gas }\end{array}$ & Electricity \\
\hline $\begin{array}{l}\text { HIGHWAY } \\
\text { Alelosobite } \\
\text { Molorgates }\end{array}$ & $\begin{array}{r}13,605.2 \\
8,945.7 \\
23.9\end{array}$ & $\begin{array}{r}3,1836 \\
1206\end{array}$ & 7.5 & & & & \\
\hline $\begin{array}{l}\text { Buece } \\
\text { Traneit } \\
\text { Intercity }\end{array}$ & $\begin{array}{r}29.7 \\
0.2\end{array}$ & $\begin{array}{r}132.1 \\
78.7 \\
21.7\end{array}$ & & & & & \\
\hline $\begin{array}{l}\text { School } \\
\text { Truct } \\
\text { Light trucks } \\
\text { Other trucks }\end{array}$ & $\begin{array}{r}29.5 \\
4,605.9 \\
4,001.7 \\
604.2\end{array}$ & $\begin{array}{r}32.7 \\
2930.2 \\
151.7 \\
2,778.5\end{array}$ & $\begin{array}{l}7.5 \\
3.0 \\
4.5\end{array}$ & & & & \\
\hline $\begin{array}{l}\text { OFF-HUGHWAY (heavy-duty) } \\
\text { Comatruction } \\
\text { Paring }\end{array}$ & $\begin{array}{l}95.1 \\
31.4 \\
627\end{array}$ & $\begin{array}{l}570.1 \\
1785 \\
301.6\end{array}$ & & & & & \\
\hline $\begin{array}{l}\text { NONHIGHWAY } \\
\text { Air } \\
\text { General aviation' } \\
\text { Domestic air carrier } \\
\text { Intemational air carriers }\end{array}$ & $\begin{array}{l}289.1 \\
42.4 \\
42.4\end{array}$ & 7500 & & $\begin{array}{r}2,016.9 \\
2,016.9 \\
89.5 \\
1,663.6 \\
263.8\end{array}$ & 935.4 & 6003 & 309.1 \\
\hline $\begin{array}{l}\text { Weter } \\
\text { Freight } \\
\text { Domestic trade } \\
\text { Foreign trade } \\
\text { Recreationgl bogts }\end{array}$ & 246.7 & $\begin{array}{r}304.8 \\
304.8 \\
236.2 \\
68.6\end{array}$ & & & $\begin{array}{r}935.4 \\
935.4 \\
87.0 \\
848.4\end{array}$ & & \\
\hline $\begin{array}{l}\text { Recreational boats } \\
\text { Pipeline } \\
\text { Natural gas } \\
\text { Crude petroleums } \\
\text { Petroleum producte } \\
\text { Coal slurry } \\
\text { Water }\end{array}$ & 246.7 & & & & & $\begin{array}{l}680.3 \\
680.3\end{array}$ & $\begin{array}{r}247.3 \\
35.2 \\
91.0 \\
67.4 \\
3.7 \\
50.0\end{array}$ \\
\hline $\begin{array}{l}\text { Rail Freighti } \\
\text { Pasenger } \\
\text { Transit }\end{array}$ & & $\begin{array}{r}405.2 \\
425.2 \\
20.0\end{array}$ & & & & & $\begin{array}{l}61.8 \\
61.8 \\
42.7\end{array}$ \\
\hline $\begin{array}{l}\text { Commuter rail } \\
\text { Intercity }\end{array}$ & & $\begin{array}{r}7.3 \\
12.7\end{array}$ & & & & & $\begin{array}{r}14.4 \\
4.7\end{array}$ \\
\hline MIITTARY OPERATIONS & 17.2 & 1738 & & S421 & 24.6 & & \\
\hline TOTAL & $14,006.6$ & 4,6778 & 7.5 & $2,559.0$ & 960.0 & 6803 & 309.1 \\
\hline
\end{tabular}

Source: Soe Appendix A for Table 2.7.

"Civilian consumption only; military consumption shown separately.

Two-axje, four-tire trucks.

- 1985 data.

"Aviation gasoline.

-All aircraft in the U.S. civil air fleet except those operated under FAR parts 121 and 127 (i.e., air carriers larger than 30 seals and/or a payload capacity of more than 7,500 pounds). General aviation includes air taxies, commuter air carriers, and air travel clubs.

This figure represents an cstimate of the energy purchased in the U.S. for international air carrier consumption.

1981 data.

1977 data.

'Includes Class 1, 2, and 3 railroads.

Based on fuel purchases.

Includes aviation gasoline and motor gasoline.

Totals may not include all possible uses of fuels for transportation (e.g., snowmobiles). 
Table 28

Distribution of Domestic Consumption of Transportation Energy by Mode and Fuel Type, 1990 (percentage)

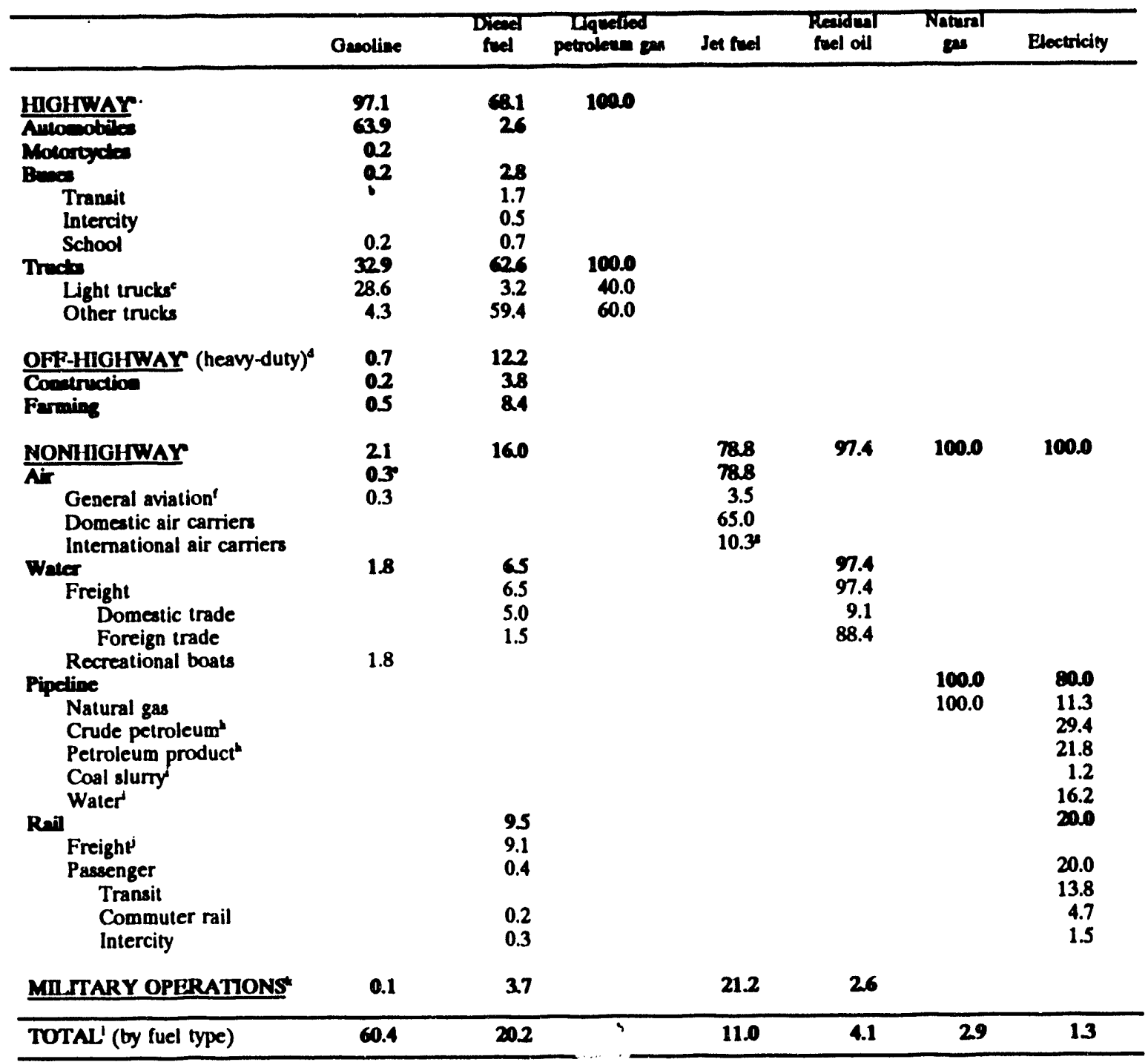

Source: See Appendix A for Table 2.7.

¿Civilian consumption only; military consumption shown separately.

"Leas tha 0.05 perceal.

Two-ade, four-tire trucks.

1985 data.

'Aviation gasoline.

'All aircraft in the U.S. civil air fleet except tbose operated under FAR parts 121 and 127 (i.e., air carrien larger than 30 seats and/or a payload capacity of more than 7,500 pounds). General aviation includes air taries, comenter air carriers, and air travel clubs.

This figure represents an estimate of the energy purchased in the U.S. for international air carrier consumption.

1981 data.

1977 date.

Includes Clas 1, 2 and 3 railrosds.

Based on fuel purchased.

Totals way not iaclude all possible uses of fuels for transportation (e.g, snowmobiles). 
Figure 27. Distribution of Transportation Energy Une by Fuel Type, 1990

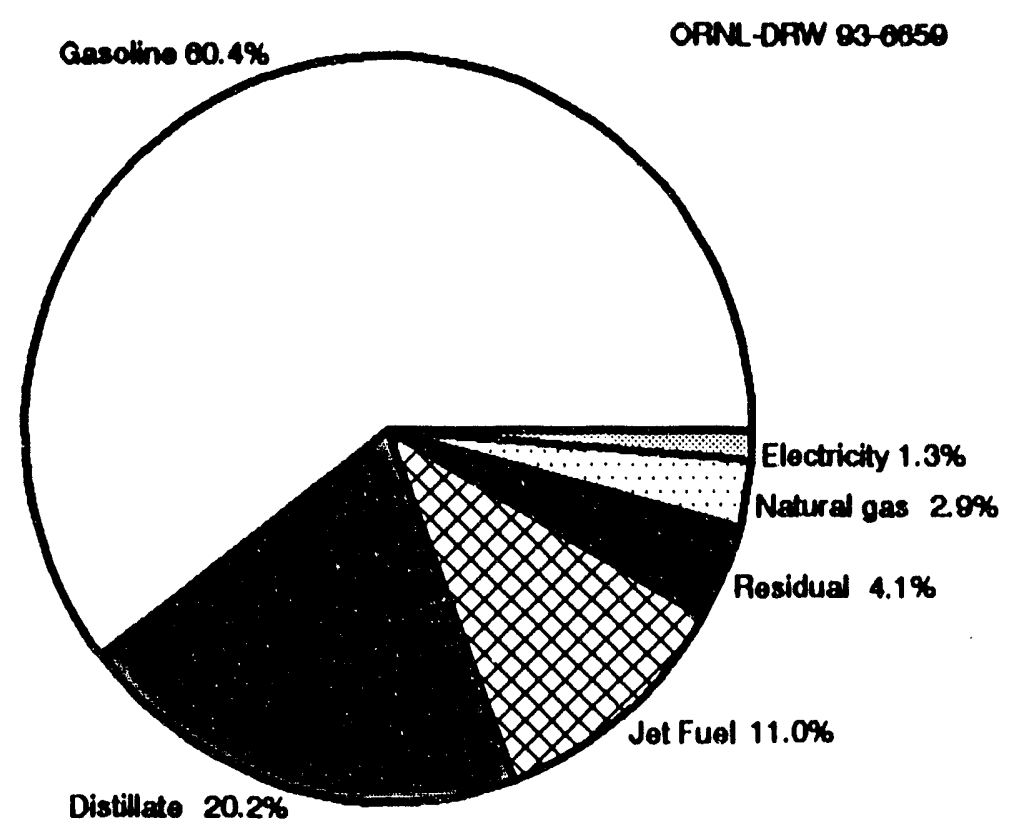

Source: See Table 2.8 .

Figure 28. Distribution of Transportation Energy Use by Mode, 1990

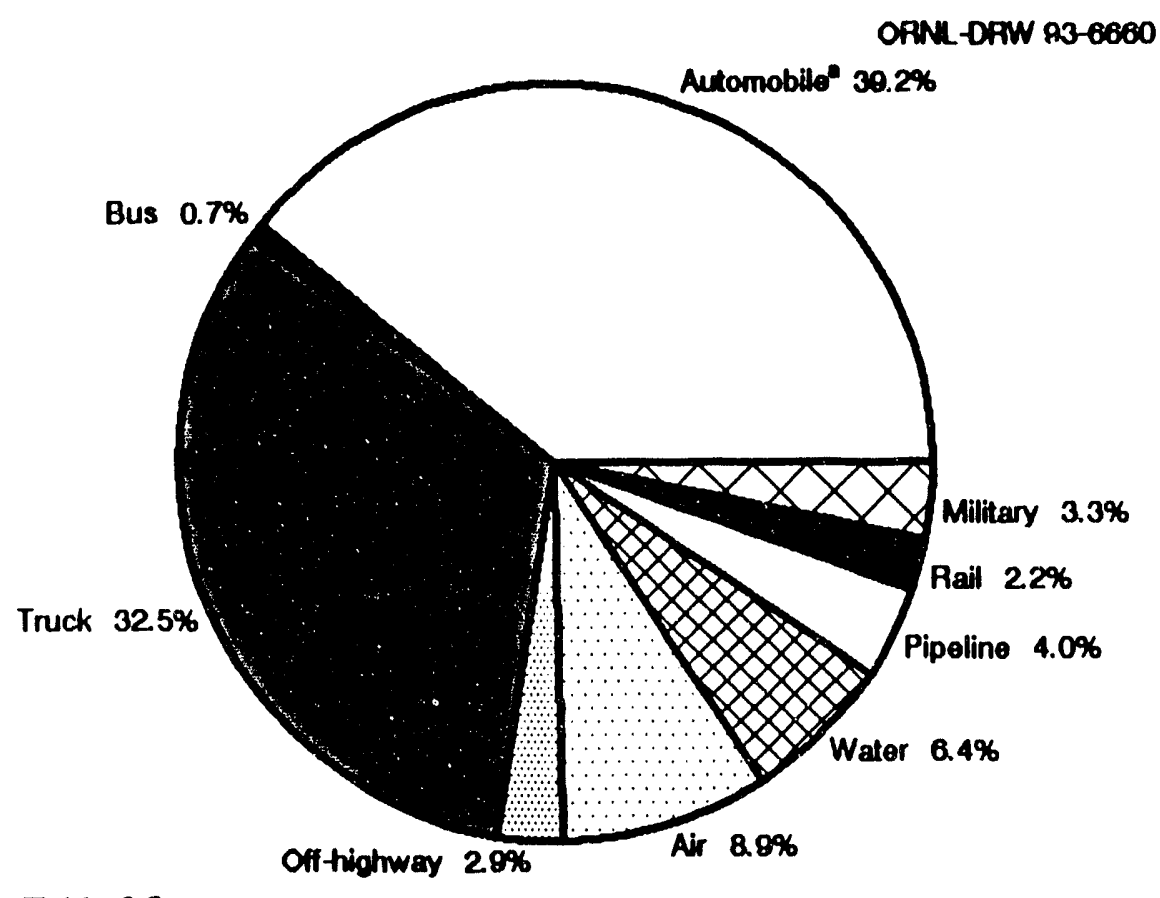

Source: See Table 2.9 .

Includes motorcycles. 
Table 29

Transportation Energy Use by Mode, 1990

\begin{tabular}{|c|c|c|c|}
\hline & Trillion Btu & $\begin{array}{l}\text { Thousand barrels per dqy } \\
\text { crude oil equivalent }\end{array}$ & $\begin{array}{l}\text { Percentage } \\
\text { of total }\end{array}$ \\
\hline HGHWAY & 16,7966 & 7,9342 & 724 \\
\hline Amtonobiles & 9,0663 & 4,2826 & 39.1 \\
\hline Molorgycles & 239 & 11.3 & $\mathbf{0 . 1}$ \\
\hline Bumes & 1628 & 769 & 0.7 \\
\hline Transit & 78.9 & 37.3 & 0.3 \\
\hline Intercity & 21.7 & 10.3 & 0.1 \\
\hline School & 62.2 & 29.4 & 0.3 \\
\hline Tructs & 7,5436 & 3,5633 & 325 \\
\hline Light truckes & $4,156.4$ & $1,963.3$ & 17.9 \\
\hline Other trucks & $3,387.2$ & $1,600.0$ & 14.6 \\
\hline OFF-HIGHWAY (heavy-duty) & $\cos 2$ & 314.2 & 29 \\
\hline Compluction & 2099 & 99.1 & 0.9 \\
\hline Farming & 455.3 & 215.1 & 20 \\
\hline NONHIGHWAY & $4,980.8$ & 2,3528 & 21.5 \\
\hline Air & $2,059.3$ & 9727 & 8.9 \\
\hline General aviation" & 131.9 & 62.3 & 0.6 \\
\hline Domestic air carriers & $1,663.6$ & 785.8 & 7.2 \\
\hline International air carriers & $263.8^{t}$ & 124.6 & 1.1 \\
\hline Waler & $1,486.9$ & 7024 & 64 \\
\hline Freight & $1,240.2$ & 585.8 & 5.3 \\
\hline Domestic trade & 323.2 & 152.7 & 1.4 \\
\hline Foreign :rade & 917.0 & 433.2 & 4.0 \\
\hline Recreational boats & 246.7 & 116.5 & 1.1 \\
\hline Pipetine & 927.6 & 4382 & 4.0 \\
\hline Natural gas & 715.5 & 338.0 & 3.1 \\
\hline Crude petroleum & 91.0 & 43.0 & 0.4 \\
\hline Petroleum product" & 67.4 & 31.8 & 0.3 \\
\hline Coal slurry & 3.7 & 1.7 & 0.0 \\
\hline Water & 50.0 & 23.6 & 0.2 \\
\hline Rai & 507.0 & 2395 & 22 \\
\hline Freight' & 425.2 & 200.9 & 1.8 \\
\hline Passenger & 81.8 & 38.6 & 0.4 \\
\hline Transit & 42.7 & 20.2 & 0.2 \\
\hline Commuter rail & 21.7 & 10.3 & 0.1 \\
\hline Intercity & 17.4 & 8.2 & 0.1 \\
\hline MIITTARY OPERATIONS & 757.7 & 357.9 & 3.3 \\
\hline TOTAL! & 23,2003 & $10,959.0$ & 100.0 \\
\hline
\end{tabular}

Source:

See Appendix A for Table 2.7

Thomend barrels per day crude oil equivaleuts besed on Btu content of a barrel of crude oil. Civilias consumption onty; eilitary cossumption shown repanately.

Two-arde, four-tire trucks.

1985 data.

-All aircraft in the U.S. civil air fleet ezcept thoue operated under PAR parts 121 and 127 (i.e., air carrien larger than 30 weats and/or a payload capacity of nore than 7,500 pounds). General aviation includes air triek, commuler air carrien, and air travel clube.

This figure represents an estimale of the energy purchased in the U.S. for interaational air carrier consumption.

1981 date.

1977 data.

'Includes Clase 1, 2, and 3 rilroads.

Beced on fuel purchered.

Purcheses were the best estimales available for fuel conumption, both donestic and abroad.

Totals may not include all poesible nees of fuels for transportation (e.g, snowmobiles). 
형

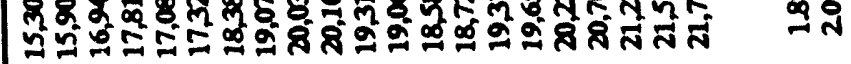

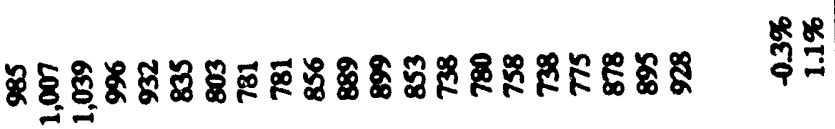

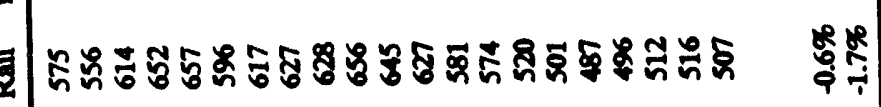

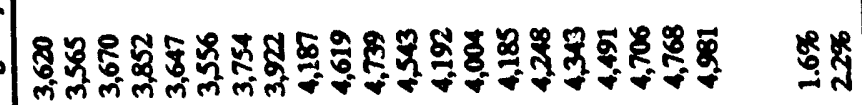

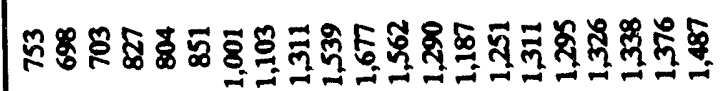

ถูำ

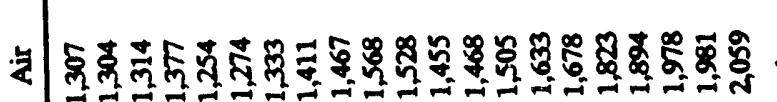

กูำ

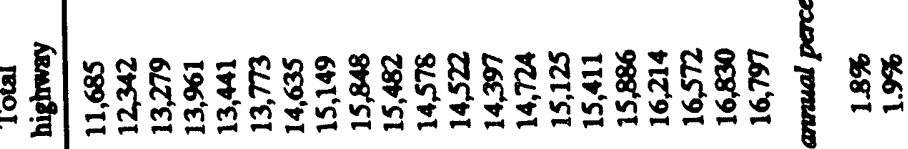

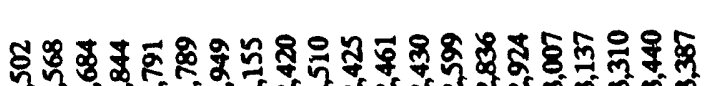

ठี

- -

点

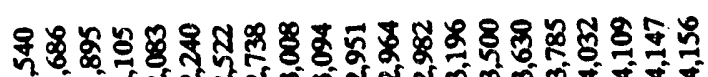

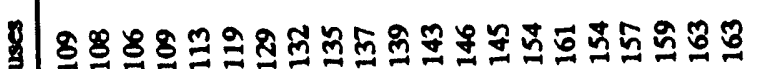

告

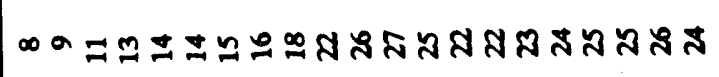

พำำ

8

ฟิ

ฟ 


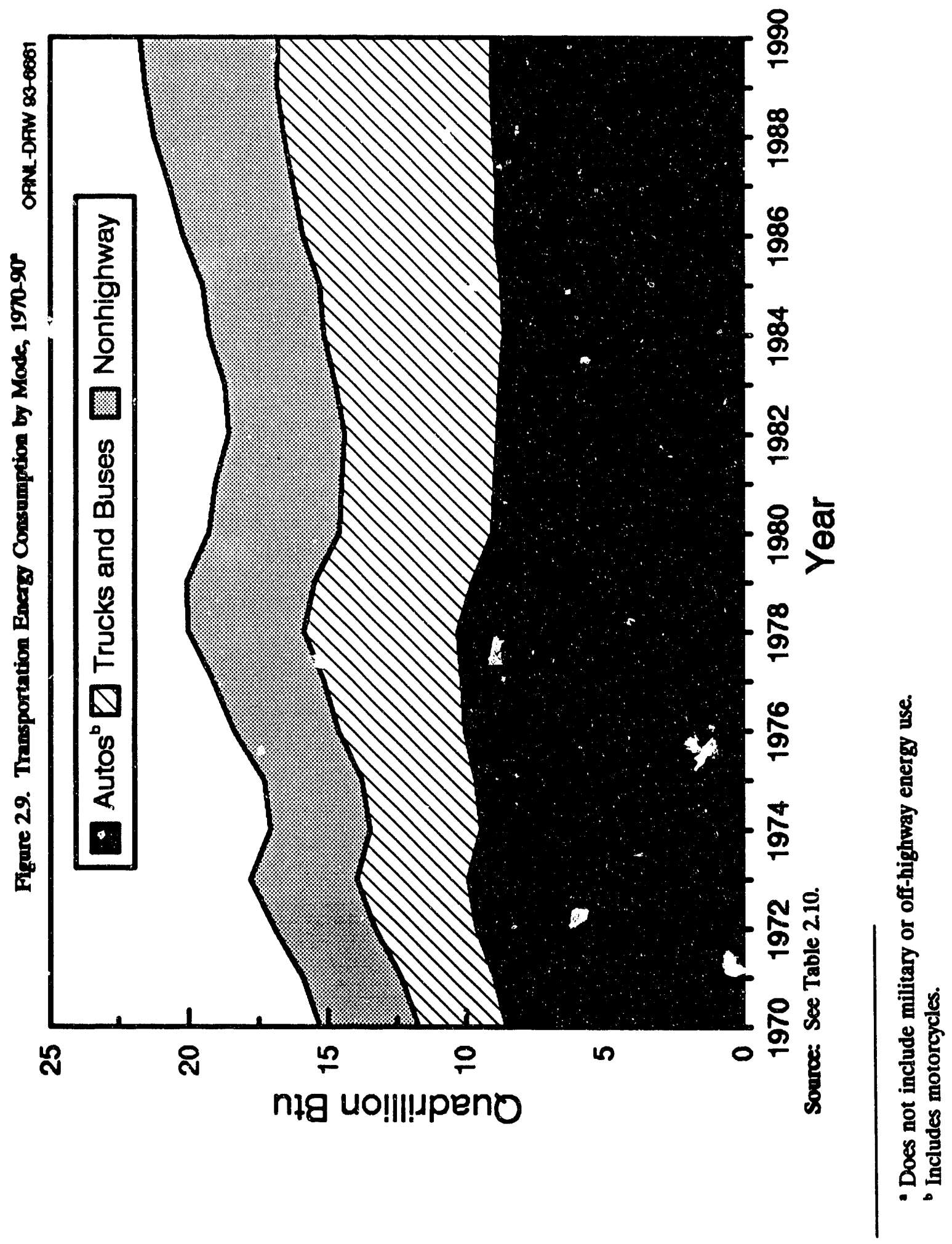


The special fuels share of highway fuel use continued to be above 15\% in 1990. Highway use of special fuels has been growing at a much faster rate than gasoline consumption.

Table 2.11

Highwa , Usage of Gasoline and Special Fuek, 1973-90 (million gallons)

\begin{tabular}{ccccc}
\hline Year & Gasoline & $\begin{array}{c}\text { Special } \\
\text { fuels }\end{array}$ & $\begin{array}{c}\text { Percent } \\
\text { special fuels }\end{array}$ & $\begin{array}{c}\text { Total highway } \\
\text { fuel use }\end{array}$ \\
\hline 1973 & 100,636 & 9,837 & 8.9 & 110,473 \\
1974 & 96,505 & 9,796 & 9.2 & 106,301 \\
1975 & 99,354 & 9,631 & 8.8 & 108,985 \\
1976 & 104,978 & 10,721 & 9.3 & 115,699 \\
1977 & 107,978 & 11,646 & 9.7 & 119,624 \\
1978 & 112,239 & 12,828 & 10.3 & 125,067 \\
1979 & 108,126 & 13,989 & 11.5 & 122,115 \\
1980 & 101,183 & 13,777 & 12.0 & 114,960 \\
1981 & 99,597 & 14,856 & 13.0 & 114,453 \\
1982 & 98,479 & 14,905 & 13.1 & 113,384 \\
1983 & 100,106 & 15,975 & 13.8 & 116,081 \\
1984 & 101,416 & 17,320 & 14.6 & 118,736 \\
1985 & 103,571 & 17,751 & 14.6 & 121,322 \\
1986 & 106,756 & 18,427 & 14.7 & 125,183 \\
1987 & 108,702 & 19,046 & 14.9 & 127,748 \\
1988 & 109,816 & 20,070 & 15.5 & 129,886 \\
1989 & 110,632 & 21,232 & 16.1 & 131,864 \\
1990 & 110,184 & 21,399 & 16.3 & 131,583 \\
& & & \\
$1973-90$ & Average annual percentage change & \\
$1982-90$ & $0.5 \%$ & $4.7 \%$ & & $1.0 \%$ \\
\hline & $1.4 \%$ & $4.6 \%$ & & $1.9 \%$ \\
\hline
\end{tabular}

Source:

U.S. Department of Transportation, Federal Highway Administration, Highway Statistics 1990, Washington, DC, 1991, pp. 6, 8, and annual.

Total highway fuel use - Calculated as the sum of gasoline and special fuels.

'Special fuels consist primarily of diesel fuel, with small quantities of liquified petroleum gas. 
2-21

\section{Section 2.2. \\ Energy Efficiency and Intensity}




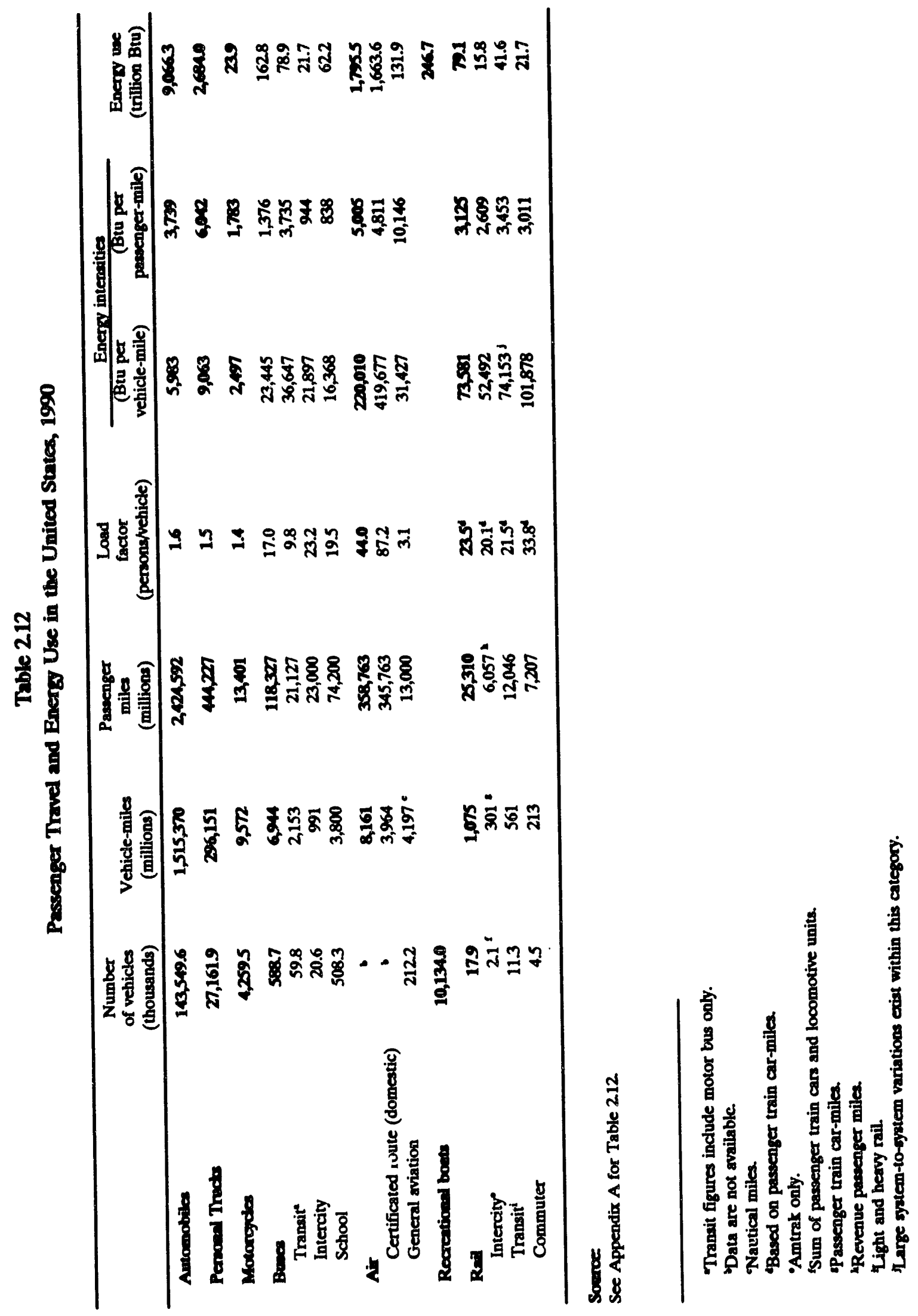




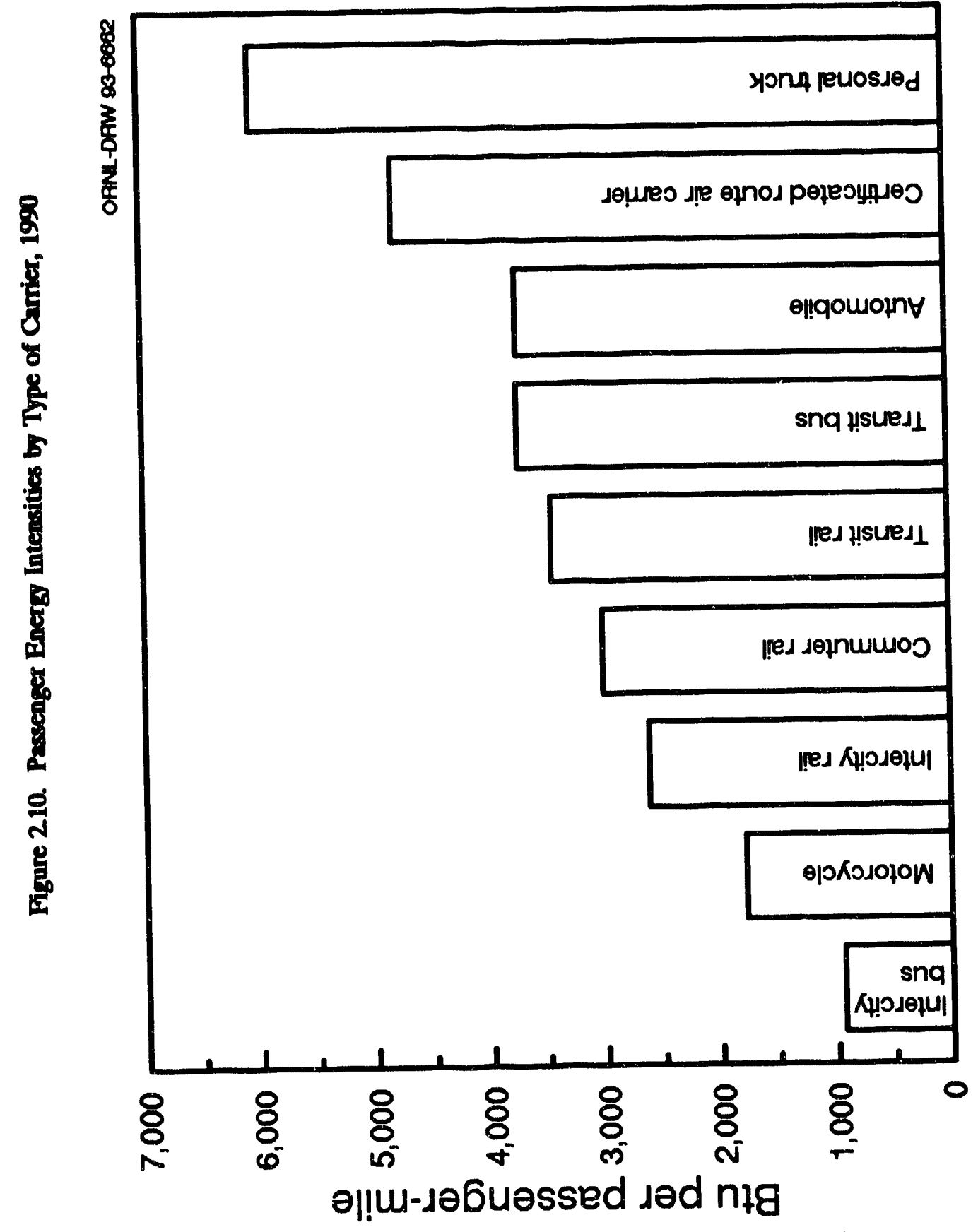

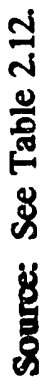




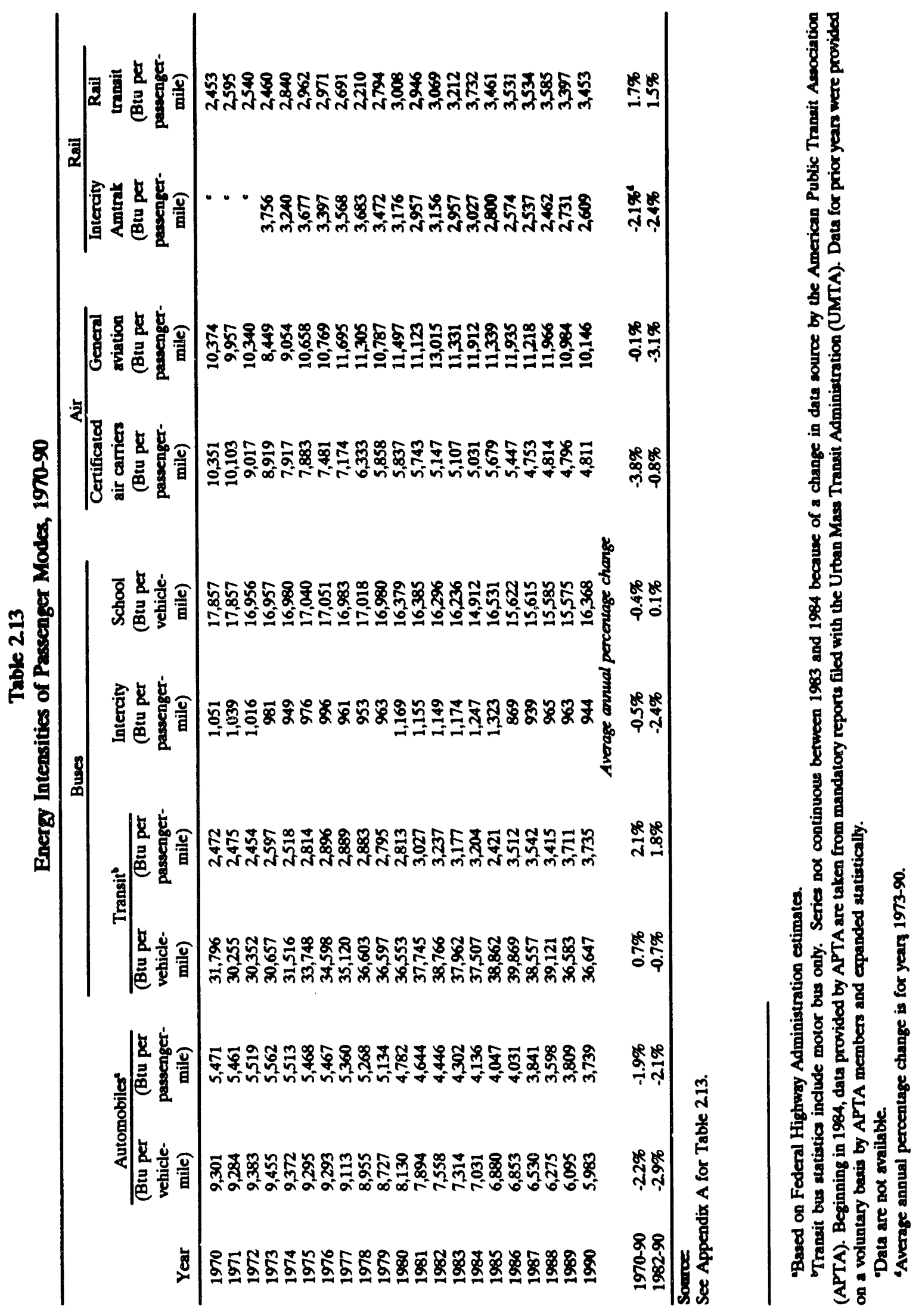




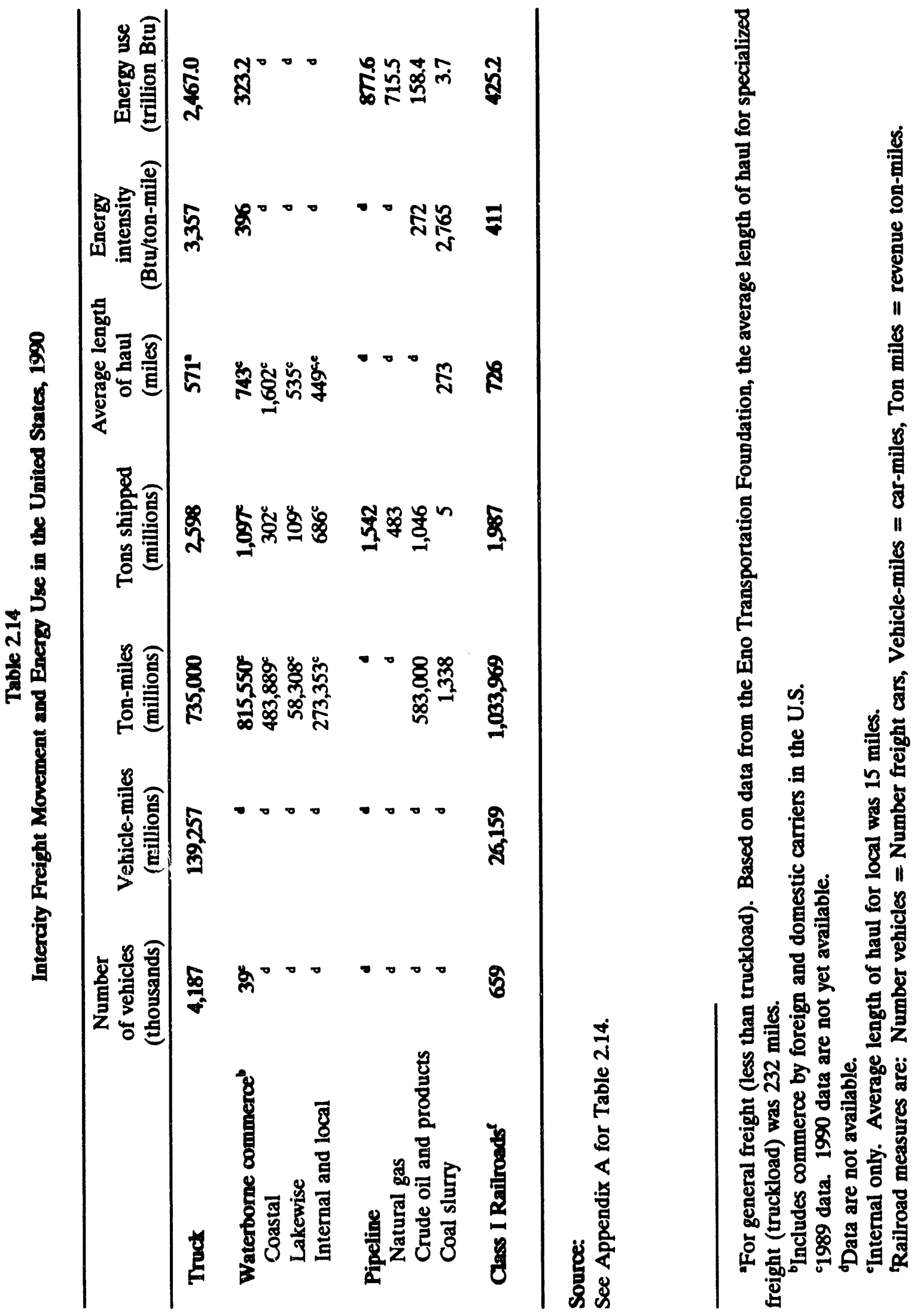




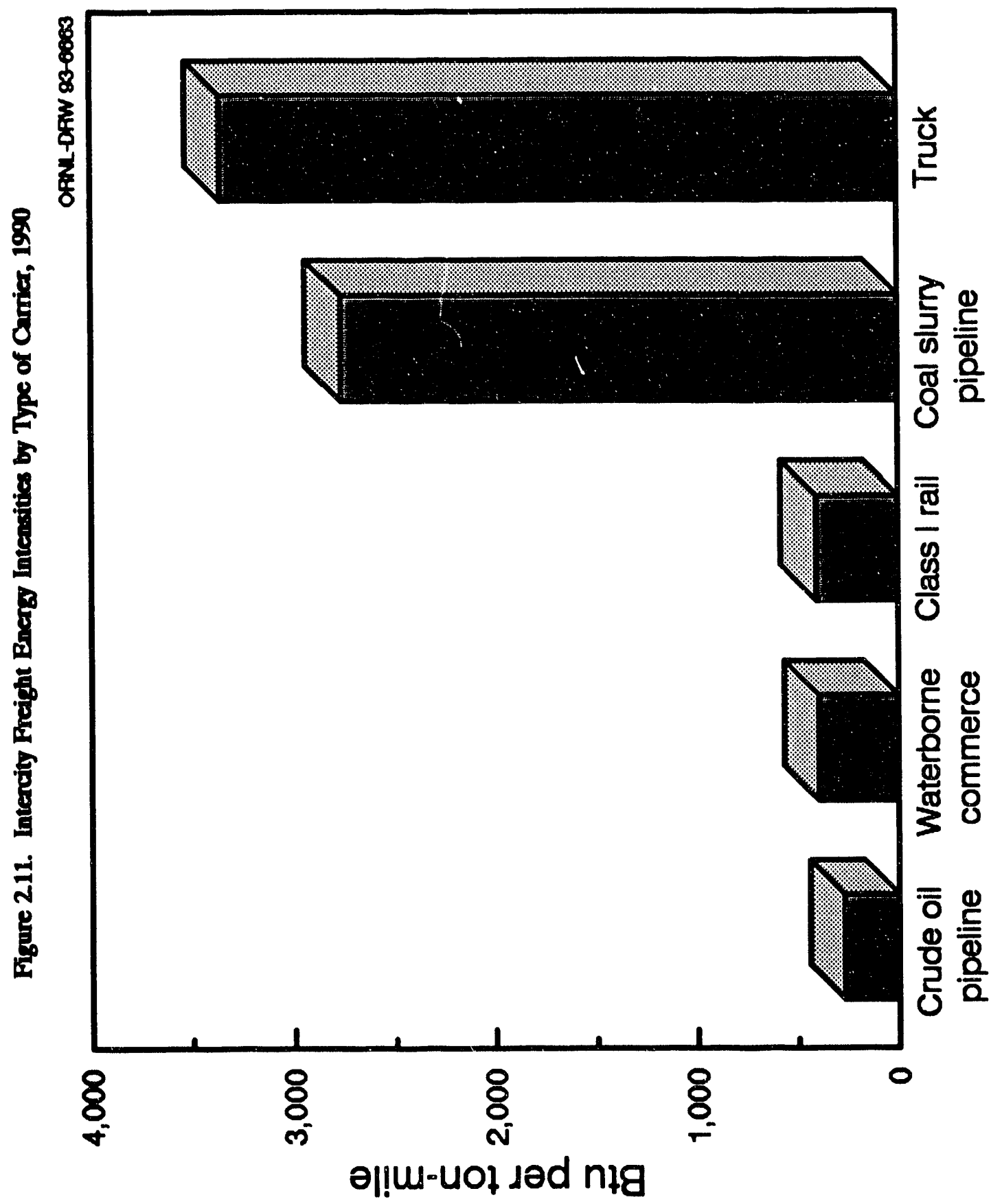

离
0
0
8
8
8
8
8
8 
All freight modes experienced energy efficiency improvements from 1970 to 1990. Domestic waterborne commerce, however, reversed this trend from 1982 to 1989 with a $3.1 \%$ decline in energy efficiency.

Table 2.15

Energy Intemsities of Preight Modes, 1970-90

\begin{tabular}{|c|c|c|c|c|c|c|}
\hline \multirow{3}{*}{ Year } & \multicolumn{3}{|c|}{ Trucks } & \multirow{2}{*}{\multicolumn{2}{|c|}{ Class I freight railroad }} & \multirow{3}{*}{$\begin{array}{l}\text { Domestic } \\
\text { waterborne } \\
\text { commerce } \\
\text { (Btu per } \\
\text { ton-mile) }\end{array}$} \\
\hline & \multirow{2}{*}{$\begin{array}{l}\text { Light truck } \\
\text { (Btu per } \\
\text { vehicle-mile) }\end{array}$} & \multirow{2}{*}{$\begin{array}{l}\text { Other trucks } \\
\text { (Btu per } \\
\text { vehicle-mile) }\end{array}$} & \multirow{2}{*}{$\begin{array}{l}\text { Total trucks } \\
\text { (Btu per } \\
\text { vehicle-mile) }\end{array}$} & & & \\
\hline & & & & $\begin{array}{l}\text { (Btu per freight } \\
\text { car-mile) }\end{array}$ & $\begin{array}{l}\text { (Btu per } \\
\text { ton-mile) }\end{array}$ & \\
\hline 1970 & 12,491 & 24,142 & 16,399 & 16,748 & 655 & 545 \\
\hline 1971 & 12,229 & 23,685 & 15,945 & 17,655 & 696 & 506 \\
\hline 1972 & 12,099 & 23,350 & 15,646 & 18,087 & 706 & 522 \\
\hline 1973 & 11,909 & 23,251 & 15,417 & 18,046 & 662 & 576 \\
\hline 1974 & 11,398 & 22,555 & 14,669 & 18,422 & 665 & 483 \\
\hline 1975 & 11,161 & 21,997 & 14,286 & 18,604 & 682 & 549 \\
\hline 1976 & 11,167 & 22,644 & 14,335 & 18,843 & 677 & 468 \\
\hline 1977 & 10,926 & 22,679 & 14,157 & 19,180 & 667 & 458 \\
\hline 1978 & 10,765 & 22,887 & 14,093 & 18,802 & 637 & 383 \\
\hline 1979 & 10,599 & 23,027 & 13,978 & 19,113 & 616 & 457 \\
\hline 1980 & 10,143 & 22,352 & 13,489 & 18,585 & 592 & 358 \\
\hline 1981 & 10,002 & 22,640 & 13,394 & 18,582 & 571 & 360 \\
\hline 1982 & 9,741 & 22,736 & 13,103 & 18,224 & 547 & 310 \\
\hline 1983 & 9,755 & 22,967 & 13,146 & 17,719 & 521 & 319 \\
\hline 1984 & 9,777 & 22,884 & 13,147 & 17,740 & 508 & 346 \\
\hline 1985 & 9,730 & 23,100 & 12,851 & 17,131 & 487 & 446 \\
\hline 1986 & 9,729 & 23,106 & 13,082 & 16,855 & 474 & 463 \\
\hline 1987 & 9,705 & 23,136 & 13,010 & 16,307 & 443 & 402 \\
\hline 1988 & 9,350 & 23,387 & 12,767 & 16,436 & 434 & 361 \\
\hline 1989 & 9,081 & 23,128 & 12,532 & 16,525 & 427 & 403 \\
\hline 1990 & 8,904 & 22,581 & 12,230 & 16,254 & 411 & $396^{\circ}$ \\
\hline \multicolumn{7}{|c|}{ Average annual percentage change } \\
\hline $1970-90$ & $-1.7 \%$ & $-0.3 \%$ & $-1.5 \%$ & $-0.1 \%$ & $-2.3 \%$ & $-1.6 \%$ \\
\hline $1982-90$ & $-1.1 \%$ & $0.1 \%$ & $-0.9 \%$ & $-1.4 \%$ & $-3.5 \%$ & $3.1 \%$ \\
\hline
\end{tabular}

Source:

See Appendix A for Table 2.15.

Two-axle, four-tire trucks.

'Assuming 1990 ton-miles remain constant from 1989. 1990 data are not yet available. 


\section{Section 2.3.} Economics 


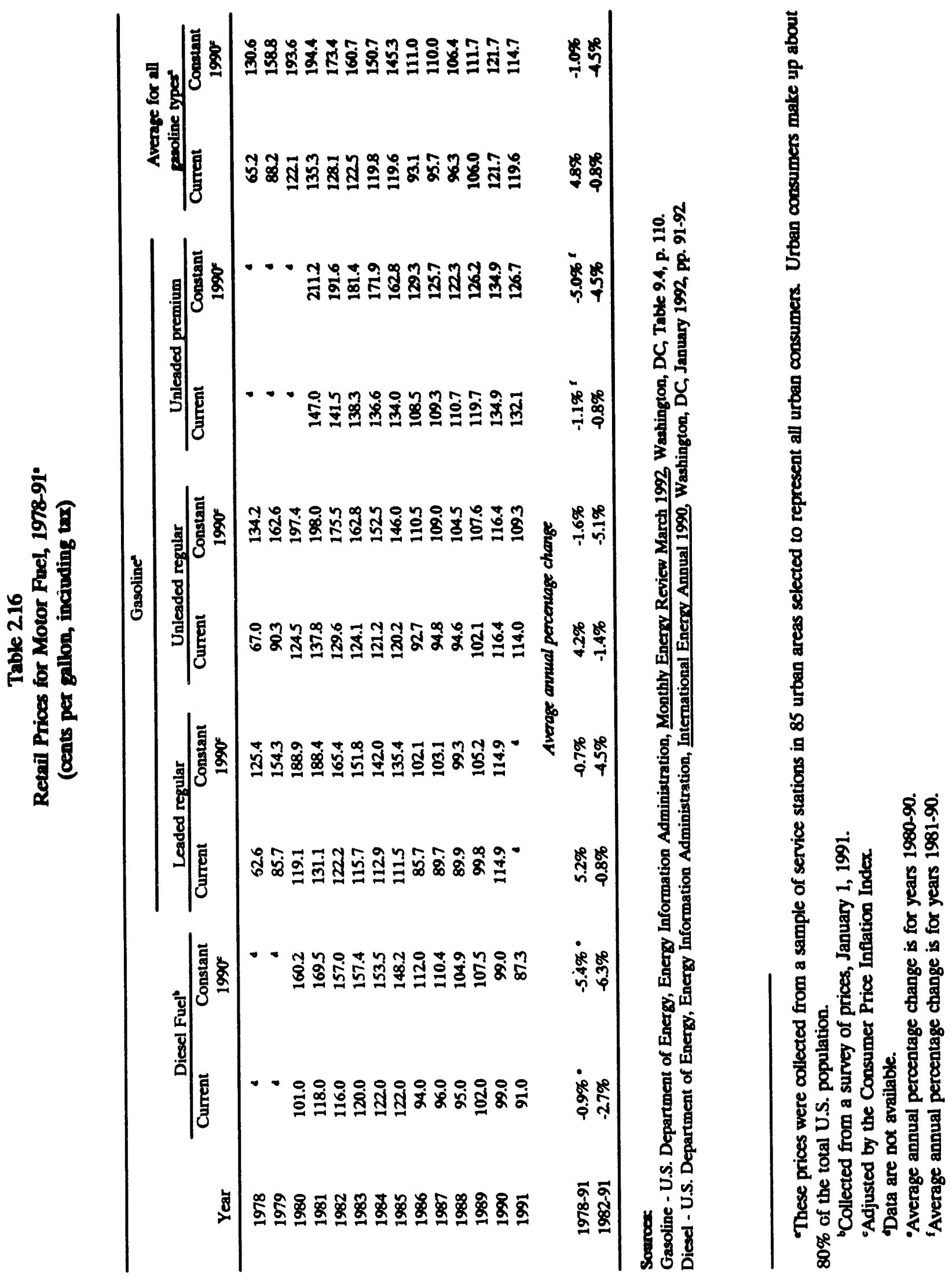




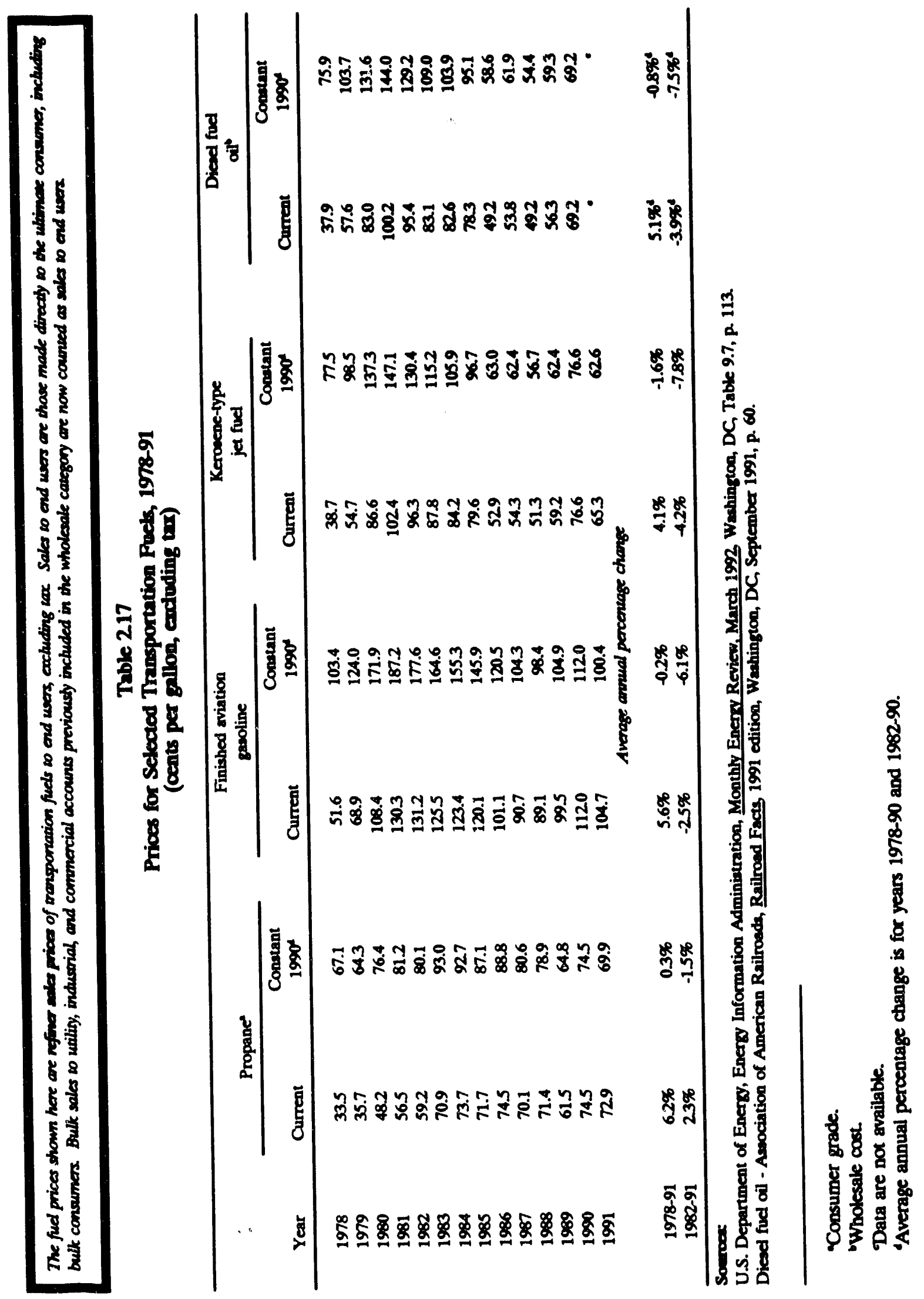




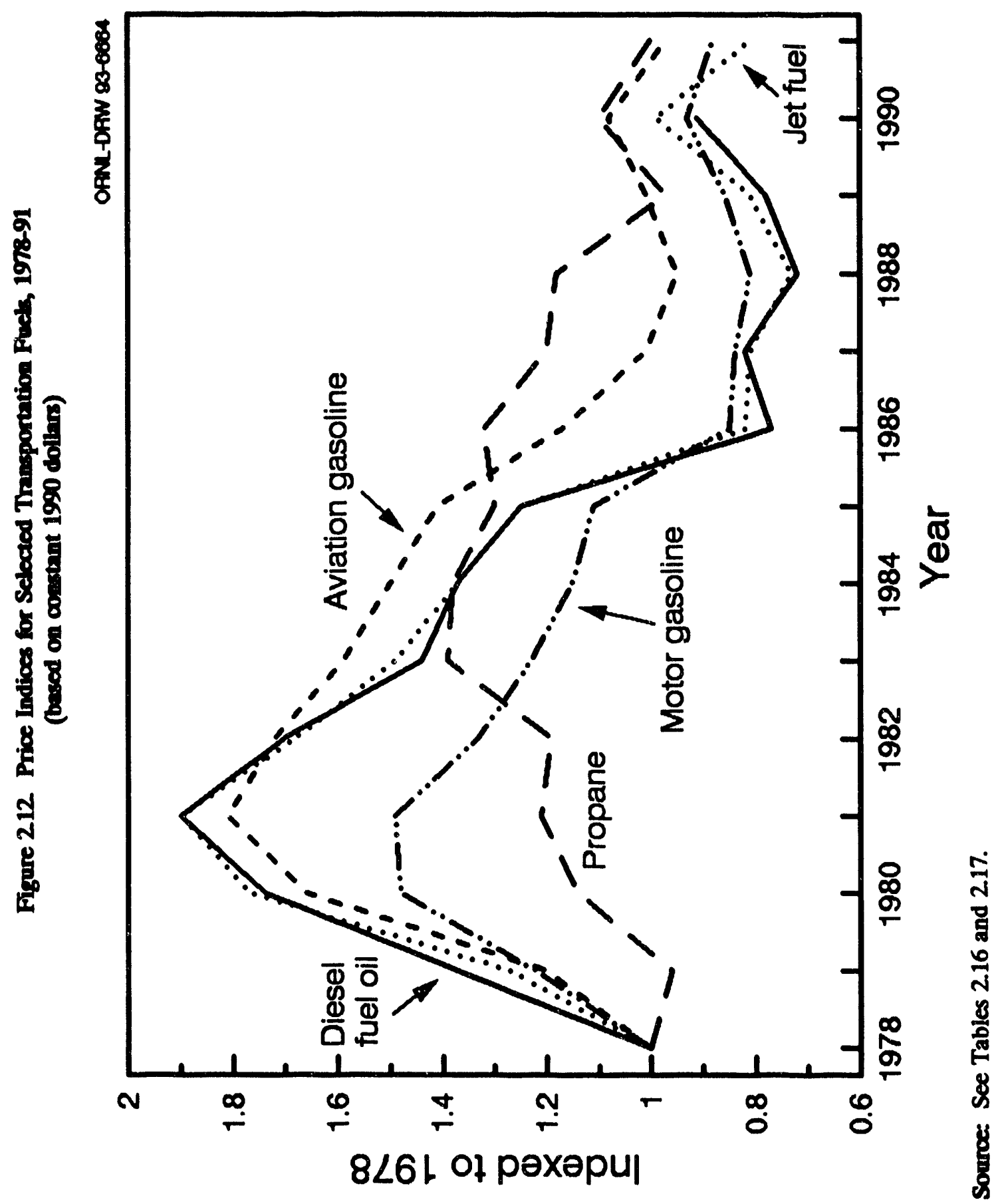


The average price of a barrel of crude oil dropped by more than three dollars from 1990 to 1991. The price of unleaded regular gasoline reflected the decline, but only dropped by $2.4 \mathrm{C}$ ( $\$ 1.01$ per barrel) in current dollars.

Table 218

Prices for a Barrel of Crude Oil and a Gallon of Gasoline, 1976-91

\begin{tabular}{|c|c|c|c|c|c|c|}
\hline \multirow[b]{2}{*}{ Year } & \multicolumn{2}{|c|}{$\begin{array}{c}\text { Crude Oil } \\
\text { (dollars per barrel) }\end{array}$} & \multicolumn{2}{|c|}{$\begin{array}{l}\text { Leaded Gasoline } \\
\text { (dollars per gallon) }\end{array}$} & \multicolumn{2}{|c|}{$\begin{array}{l}\text { Unleaded Regular Gasoline } \\
\text { (dollars per gallon) }\end{array}$} \\
\hline & Current & $\begin{array}{c}\text { Constant } \\
1990^{\circ}\end{array}$ & Current & $\begin{array}{c}\text { Constant } \\
1990^{\circ}\end{array}$ & Current & $\begin{array}{l}\text { Constant } \\
1990^{\circ}\end{array}$ \\
\hline 1976 & 10.89 & 25.00 & 0.590 & 1.354 & 0.614 & 1.407 \\
\hline 1977 & 11.96 & 25.79 & 0.622 & 1.341 & 0.656 & 1.415 \\
\hline 1978 & 12.46 & 24.96 & 0.626 & 1.254 & 0.670 & 1.342 \\
\hline 1979 & 17.72 & 31.90 & 0.857 & 1.543 & 0.903 & 1.626 \\
\hline 1980 & 28.07 & 44.52 & 1.191 & 1.889 & 1.245 & 1.974 \\
\hline 1981 & 35.24 & 50.63 & 1.311 & 1.884 & 1.378 & 1.980 \\
\hline 1982 & 31.87 & 43.15 & 1.222 & 1.654 & 1.296 & 1.755 \\
\hline 1983 & 28.99 & 38.03 & 1.157 & 1.518 & 1.241 & 1.628 \\
\hline 1984 & 28.63 & 36.02 & 1.129 & 1.420 & 1.212 & 1.525 \\
\hline 1985 & 26.75 & 32.50 & 1.115 & 1.354 & 1.202 & 1.460 \\
\hline 1986 & 14.55 & 17.34 & 0.857 & 1.021 & 0.927 & 1.105 \\
\hline 1987 & 17.90 & 20.58 & 0.897 & 1.031 & 0.948 & 1.090 \\
\hline 1988 & 14.67 & 16.21 & 0.899 & 0.993 & 0.946 & 1.045 \\
\hline 1989 & 17.97 & 18.94 & 0.998 & 1.052 & 1.021 & 1.076 \\
\hline 1990 & 22.22 & 22.22 & 1.149 & 1.149 & 1.164 & 1.164 \\
\hline 1991 & 19.05 & 18.30 & d & d & 1.140 & 1.100 \\
\hline \multicolumn{7}{|c|}{ Average annual percentage change } \\
\hline $1976-91$ & $3.8 \%$ & $-2.1 \%$ & $4.9 \%^{e}$ & $-1.2 \%$ & $4.2 \%$ & $-1.6 \%$ \\
\hline $1982-91$ & $-5.6 \%$ & $-9.1 \%$ & $-0.8 \%{ }^{\circ}$ & $-4.5 \%^{\circ}$ & $-1.4 \%$ & $-5.1 \%$ \\
\hline
\end{tabular}

Sources:

Crude Oil - U.S. Department of Energy, Energy Information Administration, Monthly Energy Review, March 1992, Washington, DC, Table 9.1, p. 107.

Gasoline - U.S. Department of Energy, Energy Information Administration Monthly Energy

Review, March 1992, Washington, DC, Table 9.4, p. 110.

\footnotetext{
'Refiner acquisition cost of composite (domestic and import) crude oil.

These prices were collected from a sample of service stations in 85 urban areas selected to represent all urban consumers. Urban consumers make up about $80 \%$ of the total U.S. population.

'Adjusted by the Consumer Price Inflation Index.

Data are not available.

'Average annual percentage changes are for years 1976-90 and 1982-90.
} 


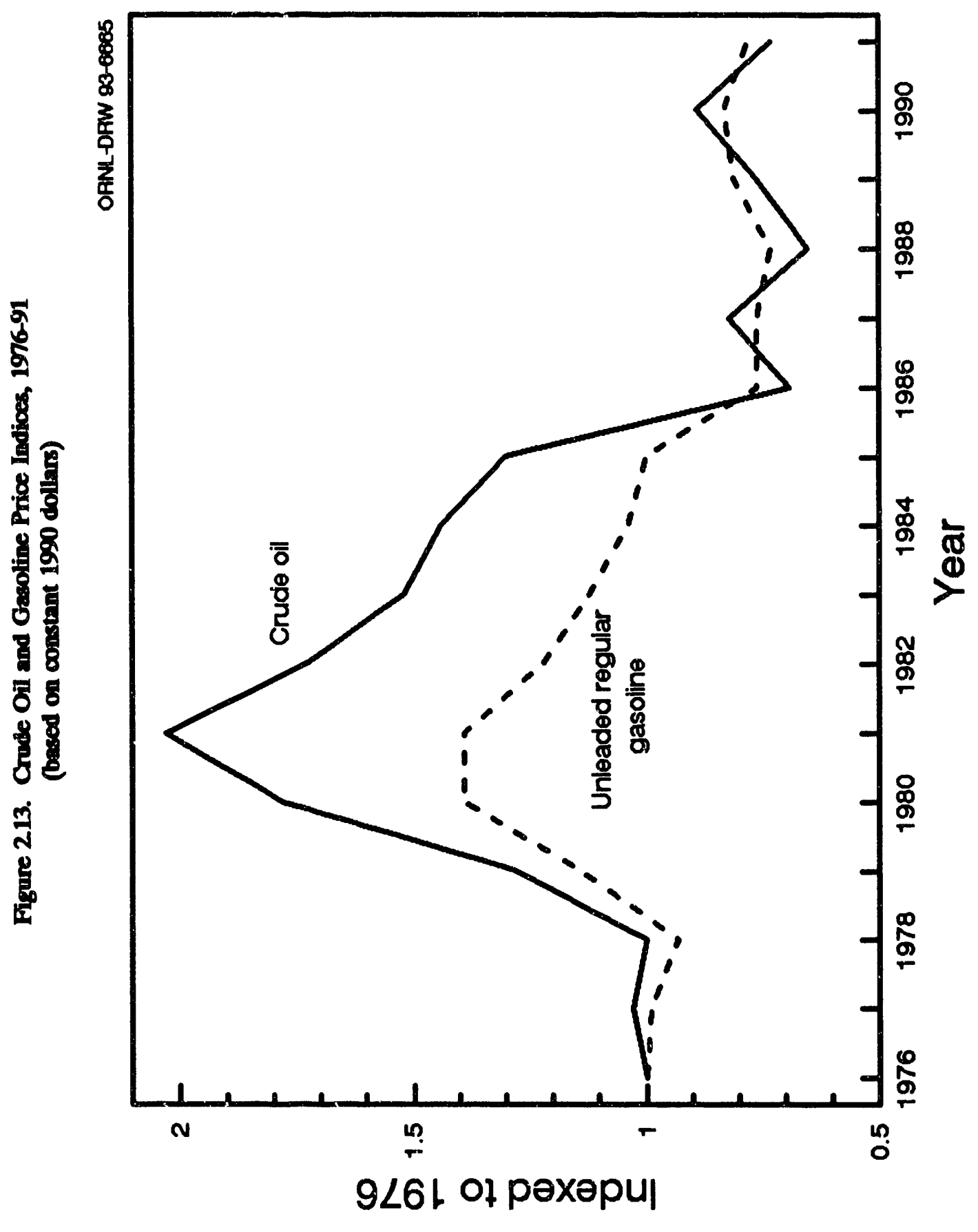

先 
Transportation's share of the Gross National Product (GNP) fell below 17\% in 1991. GNP has been growing at an average rate of $3.0 \%$ from 1982 to 1991, while transportation outlays have grown an average of $1.9 \%$ annually, in constant 1990 dollars.

Table 219

Gross National Product (GNP) as Related to Transportation, 1970-91

\begin{tabular}{|c|c|c|c|c|c|}
\hline \multirow[b]{2}{*}{ Year } & \multicolumn{2}{|c|}{$\begin{array}{l}\text { Gross National Product } \\
\text { (billion dollars) }\end{array}$} & \multicolumn{2}{|c|}{$\begin{array}{c}\text { Total transportation } \\
\text { outlays } \\
\text { (billion dollars) }\end{array}$} & \multirow{2}{*}{$\begin{array}{c}\text { Transportation } \\
\text { outlays } \\
\text { as a percent } \\
\text { of GNP }\end{array}$} \\
\hline & Current & $\begin{array}{l}\text { Constant } \\
1990^{\circ}\end{array}$ & Current & $\begin{array}{l}\text { Cointain } \\
1990^{\circ}\end{array}$ & \\
\hline $\begin{array}{l}1970 \\
1971 \\
1972 \\
1973 \\
1974 \\
1975 \\
1976 \\
1977 \\
1978 \\
1979 \\
1980 \\
1981 \\
1982 \\
1983 \\
1984 \\
1985 \\
1986 \\
1987 \\
1988 \\
1989 \\
1990 \\
1991\end{array}$ & $\begin{array}{l}1,015.5 \\
1,102.7 \\
1,212.8 \\
1,359.3 \\
1,472.8 \\
1,598.4 \\
1,782.8 \\
1,990.5 \\
2,249.7 \\
2,508.2 \\
2,732.0 \\
3,052.6 \\
3,166.0 \\
3,405.7 \\
3,772.2 \\
4,010.3 \\
4,235.0 \\
4,515.6 \\
4,873.7 \\
5,200.8 \\
5,524.5 \\
5,685.8\end{array}$ & $\begin{array}{l}3,031.3 \\
3,127.8 \\
3,304.5 \\
3,499.9 \\
3,490.0 \\
3,463.9 \\
3,671.3 \\
3,871.3 \\
4,076.6 \\
4,182.2 \\
4,167.4 \\
4,259.0 \\
4,163.3 \\
4,308.3 \\
4,573.5 \\
4,730.4 \\
4,861.8 \\
5,053.2 \\
5,268.1 \\
5,416.5 \\
5,524.5 \\
5,452.7\end{array}$ & $\begin{array}{l}195.2 \\
222.0 \\
242.3 \\
266.5 \\
282.6 \\
298.9 \\
351.1 \\
400.9 \\
453.4 \\
503.0 \\
524.9 \\
592.5 \\
591.4 \\
643.2 \\
715.5 \\
753.0 \\
771.7 \\
808.7 \\
857.6 \\
906.3 \\
969.4 \\
959.5\end{array}$ & $\begin{array}{l}582.7 \\
629.7 \\
660.2 \\
686.2 \\
669.7 \\
647.8 \\
723.0 \\
779.7 \\
821.6 \\
838.7 \\
800.7 \\
826.7 \\
777.7 \\
813.7 \\
867.5 \\
888.2 \\
885.9 \\
905.0 \\
927.0 \\
943.9 \\
969.4 \\
917.3\end{array}$ & $\begin{array}{l}19.2 \% \\
20.1 \% \\
20.0 \% \\
19.6 \% \\
19.2 \% \\
18.7 \% \\
19.7 \% \\
20.1 \% \\
20.2 \% \\
20.1 \% \\
19.2 \% \\
19.4 \% \\
18.7 \% \\
18.9 \% \\
19.0 \% \\
18.8 \% \\
18.2 \% \\
17.9 \% \\
17.6 \% \\
17.4 \% \\
17.5 \% \\
16.9 \%\end{array}$ \\
\hline \multicolumn{6}{|c|}{ Average annual percentage change } \\
\hline $\begin{array}{l}1970-91 \\
1982-91\end{array}$ & $\begin{array}{l}8.5 \% \\
6.7 \%\end{array}$ & $\begin{array}{l}2.8 \% \\
3.0 \%\end{array}$ & $\begin{array}{l}7.9 \% \\
5.5 \%\end{array}$ & $\begin{array}{l}2.2 \% \\
1.9 \%\end{array}$ & \\
\hline
\end{tabular}

Sources:

1970-86 GNP - U.S. Department of Commerce, Bureau of Census, Statistical Abstract of the United States 1988, p.410.

1987-91 GNP - U.S. Department of Commerce, Bureau of Economic Analysis, Survey of Current Business, July, 1991, and annual.

Transportation Outlays - Eno Transportation Foundation, Transportation in America, Tenth

Edition, Washington, DC, 1992, p.38.

"Adjusted by the implicit GNP price deflator. 
Transportation's share of personal consumption expenditures (PCE) dropped to 11.3\% in 1991, the lowest share in the twenty-year series.

Table 220

Personal Consumption Expenditures (PCE) \&s Related to Transportation, 1970-91

\begin{tabular}{|c|c|c|c|c|c|}
\hline \multirow[b]{2}{*}{ Year } & \multicolumn{2}{|c|}{$\begin{array}{c}\text { Personal } \\
\text { Consumption Expenditures } \\
\text { (billion dollars) }\end{array}$} & \multicolumn{2}{|c|}{$\begin{array}{c}\text { Transportation } \\
\text { Personal } \\
\text { Consumption Expenditures" } \\
\text { (billion dollars) } \\
\end{array}$} & \multirow{2}{*}{$\begin{array}{c}\text { Transportation } \\
\text { PCE } \\
\text { as a percent of } \\
\text { total PCE }\end{array}$} \\
\hline & Current & $\begin{array}{l}\text { Constant } \\
1990^{\circ}\end{array}$ & Current & $\begin{array}{l}\text { Coistant } \\
1990^{\circ}\end{array}$ & \\
\hline $\begin{array}{l}1970 \\
1971 \\
1972 \\
1973 \\
1974 \\
1975 \\
1976 \\
1977 \\
1978 \\
1979 \\
1980 \\
1981 \\
1982 \\
1983 \\
1984 \\
1985 \\
1986 \\
1987 \\
1988 \\
1989 \\
1990 \\
1991\end{array}$ & $\begin{array}{r}640.0 \\
691.6 \\
757.6 \\
837.2 \\
916.5 \\
1,012.8 \\
1,129.3 \\
1,257.2 \\
1,403.5 \\
1,566.8 \\
1,732.6 \\
1,915.1 \\
2,050.7 \\
2,234.5 \\
2,430.5 \\
2,629.0 \\
2,797.4 \\
3,009.4 \\
3,296.1 \\
3,523.1 \\
3,448.4 \\
3,887.7\end{array}$ & $\begin{array}{l}1,910.4 \\
1,961.7 \\
2,064.2 \\
2,155.6 \\
2,171.8 \\
2,194.9 \\
2,325.6 \\
2,445.1 \\
2,543.2 \\
2,612.5 \\
2,642.9 \\
2,672.0 \\
2,696.7 \\
2,826.7 \\
2,946.8 \\
3,101.1 \\
3,211.4 \\
3,367.7 \\
3,562.9 \\
3,669.2 \\
3,448.4 \\
3,716.6\end{array}$ & \begin{tabular}{r|}
81.5 \\
95.2 \\
105.8 \\
116.0 \\
119.8 \\
131.2 \\
157.1 \\
181.5 \\
199.9 \\
222.0 \\
238.5 \\
261.5 \\
267.6 \\
295.4 \\
329.5 \\
359.5 \\
366.3 \\
379.7 \\
413.2 \\
437.3 \\
453.7 \\
438.2
\end{tabular} & $\begin{array}{l}243.3 \\
270.0 \\
288.3 \\
298.7 \\
283.9 \\
284.3 \\
323.5 \\
353.0 \\
362.2 \\
370.2 \\
363.8 \\
364.8 \\
351.9 \\
373.7 \\
399.5 \\
424.1 \\
420.5 \\
424.9 \\
446.6 \\
455.4 \\
453.7 \\
418.9\end{array}$ & $\begin{array}{l}12.7 \% \\
13.8 \% \\
14.0 \% \\
13.9 \% \\
13.1 \% \\
13.0 \% \\
13.9 \% \\
14.4 \% \\
14.2 \% \\
14.2 \% \\
13.8 \% \\
13.7 \% \\
13.0 \% \\
13.2 \% \\
13.6 \% \\
13.7 \% \\
13.0 \% \\
12.6 \% \\
12.5 \% \\
12.4 \% \\
13.1 \% \\
11.3 \%\end{array}$ \\
\hline \multicolumn{6}{|c|}{ Average annual percentage change } \\
\hline $\begin{array}{l}1970-91 \\
1982-91\end{array}$ & $\begin{array}{l}9.0 \% \\
7.4 \%\end{array}$ & $\begin{array}{l}3.2 \% \\
3.6 \%\end{array}$ & $\begin{array}{l}8.3 \% \\
5.6 \%\end{array}$ & $\begin{array}{l}2.6 \% \\
2.0 \%\end{array}$ & \\
\hline
\end{tabular}

Sources:

1970-86 data - U.S. Department of Commerce, Bureau of Census, Statistical Abstract of the United States 1988 , p.412.

1987-91 data - U.S. Department of Commerce, Bureau of Economic Analysis, Survey of Current

Business, July 1992, p. 59, and annual.

Transportation Personal Consumption Expenditures include user operating expenses (new and used auto purchases, gas and oil, repair, greasing, washing, parking, storage, rental, other motor vehicles, tires, tubes and other parts, insurance premiums); purchased intercity transportation; and purchased local transportation.

${ }^{b}$ Adjusted by the implicit GNP price deflator. 
The Consumer Price Index (CPI) for transportation has more than tripled from 1970 to 1990; and the Used Car CPI continued to grow at a much faster rate than did the New Car CPI. This means that while consumers paid for a new automobile in 1990 more than double what they did in 1970, they paid almost four times more to buy a used car in 1990 than in 1970. Although the Used Car CPI declined from 1989 to 1990 , it rose again in 1991.

Table 221

Statistical Indices as Related to Transportation, 1970-91 $(1970=1.000)$

\begin{tabular}{cccccc}
\hline Year & $\begin{array}{c}\text { Consumer } \\
\text { Price Index }\end{array}$ & $\begin{array}{c}\text { Transportation } \\
\text { Consumer } \\
\text { Price Index }\end{array}$ & $\begin{array}{c}\text { New car } \\
\text { Consumer } \\
\text { Price Index }\end{array}$ & $\begin{array}{c}\text { Used car } \\
\text { Consumer } \\
\text { Price Index }\end{array}$ & $\begin{array}{c}\text { Gross National } \\
\text { Product }\end{array}$ \\
\hline 1970 & 1.000 & 1.000 & 1.000 & 1.000 & 1.000 \\
1971 & 1.043 & 1.052 & 1.041 & 1.057 & 1.086 \\
1972 & 1.077 & 1.064 & 1.032 & 1.059 & 1.194 \\
1973 & 1.144 & 1.098 & 1.033 & 1.128 & 1.339 \\
1974 & 1.270 & 1.222 & 1.092 & 1.175 & 1.450 \\
1975 & 1.386 & 1.336 & 1.186 & 1.404 & 1.574 \\
1976 & 1.466 & 1.469 & 1.261 & 1.610 & 1.756 \\
1977 & 1.561 & 1.572 & 1.328 & 1.753 & 1.960 \\
1978 & 1.680 & 1.646 & 1.429 & 1.788 & 2.215 \\
1979 & 1.869 & 1.881 & 1.543 & 1.927 & 2.470 \\
1980 & 2.122 & 2.216 & 1.667 & 1.995 & 2.690 \\
1981 & 2.342 & 2.484 & 1.768 & 2.463 & 3.006 \\
1982 & 2.486 & 2.587 & 1.836 & 2.842 & 3.118 \\
1983 & 2.566 & 2.648 & 1.883 & 3.161 & 3.354 \\
1984 & 2.675 & 2.766 & 1.938 & 3.602 & 3.715 \\
1985 & 2.770 & 2.838 & 2.000 & 3.640 & 3.954 \\
1986 & 2.824 & 2.728 & 2.087 & 3.487 & 4.176 \\
1987 & 2.927 & 2.811 & 2.162 & 3.625 & 4.447 \\
1988 & 3.046 & 2.899 & 2.206 & 3.782 & 4.799 \\
1989 & 3.193 & 3.043 & 2.249 & 3.859 & 5.121 \\
1990 & 3.365 & 3.213 & 2.283 & 3.769 & 5.382 \\
1991 & 3.508 & 3.301 & 2.364 & 3.785 & 5.599 \\
\hline
\end{tabular}

Sources:

U.S. Department of Commerce, Bureau of Economic Analysis, Survey of Current Business, Washington, DC, May 1992, p. S-6, and annual.

Gross National Product - Indexed to 1970 from Table 2.19.

Transportation Consumer Price Index includes new and used cars, gasoline, auto insurance rates, intracity mass transit, intracity bus fare, and airline fares. 


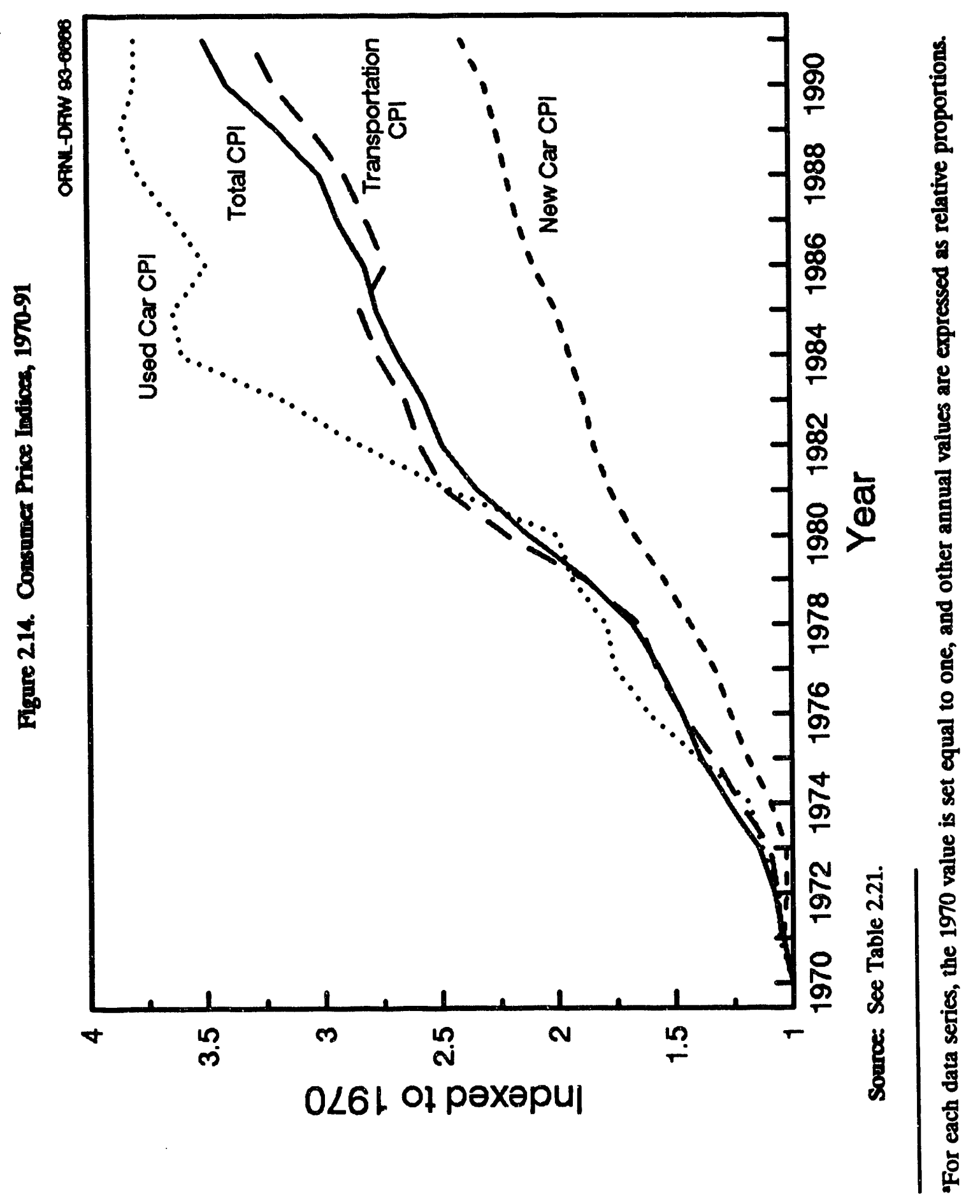


The average price of all new cars in 1990 constant dollars declined from 1990 to 1991 - the first decline since 1980. Domestic car prices, in 1990 constant dollars, have been declining since 1989. In current dollars, the price gap between domestic and import cars rose to \$2,046 in 1991 .

Table 222

Average Price of a Now Car, 1970-91

\begin{tabular}{|c|c|c|c|c|c|c|}
\hline \multirow[b]{2}{*}{ Year } & \multicolumn{2}{|c|}{ Domestic } & \multicolumn{2}{|c|}{ Import } & \multicolumn{2}{|c|}{ Total } \\
\hline & $\begin{array}{l}\text { Current } \\
\text { dollars }\end{array}$ & $\begin{array}{c}\text { Constant } \\
1990 \text { dollars }\end{array}$ & $\begin{array}{l}\text { Current } \\
\text { dollars }\end{array}$ & $\begin{array}{c}\text { Constant } \\
1990 \text { dollars" }\end{array}$ & $\begin{array}{l}\text { Current } \\
\text { dollars }\end{array}$ & $\begin{array}{c}\text { Constant } \\
1990 \text { dollars }\end{array}$ \\
\hline 1970 & 3,708 & 12,479 & 2,648 & 8,912 & 3,542 & 11,920 \\
\hline 1971 & 3,919 & 12,645 & 2,769 & 8,935 & 3,742 & 12,074 \\
\hline 1972 & 4,034 & 12,601 & 2,994 & 9,352 & 3,879 & 12,117 \\
\hline 1973 & 4,181 & 12,295 & 3,344 & 9,834 & 4,052 & 11,915 \\
\hline 1974 & 4,524 & 11,988 & 4,206 & 11,146 & 4,440 & 11,766 \\
\hline 1975 & 5,084 & 12,344 & 4,384 & 10,645 & 4,950 & 12,019 \\
\hline 1976 & 5,506 & 12,640 & 4,923 & 11,301 & 5,418 & 12,438 \\
\hline 1977 & 5,985 & 12,906 & 5,072 & 10,938 & 5,814 & 12,538 \\
\hline 1978 & 6,478 & 12,976 & 5,934 & 11,886 & 6,379 & 12,778 \\
\hline 1979 & 6,889 & 12,403 & 6,704 & 12,070 & 6,847 & 12,327 \\
\hline 1980 & 7,609 & 12,067 & 7,482 & 11,886 & 7,574 & 12,012 \\
\hline 1981 & 8,912 & 12,805 & 8,896 & 12,782 & 8,910 & 12,802 \\
\hline 1982 & 9,865 & 13,356 & 9,957 & 13,480 & 9,890 & 13,390 \\
\hline 1983 & 10,559 & 13,850 & 10,873 & 14,262 & 10,640 & 13,956 \\
\hline 1984 & 11,172 & 14,056 & 12,354 & 15,543 & 11,450 & 14,405 \\
\hline 1985 & 11,733 & 14,253 & 12,875 & 15,640 & 12,022 & 14,604 \\
\hline 1986 & 12,526 & 14,929 & 13,815 & 16,465 & 12,894 & 15,368 \\
\hline 1987 & 13,239 & 15,223 & 14,602 & 16,790 & 13,657 & 15,703 \\
\hline 1988 & 14,029 & 15,498 & 15,537 & 17,164 & 14,468 & 15,983 \\
\hline 1989 & 14,937 & 15,746 & 16,126 & 16,999 & 15,278 & 16,105 \\
\hline 1990 & 15,682 & 15,682 & 17,543 & 17,543 & 16,148 & 16,148 \\
\hline 1991 & 16,152 & 15,490 & 18,198 & 17,452 & 16,700 & 16,015 \\
\hline \multicolumn{7}{|c|}{ Average annual pc:-entage change } \\
\hline 1970-91 & $7.3 \%$ & $1.0 \%$ & $9.6 \%$ & $3.3 \%$ & $7.7 \%$ & $1.4 \%$ \\
\hline 1982-91 & $5.6 \%$ & $1.7 \%$ & $6.9 \%$ & $2.9 \%$ & $6.0 \%$ & $2.0 \%$ \\
\hline
\end{tabular}

Source:

Motor Vehicle Manufacturer's Association, Motor Vehicle Facts and Figures '92, Detroit, MI, 1992 , p.53.

"Adjusted by the Consumer Price Inflation Index. 


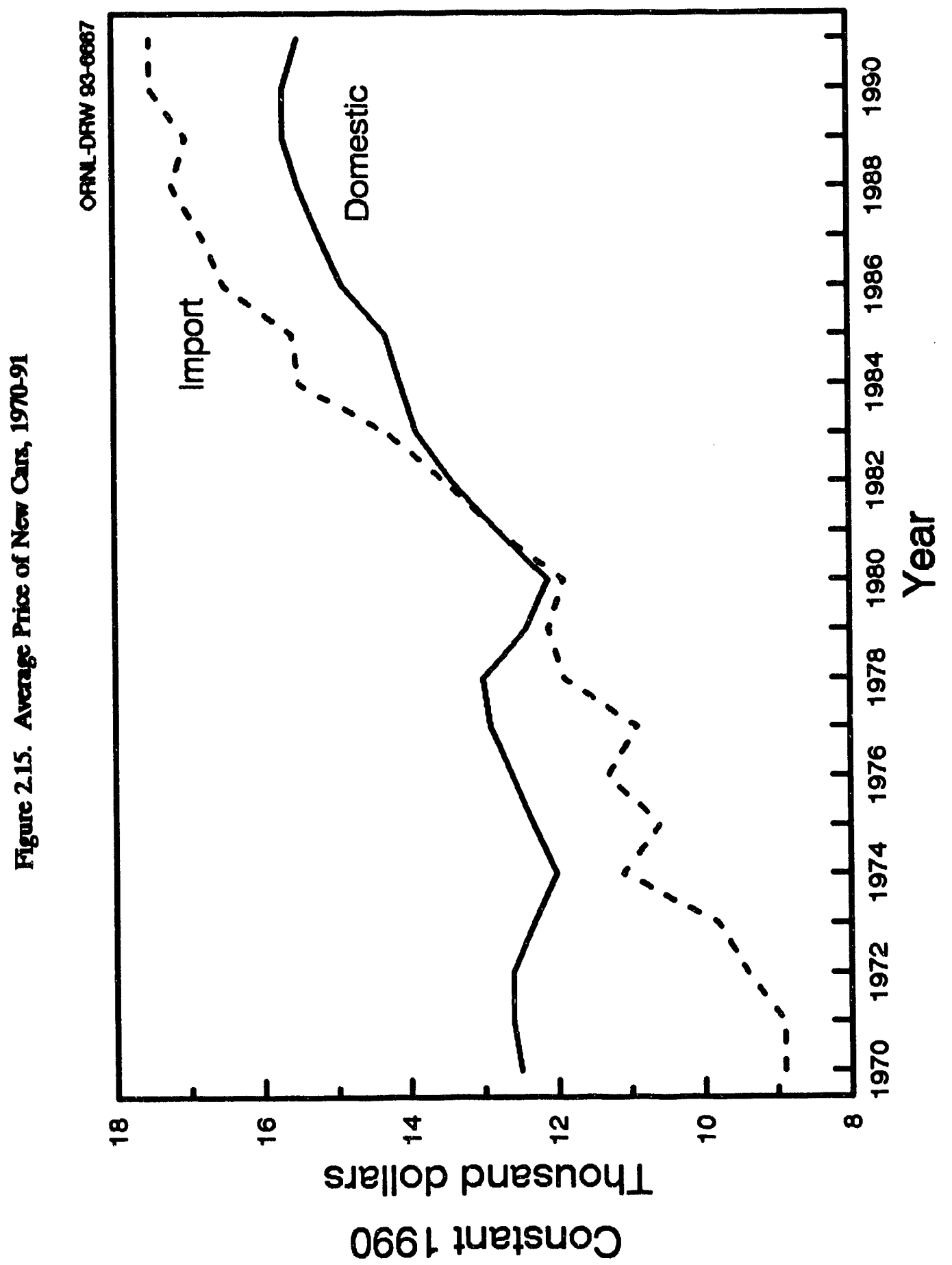




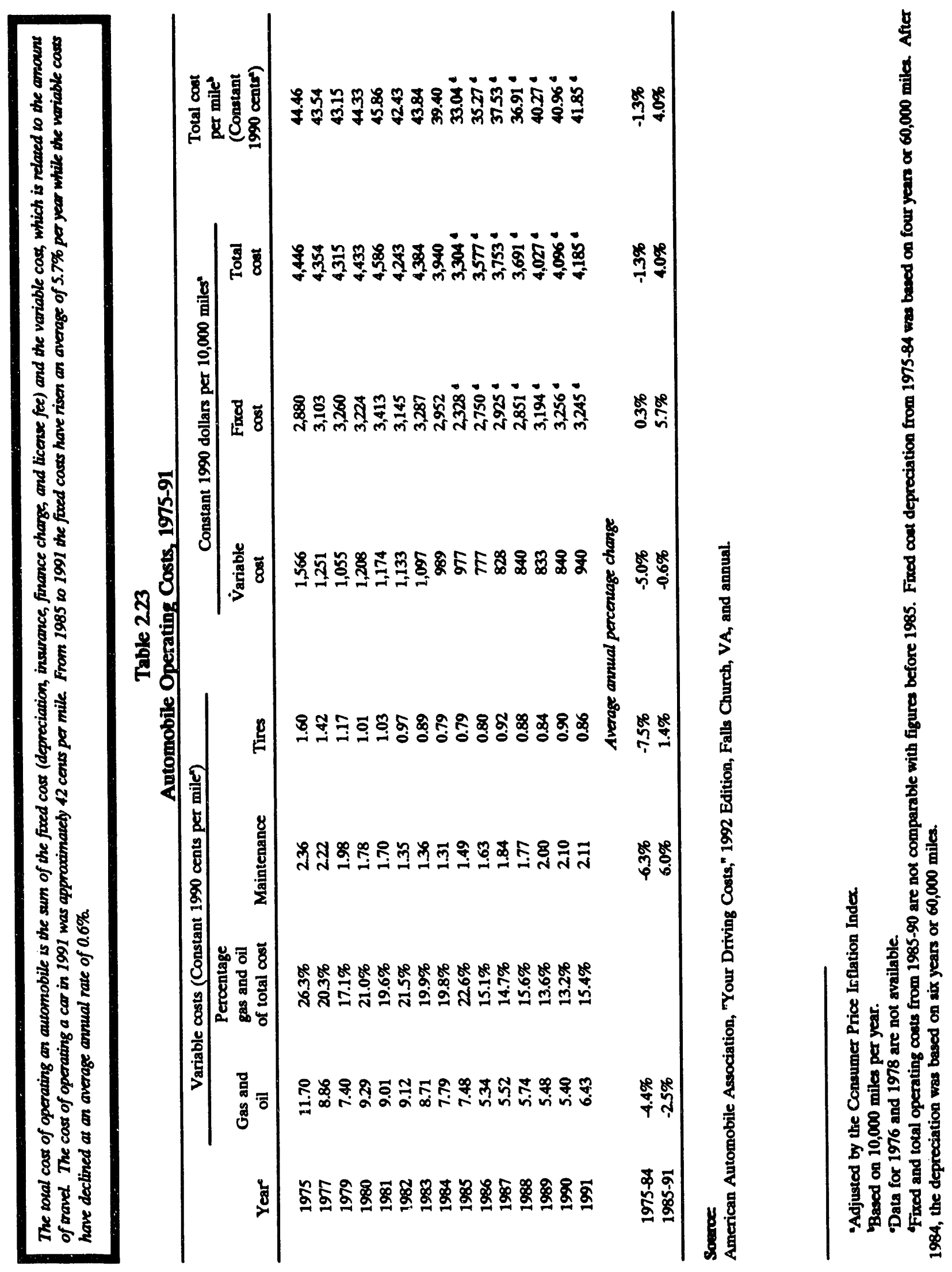




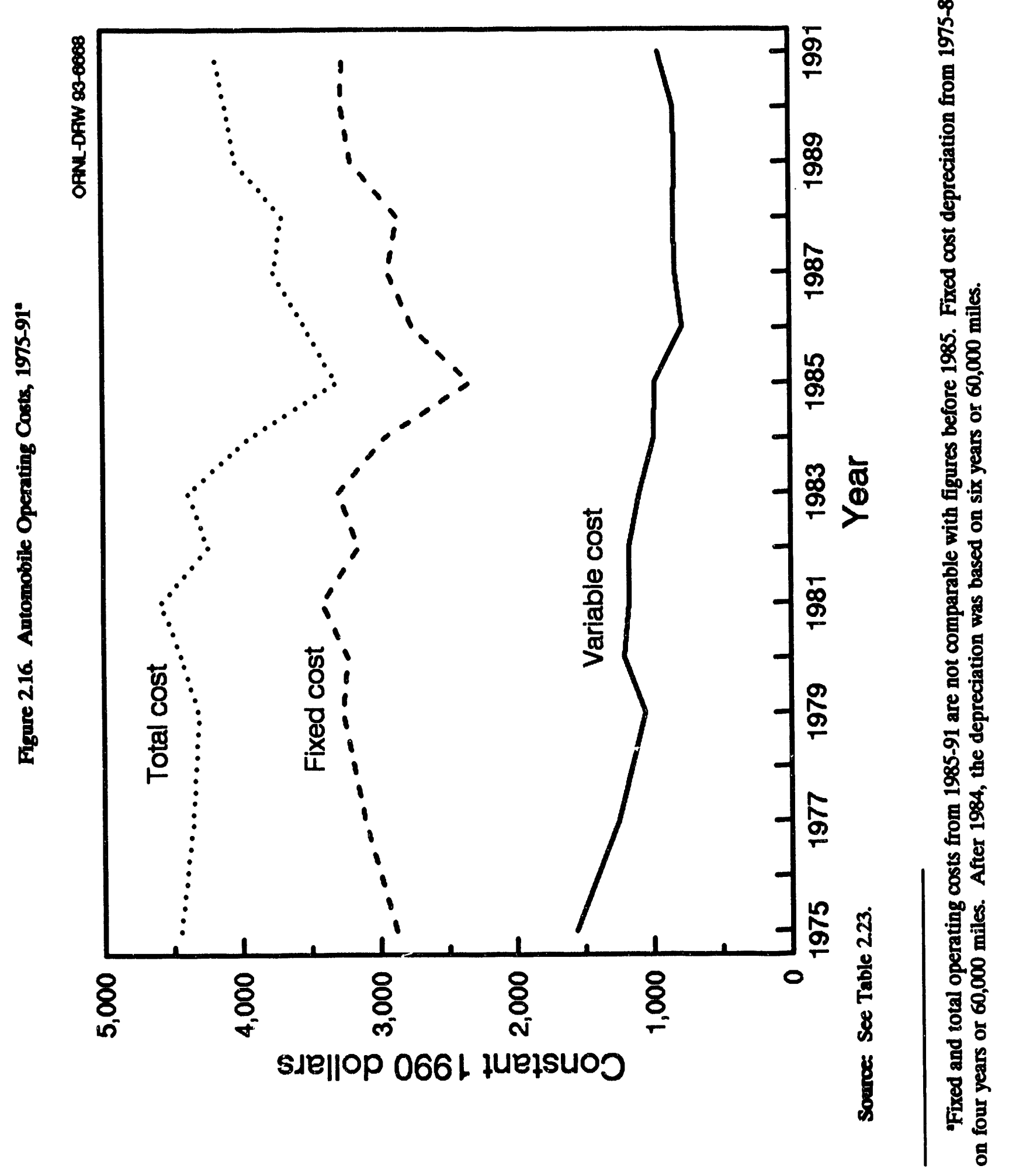




\section{CHAPTER 3 \\ HIGHWAY MODE}

This chapter presents data on highway transportation and is organized into eight sections. The first Section compares data for all types of highway transportation modes. Section 3.2 presents statistics on automobiles. Truck data are presented in Section 3.3, bus data in Section 3.4, and fleet data in Section 3.5. Federal regulations and standards on fuel economy are included in Section 3.6. Section 3.7 reports data on vehicle emissions. High-occupancy vehicle (HOV) lanes are the subject of Section 3.8.

Highway energy use represented $77.1 \%$ of transportation energy use in 1990 . Of the highway modes, automobiles ${ }^{2}$ had the greatest share of energy use, $41.6 \%$ (Table 3.1 ). The automobiles" were also responsible for the majority of vehicle miles traveled in 1990. Light trucks with two axles and four tires have experienced a rapid increase in vehicle miles traveled, an average of $6.9 \%$ annually from 1970 to 1990 (Table 3.2).

Automobile sales declined in 1991 to 8.2 million autos, dropping below 9 million for the first time since 1982 . Imports accounted for $24.9 \%$ of sales in 1991 , declining from a high of $31.1 \%$ in 1987 (Table 3.9). Fuel economy for the automobile population has increased from 13.5 miles per gallon in 1970 to 20.9 miles per gallon in 1990 (Table 3.12). As the older autos are scrapped, they are replaced with newer, more fuel efficient autos which help to raise the population fuel economy. The sales-weighted fuel economy for new automobiles remained at $27.6 \mathrm{mpg}$ for 1990 and 1991 sales periods, as well as the first six months of the 1992 sales period (Table 3.18).

Truck travel data are based mainly on the Truck Inventory and Use Survey (TIUS) conducted by the U.S. Bureau of the Census. As part of the nation's economic surveys, TIUS is required by law to be conducted every 5 years for the years ending in 2 and 7 to provide data on the physical and operational characteristics of the nation's truck population. The survey is based on a proùability sample of private and commercial trucks registered (or licensed) in each state. The most recent survey was conducted in 1987 . In addition to trucks, the following types of vehicles were also included in the 1987 survey: minivans, vans, station wagons, and jeep-like vehicles. The 1977 and 1982 surveys did not

\footnotetext{
'Motorcycles are also included in this category.
} 
include those vehicle types. The estimated number of trucks that were within the scope of the TIUS and registered in the U.S. as of July 1, 1987 was 44.6 million. These trucks were estimated to have been driven a total of 529,315 million miles during 1987 , an increase of $40.3 \%$ from 1982 . The average annual miles traveled per truck was estimated at 11,900 miles.

School and other non-revenue buses accounted for more than $81 \%$ of all 1990 buses in operation, but accounted for only 38\% of bus energy use (Tables 3.29 and 3.32). School buses have been the most efficient bus type on a vehicle-mile basis since 1970 (Table 3.32). Intercity buses travel more miles per bus than transit or school buses (Table 3.31).

Although the average Corporate Average Fuel Economy (CAFE) of automobiles and light trucks has met the CAFE standard each year except 1984, there are still manufacturers who fall short of meeting the standard. The domestic automobile CAFE estimate did not meet the 1992 standard, but the import estimate exceeded the standard, pulling the combined automobile CAFE estimate above the standard (Table 3.36). The fines collected for model year 1991 violations totalled more than 47 million dollars (Table 3.37). Since 1986 the Gas Guzzler tax has been assessed on automobiles with a fuel economy rating of less than 22.5 miles per gallon. These tax rates, which remained constant from 1986 to 1990 , doubled in 1991 (Table 3.39).

The Federal emission control requirements for automobiles, light trucks, and heavy trucks can be found in Section 3.7. These requirements were set by the Clean Air Act of 1990 (Tables 3.42 - 3.44) Because of the wide use of unleaded gasoline, the transportation sector's share of lead emissions declined from a high of $87.9 \%$ in 1978 to 31\% in 1990 (Table 3.45). The California Air Resources Board has declared emission standards for California vehicles. In order to meet these standards it is suggested that ten percent of the manufacturer's fleet in 1992 should be transitional low-emission vehicles, which have more stringent standards than conventional vehicles. Low-emission vehicles and ultra-low emission vehicles should then be phased into the fleet in 1997 (Table 3.46). As many as $10 \%$ of the manufacturer's fleet in the year 2003 should be zero-emission vehicles in order to meet the emission standards. 
Section 3.1.

\section{Highway Vehicle Characteristics}


Table 3.1

Highway Bnergy Une by Mode, 1970-90

\begin{tabular}{|c|c|c|c|c|c|c|}
\hline \multirow[t]{2}{*}{ Year } & Autos" & Buses & $\begin{array}{c}\text { Light } \\
\text { trucks }\end{array}$ & $\begin{array}{l}\text { Other } \\
\text { trucks }\end{array}$ & $\begin{array}{c}\text { Total } \\
\text { highway }\end{array}$ & \multirow{2}{*}{$\begin{array}{c}\text { Transportation } \\
\text { energy use } \\
\text { (trillion Btu) }\end{array}$} \\
\hline & \multicolumn{5}{|c|}{ (percentage of total) } & \\
\hline 1970 & $55.8 \%$ & $0.7 \%$ & $10.1 \%$ & $9.8 \%$ & $76.3 \%$ & 15,305 \\
\hline 1971 & $56.5 \%$ & $0.7 \%$ & $10.6 \%$ & $9.9 \%$ & $77.6 \%$ & 15,907 \\
\hline 1972 & $56.6 \%$ & $0.6 \%$ & $11.2 \%$ & $9.9 \%$ & $78.3 \%$ & 16,949 \\
\hline 1973 & $55.6 \%$ & $0.6 \%$ & $11.8 \%$ & $10.4 \%$ & $78.4 \%$ & 17,813 \\
\hline 1974 & $55.3 \%$ & $0.7 \%$ & $12.2 \%$ & $10.5 \%$ & $78.7 \%$ & 17,088 \\
\hline 1975 & $55.5 \%$ & $0.7 \%$ & $12.9 \%$ & $10.3 \%$ & $79.5 \%$ & 17,329 \\
\hline 1976 & $54.6 \%$ & $0.7 \%$ & $13.7 \%$ & $10.6 \%$ & $79.6 \%$ & 18,389 \\
\hline 1977 & $53.1 \%$ & $0.7 \%$ & $14.4 \%$ & $11.3 \%$ & $79.4 \%$ & 19,071 \\
\hline 1978 & $51.3 \%$ & $0.7 \%$ & $15.0 \%$ & $12.1 \%$ & $79.1 \%$ & 20,035 \\
\hline 1979 & $48.5 \%$ & $0.7 \%$ & $15.4 \%$ & $12.5 \%$ & $77.0 \%$ & 20,101 \\
\hline 1980 & $46.9 \%$ & $0.7 \%$ & $15.3 \%$ & $12.6 \%$ & $75.5 \%$ & 19,317 \\
\hline 1981 & $47.0 \%$ & $0.8 \%$ & $15.5 \%$ & $12.9 \%$ & $76.2 \%$ & 19,065 \\
\hline 1982 & $47.5 \%$ & $0.8 \%$ & $16.0 \%$ & $13.1 \%$ & $77.4 \%$ & 18,589 \\
\hline 1983 & $46.9 \%$ & $0.8 \%$ & $17.1 \%$ & $13.9 \%$ & $78.6 \%$ & 18,728 \\
\hline 1984 & $44.7 \%$ & $0.8 \%$ & $18.1 \%$ & $14.7 \%$ & $78.3 \%$ & 19,310 \\
\hline 1985 & $44.2 \%$ & $0.8 \%$ & $18.5 \%$ & $14.9 \%$ & $78.4 \%$ & 19,659 \\
\hline 1986 & $44.2 \%$ & $0.8 \%$ & $18.7 \%$ & $14.9 \%$ & $78.5 \%$ & 20,2209 \\
\hline 1987 & $42.9 \%$ & $0.8 \%$ & $19.5 \%$ & $15.2 \%$ & $78.3 \%$ & 20,704 \\
\hline 1988 & $42.3 \%$ & $0.8 \%$ & $19.3 \%$ & $15.5 \%$ & $77.9 \%$ & 21,278 \\
\hline 1989 & $42.0 \%$ & $0.8 \%$ & $19.2 \%$ & $15.9 \%$ & $77.9 \%$ & 21,598 \\
\hline 1990 & $41.6 \%$ & $0.8 \%$ & $19.1 \%$ & $15.6 \%$ & $77.1 \%$ & 21,778 \\
\hline
\end{tabular}

Source:

See Appendix A for Table 2.10.

Includes motorcycles.

'Does not include off-highway and military transportation energy use. 


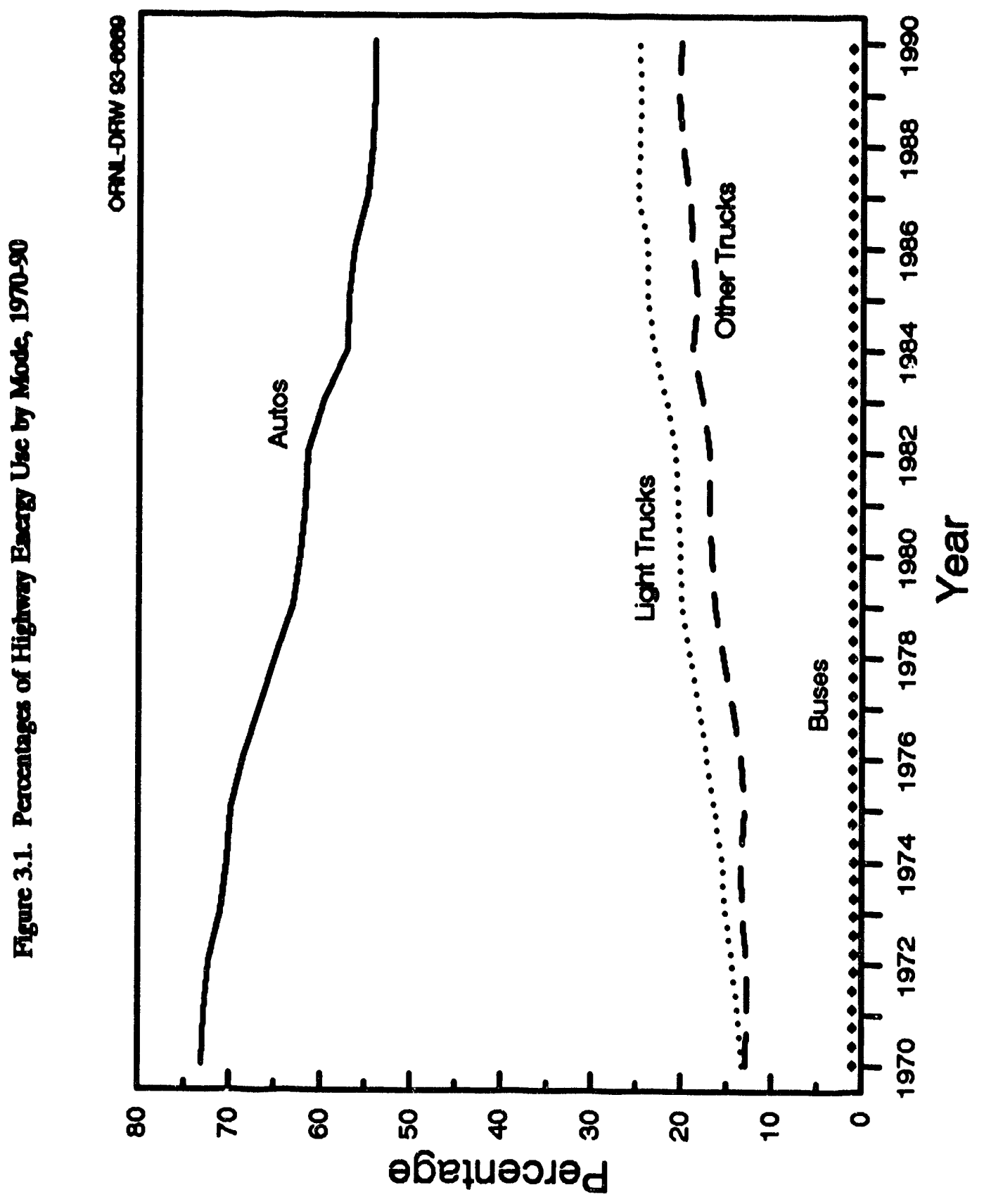

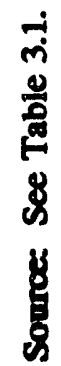


Although automobiles continued to be responsible for the majority of highway travel, two-axle, fourtire trucks had the fastest average growth in vehicle miles for 1970-90 and 1982-90.

Table 3.2

Highway Vehicle Miles Traveled by Mode, 1970-90 (million miles)

\begin{tabular}{cccccccc}
\hline Year & Automobiles & Buses & $\begin{array}{c}\text { Two-axle, } \\
\text { four-tire } \\
\text { trucks }\end{array}$ & $\begin{array}{c}\text { Other } \\
\text { single-unit } \\
\text { trucks }\end{array}$ & $\begin{array}{c}\text { Combination } \\
\text { trucks }\end{array}$ & Total \\
\hline 1970 & 919,679 & 4,544 & 123,286 & 27,081 & 35,134 & $1,109,724$ \\
1971 & 969,947 & 4,792 & 137,870 & 28,985 & 37,217 & $1,178,811$ \\
1972 & $1,025,696$ & 5,348 & 156,622 & 31,414 & 40,706 & $1,259,786$ \\
1973 & $1,051,175$ & 5,792 & 176,833 & 33,661 & 45,649 & $1,313,110$ \\
1974 & $1,012,696$ & 5,684 & 182,757 & 33,441 & 45,966 & $1,280,544$ \\
1975 & $1,039,579$ & 6,055 & 200,700 & 34,606 & 46,724 & $1,327,664$ \\
1976 & $1,084,218$ & 6,258 & 225,834 & 36,390 & 49,680 & $1,402,380$ \\
1977 & $1,115,592$ & 5,823 & 250,591 & 39,339 & 55,682 & $1,467,027$ \\
1978 & $1,153,666$ & 5,885 & 279,414 & 42,747 & 62,992 & $1,544,704$ \\
1979 & $1,122,277$ & 5,947 & 291,905 & 42,012 & 66,992 & $1,529,133$ \\
1980 & $1,121,810$ & 6,059 & 290,935 & 39,813 & 68,678 & $1,527,295$ \\
1981 & $1,141,517$ & 6,241 & 296,343 & 39,568 & 69,134 & $1,552,803$ \\
1982 & $1,176,166$ & 5,823 & 306,141 & 40,212 & 66,668 & $1,595,010$ \\
1983 & $1,206,783$ & 5,199 & 327,643 & 43,409 & 69,754 & $1,652,788$ \\
1984 & $1,233,703$ & 4,640 & 357,999 & 46,560 & 77,367 & $1,720,269$ \\
1985 & $1,269,651$ & 4,876 & 373,072 & 46,980 & 79,600 & $1,774,179$ \\
1986 & $1,312,921$ & 5,087 & 389,123 & 48,413 & 82,696 & $1,838,240$ \\
1987 & $1,364,836$ & 5,318 & 415,449 & 49,537 & 86,064 & $1,921,204$ \\
1988 & $1,439,603$ & 5,466 & 439,496 & 51,239 & 90,158 & $2,025,962$ \\
1989 & $1,488,140$ & 5,659 & 454,339 & 52,969 & 95,349 & $2,096,456$ \\
1990 & $1,524,942$ & 5,728 & 466,827 & 53,522 & 96,482 & $2,147,501$ \\
& & $4 v 96$ & & & \\
$1970-90$ & $2.6 \%$ & $1.2 \%$ & $6.9 \%$ & $3.5 \%$ & $5.2 \%$ & $3.4 \%$ \\
$1982-90$ & $3.3 \%$ & $-0.2 \%$ & $5.4 \%$ & $3.6 \%$ & $4.7 \%$ & $3.8 \%$ \\
\hline
\end{tabular}

Source:

U.S. Department of Transportation, Federal Highway Administration, Highway Statistics 1990, Washington, DC, 1991, Table VM-1, p.192, and annual.

Includes motorcycles.

'The data do not correspond with vehicle miles of travel presented in the Bus section of this chapter due to differing data sources. 


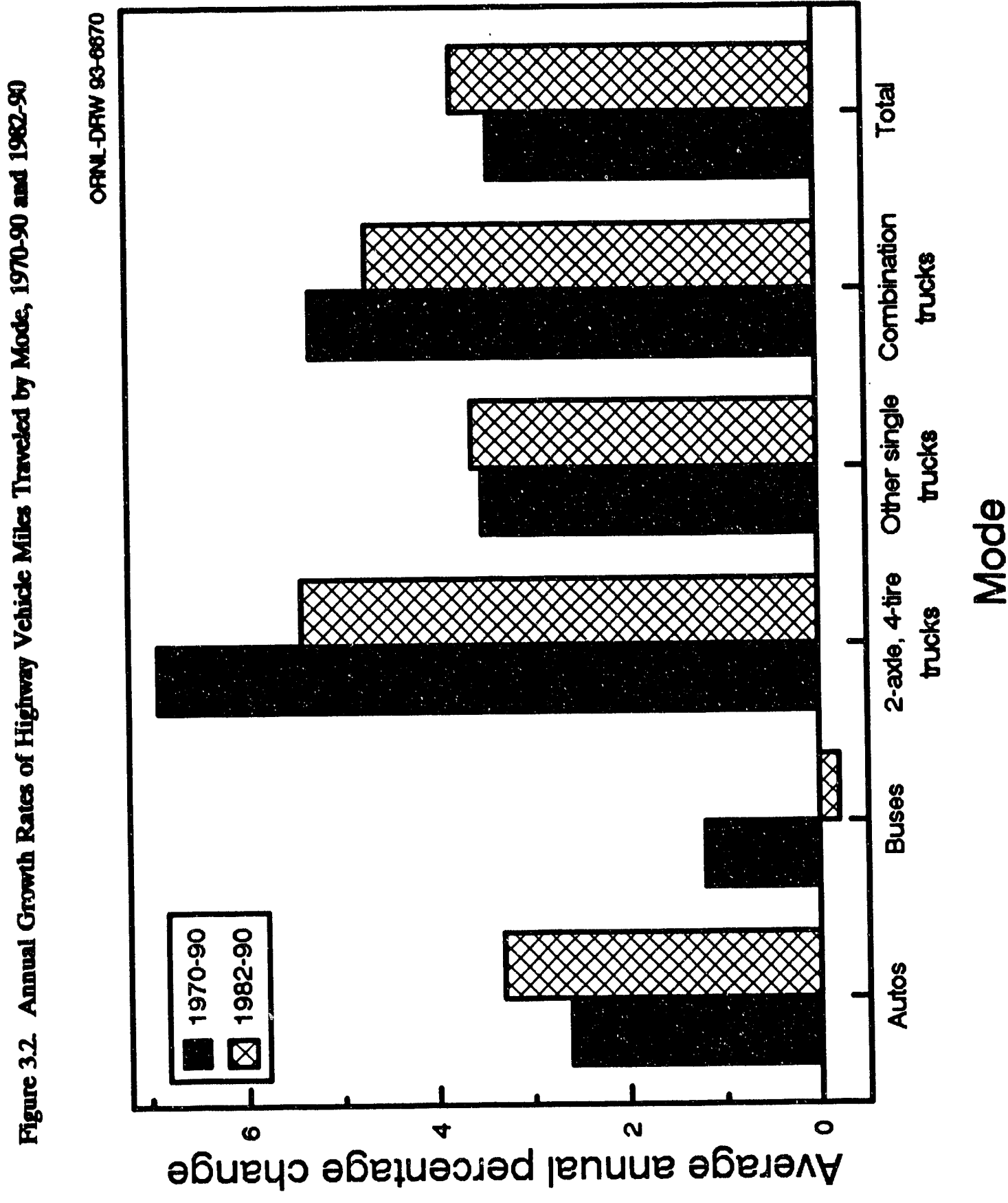

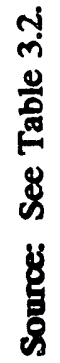


Table 3.3

Vehicle Stock and New Sales in United States, 1990 Culendar Year

\begin{tabular}{|c|c|c|c|c|c|}
\hline & & \multirow{2}{*}{$\begin{array}{c}\text { Vehicle } \\
\text { Stockb } \\
\text { (thousands) }\end{array}$} & \multicolumn{3}{|c|}{ New Sales } \\
\hline & & & $\begin{array}{c}\text { Domestic } \\
\text { (thousands) }\end{array}$ & $\begin{array}{c}\text { Import }^{\circ} \\
\text { (thousands) }\end{array}$ & $\begin{array}{c}\text { Total } \\
\text { (thousands) }\end{array}$ \\
\hline \multirow[t]{9}{*}{ Autod } & & 123,276 & $6,897(742 \%)$ & 2,404 (25.8\%) & $9,301(100.0 \%)$ \\
\hline & Two seaters & 2,846 & $35(20.1 \%)$ & $139(79.9 \%)$ & $174(100.0 \%)$ \\
\hline & Minicompact & 3,759 & $0(0.0 \%)$ & $82(100.0 \%)$ & $82(100.0 \%)$ \\
\hline & Subcompact & 28,608 & $1,014(50.2 \%)$ & $1,007(49.8 \%)$ & $2,021(100.0 \%)$ \\
\hline & Compact & 32,940 & $2,338(73.4 \%)$ & $846(26.6 \%)$ & $3,184(100.0 \%)$ \\
\hline & Midsize & 35,079 & $2,214(87.3 \%)$ & $322(12.7 \%)$ & $2,536(100.0 \%)$ \\
\hline & Large & 20,045 & $1,296(99.3 \%)$ & $9(0.7 \%)$ & $1,305(100.0 \%)$ \\
\hline & Fleets of ten or more & $8,188^{\circ}$ & $f$ & ' & $\mathbf{r}$ \\
\hline & Personal autos & 115,088 & r & ' & f \\
\hline \multicolumn{2}{|c|}{ Motorcycles } & 4,259 & 140 (33.3\%) & 322 (77.7\%) & $462(100.0 \%)$ \\
\hline \multicolumn{2}{|c|}{ Recreational vehictes } & 56,023 & $354(100.0 \%)$ & $0(0.0 \%)$ & $354(100 .(1 \%)$ \\
\hline \multirow[t]{5}{*}{ Tructor } & & 51,485 & $3,813(87.4 \%)$ & $551(126 \%)$ & $4,364(100.0 \%)$ \\
\hline & Light & 1,289 & $3,595(87.2 \%)$ & $527(12.8 \%)$ & $4,122(100.0 \%)$ \\
\hline & Medium & 1,289 & $33(68.8 \%)$ & $15(31.3 \%)$ & $48(100.0 \%)$ \\
\hline & Light-heavy & 952 & $19(82.6 \%)$ & $4(17.4 \%)$ & $23(100.0 \%)$ \\
\hline & Heavy-heavy & 2,297 & $166(97.1 \%)$ & $5(2.9 \%)$ & $171(100.0 \%)$ \\
\hline
\end{tabular}

Source:

See Appendix A for Table 3.3

Totals may not equal sum of components due to rounding.

Wehicle stock as of July 1.

'Includes domestic-sponsored imports.

These figures represent only those automobiles that could be matched to the Environmental Protection Agency size clasecs.

-Federal Government fleet data for 1990 were not available; therefore, the 1990 data were assumed to be equal to the 1988 Federal Government fleet figures.

'Data are not available.

Includes mostly on-highway motorcycles. Many states do not require registration for off-highway vehicles.

-Trucks are classified by gross vehicle weight as follows:

$\begin{array}{ll}\text { Light } & 0-10,000 \text { pounds } \\ \text { Medium } & 10,001-19,500 \text { pounds } \\ \text { Light-heavy } & 19,501-26,000 \text { pounds } \\ \text { Heavy-heavy } & 26,001 \text { pounds and over. }\end{array}$



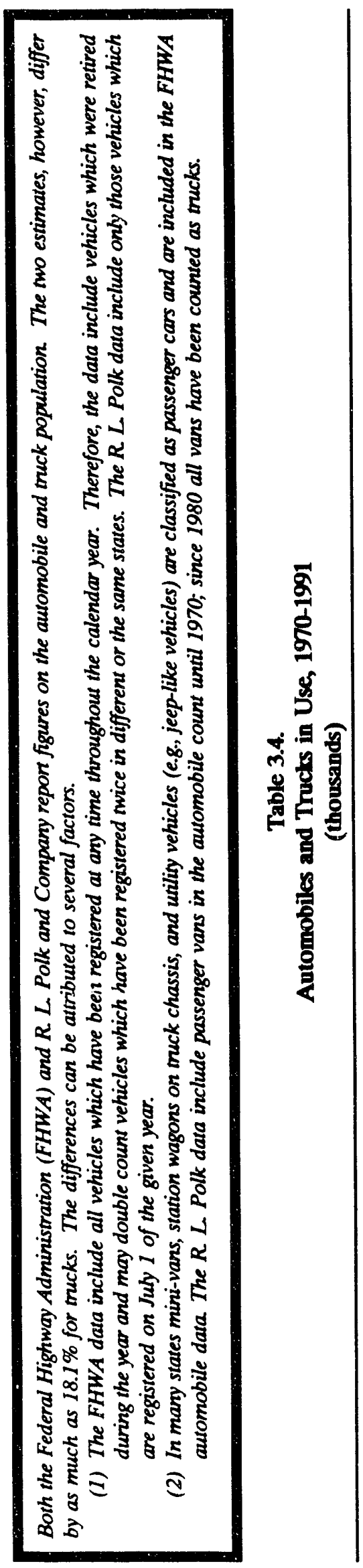

즁

훌

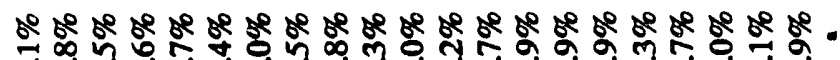

离

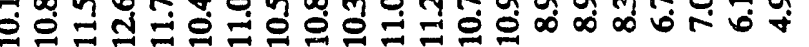

喜

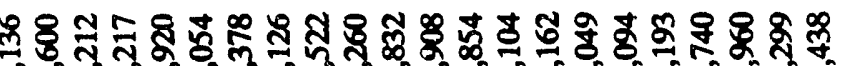

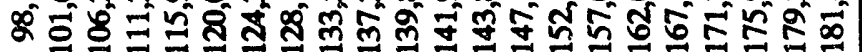

אీ

(⿸丆口

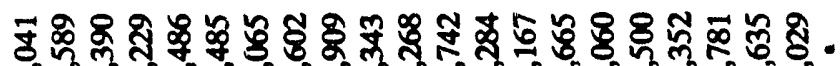

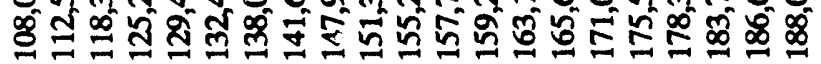

i

$\sum^{5}$

善

\&

ư

$\& \&$

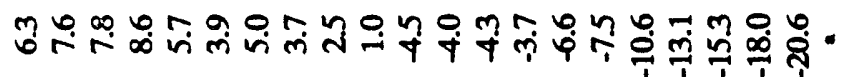

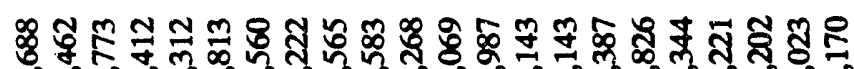

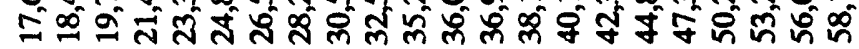

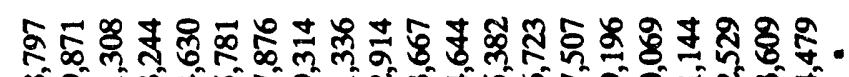

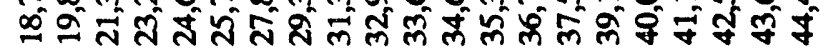

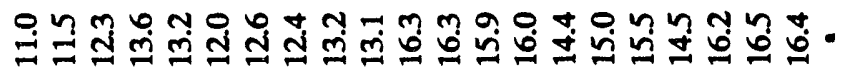

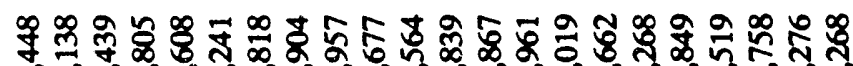

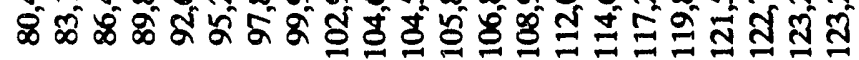

$\frac{3}{5}$

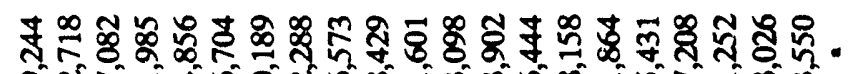

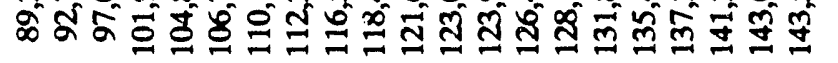

蛋

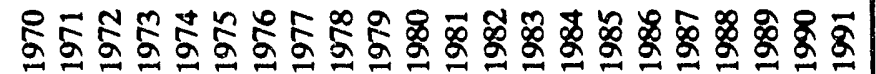

옹

然 
The average age of automobiles continued to increase in 1991 after remaining steady from 1985 to 1989. The average age gap between autos and trucks in 1991 was 0.2 years, as it was in 1990. The median age for both autos and trucks rose in 1991.

Thble 35

Average Age of Automobiles and Truch in Use, 1970-1991 (vears)

\begin{tabular}{cccccc}
\hline \multirow{2}{*}{$\begin{array}{c}\text { Calendar } \\
\text { year }\end{array}$} & \multicolumn{2}{c}{ Automobiles } & & \multicolumn{2}{c}{ Trucks } \\
\cline { 2 - 2 } \cline { 5 - 6 } & Mean & Median & & Mean & Median \\
\hline 1970 & 5.6 & 4.9 & & 7.3 & 5.9 \\
1971 & 5.7 & 5.1 & & 7.4 & 6.1 \\
1972 & 5.7 & 5.1 & & 7.2 & 6.0 \\
1973 & 5.7 & 5.1 & & 6.9 & 5.8 \\
1974 & 5.7 & 5.2 & & 7.0 & 5.6 \\
1975 & 6.0 & 5.4 & & 6.9 & 5.8 \\
1976 & 6.2 & 5.5 & & 7.0 & 5.8 \\
1977 & 6.2 & 5.6 & & 6.9 & 5.7 \\
1978 & 6.3 & 5.7 & & 6.9 & 5.8 \\
1979 & 6.4 & 5.9 & & 6.9 & 5.9 \\
1980 & 6.6 & 6.0 & & 7.1 & 6.3 \\
1981 & 6.9 & 6.0 & & 7.5 & 6.5 \\
1982 & 7.2 & 6.2 & & 7.8 & 6.8 \\
1983 & 7.4 & 6.5 & & 8.1 & 7.2 \\
1984 & 7.5 & 6.7 & & 8.2 & 7.4 \\
1985 & 7.6 & 6.9 & & 8.1 & 7.6 \\
1986 & 7.6 & 7.0 & & 8.0 & 7.7 \\
1987 & 7.6 & 6.9 & 8.0 & 7.8 \\
1988 & 7.6 & 6.8 & 7.9 & 7.1 \\
1989 & 7.6 & 6.5 & 7.9 & 6.7 \\
1990 & 7.8 & 6.5 & 8.0 & 6.5 \\
1991 & 7.9 & 6.7 & 8.1 & 6.8 \\
\hline
\end{tabular}

Source:

R. L. Polk and Co., Detroit, MI. FURTHER REPRODUCTION PROHIBITED. 


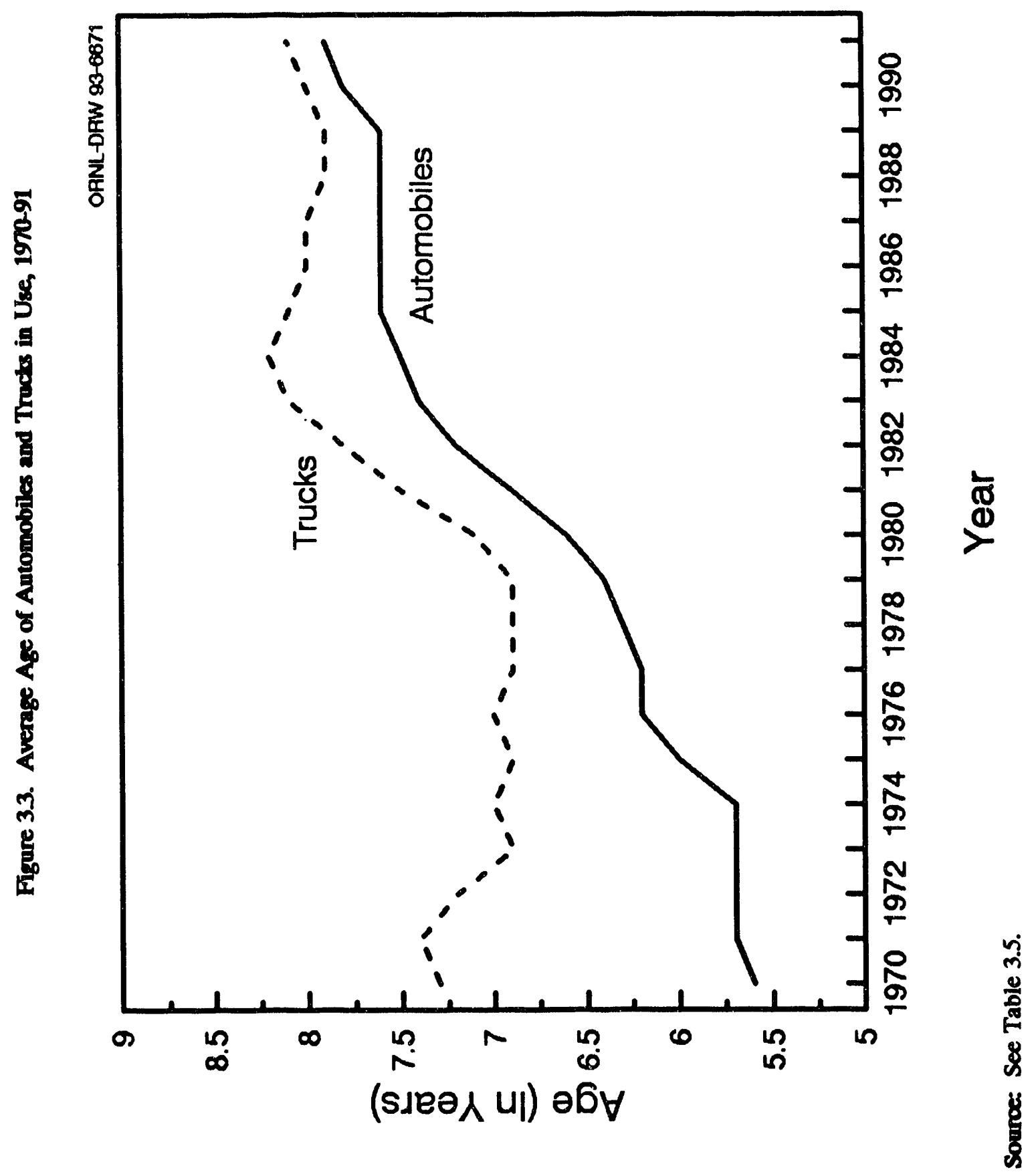


Table 3.6

Scrappage and Survival Rates for Automobiles,

All Trucks, and Light Trucks

\begin{tabular}{|c|c|c|c|c|c|c|}
\hline \multirow{2}{*}{$\begin{array}{c}\text { Vehicle } \\
\text { Age } \\
\text { (Years) }\end{array}$} & \multicolumn{2}{|c|}{$\begin{array}{c}\text { Automobiles } \\
(1978-89) \\
\end{array}$} & \multicolumn{2}{|c|}{$\begin{array}{l}\text { All Truckss } \\
\text { (1978-89) }\end{array}$} & \multicolumn{2}{|c|}{$\begin{array}{l}\text { Light Trucks } \\
(1978-88)\end{array}$} \\
\hline & $\begin{array}{l}\text { Scrappage } \\
\text { Rate }\end{array}$ & $\begin{array}{l}\text { Survival } \\
\text { Rate }\end{array}$ & $\begin{array}{l}\text { Scrappage } \\
\text { Rate }\end{array}$ & $\begin{array}{l}\text { Survival } \\
\text { Rate }\end{array}$ & $\begin{array}{c}\text { Scrappage } \\
\text { Rate }\end{array}$ & $\begin{array}{l}\text { Survival } \\
\text { Rate }\end{array}$ \\
\hline 0 & 0.00000 & 1.00000 & 0.00000 & 1.00000 & 0.00000 & 1.00000 \\
\hline 1 & 0.00441 & 0.99559 & 0.00312 & 0.99688 & 0.00249 & 0.99751 \\
\hline 2 & 0.00674 & 0.98888 & 0.00461 & 0.99228 & 0.00383 & 0.99369 \\
\hline 3 & 0.01025 & 0.97874 & 0.00676 & 0.98557 & 0.00583 & 0.98790 \\
\hline 4 & 0.01546 & 0.96361 & 0.00980 & 0.97591 & 0.00877 & 0.97923 \\
\hline 5 & 0.02303 & 0.94142 & 0.01399 & 0.96226 & 0.01296 & 0.96654 \\
\hline 6 & 0.03368 & 0.90971 & 0.01957 & 0.94343 & 0.01869 & 0.94848 \\
\hline 7 & 0.04803 & 0.86602 & 0.02663 & 0.91830 & 0.02606 & 0.92376 \\
\hline 8 & 0.06629 & 0.80861 & 0.03507 & 0.88609 & 0.03488 & 0.89154 \\
\hline 9 & 0.08790 & 0.73753 & 0.04445 & 0.84671 & 0.04454 & 0.85182 \\
\hline 10 & 0.11137 & 0.65539 & 0.05408 & 0.80092 & 0.05416 & 0.80569 \\
\hline 11 & 0.13460 & 0.56717 & 0.06320 & 0.75030 & 0.06285 & 0.75505 \\
\hline 12 & 0.15557 & 0.47894 & 0.07121 & 0.69687 & 0.07006 & 0.70215 \\
\hline 13 & 0.17300 & 0.39608 & 0.07776 & 0.64268 & 0.07562 & 0.64905 \\
\hline 14 & 0.18650 & 0.32221 & 0.08285 & 0.58944 & 0.07967 & 0.59734 \\
\hline 15 & 0.19641 & 0.25893 & 0.08662 & 0.53838 & 0.08251 & 0.54805 \\
\hline 16 & 0.20339 & 0.20626 & 0.08932 & 0.49029 & 0.08443 & 0.50178 \\
\hline 17 & 0.20818 & 0.16332 & 0.0 .3122 & 0.44557 & 0.08571 & 0.45877 \\
\hline 18 & 0.21140 & 0.12880 & $0.0 \ni 253$ & 0.40434 & 0.08655 & 0.41907 \\
\hline 19 & 0.21353 & 0.10130 & 0.09343 & 0.36656 & 0.08710 & 0.38257 \\
\hline 20 & 0.21493 & 0.07952 & 0.09403 & 0.33209 & 0.08745 & 0.34911 \\
\hline 21 & 0.21585 & 0.06236 & 0.09444 & 0.30073 & 0.08768 & 0.31850 \\
\hline 22 & 0.21644 & 0.04886 & 0.09471 & 0.27225 & 0.08783 & 0.29052 \\
\hline 23 & 0.21683 & 0.03827 & 0.09490 & 0.24641 & 0.08793 & 0.26498 \\
\hline 24 & 0.21708 & 0.02996 & 0.09502 & 0.22300 & 0.08799 & 0.24166 \\
\hline 25 & 0.21724 & 0.02345 & 0.09510 & 0.20179 & 0.08803 & 0.22039 \\
\hline
\end{tabular}

Source:

Miaou, Shaw-Pin, "Study of Vehicle Scrappage Rates," Oak Ridge National Laboratory, Oak Ridge, TN, August 1990. 


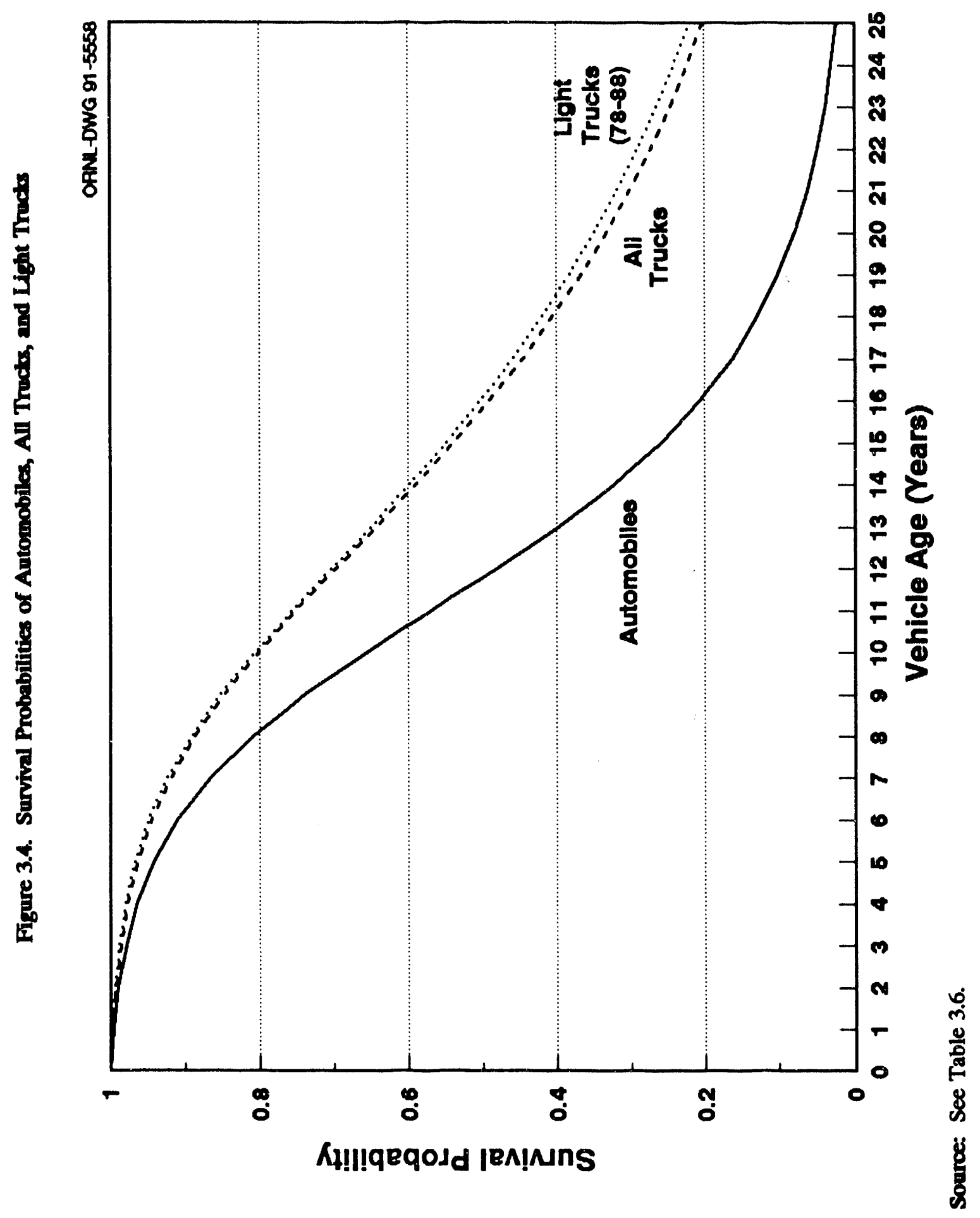


Table 3.7

Scrappage and Survival Rates for Automobiles

\begin{tabular}{|c|c|c|c|c|c|c|}
\hline \multirow{2}{*}{$\begin{array}{c}\text { Vehicle } \\
\text { Age } \\
\text { (Years) }\end{array}$} & \multicolumn{2}{|c|}{$(1966-73)$} & \multicolumn{2}{|c|}{$(1973-78)$} & \multicolumn{2}{|c|}{ (1978-89) } \\
\hline & $\begin{array}{l}\text { Scrappage } \\
\text { Rate }\end{array}$ & $\begin{array}{l}\text { Survival } \\
\text { Rate }\end{array}$ & $\begin{array}{c}\text { Scrappage } \\
\text { Rate }\end{array}$ & $\begin{array}{l}\text { Survival } \\
\text { Rate }\end{array}$ & $\begin{array}{c}\text { Scrappage } \\
\text { Rate }\end{array}$ & $\begin{array}{l}\text { Survival } \\
\text { Rate }\end{array}$ \\
\hline 0 & 0.00000 & 1.00000 & 0.00000 & 1.00000 & 0.00000 & 1.00000 \\
\hline 1 & 0.00115 & 0.99885 & 0.00347 & 0.99653 & 0.00441 & 0.99559 \\
\hline 2 & 0.00244 & 0.99641 & 0.00589 & 0.99065 & 0.00674 & 0.98888 \\
\hline 3 & 0.00513 & 0.99130 & 0.00993 & 0.98082 & 0.01025 & 0.97874 \\
\hline 4 & 0.01069 & 0.98070 & 0.01656 & 0.96457 & 0.01546 & 0.96361 \\
\hline 5 & 0.02182 & 0.95931 & 0.02714 & 0.93839 & 0.02303 & 0.94142 \\
\hline 6 & 0.04283 & 0.91822 & 0.04329 & 0.89778 & 0.03368 & 0.90971 \\
\hline 7 & 0.07844 & 0.84619 & 0.06633 & 0.83822 & 0.04803 & 0.86602 \\
\hline 8 & 0.12895 & 0.73707 & 0.09627 & 0.75753 & 0.06629 & 0.80861 \\
\hline 9 & 0.18510 & 0.60064 & 0.13071 & 0.65851 & 0.08790 & 0.73753 \\
\hline 10 & 0.23288 & 0.46076 & 0.16524 & 0.54970 & 0.11137 & 0.65539 \\
\hline 11 & 0.26512 & 0.33860 & 0.19538 & 0.44230 & 0.13460 & 0.56717 \\
\hline 12 & 0.28362 & 0.24257 & 0.21867 & 0.34558 & 0.15557 & 0.47894 \\
\hline 13 & 0.29327 & 0.17143 & 0.23503 & 0.26436 & 0.17300 & 0.39608 \\
\hline 14 & 0.29804 & 0.12034 & 0.24577 & 0.19939 & 0.18650 & 0.32221 \\
\hline 15 & 0.30034 & 0.08420 & 0.25251 & 0.14904 & 0.19641 & 0.25893 \\
\hline 16 & 0.30144 & 0.05882 & 0.25662 & 0.11079 & 0.20339 & 0.20626 \\
\hline 17 & 0.30196 & 0.04106 & 0.25908 & 0.08209 & 0.20818 & 0.16332 \\
\hline 18 & 0.30221 & 0.02865 & 0.26054 & 0.06070 & 0.21140 & 0.12880 \\
\hline 19 & 0.30232 & 0.01999 & 0.26140 & 0.04483 & 0.21353 & 0.10130 \\
\hline 20 & 0.30238 & 0.01394 & 0.26190 & 0.03309 & 0.21493 & 0.07952 \\
\hline 21 & 0.30240 & 0.00973 & 0.26220 & 0.02442 & 0.21585 & 0.06236 \\
\hline 22 & 0.30241 & 0.00679 & 0.26237 & 0.01801 & 0.21644 & 0.04886 \\
\hline 23 & 0.30242 & 0.00473 & 0.26247 & 0.01328 & 0.21683 & 0.03827 \\
\hline 24 & 0.30242 & 0.00330 & 0.26253 & 0.00980 & 0.21708 & 0.02996 \\
\hline 25 & 0.30242 & 0.00230 & 0.26257 & 0.00722 & 0.21724 & 0.02345 \\
\hline
\end{tabular}

Source:

Miaou, Shaw-Pin, "Study of Vehicle Scrappage Rates," Oak Ridge National Laboratory, Oak Ridge, TN, August 1990. 


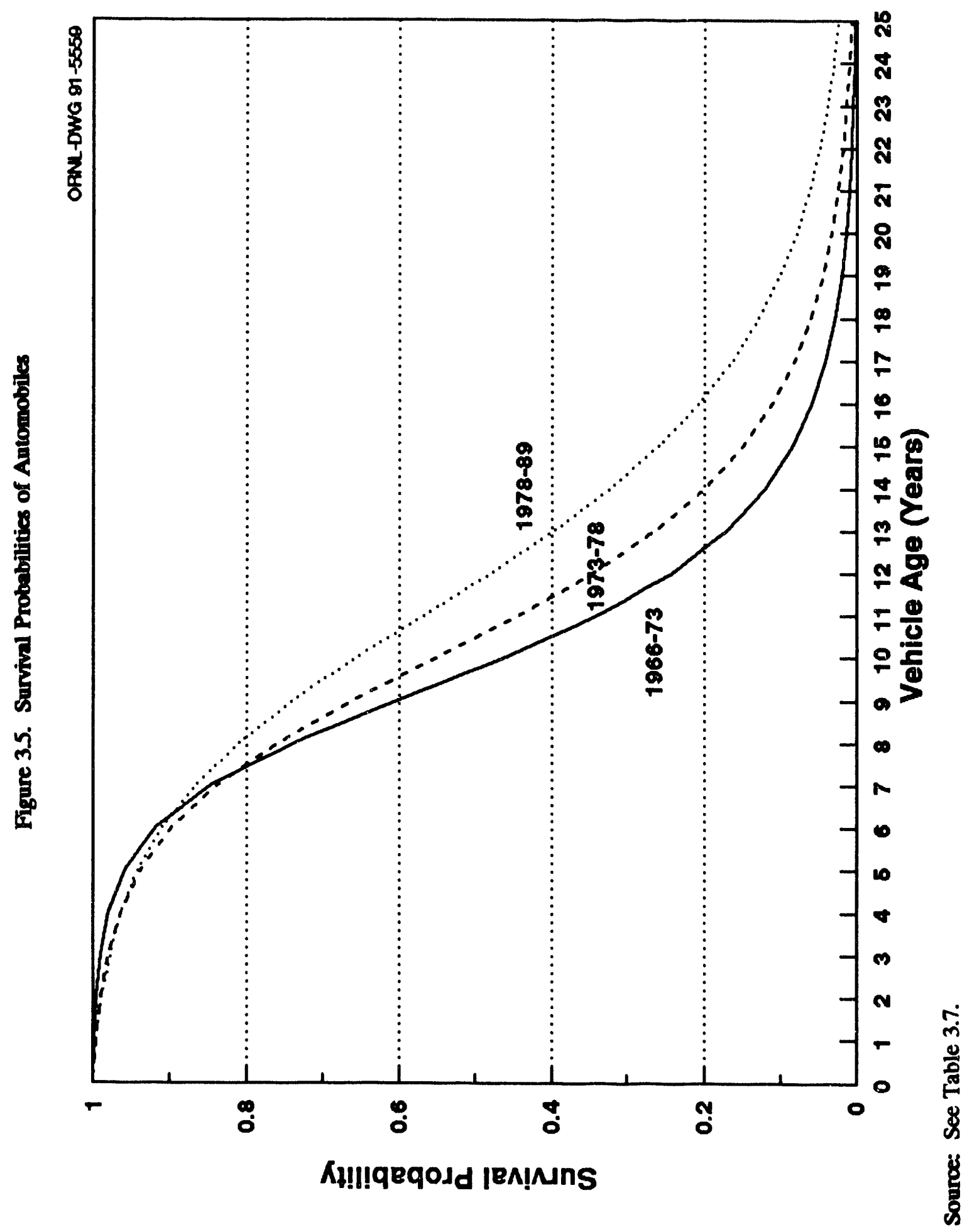


Table 3.8.

Scrappage and Survival Rates for All Trucks

\begin{tabular}{|c|c|c|c|c|c|c|}
\hline \multirow{2}{*}{$\begin{array}{c}\text { Vehicle } \\
\text { Age } \\
\text { (Years) }\end{array}$} & \multicolumn{2}{|c|}{ (1966-73) } & \multicolumn{2}{|c|}{$(1973-78)$} & \multicolumn{2}{|c|}{$(1978-89)$} \\
\hline & $\begin{array}{l}\text { Scrappage } \\
\text { Rate }\end{array}$ & $\begin{array}{l}\text { Survival } \\
\text { Rate }\end{array}$ & $\begin{array}{c}\text { Scrappage } \\
\text { Rate }\end{array}$ & $\begin{array}{l}\text { Surviva } \\
\text { Rate }\end{array}$ & $\begin{array}{c}\text { Scrappage } \\
\text { Rate }\end{array}$ & $\begin{array}{l}\text { Survival } \\
\text { Rate }\end{array}$ \\
\hline 0 & 0.00000 & 1.00000 & 0.00000 & 1.00000 & 0.00000 & 1.00000 \\
\hline 1 & 0.00582 & 0.99418 & 0.00505 & 0.99495 & 0.00312 & 0.99688 \\
\hline 2 & 0.00814 & 0.98608 & 0.00698 & 0.98801 & 0.00461 & 0.99228 \\
\hline 3 & 0.01129 & 0.97495 & 0.00958 & 0.97854 & 0.00676 & 0.98557 \\
\hline 4 & 0.01550 & 0.95983 & 0.01306 & 0.96576 & 0.00980 & 0.97591 \\
\hline 5 & 0.02101 & 0.93967 & 0.01762 & 0.94873 & 0.01399 & 0.96226 \\
\hline 6 & 0.02798 & 0.91337 & 0.02347 & 0.92647 & 0.01957 & 0.94343 \\
\hline 7 & 0.03649 & 0.88005 & 0.03073 & 0.89800 & 0.02663 & 0.91830 \\
\hline 8 & 0.04638 & 0.83923 & 0.03943 & 0.86260 & 0.03507 & 0.88609 \\
\hline 9 & 0.05730 & 0.79114 & 0.04940 & 0.81999 & 0.04445 & 0.84671 \\
\hline 10 & 0.06863 & 0.73685 & 0.06026 & 0.77058 & 0.05408 & 0.80092 \\
\hline 11 & 0.07970 & 0.67812 & 0.07147 & 0.71551 & 0.06320 & 0.75030 \\
\hline 12 & 0.08987 & 0.61718 & 0.08239 & 0.65656 & 0.07121 & 0.69687 \\
\hline 13 & 0.09872 & 0.55625 & 0.09247 & 0.59585 & 0.07776 & 0.64268 \\
\hline 14 & 0.10605 & 0.49726 & 0.10130 & 0.53548 & 0.08285 & 0.58944 \\
\hline 15 & 0.11189 & 0.44162 & 0.10871 & 0.47727 & 0.08662 & 0.53838 \\
\hline 16 & 0.11638 & 0.39023 & 0.11468 & 0.42254 & 0.08932 & 0.49029 \\
\hline 17 & 0.11976 & 0.34349 & 0.11936 & 0.37210 & 0.09122 & 0.44557 \\
\hline 18 & 0.12225 & 0.30150 & 0.12294 & 0.32636 & 0.09253 & 0.40434 \\
\hline 19 & 0.12406 & 0.26410 & 0.12562 & 0.28536 & 0.09343 & 0.36656 \\
\hline 20 & 0.12536 & 0.23099 & 0.12761 & 0.24894 & 0.09403 & 0.33209 \\
\hline 21 & 0.12629 & 0.20182 & 0.12906 & 0.21681 & 0.09444 & 0.30073 \\
\hline 22 & 0.12696 & 0.17620 & 0.13012 & 0.18860 & 0.09471 & 0.27225 \\
\hline 23 & 0.12743 & 0.15374 & 0.13089 & 0.16392 & 0.09490 & 0.24641 \\
\hline 24 & 0.12776 & 0.13410 & 0.13144 & 0.14237 & 0.09502 & 0.22300 \\
\hline 25 & 0.12799 & 0.11694 & 0.13183 & 0.12360 & 0.09510 & 0.20179 \\
\hline
\end{tabular}

Source:

Miaou, Shaw-Pin, "Study of Vehicle Scrappage Rates," Oak Ridge National Laboratory, Oak Ridge, TN, August 1990. 


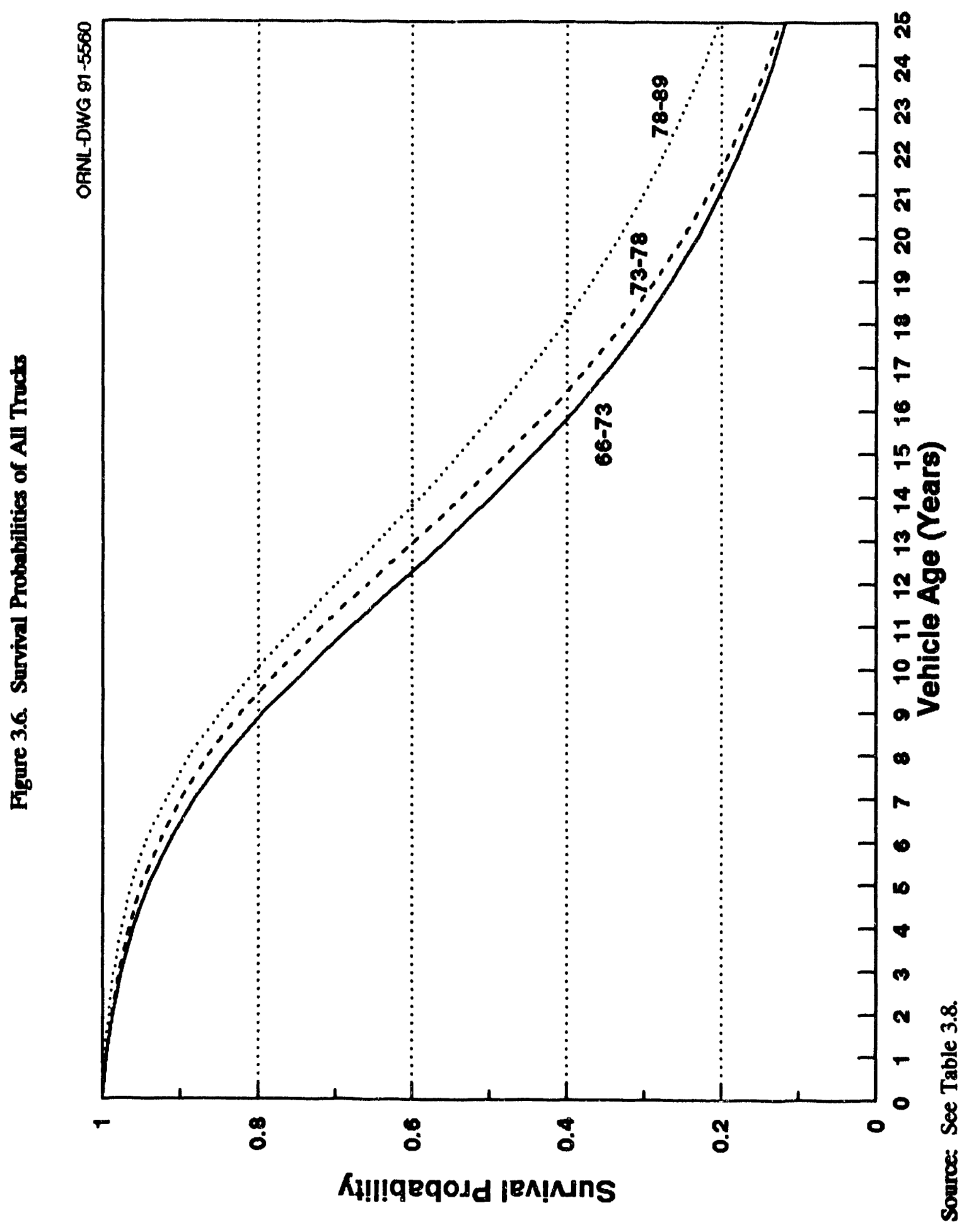


Section 3.2. Automobiles 
Although the import share of total retail automobile sales dropped to $24.9 \%$ in 1991, the percentage of transplant sales increased by nearly 3\% in the same time period. Total sales in 1991 dropped below 9 million for the first time since 1982.

Table 3.9

New Retail Automobile Sales in the United States, 1970-91

\begin{tabular}{|c|c|c|c|c|c|c|c|}
\hline \multirow{2}{*}{$\begin{array}{c}\text { Calendar } \\
\text { yuar }\end{array}$} & Domestic & Import' & Total & \multirow{2}{*}{$\begin{array}{c}\text { Percentage } \\
\text { import }\end{array}$} & \multirow{2}{*}{$\begin{array}{c}\text { Percentage } \\
\text { transplants }{ }^{8} \text { on } \\
\text { model year basis }\end{array}$} & \multirow{2}{*}{$\begin{array}{c}\text { Percentage } \\
\text { imports and } \\
\text { transplants }\end{array}$} & \multirow{2}{*}{$\begin{array}{c}\text { Percentage } \\
\text { diesel }\end{array}$} \\
\hline & \multicolumn{3}{|c|}{ (thousands) } & & & & \\
\hline 1970 & 7,119 & 1,285 & 8,404 & 15.3 & c & c & c \\
\hline 1971 & 8,681 & 1,568 & 10,249 & 15.3 & c & c & 0.06 \\
\hline 1972 & 9,327 & 1,623 & 10,950 & 14.8 & c & c & 0.05 \\
\hline 1973 & 9,676 & 1,763 & 11,439 & 15.4 & c & c & 0.06 \\
\hline 1974 & 7,454 & 1,399 & 8,853 & 15.8 & c & c & 0.20 \\
\hline 1975 & 7,053 & 1,571 & 8,624 & 18.2 & c & c & 0.31 \\
\hline 1976 & 8,611 & 1,499 & 10,110 & 14.8 & 0.0 & 14.8 & 0.22 \\
\hline 1977 & 9,109 & 2,074 & 11,183 & 18.5 & 0.0 & 18.5 & 0.34 \\
\hline 1978 & 9,312 & 2,002 & 11,314 & 17.7 & 0.0 & 17.7 & 1.02 \\
\hline 1979 & 8,341 & 2,332 & 10,673 & 21.8 & 1.3 & 23.1 & 2.54 \\
\hline 1980 & 6,581 & 2,398 & 8,979 & 26.7 & 2.1 & 28.8 & 4.31 \\
\hline 1981 & 6,209 & 2,327 & 8,536 & 27.3 & 1.8 & 29.1 & 6.10 \\
\hline 1982 & 5,759 & 2,223 & 7,982 & 27.9 & 1.4 & 29.3 & 4.44 \\
\hline 1983 & 6,795 & 2,387 & 9,182 & 26.0 & 1.3 & 27.3 & 2.09 \\
\hline 1984 & 7,952 & 2,439 & 10,391 & 23.5 & 2.0 & 25.5 & 1.45 \\
\hline 1985 & 8,205 & 2,838 & 11,043 & 25.7 & 2.2 & 27.9 & 0.82 \\
\hline 1986 & 8,215 & 3,238 & 11,453 & 28.3 & 2.8 & 31.1 & 0.37 \\
\hline 1987 & 7,081 & 3,197 & 10,278 & 31.1 & 5.2 & 36.3 & 0.16 \\
\hline 1988 & 7,526 & 3,099 & 10,626 & 29.2 & 5.8 & 35.0 & 0.01 \\
\hline 1989 & 7,073 & 2,825 & 9,898 & 28.5 & 7.3 & 35.8 & 0.13 \\
\hline 1990 & 6,897 & 2,404 & 9,301 & 25.8 & 11.2 & 37.0 & 0.08 \\
\hline 1991 & 6,137 & 2,038 & 8,175 & 24.9 & 13.7 & 38.6 & 0.13 \\
\hline \multicolumn{8}{|c|}{ Average annual percentage change } \\
\hline $1970-91$ & $-0.7 \%$ & $2.2 \%$ & $-0.1 \%$ & & & & \\
\hline $1982-91$ & $0.7 \%$ & $-1.0 \%$ & $0.3 \%$ & & & & \\
\hline
\end{tabular}

Domestic and import data - Motor Vehicle Manufacturers Association, Motor Vehicle Facts and Fiqures ' 92, Detroit, MI, 1992, p. 16, and annual.

Diesel data - H. A. Stark (ed), Ward's Communications, Inc., Ward's Automotive Yearbook, Detroit, MI, 1992 , p. 57, and annual.

Transplant data - Oak Ridge National Laboratory, Light-Duty Vehicle MPG and Market Shares Data System, Oak Ridge, TN, 1992

'Does not include import tourist deliveries.

${ }^{b}$ A transplant is an automobile which was built in the U.S. by a foreign firm. Also included are joint ventures which are built in the U.S.

${ }^{\circ}$ Data are not available. 
Compared to 1970, the automobile population has shifted toward older automobiles in 1991. Fifty percent of the automobile population in 1970 was 4.9 years old or older while half of the automobile population in 1990 was 6.7 years old or older. The percent of cars 10 years old and older has nearly tripled from $11.7 \%$ in 1970 to $30.7 \%$ in 1991 .

Table 3.10

Automobiles in Use by Age, 1970 and 1991

\begin{tabular}{|c|c|c|c|c|c|c|}
\hline \multirow[b]{2}{*}{$\begin{array}{c}\text { Age } \\
\text { (years) }\end{array}$} & \multicolumn{3}{|c|}{1970} & \multicolumn{3}{|c|}{1991} \\
\hline & $\begin{array}{l}\text { Vehicles } \\
\text { (thousands) }\end{array}$ & $\begin{array}{c}\text { Actual } \\
\text { percentage }\end{array}$ & $\begin{array}{l}\text { Cumulative } \\
\text { percentage }\end{array}$ & $\begin{array}{l}\text { Vehicles } \\
\text { (thousands) }\end{array}$ & $\begin{array}{c}\text { Actual } \\
\text { percentage }\end{array}$ & $\begin{array}{l}\text { Cumulative } \\
\text { percentage }\end{array}$ \\
\hline Under $1^{*}$ & 6,288 & 7.8 & 7.8 & 5,763 & 4.7 & 4.7 \\
\hline 1 & 9,299 & 11.6 & 19.4 & 8,696 & 7.1 & 11.7 \\
\hline 2 & 8,816 & 11.0 & 30.3 & 9,713 & 7.9 & 19.6 \\
\hline 3 & 7,878 & 9.8 & 40.1 & 10,124 & 8.7 & 27.8 \\
\hline 4 & 8,538 & 10.6 & 50.8 & 10,049 & 8.1 & 36.0 \\
\hline 5 & 8,506 & 10.6 & 61.3 & 10,214 & 8.3 & 44.2 \\
\hline 6 & 7,116 & 8.8 & 70.2 & 9,732 & 7.9 & 52.1 \\
\hline 7 & 6,268 & 7.8 & 78.0 & 9,208 & 7.5 & 59.6 \\
\hline 8 & 5,058 & 6.3 & 84.3 & 6,543 & 5.3 & 64.9 \\
\hline 9 & 3,267 & 4.1 & 88.3 & 5,721 & 4.6 & 69.5 \\
\hline 10 & 2,776 & 3.5 & 91.8 & 5,673 & 4.6 & 74.1 \\
\hline 11 & 1,692 & 2.1 & 93.9 & 5,326 & 4.3 & 78.5 \\
\hline 12 & 799 & 1.0 & 94.9 & 5,743 & 4.7 & 83.1 \\
\hline 13 & 996 & 1.2 & 96.1 & 4,891 & 4.0 & 87.1 \\
\hline 14 & 794 & 1.0 & 97.1 & 3,759 & 3.0 & 90.1 \\
\hline 15 and older & 2,336 & 2.9 & 100.0 & 12,167 & 9.9 & 100.0 \\
\hline Subtotal & 80,427 & 100.0 & & 123,322 & 100.0 & \\
\hline Age not given ${ }^{b}$ & 22 & & & 6 & & \\
\hline Total & 80,449 & & & 123,328 & & \\
\hline Average age & & 5.55 & & & 7.91 & \\
\hline Median age & & 4.93 & & & 6.73 & \\
\hline
\end{tabular}

Source:

R. L. Polk and Co., Detroit, MI. FURTHER REPRODUCTION PROHIBITED.

-Automobiles sold as of July 1 of each year.

'Approximately 22,000 automobiles in 1970 and 6,000 in 1991 could not be classified by age. 


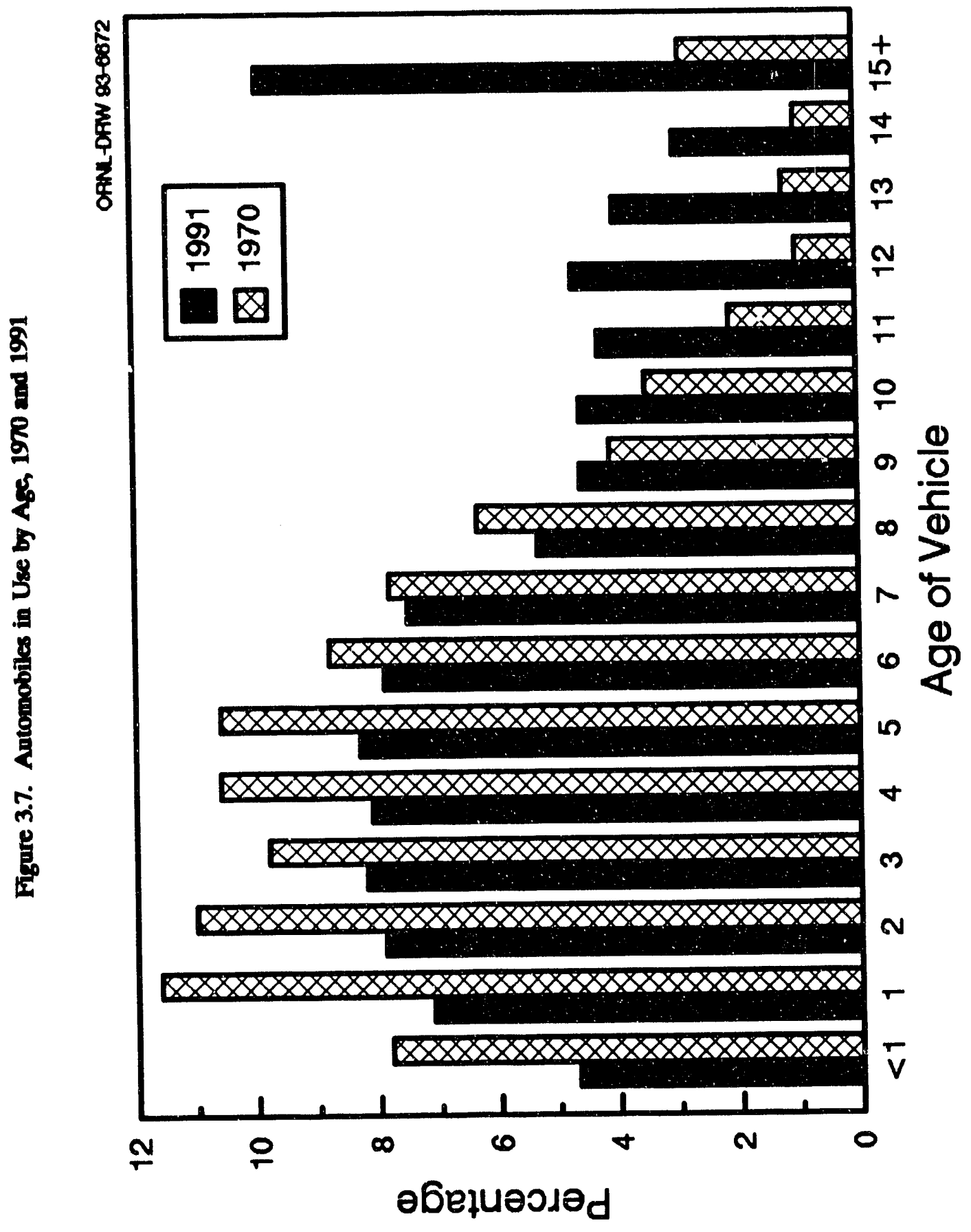

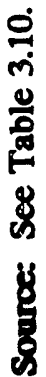


In 1991, automobiles 5 years old and younger accounted for $53 \%$ of all automobile travel. Although $70 \%$ of all automobiles in operation in 1991 were less than 10 years old, those autos were responsible for $78 \%$ of automobile travel.

Table 3.11

Automobiles in Operation

and Vehicle Travel by Age of Vehicke, 1991

\begin{tabular}{|c|c|c|c|c|c|}
\hline \multirow{2}{*}{$\begin{array}{c}\text { Vehicle } \\
\text { age } \\
\text { (years) }\end{array}$} & \multicolumn{3}{|c|}{ Number in operation } & \multicolumn{2}{|c|}{ Estimated vehicle travel } \\
\hline & $\begin{array}{l}\text { Vehicles } \\
\text { (thousands) }\end{array}$ & $\begin{array}{c}\text { Actual } \\
\text { percentage }\end{array}$ & $\begin{array}{l}\text { Cuinulative } \\
\text { percentage }\end{array}$ & $\begin{array}{c}\text { Actual } \\
\text { percentage }\end{array}$ & $\begin{array}{l}\text { Cumulative } \\
\text { percentage }\end{array}$ \\
\hline Under $1^{*}$ & 5,763 & 4.7 & 4.7 & 5.9 & 5.9 \\
\hline 1 & 8,696 & 7.1 & 11.7 & 9.3 & 15.2 \\
\hline 2 & 9,713 & 7.9 & 19.6 & 9.8 & 25.0 \\
\hline 3 & 10,124 & 8.2 & 27.8 & 9.8 & 34.7 \\
\hline 4 & 10,049 & 8.1 & 36.0 & 9.2 & 44.0 \\
\hline 5 & 10,214 & 8.3 & 44.2 & 8.6 & 52.6 \\
\hline 6 & 9,732 & 7.9 & 52.1 & 8.4 & 61.0 \\
\hline 7 & 9,208 & 7.5 & 59.6 & 7.3 & 68.3 \\
\hline 8 & 6,543 & 5.3 & 64.9 & 5.4 & 73.7 \\
\hline 9 & 5,721 & 4.6 & 69.5 & 4.1 & 77.8 \\
\hline 10 & 5,673 & 4.6 & 74.1 & 4.1 & 81.8 \\
\hline 11 & 5,326 & 4.3 & 78.5 & 3.6 & 85.4 \\
\hline 12 & 5,743 & 4.7 & 83.1 & 3.6 & 89.0 \\
\hline 13 & 4,891 & 4.0 & 87.1 & 2.9 & 91.9 \\
\hline 14 & 3,759 & 3.0 & 90.1 & 2.2 & 94.1 \\
\hline 15 and older & 12,167 & 9.9 & 100.0 & 5.9 & 100.0 \\
\hline Subtotal & 123,322 & 100.0 & & 100.0 & \\
\hline Age not given ${ }^{b}$ & 6 & & & & \\
\hline Total & 123,328 & & & & \\
\hline
\end{tabular}

Sources:

Number of vehicles in operation by age - R. L. Polk and Company, Detroit, MI. FURTHER REPRODUCTION PROHIBITED.

Vehicle travel - Average annual miles per auto by age were multiplied by the number of vehicles in operation by age to estimate the vehicle travel. Average annual miles per auto by age generated by ORNL from the 1988 Residential Transportation Energy Consumption Survey public use tape, provided by the U.S. Department of Energy, Energy Information Administration, Office of Markets and End Use, Energy End Use Division, 1990.

"Automobiles sold as of July $1,1991$.

'Approximately 6,000 automobiles could not be classified by age. 
While automobile registrations remained relatively the same from 1989 to 1990 (0.4\% increase), automobile travel increased by $2.5 \%$ in this period. The fuel economy for the automobile population reached nearly 21 miles per gallon in 1990; as the older autos are scrapped, they are replaced by newer fuel efficient autos which raises the population fuel economy.

Table 3.12

Summary Statistics for Passenger Cars, 1970-90

\begin{tabular}{ccccc}
\hline Year & $\begin{array}{c}\text { Registrations" } \\
\text { (thousands) }\end{array}$ & $\begin{array}{c}\text { Vehicle travel } \\
\text { (million miles) }\end{array}$ & $\begin{array}{c}\text { Fuel use } \\
\text { (million gallons) }\end{array}$ & $\begin{array}{c}\text { Fuel economy } \\
\text { (miles per gallon) }\end{array}$ \\
\hline 1970 & 89,244 & 916,700 & 67,820 & 13.5 \\
1971 & 92,718 & 966,340 & 71,351 & 13.5 \\
1972 & 97,082 & $1,021,365$ & 76,222 & 13.4 \\
1973 & 101,985 & $1,045,981$ & 78,668 & 13.3 \\
1974 & 104,856 & $1,007,251$ & 75,083 & 13.4 \\
1975 & 106,704 & $1,033,950$ & 76,447 & 13.5 \\
1976 & 110,189 & $1,078,215$ & 79,693 & 13.5 \\
1977 & 112,288 & $1,109,243$ & 80,397 & 13.8 \\
1978 & 116,573 & $1,146,508$ & 81,661 & 14.0 \\
1979 & 118,429 & $1,113,640$ & 77,304 & 14.4 \\
1980 & 121,601 & $1,111,596$ & 71,883 & 15.5 \\
1981 & 123,098 & $1,130,827$ & 70,954 & 15.9 \\
1982 & 123,902 & $1,166,256$ & 70,062 & 16.7 \\
1983 & 126,444 & $1,198,023$ & 69,906 & 17.1 \\
1984 & 128,158 & $1,224,919$ & 68,717 & 17.8 \\
1985 & 131,864 & $1,260,565$ & 69,268 & 18.2 \\
1986 & 135,431 & $1,301,214$ & 71,216 & 18.3 \\
1987 & 137,208 & $1,335,330$ & 70,573 & 19.2 \\
1988 & 141,252 & $1,429,579$ & 71,949 & 19.9 \\
1989 & 143,026 & $1,477,769$ & 72,749 & 20.3 \\
1990 & 143,550 & $1,515,370$ & 72,435 & 20.9 \\
& & & & \\
$1970-90$ & & Average annual percentage change & \\
$1982-90$ & $2.4 \%$ & & & $2.2 \%$ \\
\hline & $1.9 \%$ & $2.5 \%$ & $0.3 \%$ & $2.8 \%$ \\
\hline
\end{tabular}

Source:

U.S. Department of Transportation, Federal Highway Administration, Highway Statistics 1990 , Washington, DC, 1991, Table VM-1, p. 192, and annual.

"This number differs from R. L. Polk's estimates of "number of automobiles in use." See Table 3.4.

'Fuel economy for automobile population. 
The data from the Nationwide Personal Transportation Study (NPTS) is based on estimates by survey respondents. The Residential Transportation Enery Consumption Survey (RTECS) data, which represents actual odometer readings of automobiles, has little bias from respondent estimations and, therefore, is the preferred data.

Table 3.13

Average Annual Miles Per Automobile by Automobile Age

\begin{tabular}{|c|c|c|c|c|c|c|c|}
\hline \multirow{2}{*}{$\begin{array}{l}\text { Vehicle age } \\
\text { (years) }\end{array}$} & \multicolumn{4}{|c|}{$\begin{array}{l}\text { Nationwide Personal } \\
\text { Transportation Study" }\end{array}$} & \multicolumn{3}{|c|}{$\begin{array}{l}\text { Residential Transportation } \\
\text { Energy Consumption Survey }\end{array}$} \\
\hline & 1969 & 1977 & 1983 & 1990 & 1983 & 1985 & 1988 \\
\hline Under 1 & 17,500 & $1:, 800$ & 14,200 & 19,800 & 13,400 & 12,700 & 12,900 \\
\hline 1 & 16,100 & 13,400 & 17,000 & 16,900 & 13,000 & 13,000 & 13,400 \\
\hline 2 & 13,200 & 13,400 & 14,000 & 16,300 & 12,700 & 12,600 & 12,600 \\
\hline 3 & 11,400 & 12,100 & 12,500 & 14,400 & 12,100 & 12,400 & 12,100 \\
\hline 4 & 11,700 & 11,300 & 11,400 & 13,800 & 11,300 & 11,100 & 11,500 \\
\hline 5 & 10,000 & 10,700 & 11,000 & 12,600 & 9,700 & 10,600 & 10,600 \\
\hline 6 & 10,300 & 10,500 & 9,900 & 12,900 & 9,700 & 10,000 & 10,800 \\
\hline 7 & 8,600 & 9,500 & 9,400 & 12,400 & 9,500 & 9,700 & 10,000 \\
\hline 8 & 10,900 & 8,600 & 8,700 & 12,300 & 8,700 & 8,900 & 10,300 \\
\hline 9 & 8,000 & 8,800 & 8,100 & 11,200 & 8,400 & 8,600 & 8,900 \\
\hline 10 and older & 6,500 & 7,100 & 6,900 & 9,300 & 8,700 & 8,400 & 7,500 \\
\hline All vehicles & 11,600 & 10,300 & 10,400 & 12,600 & 9,400 & 9,900 & 10,200 \\
\hline
\end{tabular}

Sources:

Nationwide Personal Transportation Study - 1969-83: D. Klinger and J. Richard Kuzmyak, COMSIS Corporation, Personal Travel in the United States, Volume 1: 1983-84 Nationwide Personal Travel Study," prepared for the U.S. Department of Transportation, Washington, DC, August 1986, Table 4-22, p. 4-21.

1990: U.S. Department of Transportation, Federal Highway Administration, Office of Highway Information Management, Nationwide Personal Transportation Study, Public Use Tape, 1991.

Residential Transportation Energy Consumption Survey - Energy Information Agency, Office of Markets and End Use, Energy End Use Division, 1983, 1985, and 1988 Residential Transportation Energy Consumption Survey, Public Use Tapes.

"Includes only auto vehicles (standard auto, station wagon, taxi, and van-bus/minibus) owned by or available to the household on a regular basis.

bIncludes all household vehicles - automobiles, station wagons, pick-up trucks, vans, and utility vehicles. 
The average weight of the domestic automobile has been reduced 359 pounds from 1978 to 1992. Much of this weight reduction was due to the declining use of conventional steel and iron and the increasing use of aluminum and plastics. Conventional steel, however, remained the predominant component of automobiles in 1992 with a 44\% share of total materials.

Thble 3.14

Av: 1978, 1984, and 1992

\begin{tabular}{|c|c|c|c|c|c|c|}
\hline \multirow[b]{2}{*}{ Material } & \multicolumn{2}{|c|}{1978} & \multicolumn{2}{|c|}{1984} & \multicolumn{2}{|c|}{1992} \\
\hline & Pounds & Percentage & Pounds & Percentage & Pounds & Percentage \\
\hline Conventional steel & $1,880.0$ & 53.8 & $1,487.5$ & 47.3 & $1,379.0$ & 44.0 \\
\hline High-strength steel & 127.5 & 3.6 & 214.0 & 6.8 & 247.0 & 7.9 \\
\hline Stainless steel & 25.0 & 0.7 & 29.0 & 0.9 & 41.5 & 1.3 \\
\hline Other steels & 56.0 & 1.6 & 45.0 & 1.4 & 42.0 & 1.3 \\
\hline Iron & 503.0 & 14.4 & 454.5 & 14.5 & 429.5 & 13.7 \\
\hline Aluminum & 112.0 & 3.2 & 137.0 & 4.4 & 173.5 & 5.5 \\
\hline Rubber & 141.5 & 4.1 & 133.5 & 4.2 & 133.0 & 4.2 \\
\hline Plastics/Composites & 176.0 & 5.0 & 206.5 & 6.6 & 243.0 & 7.7 \\
\hline Glass & 88.0 & 2.5 & 87.0 & 2.8 & 88.0 & 2.8 \\
\hline Copper & 39.5 & 1.1 & 44.0 & 1.4 & 45.0 & 1.4 \\
\hline Zinc die castings & 28.0 & 0.8 & 17.0 & 0.5 & 16.0 & 0.5 \\
\hline Power metal parts & 16.0 & 0.5 & 18.5 & 0.6 & 25.0 & 0.8 \\
\hline Fluids \& lubricants & 189.0 & 5.4 & 180.0 & 5.7 & 177.0 & 5.6 \\
\hline Other materials & 112.5 & 3.2 & 88.0 & 2.8 & 96.0 & 3.1 \\
\hline Total & $3,494.0$ & 100.0 & $3,141.5$ & 100.0 & $3,135.5$ & 100.0 \\
\hline
\end{tabular}

Source:

H. A. Stark (ed), Ward's Communications, Inc., Wards Automotive Yearbook, Detroit, MI, 1992, p. 36, and annual. 
Table 3.15

Sales-Weighted Engine Size of Domestic and Import Automobiles by Size Chas, Sales Periods 1976-1992

(cubic inches -1 liter $=61.026$ cubic inches)

\begin{tabular}{|c|c|c|c|c|c|c|c|}
\hline $\begin{array}{l}\text { Model } \\
\text { year }\end{array}$ & Minicompact & Subcompact & Compect & Midsine & Large & Two seater & Floet \\
\hline 76 & & 163.1 & 304.9 & 357.0 & 414.2 & 176.2 & 298.5 \\
\hline 77 & 120.8 & 166.4 & 292.4 & 333.5 & 367.2 & 171.6 & 278.3 \\
\hline 78 & 125.5 & 162.8 & 241.0 & 298.6 & 376.3 & 183.8 & 264.4 \\
\hline 79 & 113.2 & 146.0 & 228.5 & 268.9 & 339.4 & 168.8 & 230.8 \\
\hline 80 & 115.8 & 128.2 & 184.8 & 237.9 & 312.3 & 170.0 & 196.5 \\
\hline 81 & 96.1 & 124.6 & 134.2 & 221.2 & 304.8 & 151.7 & 182.0 \\
\hline 82 & 93.5 & 127.2 & 129.3 & 212.0 & 288.4 & 147.2 & 176.1 \\
\hline 83 & 97.8 & 133.6 & 134.3 & 210.3 & 302.0 & 153.8 & 182.1 \\
\hline 84 & 132.7 & 135.3 & 135.1 & 207.3 & 297.1 & 152.4 & 181.2 \\
\hline 85 & 118.8 & 139.8 & 138.8 & 205.5 & 283.6 & 150.9 & 178.3 \\
\hline 86 & 88.4 & 133.6 & 134.6 & 194.9 & 267.3 & 172.5 & 168.3 \\
\hline 87 & 90.2 & 133.4 & 134.4 & 182.4 & 266.3 & 157.1 & 163.5 \\
\hline 88 & 92.5 & 125.0 & 135.1 & 183.1 & 263.4 & 167.9 & 162.2 \\
\hline 89 & 155.2 & 127.0 & 128.8 & 183.5 & 263.1 & 171.3 & 163.5 \\
\hline 90 & 147.7 & 119.6 & 137.5 & 190.7 & 264.3 & 157.0 & 166.1 \\
\hline 91 & 132.6 & 120.2 & 135.8 & 192.9 & 268.3 & 163.1 & 166.2 \\
\hline $92^{\circ}$ & 108.4 & 122.4 & 138.6 & 196.9 & 264.5 & 173.9 & 167.5 \\
\hline
\end{tabular}

Source:

Hu, Patricia S. and An Lu, "Light-Duty Vehicle Summary: First Six Months of Sales Period 1992," Working Paper, Oak Ridge National Laboratory, Oak Ridge, TN, July 1992, p. 31.

- These figures represent sales for the first six months of the 1992 sales period (October 91 through March 92). 
Table 3.16

Sales-Weighted Curb Weight of Domestic and Import Automobiles by Size Chas,

Sales Periods 1976-1992

(pounds)

\begin{tabular}{|c|c|c|c|c|c|c|c|}
\hline $\begin{array}{l}\text { Model } \\
\text { yea. }\end{array}$ & Minicompact & Subcompact & Compact & Midsize & Large & Two seater & Fleet \\
\hline 76 & & $2,577.2$ & $3,608.7$ & $4,046.1$ & $4,562.7$ & $2,624.1$ & $3,608.0$ \\
\hline 77 & $2,228.0$ & $2,586.3$ & $3,549.8$ & $3,900.3$ & $4,025.8$ & $2,608.1$ & $3,424.4$ \\
\hline 78 & $2,199.6$ & $2,444.3$ & $3,137.5$ & $3,426.8$ & $3,955.7$ & $2,762.5$ & $3,196.5$ \\
\hline 79 & $2,120.1$ & $2,366.7$ & $3,048.0$ & $3,286.7$ & $3,763.4$ & $2,699.1$ & $3,000.4$ \\
\hline 80 & $2,154.3$ & $2,270.4$ & $2,812.5$ & $3,080.9$ & $3,667.4$ & $2,713.6$ & $2,790.3$ \\
\hline 81 & $1,919.8$ & $2,370.5$ & $2,381.7$ & $2,995.7$ & $3,671.8$ & $2,583.0$ & $2,744.3$ \\
\hline 82 & $2,002.1$ & $2,301.7$ & $2,421.8$ & $2,991.9$ & $3,702.8$ & $2,524.8$ & $2,729.8$ \\
\hline 83 & $2,072.0$ & $2,333.9$ & $2,441.3$ & $3,026.5$ & $3,779.0$ & $2,662.5$ & $2,787.9$ \\
\hline 84 & $2,375.9$ & $2,380.4$ & $2,453.7$ & $2,990.0$ & $3,733.6$ & $2,559.3$ & $2,787.7$ \\
\hline 85 & $2,210.8$ & $2,391.8$ & $2,464.3$ & $2,953.6$ & $3,575.4$ & $2,538.6$ & $2,743.4$ \\
\hline 86 & $2,120.3$ & $2,414.8$ & $2,431.5$ & $2,856.7$ & $3,451.2$ & $2,574.5$ & $2,675.3$ \\
\hline 87 & $1,959.7$ & $2,422.5$ & $2,474.0$ & $2,856.8$ & $3,483.0$ & $2,601.8$ & $2,688.5$ \\
\hline 88 & $1,932.7$ & $2,346.3$ & $2,558.1$ & $2,880.3$ & $3,487.3$ & $2,693.0$ & $2,716.8$ \\
\hline 89 & $2,575.8$ & $2,357.3$ & $2,517.1$ & $2,984.5$ & $3,495.7$ & $2,734.9$ & $2,759.6$ \\
\hline 90 & $2,650.7$ & $2,368.4$ & $2,637.2$ & $3,065.3$ & $3,593.9$ & $2,656.3$ & $2,827.7$ \\
\hline 91 & $2,583.6$ & $2,405.8$ & $2,652.1$ & $3,084.7$ & $3,649.6$ & $2,707.3$ & $2,848.2$ \\
\hline 92 & $2,335.9$ & $2,364.7$ & $2,722.2$ & $3,161.1$ & $3,652.5$ & $2,888.0$ & $2,878.0$ \\
\hline
\end{tabular}

Source:

Hu, Patricia S. and An Lu, "Light-Duty Vehicle Summary: First Six Months of Sales Period 1992," Working Paper, Oak Ridge National Laboratory, Oak Ridge, TN, July 1992, p. 33.

- These figures represent sales for the first six months of the 1992 sales period (October 91 through March 92). 
Table 3.17

Sales-Weighted Interior Space of Domeatic and Import Automobiles iy Size Chos, Sales Periods 1976-1992

(cubic foet)

\begin{tabular}{|c|c|c|c|c|c|c|}
\hline $\begin{array}{l}\text { Model } \\
\text { year }\end{array}$ & $\begin{array}{l}\text { Minicompact } \\
(<85)\end{array}$ & $\begin{array}{c}\text { Subcompact } \\
\text { (85-99) }\end{array}$ & $\begin{array}{l}\text { Compact } \\
(100-109)\end{array}$ & $\begin{array}{l}\text { Midsize } \\
(110-119)\end{array}$ & $\underset{(>120)}{\text { Large }} \quad$ Two seater & Floet \\
\hline $76^{\circ}$ & & & & & & \\
\hline 77 & 78.8 & 89.8 & 107.1 & 113.0 & 128.0 & 107.9 \\
\hline 78 & 79.4 & 89.8 & 105.3 & 112.9 & 128.5 & 107.9 \\
\hline 79 & 80.0 & 90.2 & 105.8 & 113.4 & 130.1 & 106.9 \\
\hline 80 & 82.4 & 89.9 & 105.4 & 113.5 & 130.8 & 104.9 \\
\hline 81 & 83.3 & 90.2 & 103.6 & 113.7 & 130.6 & 105.5 \\
\hline 82 & 83.1 & 91.3 & 102.9 & 113.9 & 130.4 & 106.0 \\
\hline 83 & 82.7 & 93.3 & 103.0 & 113.1 & 131.3 & 107.3 \\
\hline 84 & 77.0 & 93.8 & 103.0 & 113.3 & 130.7 & 108.0 \\
\hline 85 & 77.8 & 94.1 & 103.1 & 113.5 & 129.7 & 107.9 \\
\hline 86 & 80.1 & 94.5 & 102.8 & 113.8 & 127.6 & 107.0 \\
\hline 87 & 81.6 & 93.1 & 103.0 & 113.9 & 127.5 & 106.9 \\
\hline 88 & 81.0 & 93.5 & 103.3 & 113.6 & 127.2 & 107.0 \\
\hline 89 & 75.0 & 93.3 & 102.7 & 113.8 & 127.4 & 107.5 \\
\hline 90 & 79.9 & 93.9 & 103.2 & 113.8 & 127.8 & 107.3 \\
\hline 91 & 79.6 & 94.4 & 103.2 & 113.8 & 128.3 & 107.1 \\
\hline $92^{\circ}$ & 79.1 & 93.8 & 104.0 & 114.2 & 129.2 & 107.3 \\
\hline
\end{tabular}

Source:

Hu, Patricia S. and An Lu, "Light-Duty Vehicle Summary: First Six Months of Sales Period 1992," Working Paper, Oak Ridge National Laboratory, Oak Ridge, TN, July 1992, p. 35.

- Interior volumes of two seaters are not reported to EPA.

- Data not available.

c These figures represent sales for the first six months of the 1992 sales period (October 91 through March 92). 


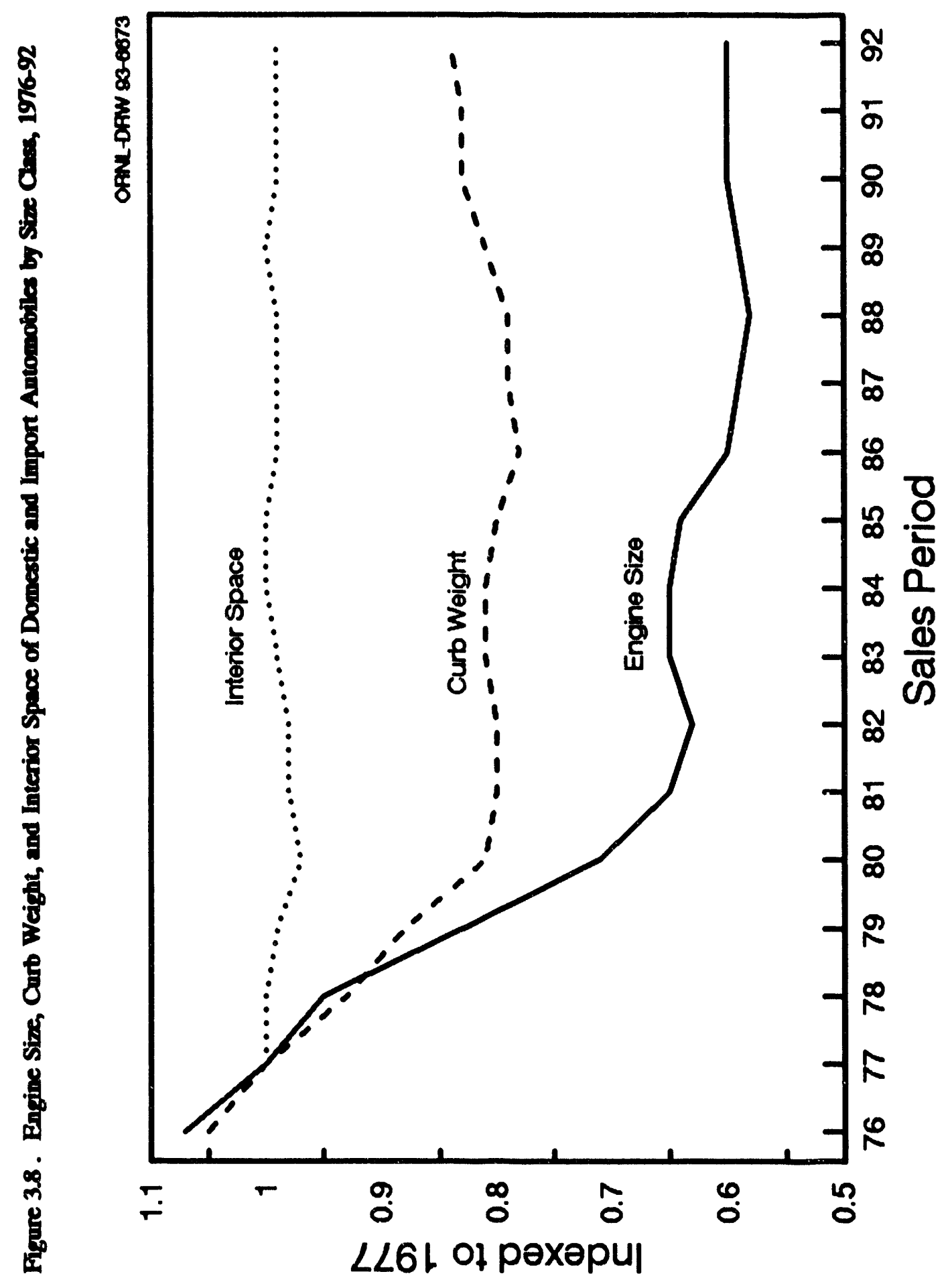

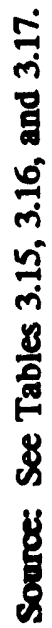




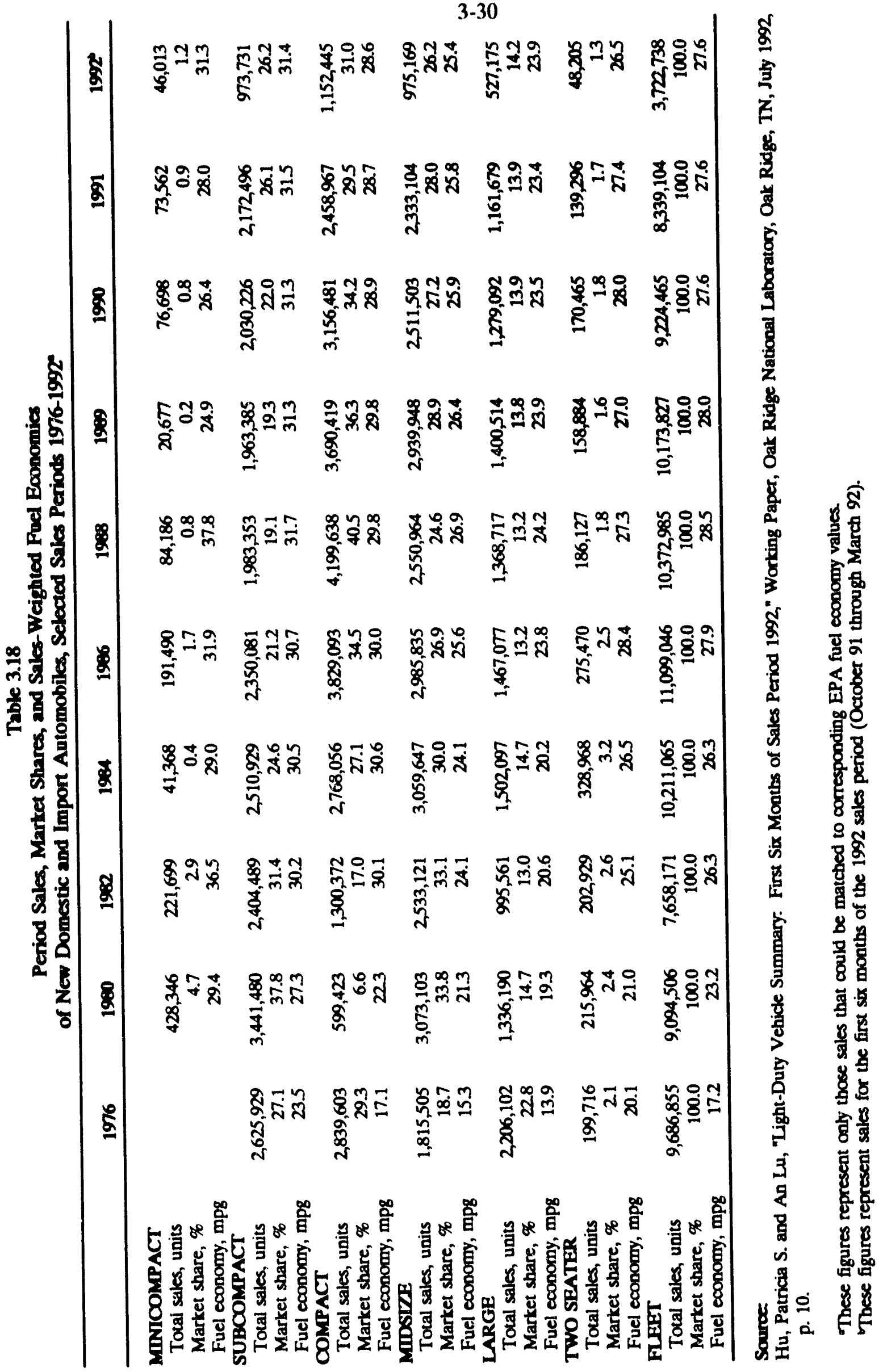


Section 3.3

Trucks 
Although light truck sales huve been declining since 1988, their share of total truck sales has been growing. In 1991 light trucks accounted for $51.5 \%$ of all truck sales, and $33.5 \%$ of all light-duty vehicle sales.

Table 3.19

New Resail Sales of Light Trucks in the United States, 1970-91

\begin{tabular}{|c|c|c|c|c|c|c|}
\hline \multirow[b]{2}{*}{$\begin{array}{l}\text { Calendar } \\
\text { Year }\end{array}$} & \multirow[b]{2}{*}{$\begin{array}{l}\text { Light truck } \\
\text { sales } \\
\text { (thousands) }\end{array}$} & \multicolumn{4}{|c|}{ Percentages } & \multirow[b]{2}{*}{$\begin{array}{l}\text { Light trucks } \\
\text { of total } \\
\text { truck sales }\end{array}$} \\
\hline & & $\begin{array}{l}\text { Import } \\
\text { of total } \\
\text { light truck }\end{array}$ & $\begin{array}{c}\text { Diesel } \\
\text { of total } \\
\text { light truck }\end{array}$ & $\begin{array}{l}\text { Four-wheel drive } \\
\text { on domestic } \\
\text { light trucks }\end{array}$ & $\begin{array}{l}\text { Light trucks } \\
\text { of light-duty } \\
\text { vehicle sales }\end{array}$ & \\
\hline 1970 & 1,463 & 4.5 & d & - & 14.8 & 80.4 \\
\hline 1971 & 1,757 & 4.8 & c & d & 14.6 & 83.4 \\
\hline 1972 & 2,239 & 6.4 & c & d & 16.7 & 83.3 \\
\hline 1973 & 2,745 & 8.5 & c & d & 18.8 & 84.2 \\
\hline 1974 & 2,338 & 7.5 & $c$ & 18.0 & 20.3 & 84.2 \\
\hline 1975 & 2,281 & $10 n$ & c & 23.4 & 20.1 & 87.9 \\
\hline 1976 & 2,956 & 8.0 & c & 23.8 & 22.0 & 89.8 \\
\hline 1977 & 3,439 & 9.4 & c & 24.6 & 22.8 & 89.7 \\
\hline 1978 & 3,808 & 3.8 & 1.0 & 28.5 & 24.5 & 89.2 \\
\hline 1979 & 3,311 & 14.1 & 1.0 & 29.4 & 22.4 & 88.7 \\
\hline 1980 & 2,440 & 19.7 & 3.2 & 20.7 & 19.8 & 88.9 \\
\hline 1981 & 2,189 & 20.3 & 3.3 & 18.6 & 19.2 & 89.8 \\
\hline 1982 & 2,470 & 16.5 & 5.0 & 16.8 & 23.0 & 92.8 \\
\hline 1983 & 2,984 & 15.6 & 4.0 & 28.5 & 24.2 & 93.6 \\
\hline 1984 & 3,863 & 15.7 & 3.8 & 27.0 & 26.9 & 93.0 \\
\hline 1985 & 4,458 & 17.2 & 3.3 & 29.1 & 28.7 & 93.6 \\
\hline 1986 & 4,594 & 20.1 & 2.6 & 27.0 & 28.6 & 94.3 \\
\hline 1987 & 4,610 & i7.9 & 2.3 & 32.0 & 31.0 & 93.9 \\
\hline 1988 & 4,800 & 12.6 & 2.0 & 32.1 & 31.1 & 93.2 \\
\hline 1989 & 4,610 & 10.9 & 2.1 & $26.9^{\circ}$ & 31.8 & 93.3 \\
\hline 1990 & 4,548 & 13.2 & $2.2^{\prime}$ & $19.8^{\circ}$ & 32.8 & 93.9 \\
\hline 1991 & 4,123 & 12.8 & 2.2 & $30.2^{\circ}$ & 33.5 & 94.5 \\
\hline \multicolumn{7}{|c|}{ Average annual percentage change } \\
\hline $1970-91$ & $5.1 \%$ & & & & & \\
\hline $1982-91$ & $5.9 \%$ & & & & & \\
\hline
\end{tabular}

\section{Sources:}

Four-wheel drive - 1970-88: H. A. Stark (ed.), Ward's Communications, Inc., Ward's Automotive Yearbook, Detroit, MI, 1989, p. 168, and annual.

1989-91: H. A. Stark (ed.), Ward's Communications, Inc., Ward's Automotive Reports, Factory Installation Report, Detroit, MI, 1992.

All other - Motor Vehicle Manufacturers Association, Motor Vehicle Facts and Figures '92, Detroit, MI,

1992 , pp. $7,16,17$, and annual. less.

-Includes domestic, domestic-sponsc ;ed import, and import trucks of 10,000 pounds gross vehicle weight and

Includes transports.

'Light-duty vehicles include cars and light trucks.

Indicates less than 1 percent.

- Data are not available.

'Based on fartory installations. 


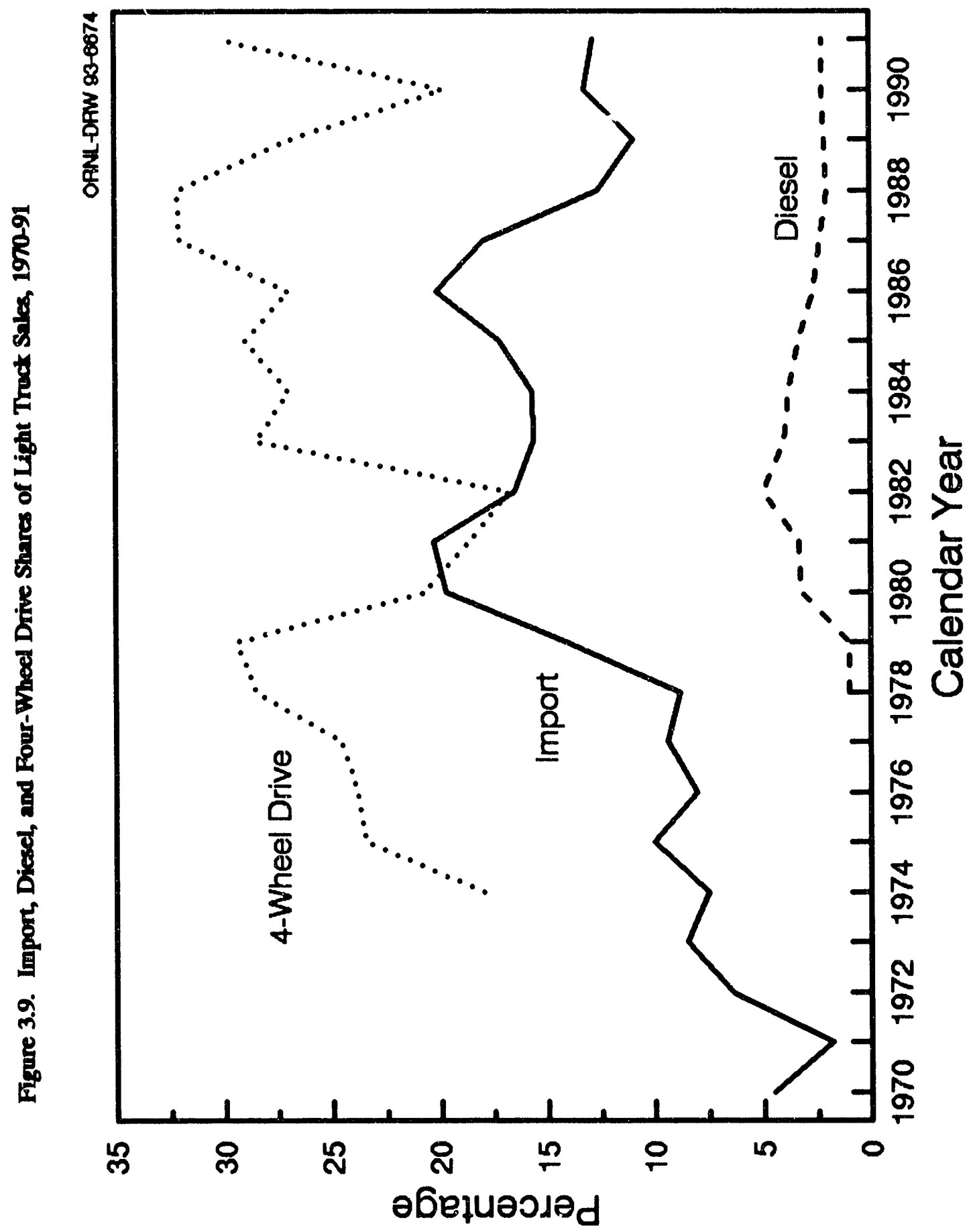

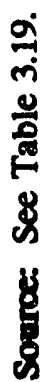




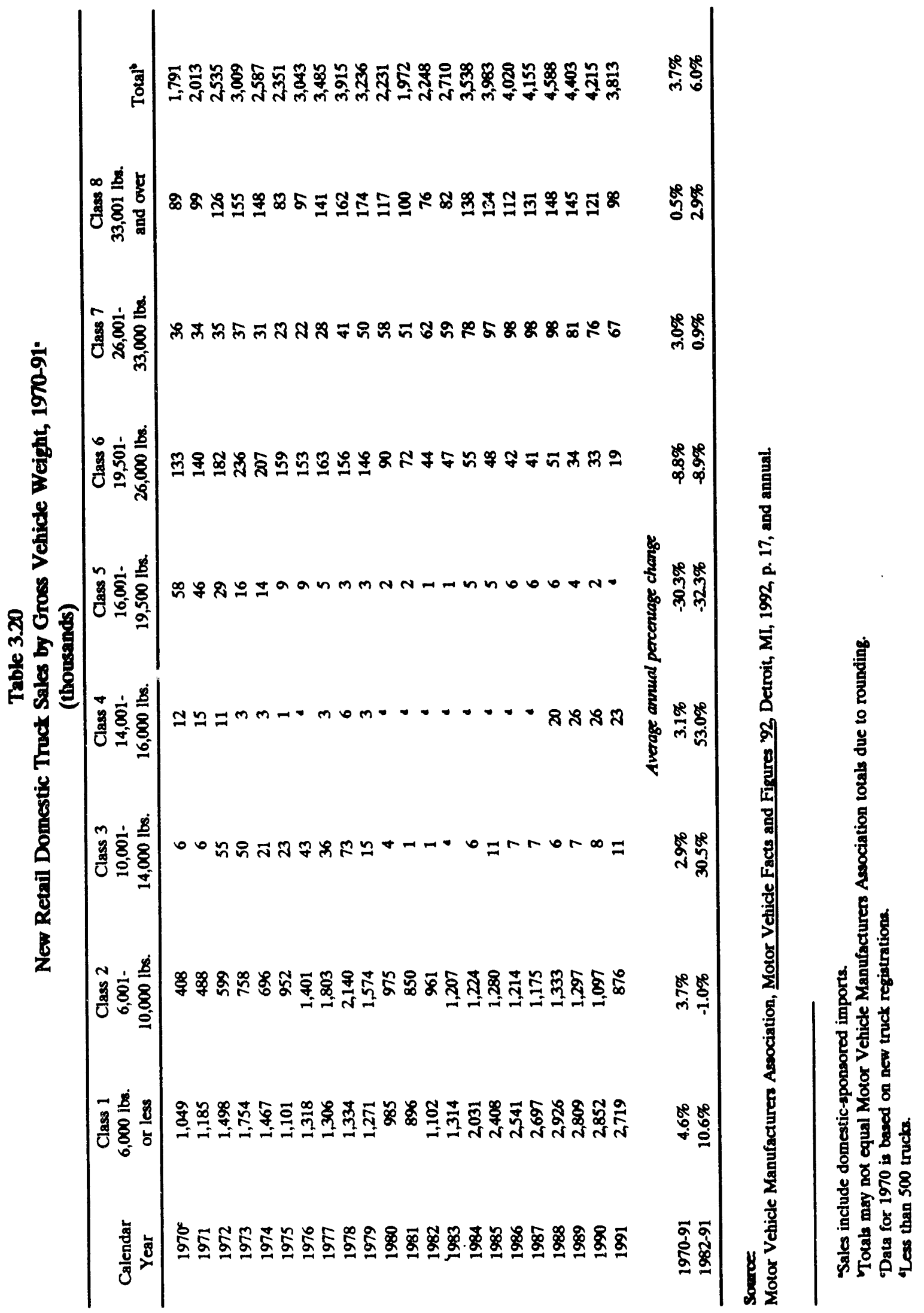


Although the average age of trucks has increased by only 0.79 years from 1970 to 1990 , the percentage of trucks ten years old or older has grown from $29.2 \%$ in 1970 to $35.0 \%$ in 1990 .

Table 3.21

Tructs in Use by Age, 1970 and 1991

\begin{tabular}{|c|c|c|c|c|c|c|}
\hline \multirow[b]{2}{*}{$\begin{array}{c}\text { Age } \\
\text { (years) }\end{array}$} & \multicolumn{3}{|c|}{1970} & \multicolumn{3}{|c|}{1991} \\
\hline & $\begin{array}{l}\text { Vehicles } \\
\text { (thousands) }\end{array}$ & $\begin{array}{c}\text { Actual } \\
\text { percentage }\end{array}$ & $\begin{array}{l}\text { Cumulative } \\
\text { percentage }\end{array}$ & $\begin{array}{l}\text { Vehicles } \\
\text { (thousands) }\end{array}$ & $\begin{array}{c}\text { Actual } \\
\text { percentage }\end{array}$ & $\begin{array}{l}\text { Cumulative } \\
\text { percentage }\end{array}$ \\
\hline Under. $1^{2}$ & 1,262 & 7.1 & 7.1 & 2,919 & 5.0 & 5.0 \\
\hline 1 & 1,881 & 10.6 & 17.8 & 4,187 & 7.2 & 12.2 \\
\hline 2 & 1,536 & 8.7 & 26.5 & 4,913 & 8.4 & 20.7 \\
\hline 3 & 1,428 & 8.1 & 34.6 & 4,922 & 8.5 & 29.1 \\
\hline 4 & 1,483 & 8.4 & 43.0 & 4,414 & 7.6 & 36.7 \\
\hline 5 & 1,339 & 7.6 & 50.5 & 4,670 & 8.0 & 44.7 \\
\hline 6 & 1,154 & 6.5 & 57.1 & 4,041 & 6.9 & 51.7 \\
\hline 7 & 975 & 5.5 & 62.6 & 3,572 & 6.1 & 57.8 \\
\hline 8 & 826 & 4.7 & 67.3 & 2,279 & 3.9 & 61.7 \\
\hline 9 & 621 & 3.5 & 70.8 & 1,917 & 3.3 & 65.0 \\
\hline 10 & 658 & 3.7 & 74.5 & 1,708 & 2.9 & 68.0 \\
\hline 11 & 583 & 3.3 & 77.8 & 1,625 & 2.8 & 70.8 \\
\hline 12 & 383 & 2.2 & 80.0 & 2,854 & 4.9 & 75.7 \\
\hline 13 & 417 & 2.4 & 82.3 & 2,508 & 4.3 & 80.0 \\
\hline 14 & 414 & 2.3 & 84.7 & 2,094 & 3.6 & 83.6 \\
\hline 15 and older & 2,710 & 15.3 & 100.0 & 9,552 & 16.4 & 100.0 \\
\hline Subtotal & 17,670 & 100.0 & & 58,175 & 100.0 & \\
\hline Age not given & 15 & & & 3 & & \\
\hline Total & 17,685 & & & 58,178 & & \\
\hline Average age & & 7.33 & & & 8.12 & \\
\hline Median age & & 5.93 & & & 6.76 & \\
\hline
\end{tabular}

Source:

R. L. Polk and Co., Detroit, MI. FURTHER REPRODUCTION PROHIBITED.

Trucks sold as of July 1 of each year.

'Approximately 15,000 trucks in 1970 and 3,000 in 1991 could not be classified by age. 
Data from the 1987 TIUS (the most recent dasa available on national touck population characteristics) were used to estimate 1991 truck travel pattems by vehicle age group. Trucks which were 10 years old or older accounted for $35 \%$ of the truck population but represented only $20.5 \%$ of total truck travel in 1991.

Table 3.22

Tructs in Operation

and Vehicle Travel by Age of Vehicie, 1991

\begin{tabular}{|c|c|c|c|c|c|c|}
\hline \multirow{2}{*}{$\begin{array}{l}\text { Vehicle } \\
\text { age } \\
\text { (years) }\end{array}$} & \multicolumn{3}{|c|}{ Number in operation } & \multicolumn{2}{|c|}{ Estimated vehicle travel } & \multirow{2}{*}{$\begin{array}{l}\text { Average } \\
\text { annual } \\
\text { miles per } \\
\text { vehicle }\end{array}$} \\
\hline & $\begin{array}{c}\text { Vehicles } \\
\text { (thousands) }\end{array}$ & $\begin{array}{c}\text { Actual } \\
\text { percentage }\end{array}$ & $\begin{array}{l}\text { Cumulative } \\
\text { percentage }\end{array}$ & $\begin{array}{c}\text { Actual } \\
\text { percentage }\end{array}$ & $\begin{array}{l}\text { Cumulative } \\
\text { percentage }\end{array}$ & \\
\hline Under $1^{\circ}$ & 2,919 & 5.0 & 5.0 & 6.3 & 6.3 & $14,900.5$ \\
\hline 1 & 4,187 & 7.2 & 12.2 & 10.2 & 16.5 & $16,852.8$ \\
\hline 2 & 4,913 & 8.4 & 20.7 & 11.9 & 28.4 & $16,719.0$ \\
\hline 3 & 4,922 & 8.5 & 29.1 & 11.5 & 39.9 & $16,074.2$ \\
\hline 4 & 4,414 & 7.6 & 36.7 & 8.9 & 48.8 & $14,005.1$ \\
\hline 5 & 4,670 & 8.0 & 44.7 & 9.4 & 58.2 & $13,952.4$ \\
\hline 6 & 4,041 & 6.9 & 51.7 & 8.0 & 66.2 & $13,687.0$ \\
\hline 7 & 3,572 & 6.1 & 57.8 & 6.5 & 72.8 & $12,643.5$ \\
\hline 8 & 2,279 & 3.9 & 61.7 & 3.8 & 76.5 & $11,387.2$ \\
\hline 9 & 1,917 & 3.3 & 65.0 & 3.0 & 79.5 & $10,665.3$ \\
\hline 10 & 20,341 & 35.0 & 100.0 & 20.5 & 100.0 & $6,960.1$ \\
\hline Subtotal & 58,175 & 100.0 & & $\overline{100.0}$ & & \\
\hline
\end{tabular}

Age not given 3

Total $\quad 58,178$

Sources:

Number of trucks in operation by age - R. L. Polk and Company, Detroit, MI. FURTHER REPRODUCTION PROHIBITED.

Vehicle travel - The average annual vehicle miles per truck by age were multiplied by the number of trucks in operation by age to estimate the vehicle travel. Average annual miles per truck by age were generated by ORNL from the 1987 Truck Inventory and Use Survey public use tape provided by U.S. Department of Commerce, Bureau of the Census, Washington, DC, 1990.

Trucks sold as of July $1,1991$.

${ }^{b}$ Approximately 3,000 vehicles could not be classified by age. 


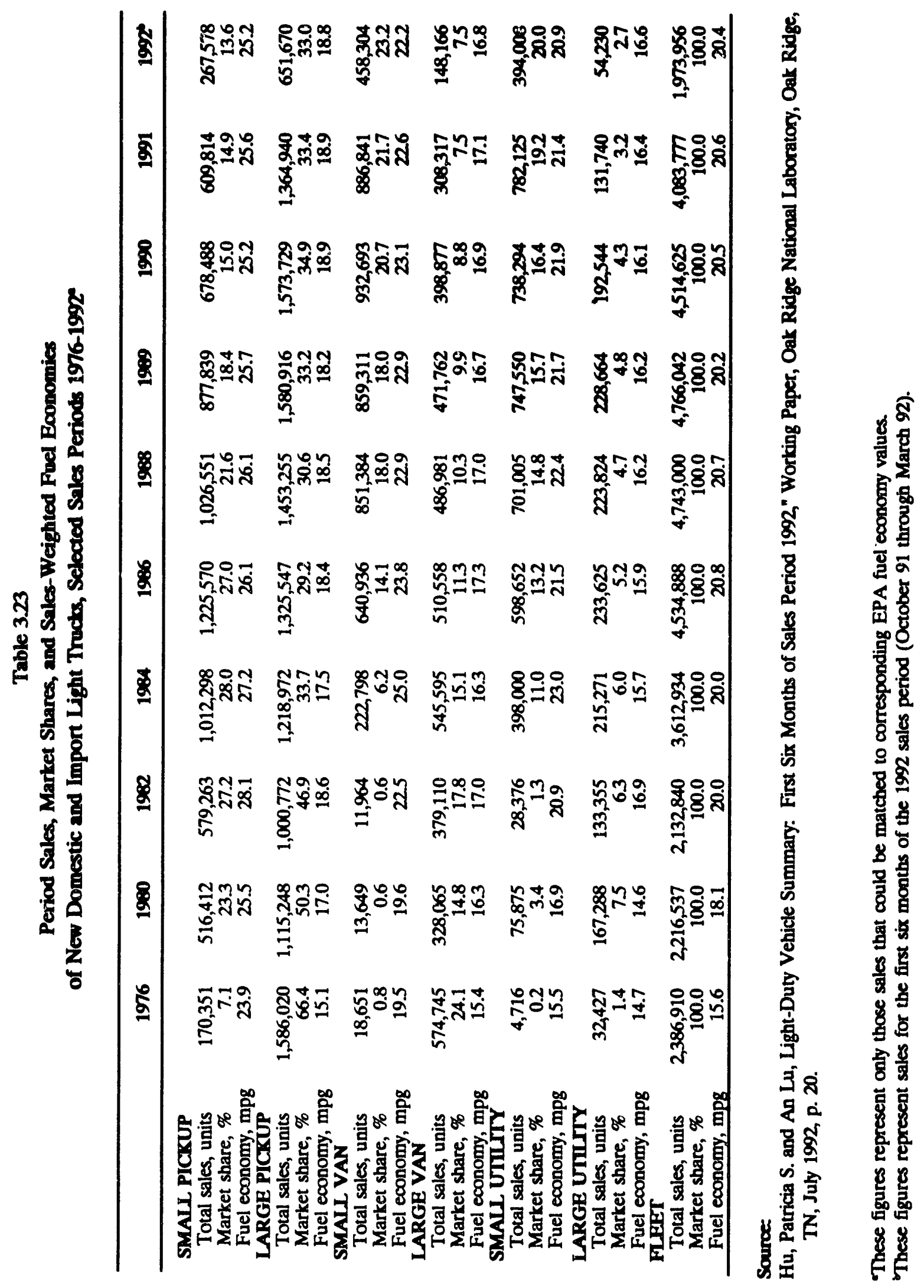


Two-axle, four-tire truck average fuel economy axceeded $14 \mathrm{mpg}$ for the first time in 1990 . Because the more fuel efficient trucks are entering the population, the fuel use for two-axle, four-tire trucks has grown at a slower rate than the vehicle travel. These trucks are being driven longer distances each year, as evidenced by a greater increase in travel than in registrations.

Table 324

Enmmary Statistics for Two-Ade, Fowr-Tire Trecks, 1970-90

\begin{tabular}{lcccc}
\hline Year & $\begin{array}{c}\text { Registrations } \\
\text { (thousands) }\end{array}$ & $\begin{array}{c}\text { Vehicle travel } \\
\text { (million miles) }\end{array}$ & $\begin{array}{c}\text { Fuel use } \\
\text { (million gallons) }\end{array}$ & $\begin{array}{c}\text { Fuel economy } \\
\text { (miles per gallon) }\end{array}$ \\
\hline 1970 & 14,211 & 123,286 & 12,313 & 10.0 \\
1971 & 15,181 & 137,870 & 13,484 & 10.2 \\
1972 & 16,428 & 156,622 & 15,150 & 10.3 \\
1973 & 18,083 & 176,833 & 16,828 & 10.5 \\
1974 & 19,335 & 182,757 & 16,657 & 11.0 \\
1975 & 20,418 & 200,700 & 17,903 & 11.2 \\
1976 & 22,301 & 225,834 & 20,164 & 11.2 \\
1977 & 23,624 & 250,591 & 21,055 & 11.4 \\
1978 & 25,476 & 279,414 & 24,055 & 11.6 \\
1979 & 27,022 & 291,905 & 24,742 & 11.8 \\
1980 & 27,876 & 290,935 & 23,594 & 12.3 \\
1981 & 28,928 & 296,343 & 23,697 & 12.5 \\
1982 & 29,792 & 306,141 & 23,845 & 12.8 \\
1983 & 31,214 & 327,643 & 25,556 & 12.8 \\
1984 & 32,106 & 357,999 & 27,687 & 12.9 \\
1985 & 33,865 & 373,072 & 29,021 & 12.9 \\
1986 & 34,820 & 389,047 & 30,265 & 12.9 \\
1987 & 35,841 & 415,449 & 32,266 & 12.9 \\
1988 & 37,096 & 439,496 & 32,803 & 13.4 \\
1989 & 37,918 & 454,339 & 33,005 & 13.8 \\
1990 & 38,652 & 466,827 & 33,140 & 14.1 \\
& & & & \\
$1970-90$ & & Average annual percentage change & \\
$1982-90$ & $5.1 \%$ & & & $1.7 \%$ \\
\hline
\end{tabular}

Source:

U.S. Department of Transportation, Federal Highway Administration, Highway Statistics 1990, Washington, DC, 1991, Table VM-1, p. 192, and annual. 

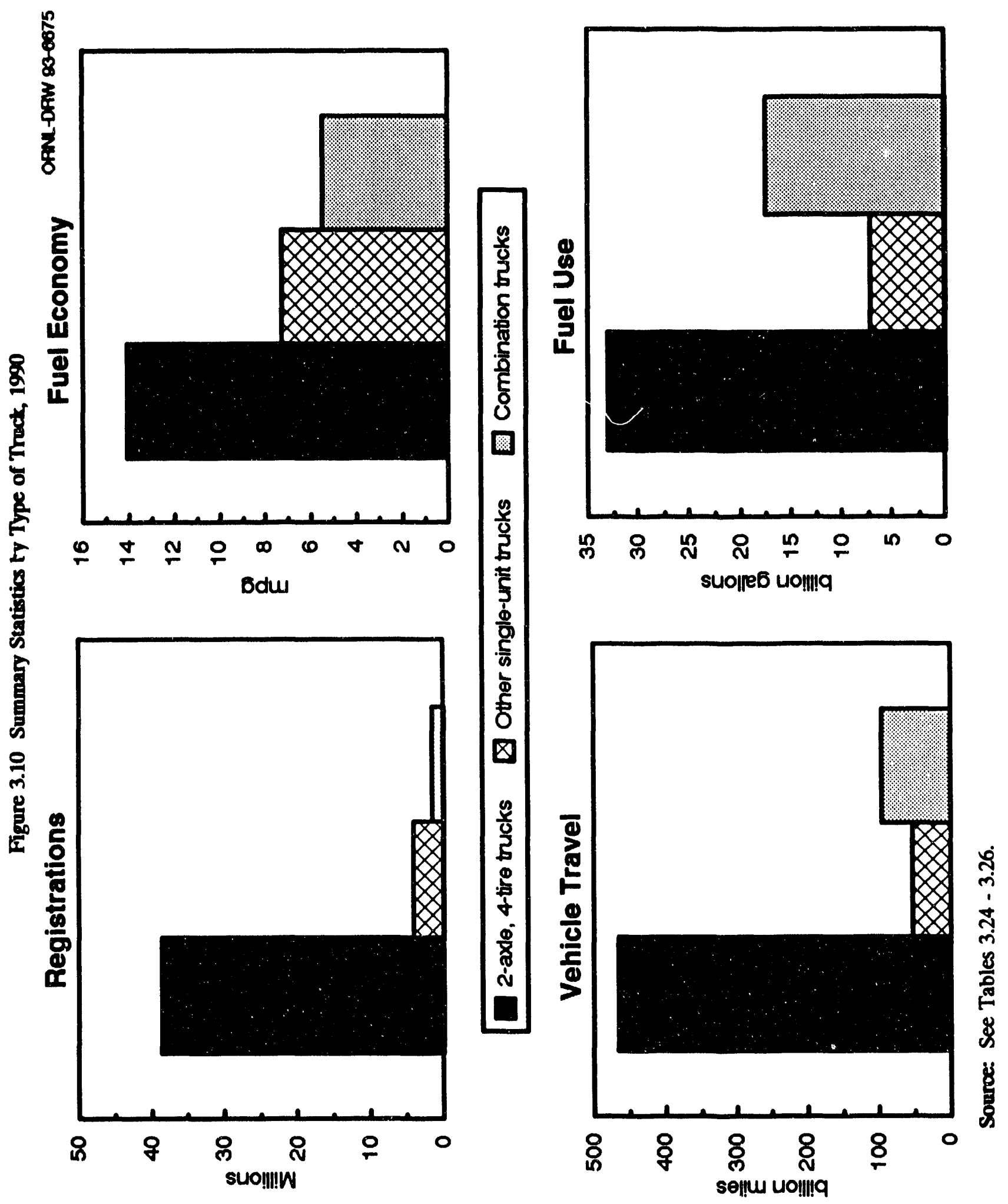
Although registrations and vehicle travel for other single-unit trucks rase from 1989 to 1990 , fuel use declined slightly due to the increase in average fuel economy. The "other single-unit truck" sector has grown at slower rates than the two-axle, four-tive trucks and the combination trucks from 1970 to 1990. (See Figure 3.10.)

Table 3.25

Summary Statistics for Other Single-Unit Trucks, 1970-90

\begin{tabular}{ccccc}
\hline Year & $\begin{array}{c}\text { Regictrations } \\
\text { (thousands) }\end{array}$ & $\begin{array}{c}\text { Vehicle travel } \\
\text { (million miles) }\end{array}$ & $\begin{array}{c}\text { Fuel use } \\
\text { (million gallons) }\end{array}$ & $\begin{array}{c}\text { Fuel economy } \\
\text { (miles per gallon) }\end{array}$ \\
\hline 1970 & 3,681 & 27,081 & 3,968 & 6.8 \\
1971 & 3,770 & 28,985 & 4,212 & 6.9 \\
1972 & 3,918 & 31,414 & 4,560 & 6.9 \\
1973 & 4,131 & 33,661 & 4,859 & 6.9 \\
1974 & 4,211 & 33,441 & 4,687 & 7.1 \\
1975 & 4,232 & 34,606 & 4,825 & 7.2 \\
1976 & 4,350 & 36,390 & 5,140 & 7.1 \\
1977 & 4,450 & 39,339 & 5,559 & 7.1 \\
1978 & 4,518 & 42,727 & 6,106 & 7.0 \\
1979 & 4,505 & 42,012 & 6,036 & 7.2 \\
1980 & 4,374 & 39,813 & 5,557 & 7.1 \\
1981 & 4,455 & 39,568 & 5,574 & 7.1 \\
1982 & 4,325 & 40,212 & 5,661 & 7.1 \\
1983 & 4,204 & 43,409 & 6,118 & 7.1 \\
1984 & 4,061 & 46,560 & 6,582 & 7.0 \\
1985 & 3,927 & 46,980 & 6,735 & 7.0 \\
1986 & 3,850 & 48,308 & 6,929 & 7.0 \\
1987 & 3,884 & 49,537 & 7,091 & 7.1 \\
1988 & 3,957 & 51,239 & 7,260 & 7.2 \\
1989 & 4,103 & 52,969 & 7,413 & \\
1990 & 4,220 & 53,522 & 7,339 & \\
& & & & $0.4 \%$ \\
$1970-90$ & & Average annual percentage change & \\
$1982-90$ & $0.7 \%$ & $3.5 \%$ & $3.1 \%$ & \\
\hline & $-0.3 \%$ & $3.6 \%$ & $3.3 \%$ & \\
\hline
\end{tabular}

Source:

U.S. Department of Transportation, Federal Highway Administration, Highway Statistics 1990 , Washington, DC, 1991, Table VM-1, p. 192, and annual.

"Other single-unit trucks are defined as all single-unit trucks with more than two axles or more than four tires. 

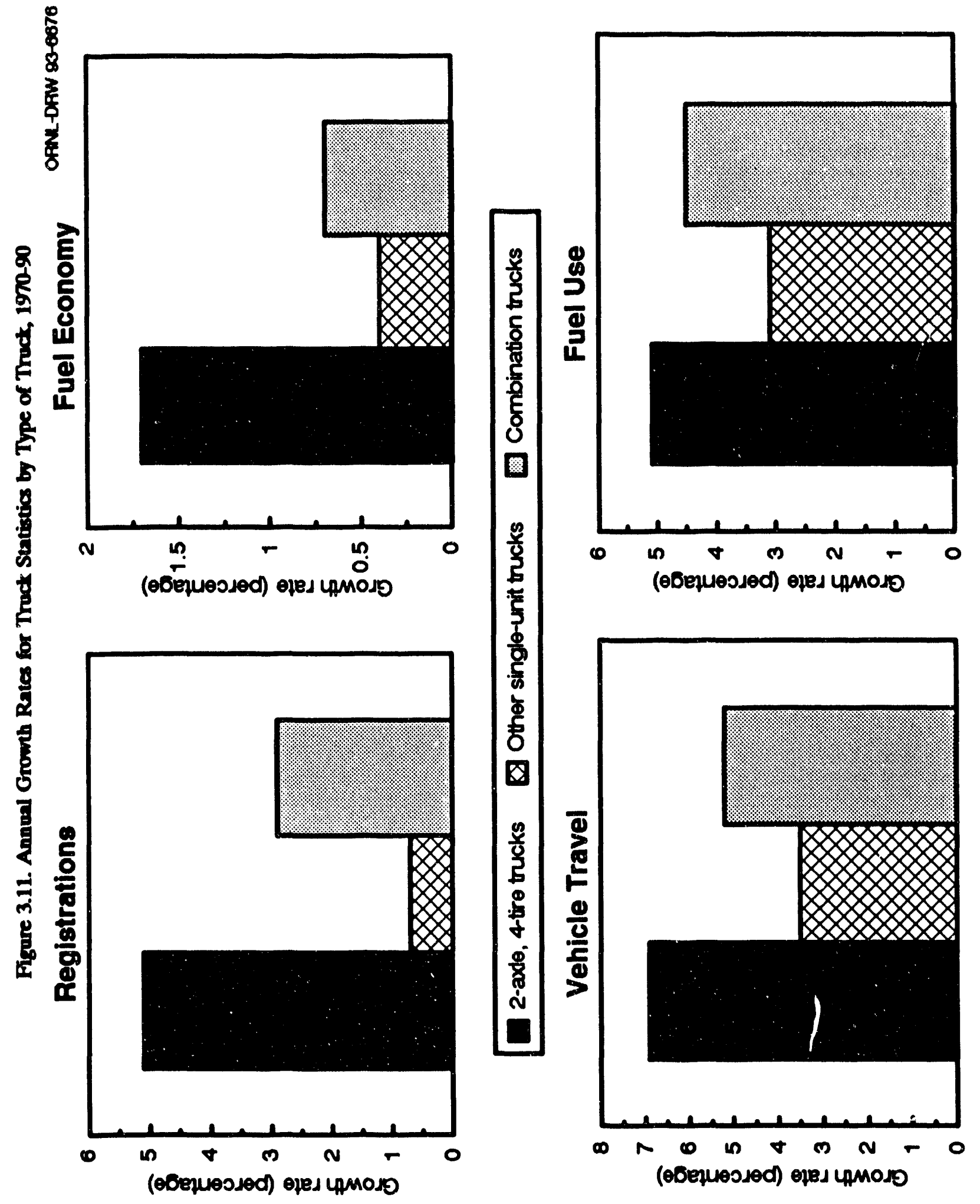
The average miles traveled per combination truck (vehicle travel divided by registrations) has increased from 38,822 miles in 1970 to 60,039 miles in 1990. Since the fuel economy for combination trucks has increased by only 0.7 miles per gallon in this time period, fuel use has increased nearly as much as the vehicle travel.

Tuble 3.26

Summary Statiatice for Combination Tructs, 1970-90

\begin{tabular}{|c|c|c|c|c|}
\hline Year & $\begin{array}{l}\text { Registrations } \\
\text { (thousands) }\end{array}$ & $\begin{array}{l}\text { Vehicie travel } \\
\text { (million miles) }\end{array}$ & $\begin{array}{l}\text { Puel use } \\
\text { (million gallons) }\end{array}$ & $\begin{array}{l}\text { Fuel connomy" } \\
\text { (miles per gallon) }\end{array}$ \\
\hline 1970 & 905 & 35,134 & 7,347 & 4.8 \\
\hline 1971 & 919 & 37,217 & 7,595 & 4.9 \\
\hline 1972 & 961 & 40,706 & 8,120 & 5.0 \\
\hline 1973 & 1,029 & 45,649 & 9,026 & 5.1 \\
\hline 1974 & 1,085 & 45,966 & 8,800 & 5.2 \\
\hline 1975 & 1,131 & 46,724 & 8,653 & 5.4 \\
\hline 1976 & 1,225 & 49,680 & 9,536 & 5.2 \\
\hline 1977 & 1,240 & 55,683 & 10,673 & 5.2 \\
\hline 1978 & 1,342 & 62,992 & 12,113 & 5.2 \\
\hline 1979 & 1,386 & 66,992 & 12,864 & 5.2 \\
\hline 1980 & 1,417 & 68,678 & 12,703 & 5.4 \\
\hline 1981 & 1,261 & 69,134 & 12,960 & 5.3 \\
\hline 1982 & 1,265 & 66,668 & 12,636 & 5.3 \\
\hline 1983 & 1,304 & 69,754 & 13,447 & 5.2 \\
\hline 1984 & 1,340 & 77,367 & 14,781 & 5.2 \\
\hline 1985 & 1,403 & 79,600 & 15,280 & 5.2 \\
\hline 1986 & 1,399 & 81,833 & 15,716 & 5.2 \\
\hline 1987 & 1,419 & 86,064 & 16,493 & 5.2 \\
\hline 1988 & 1,476 & 90,158 & 17,123 & 5.3 \\
\hline 1989 & 1,589 & 95,349 & 17,495 & 5.5 \\
\hline 1990 & 1,607 & 96,482 & 17,577 & 5.5 \\
\hline \multicolumn{5}{|c|}{ Average annual percentage change } \\
\hline $1970-90$ & $2.9 \%$ & $5.2 \%$ & $4.5 \%$ & $0.7 \%$ \\
\hline $1982-90$ & $3.0 \%$ & $4.7 \%$ & $4.2 \%$ & $0.5 \%$ \\
\hline
\end{tabular}

Source:

Department of Transportation, Federal Highway Administration, Highway Statistics 1990, Washington, DC, 1991, Table VM-1, p. 192, and annual.

The fuel economy for combination trucks is not the same as the fuel economy for Class 8 trucks. Fuel economy for Class 8 trucks is shown in Table 3.25. 
Table 3.27

Truct Fuel Bconomy by Sire Clas, 197, 1982, and 1987 (miles per gallon)

\begin{tabular}{ccccc}
\hline Size Class & Weight & $\begin{array}{c}1977 \\
\text { TIUS }\end{array}$ & $\begin{array}{c}1982 \\
\text { TIUS }^{\circ}\end{array}$ & $\begin{array}{c}1987 \\
\text { TIUS }^{\circ}\end{array}$ \\
\hline Class 1 & 6,000 pounds and less & 13.2 & 14.2 & 15.0 \\
Class 2 & $6,001-10,000$ pounds & 11.5 & 11.1 & 10.9 \\
Class 3 & $10,000-14,000$ pounds & 9.4 & 8.1 & 8.1 \\
Class 4 & $14,001-16,000$ pounds & 6.9 & 7.5 & 7.5 \\
Class 5 & $16,001-19,500$ pounds & 7.6 & 7.2 & 7.1 \\
Class 6 & $19,501-26,000$ pounds & 6.1 & 6.9 & 6.4 \\
Class 7 & $26,001-33,000$ pounds & 5.3 & 6.2 & 6.1 \\
Class 8 & 33,001 and over & 4.8 & 5.2 & 5.3 \\
\hline
\end{tabular}

Source:

Estimates are based on data provided on the following public use tapes: U.S. Department of Commerce, Bureau of the Census, 1977 Census of Transportation, Truck Inventory and Use Survey, Washington, DC, 1980; U.S. Department of Commerce, Bureau of the Census, 1982 Census of Transportation, Truck Inventory and Use Survey, Washington, DC, 1985; and U.S. Department of Commerce, Bureau of the Census, 1987 Census of Transportation, Truck Inventory and Use Survey, Washington, DC, 1990.

Table 3.28

Percentage of Tructs by Sire Cira, 197, 1982, and 1987

(percentage)

\begin{tabular}{ccccc}
\hline Size Class & Weight & $\begin{array}{c}1977 \\
\text { TIUS }\end{array}$ & $\begin{array}{c}1982 \\
\text { TIUS }^{\natural}\end{array}$ & $\begin{array}{c}1987 \\
\text { TIUS }^{\circ}\end{array}$ \\
\hline Class 1 & 6,000 pounds and less & 66.0 & 77.8 & 85.4 \\
Class 2 & $6,001-10,000$ pounds & 17.9 & 11.6 & 6.5 \\
Class 3 & $10,000-14,000$ pounds & 3.1 & 1.6 & 1.2 \\
Class 4 & $14,001-16,000$ pounds & 1.3 & 0.9 & 0.5 \\
Class 5 & $16,001-19,500$ pounds & 2.1 & 1.0 & 0.6 \\
Class 6 & $19,501-26,000$ pounds & 3.4 & 2.4 & 1.7 \\
Class 7 & $26,001-33,000$ pounds & 1.5 & 1.0 & 0.8 \\
Class 8 & 33,001 and over & 4.6 & 3.8 & 3.3 \\
\hline
\end{tabular}

Source:

Estimates are based on data provided on the following public use tapes: U.S. Department of Commerce, Bureau of the Census, 1977 Census of Transportation, Truck Inventory and Use Survey Washington, DC, 1980; U.S. Department of Commerce, Bureau of the Census, 1982 Census of Transportation, Truck Inventory and Use Survey, Washington, DC, 1985; and U.S. Department of Commerce, Bureau of the Census, 1987 Census of Transportation, Truck Inventory and Use Survey, Washington, DC, 1990.

Truck Inventory and Use Survey. 
Section 3.4 Buses 
Table 329

Busces in Operation by Type, 1970-90

\begin{tabular}{|c|c|c|c|c|c|c|}
\hline \multirow[b]{2}{*}{ Year } & \multicolumn{2}{|c|}{ Transite } & \multirow[b]{2}{*}{$\begin{array}{l}\text { Intercity } \\
\text { bus }\end{array}$} & \multirow{2}{*}{$\begin{array}{l}\text { School and } \\
\text { other } \\
\text { nonrevenue }\end{array}$} & \multirow[b]{2}{*}{ Other } & \multirow[b]{2}{*}{ Total } \\
\hline & $\begin{array}{l}\text { Motor } \\
\text { bus }\end{array}$ & $\begin{array}{l}\text { Troley } \\
\text { cosach }^{6}\end{array}$ & & & & \\
\hline 1970 & 49,700 & 1,050 & 22,000 & 288,700 & 16,112 & 377,562 \\
\hline 1971 & 49,150 & 1,037 & 21,900 & 307,300 & 17,688 & 397,075 \\
\hline 1972 & 49,075 & 1,030 & 21,400 & 318,200 & 17,161 & 406,866 \\
\hline 1973 & 48,286 & 794 & 20,800 & 336,000 & 19,040 & 424,920 \\
\hline 1974 & 48,700 & 718 & 21,000 & 356,900 & 19,730 & 447,048 \\
\hline 1975 & 50,811 & 703 & 20,500 & 368,300 & 21,842 & 462,156 \\
\hline 1976 & 52,382 & 685 & 20,100 & 381,498 & 23,674 & 478,339 \\
\hline 1977 & 51,968 & 645 & 20,300 & 393,810 & 24,038 & 490,761 \\
\hline 1978 & 52,866 & 593 & 20,250 & 398,804 & 32,841 & 505,354 \\
\hline 1979 & 54,490 & 725 & 20,680 & 415,117 & 35,753 & 526.765 \\
\hline 1980 & 59,411 & 823 & 21,400 & 418,255 & 28,930 & 528,789 \\
\hline 1981 & 60,393 & 751 & 21,500 & 432,813 & 28,437 & 543,894 \\
\hline 1982 & 62,114 & 763 & 22,000 & 442,133 & 32,190 & 559,200 \\
\hline 1983 & 62,093 & 686 & 23,500 & 470,727 & 25,878 & 582,884 \\
\hline 1984 & 67,294 & 664 & 25,000 & 471,461 & 23,049 & 583,671 \\
\hline 1985 & 64,258 & 676 & 20,200 & 480,400 & 34,924 & 593,485 \\
\hline 1986 & 66,218 & 680 & 20,300 & 479,076 & 35,672 & 593,728 \\
\hline 1987 & 63,017 & 671 & 20,100 & 486,753 & 36,544 & 602,055 \\
\hline 1988 & 62,572 & 710 & 19,887 & 498,907 & 35,777 & 615,669 \\
\hline 1989 & 58,919 & 725 & 20,043 & 507,628 & 36,394 & 625,040 \\
\hline 1990 & 59,753 & 832 & 20,680 & 508,261 & 37,461 & 626,987 \\
\hline \multicolumn{7}{|c|}{ Average annual percensage change } \\
\hline $1970-90$ & $0.9 \%$ & $-1.2 \%$ & $-0.3 \%$ & $2.9 \%$ & $4.3 \%$ & $2.6 \%$ \\
\hline $1982-90$ & $-0.5 \%$ & $1.1 \%$ & $-0.8 \%$ & $1.8 \%$ & $1.9 \%$ & $1.4 \%$ \\
\hline
\end{tabular}

Sources:

Transit buses - American Public Transit Association, 1991 Transit Fact Book, Washington, DC, October 1991, p. 76, and annual.

Intercity buses - 1970-84: American Bus Association, 1984 Annual Report, Washington, DC, and annual. 1985-88: U.S. Department of Transportation, Transportation Systems Center, National Transportation Statistics, Cambridge, MA, August 1990, Figure 5, p. 8, and annual.

1989-90: Estimated as $38 \%$ of commercial buses (less transit motor buses). Commercial bus total found in Highway Statistics 1990, Table MV-10, and annual.

Other buses - Derived by subtracting Transit, Intercity, and School buses from Total buses.

School buses alıd Total buses - U.S. Department of Transportation, Federal Highway Administration, Highway Statistics 1990, Washington, DC, 1991, Table MV-10, p. 20, and annual.

-Series not continuous between 1983 and 1984 because of a change in data source by the American Public Transit Association (APTA). Beginning in 1984, data provided by APTA are taken from mandatory reports filed with the Urban Mass Transit Administration (UMTA). Data for prior years were provided on a voluntary basis by APTA members and expanded statistically.

Trolley coach - a rubber tired transit vehicle that usually draws its power from overhead wires.

Includes some industrial and other private buses.

Includes government buses, private buses, and other miscellaneous buses. 
Although school buses comprise $81 \%$ of the bus vehicle stock, only $55 \%$ of bus vehicle travel was attributed to school buses in 1990 . Intercity buses were the only bus type to experience declines in passenger travel and vehicle unovel from $1970-90$ and $1982-90$.

Table $\mathbf{3 3 0}$

Passenger and Vehicle Traved by Bos Type, 1970-90

\begin{tabular}{|c|c|c|c|c|c|}
\hline \multirow{2}{*}{ Year } & \multicolumn{2}{|c|}{$\begin{array}{l}\text { Passenger travel } \\
\text { (million miles) }\end{array}$} & \multicolumn{3}{|c|}{$\begin{array}{l}\text { Vehicle trave, } \\
\text { (million miles) }\end{array}$} \\
\hline & Transit bus & Intercity bus & Transit bus & Intercity bus & School bus \\
\hline 1970 & 18,120 & 25,300 & 1,409 & 1,209 & 2,100 \\
\hline 1971 & 16,810 & 25,500 & 1,375 & 1,202 & 2,212 \\
\hline 1972 & 16,180 & 25,600 & 1,308 & 1,182 & 2,359 \\
\hline 1973 & 16,170 & 26,400 & 1,370 & 1,178 & 2,412 \\
\hline 1974 & 17,910 & 27,700 & 1,431 & 1,195 & 2,450 \\
\hline 1975 & 18,300 & 25,400 & 1526 & 1,126 & 2,500 \\
\hline 1976 & 18,890 & 25,100 & 1,581 & 1,118 & 2,862 \\
\hline 1977 & 19,730 & 25,700 & 1,623 & 1,102 & 2,950 \\
\hline 1978 & 20,708 & 25,400 & 1,631 & 1,081 & 2,991 \\
\hline 1979 & 21,393 & 27,200 & 1,634 & 1,132 & 2,980 \\
\hline 1980 & 21,790 & 27,400 & 1,677 & 1,162 & 2,900 \\
\hline 1981 & 21,012 & 27,100 & 1,685 & 1,134 & 2,960 \\
\hline 1982 & 19,987 & 26,900 & 1,669 & 1,115 & 3,062 \\
\hline 1983 & 20,047 & 26,500 & 1,678 & 1,120 & $3, C^{2} \times 8$ \\
\hline 1984 & 21,595 & 27,100 & 1,845 & 1,098 & 3,400 \\
\hline 1985 & 21,161 & 23,800 & 1.863 & 933 & 3,448 \\
\hline 1986 & 21,395 & 23,700 & 2,002 & 1,021 & 3,700 \\
\hline 1987 & 20,970 & 23,000 & 2.079 & 991 & 3,900 \\
\hline 1988 & 20,753 & 23,100 & 2,097 & 996 & 4,100 \\
\hline 1989 & 20,768 & 24,000 & 2,109 & 1,034 & 4,000 \\
\hline 1990 & 21,127 & 23,000 & 2,153 & 991 & 3,800 \\
\hline \multicolumn{6}{|c|}{ Average annual percentage change } \\
\hline $1970-90$ & $0.8 \%$ & $-0.5 \%$ & $2.1 q^{\prime}$ & $-1.0 \%$ & $3.0 \%$ \\
\hline $1982-90$ & $0.7 \%$ & $-1.9 \%$ & $3.2 \%$ & $-1.5 \%$ & $2.7 \%$ \\
\hline
\end{tabular}

Sourceer:

Transit buses - 1970-90: American Public Transit Association, 1991 Transit Fact Book, Washington, DC, October 1991 , pp. 73, 74, and annual.

Intercity buses - 1970-84: Americar Bus Association, Annual Report, Washington, DC, Annual. 1985-90: Ėno Transportation Foundation, Transpurtation in America, Ninth edition-December supplement, Washington, DC, 1991, p. 11.

1986-90 vehicle travel: Estimated using passenger travel and an average load factor of $\mathbf{2 3 . 2}$

School buses - 1970-84: U.S. Department of Transportation, Federal Highway Administration, Highway Statistics 1984. Washington, DC, Table VM-1, p. 175, and annual.

1985-87: U.S. Department of Transportation, Research and Special Programs Administration, National Transportation Statistics, 1989, Figure 2, p. 7, and annual.

1988-90: National Safety Council, Accident Facts, 1991 Edition, Chicago, IL, p. 71, and annual.

Transit bus statistics include motor bus only. Series not continuous between 1983 and 1984 because of a change in data source by the American Public Transit Association (APTA). Beginning in 1984, data provided by APTA are taken from mandatory reports filed with the Urban Mass Transit Ar'ministratico (UMTA). Data for prior years were provided on a voluntary basis by APTA members and expanded statistically. 
The average annual miles per transit bus has been growing each year since 1982. School buses travel the least per bus, but travel more total vehicle miles than the other bus types.

Table 3.31

Average Annual Miles per Bus by Type, 1970-90

(miles)

\begin{tabular}{cccc}
\hline Year & Transit bus & Intercity bus & School bus \\
\hline 1970 & 28,350 & 54,955 & 7,274 \\
1971 & 27,976 & 54,886 & 7,198 \\
1972 & 26,653 & 55,234 & 7,414 \\
1973 & 28,373 & 56,635 & 7,179 \\
1974 & 29,384 & 56,905 & 6,865 \\
1975 & 30,033 & 54,927 & 6,788 \\
1976 & 30,182 & 55,622 & 7,502 \\
1977 & 31,231 & 54,286 & 7,491 \\
1978 & 30,852 & 53,383 & 7,500 \\
1979 & 29,987 & 54,739 & 7,179 \\
1980 & 28,227 & 54,299 & 6,934 \\
1981 & 27,901 & 52,744 & 6,839 \\
1982 & 26,870 & 50,682 & 6,926 \\
1983 & 27,024 & 47,660 & 6,581 \\
1984 & 27,417 & 43,920 & 7,212 \\
1985 & 28,992 & 46,188 & 7,177 \\
1986 & 30,233 & 50,296 & 7,723 \\
1987 & 32,991 & 49,304 & 8,012 \\
1988 & 33,513 & 50,083 & 8,218 \\
1989 & 35,795 & 51,589 & 7,880 \\
1990 & 36,032 & 47,921 & 7,476 \\
& & & \\
& Average rannual percentage change & \\
$1970-90$ & & & \\
$1982-90$ & $1.29 \%$ & $-0.7 \%$ & $0.1 \%$ \\
\hline & $3.7 \% \%$ & $-0.7 \%$ & $1.0 \%$ \\
\hline
\end{tabular}

Source:

Annual miles were obtained by dividing the total vehicles miles (from Table 3.30) by the number of vehicles (from Table 3.29).

Transit bus statistics include motor bus only. Series not continuous between 1983 i..3d 1984 because of a change in data source by the American Public Transit Association (APTA). Beginning in 1984, data provided by APTA are taken from mandatory reports filed with the Urban Mass Transit Administration (UMTA). Data for prior years were provided on a voluntary basis by APTA members and expanded statistically. 
Transit buses, which were the least efficient bus type on a Btu per vehicle-mile basis, accounted for nearly half of total bus energy use in 1990. School buses, which were the mast efficient on a Btu per vehiclemile basis, accounted for $38 \%$ of bus energy use in 1990 .

Table 3.32

Energy Consumption and Energy Intensitiea by Type of Bus, 1970-90

\begin{tabular}{|c|c|c|c|c|c|c|}
\hline \multirow[b]{2}{*}{ Year } & \multicolumn{3}{|c|}{ Energy use (trillion Btu) } & \multicolumn{3}{|c|}{ Energy Intensity (Btu per vehicle-mile) } \\
\hline & $\begin{array}{c}\text { Transit } \\
\text { bus }\end{array}$ & $\begin{array}{c}\text { Intercity } \\
\text { bus }\end{array}$ & $\begin{array}{c}\text { School } \\
\text { bus }\end{array}$ & $\begin{array}{c}\text { Transit } \\
\text { bus }\end{array}$ & $\begin{array}{c}\text { Intercity } \\
\text { bus }\end{array}$ & $\begin{array}{c}\text { School } \\
\text { bus }\end{array}$ \\
\hline 1970 & 44.8 & 26.6 & 37.5 & 31,796 & 22,002 & 17,857 \\
\hline 1971 & 41.6 & 26.5 & 39.5 & 30,255 & 22,047 & 17,857 \\
\hline 1972 & 39.7 & 26.0 & 40.0 & 30,352 & 21,997 & 16,956 \\
\hline 1973 & 42.0 & 25.9 & 40.9 & 30,657 & 21,986 & 16,957 \\
\hline 1974 & 45.1 & 26.3 & 41.6 & 31,516 & 22,008 & 16,980 \\
\hline 1975 & 51.5 & 24.8 & 42.6 & 33,748 & 22,025 & 17,040 \\
\hline 1976 & 54.7 & 25.0 & 48.8 & 34,598 & 22,361 & 17,051 \\
\hline 1977 & 57.0 & 24.7 & 50.1 & 35,120 & 22,414 & 16,983 \\
\hline 1978 & 59.7 & 24.2 & 50.9 & 36,603 & 22,387 & 17,018 \\
\hline 1979 & 59.8 & 26.2 & 50.6 & 36,597 & 23,145 & 16,980 \\
\hline 1980 & 61.3 & 29.3 & 47.5 & 36,553 & 25,215 & 16,379 \\
\hline 1981 & 63.6 & 31.3 & 48.5 & 37,745 & 27,601 & 16,385 \\
\hline 1982 & 64.7 & 30.9 & 49.9 & 38,766 & 27,713 & 16,296 \\
\hline 1983 & 63.7 & 31.1 & 50.3 & 37,962 & 27,768 & 16,236 \\
\hline 1984 & 69.2 & 33.8 & 50.7 & 37,507 & 30,783 & 14,912 \\
\hline 1985 & 72.4 & 31.5 & 57.0 & 38,862 & 31,722 & 16,531 \\
\hline 1986 & 75.6 & 20.6 & 57.8 & 39,873 & 20,176 & 15,622 \\
\hline 1987 & 74.3 & 21.6 & 60.9 & 38,557 & 21,796 & 15,615 \\
\hline 1988 & 73.0 & 22.3 & 63.9 & 39,121 & 22,390 & 15,585 \\
\hline 1989 & 77.3 & 23.1 & 62.3 & 36,583 & 22,340 & 15,575 \\
\hline 1990 & 78.9 & 21.7 & 62.2 & 36,647 & 21,897 & 16,368 \\
\hline \multicolumn{7}{|c|}{ Average annual percentage change } \\
\hline $1970-90$ & $2.9 \%$ & $-1.0 \%$ & $2.6 \%$ & $0.7 \%$ & $-0.5 \%$ & $0.1 \%$ \\
\hline $1982-90$ & $2.5 \%$ & $-4.3 \%$ & $2.8 \%$ & $-0.7 \%$ & $-7.6 \%$ & $-0.4 \%$ \\
\hline
\end{tabular}

Source:

Energy use - See Appendix A for Table 2.10.

Energy intensities by vehicle-mile were calculated by dividing energy use by vehicle-miles

Transit bus statistics include motor bus only. Series not continuous between 1983 and 1984 because of a change in data source by the American Public Transit Association (APTA). Beginning in 1984, data provided by APTA are taken from mandatory reports filed with the Urban Mass Transit Administration (UMTA). Data for prior years were provided on a voluntary basis by APTA members and expanded statistically. 


\section{Section 3.5 \\ Fleets}




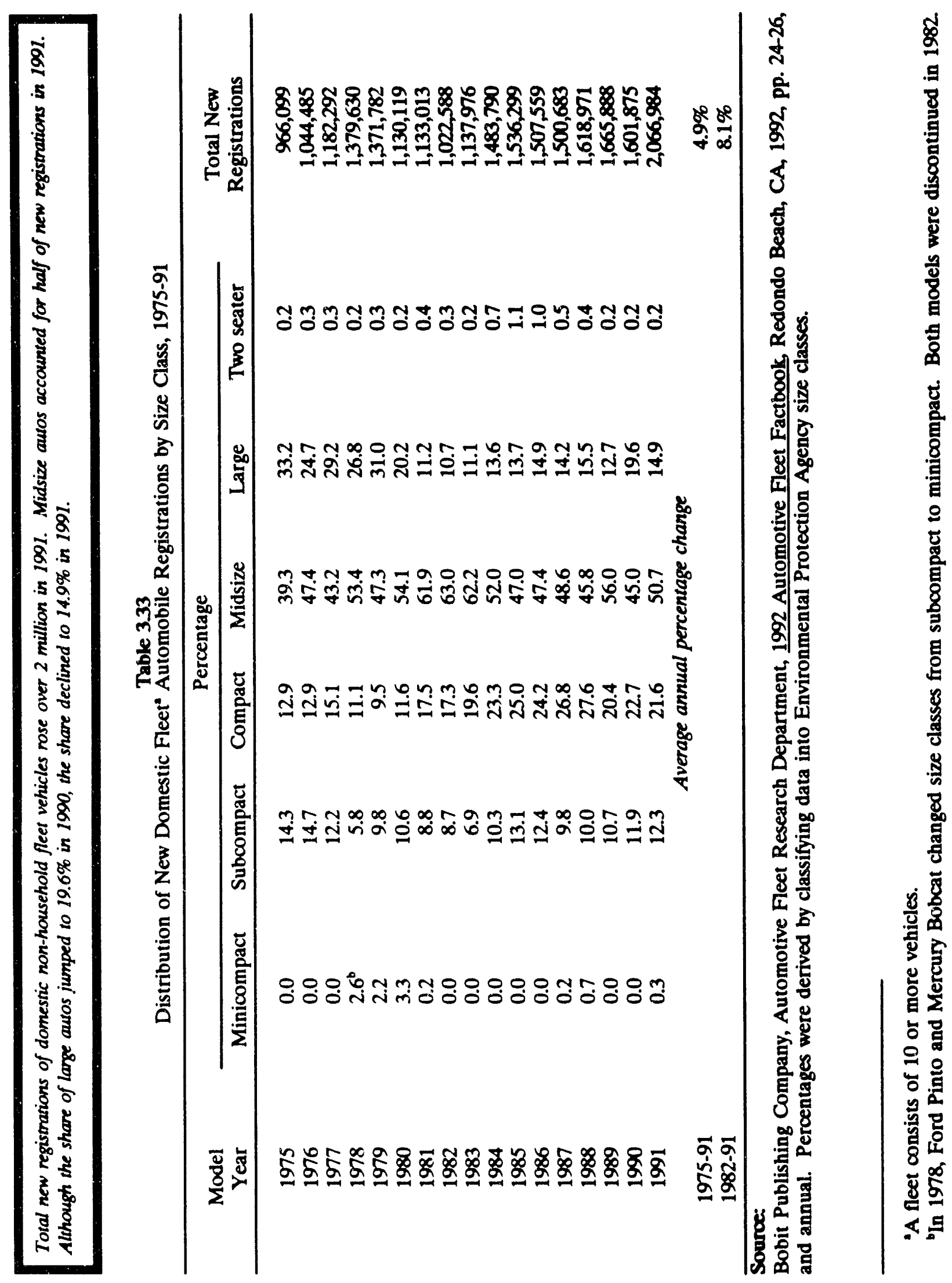




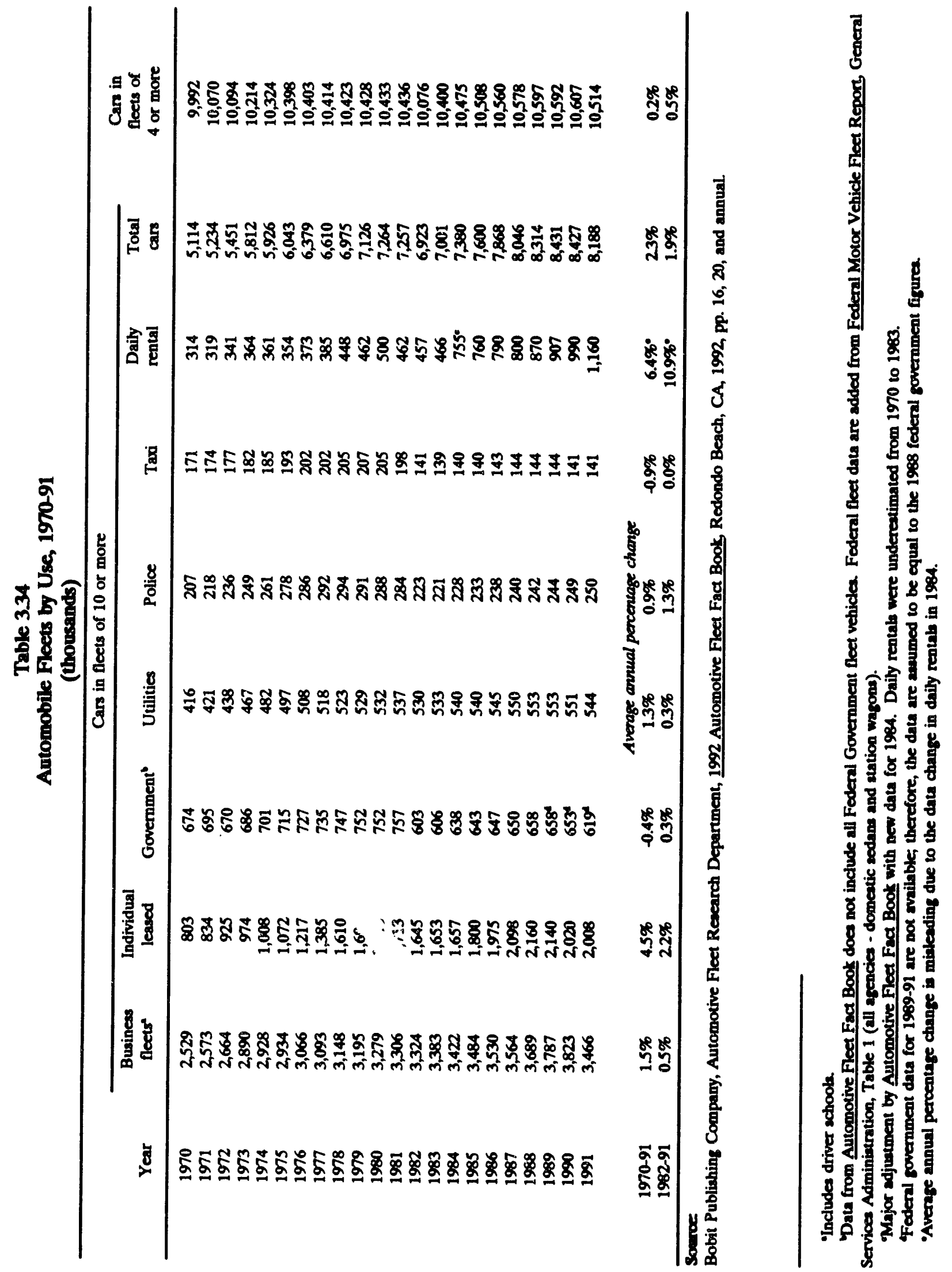




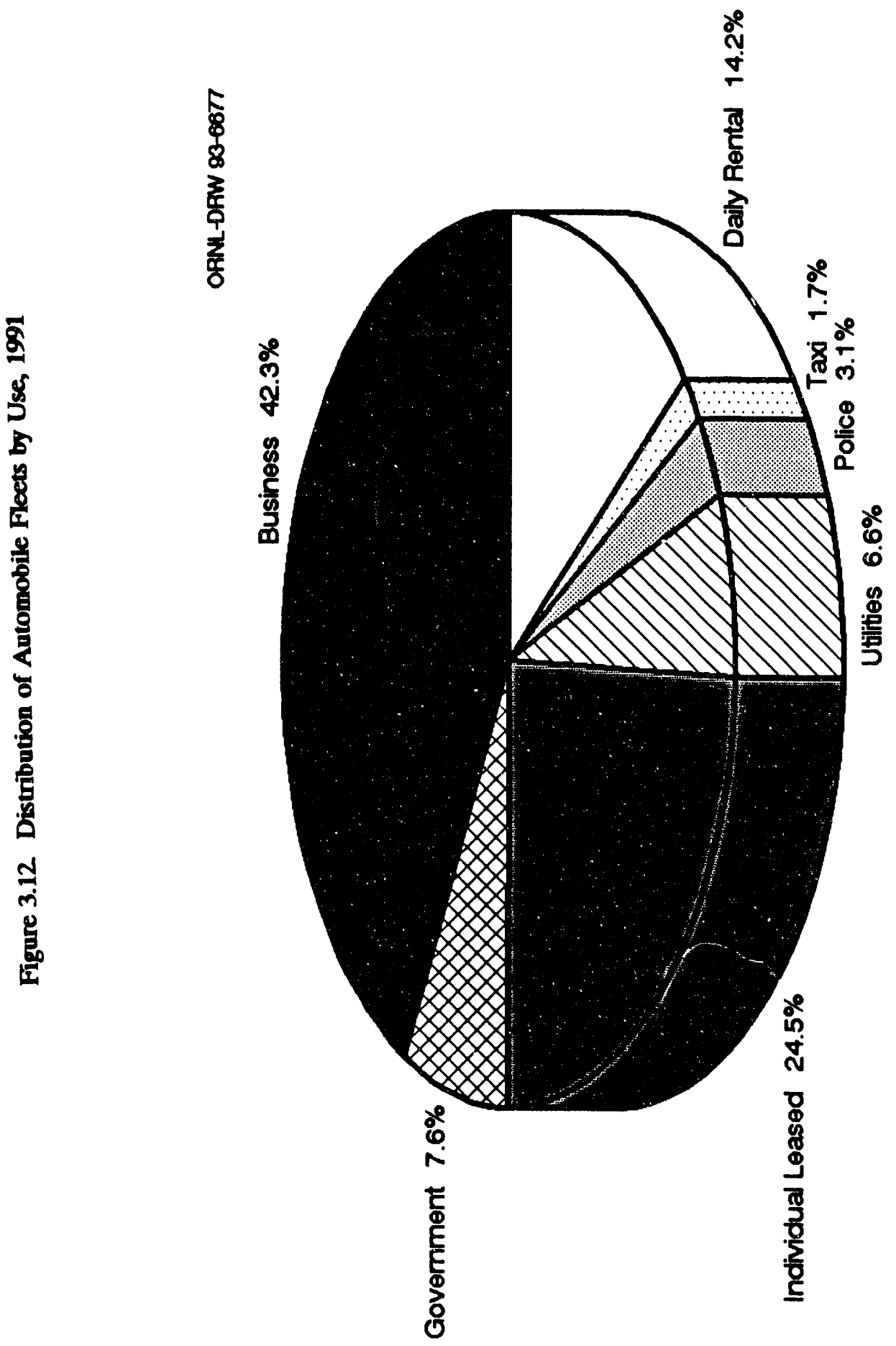

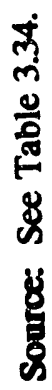


Table 3.35

Federal Government Vehicles by Agency, Fiscal Year 1988

\begin{tabular}{|c|c|c|c|c|c|c|}
\hline \multirow[b]{2}{*}{ Department or Agency } & \multirow[b]{2}{*}{ Autos } & \multirow[b]{2}{*}{ Busea } & \multicolumn{3}{|c|}{ Trucks and Truck Tractors } & \multirow[b]{2}{*}{ Total } \\
\hline & & & $\begin{array}{l}8,500 \text { lbes. } \\
\text { or leas" }\end{array}$ & $\begin{array}{r}8,501 \text { to } \\
23,999 \text { lbs. } \\
\end{array}$ & $\begin{array}{c}24,000 \mathrm{lbs} \\
\text { or over }\end{array}$ & \\
\hline CTVILAN AGENCIRS & 86,884 & 2,393 & 96,866 & 13,884 & 4,977 & 205,004 \\
\hline Government Printing Office & 6 & $\mathbf{0}$ & 59 & $\mathbf{0}$ & $\mathbf{0}$ & 65 \\
\hline Library of Congreas & 1 & 0 & $\mathbf{0}$ & $\mathbf{0}$ & $\mathbf{0}$ & 1 \\
\hline Department of the State & 1,220 & $\mathbf{0}$ & 1,187 & 772 & 67 & 3,246 \\
\hline Department of the Treasury & 8,559 & 11 & 1,485 & 51 & 2 & 10,108 \\
\hline Department of Justice & 14,888 & 138 & 4,440 & 479 & 92 & 20,037 \\
\hline Department of the Interior & 1,663 & 111 & 8,499 & 2,753 & 1,674 & 14,700 \\
\hline Department of Agriculture & 3,911 & 41 & 24,049 & 4,154 & 518 & 32,673 \\
\hline Department of Commerce & 93 & 14 & 376 & 189 & 14 & 686 \\
\hline Department of Labor & 175 & 12 & 412 & 13 & 6 & 618 \\
\hline Department of Health \& Human Services & 90 & 9 & 276 & 91 & 55 & 521 \\
\hline Department of Transportation & 80 & 8 & 394 & 126 & 45 & 653 \\
\hline Department of Energy & 1,853 & 255 & 6,586 & 1,829 & 751 & 11,274 \\
\hline Agency for International Development & 370 & 22 & 204 & 57 & 16 & 979 \\
\hline American Battle Monuments Commission & 13 & $\mathbf{0}$ & 37 & 12 & $\mathbf{0}$ & 62 \\
\hline Environmental Protection Agency & 303 & 3 & 301 & 13 & 9 & 629 \\
\hline Foderal Communications Commission & 61 & $\mathbf{0}$ & 34 & 4 & $\mathbf{0}$ & 99 \\
\hline Federal Emergency Management Agency & 35 & 14 & 76 & 9 & 9 & 143 \\
\hline General Services Administration & 50,869 & 1,605 & 44,230 & 2,001 & 1,347 & 100,052 \\
\hline International Boundary \& Water Commission & $\mathbf{0}$ & $\mathbf{0}$ & 7 & 10 & 23 & 40 \\
\hline Merit Systems Protoction Board & $\mathbf{0}$ & $\mathbf{0}$ & 1 & $\mathbf{0}$ & $\mathbf{0}$ & 1 \\
\hline National Acronautics \& Space Administration & 135 & 11 & 714 & 219 & 49 & 1,155 \\
\hline National Gallery of Art & $\mathbf{0}$ & $\mathbf{0}$ & 3 & 1 & $\mathbf{0}$ & \\
\hline National Science Foundation & 23 & 8 & 122 & 27 & 2 & 182 \\
\hline Overneas Private Investment Corporation & 1 & $\mathbf{0}$ & $\mathbf{0}$ & $\mathbf{0}$ & $\mathbf{0}$ & \\
\hline Panama Canal Commission & 186 & 13 & 524 & 79 & 45 & 847 \\
\hline Peace Corps & 147 & 9 & 214 & 3 & $\mathbf{0}$ & 373 \\
\hline Railroad Retirement！ & 1 & $\mathbf{0}$ & $\mathbf{0}$ & $\mathbf{0}$ & $\mathbf{0}$ & 1 \\
\hline Smitheonian Institution & 23 & 6 & 154 & 44 & 24 & 251 \\
\hline Tennessec Valicy Authority & 1,513 & 4 & 1,303 & 733 & 159 & 3,712 \\
\hline United State Information Agency & 455 & 12 & 323 & 29 & $\mathbf{0}$ & 819 \\
\hline U.S. Soldiers' and Airmen's Home & 12 & 6 & 25 & 6 & 10 & 59 \\
\hline Veterans Administration & 198 & 81 & 494 & 180 & 60 & 1,103 \\
\hline UNTTED STATES POSTAL, SERVICX & 12,260 & 13 & 128,326 & 10,805 & 3,574 & 154,978 \\
\hline MII TTARY AGENCIES & 22,937 & 6,417 & 102,105 & 14,027 & 8,214 & 153,700 \\
\hline Army & 8,292 & 2,484 & 24,890 & 5,781 & 2,147 & 43,594 \\
\hline Navy & 3,624 & 997 & $\mathbf{2 3 , 7 2 8}$ & 2,707 & 2,204 & 33,260 \\
\hline Marine Corps & 725 & 321 & 4,730 & 841 & 607 & 7,224 \\
\hline Air Force & 6,327 & 2574 & 43,603 & 3,658 & 3,034 & 59,196 \\
\hline Civil Works, Corps of Engineers & 721 & 21 & 4,412 & 982 & 204 & 6,340 \\
\hline Defense Agencies & 3,248 & 20 & 742 & 58 & 18 & 4,086 \\
\hline TOTAL & 122,081 & 8,823 & 327,297 & 38,716 & 16,765 & 513,682 \\
\hline
\end{tabular}

Sounce:

U.S. General Services Administration, Federal Supply Service, Federal Motor Fleet Repon, Washington, DC, September 1990 , p. 27.

"Based on gross vehicle weight rating (GVWR).

Includes ambulances. 


\section{Section 3.6 \\ Federal Standards and Motor Vehicle Fuel Economy}


Except for the automobile fuel economy in model year 1984, the sales-weighted fuel economies of automobiles and light trucks have, on average, met the fuel economy standards set by the federal government. This does not mean, however, that each manufacturer is meeting the standands each year. Some manufacturers still fall shor, while others exceed the standands. The domestic automobile CAFE estimate did not meet the 1992 standand, but the import estimate axceeded the standard, pulling the combined automobile CAFE estimate above the standand.

Table 3.36

Corporate Average Puel Boosomy (CAFE)

Standands versus Sales-Weighted Puel Boonomy Bstimates

for Automobiles and Light Tructs, 1978-92 (miles per gallon)

\begin{tabular}{|c|c|c|c|c|c|c|c|c|}
\hline \multirow{3}{*}{$\begin{array}{c}\text { Model } \\
\text { Year }\end{array}$} & \multicolumn{4}{|c|}{ Automobiles } & \multicolumn{4}{|c|}{ Light Trucks ${ }^{b}$} \\
\hline & \multirow{2}{*}{$\begin{array}{c}\text { CAFE } \\
\text { Standards }\end{array}$} & \multicolumn{3}{|c|}{ CAFE Estimates" } & \multirow{2}{*}{$\begin{array}{c}\text { CAFE } \\
\text { Standards }\end{array}$} & \multicolumn{3}{|c|}{ CAFE Estimates ${ }^{\circ}$} \\
\hline & & Domestic & Import & Combined & & Domestic & Import & Combined \\
\hline 1978 & 18.0 & 18.7 & 27.3 & 19.9 & d & - & - & - \\
\hline 1979 & 19.0 & 19.3 & 26.1 & 20.3 & 17.2 & 17.7 & 20.8 & 18.2 \\
\hline 1980 & 20.0 & 22.6 & 29.6 & 24.3 & $d$ & 16.8 & 24.3 & 18.5 \\
\hline 1981 & 22.0 & 24.2 & 31.5 & 25.9 & d & 18.3 & 27.4 & 20.1 \\
\hline 1982 & 24.0 & 25.0 & 31.1 & 26.6 & 17.5 & 19.2 & 27.0 & 20.5 \\
\hline 1983 & 26.0 & 24.4 & 32.4 & 26.4 & 19.0 & 19.6 & 27.1 & 20.7 \\
\hline 1984 & 27.0 & 25.5 & 32.0 & 26.9 & 20.0 & 19.3 & 26.7 & 20.6 \\
\hline 1985 & 27.5 & 26.3 & 31.5 & 27.6 & 19.5 & 19.6 & 26.5 & 20.7 \\
\hline 1986 & 26.0 & 26.9 & 31.6 & 28.2 & 20.0 & 19.9 & 25.9 & 21.5 \\
\hline 1987 & 26.0 & 27.0 & 31.2 & 28.5 & 20.5 & 20.5 & 25.2 & 21.7 \\
\hline 1988 & 26.0 & 27.4 & 31.5 & 28.8 & 20.5 & 20.6 & 24.6 & 21.3 \\
\hline 1989 & 26.5 & 27.2 & 30.8 & 28.4 & 20.5 & 20.4 & 23.5 & 20.9 \\
\hline 1990 & 27.5 & 26.9 & 29.8 & 28.0 & 20.0 & 20.2 & 23.0 & 20.7 \\
\hline 1991 & 27.5 & 27.4 & 29.8 & 28.3 & 20.2 & 20.9 & 23.0 & 21.3 \\
\hline 1992 & 27.5 & 26.9 & 29.0 & 27.8 & 20.2 & 20.4 & 22.4 & 20.8 \\
\hline
\end{tabular}

Source:

U.S. Department of Transportation, NHTSA, "Summary of Fuel Economy Performance," Washington, DC, March 1992.

'Only vehicles with at least 75 percent domestic content can be counted in the average fuel economy for a manufacturer.

'Represents two- and four-wheel drive trucks combined. Gross vehicle weight of 0-6,000 pounds for model year 1979 and $0-8,500$ pounds for subsequent years.

'All CAFE calculations are sales-weighted.

'Standards were set for two-wheel drive and four-wheel drive light trucks separately, but no combined standard was set in this year.

'Data are not available. 


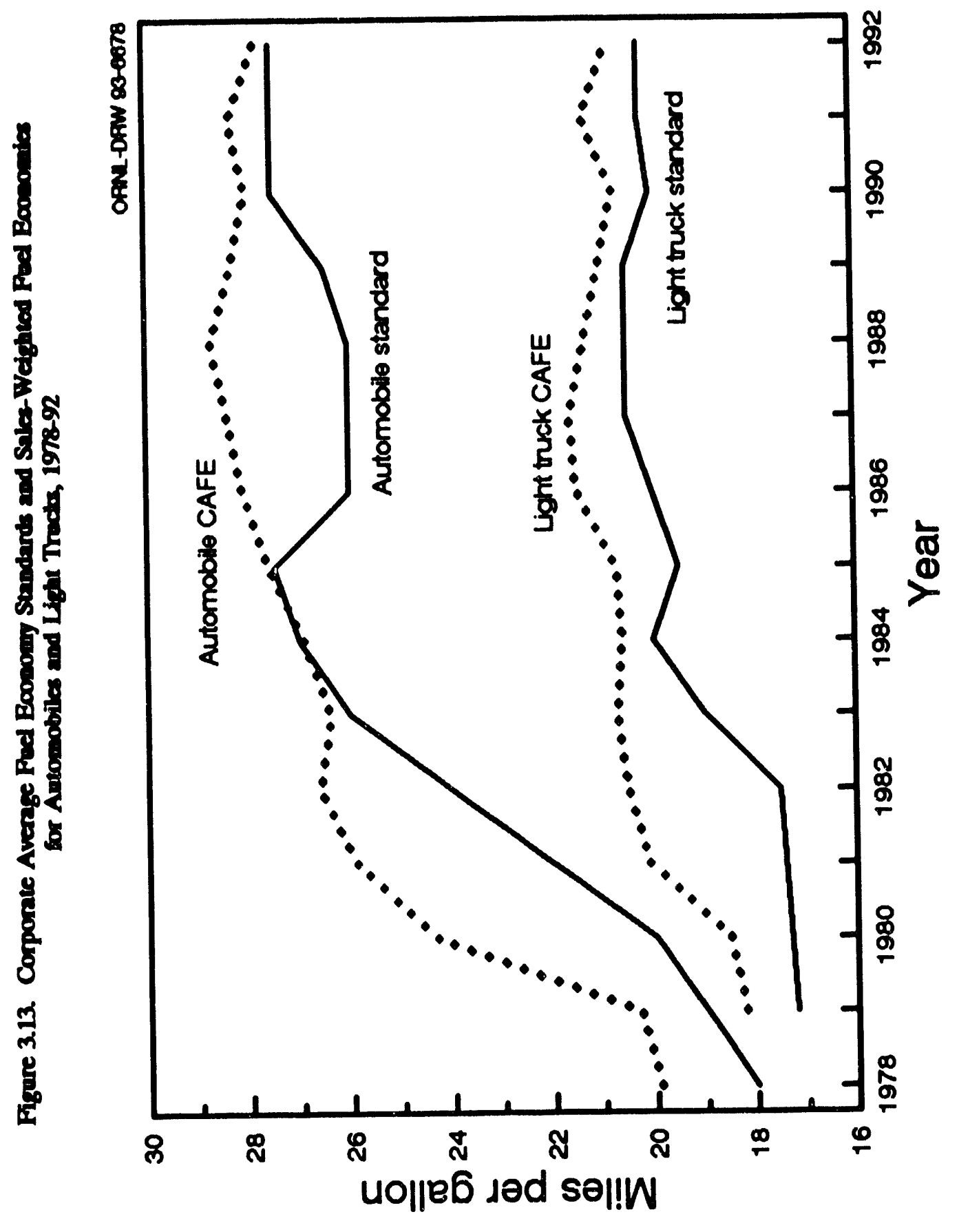

4
0
$m$
0
0
0
8
8
8
8
8 
Table 3.37.

Corporate Average Puel Bconomy (CAFE) Fines Collectod, 1983-91

\begin{tabular}{crc}
\hline & \multicolumn{2}{c}{ Thousands } \\
\cline { 2 - 3 } $\begin{array}{c}\text { Model } \\
\text { year }\end{array}$ & $\begin{array}{c}\text { Current } \\
\text { dollars }\end{array}$ & $\begin{array}{c}1990 \text { constant } \\
\text { dollars }\end{array}$ \\
\hline 1983 & 58 & 76 \\
1984 & 5,958 & 7,496 \\
1985 & 15,565 & 18,908 \\
1986 & 29,872 & 35,603 \\
1987 & 30,981 & 35,623 \\
1988 & 43,622 & 48,190 \\
1989 & 46,122 & 48,619 \\
1990 & 47,582 & 47,582 \\
$1991^{\circ}$ & 11,249 & 10,788 \\
\hline Total & 231,009 & 252,885
\end{tabular}

Source:

U.S. Department of Transportation, National Highway Traffic Safety Administration, Office of Vehicle Safety Compliance, Washington, DC, July 1992.

Table 3.38

Tax Receipts from the Sale of Gas Guzalers, 1980-91

\begin{tabular}{ccc}
\hline & \multicolumn{2}{c}{ Thousands } \\
\cline { 2 - 3 } Fiscal & $\begin{array}{c}\text { Current } \\
\text { dollars }\end{array}$ & $\begin{array}{c}1990 \text { constant } \\
\text { dollars' }\end{array}$ \\
\hline 1980 & 740 & 1,174 \\
1981 & 780 & 1,121 \\
1982 & 1,720 & 2,329 \\
1983 & 4,020 & 5,273 \\
1984 & 8,820 & 11,097 \\
1985 & 39,790 & 48,336 \\
1986 & 147,660 & 175,987 \\
1987 & 145,900 & 167,759 \\
1988 & 116,780 & 129,008 \\
1989 & 109,640 & 115,575 \\
1990 & 103,200 & 103,200 \\
1991 & 118,400 & 113,546 \\
\hline Total & 797,450 & 874,405 \\
& & \\
Source: & & \\
Motor Vehicle Manufacturers Association, Motor Vehicle \\
Facts and Figures 92, Detroit, MI, 1992, p. 87.
\end{tabular}

-Adjusted using the Consumer Price Inflation Index.

'Includes only those fines collected at time of publication. 


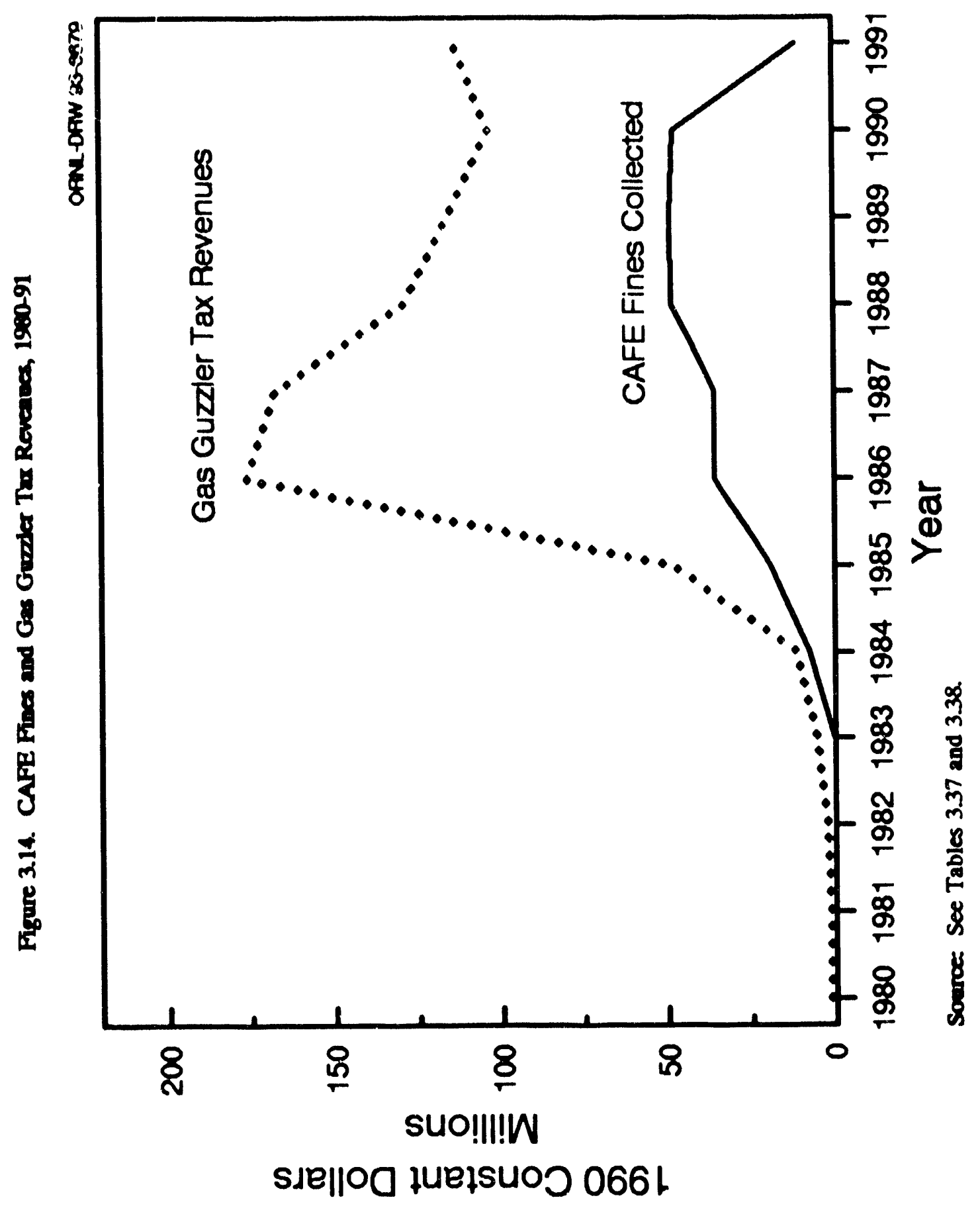


Consumers must pay the Gas (juzaler Tax when punchasing an automobile that has an Environmental Protection Agency (EPA) fuel economy rating less than that stipulated in the table below. The Gas Guzzler Tax doubled in 1991 after remaining constant from 1986 to 1990.

Table 3.39

The Gas Geumler Tru on New Cars (dollars per vehicte)

\begin{tabular}{crrrrrrrr}
\hline $\begin{array}{c}\text { Vehicle fuel } \\
\text { economy } \\
\text { (mpg) }\end{array}$ & 1980 & 1981 & 1982 & 1983 & 1984 & 1985 & $1986-90$ & $1991+$ \\
\hline Over 22.5 & 0 & 0 & 0 & 0 & 0 & 0 & 0 & 0 \\
$22.0-22.5$ & 0 & 0 & 0 & 0 & 0 & 0 & 500 & 1000 \\
$21.5-22.0$ & 0 & 0 & 0 & 0 & 0 & 0 & 500 & 1000 \\
$21.0-21.5$ & 0 & 0 & 0 & 0 & 0 & 0 & 650 & 1300 \\
$20.5-21.0$ & 0 & 0 & 0 & 0 & 0 & 500 & 650 & 1300 \\
$20.0-20.5$ & 0 & 0 & 0 & 0 & 0 & 500 & 850 & 1700 \\
$19.5-20.0$ & 0 & 0 & 0 & 0 & 0 & 600 & 850 & 1700 \\
$19.0-19.5$ & 0 & 0 & 0 & 0 & 450 & 600 & 1050 & 2100 \\
$18.5-19.0$ & 0 & 0 & 0 & 350 & 450 & 800 & 1050 & 2100 \\
$18.0-18.5$ & 0 & 0 & 200 & 350 & 600 & 800 & 1300 & 2600 \\
$17.5-18.0$ & 0 & 0 & 200 & 500 & 600 & 1000 & 1300 & 2600 \\
$17.0-17.5$ & 0 & 0 & 350 & 500 & 750 & 1000 & 1500 & 3000 \\
$16.5-17.0$ & 0 & 200 & 350 & 650 & 750 & 1200 & 1500 & 3000 \\
$16.0-16.5$ & 0 & 200 & 450 & 650 & 950 & 1200 & 1850 & 3700 \\
$15.5-16.0$ & 0 & 350 & 450 & 800 & 950 & 1500 & 1850 & 3700 \\
$15.0-15.5$ & 0 & 350 & 600 & 800 & 1150 & 1500 & 2250 & 4500 \\
$14.5-15.0$ & 200 & 450 & 600 & 1000 & 1150 & 1800 & 2250 & 4500 \\
$14.0-14.5$ & 200 & 450 & 750 & 1000 & 1450 & 1800 & 2700 & 5400 \\
$13.5-14.0$ & 300 & 550 & 750 & 1250 & 1450 & 2200 & 2700 & 5400 \\
$13.0-13.5$ & 300 & 550 & 950 & 1250 & 1750 & 2200 & 3200 & 6400 \\
$12.5-13.0$ & 550 & 650 & 950 & 1550 & 1750 & 2650 & 3200 & 6400 \\
Under 12.5 & 550 & 650 & 1200 & 1550 & 2150 & 2650 & 3850 & $\mathbf{7 7 0 0}$ \\
\hline
\end{tabular}

Source:

Internal Revenue Service, Form 6197, "Gas Guzzler Tax" and annual. 
Two separate studies by the Federal Highway Administration have measured the effects of speed on the fuel economy of automobiles. (The 1984 study also included light trucks.) The fuel economy loss will vary for each individual vehicle; these data are averages for the tested vehicles. Both stu-ies indicated that maximum fuel efficiency was achieved at speeds of 35 to $40 \mathrm{mph}$.

Table 3.40

Fuel Economy by Specd, 1973 and 1984

(miles per gallon)

\begin{tabular}{ccc}
\hline $\begin{array}{c}\text { Speed } \\
\text { (miles per hour) }\end{array}$ & $1973^{\circ}$ & $1984^{\mathrm{b}}$ \\
\hline & $\mathrm{c}$ & \\
15 & $\mathrm{c}$ & 21.1 \\
20 & $\mathrm{c}$ & 25.5 \\
25 & 21.1 & 30.0 \\
30 & 21.1 & 31.8 \\
35 & 21.1 & 33.6 \\
40 & 20.3 & 33.6 \\
45 & 19.5 & 33.5 \\
50 & 18.5 & 31.9 \\
55 & 17.5 & 30.3 \\
60 & 16.2 & 27.6 \\
65 & 14.9 & 24.9 \\
70 & $c$ & 22.5 \\
75 & & 20.0
\end{tabular}

Fuel economy loss

$55-65 \mathrm{mph}$

$65-70 \mathrm{mph}$

$55-70 \mathrm{mph}$
$12.4 \%$

$8.0 \%$

$19.5 \%$
$17.8 \%$

$9.6 \%$

$25.7 \%$

\section{Sources:}

1973- U.S. Department of Transportation, Federal Highway

Administration, Office of Highway Planning, The Effect of Speed on Automobile Gasoline Consumption Rates, Washington, DC, October 1973.

1984 - U.S. Department of Transportation, Federal Highway

Administration, Fuel Consumption and Emission Values for

Traffic Models, Washington, DC, May 1985.

"Model years 1970 and earlier automobiles.

"Model years 1981-84 automobiles and light trucks.

'Data are not aua:!able. 


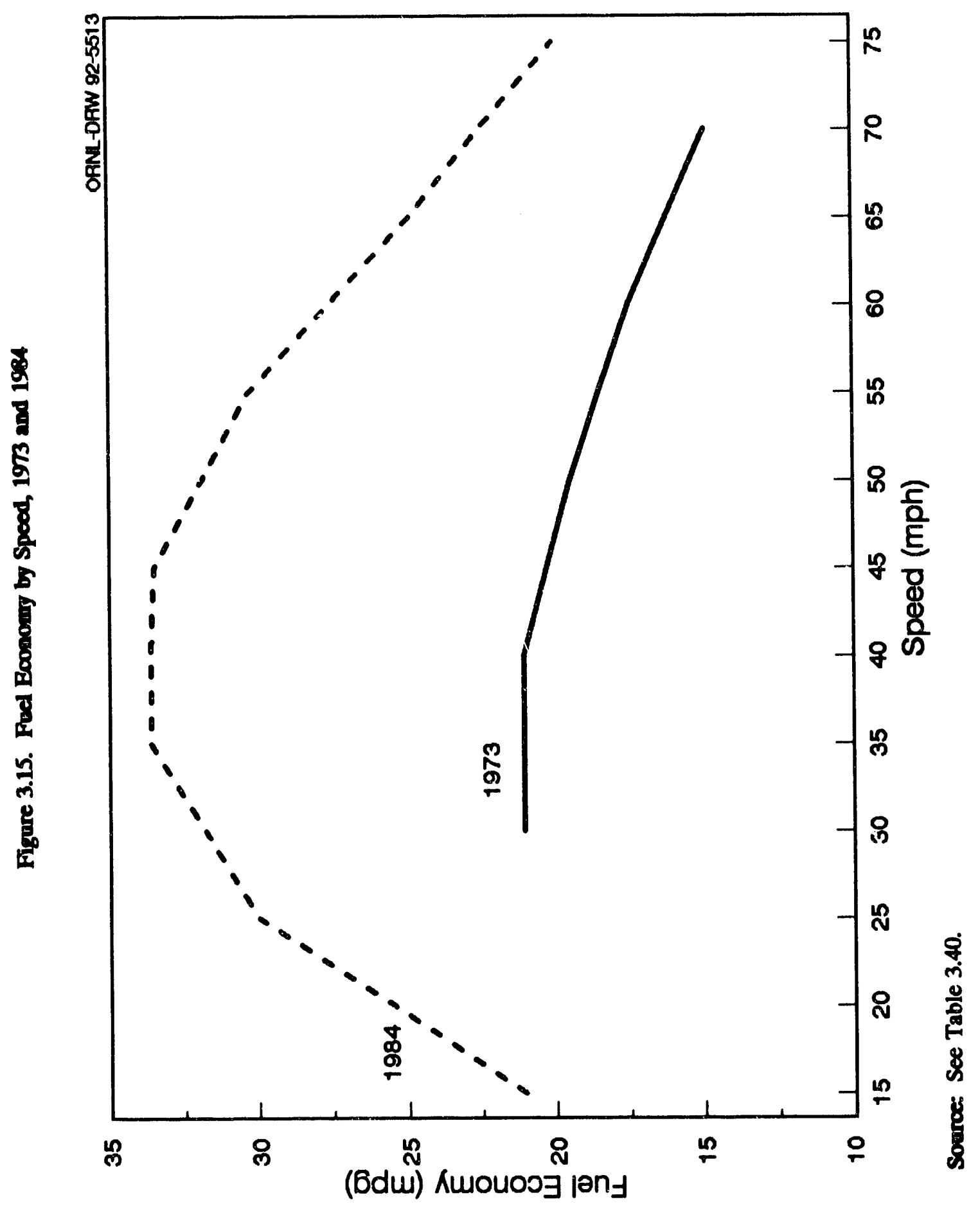


For the first time since 1973, average nural meersate speed rase 1060 miles per how in 1989 and stayed as that speed in 1990. Average urban Interstate speed declined slightly in 1990 - the fors decline in ven years.

Fgure 3.16. Average Intesutate Speods, 1970-90

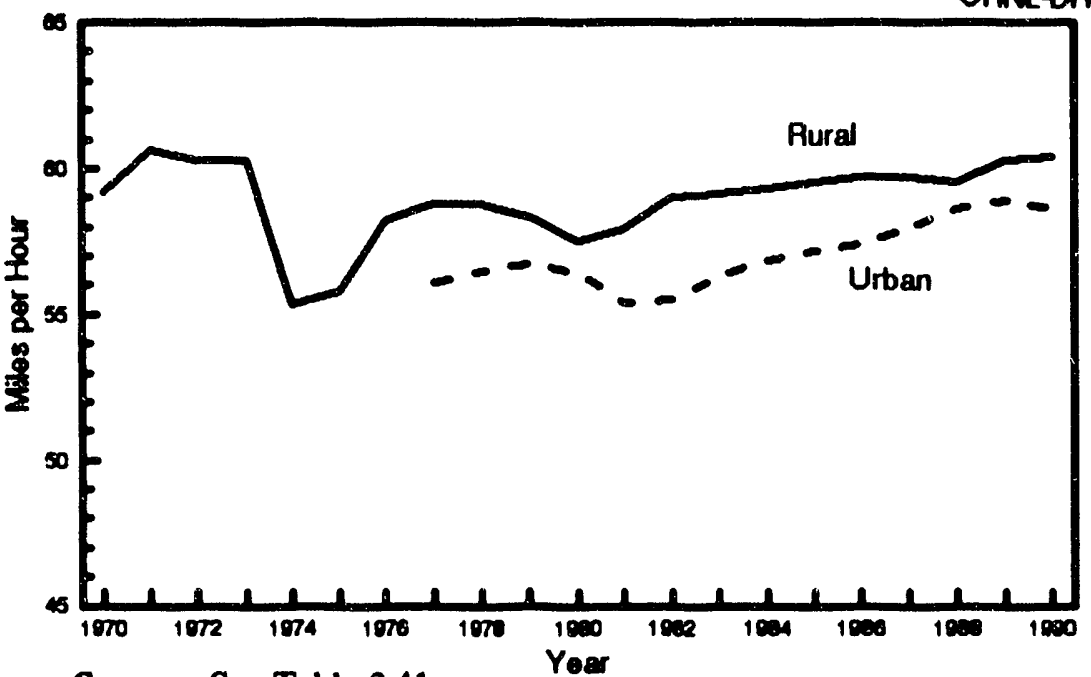

Source: See Table 3.41

Table 3.41

Averge Urban and Rural Interstate Speeds, 1970-90" (miles per hour)

\begin{tabular}{ccc}
\hline Year & Urban Interstate & Rural Interetate \\
\hline 1970 & $\vdots$ & 59.2 \\
1971 & $\vdots$ & 60.6 \\
1972 & $\vdots$ & 60.3 \\
1973 & $\vdots$ & 60.3 \\
1974 & 55.3 \\
1975 & 56.1 & 55.8 \\
1976 & 56.5 & 58.2 \\
1977 & 56.7 & 58.8 \\
1978 & 56.4 & 58.8 \\
1979 & 55.4 & 58.3 \\
1980 & 55.5 & 57.5 \\
1981 & 56.3 & 57.9 \\
1982 & 56.8 & 59.0 \\
1983 & 57.2 & 59.1 \\
1984 & 57.2 & 59.3 \\
1985 & 57.4 & 59.5 \\
1986 & 58.0 & 59.7 \\
1987 & 58.6 & 59.7 \\
1988 & 58.9 & 59.5 \\
1989 & 58.6 & 60.3 \\
1990 & & 60.4 \\
\hline
\end{tabular}

Somroes

U.S. Department of Transportation, Federal Highway Administration, Highway Statistics 1990, Washington, DC, 1991, Table VS-1, p. 199, and annual.

-Data from 1970-79 represent only free-moving traffic, on level, straight, uncongested sections of Interstate. Beginning with fiscal year 1980, the data show the speeds of all vehicular traffic.

'Data are not available. 
The Environmental Protection Agency (EPA) new vetictes to datemine the fuel economy ratinge. The ciry and highway fuel economies that are pasted on the windows of new vethicles ane datermined by texting the vethicte during thase driving gycles. The driving cycles simulate the performance of an angine while diving in the city of on the highway. Once the wrban cycle

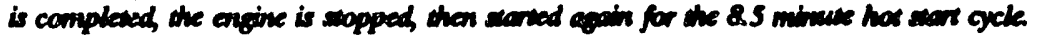

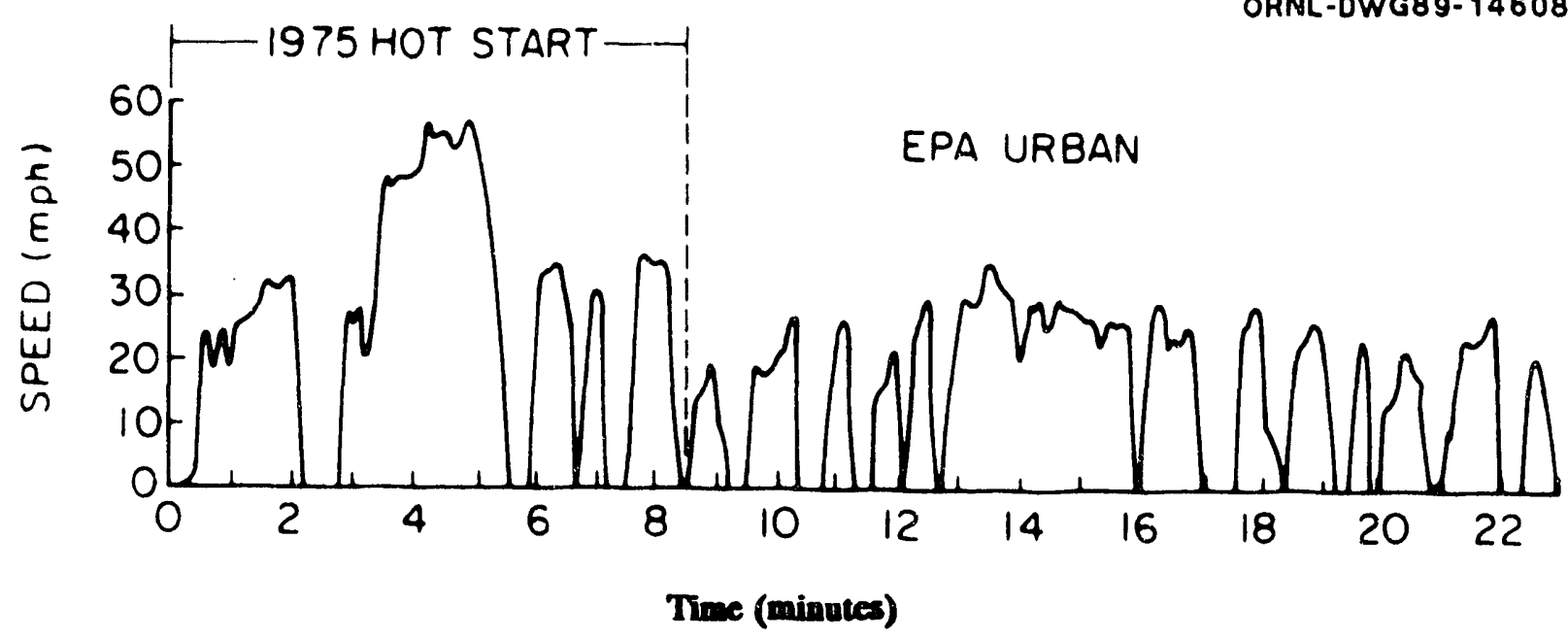

Figure 3.17. Urban Driving Cycle

Length of cycle: 1870 seconds, including idle time.

Average speed: $21.3 \mathrm{mph}$ with idle; $26.5 \mathrm{mph}$ without idle.

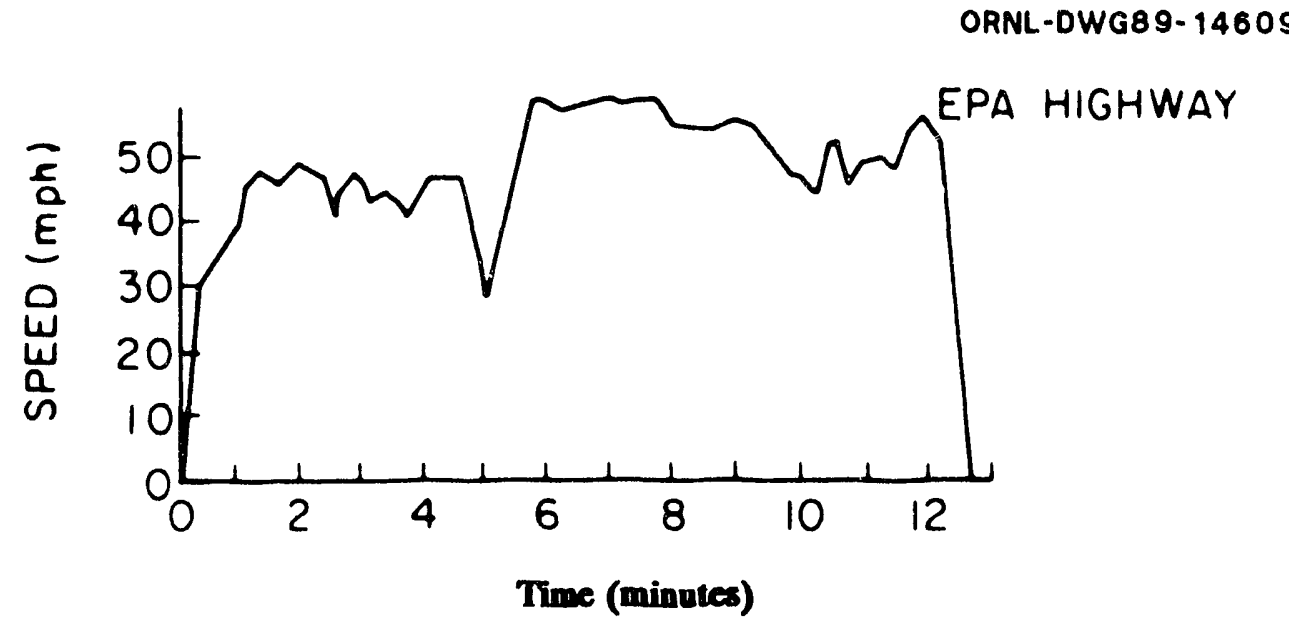

Figure 3.18. Highway Driving Cycle

Length of cycle: 765 seconds.

Average speed: $48.5 \mathrm{mph}$.

Source:

Code of Federal Regulations, 40CFR, "Subpart B - Fuel Economy Regulations for 1978 and Later Model Year Automobiles - Test Procedures," July 1, 1988 edition, p. 676. 


\section{Section 3.7 \\ Vehicle Emissions}


The Environmental Protection Agency (EPA) tests transient emissions from heavy-duty diesel engines using the 1984 Transient Federal Test Procedure. The engine is subjected to a cycle of varying speed and load for twenty minutes.

Figure 3.19. Torque and Speed Cycles for Tramient Emissions Testing of a Typical Heavy-Duty Diesel Engine

ORNLLDRW $93-6681$
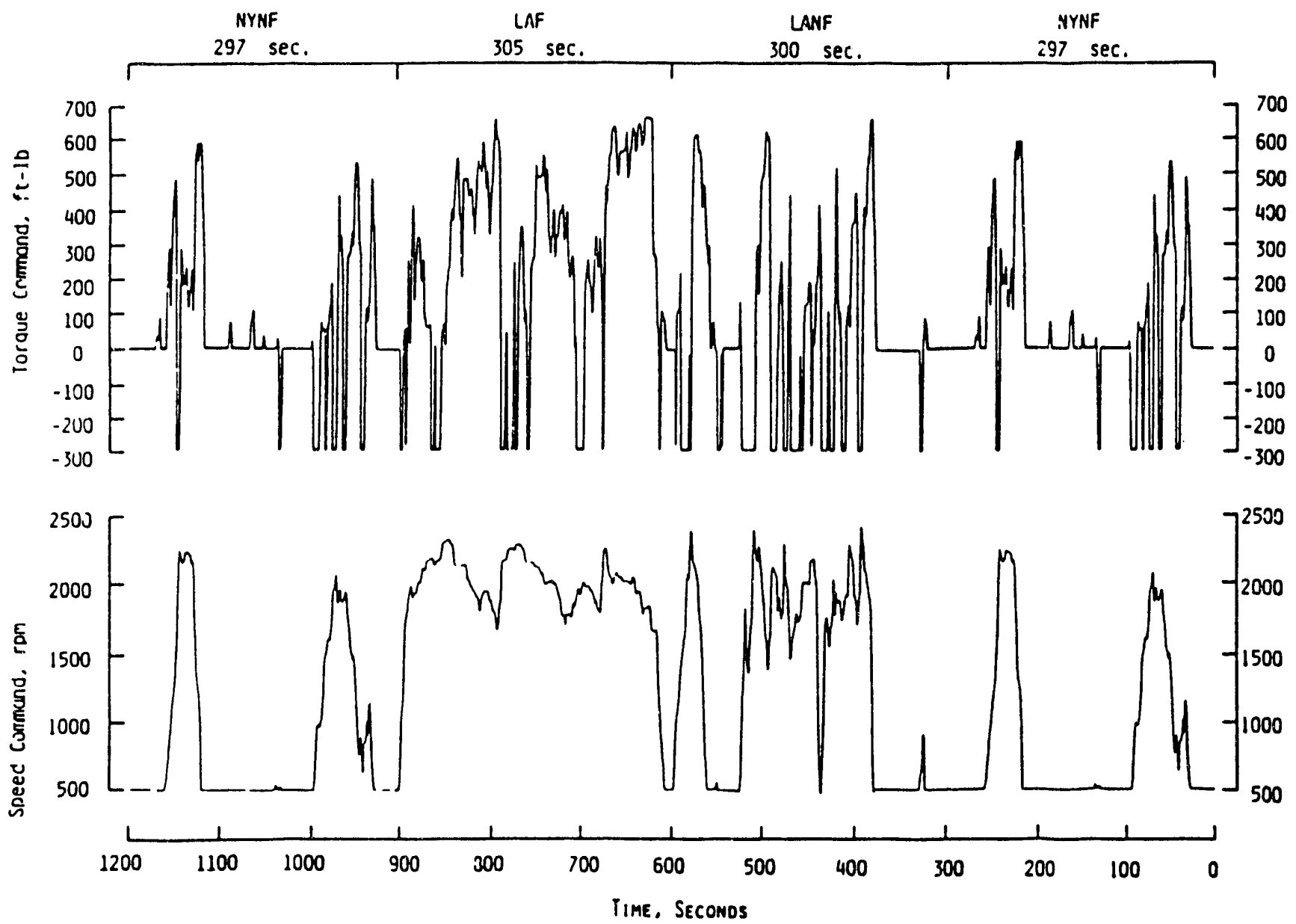

Source: Carroll, James N., et. al., "Emission Comparison of DDC 6V-92TA on Alcohol Fuels," Truck and Bus Meeting and Exposition, Detroit, MI, 1990, p.3. 
The Clean Air Act Amendment of 1990 established higher emission control standards. These standards will become effective in 1994.

Table 3.42

Foderal Emission Control Requirements for Automobiles and Light Tructs, 1976-94" (grams per mile)

\begin{tabular}{|c|c|c|c|c|c|c|c|c|}
\hline \multirow[b]{2}{*}{$\begin{array}{l}\text { Model } \\
\text { Year }\end{array}$} & \multicolumn{4}{|c|}{ Automobiles } & \multicolumn{4}{|c|}{ Light trucks ${ }^{b}$} \\
\hline & $\begin{array}{l}\text { Hydro- } \\
\text { carbons } \\
\text { (HC) }\end{array}$ & $\begin{array}{c}\text { Carbon } \\
\text { monaxide } \\
\text { (CO) }\end{array}$ & $\begin{array}{l}\text { Nitrogen } \\
\text { oxides } \\
\text { (NO) }\end{array}$ & Particulation & $\begin{array}{l}\text { Hydro- } \\
\text { carbone } \\
\text { (HC) }\end{array}$ & $\begin{array}{c}\text { Carbon } \\
\text { monoxide } \\
\text { (CO) }\end{array}$ & $\begin{array}{l}\text { Nitrogen } \\
\text { aridea } \\
\text { (NOJ) }\end{array}$ & Particulatere \\
\hline 1976 & 1.50 & 15.0 & 3.1 & d & 2.0 & 20.0 & 3.1 & d \\
\hline 1977 & 1.50 & 15.0 & 2.0 & d & 2.0 & 20.0 & 3.1 & d \\
\hline 1978 & 1.50 & 15.0 & 2.0 & d & 2.0 & 20.0 & 3.1 & d \\
\hline 1979 & 1.50 & 15.0 & 2.0 & d & 1.7 & 18.0 & 2.3 & d \\
\hline 1980 & 0.41 & 7.0 & 2.0 & d & 1.7 & 18.0 & 2.3 & d \\
\hline 1981 & 0.41 & 3.4 & 1.0 & $d$ & 1.7 & 18.0 & 2.3 & 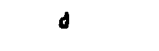 \\
\hline 1982 & 0.41 & 3.4 & 1.0 & 0.6 & 1.7 & 18.0 & 2.3 & 0.60 \\
\hline 1983 & 0.41 & 3.4 & 1.0 & 0.6 & 1.7 & 18.0 & 2.3 & 0.60 \\
\hline 1984 & 0.41 & 3.4 & 1.0 & 0.6 & 0.8 & 10.0 & 2.3 & 0.60 \\
\hline 1985 & 0.41 & 3.4 & 1.0 & 0.6 & 0.8 & 10.0 & 2.3 & 0.60 \\
\hline 1986 & 0.41 & 3.4 & 1.0 & 0.6 & 0.8 & 10.0 & 2.3 & 0.60 \\
\hline 1987 & 0.41 & 3.4 & 1.0 & 0.2 & 0.8 & 10.0 & 2.3 & 0.26 \\
\hline 1988 & 0.41 & 3.4 & 1.0 & 0.2 & 0.8 & 10.0 & $1.2^{\circ}$ & 0.26 \\
\hline 1989 & 0.41 & 3.4 & 1.0 & 0.2 & 0.8 & 10.0 & $1.2^{\mathrm{e}}$ & 0.26 \\
\hline 1990 & 0.41 & 3.4 & 1.0 & 0.2 & 0.8 & 10.0 & $1.2^{\circ}$ & 0.26 \\
\hline 1991 & 0.41 & 3.4 & 1.0 & 0.2 & 0.8 & 10.0 & $1.2^{\circ}$ & 0.26 \\
\hline 1992 & 0.41 & 3.4 & 1.0 & 0.2 & 0.8 & 10.0 & $1.2^{e}$ & 0.26 \\
\hline 1993 & 0.41 & 3.4 & 1.0 & 0.2 & 0.8 & 10.0 & $1.2^{\circ}$ & 0.26 \\
\hline 1994 & 0.25 & 3.4 & 0.4 & 0.08 & $0.25^{e}$ & $3.4^{e}$ & $1.2^{e}$ & 0.26 \\
\hline 1995-on & 0.25 & 3.4 & 0.4 & 0.08 & $0.25^{e}$ & $3.4^{e}$ & $0.4^{\prime}$ & 0.08 \\
\hline
\end{tabular}

Sources:

1976-93: Code of Federal Requlations 40CFR86, "Control of Air Pollution from New Motor Vehicles and New Motor Vehicle Engines: Certification and Testing Procedures," July 1, 1987 edition, p. 264.

1994-on: Clean Air Act Amendment of 1990.

-California standards not included.

'Applies to trucks under 6,000 pounds gross vehicle weight rating (GVWR) until model year 1978 and under 8,500 pounds GVWR beginning in model year 1979.

'Applies to diesel engines only.

${ }^{d}$ No standard was set for this year.

'Applies to light trucks up to and including 3,750 pounds loaded vehicle weight (LVW).

'Applies to light trucks up to and including 3,750 pounds loaded vehicle weight (LVW). Does not apply to diesel-fueled light trucks. 
The Clean Air Act Amendment of 1990 established higher emission control standards. These standards will become effective in 1994.

Table 3.43

Foderal Emission Control Requirements for Heavy-Duty Gasoline Trucks, 1976-94" (grams per brake horsepower bour)

\begin{tabular}{|c|c|c|c|c|}
\hline Model Year & $\begin{array}{c}\text { Hydrocarbons } \\
\text { (HC) }\end{array}$ & $\begin{array}{l}\text { Carbon monoxide } \\
\text { (CO) }\end{array}$ & $\begin{array}{l}\text { Nitrogen oxides } \\
\left(\mathrm{NO}_{2}\right)\end{array}$ & $\begin{array}{c}\text { Hydrocarbons + } \\
\text { nitrogen oxides } \\
\left(\mathrm{HC}+\mathrm{NO}_{2}\right)\end{array}$ \\
\hline 1976 & b & 40.0 & b & 16.0 \\
\hline 1977 & b & 40.0 & b & 16.0 \\
\hline 1978 & b & 40.0 & $b$ & 16.0 \\
\hline 1979 & 1.5 & 25.0 & b & 10.0 \\
\hline 1980 & 1.5 & 25.0 & $b$ & 10.0 \\
\hline 1981 & 1.5 & 25.0 & b & 10.0 \\
\hline 1982 & 1.5 & 25.0 & b & 10.0 \\
\hline 1983 & 1.5 & 25.0 & $b$ & 10.0 \\
\hline 1984 & 1.3 & 15.5 & 10.7 & $b$ \\
\hline 1985 & 2.5 & 40.0 & 10.7 & b \\
\hline 1986 & 2.5 & 40.0 & 10.7 & $b$ \\
\hline 1987 & 1.9 & 37.1 & 10.6 & b \\
\hline 1988 & 1.9 & 37.1 & 10.6 & $b$ \\
\hline 1989 & 1.9 & 37.1 & 10.6 & b \\
\hline 1990 & 1.9 & 37.1 & 6.0 & $b$ \\
\hline 1991 & 1.9 & 37.1 & 5.0 & b \\
\hline 1992 & 1.9 & 37.1 & 5.0 & $b$ \\
\hline 1993 & 1.9 & 37.1 & 5.0 & $b$ \\
\hline 1994 & $1.9^{c}$ & 37.1 & $5.0^{c}$ & b \\
\hline 1995 & $1.9^{c}$ & $37.1^{c}$ & $5.0^{\circ}$ & $b$ \\
\hline 1996 & $1.9^{c}$ & $37.1^{c}$ & $5.0^{\circ}$ & b \\
\hline 1997 & $1.9^{c}$ & $37.1^{c}$ & $5.0^{c}$ & $b$ \\
\hline 1998 & $1.9^{c}$ & $37.1^{c}$ & $4.0^{\circ}$ & $b$ \\
\hline
\end{tabular}

Sources:

1976-93: Code of Federal Regulations, 40CFR86, "Control of Air Pollution from New Motor

Vehicles and New Motor Vehicles Engines: Certification and Testing Procedures," July 1, 1987 edition, p. 264.

1994-on: Clean Air Act Amendment of 1990.

'Applies to trucks greater than 6,000 pounds gross vehicle weight until model year 1978; greater than 8,500 pounds gross vehicle weight from model year 1979-1986; and greater than 14,000 pounds gross vehicle weight starting in 1987.

'No standard was set for this year.

'Heavy-duty trucks must meet these standards or standards which reflect the greatest degree of emission reduction achievable through the application of the technology available. 
The Clean Air Act Amendment of 1990 established higher emission control standards. These standands will become effective in 1994.

Table 3.44

Foderal Emission Control Requirements for Heavy-Duty Diesel Trucks, 1976-94" (grams per brake borsepower bour)

\begin{tabular}{|c|c|c|c|c|c|}
\hline $\begin{array}{l}\text { Model } \\
\text { Year }\end{array}$ & $\begin{array}{l}\text { Hydro- } \\
\text { carbons } \\
\text { (HC) }\end{array}$ & $\begin{array}{c}\text { Carbon } \\
\text { monoxide } \\
(\mathrm{CO})\end{array}$ & $\begin{array}{c}\text { Nitrogen } \\
\text { oxides } \\
\text { (NO.) } \\
\end{array}$ & $\begin{array}{c}\text { Hydrocarbons }+ \\
\text { nitrogen } \\
\text { oxides } \\
\left(\mathrm{HC}+\mathrm{NO}_{2}\right) \\
\end{array}$ & Particulates \\
\hline 1976 & $b$ & 40.0 & $b$ & 16.0 & $b$ \\
\hline 1977 & $b$ & 40.0 & b & 16.0 & b \\
\hline 1978 & b & 40.0 & $b$ & 16.0 & b \\
\hline 1979 & 1.5 & 25.0 & $b$ & 10.0 & $b$ \\
\hline 1980 & 1.5 & 25.0 & $b$ & 10.0 & $b$ \\
\hline 1981 & 1.5 & 25.0 & b & 10.0 & $b$ \\
\hline 1982 & 1.5 & 25.0 & $b$ & 10.0 & $b$ \\
\hline 1983 & 1.5 & 25.0 & $b$ & 10.0 & b \\
\hline 1984 & 1.3 & 15.5 & 10.7 & 5.0 & $b$ \\
\hline 1985 & 1.3 & 15.5 & 10.7 & $b$ & $b$ \\
\hline 1986 & 1.3 & 15.5 & 10.7 & b & $b$ \\
\hline 1987 & 1.3 & 15.5 & 10.7 & $b$ & b \\
\hline 1988 & 1.3 & 15.5 & 10.7 & $b$ & 0.60 \\
\hline 1989 & 1.3 & 15.5 & 10.7 & $b$ & 0.60 \\
\hline 1990 & 1.3 & 15.5 & 6.0 & $b$ & 0.60 \\
\hline 1991 & 1.3 & 15.5 & 5.0 & $b$ & 0.25 \\
\hline 1992 & 1.3 & 15.5 & 5.0 & $b$ & 0.25 \\
\hline 1993 & 1.3 & 15.5 & 5.0 & b & 0.25 \\
\hline 1994 & $1.3^{c}$ & 15.5 & 5.0 & b & 0.10 \\
\hline 1995 & $1.3^{c}$ & $15.5^{\mathrm{c}}$ & $5.0^{\circ}$ & b & $0.10^{c}$ \\
\hline 1996 & $1.3^{c}$ & $15.5^{\mathrm{c}}$ & $5.0^{c}$ & b & $0.10^{c}$ \\
\hline 1997 & $1.3^{c}$ & $15.5^{c}$ & $5.0^{\circ}$ & b & $0.10^{c}$ \\
\hline 1998 & $1.3^{c}$ & $15.5^{\mathrm{c}}$ & $4.0^{\circ}$ & $b$ & $0.10^{c}$ \\
\hline
\end{tabular}

Sources:

1976-93: Code of Federal Regulations, 40CFR86, "Control of Air Pollution from New Motor Vehicles and New Motor Vehicle Engines: Certification and Testing Procedures," July 1, 1987 edition, p. 264.

1994-on: Clean Air Act Amendment of 1990.

Applies to trucks greater than 6,000 puunds gross vehicle weight until model year 1978; greater than 8,500 pounds gross vehicle weight beginning in model year 1979.

'No standard was set for this year.

'Heavy-duty trucks must meet these standards or standards which reflect the greatest degree of emission reduction achievable through the application of the technology available. 


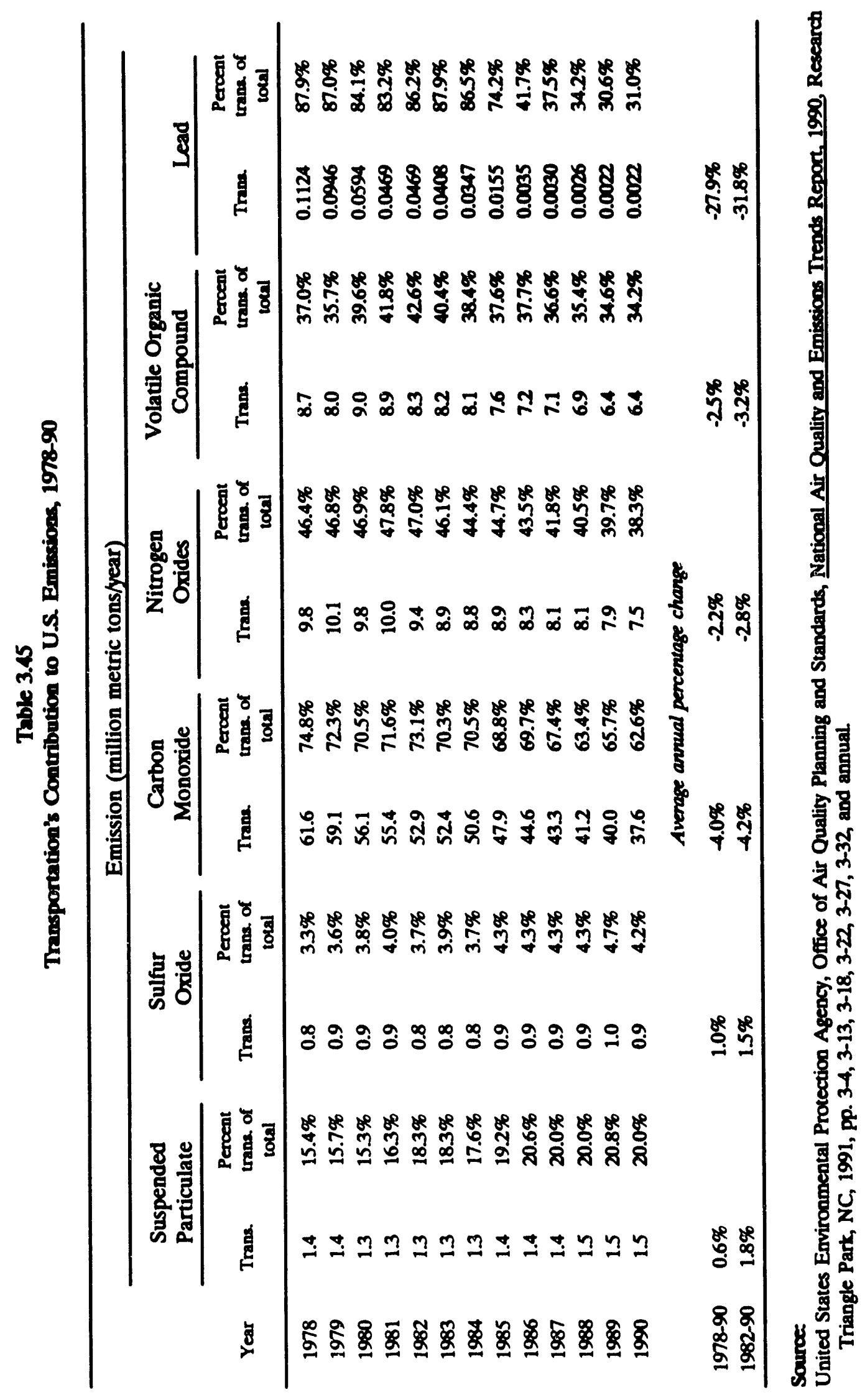


Table 3.46

Exhaust Emission Standards for Clean-Puel Vehicles in the Californis Pilot Teat Program (50,000 mile standard is grams per mile)

\begin{tabular}{|c|c|c|c|c|c|}
\hline & $\begin{array}{l}\text { LDV \& LDT } \\
\leq 6,000 \mathrm{GVWR} \\
\leq 3,750 \mathrm{LVW}\end{array}$ & $\begin{array}{c}\text { LDT } \\
\leq 6,000 \text { GVWR } \\
>3,750 \text { LVW } \\
\leq 5,750 \mathrm{LVW} \\
\end{array}$ & $\begin{array}{c}\text { LDT } \\
>6,000 \text { OVWR } \\
\leq 3,750 \mathrm{TW} \\
\end{array}$ & $\begin{array}{c}\text { LDT * } \\
>6,000 \text { GVWR } \\
>3,750 \text { TW } \\
\leq 5,750 \text { TW }\end{array}$ & $\begin{array}{c}\text { LDT } \\
>6,000 \text { GVWR } \\
>5,750 \mathrm{TW}\end{array}$ \\
\hline \multicolumn{6}{|c|}{ Oowreationel valdides } \\
\hline Non-methane hydrocarbons & 0.250 & 0.320 & 0.250 & 0.320 & 0.390 \\
\hline Carbon monoxide & 3.400 & 4.400 & 3.400 & 4.400 & 5.000 \\
\hline Nitrogen oxides & 0.400 & 0.700 & 0.400 & 0.700 & 1.100 \\
\hline Formaldehyde & • & & & & \\
\hline \multicolumn{6}{|c|}{ Trascition bowesimion velictes (TUBVa) } \\
\hline Non-methane organic gases & 0.125 & 0.160 & - & • & • \\
\hline Carbon monoxide & 3.400 & 4.400 & - & - & - \\
\hline Nitrogen oxides & 0.400 & 0.700 & - & - & • \\
\hline Formaldehyde & 0.015 & 0.018 & - & - & - \\
\hline \multicolumn{6}{|c|}{ Low-canimion velicice (LBVa) } \\
\hline Non-methane organic gases & 0.075 & 0.100 & 0.125 & 0.160 & 0.195 \\
\hline Carton monoxide & 3.400 & 4.400 & 3.400 & 4.400 & 5.000 \\
\hline Nitrogen axides & 0.200 & 0.400 & 0.400 & 0.700 & 1.100 \\
\hline Formaldehyde & 0.015 & 0.018 & 0.015 & 0.018 & 0.022 \\
\hline \multicolumn{6}{|c|}{ Uhro-tow conimion velictos (ULEV) } \\
\hline Non-methane organic gasca & 0.040 & 0.050 & 0.075 & 0.100 & 0.117 \\
\hline Carbon monoxide & 1.700 & 2.200 & 1.700 & 2.200 & 2.500 \\
\hline Nitrogen arides & 0.200 & 0.400 & 0.200 & 0.400 & 0.600 \\
\hline Formaldehyde & 0.008 & 0.009 & 0.008 & 0.009 & 0.011 \\
\hline \multicolumn{6}{|c|}{ Zero-cimion valides (ZBVs) } \\
\hline Non-methane organic gases & 0.0 & 0.0 & 0.0 & 0.0 & 0.0 \\
\hline Carton monaxide & 0.0 & 0.0 & 0.0 & 0.0 & 0.0 \\
\hline Nitrogen axides & 0.0 & 0.0 & 0.0 & 0.0 & 0.0 \\
\hline Formaldetiyde & 0.0 & 0.0 & 0.0 & 0.0 & 0.0 \\
\hline
\end{tabular}

Soumer

U.S. Environmental Protection Agency, Office of Mobile Sources, "California Pilot Teat Program," Public Outreach Mecting, Ann Arbor, MI, May 17, 1991.
Nole: LDV = light-duty vehicle
LD' = light-duty truck
GVRW = groses vehicle weight rating
LVW = loaded vehicle weight
TW $=$ tare weight

The clean-fuel vehicle standards are not effective until the 1998 model year.

Not applicable.

There is no TLEV category for this vehicle class. 
The California Air Resounces Board has proposed these figures for fleet mixture in onder to meet the emission standards. By the year 2001 it is proposed that $90 \%$ of the manufacturer's fleet be lowemission vehicles.

Table 3.47

California Air Resources Board Propoenl for Moeting Bminsion Standards

\begin{tabular}{ccc}
\hline Year & $\begin{array}{c}\text { Percent of } \\
\text { manufacturer's } \\
\text { fleet }\end{array}$ & Vehicle type \\
\hline 1989 & 100 & CV \\
1993 & 100 & CV \\
1994 & 90 & CV \\
& 10 & TLEV \\
1995 & 85 & CV \\
& 15 & TLEV \\
1996 & 80 & CV \\
& 20 & TLEV \\
1997 & 73 & CV \\
& 25 & LEV \\
& 2 & ULEV \\
$1998-2000$ & 48 & CV \\
& 48 & LEV \\
& 2 & ULEV \\
& 2 & ZEV \\
& 90 & LEV \\
$2001-2002$ & 5 & ULEV \\
& 5 & ZEV \\
& LEV \\
$2003^{\circ}$ & 75 & ULEV \\
& 15 & ZEV \\
\hline
\end{tabular}

Source:

California Air Resources Board, Mobile Sources Division, El Monte, CA, 1990.

- CV - Conventional vehicles

TLEV - Transition low emission vehicles

LEV - Low emission vehicles

ULEV - Ultra low emission vehicles

ZEV - Zero emission vehicles

bleet average of non-methane organic gases $=0.062$ in 2003 . 
Four fuels are projected as capable of meeting the requirements for the transitional low-emission vehicles, low-emission vehicles, ultra-low emission vehicles, and zero-emission vehicles. Gasoline, alcohol, compressed natural gas, and liquified petroleum gas, with fuel and vehicle improvements, are projected as capable of meeting the first three levels. Electric vehicles are phased in as ultra-low emission vehicles and are the only vehicle type expected to be zero-emission vehicles.

Table 3.48

Possible Fuel/Vehicles for Clean-Fued Venicices

\section{TRANSTTIONAL LOW-EMISSION VEHICLES (TLEVs)}

- Gasoline - small/medium displacement engines, heated fuel preparation system, close-coupled catalyst

- Alcohol - improved close-coupled catalyst

- Compressed natural gas - underfloor catalyst

- Liquified petnolcum gas - close-coupled catalyst

\section{LOW-EMISSION VEHICLES (LEVs)}

- Gasoline - electrically heated catalyst, phase 2 gasoline

- Alcohol - heated fuel preparation system, close-coupled catalyst

- Compressed natural gas - electronic fuel injection, close-coupled catalyst

- Liquified petrolewn gas - electronic fuel injection, close-coupled catalyst

\section{ULTRA-LOW EMISSION VEHICLES (ULEVs)}

- Gasoline - heated fuel preparation system, electrically heated catalyst, phase 2 gasoline

- Alcohol - heated fuel preparation system, electrically heated catalyst

- Compressed natural gas - electronic fuel injection, electrically heated catalyst

- Electriciny - range-extended hybrid vehicles, battery powered vehicles with auxiliary combustion heaters

\section{ZERO-EMISSION VEHICLES (ZEVs)}

- Electricity - battery-powcred vehicles

\section{Source:}

U.S. Department of Energy, Office of Transportation Technologies, "Electric Vehicle Progress," Washington, DC, January 1991, p.3. 


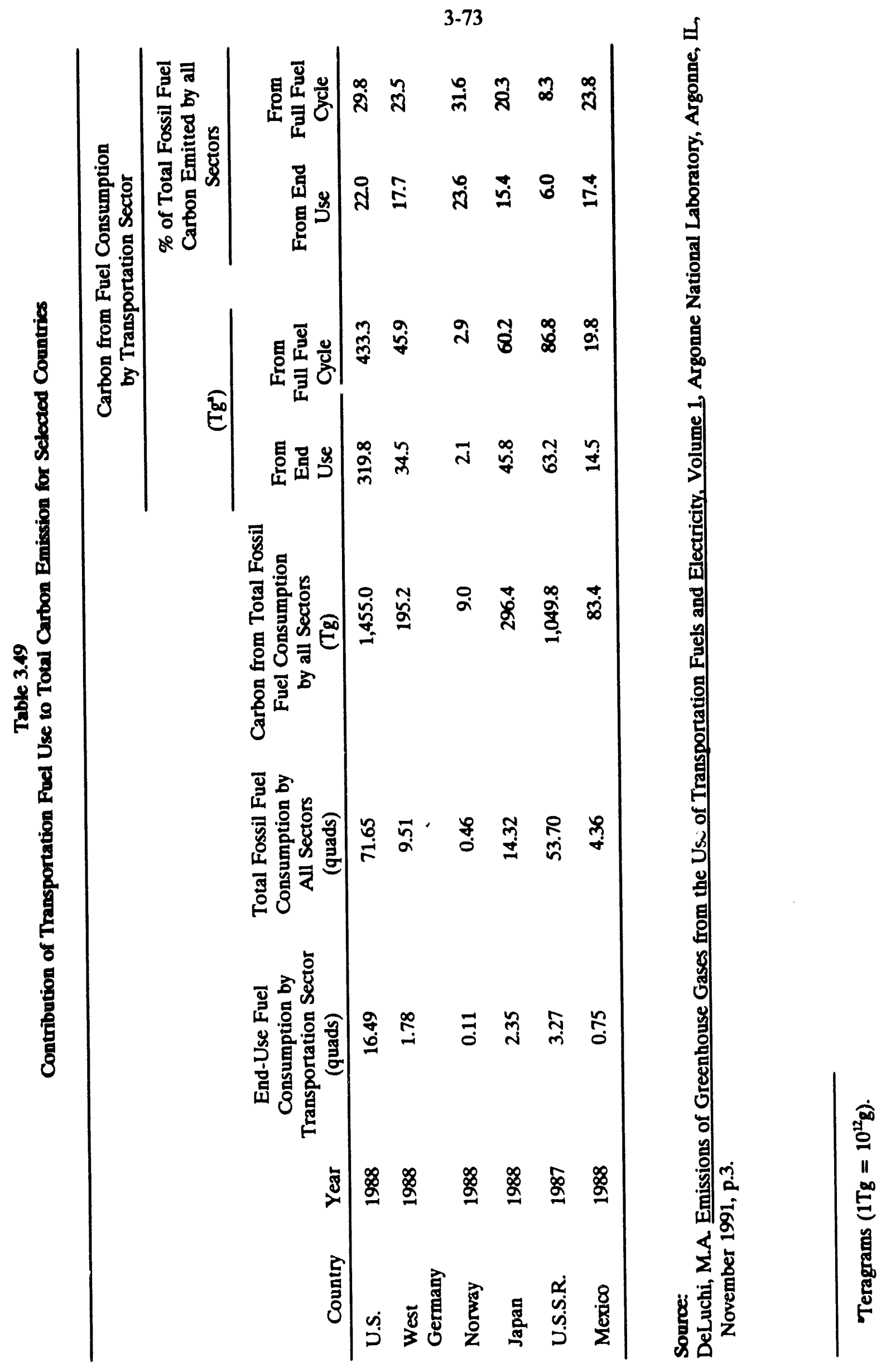




\section{Section 3.8 High-Occupancy Vehicle Lanes}


High-occupancy vehicle (HOV) lanes are special highway lanus meant for the exchusive use of vehicles with a specified number of passengers. Vehicles that use HOV lanes are usually guaranteed a shorter and less congested trip than those using regular traffic lanes. In 1990 there were 332 miles of HOV lanes in operation in the U.S. Eighteen areas had HOV facilities in 1990, and 6 more areas had HOV facilities in development at that time (see Figure 3.20).

Table 350

Miles of High-Occupangy Vehicle Lanes, 196990

\begin{tabular}{cc}
\hline Year & Miles \\
\hline 1969 & 5 \\
1970 & 10 \\
1971 & 15 \\
1972 & 15 \\
1973 & 28 \\
1974 & 32 \\
1975 & 36 \\
1976 & 43 \\
1977 & 47 \\
1978 & 66 \\
1979 & 66 \\
1980 & 96 \\
1981 & 96 \\
1982 & 111 \\
1983 & 129 \\
1984 & 149 \\
1985 & 168 \\
1986 & 196 \\
1987 & 209 \\
1988 & 247 \\
1989 & 278 \\
1990 & 339 \\
Average arnual percentage change \\
$1969-90$ & $22.9 \%$ \\
$1982-90$ & $15.0 \%$ \\
\hline & \\
\hline &
\end{tabular}

Source:

Texas Transportation Institute, High-Occupancy Vehicle System Development in the United States, College Station, TX, December 1990 , p. 9.

'Data shown are for continuously operating HOV lanes located either on freeways or in separate rights-of-way in the U.S. Mileage is not shown for HOV lanes that have been discontinued. 


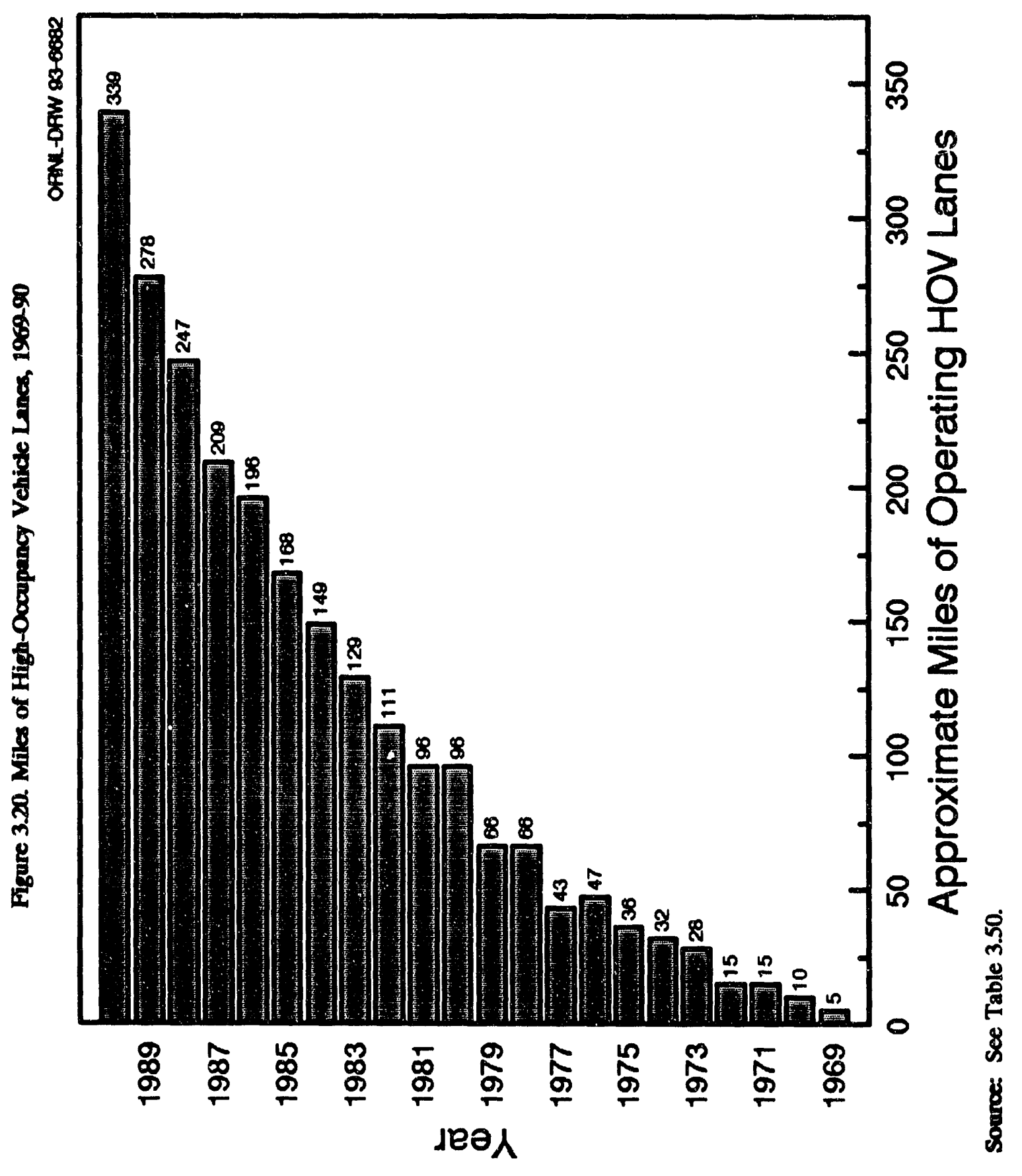




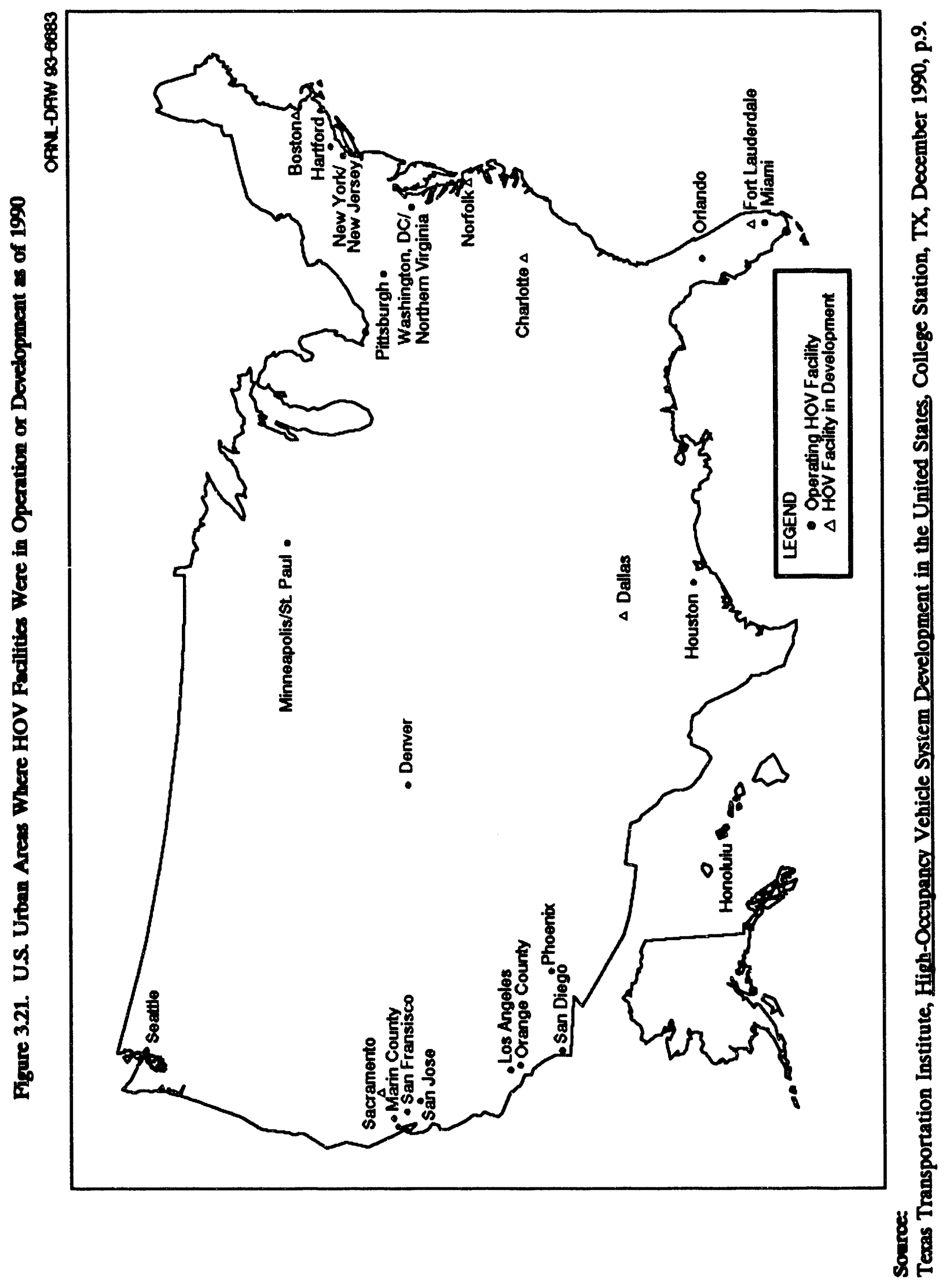




\section{CHAPTER 4 \\ PERSONAL TRAVEL STATISTICS}

From 19850 to 1990 , the average annual increase in the number of vehicles surpasses the increases in population, households, licensed drivers, and employed persons. Since 1985 there has been more than one vehicle for every licensed driver in the U.S. (Table 4.1).

Each year since 1979 the U.S. Travel Data Center has conducted the National Travel Survey on a regular basis to provide timely and relevant information on major travel trends in the U.S. In this survey, a trip is defined as "each time one person goes to a place at least 100 miles away from home and returns." The following trips are excluded from the survey: travel as part of an operation crew on a train, airplane, truck, bus, or ship; commuting to a place of work; and student trips to or from school. Data from the 1990 National Travel Survey are contained in Tables 4.4-4.6. According to the survey, the average trip distance in 1990 was 72 miles shorter than in 1988 due to shorter trips taken by cars, trucks, and recreational vehicles. The average trip distance by airplane, however, was longer in 1990 than in 1988 (Table 4.4). Twenty percent of all vacation trips in 1990 were less than 300 miles (Table 4.5).

The majority of data on personal travel come from the Nationwide Personal Transportation Survey (NPTS). The NPTS is a national survey designed to collect data on the nature and characteristics of personal travel. Not to be confused with the National Travel Survey, the definition of a trip in the NPTS is "any one-way travel from one address (place) to another by private motor vehicle, public transportation, bicycle, or walking." Excluded from the survey are jogging and walking for exercise, as well as all bicycling and walking for individuals under 5 years of age. The survey collects detailed data on household trips, their purposes and the transportation modes used. The NPTS is sponsored by several agencies of the U.S. Department of Transportation and is conducted approximately every seven years. The data presented include information from surveys done in 1969, 1977, 1983, and 1990. Tables 4.7-4.20 and Figures 4.5-4.14 are taken directly from the U.S. Department of Transportation, Federal Highway Administration, 1990 Nationwide Personal Transportation Survey: Summary of Travel Trends which was prepared by Oak Ridge National Laboratory 
for the Federal Highway Administration. Since all of the NPTS surveys differ somewhat in terminology, survey procedure, and target population, one should be cautious when comparing statistics from one survey to the next. 


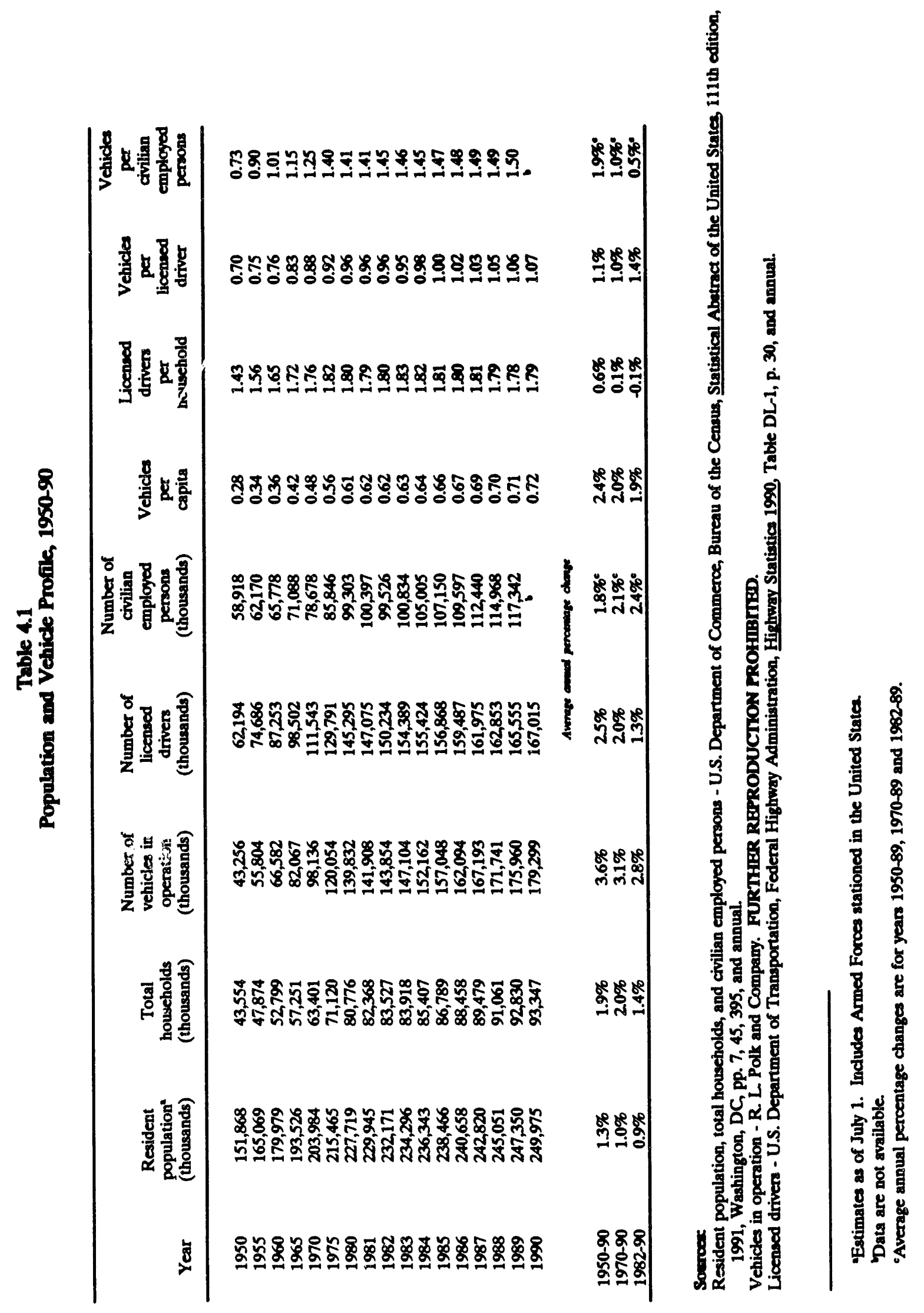




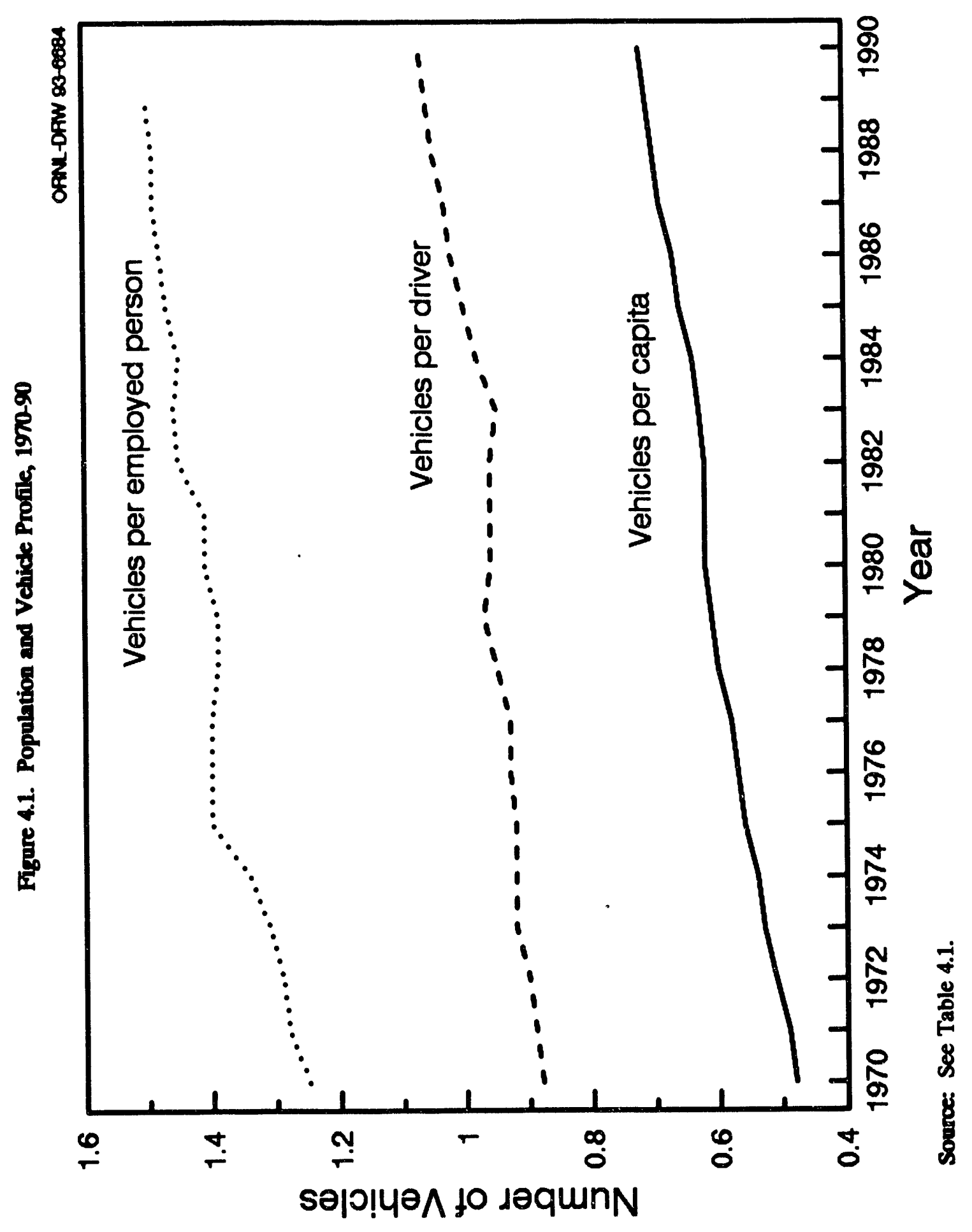




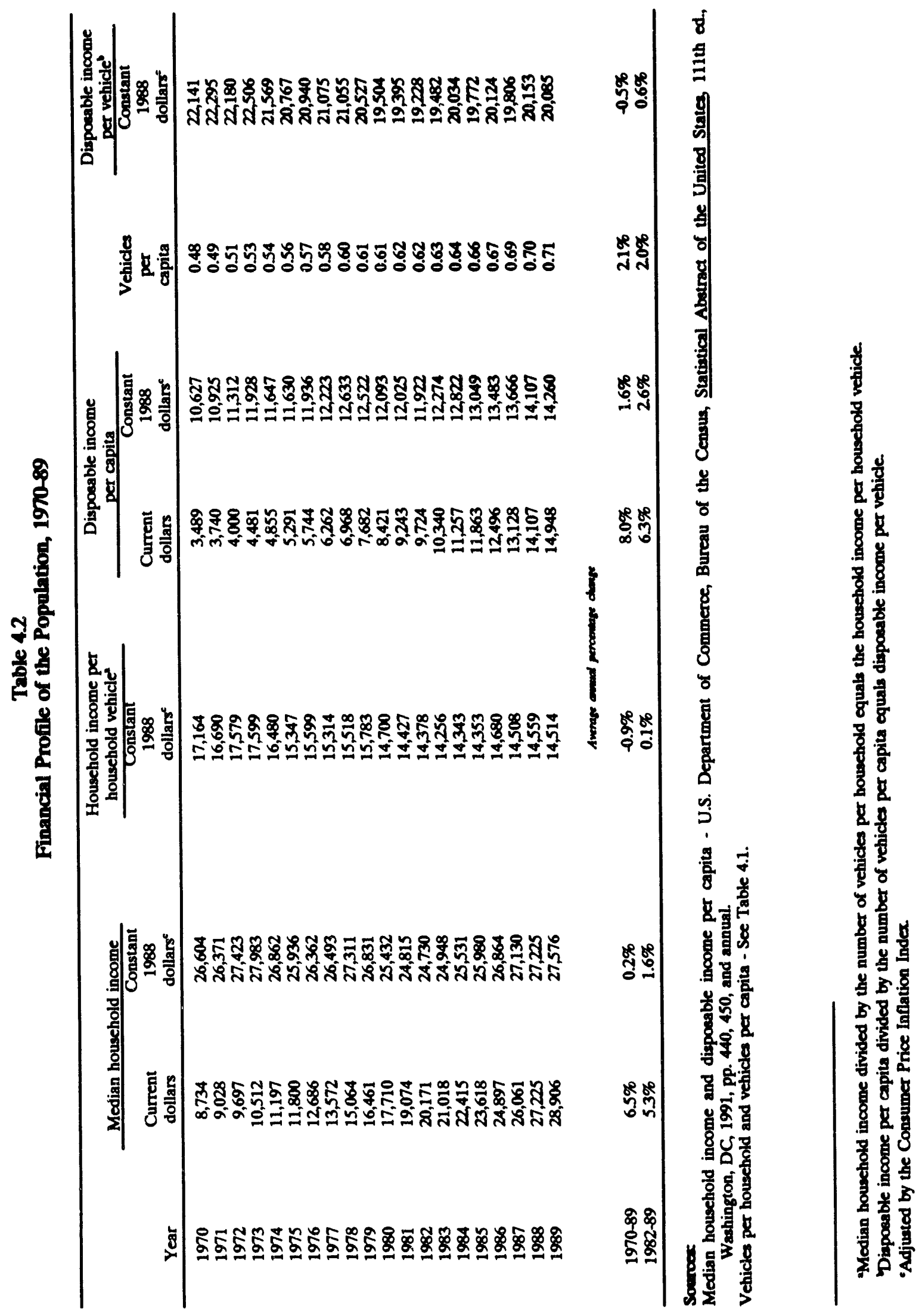




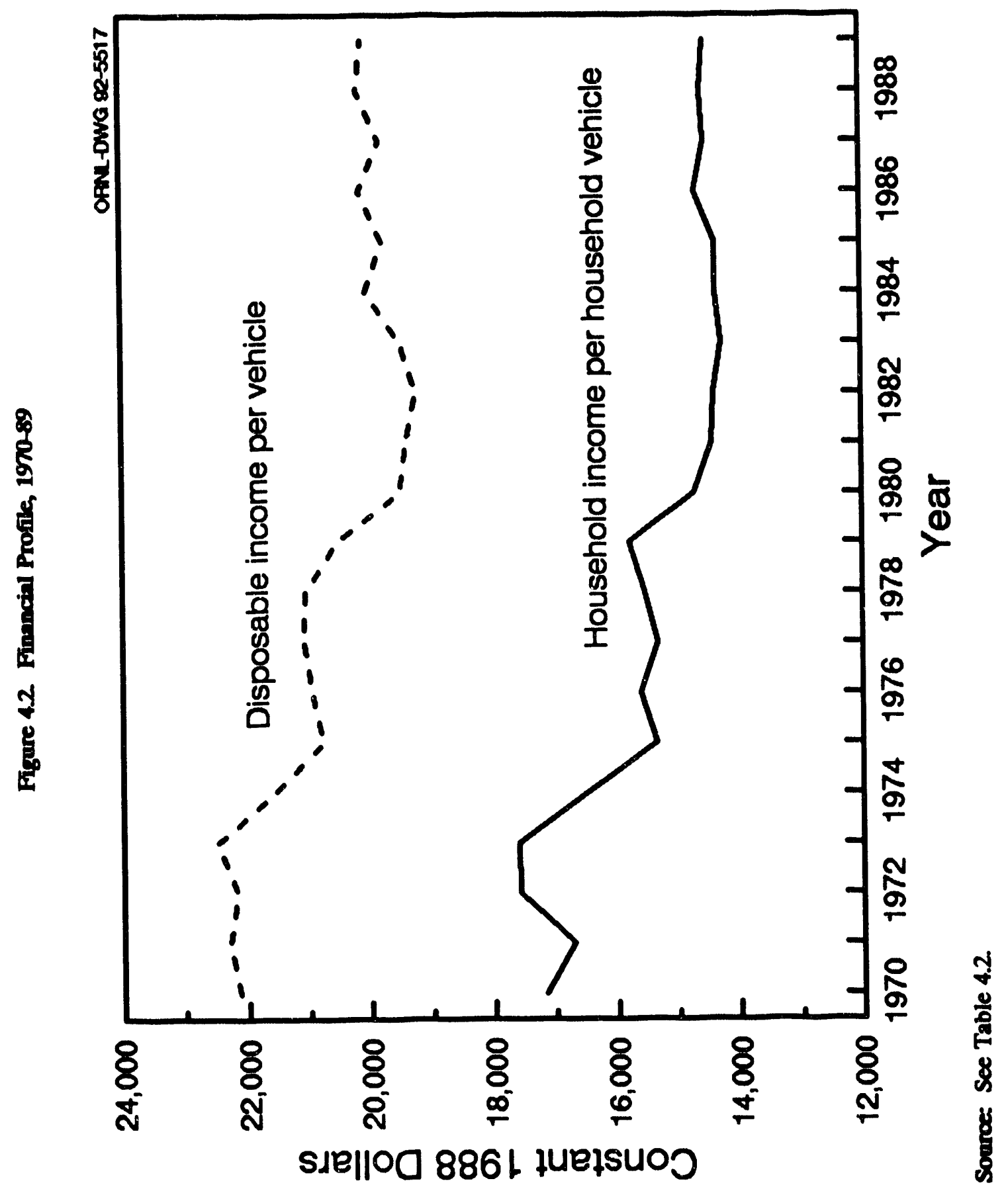



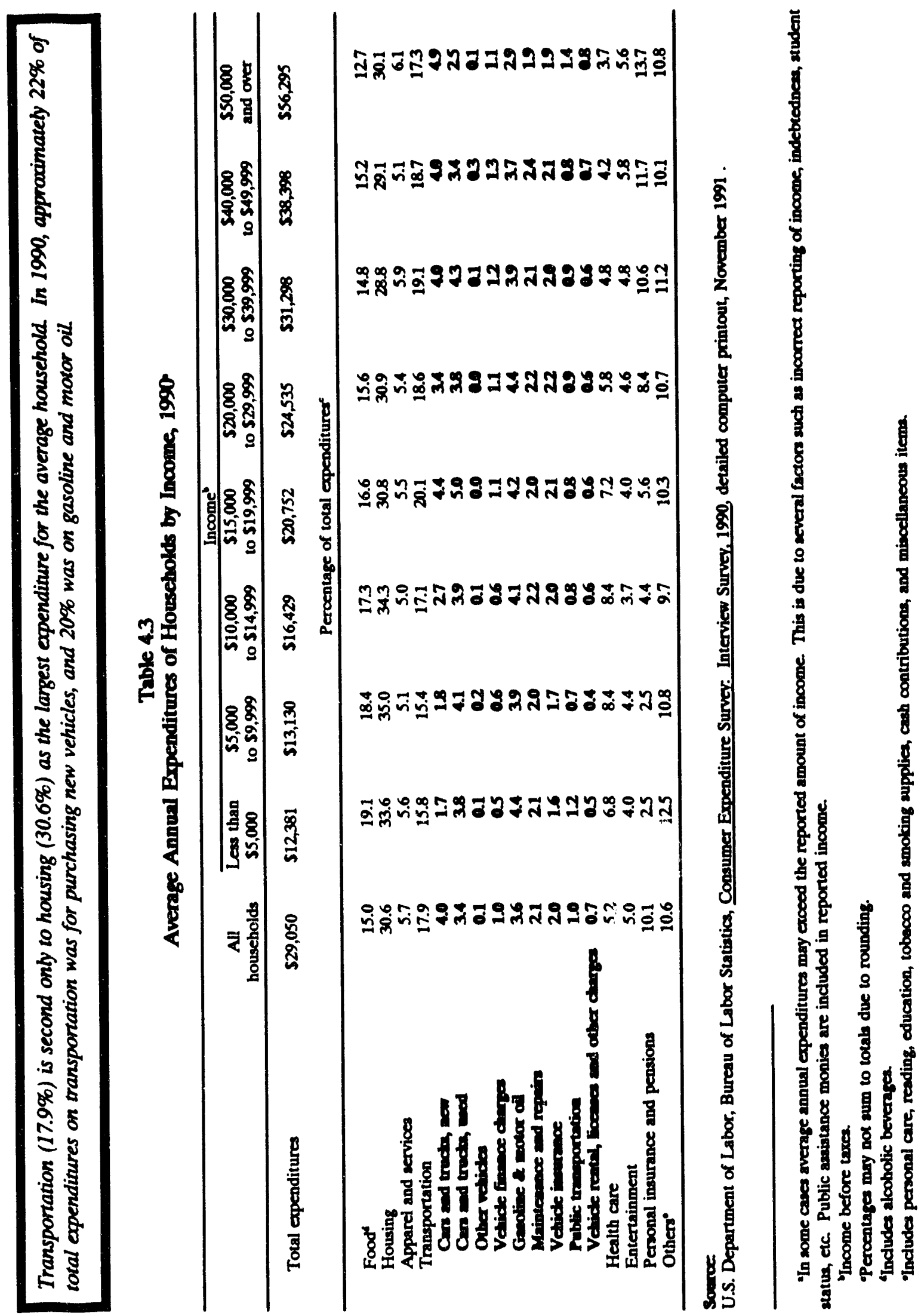
Table 44

Demographic Characteristics of Auto/Truct/Recreational Vehicle (RV) and Air Travelers 1988-90 (percentage)

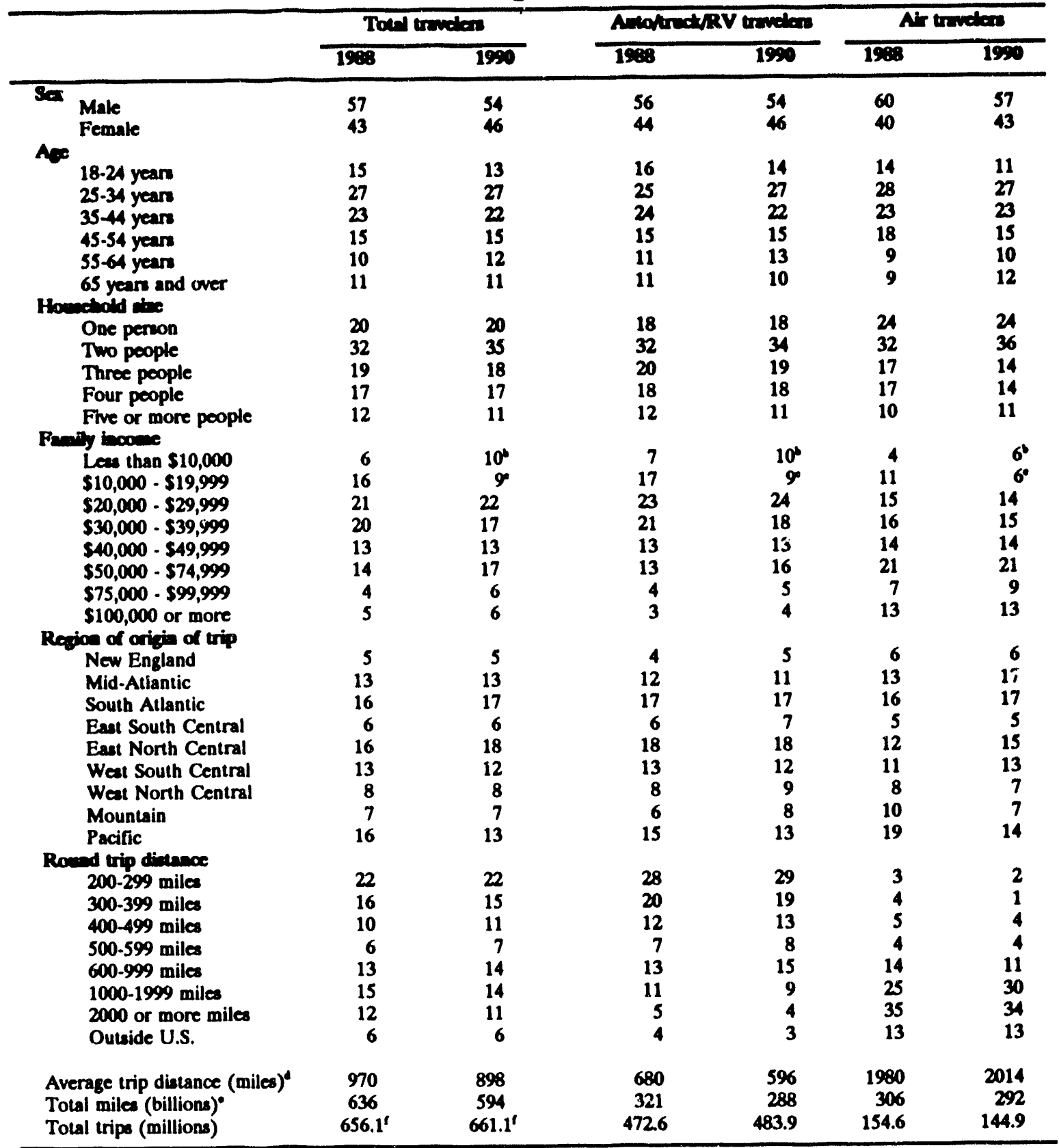

Sourcex

U.S. Travel Data Center, 1988 Travel Market Close-Up, Washington, DC, 1989, pp. 1, 29, 81, 89, and 93.

U.S. Travel Data Center, 1990 Travel Market Repont, Washington, DC, 1991, Appendix F, pp. 1, 29, 81, 89, and 93.

The sum of the components may not equal 100 percent due to rounding. A trip is defined as "cach time a person goes to a place at least $\mathbf{1 0 0}$ miles from home and returns."

Leas than $\$ 15,000$

$\$ 15,000-\$ 19,999$.

"Based on total trips taken in category, not total travelers.

Total number of trips multiplied by average trip distance.

The total exceeds the sum of automobile and air travel because some trips are made by bus and rail. 


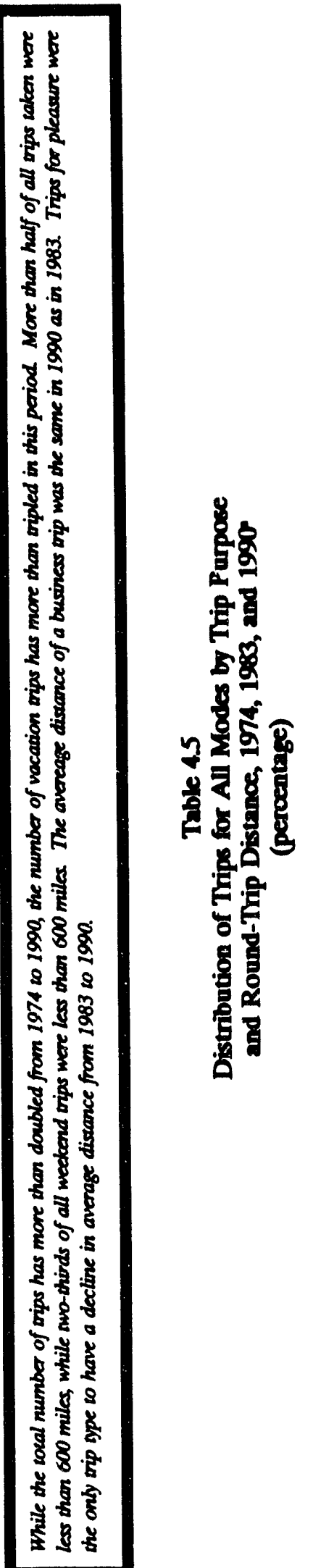

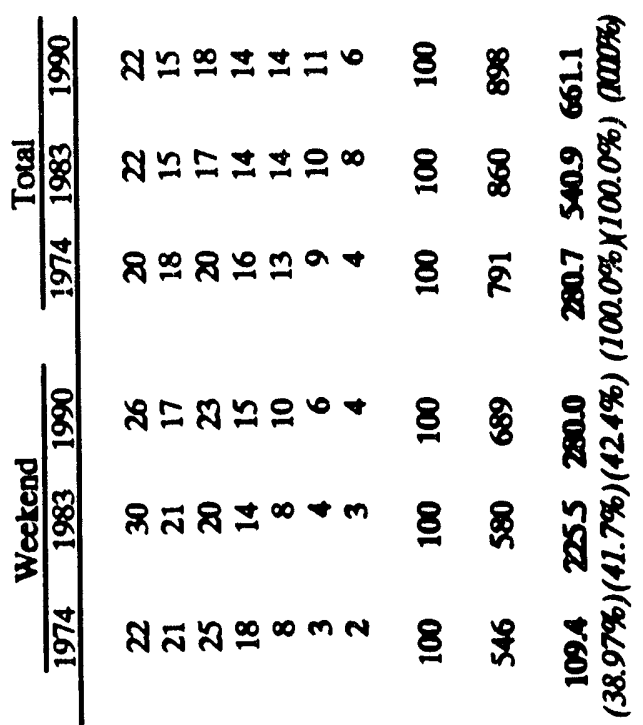

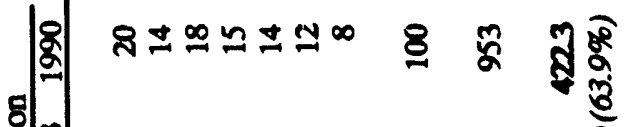

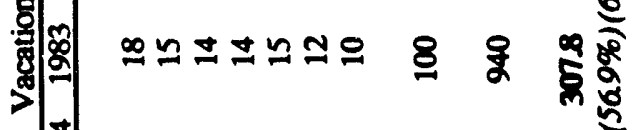

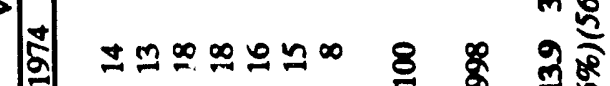

7 政

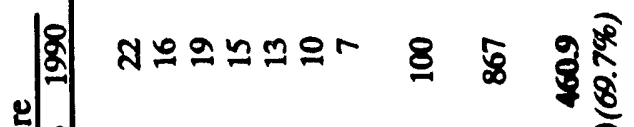

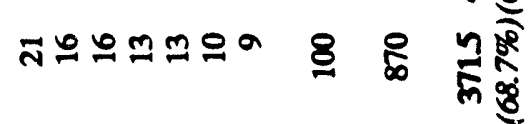

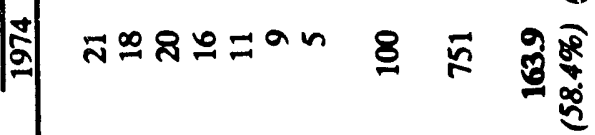

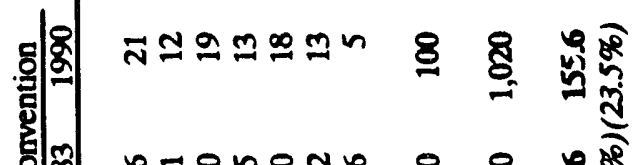

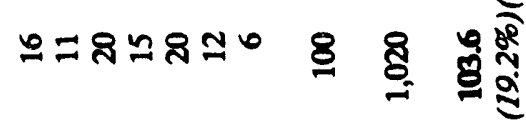

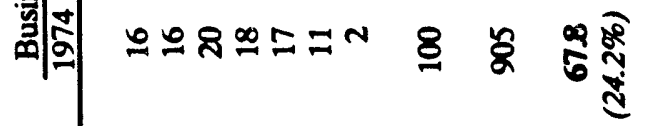

8)

สิด

ฉి

केष

\&.

今气

意

रणिए है

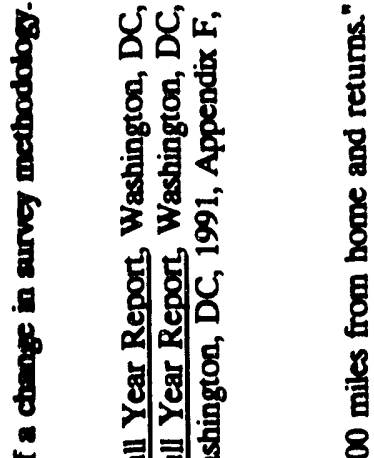

司司要 8

8 占占要

8

ริ)

$8 \%$ 항

브른

的

옹

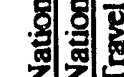

88

요 8

욜

Б워용

或窎

क पै 8

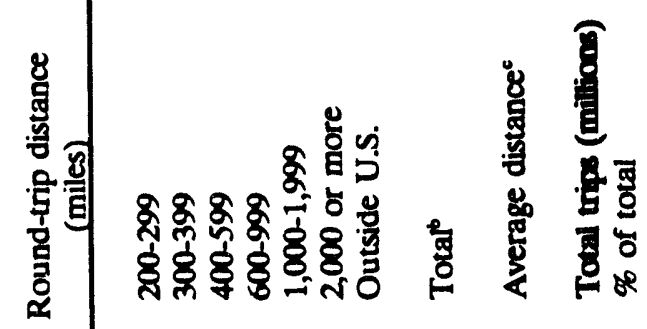

确 颉

自最

进旨兽

$\overline{9} \overline{9}$

色

点

8 骂

ทุ่ คุ

읍

宫器总

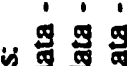

강 형 정 


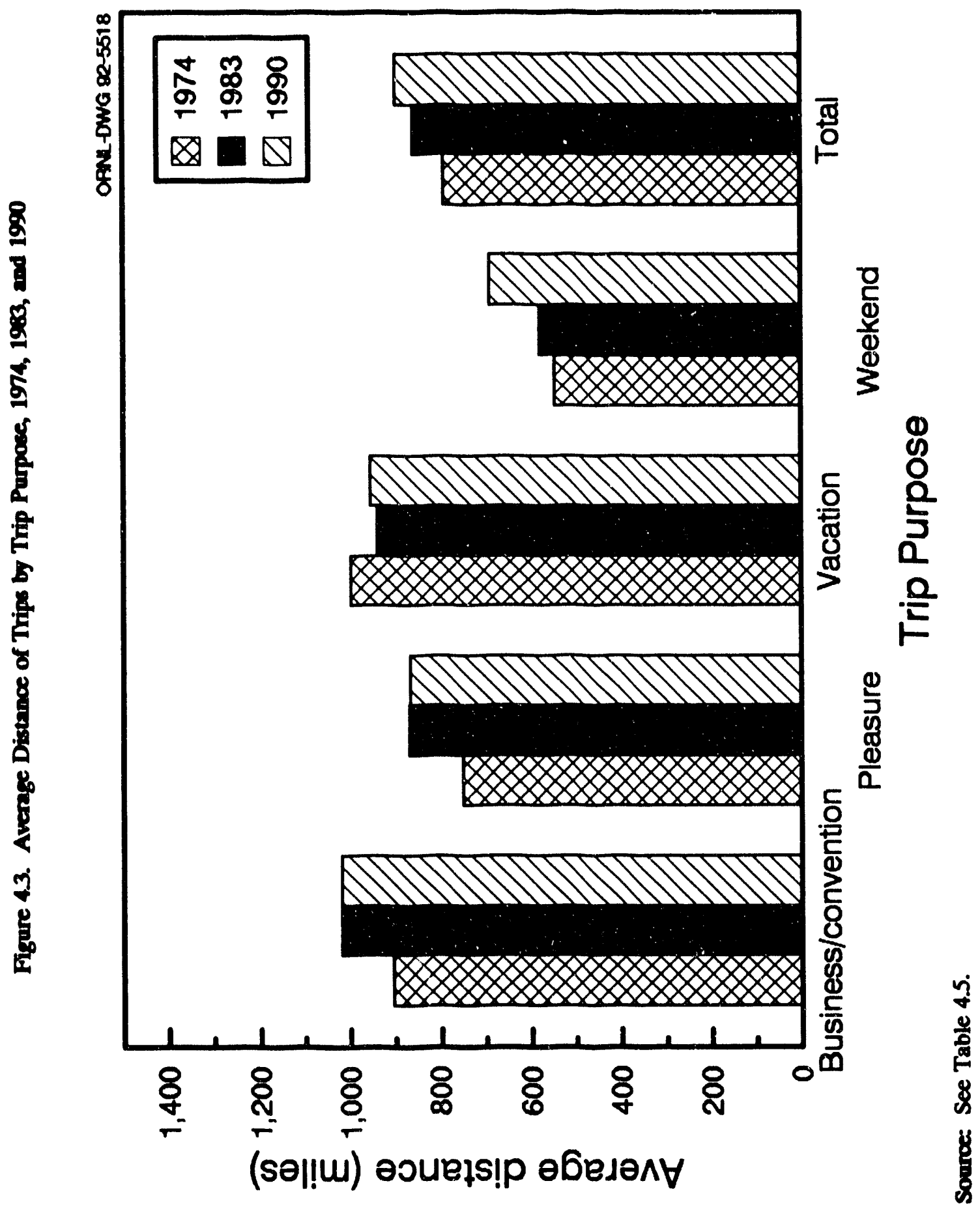


Regardless of the trip purposes, the majority of trips in 1990 were taken using auto/truck/RV. Of the four trip puryoses, business trips had the highest percentage of trips by airplane (37\%), while weekend trips had the lowest percentage (13\%). Since business trips are more likely to be taken by airplane, they have the longest average trip length (1,020 miles) while weekend trips have the shortest (689 miles).

Table 4.6

Mode of Travel by Trip Purpose, 1990

\begin{tabular}{lrrrrr}
\hline \multirow{2}{*}{ Mode } & Pleasure & Business & Vacation & Weekend & Total \\
\cline { 2 - 6 } & \multicolumn{7}{c}{ (percentage) } \\
\hline Auto/truck/RV' & 77 & 58 & 74 & 83 & 73 \\
Airplane & 18 & 37 & 20 & 13 & 22 \\
Bus & 3 & 2 & 3 & 2 & 3 \\
Train & 1 & $c$ & 1 & 1 & 1 \\
Other & 1 & 2 & 1 & 1 & 2 \\
& & & & & \\
Total number of trips (millions) & 460.9 & 155.6 & 422.3 & 280.2 & $661.1^{\text {d }}$ \\
Average trip distance (miles) & 867.0 & 1020.0 & 953.0 & 689.0 & 898.0 \\
\hline
\end{tabular}

Source:

U.S. Travel Data Center, 1990 Travel Market Report, Washington, D.C., 1991, Appendix F, pp. 1, 5.

Figure 4.4. Mode of Trevel by Trip Purpose, 1990

ORNL-DRW 93-6685

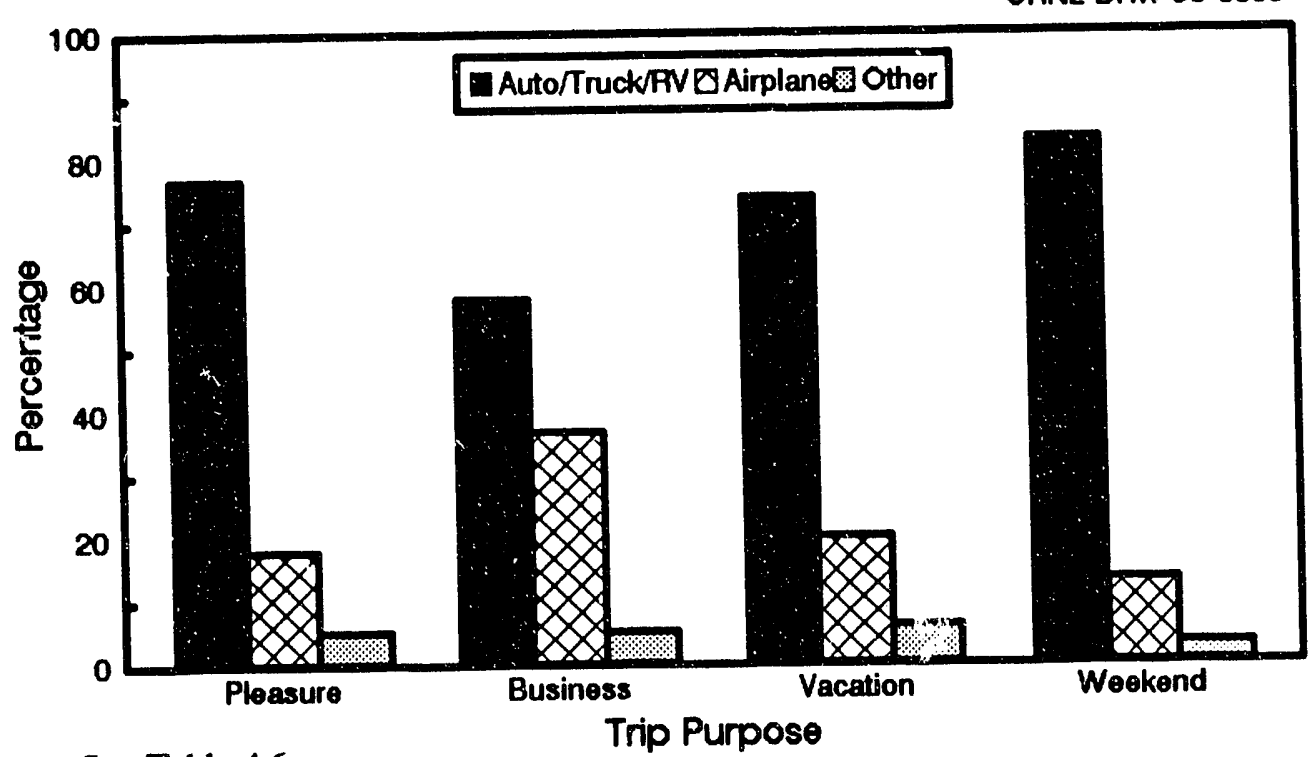

Source: See Table 4.6.

The sum of the components may not equal 100 percent due to rounding. A trip is defined as "each time a persor goes to a place at least 100 miles from home and returns."

"This category also includes rental cars. $R V=$ recreational vehicle.

Less than 1 percent.

'The sum of the components may not equai the $t \mathrm{t}$ : al number of trips due to multiple responses. 
According to the U.S. Census data, the percentage of workers who carpooled has dropped from $19.7 \%$ in 1980 to $13.4 \%$ in 1990 . The percent of workers using public transit declined from $6.4 \%$ to $5.3 \%$ during the same time period. The average travel time increased by 0.7 minutes from 1980 to 1990 .

Table 4.7

Means of Transportation to Wort for the United States: 1980 and 1990 Census

\begin{tabular}{|c|c|c|c|c|}
\hline \multirow[b]{2}{*}{ Means of Transportation } & \multicolumn{2}{|c|}{1980 Census } & \multicolumn{2}{|c|}{1990 Census } \\
\hline & $\begin{array}{c}\text { Number } \\
\text { of Workers }\end{array}$ & Percentage & $\begin{array}{c}\text { Number } \\
\text { of Workers }\end{array}$ & Percentage \\
\hline Private vehicle & $81,258,496$ & 84.1 & $99,592,932$ & 86.5 \\
\hline Drove alone & $62,193,449$ & 64.4 & $84,215,298$ & 73.2 \\
\hline Carpooled & $19,065,047$ & 19.7 & $15,377,634$ & 13.4 \\
\hline Public Transportation & $6,175,061$ & 6.4 & $6,069,589$ & 5.3 \\
\hline Bus or trolley bus" & $3,924,787$ & 4.1 & $3,445,000$ & 3.0 \\
\hline Streetcar or trolley car & 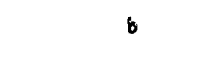 & b & 78,130 & 0.1 \\
\hline Subway or elevated & $1,528,852$ & 1.6 & $1,755,476$ & 1.5 \\
\hline Railroad & 554,089 & 0.6 & 574,052 & 0.5 \\
\hline Ferryboat & $b$ & $b$ & 37,497 & 0.0 \\
\hline Taxicab & 167,133 & 0.2 & 179,434 & 0.2 \\
\hline Other Means & 703,273 & 0.7 & 808,582 & 0.7 \\
\hline Motorcycle & 419,007 & 0.4 & 237,404 & 0.2 \\
\hline Bicycle & 468,348 & 0.5 & 466,856 & 0.4 \\
\hline Walked only & $5,413,248$ & 5.6 & $4,488,886$ & 3.9 \\
\hline Worked at home & $2,179,863$ & 2.3 & $3,406,025$ & 3.0 \\
\hline Total Workers & $96,617,296$ & 100.0 & $115,070,274$ & 100.0 \\
\hline $\begin{array}{l}\text { Average travel time } \\
\text { (minutes) }\end{array}$ & 21.7 & & 22.4 & \\
\hline
\end{tabular}

Source:

Data provided by the Journey-to-Work and Migration Statistics Branch, Population Division, U.S. Bureau of the Census.

"This category was "Bus or streetcar" in 1980.

'Data are not available. 
Table 4.8

Summary Statistics on Demographic Characteristics

and Total Travel

$1969,1977,1983$, and 1990 Series of the NPTS

\begin{tabular}{|c|c|c|c|c|c|c|}
\hline & & & & & & \\
\hline & 1969 & 1977 & 1983 & 1990 & $69-90^{\circ}$ & $69-90^{5}$ \\
\hline HOUSEAOLDS $(000)$ & & & & & & \\
\hline All & 62,504 & 75,412 & 85,371 & 93,347 & 1.9 & 49 \\
\hline 1 person & 10,980 & 16,214 & 19,354 & 22,999 & 3.6 & 109 \\
\hline 2 persons & 18,448 & 22,925 & 27,169 & 30,114 & 2.4 & 63 \\
\hline 3 perscns & 10,746 & 13,046 & 14,756 & 16,128 & 2.0 & 50 \\
\hline $4+$ persons & 22,330 & 23,227 & 24,092 & 24,106 & 0.4 & 8 \\
\hline PERSONS (000) & & & & & & \\
\hline All & 197,213 & 213,141 & 229,453 & $239,416^{\circ}$ & 0.9 & 21 \\
\hline Under 16 & 60,100 & 54,958 & 53,682 & 54,303 & -0.5 & -10 \\
\hline $16-19$ & 14,598 & 16,552 & 15,268 & $13,8 j 1$ & -0.2 & -5 \\
\hline $20-34$ & 40,060 & 52,252 & 60,788 & 59,517 & 1.9 & 49 \\
\hline $35-64$ & 62,982 & 66,988 & 75,353 & 82,480 & 1.3 & 31 \\
\hline $65+$ & 19,473 & 22,391 & 24,362 & 26,955 & 1.6 & 38 \\
\hline All Male & 94,465 & 102,521 & 111,514 & 114,441 & 0.8 & 21 \\
\hline All Male -16 and older & 66,652 & 74,542 & 83,645 & 86,432 & 1.1 & 30 \\
\hline All Female & 102,748 & 110,620 & 117,939 & 124,975 & 0.8 & 22 \\
\hline All Female - 16 and older & 73,526 & 83,721 & 92,080 & 96,371 & 1.1 & 31 \\
\hline All - 5 and older & NA & 198,434 & 212,932 & 222,101 & 0.94 & 12 \\
\hline LICENSED DRIVERS $(000)$ & & & & & & \\
\hline All & 102,986 & 127,552 & 147,015 & $163,025^{\circ}$ & 2.2 & 58 \\
\hline Male & 57,981 & 66,199 & 75,639 & 80,289 & 1.6 & 38 \\
\hline Female & 45,005 & 61,353 & 71,376 & 82,707 & 2.9 & 84 \\
\hline WORKERS (000) & & & & & & \\
\hline All & 75,758 & 93,019 & 103,244 & $118,343^{\circ}$ & 2.1 & 56 \\
\hline Male & 48,487 & 55,625 & 58,849 & 63,996 & 1.3 & 32 \\
\hline Female & 27,271 & 37,394 & 44,395 & 54,334 & 3.3 & 99 \\
\hline HOUSEHOLD VEHICIES $(000)$ & 72,500 & 120,098 & 143,714 & 165,221 & 4.0 & 128 \\
\hline $\begin{array}{l}\text { HOUSFHOLD VEHICTB TRIPS } \\
(000,000)\end{array}$ & 87,284 & 108,826 & 126,874 & 158,927 & 29 & 82 \\
\hline HOUSEHOLD VMT $(000,000)$ & 775,940 & 907,603 & $1,002,139$ & $1,409,600$ & 2.9 & 82 \\
\hline PIERSON TRIPS' $(000,000)$ & 145,146 & 211,778 & 224,385 & 249,562 & 26 & 72 \\
\hline $\begin{array}{l}\text { PERSON MIIAS OF TRAVEI: } \\
(000,000)\end{array}$ & $1,404,137$ & $1,879,215$ & $1,946,662$ & $2,315,300$ & 24 & 65 \\
\hline
\end{tabular}

Source: U.S. Department of Transportation, Federal Highway Administration, 1990 Nationwide Personal Transportation Study: Summary of Travel Trends, Table 1, Washington, DC, March 1992.

'Compounded annual percentage change rate.

'Percentage change rate.

"Includes "don't know" and "refusals."

TFor years 1977-1990.

-1969 survey includes only automobiles, station wagons, and vanbuses/minibuses as housebold vehicles.

${ }^{\prime} 1969$ survey does not include walk and bicycle trips. 


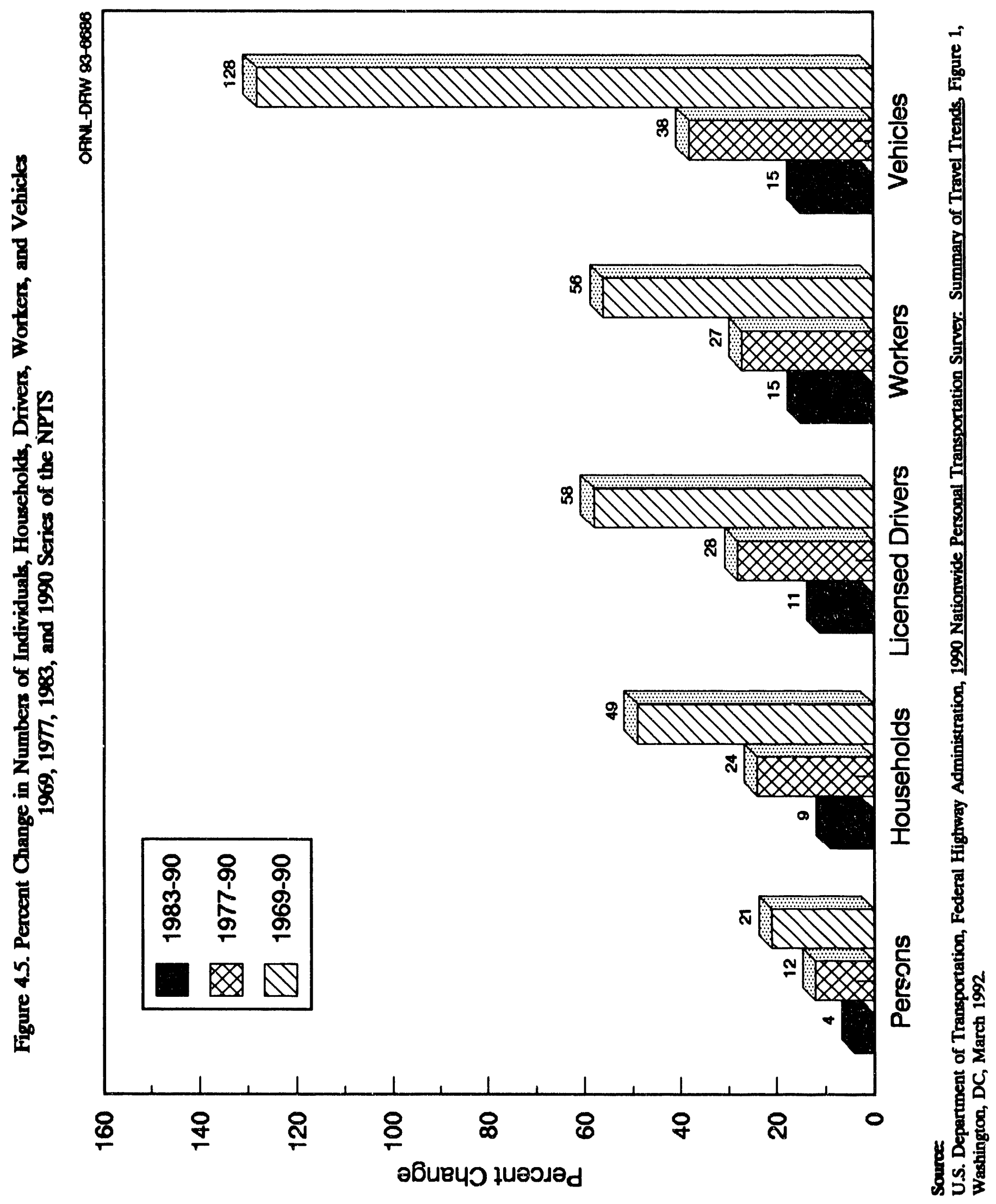


The pencentage of households without a vehicle dropped from $20.6 \%$ in 1969 to $9.2 \%$ in 1990, while the percentage of households with three or more vehicles available quadrupled. Over the 1969 to 1990 period, the total number of households increased by $49 \%$ while the number of household vehicles increased by $128 \%$.

Table 4.9

Number of Households by Vehicles Available $1969,1977,1983$, and 1990 Series of the NPTS

(thousands)

\begin{tabular}{|c|c|c|c|c|c|c|}
\hline \multirow{2}{*}{$\begin{array}{l}\text { Number } \\
\text { of Vehicles } \\
\text { Owned }\end{array}$} & \multirow[b]{2}{*}{$1969^{\prime}$} & \multirow[b]{2}{*}{1977} & \multirow[b]{2}{*}{1983} & \multirow[b]{2}{*}{1990} & \multicolumn{2}{|c|}{ Change } \\
\hline & & & & & $69-90^{b}$ & $69-90^{c}$ \\
\hline No Vehicle & $\begin{array}{r}12,876 \\
(20.6 \%)\end{array}$ & $\begin{array}{r}11,538 \\
(15.3 \%)\end{array}$ & $\begin{array}{r}11,548 \\
(13.5 \%)\end{array}$ & $\begin{array}{r}8,573 \\
(9.2 \%)\end{array}$ & -1.9 & -33 \\
\hline 1 Vehicle & $\begin{array}{r}30,252 \\
(48.4 \%)\end{array}$ & $\begin{array}{r}26,092 \\
(34.6 \%)\end{array}$ & $\begin{array}{r}28,780 \\
(33.7 \%)\end{array}$ & $\begin{array}{r}30,654 \\
(32.8 \%)\end{array}$ & 0.1 & 1 \\
\hline 2 Vehicles & $\begin{array}{r}16,501 \\
(26.4 \%)\end{array}$ & $\begin{array}{r}25,942 \\
(34.4 \%)\end{array}$ & $\begin{array}{r}28,632 \\
(33.5 \%)\end{array}$ & $\begin{array}{r}35,872 \\
(38.4 \%)\end{array}$ & 3.8 & 117 \\
\hline $3+$ Vehicles & $\begin{array}{r}2,875 \\
(4.6 \%)\end{array}$ & $\begin{array}{r}11,840 \\
(15.7 \%)\end{array}$ & $\begin{array}{r}16,411 \\
(19.2 \%)\end{array}$ & $\begin{array}{r}18,248 \\
(19.5 \%)\end{array}$ & 9.2 & 535 \\
\hline $\begin{array}{l}\text { ALL } \\
\text { HOUSEHOLDS }\end{array}$ & 62,504 & 75,412 & 85,371 & 93,347 & 1.9 & 49 \\
\hline $\begin{array}{l}\text { ALL } \\
\text { HOUSEHOLD } \\
\text { VEHICLES }\end{array}$ & 72,500 & 120,098 & 143,714 & 165,221 & 4.0 & 128 \\
\hline $\begin{array}{l}\text { VEHICLES PER } \\
\text { HOUSEHOLD }\end{array}$ & 1.16 & 1.59 & 1.68 & 1.77 & 20 & 53 \\
\hline
\end{tabular}

Source: U.S. Department of Transportation, Federal Highway Administration, 1990 Nationwide Personal Transportation Survey: Summary of Travel Trends, Table 4, Washington, DC, March 1992.

"The 1969 survey does not include pickups or other light trucks as household vehicles. ${ }^{b}$ Compounded annual percentage change rate.

'Percentage change rate. 


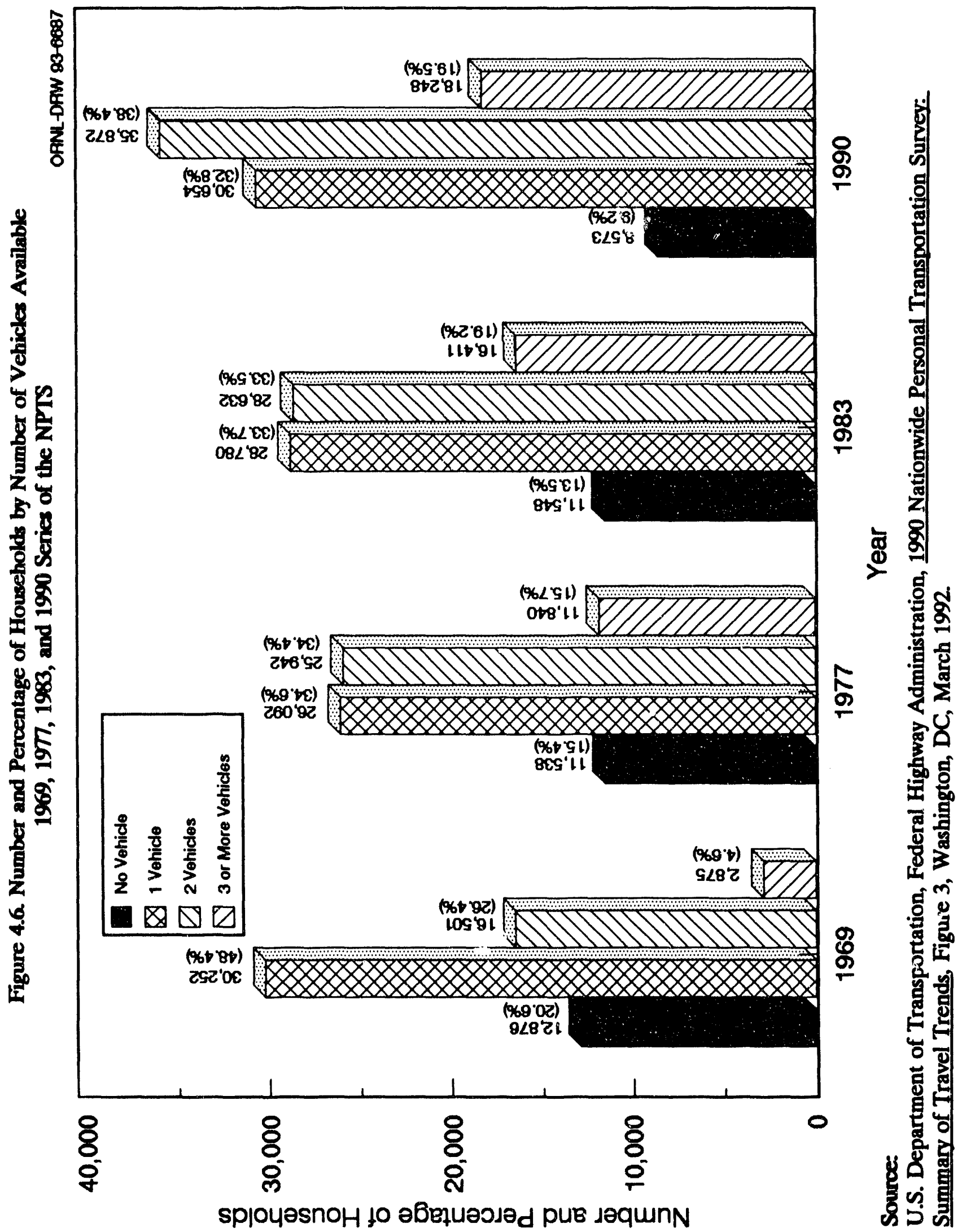


Both annual VMT and annual vehicle trips per household increased by $22 \%$ between 1969 and 1990. Work trips continue to account for the largest proportion of household travel, both in terms of miles and in number of trips. Average vehicle trip lengths, which had been decreasing from 1969 to 1983, showed increases in 1990. The largest increase in trip length was in work trips.

Table 4.10

Average Annual VMT, Vehicle Trips ard Trip Length

Per Household for Selected Trip Purposes

$1969,1977,1983$, and 1990 Series of the NPTS

\begin{tabular}{|c|c|c|c|c|c|}
\hline Trip Purpose & 1969 & 1977 & 1983 & 1990 & $\begin{array}{c}\text { Percent } \\
\text { Change } \\
69-90\end{array}$ \\
\hline \multicolumn{6}{|c|}{ Average Annual VMT } \\
\hline Home to Work & 4,183 & 3,815 & 3,538 & 4,853 & 16 \\
\hline Shopping & 929 & 1,336 & 1,567 & 1,743 & 88 \\
\hline Other Family or Personal Business & 1,270 & 1,444 & 1,816 & 3,014 & 137 \\
\hline Social and Recreation & 4,094 & 3,286 & 3,534 & 4,060 & -1 \\
\hline Alf & 12423 & 12036 & 11.739 & 15.100 & 22 \\
\hline \multicolumn{6}{|c|}{ Average Annual Vehicle Trips } \\
\hline Home to Work & 445 & 423 & 414 & 448 & 0.7 \\
\hline Shopping & 213 & 268 & 297 & 345 & 62 \\
\hline Other Family or Personal Business & 195 & 215 & 272 & 411 & 111 \\
\hline Social and Recreation & 312 & 320 & 335 & 349 & 12 \\
\hline Alr & 1.396 & 1.442 & 1.486 & 1.702 & 22 \\
\hline \multicolumn{6}{|c|}{ Average Vehicle Trip Length (Miles) } \\
\hline Home to Work & 9.4 & 9.1 & 8.5 & 11.0 & 17 \\
\hline Shopping & 4.4 & 5.0 & 5.3 & 5.1 & 16 \\
\hline Other Family or Personal Business & 6.5 & 6.8 & 6.7 & 7.4 & 14 \\
\hline Social and Recreation & 13.1 & 10.3 & 10.5 & 11.8 & -10 \\
\hline All & 8.9 & 8.4 & 7.9 & 9.0 & 1 \\
\hline
\end{tabular}

Source: U.S. Department of Transportation, Federal Highway Administration, 1990 Nationwide Personal Transportation Survey: Summary of Travel Trends, Table 7, Washington, DC, March 1992.

'Includes trip purposes not shown above. 

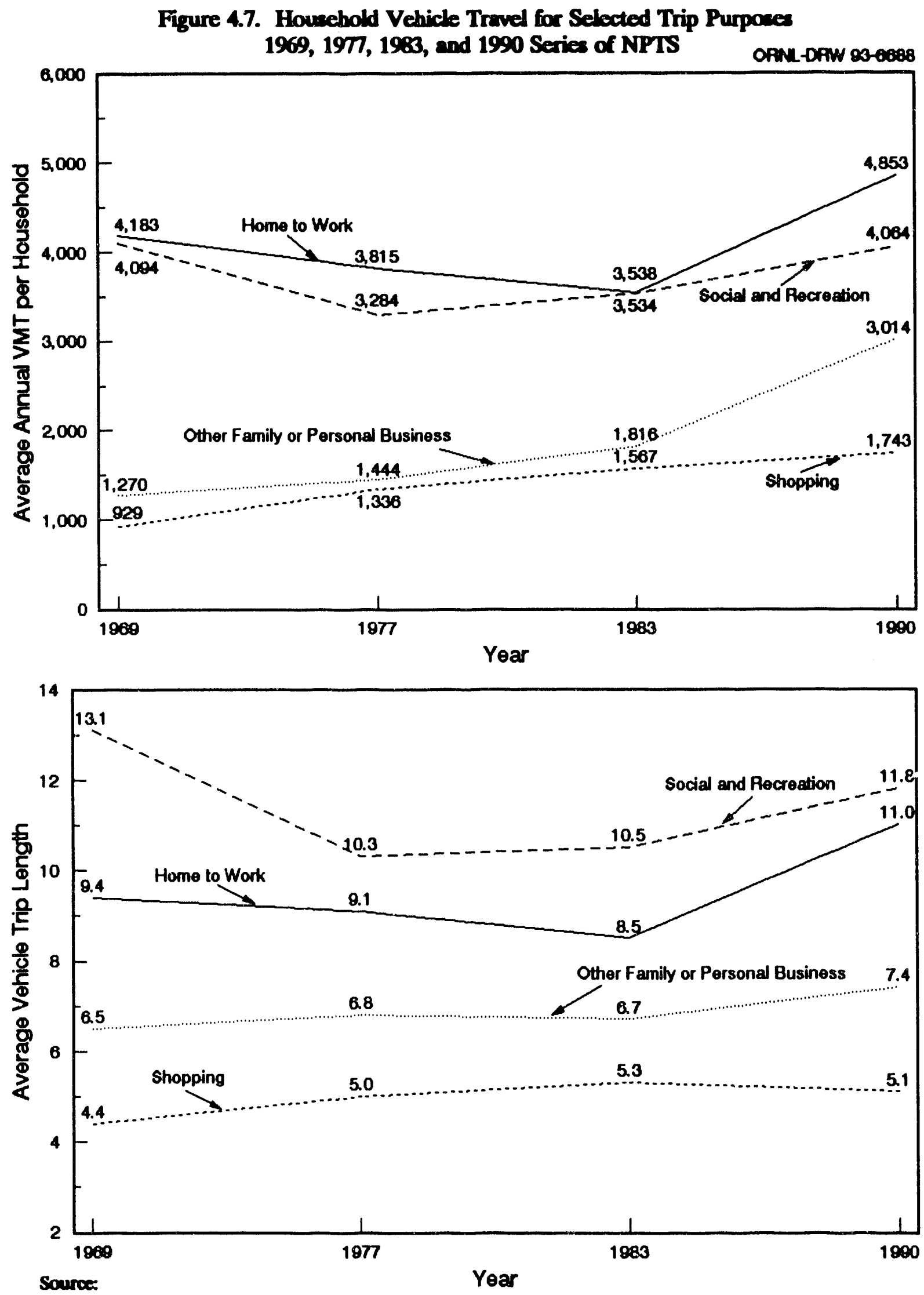

U.S. Department of Transportation, Federal Highway Administration, 1990 Nationwide Personal Transportation Surver: Summary of Travel Trends, Figure 5, Washington, DC, March 1992. 
The average vehicle occupancy, calculated as person miles per vehicle mile, was at its lowest level since 1977 for every trip purpose. Several factors contributed to this decline in the vehicle occupancy rate, including the increased number of vehicles per household and the decrease in average household size.

Table 4.11

Average Vehicle Occupancy for Selected Trip Purposes 1977,1983 , and 1990 Series of the NPTS (person miles per vehicle mile)

\begin{tabular}{|lrrrrrr|}
\hline & & & \multicolumn{3}{c|}{ Change } \\
\cline { 6 - 7 } Trip Purpose & 1977 & 1983 & 1990 & $77-90^{\circ}$ & $77-90^{\circ}$ \\
\hline Home to Work & 1.3 & 1.3 & 1.1 & -1.3 & -15 \\
Shopping & 2.1 & 1.8 & 1.7 & -1.6 & -19 \\
$\begin{array}{l}\text { Other Family or } \\
\text { Personal Business }\end{array}$ & 2.0 & 1.8 & 1.8 & -0.8 & -10 \\
Social and Recreation & 2.4 & 2.1 & 2.1 & -1.0 & -13 \\
& & & & & \\
All Purposes & & 1.9 & 1.7 & 1.6 & -1.3 & -16 \\
\hline
\end{tabular}

Source: U.S. Department of Transportation, Federal Highway Administration, 1990 Nationwide Personal Transportation Survey: Summary of Travel Trends, Table 8, Washington, DC, March 1992.

'Compounded annual percentage change rate.

'Percentage change rate.

'Includes other purposes not shown above such as trips to school, church, doctor, dentist, and work-related business trips. 


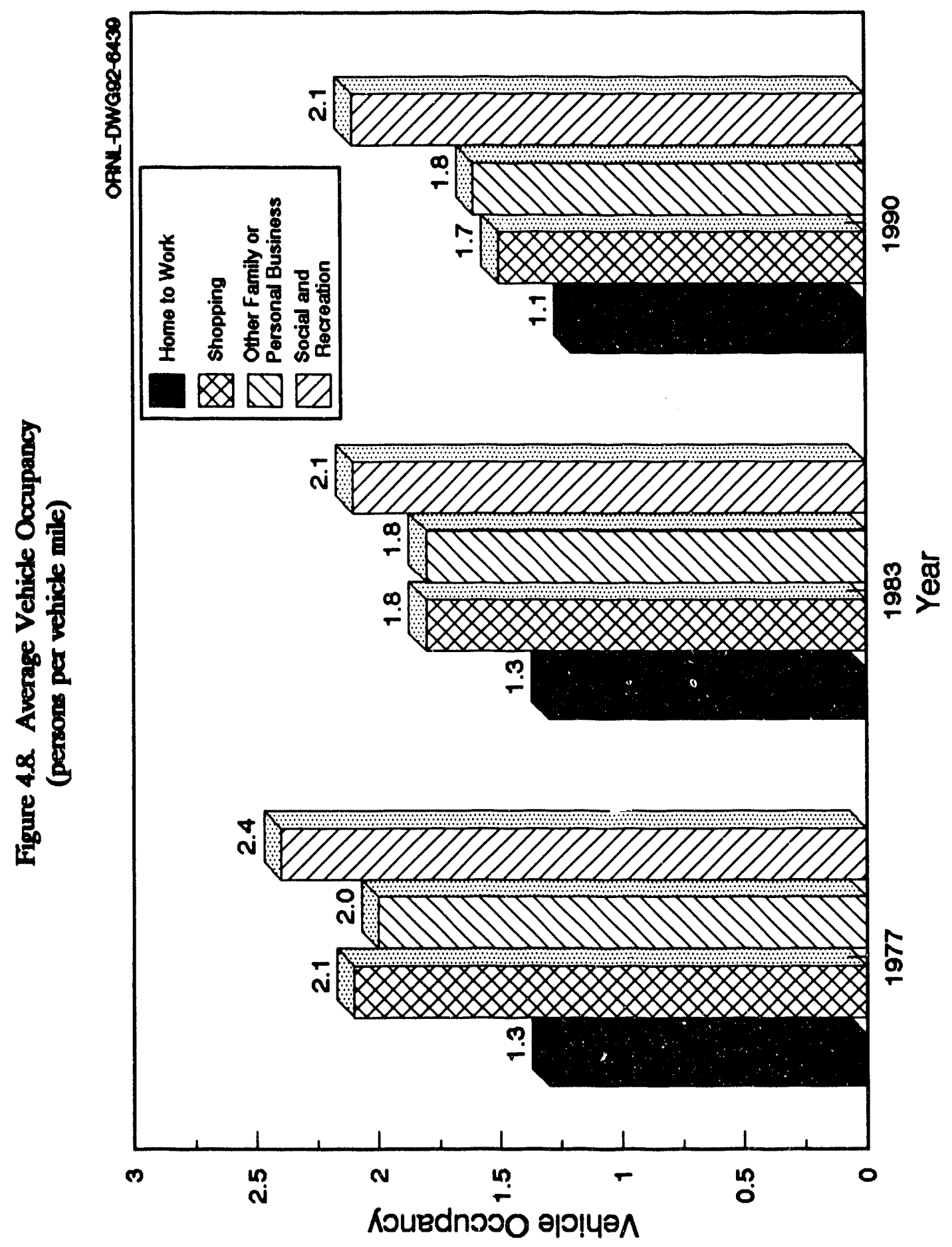

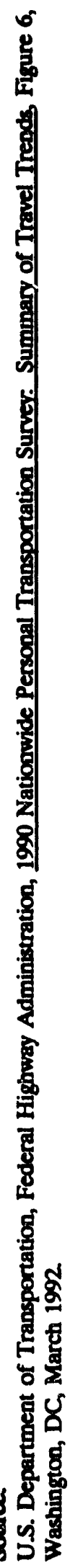


Figure 4.9. Distribution of Journeg-to-Wot Trips by Usual Mode'

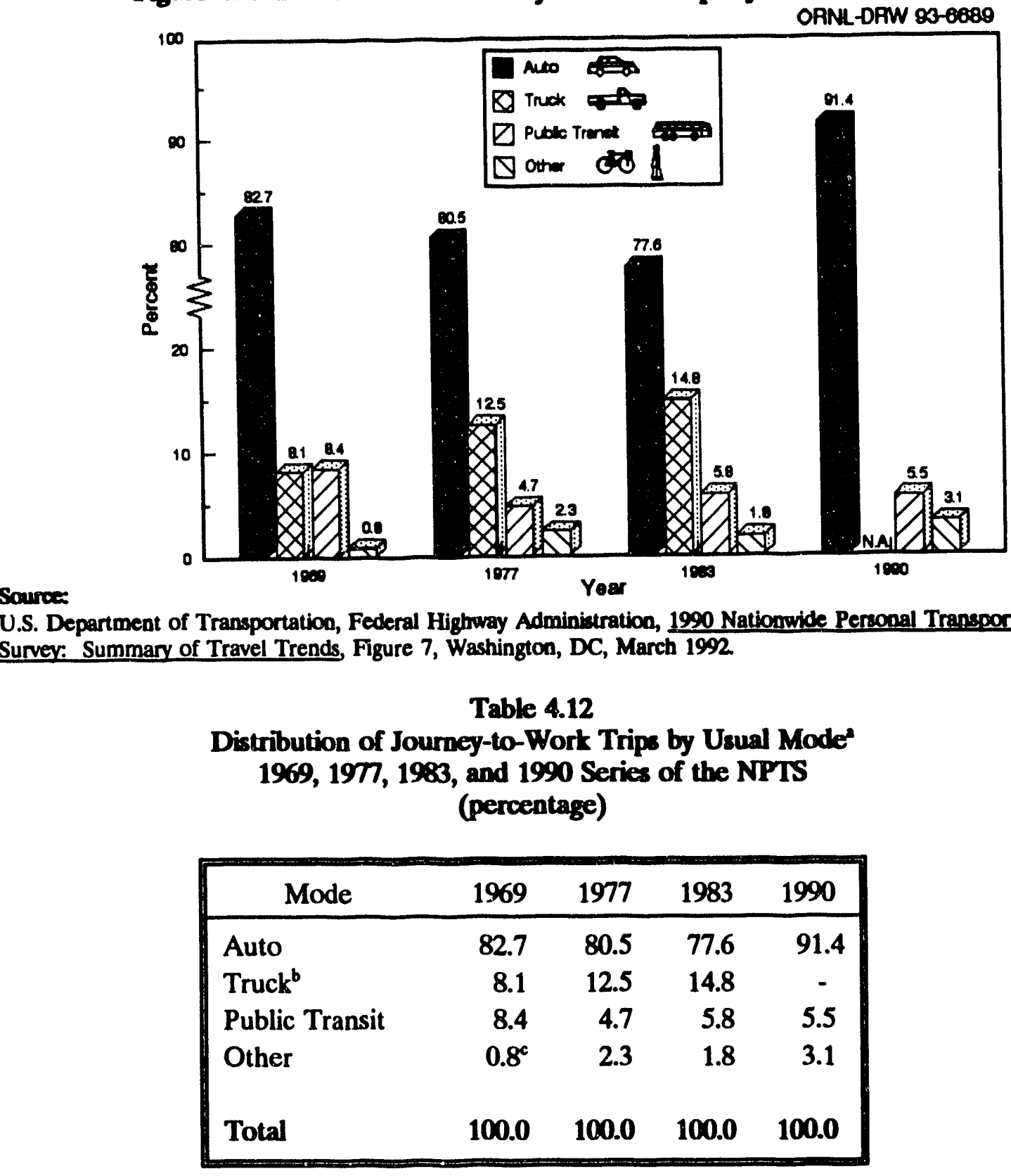

Source:

Source: U.S. Department of Transportation, Federal Highway Administration, 1990 Nationwide Personal Transportation Survey: Summary of Travel Trends, Table 9, Washington, DC, March 1992.

'Usual mode is defined as the main means of transportation to work during the week preceding the interview. 1990 survey combines automobile and truck as a single mode.

bHousehold-based trucks, primarily pickups.

'Excludes walk trips. 
The average commute trip length increased by 7\% from 1983 to 1990 , from 9.9 miles to 10.6 miles. Yet the commute time declined by $3 \%$ during the same period. This observation might be partially due to the fact that a greater number of suburban and exurban residential areas and employment centers were developed. The resulting commutes are longer but are travelled at faster speeds. The decline in travel time is also influenced by changes in commuting modes, with a decrease in transit and carpooling and an increase in driving alone.

Table 413

Commuting Patterns of Journey-to-Work Trips by Mode $1969,1977,1983$, and 1990 Series of the NPTS

\begin{tabular}{|c|c|c|c|c|c|c|}
\hline \multirow[b]{2}{*}{ Mode } & \multirow[b]{2}{*}{1969} & \multirow[b]{2}{*}{1977} & \multirow[b]{2}{*}{1983} & \multirow[b]{2}{*}{1990} & \multicolumn{2}{|c|}{ Change } \\
\hline & & & & & $69-90^{4}$ & $69-90^{b}$ \\
\hline \multicolumn{7}{|c|}{ Average Commute Trip Distance (Miles) } \\
\hline Auto & 9.4 & 9.2 & 9.9 & 10.4 & 0.5 & 11 \\
\hline Truck $^{c}$ & 14.2 & 10.6 & 11.4 & 13.0 & -0.4 & -8 \\
\hline Bus & 8.7 & 7.2 & 8.6 & 9.3 & 0.3 & 7 \\
\hline ALL & 9.9 & 9.2 & 9.9 & 10.6 & 0.3 & 7 \\
\hline \multicolumn{7}{|c|}{ Average Commute Travel Time (Minutes) } \\
\hline ALL & 22 & 20.4 & 20.4 & 19.7 & -0.5 & -10 \\
\hline
\end{tabular}

Source: U.S. Department of Transportation, Federal Highway Administration, 1990 Nationwide Personal Transportation Survey: Summary of Travel Trends, Table 10, Washington, DC, March 1992

'Compounded annual percentage change rate.

bercentage change rate.

${ }^{\text {c} H o u s e h o l d-b a s e d ~ t r u c k s, ~ p r i m a r i l y ~ p i c k u p s . ~}$ 


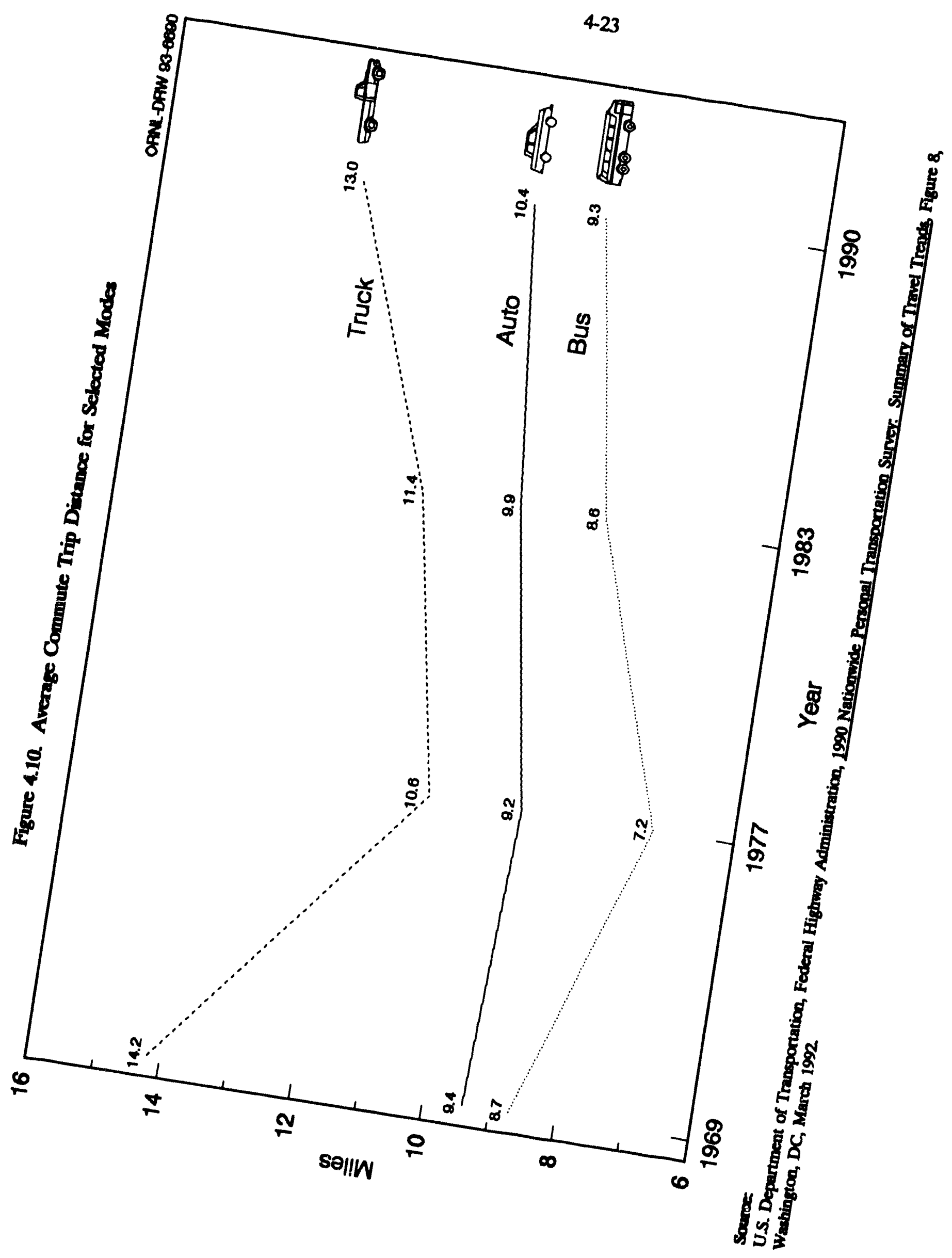



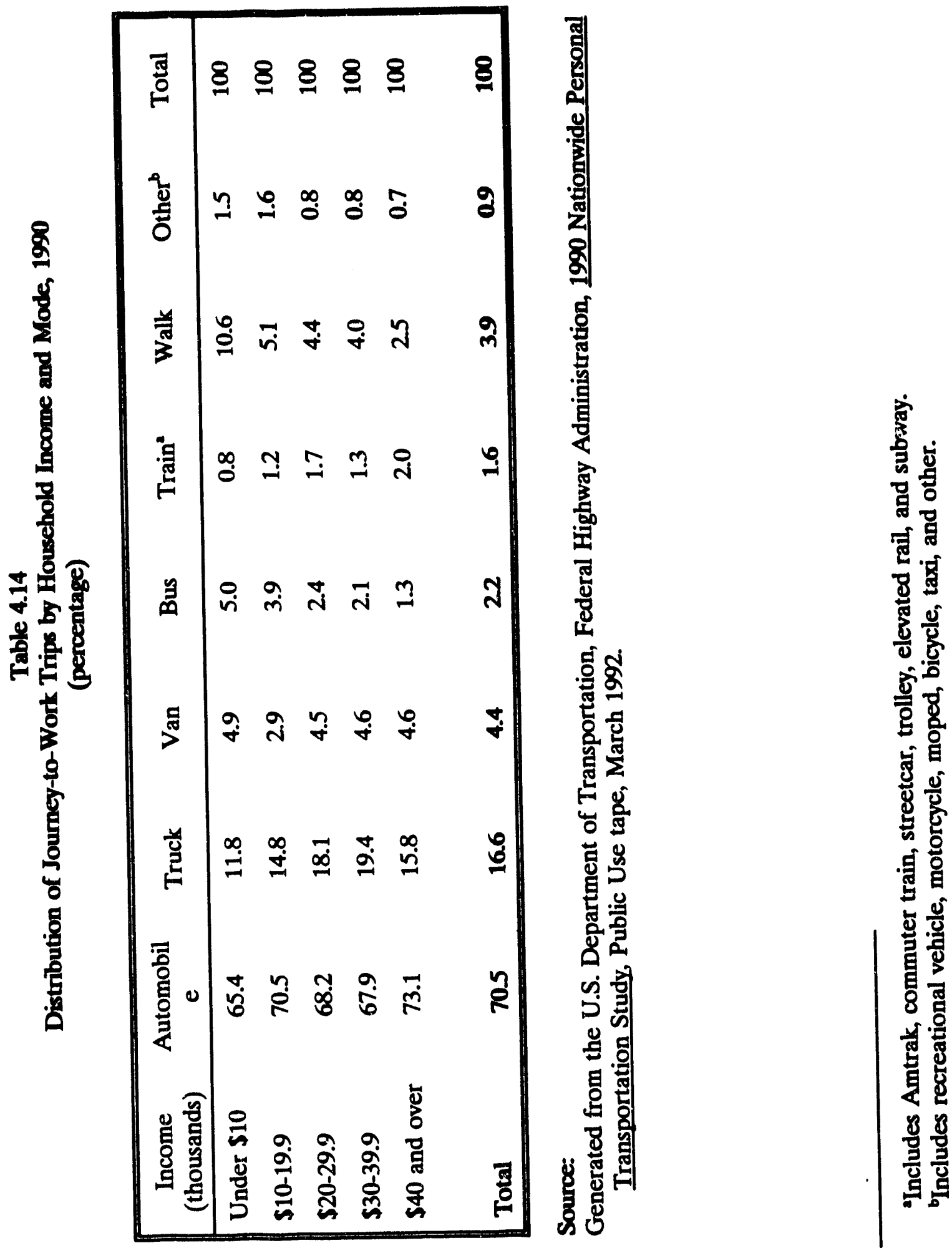


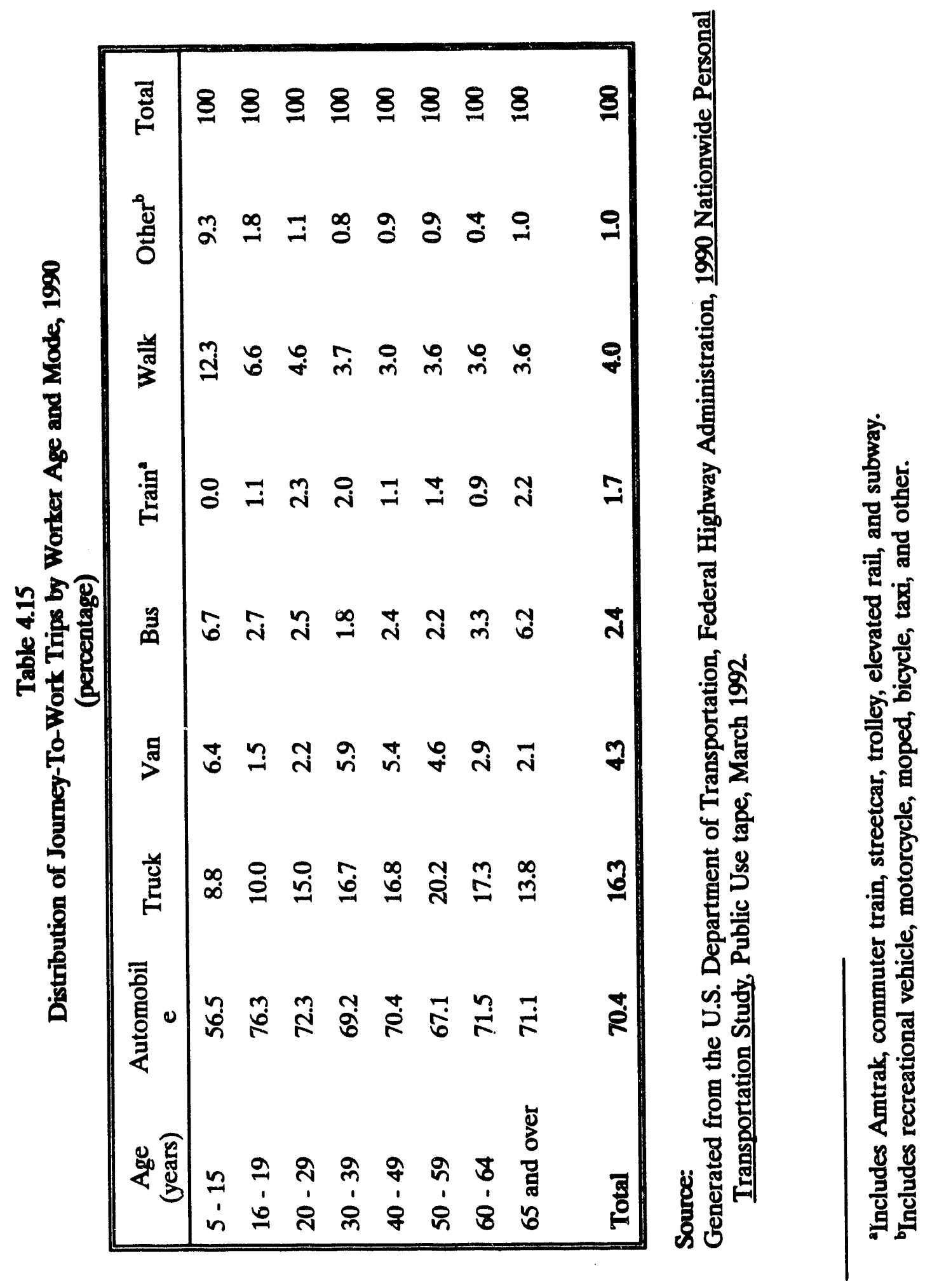




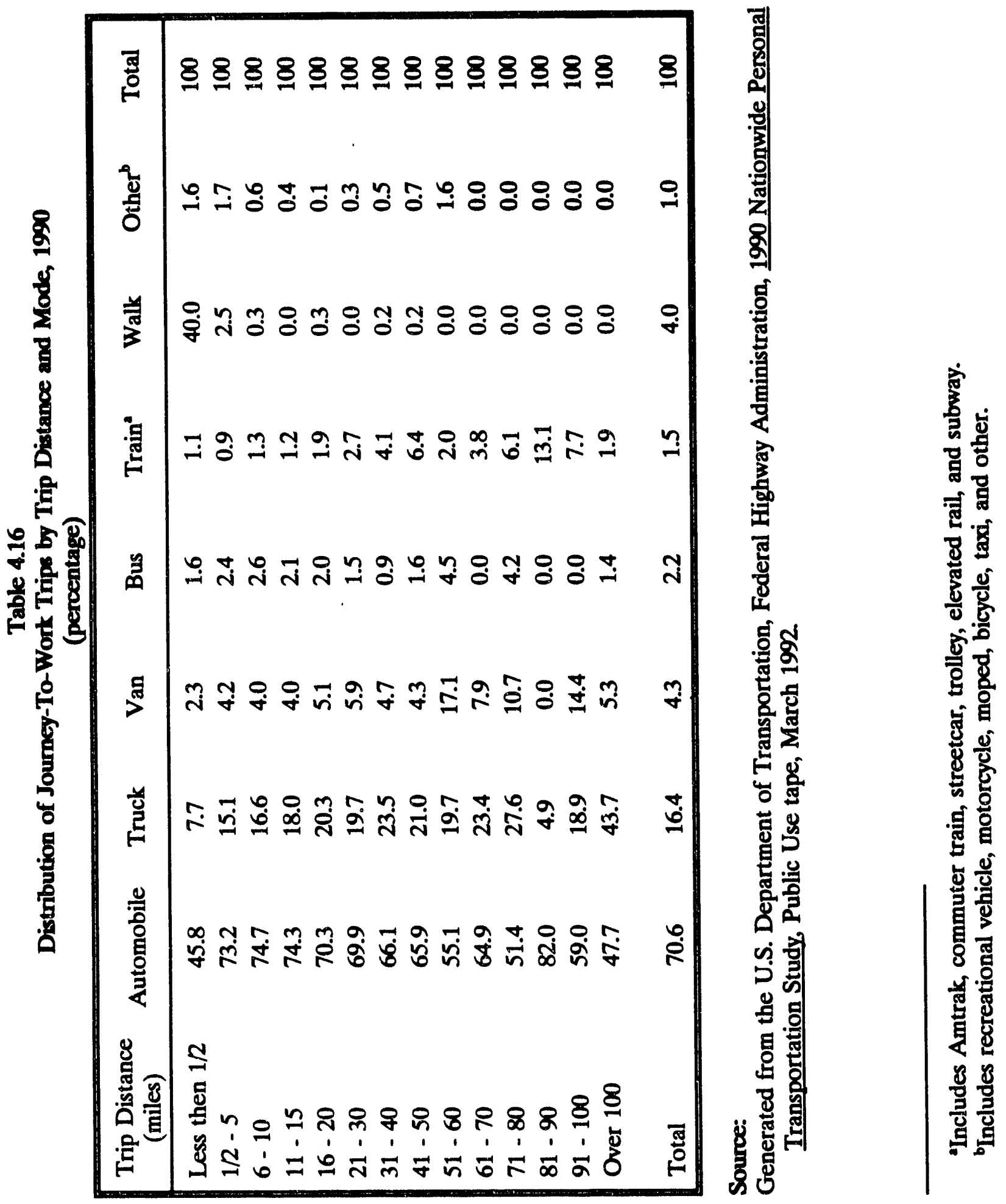




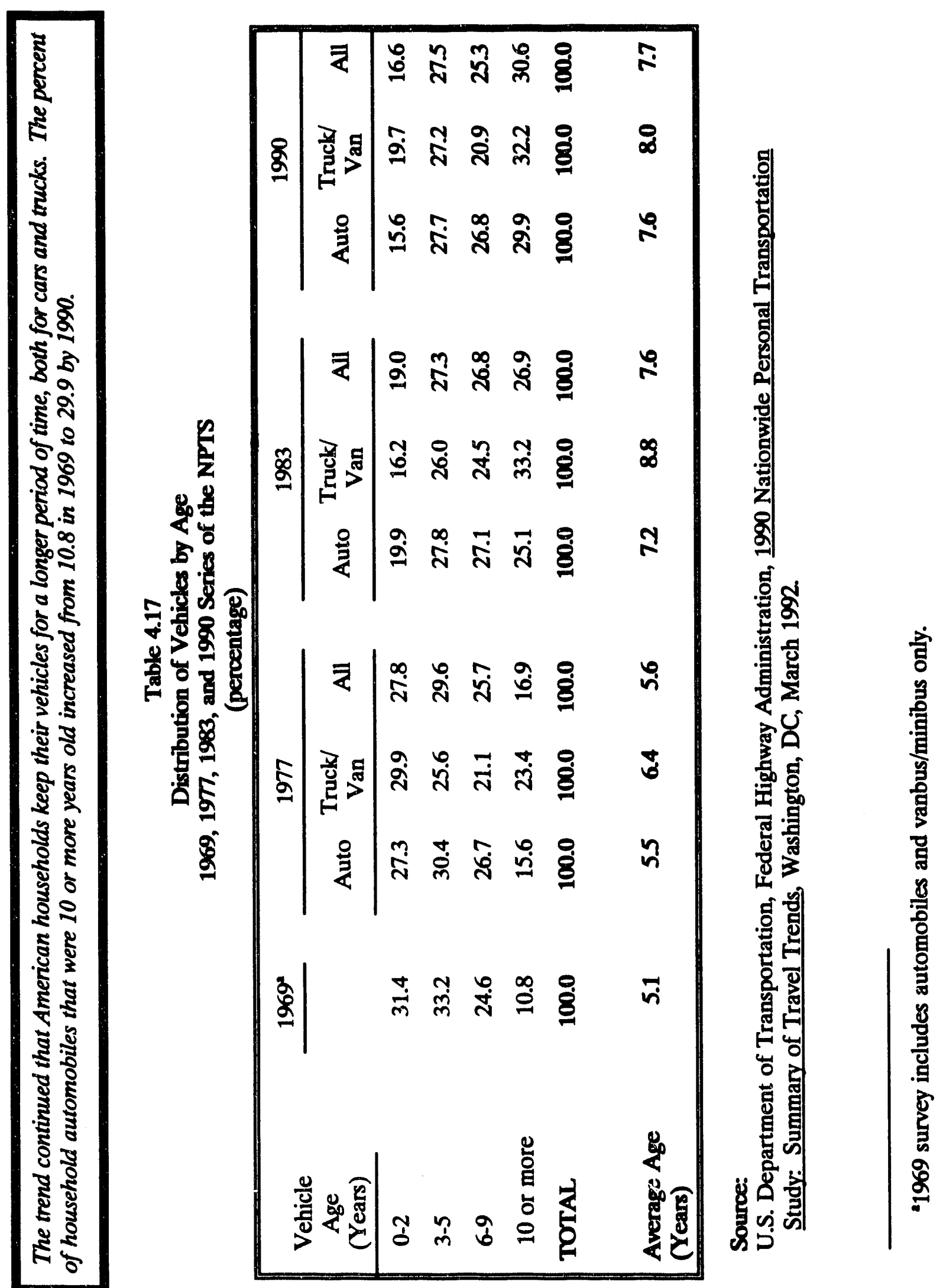


Figure 4.11. Distribution of Autonobiles by Vehicle Age

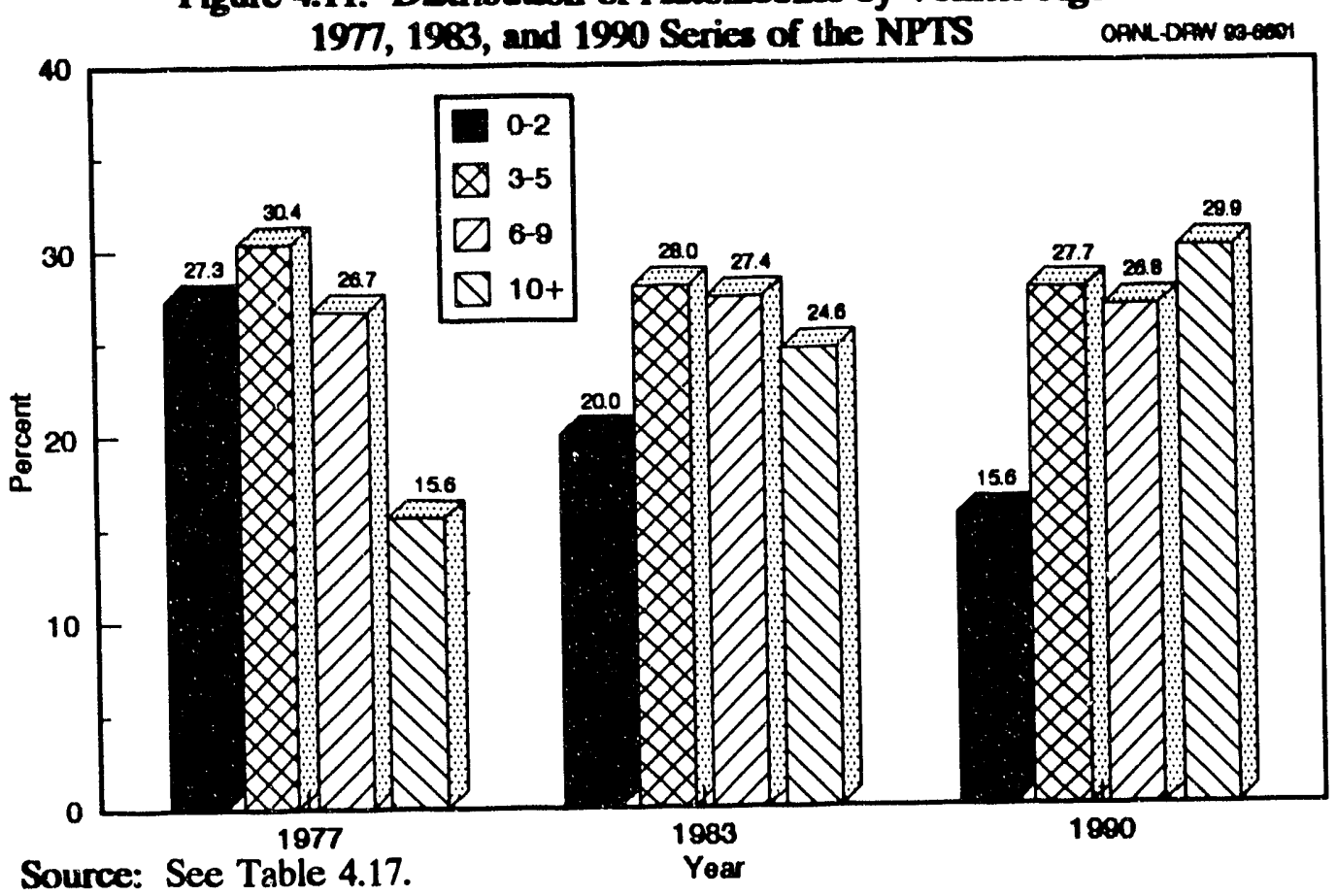

Figure 4.12 Distribution of Household-Based Trucks by Vehicle Age 1977,1983 , and 1990 Series of the NPTS

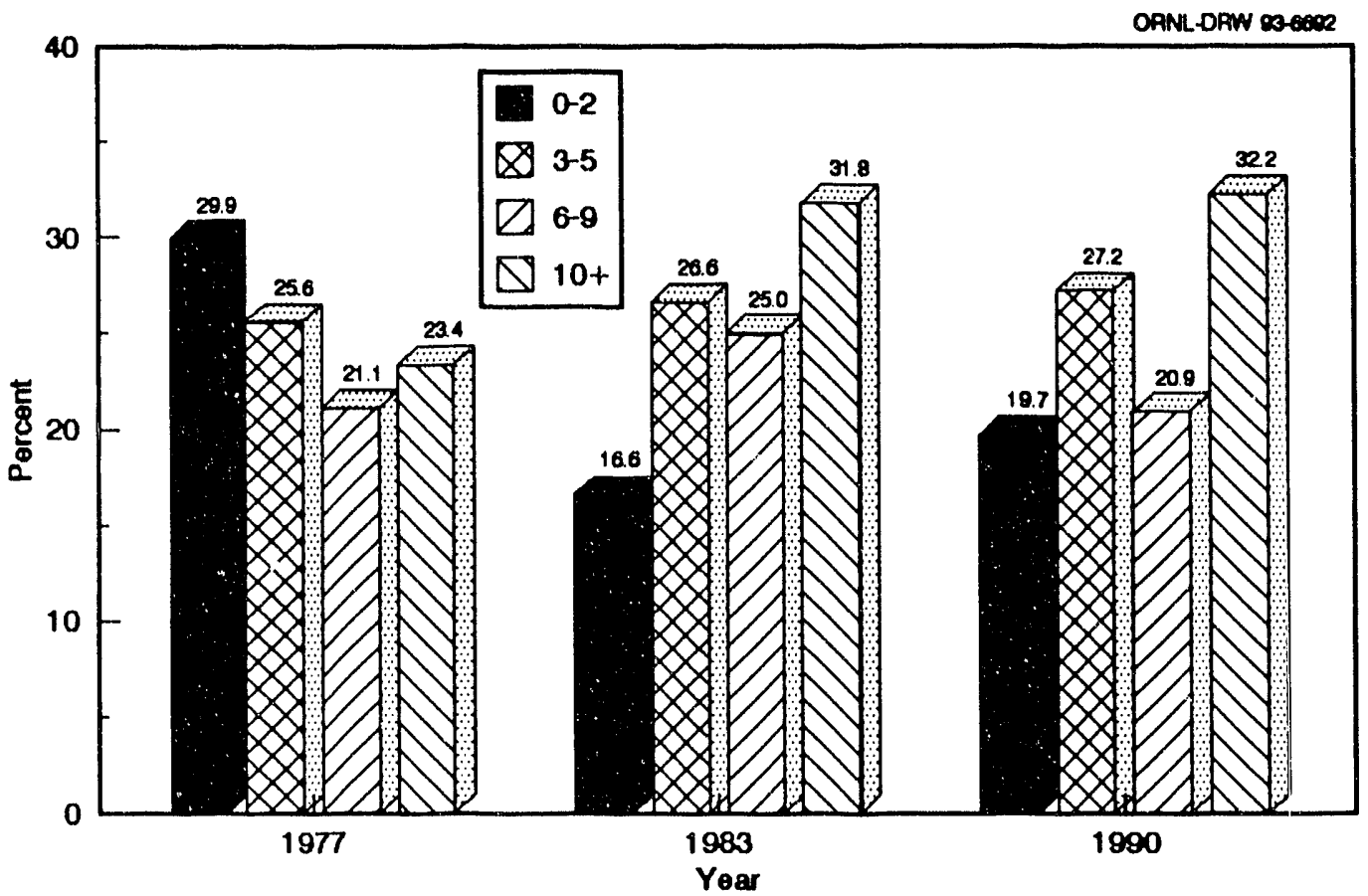

Source: See Table 4.17. 
Table 4.18

Average Annual Miles per Vehicle by Number of Vehicles Available $1969,1977,1983$, and 1990 Series of the NPTS

\begin{tabular}{|lrrrrrr|}
\hline & & & & & \multicolumn{3}{c|}{ Change } \\
\cline { 7 - 8 } Number of Vehicles & $1969^{\circ}$ & 1977 & 1983 & 1990 & $69-90^{b}$ & $69-90^{\circ}$ \\
\hline One & 10,800 & 10,051 & 10,257 & 12,125 & 0.6 & 12 \\
Two & 12,000 & 10,874 & 10,854 & 12,978 & 0.4 & 8 \\
Three or more & 12,800 & 10,791 & 9,793 & 11,972 & -0.3 & -6 \\
& & & & & & \\
TOTAL & 11,600 & 10,679 & 10,315 & 12,458 & 0.3 & 7 \\
\hline
\end{tabular}

1969 survey includes autos, vanbus/minibus only.

bompounded annual percentage change rate.

'Percentage change rate.

Sounce:

U.S. Department of Transportation, Federal Highway Administration, 1990 Nationwide Personal Transportation Study: Summary of Travel Trends, Table 13, Washington, DC, March 1992.

Figure 4.13. Average Annual Miles Per Vehicle by Number of Vehicles Available $1969,1977,1983$, and 1990 Series of the NPTS

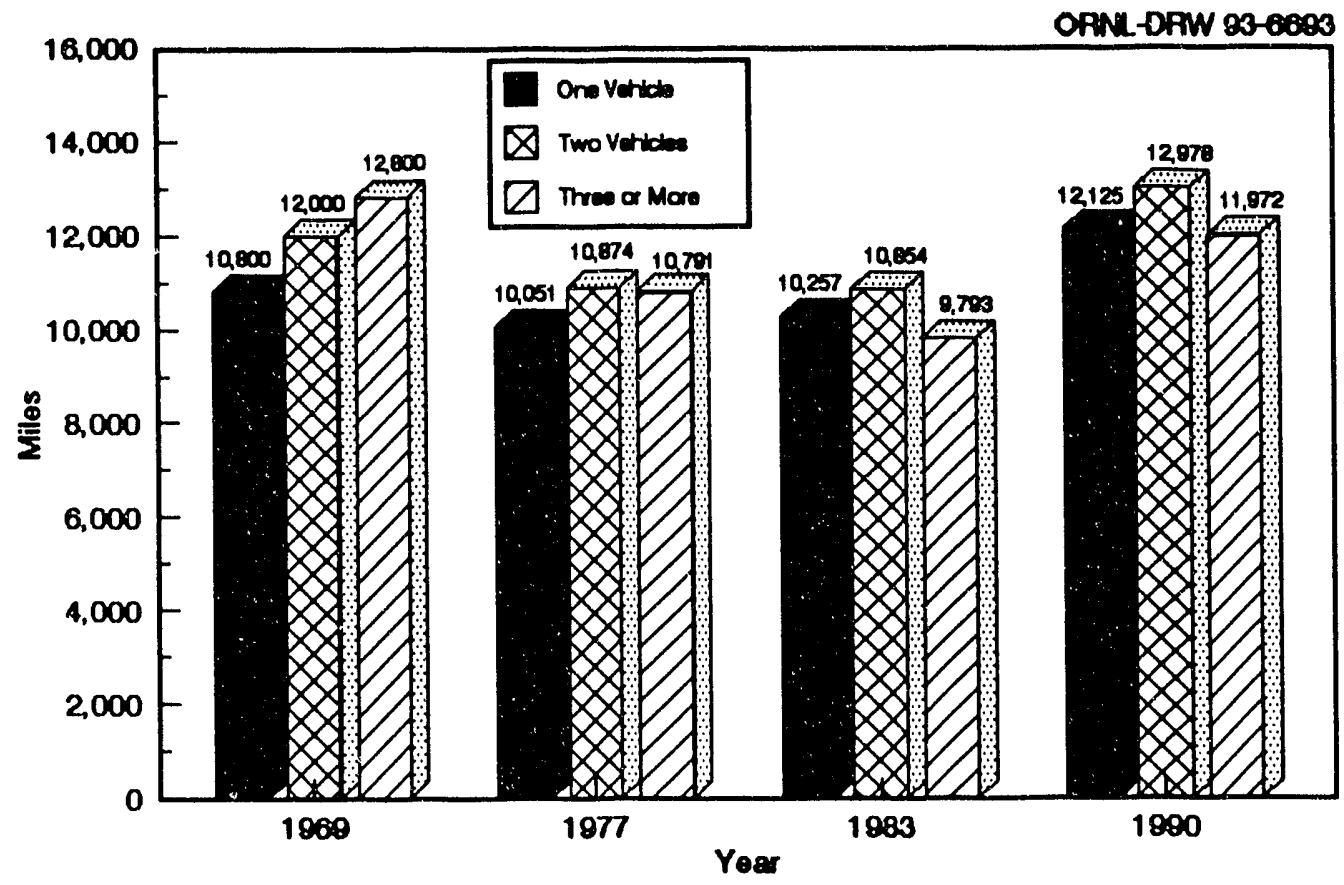

Source

U.S. Department of Transportation, Federal Highway Administration, 1990 Nationwide Pereonal Transportation Surver: Summary of Travel Trends, Figure 12, Washington, DC, March 1992. 
Table 4.19

Average Annual Miles Per Vehicle by Number of Adults in Household 1977,1983 , and 1990 Series of the NPTS

\begin{tabular}{|lrrrrrr|}
\hline & & & & \multicolumn{3}{c|}{ Change } \\
\cline { 6 - 7 } Number of Adults & 1977 & 1983 & 1990 & $77-90^{\circ}$ & $77-90^{\circ}$ \\
\hline One & 9,423 & 9,517 & 11,416 & 1.5 & 21 \\
Two & 10,785 & 10,303 & 12,573 & 1.2 & 17 \\
Three or more & 10,943 & 10,679 & 13,084 & 1.4 & 20 \\
& & & & & \\
ALL & 10,679 & 10,315 & 12,458 & 1.2 & 17 \\
\hline
\end{tabular}

'Compounded annual percentage change rate.

bercentage change rate.

\section{Source:}

U.S. Department of Transportation, Federal Highway Administration, 1990 Nationwide Personal Transportation Study: Summary of Travel Trends, Table 14, Washington, DC, March 1992.

Figure 4.14. Average Annual Miles Per Vehicle by Number of Adults in Household 1977,1983 , and 1990 Series of the NPTS

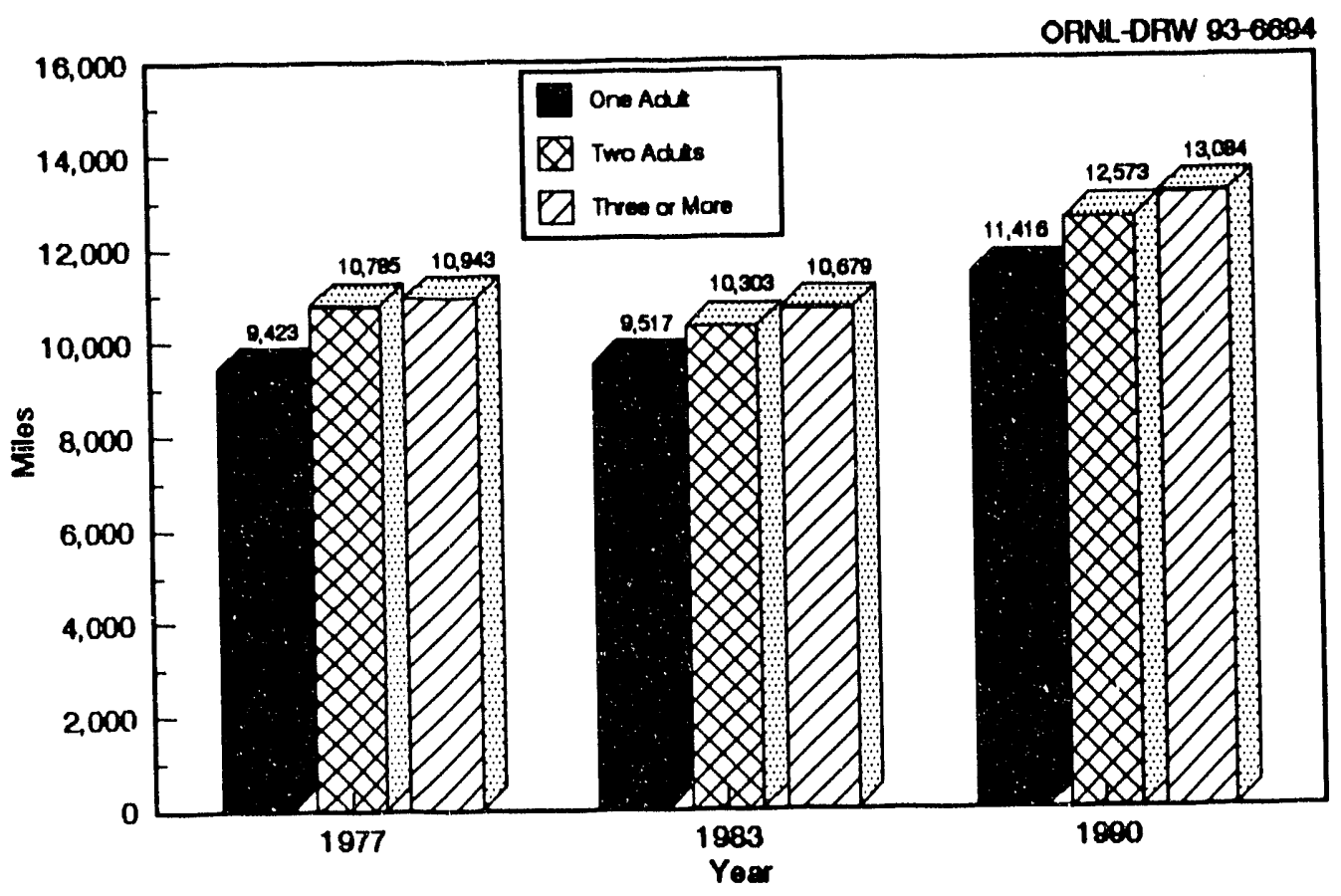

Source:

U.S. Department of Transportation, Federal Highway Administration, 1990 Nationwide Personal Transportation Survey: Summary of Travel Trends, Figure 1, Washington, DC, March 1992. 
Although travel by males still accounts for a majority of the total traveh travel by females continues to increase. A significant jump in the share of travel by females was observed in the past 20 years - from $26.8 \%$ in 1969 to $35.4 \%$ in 1990 . From 1983 to 1990, the share of travel by males, compared across all age groups, either remained relatively constant or decreased. In contrast, travel by females increased across all age groups, except for the 55 to 64 age group.

Table 420

Distribution of Annual Miles by Driver Age and Sex $1969,1977,1983$, and 1990 Series of the NPTS (percentage)

\begin{tabular}{|c|c|c|c|c|}
\hline Age & 1969 & 1977 & 1983 & 1990 \\
\hline \multicolumn{5}{|c|}{ MALE } \\
\hline 16-19. & 3.1 & 3.2 & 2.0 & 2.0 \\
\hline $20-34$ & 27.0 & 29.7 & 28.6 & 24.3 \\
\hline $35-54$ & 30.1 & 27.2 & 27.0 & 27.1 \\
\hline $55-64$ & 9.3 & 8.5 & 9.3 & 6.8 \\
\hline $65+$ & 3.7 & 3.7 & 3.8 & 4.4 \\
\hline TOTAL & 732 & 723 & 70.7 & 64.6 \\
\hline \multicolumn{5}{|c|}{ FEMALE } \\
\hline $16-19$ & 1.5 & 1.6 & 1.1 & 1.5 \\
\hline $20-34$ & 9.9 & 11.9 & 12.4 & 14.6 \\
\hline $35-54$ & 11.3 & 10.1 & 10.9 & 14.3 \\
\hline $55-64$ & 2.9 & 2.8 & 3.4 & 2.9 \\
\hline $65+$ & 1.2 & 1.3 & 1.5 & 2.1 \\
\hline TOTAL & 26.8 & 27.7 & 29.3 & 35.4 \\
\hline
\end{tabular}

Source:

U.S. Department of Transportation, Federal Highway Administration, 1990 Nationwide Personal Transportation Survey: Summary of Travel Trends, Washington, DC, March 1992. 
As households owned more vehicles, the average annual miles for the most frequently driven vehicle increased. For example, the mast frequently driven vehicle in five-vehicle households was driven $31 \%$ more per year than the one in two-vehicle households $(20,300$ miles vs. 15,500 miles).

Table 421

Average Annual Miles per Vehicle by

Household Vehicle Ownerahip, 1990

\begin{tabular}{ccccccc}
\hline $\begin{array}{c}\text { Total number of } \\
\text { vehicles owned } \\
\text { by household }\end{array}$ & $\# 1$ & $\# 2$ & $\# 3$ & $\# 4$ & $\# 5$ & $\begin{array}{c}\text { All } \\
\text { vehicles }\end{array}$ \\
\cline { 2 - 7 } & 11,500 & - & - & - & - & 11,500 \\
2 & 15,500 & 8,400 & - & - & - & 12,200 \\
3 & 17,500 & 9,900 & 4,900 & - & - & 11,200 \\
4 & 18,800 & 11,600 & 7,100 & 3,800 & - & 10,900 \\
5 & 20,300 & 12,800 & 8,900 & 5,100 & 2,900 & 10,600 \\
\hline
\end{tabular}

Source:

Generated from the U.S. Department of Transportation, Federal Highway Administration, 1990 Nationwide Personal Transportation Survey, Public Use tape, March 1992.

'Vehicles are ranked by descending annual miles driven. 


\section{CHAPTER 5 \\ ALTERNATIVE FUELS STATISTICS}

In 1991, the transportation sector alone consumed 21.4 quads of petroleum fueis, accounting for $65.4 \%$ of total petroleum consumed in the United States. With decreasing in domestic oil production and rising demand, the amount of imported crude oil and petroleum products has increased at an average rate of $6.8 \%$ per year since 1985 . In 1991, 47\% of the U.S. petroleum consumed was imported. These statistics suggest that addressing the nation's dependence on petroleum will require reducing the dependence of the transportation sector on petroleum fuels.

Conventional petroleum fuels in motor vehicles are among the major contributors to environmental pollution around the world. Typically, motor vehicles emissions account for $30-50 \%$ of urban hydrocarbon, $80-90 \%$ of carbon monoxide and $40-60 \%$ of nitrogen oxide emissions. Alternative and reformulated fuels may offer the potential to reduce these pollutants significantly.

Because of increasing concerns about environmental pollution and the growing U.S. dependence on petroleum, the policy-makers began to search for ways of diversifying energy sources by switching from conventional to alternative and reformulated fuels". "The Clean Air Act Amendments of 1990 (CAAA) include programs for oxygenated gasoline and for reformulated gasoline (RFG). The oxygenated gasoline program requires that, beginning November 1, 1992, gasoline with a minimum oxygen content of 2.7 weight percent must be sold during winter months in about $\mathbf{4 0}$ cities not in compliance with carbon monoxide (CO) standards. RFGs are required by January 1, 1995, in nine areas with extreme or severe ozone pollution problems ("covered ozone nonattainment areas"). About 100 other cities with marginal, moderate, or serious ozone problems may "opt-in" to the RFG program.

'Information about the California emission standards is contained in Chapter 3 , Section 3.7 Vehicle Emissions. 
The law specifies both a formula and also emissions performance standards for RFG. The nine areas in the extreme and serious ozone nonattainment categories currently comprise about 25 percent of the nation's gasoline market. However, because of the gasoline distribution system, surrounding areas will probably receive RFG as well. Taking these surrounding areas into consideration, the minimum market for RFG in 1995 - is expected to be 30 percent of the current market.

"Other areas are allowed to petition the EPA to opt-in to the oxygenated and RFG programs. The most likely areas to request clean gasolines are the other less severe ozone and $\mathrm{CO}$ non-attainment areas, which account for 20 to 35 percent of current gasoline demand. A significant motivation to enter the programs will come in November 1993, when State Implementation Plans (SIPs) are required. In the SIPs, states will have to demonstrate their strategies for achieving compliance with clean air standards. Using clean gasolines to reduce vehicular emissions could be more attractive than other alternatives. The total market for clean gasolines is uncertain, but it could exceed $\mathbf{5 0}$ percent by 1996-1997.

"Besides requiring RFG in the covered ozone nonattainment areas, the CAAA requires that gasoline in all other areas not be any more polluting than it was in $\mathbf{1 9 9 0 .}$ Without this "anti-dumping" provision, the potential exists for emissions from conventional gasoline to worsen as polluting fuel components are removed from and environmentally beneficial components are added to gasoline to be sold as RFG.

"In addition to constraints on the quality of gasoline, the CAAA also limits highway diesel fuel to a maximum sulfur content of 0.05 weight percent and a minimum cetane index of 40, effective October $1,1993$.

"With the passage of the CAAA, environmental regulations will dictate the market, define product composition and performance, influence technology, change consumer expectations of performance, and determine the feasibility of various production and supply options"."

'G.R. Hadder, Oak Ridge National Laboratory, Reformulated Gasoline: Costs and Refinery Impacts, (ORNL-6747, Draft), Oak Ridge, TN, March 1993, pp. 1-1 \& 1-2. 
In 1988 the Alternative Motor Fuels Act (AMFA) was established to encourage the use of alternative fuels in the U.S. transportation sector. As a result of the AMFA, the Alternative Fuels Data Center (AFDC) was established by the Department of Energy. Information about the AFDC and statistics and maps generated by the AFDC are presented in this chapter, as well as information about the U.S. Advanced Battery Consortium. Also presented in this chapter are the characteristics of selected alternative fuels and statistics on the use of gasohol, a blend of gasoline and ethanol. 


\section{THE ALTERNATTVE FUELS DATA CENTER}

The Department of Energy (DOE) has established the Alternative Fuels Data Center (AFDC) in support of its work aimed at fulfilling the Alternative Motor Fuels Act (AMFA) directives. The AFDC is operated and managed by the National Renewable Energy Laboratory (NREL) in Golden, Colorado.

The purposes of the AFDC are:

- to gather and analyze information on the fuel consumption, emissions, operation, and durability of alternative fuel vehicles; and

- to provide unbiased, accurate information on alternative fuels and alternative fuel vehicles to government agencies, private industry, research institutions, and other interested organizations.

The data are collected for three specific vehicle types: (1) lightduty vehicles, including automobiles, light trucks, and mini-vans; (2) heavy-duty vehicles such as tractor trailers and garbage trucks; and (3) urban transit buses. An Oracle Relational Database Management System is used to manage the data, along with a statistical software package capable of providing statistical, graphic, and textual information to users. The next two tables and four graphs contain statistics which were generated by the AFDC. Future editions of the Transportation Energy Data Book will continue to present graphical and statistical information from the AFDC.

The Department of Energy is now sponsoring the National Alternative Fueb Hotline for Transportation Technologies in order to assist the general public and interested organizations in improving their understanding of alternative transportation fuels. The Hotline can be reached by dialing 1-800-423-1DOE 
In fiscal year (FY) 1991, there were 81 AMFA Federal vehicles at four geographic locations in the U.S. Of these 81 vehicles, 16 are conventional gasoline fuel vehicles (control vehicles) and 65 are alternative fuel vehicles (AFVs) which are capable of operating on any mixture of gasoline and methanoh up to a mixture of $85 \%$ methanol. For comparative purposes, the vehicles were categorized into three groups:

M85 AFVs 57 vehicles which operated on M85 (85\% methanol, 15\% unleaded gasoline) predominantly

Gasoline AFVs 8 alternative fuel vehicles which operated on unleaded gasoline

Conventional predominantly

gasoline vehicles 16 conventional vehicles which operated only on unleaded gasoline

Table 5.1

On-Road Fuel/Energy Economy Summary for the AMTA Federal Vehicles, FY 1991

\begin{tabular}{|c|c|c|c|c|}
\hline Vehicle site and type & $\begin{array}{l}\text { Number } \\
\text { of } \\
\text { vehicles }\end{array}$ & $\begin{array}{l}\text { miles per } \\
\text { gallon }\end{array}$ & $\begin{array}{c}\text { mpg-gasoline } \\
\text { energy equivalent }\end{array}$ & Btu/mile \\
\hline $\begin{array}{l}\text { Washington, DC } \\
\text { M85 AFVs } \\
\text { Gasoline AFVs } \\
\text { Conventional gasoline vehicles }\end{array}$ & $\begin{array}{r}21 \\
2 \\
4\end{array}$ & $\begin{array}{l}10.9 \\
19.1\end{array}$ & 19.3 & $\begin{array}{l}5,959 \\
6,243\end{array}$ \\
\hline $\begin{array}{l}\text { Detroit, MI } \\
\text { M85 AFVs } \\
\text { Gasoline AFVs } \\
\text { Conventional gasoline vehicles }\end{array}$ & $\begin{array}{r}18 \\
2 \\
4\end{array}$ & $\begin{array}{l}14.1 \\
22.5\end{array}$ & 24.8 & $\begin{array}{l}4,536 \\
5,404\end{array}$ \\
\hline $\begin{array}{l}\text { Los Angeks, CA } \\
\text { M85 AFVs } \\
\text { Gasoline AVFs }{ }^{b} \\
\text { Conventional gasoline vehicles }\end{array}$ & $\begin{array}{l}9 \\
2 \\
4\end{array}$ & $\begin{array}{l}13.5 \\
24.6\end{array}$ & 23.7 & $\begin{array}{l}4,672 \\
4,771\end{array}$ \\
\hline $\begin{array}{l}\text { San Diego, CA } \\
\text { M85 AFVs } \\
\text { Gasoline AVFs } \\
\text { Conventional gasoline vehicles }\end{array}$ & $\begin{array}{l}9 \\
2 \\
4\end{array}$ & $\begin{array}{l}14.7 \\
21.6\end{array}$ & 25.9 & $\begin{array}{l}4,265 \\
5,249\end{array}$ \\
\hline
\end{tabular}

Source:

Office of Transportation Technologies, U.S. Department of Energy, Federal Alternative Fuel Program Light Duty Vehicle Operations, Washington, DC, March 1992, pp. 2, 13. Generated by the Alternative Fuel Data Center, Golden, CO.

'Because gasoline has almost twice the energy content per gallon as M85, regular mpg data are not comparable in terms of energy efficiency.

'No information was collected on these vehicles in FY 1991. 
As of August 1992 there were 3,691 alternative refuel sites in the United States. This list includes public and private refuel sites, however, not all of these sites are available to the public.

Table 5.2

Number of Alternative Refuel Sites by State and Fuel Type, 1992

\begin{tabular}{|c|c|c|c|c|c|}
\hline State & $\begin{array}{l}\text { M85 } \\
\text { Sites }\end{array}$ & $\begin{array}{l}\text { NG } \\
\text { Sites }\end{array}$ & $\begin{array}{l}\text { LPG } \\
\text { Sites }\end{array}$ & $\begin{array}{c}\text { E85 } \\
\text { Sites }\end{array}$ & TOTAL \\
\hline 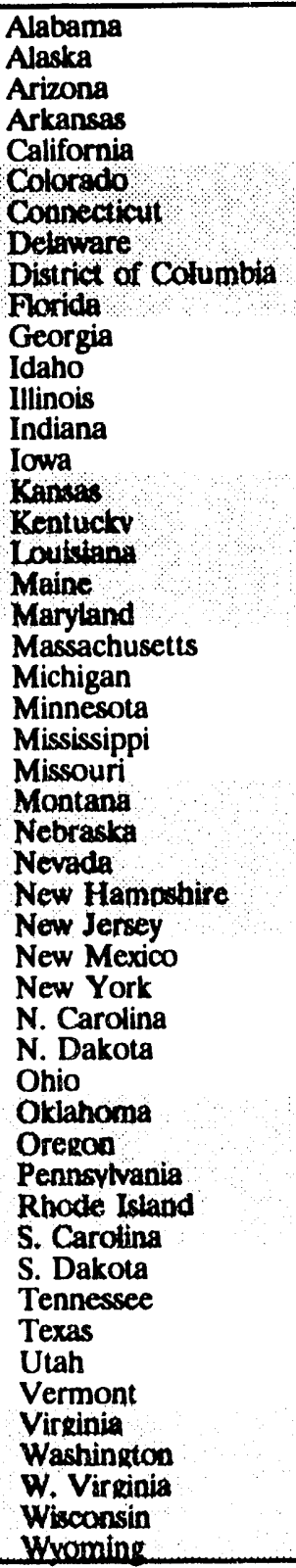 & $\begin{array}{l}1 \\
27 \\
1 \\
1\end{array}$ & $\begin{array}{c}3 \\
9 \\
1 \\
7 \\
11 \\
8 \\
1 \\
3 \\
27 \\
13 \\
4 \\
28 \\
1 \\
2 \\
3 \\
10 \\
4 \\
3 \\
18 \\
1 \\
21 \\
2\end{array}$ & $\begin{array}{l}85 \\
8 \\
45 \\
104 \\
214 \\
19 \\
19 \\
222 \\
80 \\
20 \\
165 \\
124 \\
108 \\
38 \\
35 \\
44 \\
12 \\
21 \\
41 \\
182 \\
125 \\
75 \\
83 \\
48 \\
67 \\
20 \\
31 \\
36 \\
46 \\
100 \\
72 \\
17 \\
98 \\
56 \\
21 \\
132 \\
5 \\
43 \\
24 \\
80 \\
202 \\
20 \\
33 \\
38 \\
37 \\
16 \\
139 \\
33 \\
\end{array}$ & 1 & $\begin{array}{c}91 \\
8 \\
56 \\
110 \\
266 \\
68 \\
21 \\
8 \\
2 \\
239 \\
97 \\
20 \\
180 \\
147 \\
110 \\
42 \\
36 \\
45 \\
12 \\
29 \\
41 \\
187 \\
134 \\
75 \\
83 \\
51 \\
56 \\
21 \\
31 \\
43 \\
57 \\
112 \\
73 \\
20 \\
127 \\
69 \\
25 \\
160 \\
6 \\
43 \\
27 \\
84 \\
212 \\
24 \\
33 \\
41 \\
56 \\
18 \\
160 \\
35 \\
\end{array}$ \\
\hline United States & 43 & 349 & 3.297 & 2 & 3,691 \\
\hline
\end{tabular}

Source:

Data provided by Alternative Fuels Data Center, National Renewabie Energy Laboratory,Golden, CO, August 1992. 


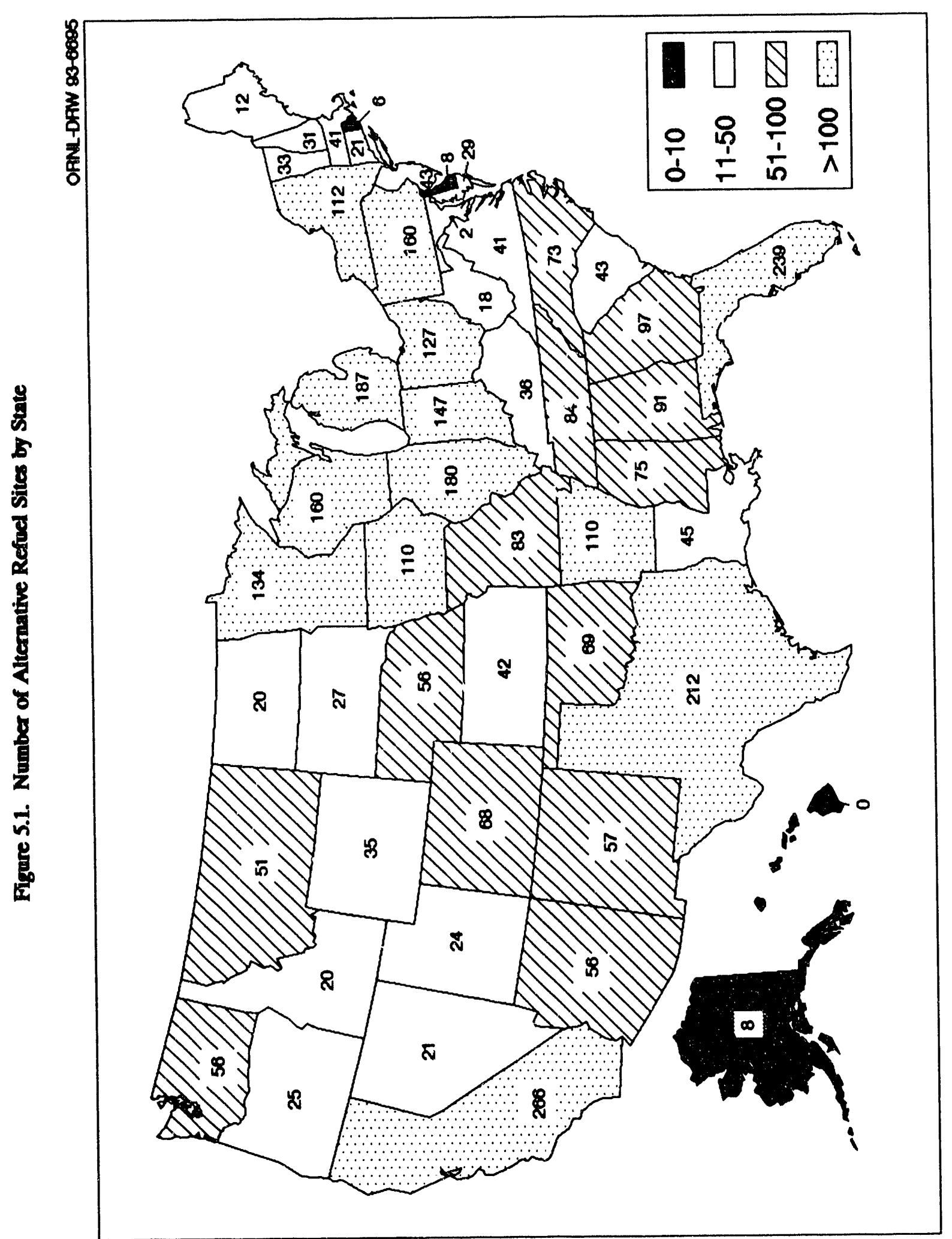

ก
s.
8
8
8
8
8
8 
5-8

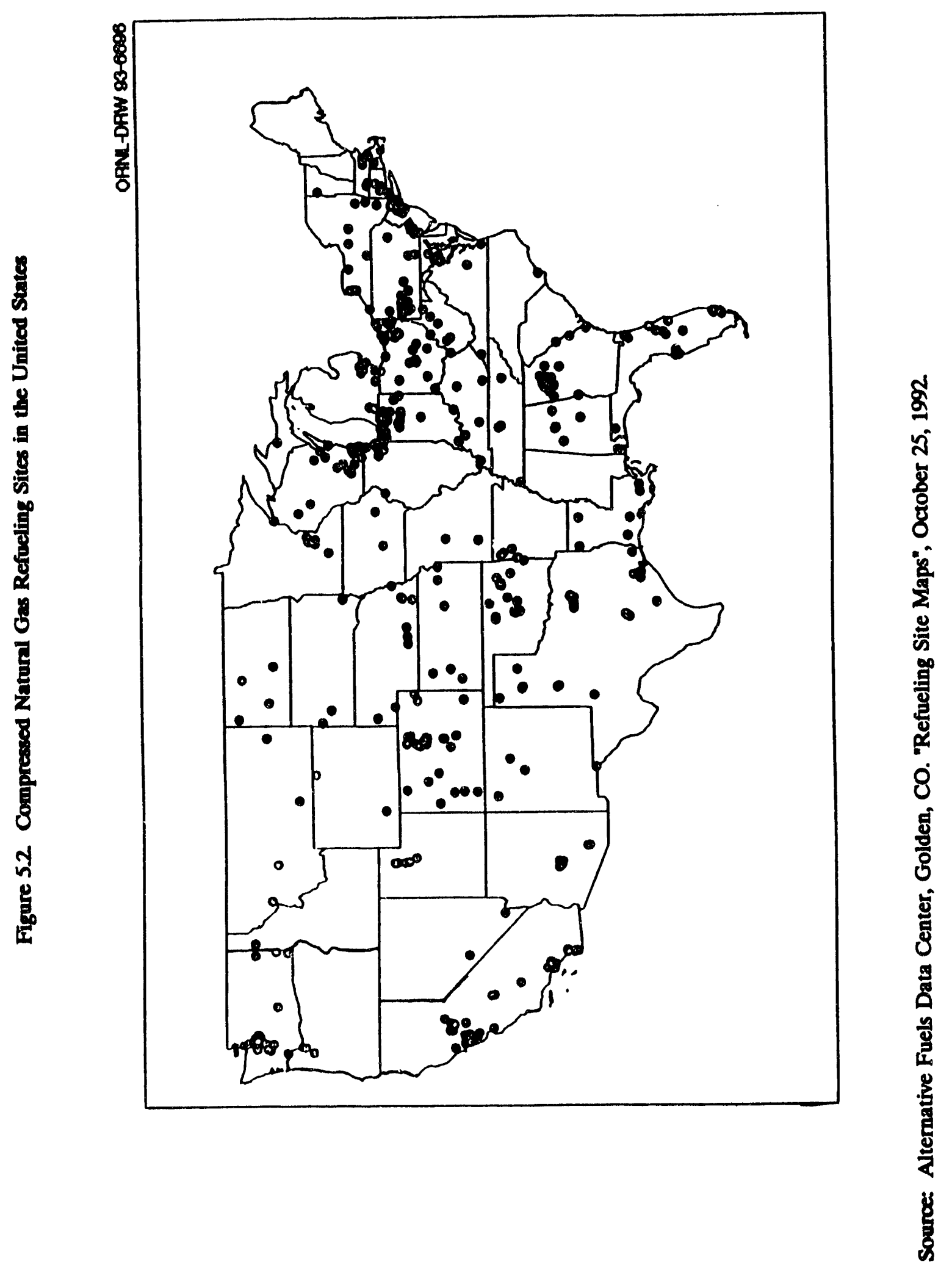


Figure 5.3. A Map Emmple of Compressed Natural Ges Refueling Siles for the State of Indiama

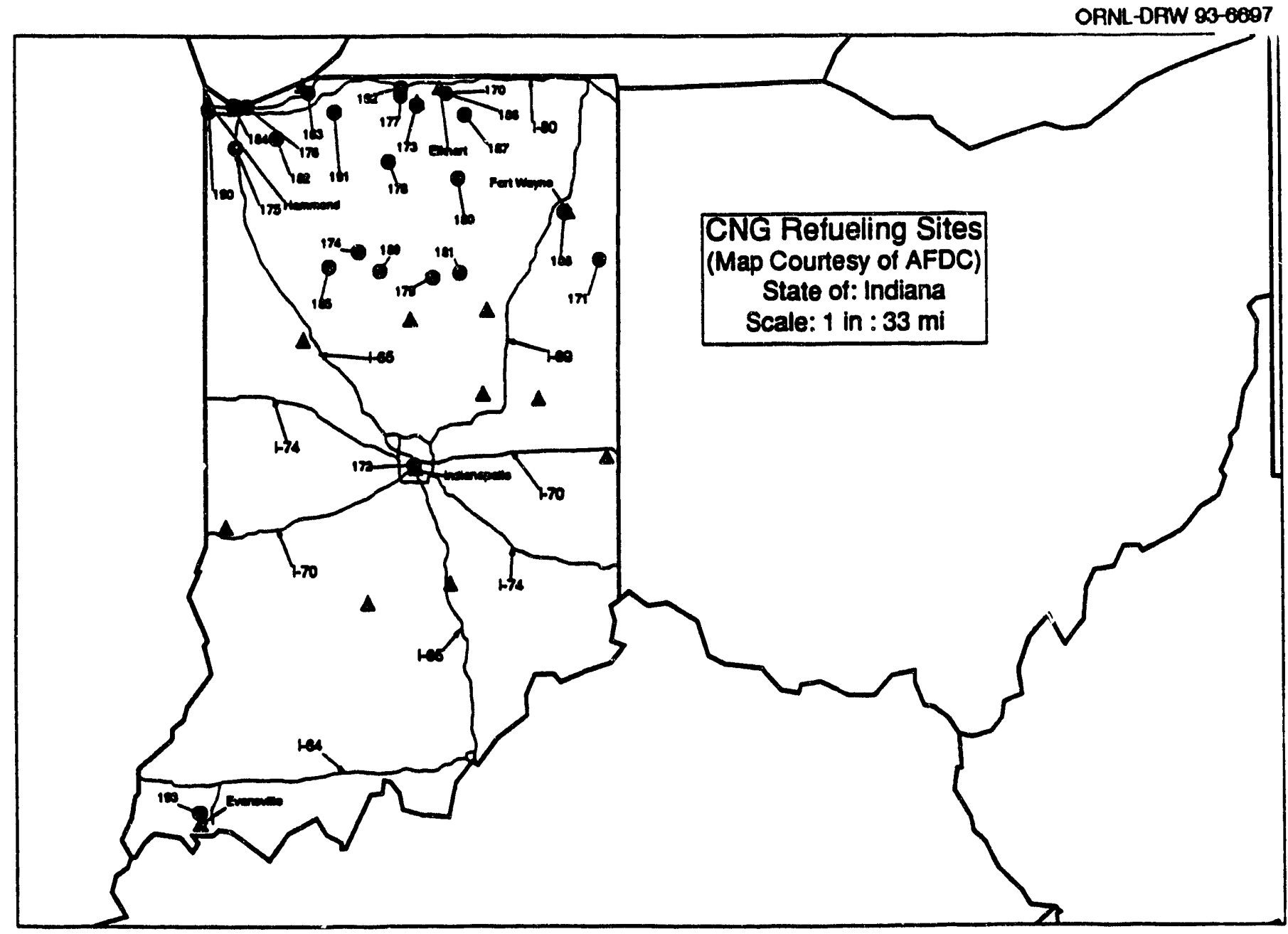

SYMBOLS:

- = Refueling Site

$\Delta=$ City Location

\section{DESIGNATIONS:}

I-80 = Interstate 80 , for example

123 = Refueling Site Map Number

Source: Alternative Fuels Data Center, Golden, CO, "Refueling Site Maps", October 25, 1992. 
Figure 5.4. A Map Bomple of Methnol and Bthnod Refieling Sites for the State of Califorain

ORNL-DAW $93-6808$

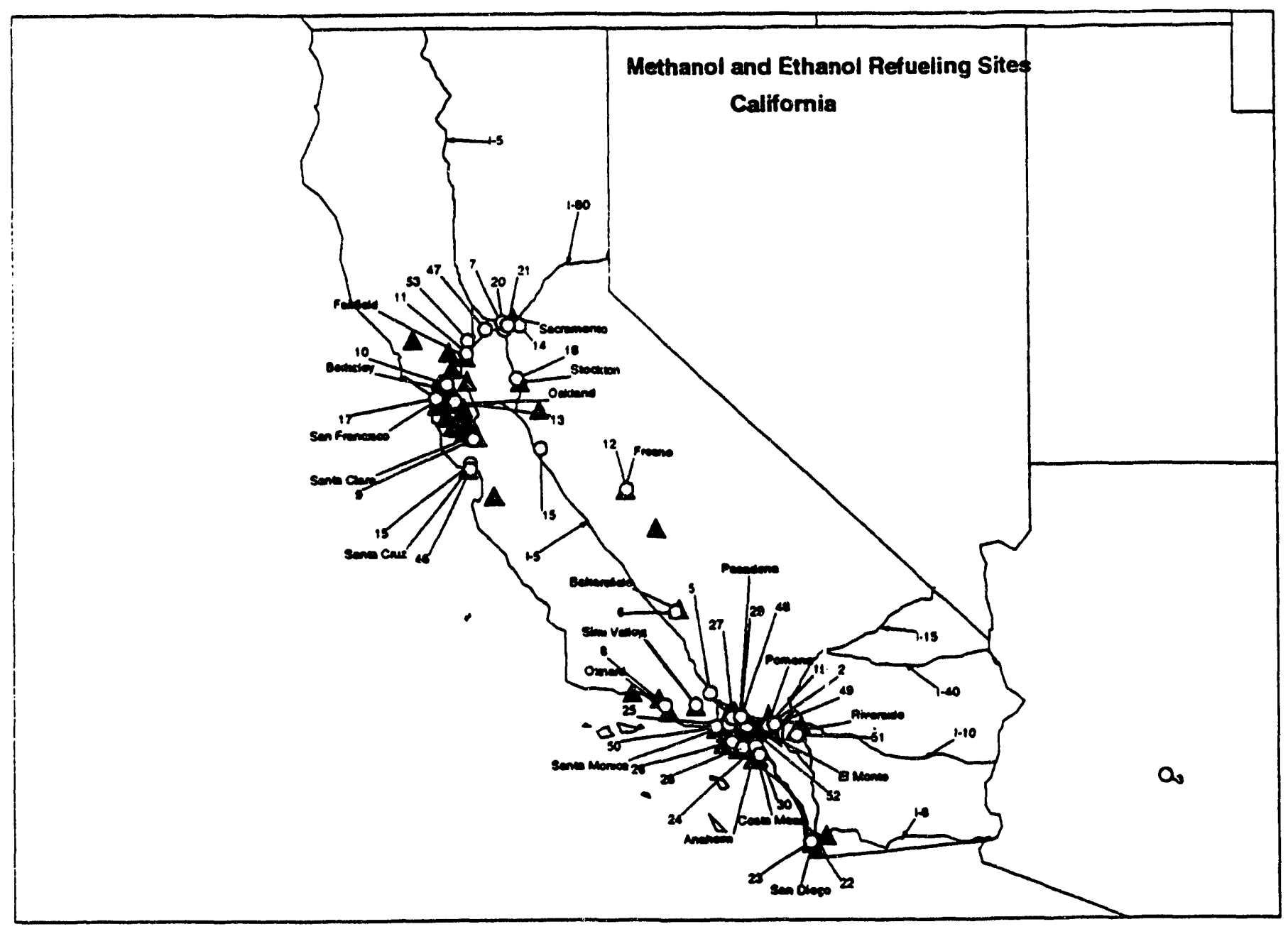

\section{SYMBOLS:}

- = Refueling Site

$\star$ = City Location

\section{DESIGNATIONS:}

I-80 = Interstate 80, for example

123 = Refueling Site Map Number

Source: Alternative Fuels Data Center, Golden, CO. "Refueling Site Maps", August 25, 1992. 
Executive Order 12759 of April 17, 1991, Federal Energy Management, Section 11, "Procurement of Alternative Fueled Vehicles" requires that the "maximum number practicable of vehicles acquired annually are alternative fueled vehicles." The guidance document developed by DOE with interagency consultation established goals for the Federal procurement of altemative fueled vehicles (AFVs) (Figure 5.5). The breakdown of Federal agency requests for AFVs in the 1993 fiscal year by vehicle type and fuel type is shown in Figure 5.6.

Figure 5.5. Target Acquizition of Altenative Puel Vehickes for Foderal Floets

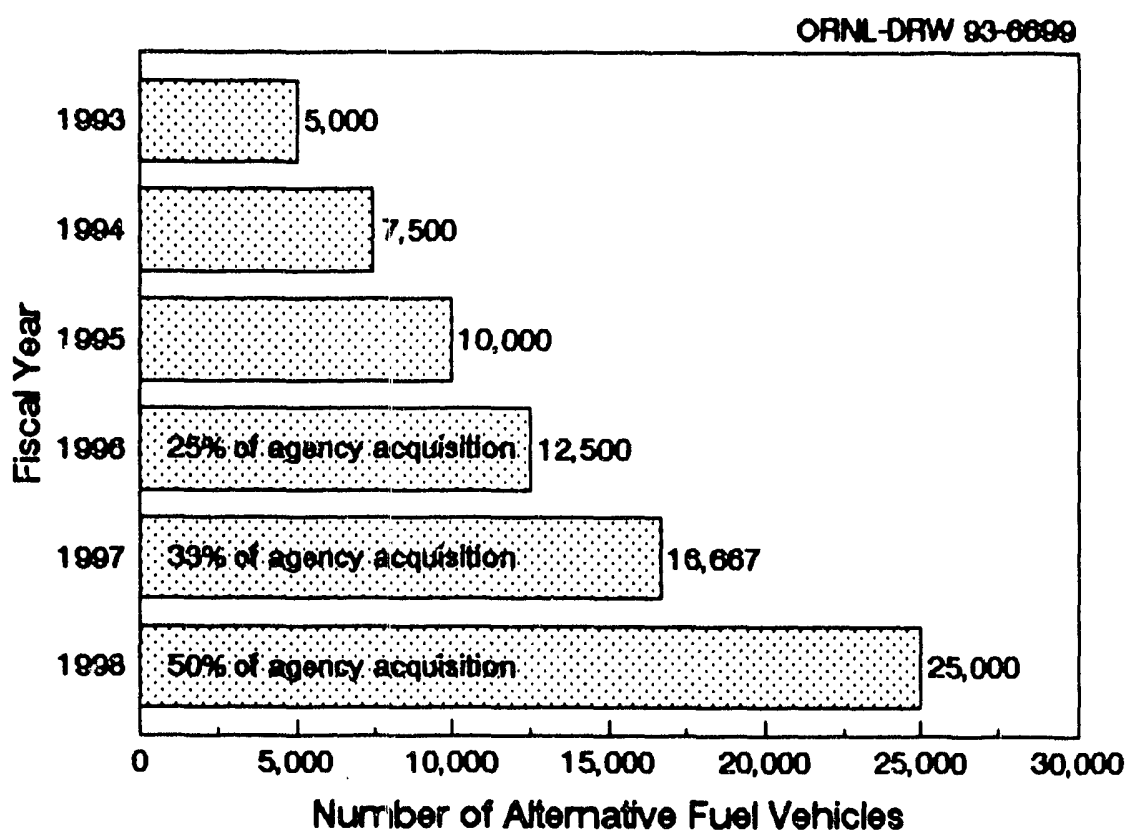

Figure 5.6. FY 1993 Agency Requests for Alernative Fuel Vehicles

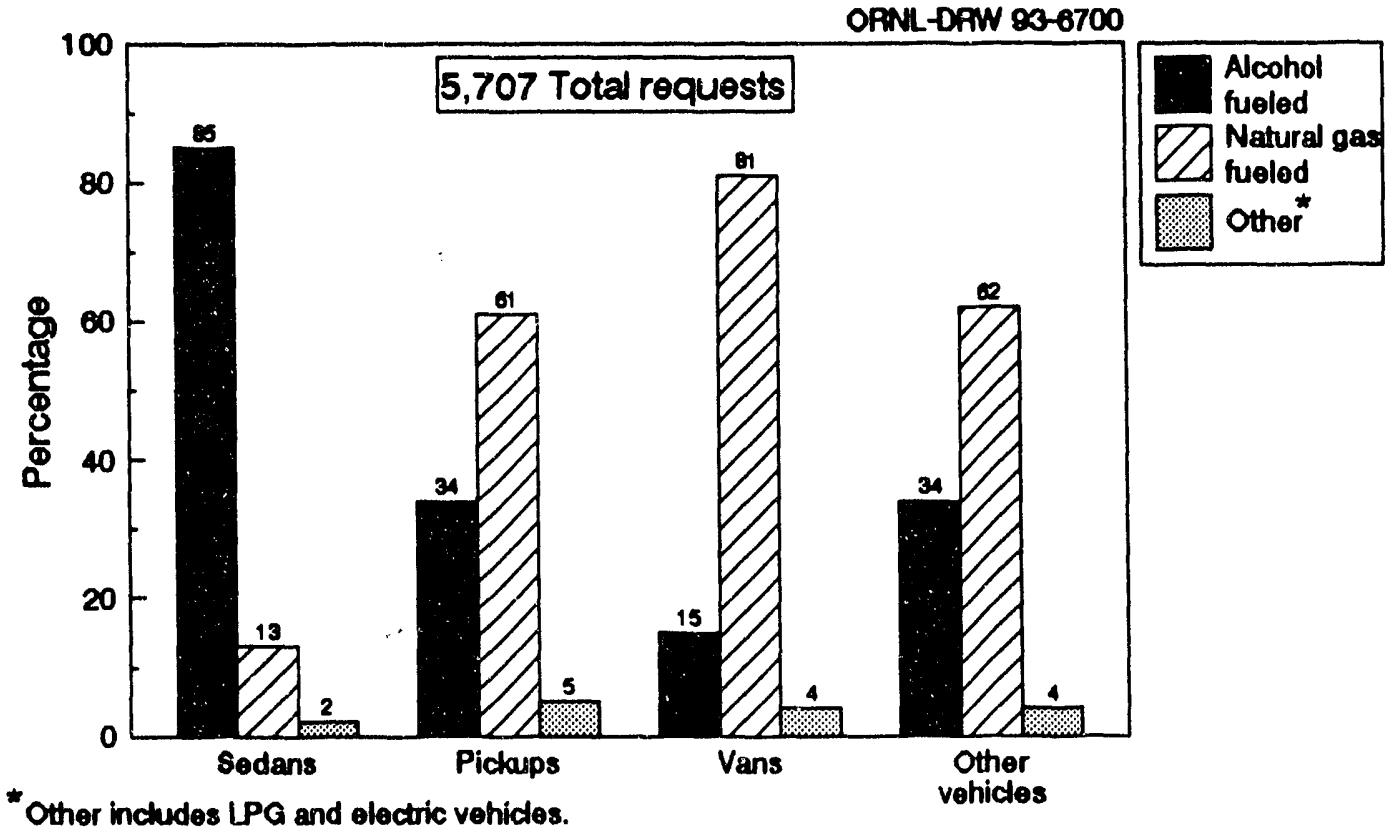

Source:

Office of Transportation Technologies, U.S. Department of Energy, "Alternative Fuel

Vehicles for the Federal Fleet: Results of the 5-Year Planning Process,"

Washington, DC, August 1992, pp. 4, 13. 


\section{U.S. ADVANCED BATTERY CONSORTIUM}

Electric vehicles are the subject of intense research and development because they are required to be sold in California in 1998 (2\%) rising to $10 \%$ in 2003 under the California Low-Emission Vehicle (LEV) program. Other states have indicated that they will also enforce the LEW program. One of the greatest advantages in using electric vehicles is that there are no vehicle emissions. The U.S. Advanced Battery Consortium (USABC) was established in January 1991 to concentrate efforts on battery development for future electric vehicles. The USABC consists of: the Big Three U.S. auto manufacturers (Chrysler, Ford, General Motors); the Electric Power Research Institute; the electric utility industry; and the U.S. Department of Energy.

In FY 1992, the USABC has focused on establishing agreements for the development of advanced batteries. The USABC also entered a series of Cooperative Research and Development Agreements (CRADAs) with several DOE National Laboratories during this period. The following agreements have been concluded:

- the development of nickel metal hydride battery by to Ovonics Battery Company

- CRADA with National Renewable Energy Laboratory to develop advanced insulation for high temperature batteries

- CRADA with Lawrence Berkeley Laboratory for lithium polymer battery technology development

- the development of lithium polymer battery jointly with W.R. Grace Consortium

- CRADAs with Argonne National Laboratory for development of lithium iron disulfide battery technology and testing of advanced batteries

- CRADA with Idaho National Engineering Laboratory for testing of advanced batteries

- CRADA with Sandia National Laboratory for development of lithium polymer battery technology and battery reclamation. 
In FY 1992 the USABC reviewed the development criteria for mid-term goals. Reassessment of these criteria, which were originally defined in earty 1991, resulted in no significant changes. Concerns about the potential for advanced batteries to meet the high power requirements itemanded by the automotive customer and the ability of batteries to rapidly recharge are reflected in the revised goals.

Tuble 5.3

Advanced Battery Technology Goals of the U.S. Advanced Battery Consortium

\begin{tabular}{|c|c|c|}
\hline & $\begin{array}{l}\text { Mid-term goal } \\
(1995-1998)\end{array}$ & Long-term goal" \\
\hline Power density $\mathrm{W} / \mathrm{L}$ & 250 & 600 \\
\hline $\begin{array}{l}\text { Specific power (charge) W/kg } \\
(80 \% \mathrm{DoD} / 30 \mathrm{sec})\end{array}$ & $\begin{array}{l}150 \\
\text { (200 desired) }\end{array}$ & 400 \\
\hline $\begin{array}{l}\text { Specific power (recharge) W/kg } \\
(20 \% \mathrm{DOD} / 10 \mathrm{sec})\end{array}$ & 75 & \\
\hline $\begin{array}{l}\text { Energy density } W h / L \\
\text { (C/3 discharge rate) }\end{array}$ & 135 & 300 \\
\hline $\begin{array}{l}\text { Specific energy Wh/kg } \\
\text { ( } C / 3 \text { discharge rate) }\end{array}$ & $\begin{array}{l}80 \\
\text { (100 desired) }\end{array}$ & 200 \\
\hline Power/energy ratio & $1.5-2.5$ & \\
\hline Life (years) & 5 & 10 \\
\hline $\begin{array}{l}\text { Cycle life (cycles) } \\
\text { (80\% DoD) }\end{array}$ & 600 & 1000 \\
\hline $\begin{array}{l}\text { Power and capacity degradation } \\
\text { (\% of rated spec) }\end{array}$ & $20 \%$ & $20 \%$ \\
\hline $\begin{array}{l}\text { Ultimate price }(\$ / k W h) \\
(10,000 \text { units @ } 40 \mathrm{kWh})\end{array}$ & $<\$ 150$ & $<\$ 100$ \\
\hline Operating environment & -30 to $65^{\circ} \mathrm{C}$ & -40 to $85^{\circ} \mathrm{C}$ \\
\hline Normal recharge time & $<6$ hours & 3 to 6 hours \\
\hline Fast recharge time & $\begin{array}{l}50 \% \text { of capacity } \\
\text { in }<30 \text { minutes }\end{array}$ & \\
\hline $\begin{array}{l}\text { Continuous discharge in } 1 \text { hour } \\
\text { (no failure) energy }\end{array}$ & $\begin{array}{l}75 \% \\
\text { (of rated energy capacity) }\end{array}$ & $\begin{array}{l}75 \% \\
\text { (of rated capacity) }\end{array}$ \\
\hline
\end{tabular}

\section{Source:}

U.S. Department of Energy, Office of Transportation Technologies, Washington, DC, 1991.

‘Competitive with today's internal combustion engine vehicles. 
While properties such as Reid vapor pressure and octane number can be determined for neat angenates, these vatues do not represent their behavior in a final gasoline blend. Blending mumbers are therefore used for this puppose. The blending numbers vary by caggenate type, concentration, and basestock composition. The blending numbers on this table are directly related to the basestock tested and should not be used out of context.

Table 5.4

Basic Chemistry of Varions Tramsportation Fuek

\begin{tabular}{|c|c|c|c|c|}
\hline \multicolumn{5}{|c|}{ Chemical Fomulae } \\
\hline \multirow[t]{3}{*}{$\begin{array}{l}\text { Ethanol (Ethyl Alcohol) } \\
\text { Methanol (Methyl Aloobol) } \\
\text { Ethane } \\
\text { Methane } \\
\text { Gasoline }\end{array}$} & \multicolumn{4}{|c|}{$\begin{array}{l}\mathrm{CH}_{3} \mathrm{CH}_{2} \mathrm{OH} \text { (or } \mathrm{C}_{2} \mathrm{H}_{5} \mathrm{OH} \text { ) } \\
\mathrm{CH}_{3} \mathrm{OH} \\
\mathrm{CH}_{3} \mathrm{CH}_{3} \text { (or } \mathrm{C}_{2} \mathrm{H}_{6} \text { ) } \\
\qquad \mathrm{CH}_{4} \\
\qquad \mathrm{C}_{4} \mathrm{H}_{10} \text { to } \mathrm{C}_{12} \mathrm{H}_{\mathrm{x}}\end{array}$} \\
\hline & \multicolumn{3}{|c|}{ Phusical Properties } & \multirow[b]{2}{*}{ Gesoline } \\
\hline & & Ethanol & Methanol & \\
\hline Molecular Weight (MW) & & 46.07 & 32.04 & - \\
\hline Specific Grevity $\left(60^{\circ} \mathrm{F} / 60^{\circ} \mathrm{F}\right)$ & & 0.794 & 0.796 & $0.72-0.78$ \\
\hline Density (lb/gal @60) & & 6.61 & 6.63 & $6.0-6.5$ \\
\hline Boiling Point & & $7^{\circ} \mathrm{C}\left(173^{\circ} \mathrm{F}\right)$ & $65^{\circ} \mathrm{C}\left(149^{\circ} \mathrm{F}\right)$ & $27-225^{\circ} \mathrm{C}\left(80-437^{\circ} \mathrm{F}\right)$ \\
\hline \multicolumn{5}{|l|}{ Reid Vapor Pressure (RVP) } \\
\hline Neat (psi) & & 2.3 & 4.6 & $\cdot$ \\
\hline Blending number(psi) & & $12-27$ & $93-98$ & $8-15$ \\
\hline \multicolumn{5}{|l|}{ Octane Number } \\
\hline Neat & & 97 & 98 & - \\
\hline Blending number & & $111^{b}$ & $115^{c}$ & $84-93$ \\
\hline \multicolumn{5}{|c|}{$\begin{array}{l}\text { Water solubility (volume \% @ } 70^{\circ} \mathrm{F} \text { ) } \\
\text { Latent heat of vaporimation }\end{array}$} \\
\hline $\begin{array}{l}\text { Latent beat or vaporimaion } \\
\text { Btu/gal @ 60\% F }\end{array}$ & & 2,378 & 3,340 & 900 \\
\hline Btu/lb@60\% & & 396 & 506 & 150 \\
\hline \multicolumn{5}{|l|}{ Heating Value (lower) } \\
\hline Btu/lb & & 11,500 & 8,570 & $18,000-19,000$ \\
\hline Btu/gal @60 F & & 76,000 & 56,800 & $109,000-119,000$ \\
\hline Energy Release (Btu/fit $\left.{ }^{3}\right)$ & & 94.7 & 94.5 & 95.2 \\
\hline Stoichiometric air/fuel weight & & 9.00 & 6.45 & 14.7 \\
\hline
\end{tabular}

Source:

Tshiteya, Rene M. and Ezio N. Vermiglio, Properties of Alcohol Transportation Fuels, Alcohol Fuels Reference Work \#1, prepared for the Biofuels Systems Division, U.S. Department of Energy, by Meridian Corporation, Alexandria, VA, July 1991, pp. 2-i, 2-8.

'Not applicable.

'For $10 \%$ ethanol blending with gasoline.

'For 5\% methanol blending with gasoline.

${ }^{\mathrm{N}}$ Negligible. 
The warranties of most passenger vehicles sold in the United States civer up to the following fuel concentrations in gasoline: Ethanoh, 10\%; ETBE, 17\%; Methainol, 3.5\%; MTBE, up to 15\%.

Trbile 5.5.

Reid Vapor Pressure of Varions Aloohol/Ether/Gasoline Blends

\begin{tabular}{|c|c|c|c|c|c|}
\hline \multirow{2}{*}{$\begin{array}{l}\% \text { of } \\
\text { Gasoline }\end{array}$} & \multirow{2}{*}{$\begin{array}{c}\% \text { of } \\
\text { Alcohol/Ether }\end{array}$} & \multicolumn{4}{|c|}{ Blending Agent } \\
\hline & & Ethanol & ETBE & Methanol & $\mathrm{MTBE}^{\mathrm{b}}$ \\
\hline 100 & 0 & 9.00 & 9.00 & 9.00 & 9.00 \\
\hline 95 & 5 & 10.10 & 8.80 & 12.30 & 9.40 \\
\hline 90 & 10 & 10.00 & 8.60 & 12.40 & 9.20 \\
\hline 85 & 15 & 9.90 & 8.30 & 12.30 & 9.10 \\
\hline 80 & 20 & 9.75 & 8.10 & 12.20 & 9.10 \\
\hline 75 & 25 & c & 7.90 & $c$ & - \\
\hline 70 & 30 & 9.50 & c & 12.05 & c \\
\hline 50 & 50 & 8.70 & c & 11.40 & 8.80 \\
\hline 30 & 70 & 7.00 & c & 10.00 & - \\
\hline 15 & 85 & $5.00^{d}$ & c & $7.90^{\circ}$ & c \\
\hline 10 & 90 & 4.30 & c & 7.20 & 8.10 \\
\hline 0 & 100 & 2.30 & 4.40 & 4.60 & 7.80 \\
\hline
\end{tabular}

Source:

Tshiteya, Rene M. and Ezio N. Vermiglio, Properties of Alcohol Transportation Fuels, Alcohol Fuels Reference Work \#1, prepared for the Biofuels Systems Division, U.S. Department of Energy, by Meridian Corporation, Alexandria, VA, July 1991, p. 4-i.

'Ethyl-tertiary-butyl ether.

'Methyl-tertiary-butyl ether.

'Data are not available.

${ }^{d}$ Estimated. 
Table 5.6.

U.S. Production of Methrnol and Eimanol, 1978-1991

(million grllows)

\begin{tabular}{ccc}
\hline Year & Ethanol & Methanol \\
\hline 1978 & 20 &. \\
1979 & 40 & 1,111 \\
1980 & 80 & 1,079 \\
1981 & 85 & 1,294 \\
1982 & 234 & 1,139 \\
1983 & 443 & 1,204 \\
1984 & 567 & 1,239 \\
1985 & 793 & 760 \\
1986 & 798 & 1,110 \\
1987 & 825 & 1,108 \\
1988 & 800 & 1,237 \\
1989 & 750 & 1,085 \\
1990 & 756 & 1,214 \\
1991 & 875 & $1,307^{\circ}$ \\
& & \\
& Average & annual percentage change \\
$1978-91$ & $33.7 \%$ & $1.4 \%{ }^{\circ}$ \\
$1982-91$ & $15.8 \%$ & $1.5 \%$ \\
\hline
\end{tabular}

Sources:

Ethanol - Information Resources, Inc., Washington, DC, 1991.

Methanol - EA-Mueller,Inc., Baltimore, MD, 1992.

1991 estimate - Crocco and Associates, Houston, TX, 1992.

-Data are not available

${ }^{\text {bEstimate. }}$

'Average annual percentage change is for years 1979-90. 
As of September 1992, nine states offered tax exemptions to encourage the use of gasohol for transportation purposes. Alaska offered the greatest axemption of eight cents per gallom, while lowa and Connecticut both had the lowest exemption of one cent per gallon. Some states, such as Minnesota, New Jersey, and New Mexico, have discontinued the exemption of gasohol in recent years.

Table 5.7.

State Trx Exemptions for Greohol

September 1992

\begin{tabular}{lc}
\hline State & $\begin{array}{c}\text { Exemption } \\
\text { (cents/gallon of gasohol) }\end{array}$ \\
\hline Alaska & 8.0 \\
Connecticut & 1.0 \\
Idaho & 4.0 \\
lowa & 1.0 \\
Nebraska & 2.0 \\
Oregon & 5.0 \\
South Dakota & 2.0 \\
Washington & 2.3 \\
Wyoming & 4.0 \\
& \\
\hline
\end{tabular}

Source:

U.S. Department of Transportation, Federal Highway Administration, "Monthly Motor Fuel Reported by the States, June 1992,"

October 1992, Washington, DC, Table MF-121T. 


\section{$5-18$}

Table 5.8

Gasohol Consumption by Reporting States, 1980-91. (thousands of gallons)

\begin{tabular}{|c|c|c|c|c|c|c|c|c|}
\hline & 1980 & 1982 & 1984 & 1986 & 1988 & 1989 & 1990 & $1991^{\circ}$ \\
\hline $\begin{array}{l}\text { Alabama } \\
\text { Alarka }\end{array}$ & & 11,522 & 34,899 & $\begin{array}{c}261,286 \\
171\end{array}$ & $\begin{array}{c}416,308 \\
215\end{array}$ & $\begin{array}{c}195,725 \\
12\end{array}$ & 197,856 & 194,733 \\
\hline $\begin{array}{l}\text { Arizona } \\
\text { Artanasa }\end{array}$ & $\begin{array}{l}2,798 \\
8,250\end{array}$ & $\begin{array}{l}5,096 \\
8,462\end{array}$ & 28.871 & & & & 62,004 & 38.638 \\
\hline California & 147,795 & $\begin{array}{c}8,462 \\
464,004\end{array}$ & 401,837 & 189,046 & 489,235 & 369,185 & 479,716 & 596,859 \\
\hline $\begin{array}{l}\text { Colorado } \\
\text { Connecticus }\end{array}$ & $\begin{array}{c}3 \\
15,849\end{array}$ & $\begin{array}{l}2,990 \\
4,461\end{array}$ & 82,243 & $\begin{array}{l}20,662 \\
5,7 \times 3\end{array}$ & $\$ 0,707$ & 70,522 & 91,263 & 100,844 \\
\hline Detwivare & 1,512 & 34 & 81 & 205 & 210 & 323 & & 304 \\
\hline Florida & 14,359 & 103,053 & 503,751 & 304041 & r,312 & 77,657 & 77,558 & 95,556 \\
\hline $\begin{array}{l}\text { Georgia } \\
\text { Hawaii }\end{array}$ & $\begin{array}{c}11,063 \\
1,095\end{array}$ & $\begin{array}{l}148 \\
368\end{array}$ & 18 & & 6,291 & 30,265 & 88,672 & 94,980 \\
\hline Idaho & & 2,464 & 8,067 & 22,016 & 45,012 & 64,830 & 70,199 & \\
\hline $\begin{array}{l}\text { Illinois } \\
\text { Indiana }\end{array}$ & 15,088 & $\begin{array}{l}251,200 \\
120,569\end{array}$ & $\begin{array}{l}562,036 \\
587,396\end{array}$ & $\begin{array}{c}1,286,828 \\
668,638\end{array}$ & $\begin{array}{c}1,406,620 \\
651,544\end{array}$ & $\begin{array}{c}1,278,517 \\
610,320\end{array}$ & $\begin{array}{c}1,341,148 \\
638,337\end{array}$ & $\begin{array}{c}1,374,728 \\
170,607\end{array}$ \\
\hline lowe & 155,947 & 498,636 & 457,125 & 385,130 & 402844 & 385,991 & 374,097 & 461,975 \\
\hline $\begin{array}{l}\text { Kanan } \\
\text { Kentuchy }\end{array}$ & $\begin{array}{c}37,786 \\
4,763\end{array}$ & $\begin{array}{r}7,448 \\
18,872\end{array}$ & $\begin{array}{l}273,077 \\
328,238\end{array}$ & $\begin{array}{l}232,604 \\
736,349\end{array}$ & $\begin{array}{l}120,763 \\
656,845\end{array}$ & $\begin{array}{r}98,844 \\
403,859\end{array}$ & $\begin{array}{r}73,971 \\
355,987\end{array}$ & $\begin{array}{l}71,242 \\
346,130\end{array}$ \\
\hline Michigan & 29,924 & 206,794 & 577,723 & 382,010 & 499,565 & 402,714 & 510,447 & 662,986 \\
\hline Minnesota & 11,776 & 4,653 & 2,707 & 374,032 & 171,929 & 170,499 & 244,336 & 461,613 \\
\hline Missouri & & 9,000 & 13,860 & 14,316 & 134,832 & 157,056 & 267,408 & 219,120 \\
\hline Montana & 158 & 10,170 & 10,181 & 3,454 & 257 & 80 & 1,423 & 5,626 \\
\hline $\begin{array}{l}\text { Nebrakas } \\
\text { Nevida }\end{array}$ & $\begin{array}{r}30,067 \\
641\end{array}$ & $\begin{array}{c}89,698 \\
964\end{array}$ & 206,455 & $\begin{array}{l}216,356 \\
18,650\end{array}$ & $\begin{array}{l}258,073 \\
56,716\end{array}$ & $\begin{array}{l}271,082 \\
37,342\end{array}$ & $\begin{array}{r}300,632 \\
49,167\end{array}$ & $\begin{array}{l}30,616 \\
66,209\end{array}$ \\
\hline $\begin{array}{l}\text { Now Hampahite } \\
\text { Now Jerney }\end{array}$ & $\begin{array}{l}3,642 \\
6,567\end{array}$ & & & & & & & \\
\hline New Mexico & & 1,082 & 63,756 & 58,752 & 147,656 & 171,297 & 156,935 & 152,856 \\
\hline N. Carolina & 10,688 & 7,456 & 34,037 & & & & & 50,574 \\
\hline $\begin{array}{l}\text { N. Dakola } \\
\text { Ohio }\end{array}$ & $\begin{array}{l}13,491 \\
16,726\end{array}$ & $\begin{array}{c}6,499 \\
91,679\end{array}$ & 5,469 & $\begin{array}{c}65,327 \\
814,579\end{array}$ & $\begin{array}{c}44,317 \\
981.874\end{array}$ & $\begin{array}{r}37,966 \\
958.123\end{array}$ & $\begin{array}{c}35,821 \\
1,072,040\end{array}$ & $\begin{array}{c}53,356 \\
1,116,757\end{array}$ \\
\hline Oklahoma & 28,910 & $\begin{array}{c}91,679 \\
155,053\end{array}$ & $\begin{array}{r}495,595 \\
23,620\end{array}$ & 26,994 & & & & \\
\hline S. Carolina & $\begin{array}{r}1,763 \\
11,608\end{array}$ & 59,688 & 154 & 15,550 & 102,333 & 82,454 & 62,549 & 72 \\
\hline $\begin{array}{l}\text { S. Dakota } \\
\text { Teaneacece }\end{array}$ & 10,507 & 13,800 & $\begin{array}{l}41,343 \\
264,167\end{array}$ & $\begin{array}{l}63,484 \\
394,469\end{array}$ & $\begin{array}{l}58,150 \\
580,227\end{array}$ & $\begin{array}{r}56,524 \\
373,391\end{array}$ & $\begin{array}{r}60,000 \\
246,713\end{array}$ & $\begin{array}{l}136,249 \\
178,373\end{array}$ \\
\hline $\begin{array}{l}\text { Texas } \\
\text { Utah }\end{array}$ & & 38,142 & 207,152 & 362,243 & 341,682 & 216,607 & 247,384 & 244,095 \\
\hline $\begin{array}{l}\text { Utah } \\
\text { Virginia }\end{array}$ & & $\begin{array}{c}500 \\
30.834\end{array}$ & $\begin{array}{c}26,358 \\
131,618\end{array}$ & 2,409 & 358 & 427 & 485 & 300 \\
\hline $\begin{array}{l}\text { Virginia } \\
\text { Washington }\end{array}$ & $\begin{array}{c}1,991 \\
14,063\end{array}$ & $\begin{array}{c}30,834 \\
7,230\end{array}$ & $\begin{array}{c}131,618 \\
9,143\end{array}$ & 423,709 & 282,181 & 251,793 & 161,202 & 152,968 \\
\hline $\begin{array}{l}\text { Washington } \\
\text { W. Virginia }\end{array}$ & $\begin{array}{c}14,063 \\
692\end{array}$ & 7,230 & 9,143 & 26,797 & 54,519 & 64,169 & 86,847 & 101,009 \\
\hline $\begin{array}{l}\text { Wieconsin } \\
\text { Wyoming }\end{array}$ & 611 & $\begin{array}{c}2,718 \\
259\end{array}$ & $\begin{array}{c}1,962 \\
309\end{array}$ & $\begin{array}{c}15,312 \\
55\end{array}$ & $\begin{array}{c}20,175 \\
62\end{array}$ & $\begin{array}{r}47,620 \\
2,668\end{array}$ & $\begin{array}{l}82,961 \\
9,513\end{array}$ & $\begin{array}{r}204,978 \\
34,498\end{array}$ \\
\hline Total & 497,220 & 2259,046 & $5,420,464$ & $7,807,285$ & $8,137,683$ & $6,940,615$ & $7,492,231$ & $7,502,313^{3}$ \\
\hline
\end{tabular}

Sourcer:

1980-1990: U.S. Department of Transportation, Foderal Highway Administration, Hiphway Statistics 1990, Washington, DC, 1991, Table MF-33GLA, p. 11, and annual.

1991: U.S. Department of Transportation, Federal Highway Administration, "Monthly Motor Fuel Reported by Statea, April 1992," Washington, DC, July 1992, Table MF-33GLA.

The data reflect gallons of gasohol reported by the distributors in each of the selected states. Blanks indicate data were not reported for the state that year.

'Preliminary data. 
Figure 5.7. Gasohol Consumption of Selected States, 1980-91
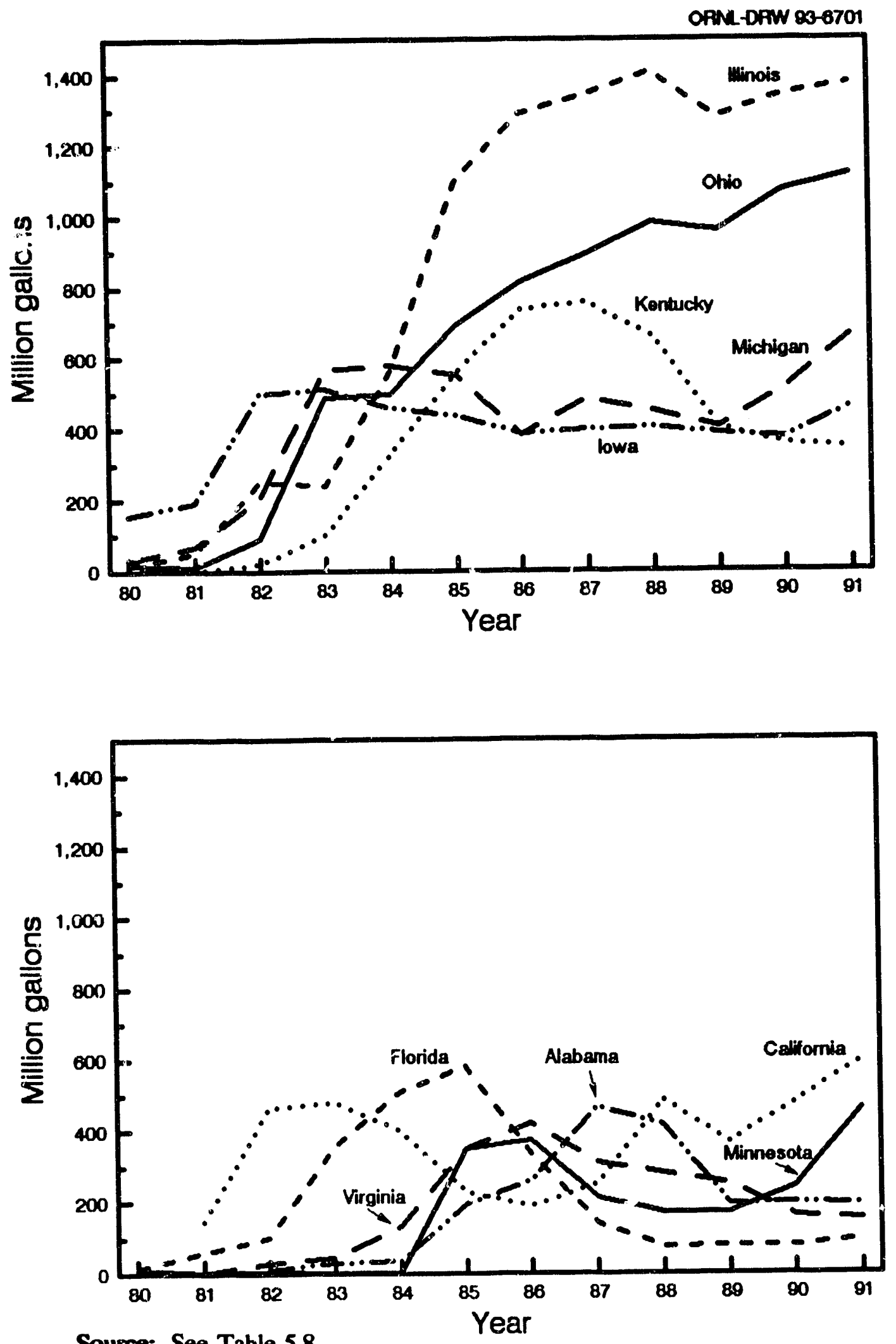

Source: See Table 5.8 . 


\section{CHAPTER 6 NONHIGHWAY MODES}

This chapter presents statistics for four major nonhighway transportation modes: air, water, pipeline, and rail. The combined energy use for these four modes accounted for over $22 \%$ of the total energy use in the transportation sector in 1990 (Table 6.1). Air transportation accounted for the largest share ( $41 \%)$ of nonhighway transportation energy consumption (Figure 6.1).

Section 6.1 discusses data on air transportation. Statistics on water transportation are included in Section 6.2; pipeline data in Section 6.3; and rail data in Section 6.4 . 
Table 6.1

Nonhighway Energy Use by Mode, 1970-90

\begin{tabular}{|c|c|c|c|c|c|c|}
\hline \multirow[t]{2}{*}{ Year } & Air & Water & Pipeline & Rail & $\begin{array}{c}\text { Nonhighway } \\
\text { transportation } \\
\text { energy use }\end{array}$ & \multirow{2}{*}{$\begin{array}{c}\text { Transportation } \\
\text { energy use } \\
\text { (trillion Btu) }\end{array}$} \\
\hline & \multicolumn{4}{|c|}{ (percent of total) } & & \\
\hline 1970 & $8.5 \%$ & $4.9 \%$ & $6.4 \%$ & $3.8 \%$ & $23.7 \%$ & 15,305 \\
\hline 1971 & $8.2 \%$ & $4.4 \%$ & $6.3 \%$ & $3.5 \%$ & $22.4 \%$ & 15,907 \\
\hline 1972 & $7.8 \%$ & $4.1 \%$ & $6.1 \%$ & $3.6 \%$ & $21.7 \%$ & 16,949 \\
\hline 1973 & $7.7 \%$ & $4.6 \%$ & $5.6 \%$ & $3.7 \%$ & $21.6 \%$ & 17,813 \\
\hline 1974 & $7.3 \%$ & $4.7 \%$ & $5.5 \%$ & $3.8 \%$ & $21.3 \%$ & 17,088 \\
\hline 1975 & $7.4 \%$ & $4.9 \%$ & $4.8 \%$ & $3.4 \%$ & $20.5 \%$ & 17,329 \\
\hline 1976 & $7.2 \%$ & $5.4 \%$ & $4.4 \%$ & $3.4 \%$ & $20.4 \%$ & 18,389 \\
\hline 1977 & $7.4 \%$ & $5.8 \%$ & $4.1 \%$ & $3.3 \%$ & $20.6 \%$ & 19,071 \\
\hline 1978 & $7.3 \%$ & $6.5 \%$ & $3.9 \%$ & $3.1 \%$ & $20.9 \%$ & 20,035 \\
\hline 1979 & $7.8 \%$ & $7.7 \%$ & $4.3 \%$ & $3.3 \%$ & $23.0 \%$ & 20,101 \\
\hline 1980 & $7.9 \%$ & $8.7 \%$ & $4.6 \%$ & $3.3 \%$ & $24.5 \%$ & 19,317 \\
\hline 1981 & $7.6 \%$ & $8.2 \%$ & $4.7 \%$ & $3.3 \%$ & $23.8 \%$ & 19,065 \\
\hline 1982 & $7.9 \%$ & $6.9 \%$ & $4.6 \%$ & $3.1 \%$ & $22.6 \%$ & 18,589 \\
\hline 1983 & $8.0 \%$ & $6.3 \%$ & $3.9 \%$ & $3.1 \%$ & $21.4 \%$ & 18,728 \\
\hline 1984 & $8.5 \%$ & $6.5 \%$ & $4.0 \%$ & $2.7 \%$ & $21.7 \%$ & 19,310 \\
\hline 1985 & $8.5 \%$ & $6.7 \%$ & $3.9 \%$ & $2.5 \%$ & $21.6 \%$ & 19,659 \\
\hline 1986 & $9.0 \%$ & $6.4 \%$ & $3.6 \%$ & $2.4 \%$ & $21.5 \%$ & 20,229 \\
\hline 1987 & $9.2 \%$ & $6.4 \%$ & $3.7 \%$ & $2.4 \%$ & $21.7 \%$ & 20,704 \\
\hline 1988 & $9.3 \%$ & $6.3 \%$ & $4.1 \%$ & $2.4 \%$ & $22.1 \%$ & 21,278 \\
\hline 1989 & $9.2 \%$ & $6.4 \%$ & $4.1 \%$ & $2.4 \%$ & $22.1 \%$ & 21,598 \\
\hline 1990 & $9.5 \%$ & $6.8 \%$ & $4.3 \%$ & $2.3 \%$ & $22.9 \%$ & 21,778 \\
\hline
\end{tabular}

Source.

See Appendix A for Table 2.10.

'Does not include off-highway and military transportation eriergy use. 


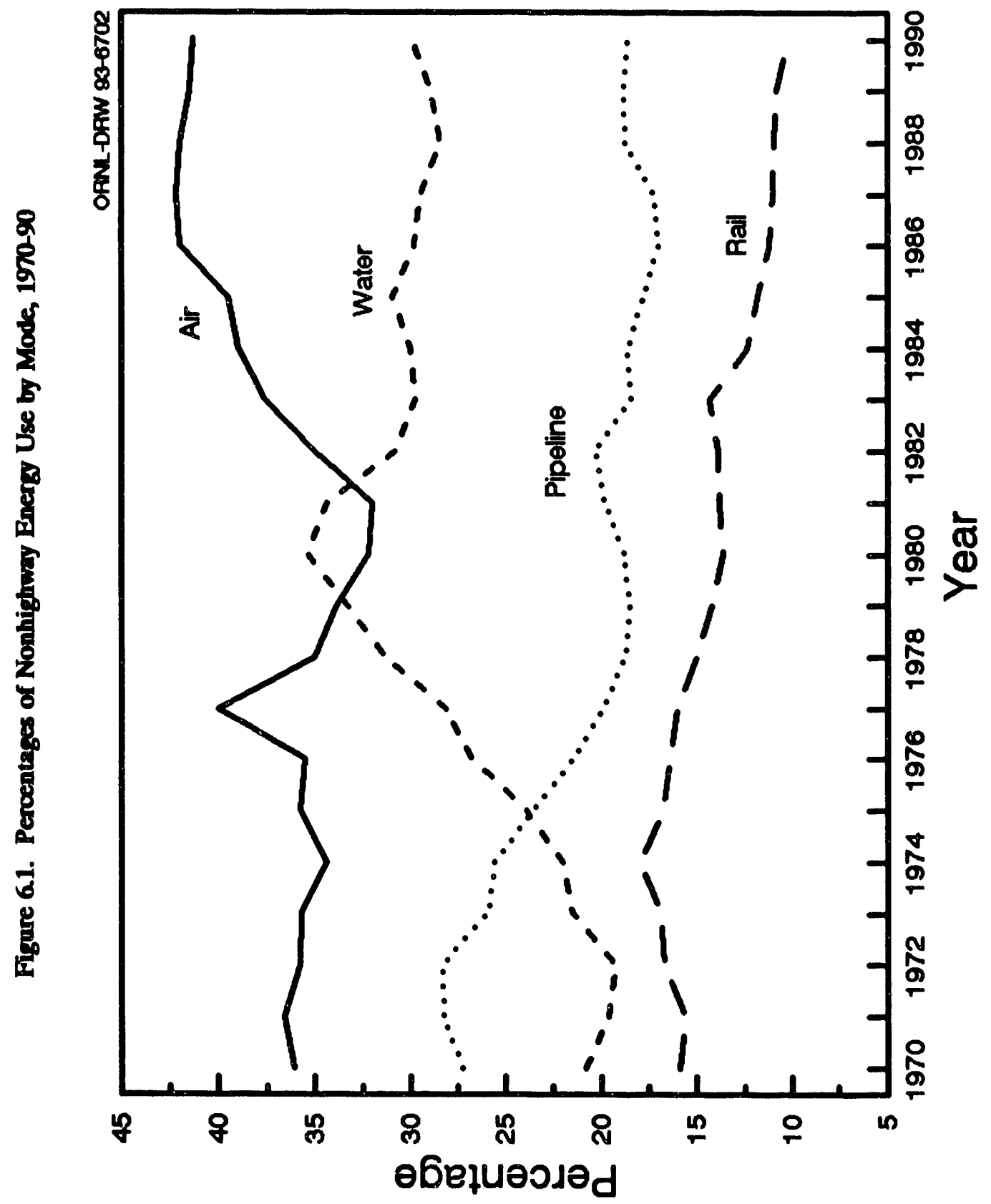

$\dot{8}$
0
0
8
8
8
8
8
8 
Section 6.1

Air 
Air transportation activities can be categorized into two types: air carrier and general aviation. General aviation aircraft serve a variety of purposes, such as business and flight instruction, and include all aircraft which do not belong to the air carrier fleet. Since most of the aircraft in this category are used for personal activities, they do not provide commercial passenger or freight services. Although general aviation aircraft account for the majority of the number of aircraft in operation and fly almost five times as many hours as their counterparts in the air carrier category, the lower speeds and the smaller loads of general aviation aircraft resulted in a significantly smaller share of total aircraft energy use than that of the air carrier fleet, $5.7 \%$ and $94.3 \%$, respectively (Tables 6.2 and 6.4).

Aircraft-miles for domestic and international certificated route air carriers increased by $6.4 \%$ from 1989 to 1990 , while revenue cargo ton-miles increased by $9.5 \%$ in the same time period. The movement of cargo by air carriers has been rapidly growing, evidenced by the average annual increase of $9.8 \%$ from 1982 to 1990 . Revenue passenger-miles continued to increase in 1990; the passenger load factor, however, declined to $62.7 \%$ from a high of $63.6 \%$ in 1989 . The average passenger trip length for scheduled domestic services increased in 1990 to more than 800 miles (Table 6.2).

Air carriers are classified based on operating revenues for the purposes of statistical and financial reporting and analysis. The classifications, which were updated in January 1984, are as follows:

\section{Carrier Group}

Major

National

Large regional

Medium regional
Operating Revenue

(millions of dollars)

Over $\$ 1,000$

$\$ 100-1,000$

$\$ 10-99.9$

\$0 $\quad-9.99$ 
International ${ }^{2}$ certificated route air carriers more than doubled their revenue aircraft-miles, revenue passenger-miles, available seat-miles, and revenue cargo ton-miles from 1982 to 1990 . The energy use for international air carriers did not quite double in this time period due to increased aircraft efficiency. The domestic carriers also experienced an increase in all types of activity from 1982 to 1990, but not as great an increase as the international air carriers (Table 6.3).

Intercity passenger travel by general aviation was 13 billion passenger-miles in 1990, which is only a slight decline from 1989. The hours flown by general aviation aircraft and the number of aircraft also declined from 1989 to 1990 . These declines most likely led to the decline in energy use, which fell from 134 trillion Btu in 1989 to 132 trillion Btu in 1990.

'Operating outside the territory of the U.S., including operations between the U.S. and foreign countries and the U.S. and its territories or possessions. 


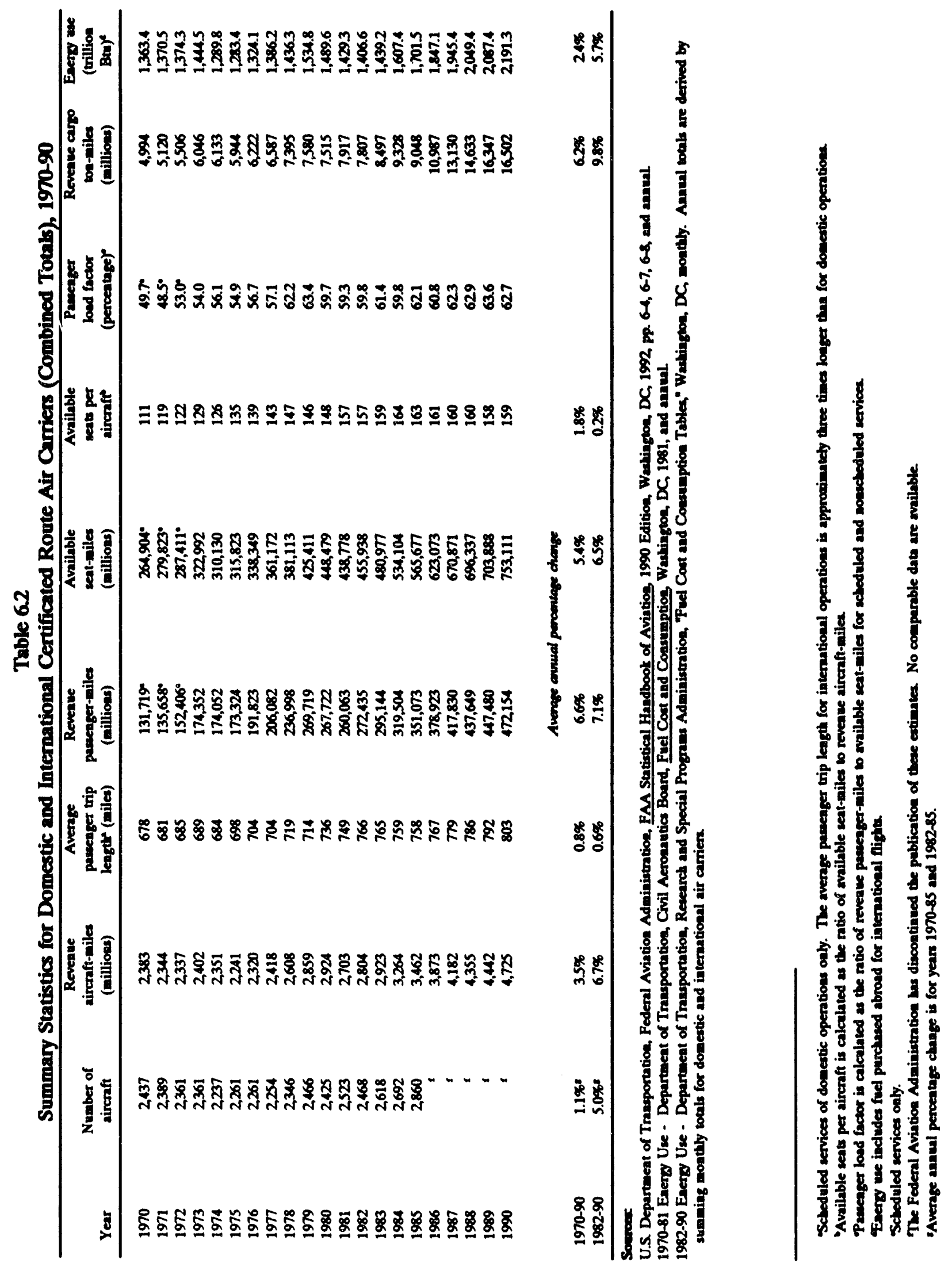




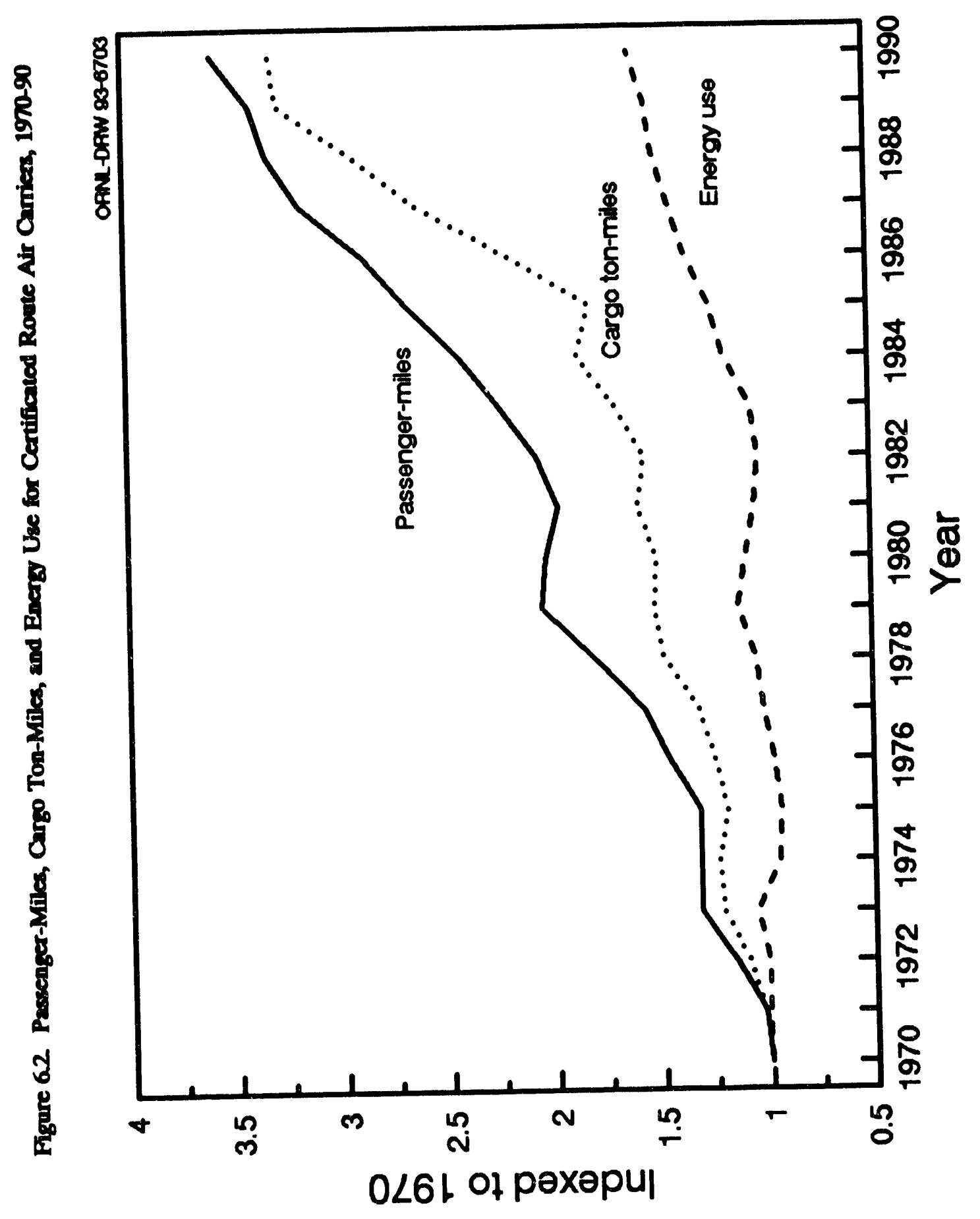

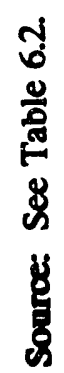




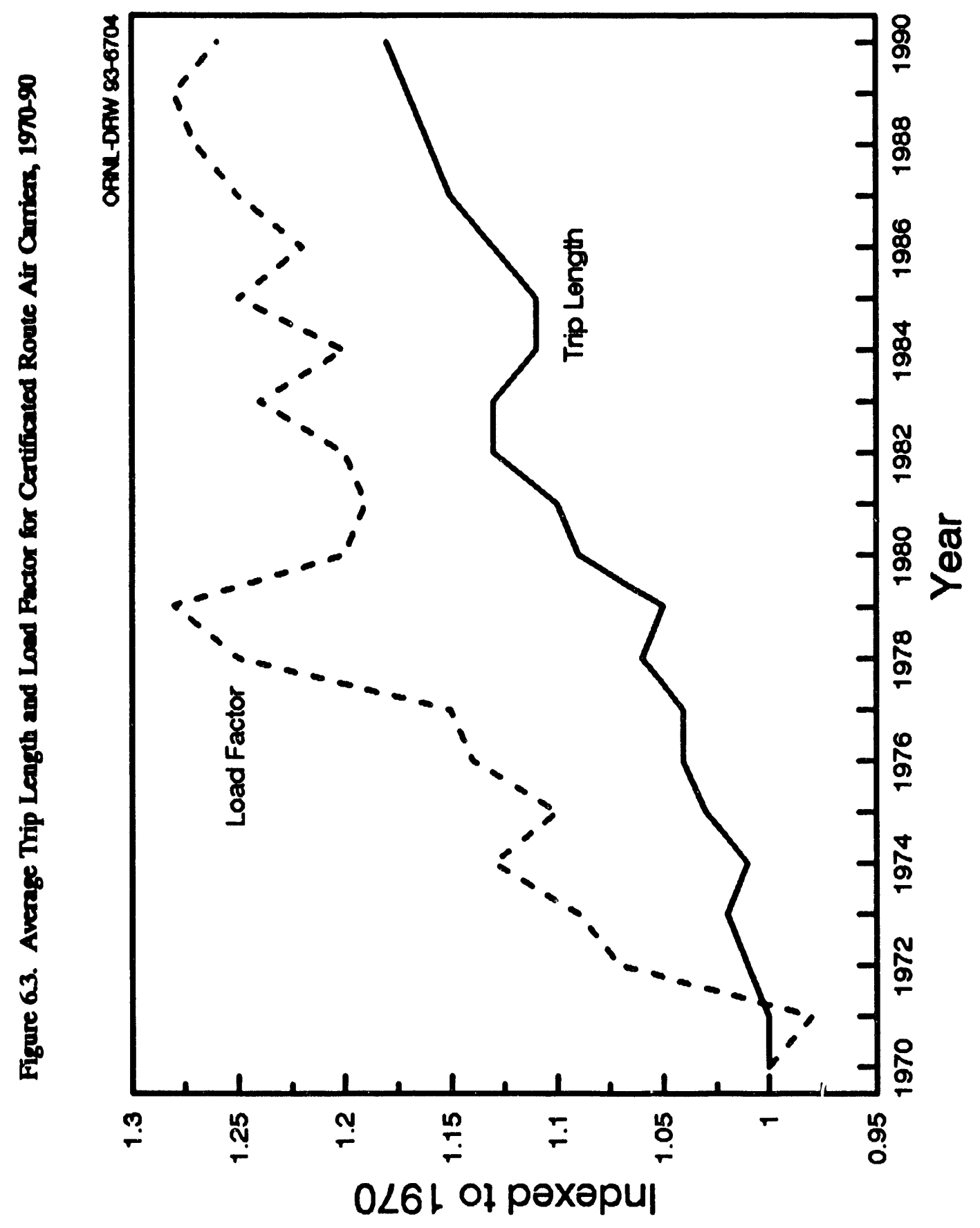

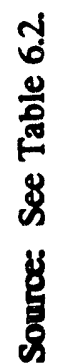




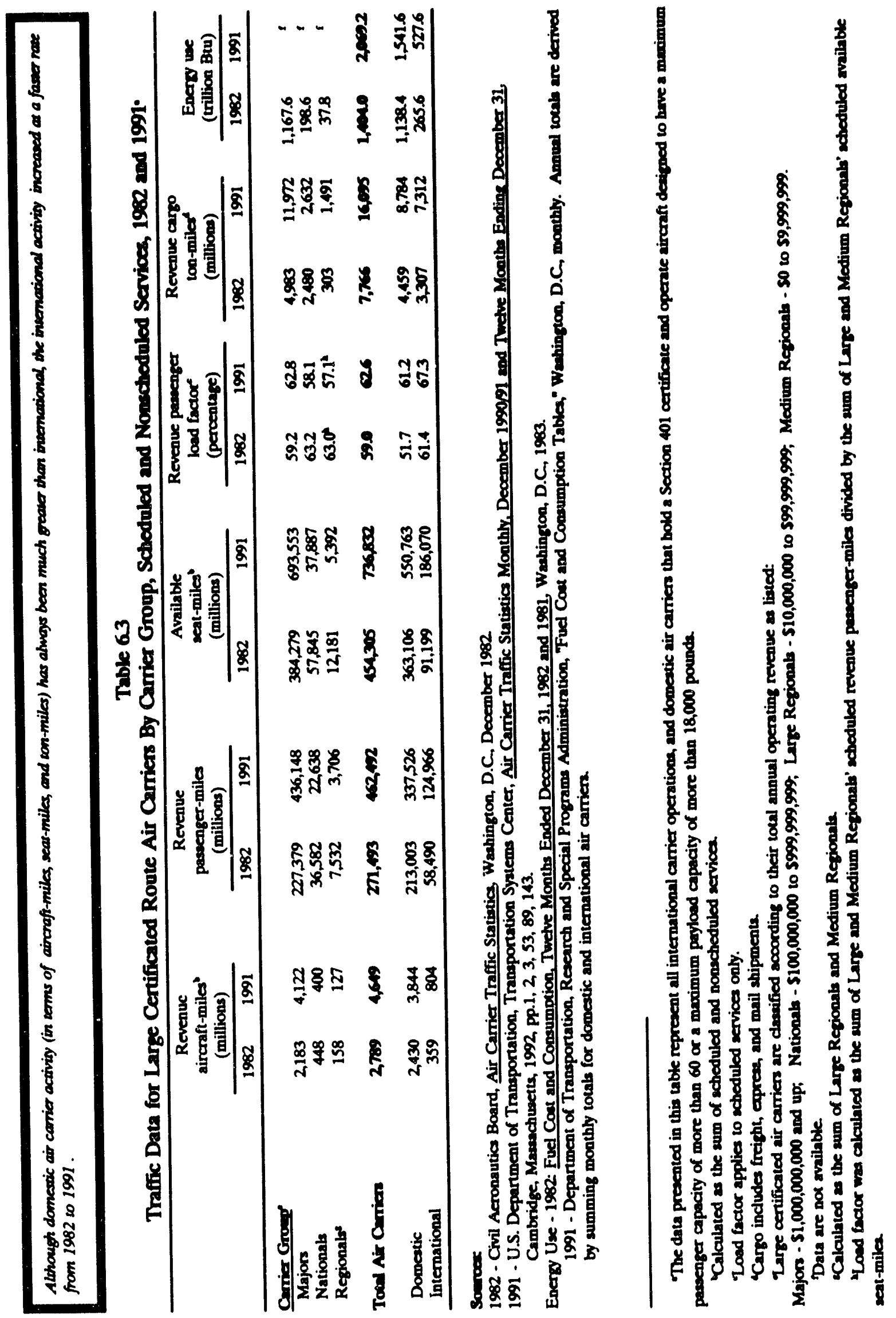




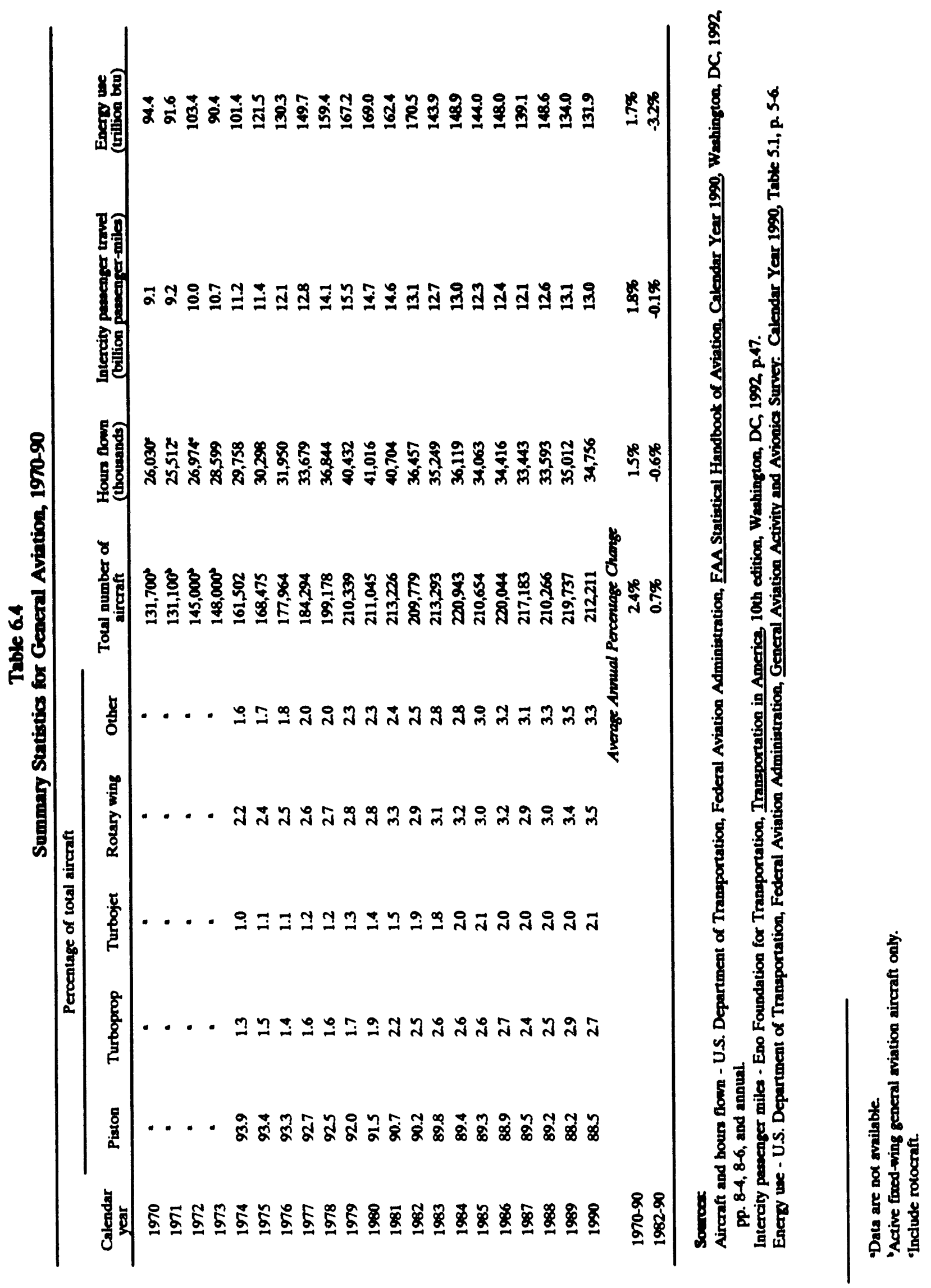


6-12

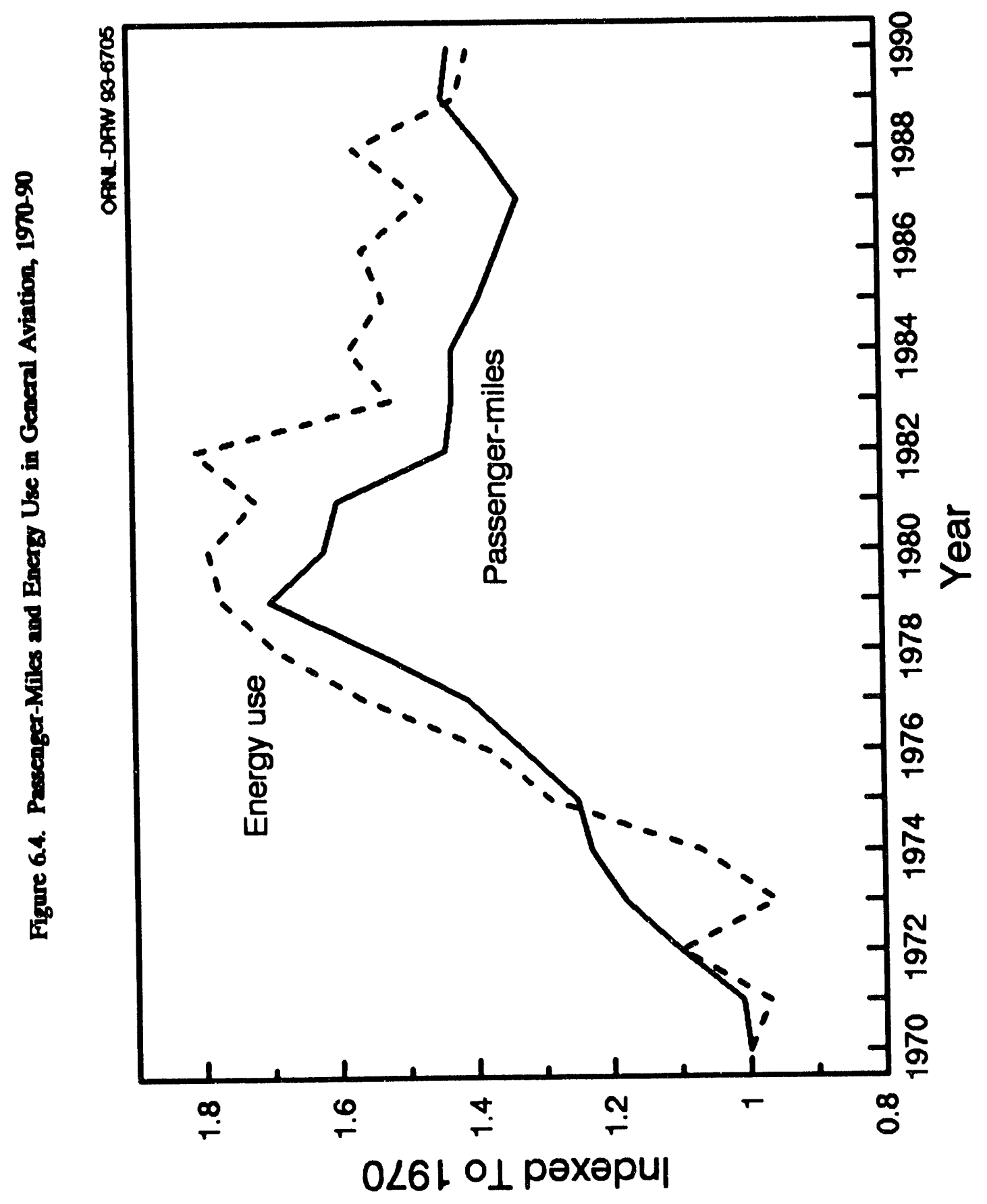


6-13

Section 6.2 Water 
Due to delays in the release of 1990 data from the U.S. Department of the Army, Corps of Engineers, the data in this chapter were not able to be updated. The latest available data are presented.

Domestic marine traffic includes all movements between points in the United States, Puerio Rico, and the Virgin Islands. All movements between the United States and foreign countries are classified as forcign traffic. Although w'clining since 1986, domestic traffic still accounted for more than half of the total tons shipped in waterborne commerce. The combined foreign and domestic tonnage in 1989 reached a record high of 2,140 million tons (Table 6.5).

The average length of haul for domestic waterborne commerce dropped in 1989 to its iowest point since 1977. This decline in average length of haul, together with a decline in tons shipped in 1989 , resulted in a $8.3 \%$ decline in ton-miles. Despite these declines, energy use for domestic waterborne commerce rose $2.3 \%$ from 1988 to 1989 (Table 6.6).

The commodities most often moved by domestic commerce in 1989 were petroleum and products $(41.8 \%)$ and coal and coke (19.2\%). The longest average haul per ton for total domestic commerce in 1989 was grain, which had an average of 1,072 miles (Table 6.7). 
Over I billion tons were shipped in intemational waterbome commence in 1989. Domestic commerce accounted for $51.5 \%$ of total tonnage, which is only $0.5 \%$ above the lowest domestic shane in $19^{-7} 7$.

Table 65

Tonnage Statistics for Domestic and

International Waterborne Commerce, 1970-89

(million tons shipped)

\begin{tabular}{ccccc}
\hline Year & $\begin{array}{c}\text { Foreign and } \\
\text { domestic total }\end{array}$ & $\begin{array}{c}\text { Foreign } \\
\text { total }\end{array}$ & $\begin{array}{c}\text { Domestic } \\
\text { total }^{\text {b }}\end{array}$ & $\begin{array}{c}\text { Percent domestic } \\
\text { of total }\end{array}$ \\
\hline 1970 & 1,532 & 581 & 951 & $62.1 \%$ \\
1971 & 1,513 & 566 & 947 & $62.6 \%$ \\
1972 & 1,617 & 630 & 987 & $61.0 \%$ \\
1973 & 1,761 & 767 & 994 & $56.4 \%$ \\
1974 & 1,747 & 764 & 983 & $56.3 \%$ \\
1975 & 1,695 & 749 & 946 & $55.8 \%$ \\
1976 & 1,835 & 856 & 979 & $53.4 \%$ \\
1977 & 1,908 & 935 & 973 & $51.0 \%$ \\
1978 & 2,021 & 946 & 1,075 & $53.2 \%$ \\
1979 & 2,073 & 993 & 1,080 & $52.1 \%$ \\
1980 & 1,999 & 921 & 1,078 & $53.9 \%$ \\
1981 & 1,942 & 887 & 1,055 & $54.3 \%$ \\
1982 & 1,777 & 820 & 957 & $53.9 \%$ \\
1983 & 1,708 & 751 & 957 & $56.0 \%$ \\
1984 & 1,836 & 803 & 1,033 & $56.3 \%$ \\
1985 & 1,788 & 774 & 1,014 & $56.7 \%$ \\
1986 & 1,874 & 837 & 1,037 & $55.3 \%$ \\
1987 & 1,967 & 891 & 1,076 & $54.7 \%$ \\
1988 & 2,088 & 976 & 1,112 & $53.3 \%$ \\
1989 & 2,140 & 1,038 & 1,103 & $51.5 \%$ \\
& Average annual percentage & change & \\
$1970-89$ & $1.8 \%$ & $3.1 \%$ & $0.8 \%$ & \\
$1982-89$ & $2.7 \%$ & $3.4 \%$ & $2.0 \%$ & \\
\hline & & & & \\
\hline
\end{tabular}

Source:

U.S. Department of the Army, Corps of Engineers, Waterborne Commerce of the United States,

Calendar Year 1989, Part 5: National Summaries, New Orleans, Louisiana, 1991, p. 5.

"All movements between the U.S. and foreign countries and between Puerto Rico and Virgin Islands and foreign countries are classified as foreign trade.

${ }^{b}$ All movements between U.S. ports, continental and noncontiguous, and on the inland rivers, canals, and connecting channels of the U.S., Puerto Rico, and the Virgin Islands, excluding the Panama Canal. 
The average length of haul dropped in 1989 to its lowest point since 1977. Although the tons shipped and ton-miles also declined in 1989, the number of vessels and energy use increased slightly from 1988 to 1989.

Table 66

Summary Statistics for Domestic Waterborne Commerce, $1970-89$

\begin{tabular}{|c|c|c|c|c|c|c|}
\hline Year & $\begin{array}{c}\text { Number of } \\
\text { vessels }\end{array}$ & $\begin{array}{l}\text { Ton-miles } \\
\text { (billions) }\end{array}$ & $\begin{array}{l}\text { Tons shipped } \\
\text { (millions) }\end{array}$ & $\begin{array}{l}\text { Average } \\
\text { length } \\
\text { of haul } \\
\text { (miles) }\end{array}$ & $\begin{array}{c}\text { Energy } \\
\text { intensity } \\
\text { (Btu/ton-mile) }\end{array}$ & $\begin{array}{c}\text { Energy use } \\
\text { (trillion Btu) }\end{array}$ \\
\hline 1970 & 25,832 & 596 & 949 & 628.2 & 545 & 324.8 \\
\hline 1971 & 26,063 & 593 & 944 & 628.1 & 506 & 300.0 \\
\hline 1972 & 27,347 & $6 \times 4$ & 985 & 612.8 & 522 & 315.1 \\
\hline 1973 & 28,431 & 585 & 990 & 590.7 & 576 & 337.0 \\
\hline 1974 & 29,328 & 586 & 979 & 599.1 & 483 & 283.3 \\
\hline 1975 & 31,666 & 566 & 944 & 599.9 & 549 & 311.0 \\
\hline 1976 & 33,204 & 592 & 976 & 606.3 & 468 & 277.3 \\
\hline 1977 & 35,333 & 599 & 969 & 618.0 & 458 & 274.3 \\
\hline 1978 & 35,723 & 827 & 1,072 & 771.6 & 383 & 316.6 \\
\hline 1979 & 36,264 & 829 & 1,076 & 770.0 & 457 & 378.7 \\
\hline 1980 & 38,792 & 922 & 1,074 & 856.4 & 358 & 329.8 \\
\hline 1981 & 42,079 & 929 & 1,051 & 884.0 & 360 & 334.5 \\
\hline 1982 & 42,079 & 886 & 954 & 929.0 & 310 & 274.9 \\
\hline 1983 & 41,784 & 920 & 953 & 964.6 & 319 & 293.7 \\
\hline 1984 & 41,784 & 888 & 1,029 & 862.5 & 346 & 307.3 \\
\hline 1985 & 41,672 & 893 & 1,011 & 883.5 & 446 & 398.6 \\
\hline 1986 & 40,308 & 873 & 1,033 & 845.3 & 463 & 404.0 \\
\hline 1987 & 40,000 & 895 & 1,072 & 835.0 & 402 & 370.7 \\
\hline 1988 & 39,192 & 890 & 1,112 & 804.3 & 361 & 321.3 \\
\hline 1989 & 39,209 & 816 & 1,097 & 743.2 & 403 & 328.6 \\
\hline \multicolumn{7}{|c|}{ Average annual percensage change } \\
\hline $1970-89$ & $2.2 \%$ & $1.7 \%$ & $0.8 \%$ & $0.9 \%$ & $-1.6 \%$ & $0.1 \%$ \\
\hline $1982-89$ & $-1.0 \%$ & $-1.2 \%$ & $2.0 \%$ & $-3.1 \%$ & $3.8 \%$ & $2.6 \%$ \\
\hline
\end{tabular}

Sources:

1970-88 Number of vessels - Personal communication with the U.S. Department of the Army, Corps of Engineers, New Orleans, Louisiana, 1988.

1989 Number of vessets - U.S. Department of the Army, Corps of Engineers, Waterborne Transportation Lines of the United States, 1989, New Orleans, Louisiana, 1991.

1970-89 Ton-miles, tons shipped, average iength of haul - U.S. Department of the Army, Corps of Engineers, Waterborne Commerce of the United States, Calendar Year 1989, Part 5: National Summaries, New Orleans, Louisiana, 1991, p. 89, and annual.

Energy Use - See Appendix A for Table 2.7.

"Grand total for self-propelled and nonself-propelled.

These figures are not consistent with the figures on Table 6.5 because intraterritory tons are not included in this table. 


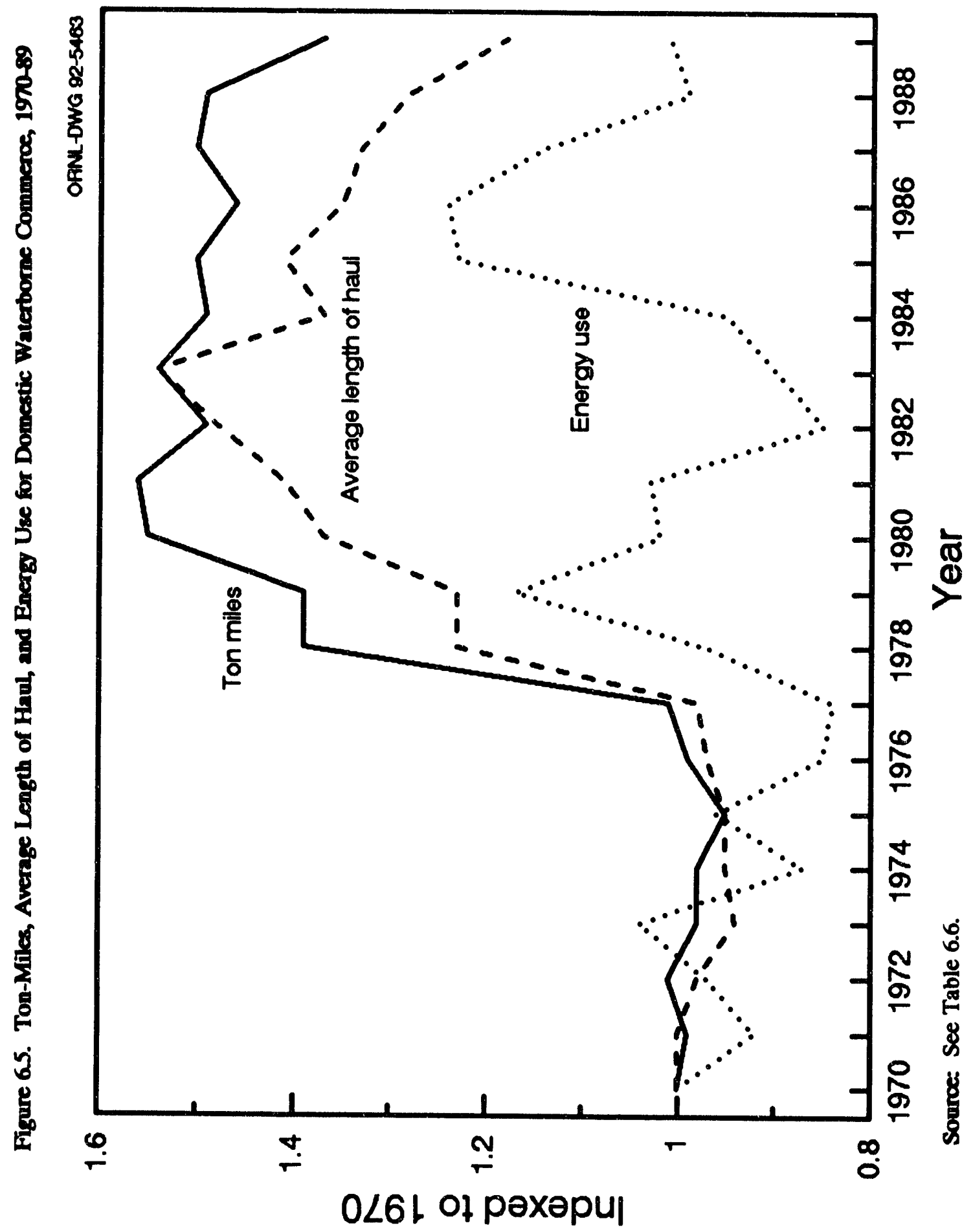




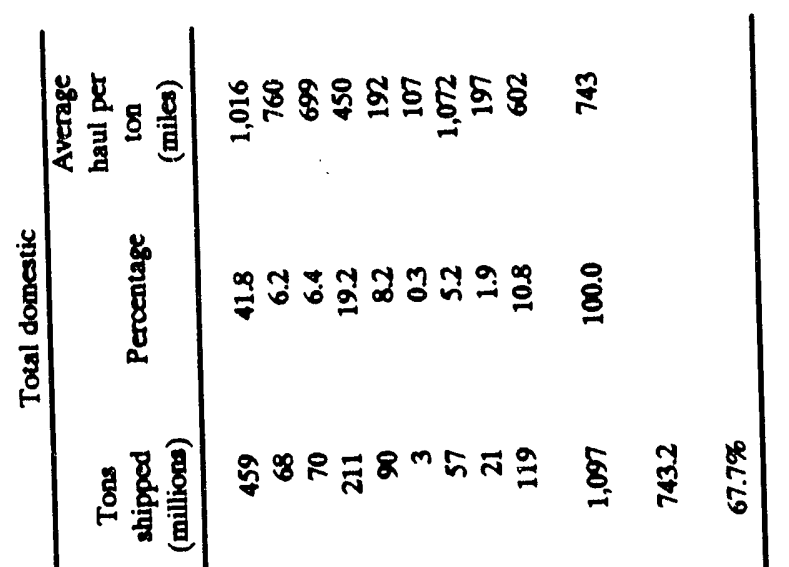

ช

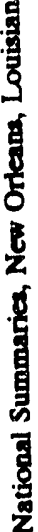

年|

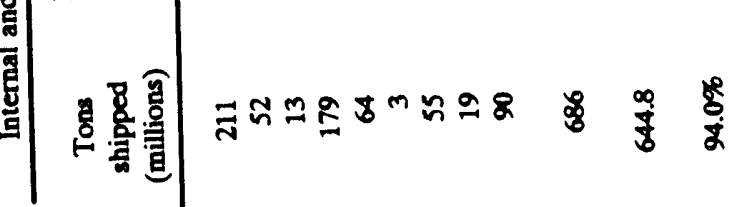

|

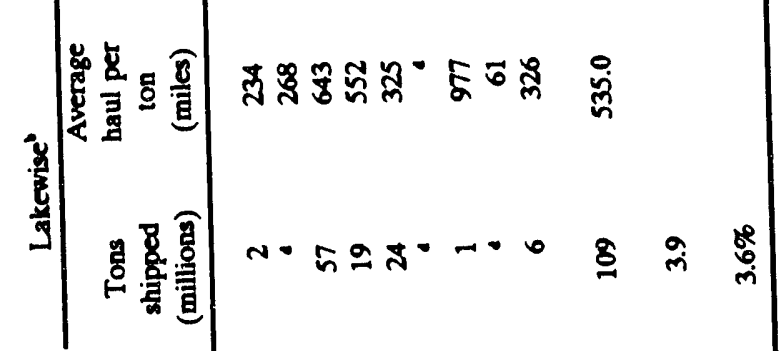

|

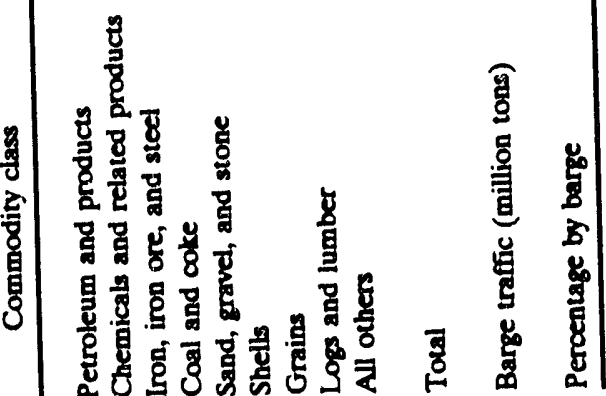

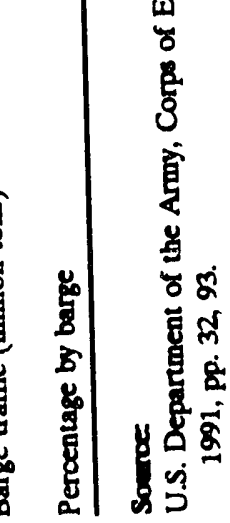

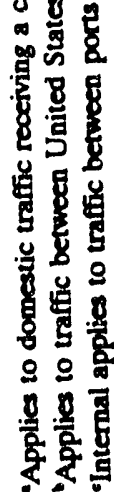




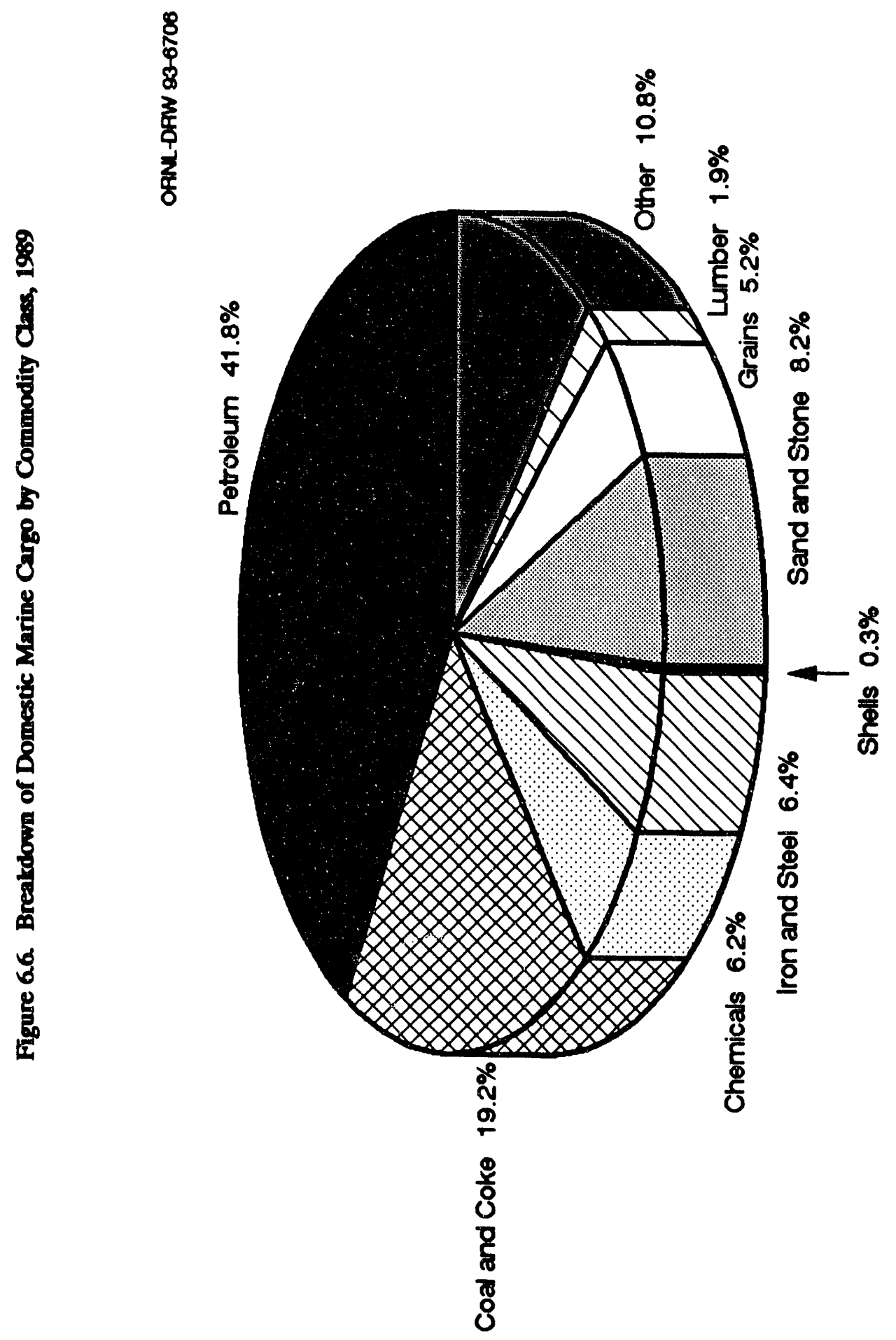

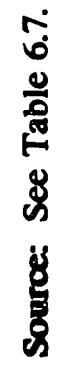


Section 6.3

Pipeline 
Although the tons of petroleum transported by pipeline fell slightly from 1989 to 1990, the tonmiles stayed constant, indicating a slight increase in the distance the petroleum was moved. This increase in transport distance was probably due to an increase in the movement of refined petroleum products, since crude petroleum had a slight decline in ton-miles from 1989 to 1990.

Table 68

Pipeline Shipments of Energy, 1972-90

\begin{tabular}{|c|c|c|c|c|c|c|}
\hline \multirow[b]{2}{*}{ Year } & \multirow{2}{*}{$\begin{array}{c}\text { Domestic } \\
\text { natural gas } \\
\text { consumption } \\
\text { (billion cubic feet) }\end{array}$} & \multicolumn{2}{|c|}{ Total petroleum transported } & \multirow{2}{*}{$\begin{array}{l}\text { Crude } \\
\text { petroleum } \\
\text { (billion } \\
\text { ton-miles) }\end{array}$} & \multirow{2}{*}{$\begin{array}{l}\text { Refined petroleum } \\
\text { products } \\
\text { (billion } \\
\text { ton-miles) }\end{array}$} & \multirow[b]{2}{*}{$\begin{array}{l}\text { Energy use } \\
\text { (trillion Btu) }\end{array}$} \\
\hline & & $\begin{array}{l}\text { (million } \\
\text { tons) }\end{array}$ & $\begin{array}{c}\text { (billion } \\
\text { ton-miles) }\end{array}$ & & & \\
\hline 1972 & 22,100 & 876 & 476 & $\mathbf{2 8 5}$ & 191 & 985.3 \\
\hline 1973 & 22,049 & 912 & 507 & 302 & 205 & 942.2 \\
\hline 1974 & 21,223 & 879 & 506 & 303 & 203 & 877.9 \\
\hline 1975 & 19,538 & 879 & 507 & 288 & 219 & 781.2 \\
\hline 1976 & 19,946 & 934 & 515 & 303 & 212 & 749.0 \\
\hline 1977 & 19,521 & 986 & 546 & 327 & 219 & 727.5 \\
\hline 1978 & 19,627 & 982 & 586 & 360 & 226 & 680.0 \\
\hline 1979 & 20,241 & 978 & 608 & 372 & 236 & 793.4 \\
\hline 1980 & 19,877 & 961 & 588 & 363 & 226 & 838.5 \\
\hline 1981 & 19,404 & 943 & 564 & 333 & 231 & 848.1 \\
\hline 1982 & 18,001 & 964 & 566 & 335 & 231 & 798.8 \\
\hline 1983 & 16,835 & 983 & 556 & 332 & 224 & 684.6 \\
\hline 1984 & 17,951 & 1,007 & 568 & 333 & 235 & 726.2 \\
\hline 1985 & 17,281 & 1,019 & 564 & 334 & 230 & 704.7 \\
\hline 1986 & 16,221 & 1,035 & 578 & 335 & 243 & 684.1 \\
\hline 1987 & 17,211 & 1,045 & 587 & 342 & 245 & 721.3 \\
\hline 1988 & 18,030 & 1,067 & 601 & 351 & 250 & 824.0 \\
\hline 1989 & 18,801 & 1,053 & 584 & 339 & 246 & 841.6 \\
\hline 1990 & 18,721 & 1,046 & 584 & 335 & 249 & 873.9 \\
\hline \multicolumn{7}{|c|}{ Average annual percentage change } \\
\hline $1972-90$ & $-0.9 \%$ & $1.0 \%$ & $1.1 \%$ & $0.9 \%$ & $1.5 \%$ & $-0.7 \%$ \\
\hline $1982-90$ & $0.5 \%$ & $1.0 \%$ & $0.4 \%$ & $0.0 \%$ & $0.9 \%$ & $1.1 \%$ \\
\hline
\end{tabular}

Sources:

Natural gas consumption - U.S. Department of Energy, Energy Information Administration, Natural Gas Annual 1990, Washington, DC, December 1991, p. 20, and annual.

Petroleum transport, crude petroleum, and refined petroleum products - Transportation Policy Associates, Transportation in America, Tenth edition, Washington, DC, 1992, pp. 46, 59.

Energy use - See Appendix A for Table 2.7.

"Natural gas consumption is the best available indicator for the amount of natural gas transported by pipeline.

'Represents energy use for natural gas, crude petroleum, and refined petroleum pipelines. 
6-22

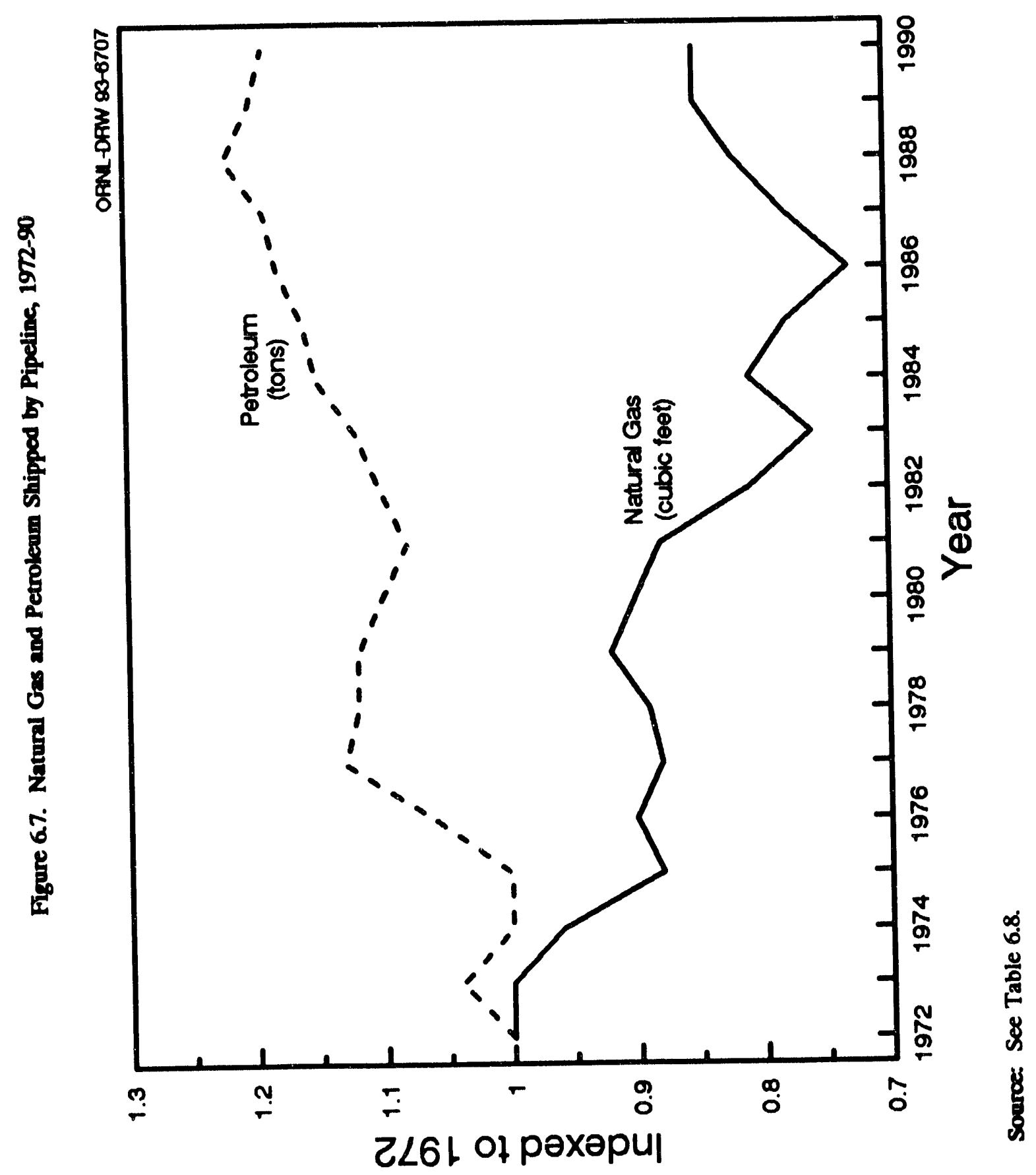


6-23

Section 6.4

Railroad 
Fourteen railroad systems in $\mathbf{1 9 9 0}$ were designated by the Interstate Commerce Commission (ICC) as Class I freight railroads (Table 6.9). This designation was assigned on the basis of the annual gross revenue of the railroad. A railroad whose revenues were 93.5 million dollars or more in 1989 was designated as a Class I railroad in 1990. The threshold for 1990 was set at $\mathbf{9 4 . 4}$ million dollars. The Class I designation is dropped if the railroad fails to meet the annual earnings threshold for three consecutive years.

The revenue ton-miles for Class I freight railroads continued to be over 1 trillion ton-miles in 1990, as the average length of haul rose slightly and ton-miles remained relatively constant from 1989 to 1990 . Train-miles and car-miles declined slightly from 1989 to 1990, while the number of Class I railroad locomotives and freight cars declined to the lowest point in the twenty-year series.

The railroad freight industry experienced a $22 \%$ drop in its revenue carloadings from 1974 to 1990. During this 16-year period, coal has not only remained the major commodity being hauled by the railroads, but its share of revenue carloads also increased by $30 \%$ from 1974 to 1990 . The largest decline, on the other hand, was for metallic ores, which dropped $78 \%$ during the period (Table 6.11).

The National Railroad Passenger Corporation (Amtrak) reached over 6 billion passenger-miles in 1990 and continued to increase in 1991. Car-miles increased to more than 300 million and train-miles to 33 million in 1990. The average trip length increased by 11 miles from 1989 to 1991 . Even with the increased activity of Amtrak, energy use declined slightly from 16 trillion Btu in 1989 to 15.7 trillion Btu in 1991 (Table 6.12).

Rail transit operations experienced increases in vehicle-miles and average trip length, but passenger-miles declined from 1989 to 1990 because of the drop in the number of passenger trips. Energy use also declined from 1989 to 1990 , possibly due to improvement in transit rail efficiency (Table 6.13). 
Table 6.9

Coss I Railroad Freight Systems in the United States Ranked by Revenue Ton-Miles, 1990

\begin{tabular}{lrr}
\hline \multicolumn{1}{c}{ Railroad } & $\begin{array}{c}\text { Revenue } \\
\text { ton-miles } \\
\text { (millions) }\end{array}$ & Percent \\
\hline Burlington Northern Railroad Company & 234,291 & 22.7 \\
Union Pacific Railroad & 189,599 & 18.3 \\
CSX Transportation, Incorporation & 149,362 & 14.5 \\
Norfolk Southern Corporation & 108,641 & 10.5 \\
Southern Pacific Transportation Company & 86,094 & 8.3 \\
Consolidated Rail Corporation (Conrail) & 84,106 & 8.1 \\
Atchison, Topeka and Santa Fe Railway & 77,929 & 7.5 \\
Chicago and North Western Transportation Company & 28,495 & 2.8 \\
Soo Line Railroad & 22,928 & 2.2 \\
Illinois Central Railroad & 17,518 & 1.7 \\
Denver and Rio Grande Western Railroad & 13,695 & 1.3 \\
Kansas City Southern Railway & 12,014 & 1.2 \\
Grand Trunk Corporation & 5,024 & 0.5 \\
Florida East Coast Railway & 4,274 & 0.4 \\
Total & & 100.0 \\
\hline
\end{tabular}

Source:

Association of American Railroads, Analysis of Class I Railroads 1990, July 1991, p. 163. 


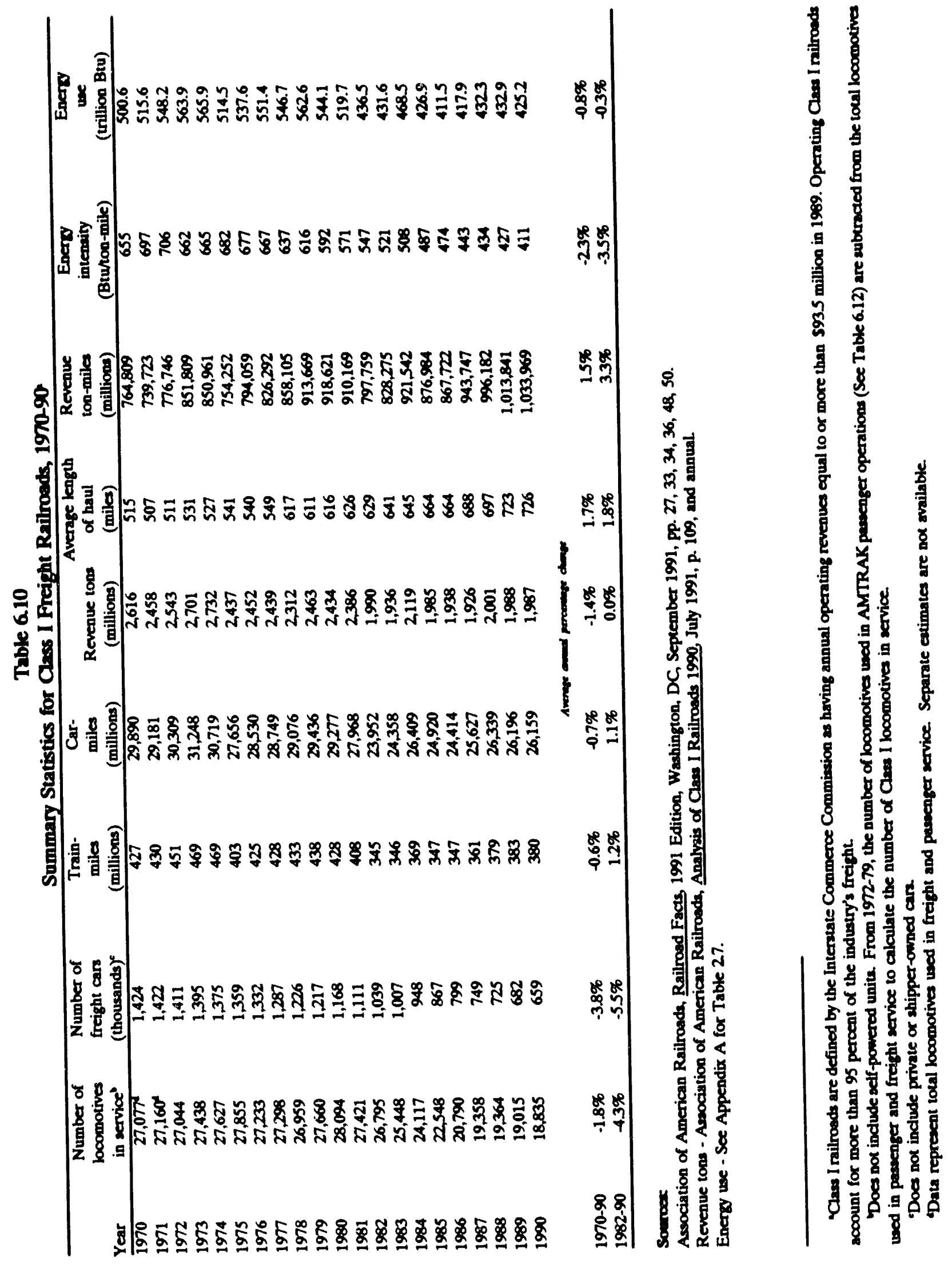




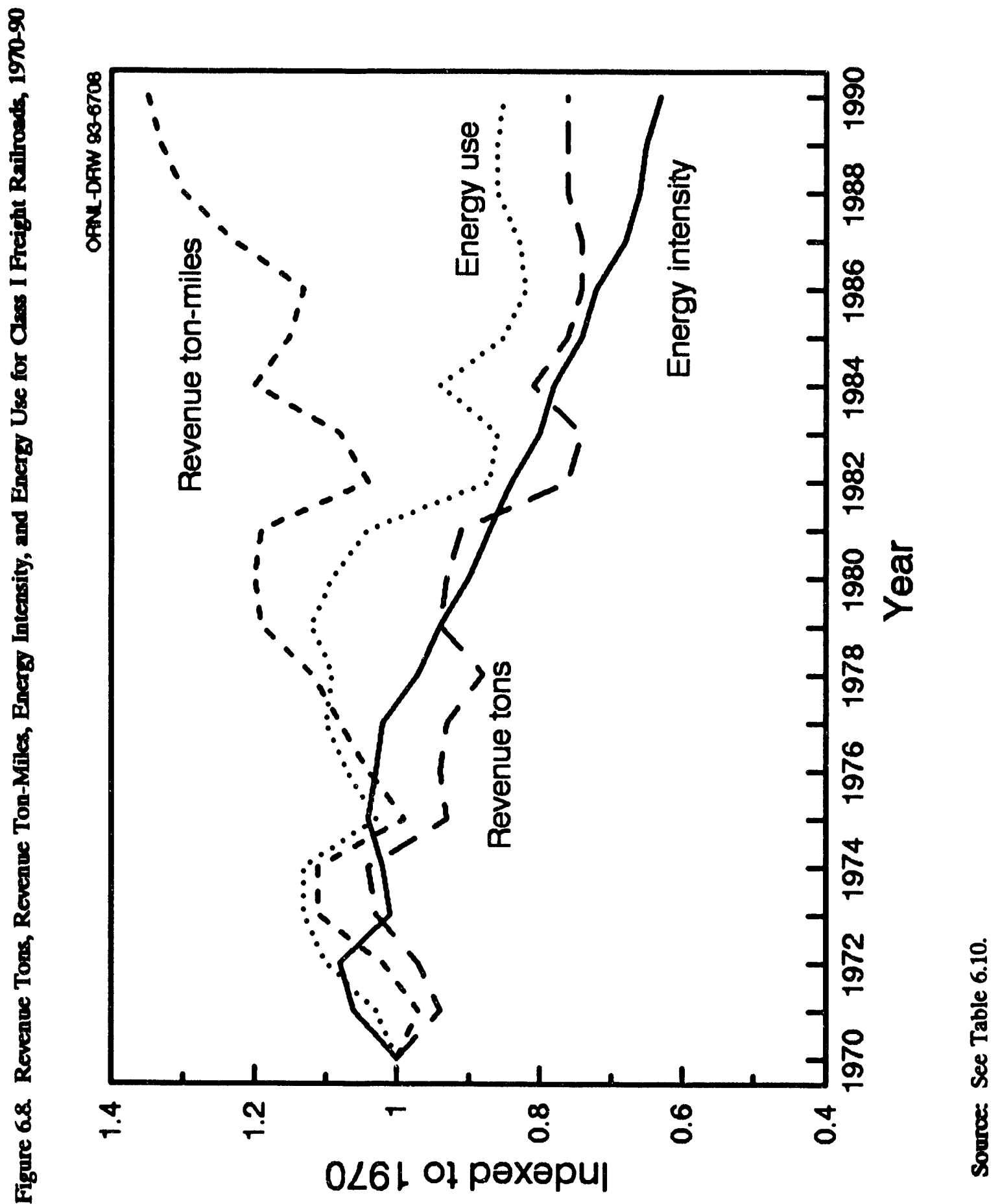


Although revenue carloadings declined by $20 \%$ from 1974 to 1990 , coal is still the commodity with the highest share of carloadings. Many commodities drastically reduced rail shipments from 1974 to 1990, such as stone, clay and glass; metallic ores; primary metal products; and lumber and wood products.

Table 6.11

Railroad Revenue Carloadings by Commodity Group, 1974 and 1990

\begin{tabular}{|c|c|c|c|c|}
\hline \multirow[b]{2}{*}{ Commodity group } & \multicolumn{2}{|c|}{$\begin{array}{l}\text { Carloadings } \\
\text { (thousands) }\end{array}$} & \multirow{2}{*}{$\begin{array}{c}1990 \\
\text { Percent } \\
\text { distribution }\end{array}$} & \multirow{2}{*}{$\begin{array}{c}\text { Percentage } \\
\text { change } \\
1974-90\end{array}$} \\
\hline & $\overline{1974}$ & 1990 & & \\
\hline Coal & 4,544 & 5,912 & 27.6 & 30.1 \\
\hline Farm products & 3,021 & 1,690 & 7.9 & -44.1 \\
\hline Chemicals and allied products & 1,464 & 1,531 & 7.2 & 4.6 \\
\hline Nonmetallic minerals & 821 & 1,202 & 5.6 & 46.4 \\
\hline Food and kindred products & 1,777 & 1,307 & 6.1 & -26.4 \\
\hline Lumber and wood products & 1,930 & 780 & 3.6 & -59.6 \\
\hline Metallic ores & 1,910 & 508 & 2.4 & -73.4 \\
\hline Stone, clay and glass & 2,428 & 539 & 2.5 & -77.8 \\
\hline Pulp, paper, and allied product: & 1,180 & 611 & 2.9 & -48.2 \\
\hline Petroleum products & 877 & 573 & 2.7 & -34.7 \\
\hline Primary metal products & 1,366 & 477 & 2.2 & -65.1 \\
\hline Waste and scrap material & 889 & 439 & 2.1 & 50.6 \\
\hline Transportation equipment & 1,126 & 1.091 & 5.1 & -3.1 \\
\hline Others & 3,451 & 4,741 & 22.2 & 37.4 \\
\hline Total & 26,784 & 21,401 & 100.0 & -20.1 \\
\hline
\end{tabular}

Sources:

1974 - Association of American Railroads, Railroad Facts, 1976 Edition, Washington, DC, 1975, p. 26.

1990 - Fsssociation of American Railroads, Railroad Facts, 1991 Edition, Washington, DC, September 1991, p. 23. 


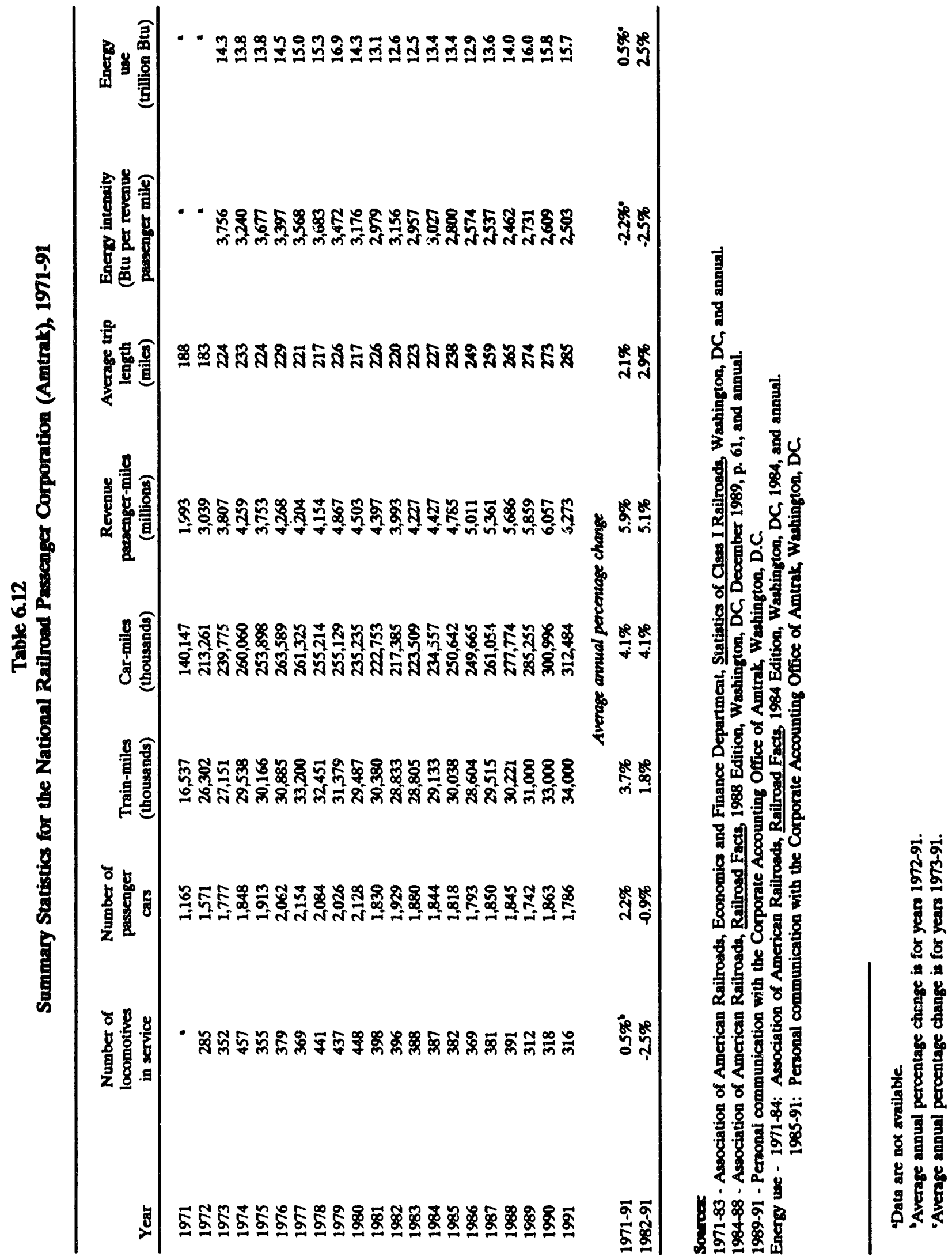




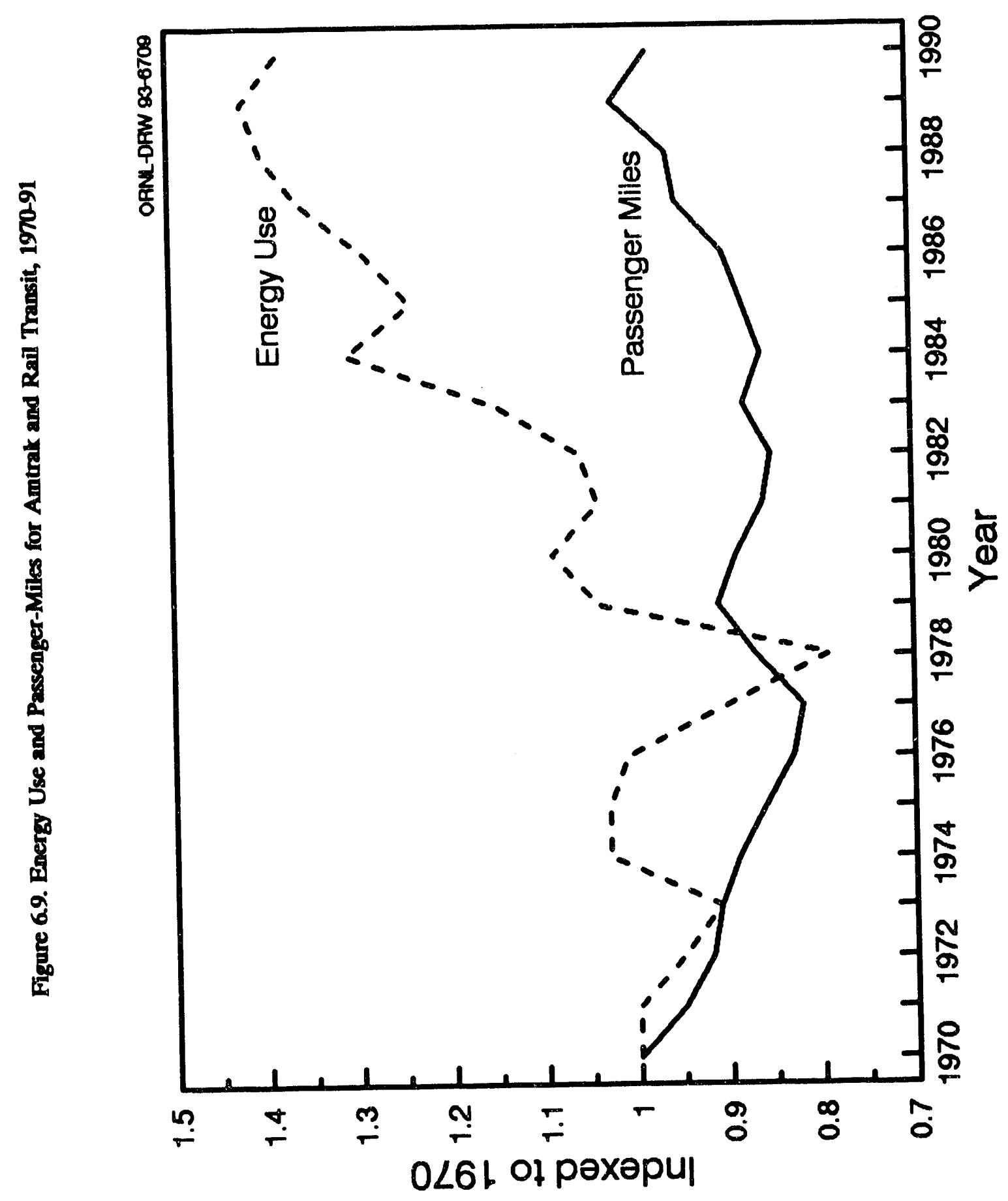



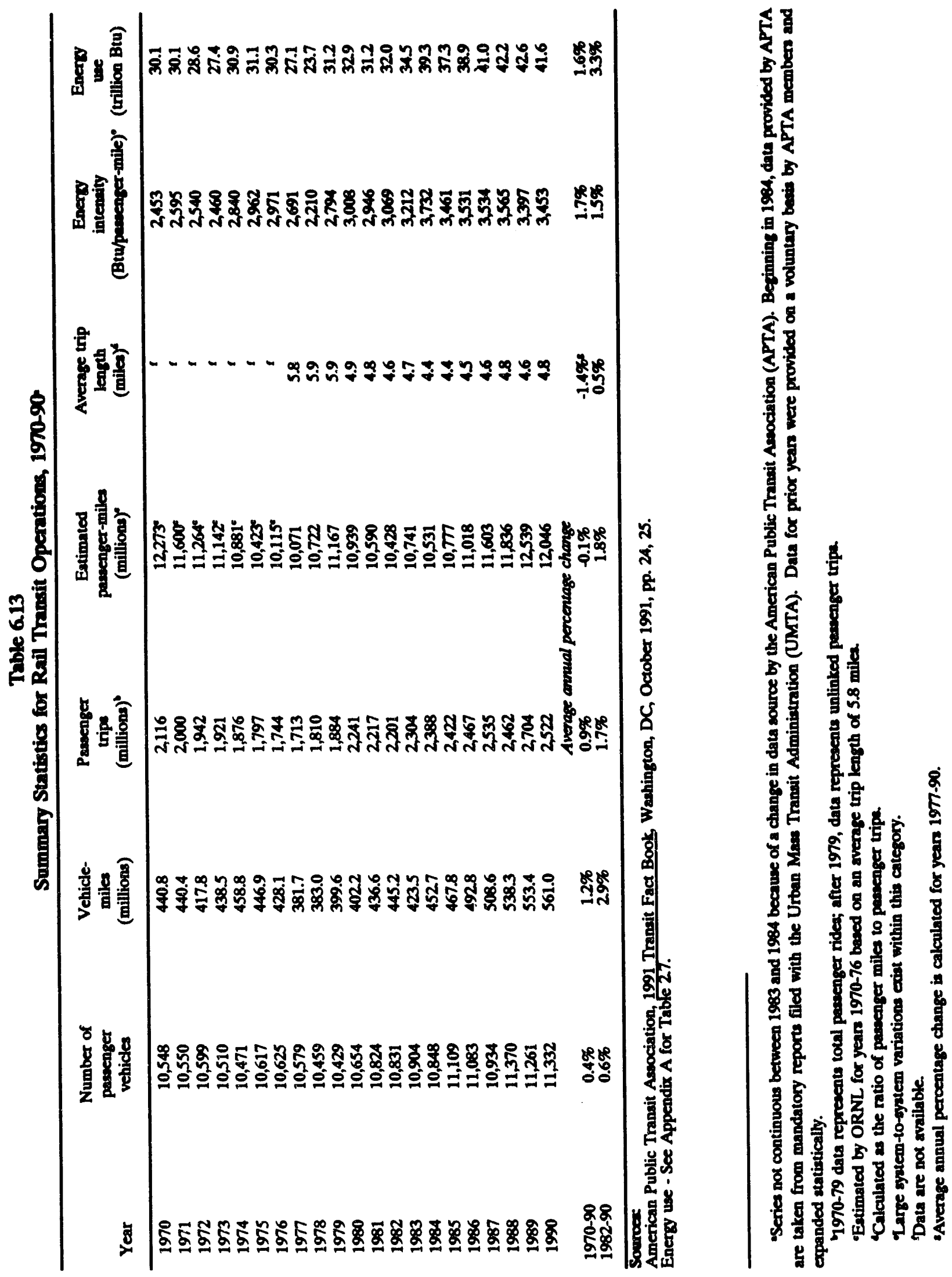


\section{APPENDIX A}

\section{SOURCES}

This appendix, first included in Edition 10 of the Transportation Energy Data Book, contains documentation of the estimation procedures used by ORNL. The reader can examine the methodology behind the estimates and form an opinion as to their utility.

The appendix is arranged by table number and subject heading. Only tables which contain ORNL estimations are documented in Appendix A; all other tables have sources listed at the bottom of the table. Abbreviations are used throughout the appendix; so a list of abbreviations is also included. 


\section{List of Abbreviations Used in Appendix A}

\begin{tabular}{ll} 
AAR & Association of American Railroads \\
APTA & American Public Transit Association \\
Amtrak & National Railroad Passenger Corporation \\
Btu & British thermal unit \\
DOC & Department of Commerce \\
DOE & Department of Energy \\
DOT & Department of Transportation \\
EIA & Energy Information Administration \\
EPA & Environmental Protection Agency \\
FAA & Federal Aviation Administration \\
FHWA & Federal Highway Administration \\
gVw & gross vehicle weight \\
Ipg & liquefied petroleum gas \\
MIC & Motorcycle Industry Council \\
mpg & miles per gallon \\
MVMA & Motor Vehicle Manufacturers Association \\
NHTSA & National Highway Traffic Safety Administration \\
NPTS & Nationwide Personal Transportation Study \\
ORNL & Oak Ridge National Laboratory \\
pmt & passenger-miles traveled \\
RECS & Residential Energy Consumption Survey \\
RTECS & Residential Transportation Energy Consumption Survey \\
TIUS & Truck Inventory and Use Survey \\
TPA & Transportation Policy Associates \\
TSC & Transportation Systems Center \\
vmt & vehicle-miles traveled \\
\hline
\end{tabular}


Tablé 27

Domestic Consumption of Transportation Energy by Mode and Fuel Type, 1990

Most of the source data were given in gallons. It was converted to Btu by using the conversion factors in Appendix B.

\section{Highway}

\section{Automobiles}

Total gallons of fuel taken from DOT, FHWA, Highway Statistics 1990, Table VM1, p. 192. These were distributed as follows: $98.8 \%$ gasoline and $1.2 \%$ diesel. Percentages were derived from the DOE, EIA, Office of Markets and End Use, Energy End Use Division, Household Vehicles Energy Consumption 1988, March 1990 , p. 65.

\section{Motorcycles}

DOT, FHWA, Highway Statistics 1990, Table VM-1, p.192. For conversion purposes, fuel for all motorcycles was assumed to be gasoline.

\section{Buses}

Transit:

Diesel: APTA, 1991 Transit Fact Book, October 1991, Washington, DC, p. 93.

Gasoline: Total gallons of gasoline used by transit vehicles taken from APTA, 1991 Transit Fact Book, October 1991, Washington, DC, p. 93. According to APTA's Research and Statistics Department, motor bus accounts for approximately $5 \%$ of total transit gasoline use.

Intencity:

Estimate provided by Frank Smith, Transportation Policy Associates, Washington, DC.

\section{Schook:}

Estimate provided by Frank Smith, Transportation Policy Associates, Washington, DC.

Trucks

Total:

Sum of light trucks and other trucks. 
Light Trucks:

DOT, FHWA, Highway Statistics 1990 , Table VM-1, p. 192, for single-unit, 2axle, 4-tire trucks. $96.6 \%$ of fuel assumed to be gasoline, $3.3 \%$ diesel, and $0.1 \% \mathrm{lpg}$; percentages were generated from the 1987 TIUS Public Use Tape.

\section{Other Trucks:}

DOT, FHWA, Highway Statistics 1990 Table VM-1, p. 192. Total gallons for other trucks was the difference between total and 2-axle, 4-tire trucks. These gallons were distributed as follows based on data from the 1987 TIUS Public Use Tape: $19.4 \%$ of fuel assumed to be gasoline, $80.4 \%$ diesel, and $0.2 \% \mathrm{lpg}$.

\section{Off Highway}

Data supplied by Marianne Mintz, Argonne National Laboratory, from the Public Use Data Base, National Energy Accounts, DOC, OBA-NEA-10, August 1988.

\section{Non-Highway}

Air

\section{General Aviation:}

DOT, FAA, General Aviation Activity and Avionics Survey: Annual Summary Report Calendar Year 1990, Table 5.1, p. 5-6. Jet fuel was converted from gallons to Btu using 135,000 Btu/gallon (kerosene-type jet fuel).

\section{Damestic and Intemational Air Carrier:}

DOT, Research and Special Programs Administration, Data Administration Division, "Fuel Cost and Consumption Tables;" annual figures were obtained by summing monthly totals. Because the data for international included fuel purchased abroad, the international total was divided in half to estimate domestic fuel purchases for international flights.

Water

Freight:

Total - DOE, EIA, Fuel Oil and Kerosene Sales, 1990, p.42. Adjusted sales of distillate and residual fuel oil for vessel bunkering. 
Domestic and Foreign - Total freight energy use was distributed as follows: Distillate fuel - $77.5 \%$ domestic, $22.5 \%$ foreign

Residual fuel $-9.3 \%$ domestic, $90.7 \%$ foreign

Percentages were derived from the DOC, U.S. Foreign Trade, Bunker Fuels, "Oil and Coal Laden in the U.S. on Vessels Engaged in Foreign Trade," 1988. This report was discontinued in 1989.

\section{Recreational Boating:}

Fuel use by recreational boating was calculated using the methodology developed by D. L. Greene in the report, Off-Highway Use of Gasoline in the United States (DOT, FHWA, July 1986, p. 3-22). Results from Model 1 in the report indicated an average annual consumption of 205 gallons per boat. Total consumption in gallons was then calculated using the following equation: Total $=0.95$ (Gal/boat) (number of boats). An estimate of number of recreational boats in operation was found in Boating Industry Magazine, Annual Report, "The Boating Business 1990" (Communication Channels, Inc., Chicago, IL). The total was the sum of inboard, outboard and inboard/outdrive boats.

\section{Pipeline}

\section{Natural Gas:}

The amount of natural gas used to transport natural gas was defined as "pipeline fuel" as reported in DOE, EIA, Natural Gas Annual 1990, Table 1, p. 20. Cubic feet were converted to Btu using $1,031 \mathrm{Btu} / \mathrm{ft}^{3}$. Electricity use was estimated using the following procedure as reported on p. 5-110 of J. N. Hooker et al., End Use Energy Consumption DataBase: Transportation Sector. The energy consumption of a natural gas pipeline was taken to be the energy content of the fuel used to drive the pumps. Some $94 \%$ of the installed pumping horsepower was supplied by natural gas. The remaining $6 \%$ of the horse power was generated more efficiently, mostly by electric motors. The energy consumed by natural gas pipeline pumps that were electrically powered was not known. In order to estimate the electricity consumed, the Btu of natural gas pipeline fuel consumed was multiplied by a factor of 0.015 . From this computed value, electricity efficiency and generation loss must be taken into account. The electricity energy use in Btu must be converted to $\mathrm{kWhr}$, using the conversion factor $29.305 \times 10^{-5} \mathrm{kWhr} / \mathrm{Btu}$. Electricity generation and distribution efficiency was $29 \%$. When generation and distribution efficiency are taken into account, $1 \mathrm{kWhr}$ equals $11,765 \mathrm{Btu}$. 
Crude petrolewm and petroleum product:

J. N. Hooker, Oil Pipeline Energy Consumption and Efficiency, ORNL-5697, ORNL, Oak Ridge, TN, 1981. (Latest available data.)

\section{Coal slumy and water.}

W. F. Banks, Systems, Science and Software, Energy Consumption in the

Pipeline Industry, LaJolla, CA, October 1977. (Latest available data.)

Rail

Total:

DOE, EIA, Fuel Oil and Kerosene Sales, 1990, p.42. Adjusted sales of deliveries of distillate fuel oil for railroad.

Freight:

Distillate fuel oil was obtained by subtracting total passenger fuel use from total distillate as reported by EIA.

Passenger:

Transit and Commuter - APTA, 1991 Transit Fact Book, October 1991, Washington, DC, p. 93. Transit was defined as the sum of "heavy rail" and "all other."

Intercity - Sum of fuel used by Amtrak and Class I passenger trains. Source for Amtrak was personal communication with the Corporate Accounting Office of Amtrak, Washington, DC. Source for fuel use by Class I passenger trains was the AAR, Statistics of Class I Railroads 1990, July 1991, p. 157. Fuel use for Class I passenger was derived as follows: fuel use for passenger locomotive, including weighted percent of fuel for yard switching. Diesel fuel consumed by work train was not included as it was considered to be indirect energy.

\section{Military Operations}

Defense Logistics Agency, Defense Fuel Supply Center, Fact Book Fiscal Year 1990, "Barrels and Dollars per Barrel," p. 33. For conversion purposes, estimates of jet fuel purchases were $64 \% \mathrm{JP} 4,22 \% \mathrm{JP5}$, and 14\% JP8, based on the breakdown from "Petroleum Procurement," p. 31. The purchases were the best estimates available for fuel consumption, both domestic and abroad. An estimate of $68.9 \%$ was purchased in the United States. 
Table 210

Transportation Energy Consumption by Mode, 1970-90

\section{Highway}

\section{Automobiles}

Total gallons of fuel for automobiles was taken from DOT, FHWA, Highway Statistics Summary to 1985, Table VM-201A; and Table VM-1 in the 1986-90 annual editions. Fuel for automobiles was distributed between fuel types for conversion into Btu's as follows:

$1970-80-94.7 \%$ gasoline, $5.3 \%$ diesel as reported in the DOE, EIA, Office of Energy Markets and End Use, Residential Energy Consumption Survey: Consumption Patterns of Household Vehicles. June 1979 to December 1980 , p. 10.

1981-82 - $94.1 \%$ gasoline, $5.9 \%$ diesel as reported in the DOE, EIA, Office of Energy Markets and End Use, Residential Energy Consumption Survey: Consumption Patterns of Household Vehicles, Supplement: January 1981 to September 1981, pp. 11, 13.

1983-84 - 97.5\% gasoline, $2.5 \%$ diesel as reported in the DOE, EIA, Office of Markets and End Use, Energy End Use Division, Residential Transportation Energy Consumption Survey: Consumption Patterns of Household Vehicles, 1983, Jan., 1985, pp. 7, 9.

1985-87 - $98.5 \%$ gasoline, $1.5 \%$ diesel as reported in the DOE, EIA, Office of Energy Markets and End Use, Residential Transportation Energy Consumption Survey: Consumption Patterns of Household Vehicles 1985, April 1987, pp. 25, 27.

1988-90 - 98.8\% gasoline and 1.2\% diesel as reported in the DOE, EIA, Office of Markets and End Use, Energy End Use Division, Household Vehicles Energy Consumption 1988, March 1990, p. 65.

\section{Motorcycles}

Department of Transportation, $F$ ral Highway Administration, Highway Statistics Summary to 1985, Table VM-201A; and Table VM-1 in the 1986-90 annual editions. For conversion purposes, fuel for all motorcycles was assumed to be gasoline.

Buses

Sum of transit, intercity and school. 
Transit:

Diesel - APTA, 1991 Transit Fact Book, October 1991, Washington, DC, p. 93, and annual.

Gasoline - Total gallons of gasoline used by transit vehicles taken from APTA, 1991 Transit Fact Book, October 1991, Washington, DC, p. 93. According to APTA's Research and Statistics Department, motor bus accounts for approximately $5 \%$ of total transit gasoline use.

Intercity:

1970-84 - American Bus Association, Annual Report, Washington, DC, annual.

1985-86 - Eno Transportation Foundation, Transportation in America, Seventh edition, Washington, DC, p. 9.

1987-90 - Personal communication with Frank Smith, TPA, Washington, DC.

School:

1970-84 - DOT, FHWA, Highway Statistics 1984, Washington, DC,

Table VM-1, and annual.

1985-86 - DOT, Research and Special Programs Administration, National

Transportation Statistics, Figure 2, p. 5, and annual.

1987-90 - Personal communication with Frank Smith, TPA, Washington, DC.

Trucks

Light Trucks:

Defined as 2-axle, 4-tire trucks. Total gallons of fuel was taken from DOT, FHWA, Highway Statistics Summary to 1985, Table VM-201A, and Table VM-1 of the 1986-90 annual editions. Based on data from the 1982 TIUS Public Use Tape, fuel use for 1970-1987 was distributed among fuel types as follows: $95.3 \%$ gasoline; $3.5 \%$ diesel; and $1.2 \% \mathrm{lpg}$. Fuel use for 1990 was distributed based on the 1987 TIUS: $96.6 \%$ gasoline; $3.3 \%$ diesel; and $0.1 \%$ lpg.

Other Trucks:

Defined as the difference between total trucks and 2-axle, 4-tire trucks. Total gallons of fuel was taken from DOT, FHWA, Highway Statistics Summary to 1985, Table VM-201A, and Table VM-1 of the 1986-90 annual editions. Based on data from the 1982 TIUS Public Use Tape, fuel use for 1970-1987 was distributed among fuel types as follows: $39.6 \%$ gasoline; $59.4 \%$ diesel; and $1.0 \% \mathrm{lpg}$. Fuel use for $1988-90$ was distributed based on the 1987 TIUS: $19.4 \%$ gasoline; $80.4 \%$ diesel; and $0.2 \%$ lpg. 


\section{Total Highway}

Sum of autos, motorcycles, buses, light trucks, and other trucks.

\section{Non-Highway}

Air

Sum of fuel use by General Aviation and Certificated Route Air Carrier.

General Aviation:

1970-74 - DOT, TSC, National Transportation Statistics, Cambridge, MA, 1981. 1975-85 - DOT, FAA, FAA Aviation Forecasts, Washington, DC, annual. 1985-90 - DOT, FAA, General Aviation Activity and Avionics Survey: Annual Summary Report, Calendar Year 1990, Table 5.1, p. 5-6. Jet fuel was converted from gallons to Btu using 135,000 Btu/gallon (kerosene-type jet fuel).

\section{Certificated Route Air Carrier.}

1970-81 - DOT, Civil Aeronautics Board, Fuel Cost and Consumption, Washington, DC, annual.

1982-90 - DOT, Research and Special Programs Administration, Data Administration Division, "Fuel Cost and Consumption Tables;" annual figures were obtained by summing monthly totals. Because the data for international included fuel purchased abroad, the international total was divided in half to estimate domestic fuel purchases for international flights.

\section{Water}

Sum of vessel bunkering fuel (i.e., freight) and fuel used by recreational boats.

\section{Freight:}

Total - DOE, EIA, Fuel Oil and Kerosene Sales, 1990, p.42. Adjusted sales of distillate and residual fuel oil for vessel bunkering.

Domestic and Foreign - 1970-88 - DOC, U.S. Foreign Trade, Bunker Fuels, "Oil and Coal Laden in the U.S. on Vessels Engaged in Foreign Trade," 1988, annual. In this were fuel oil (i.e., residual) and diesel oil laden in the U.S. on vessels engaged in foreign trade. The totals for residual and diesel used by foreign vessels and American vessels for foreign trade were subtracted from the EIA totals for residual and diesel deliveries to obtain the value for domestic trade.

1989-90 - Total freight energy use was distributed as follows:

Distillate fuel - $77.5 \%$ domestic, $22.5 \%$ foreign

Residual fuel $-9.3 \%$ domestic, $90.7 \%$ foreign 
Percentages were derived from the DOC, U.S. Foreign Trade, Bunker Fuels, "Oil and Coal Laden in the U.S. on Vessels Engaged in Foreign Trade," 1988. This report was discontinued in 1989.

\section{Recreational Boating:}

1970-1984 - DOT, FHWA, Highway Statistics, Washington, DC,

Table MF-24, annual.

1985-1990 - Fuel use by recreational boating was calculated using the methodology developed by D. L. Greene in the report, Off-Highway Use of Gasoline in the United States (DOT, FHWA, July 1986, p. 3-22). Results from Model 1 in the report indicated an average annual consumption of 205 gallons per boat. Total consumption in gallons was then calculated using the following equation: Total $=0.95$ (Ga/boat) (number of boats). An estimate of number of recreational boats in operation was found in Boating Industry Magazine, Annual Report, "The Boating Business 1990" (Communication Channels, Inc., Chicago, IL). The total was the sum of inboard, outboard and inboard/outdrive boats.

\section{Pipeline}

\section{Natural Gas:}

The amount of natural gas used to transport natural gas was defined as "pipeline fuel" as reported in DOE, EIA, Natural Gas Annual 1990, Table 1, p. 20. Cubic feet were converted to Btu using $1,031 \mathrm{Btu} / \mathrm{ft}^{3}$. Electricity use was estimated using the following procedure as reported on p. 5-110 of J. N. Hooker et al., End Use Energy Consumption DataBase: Transportation Sector. The energy consumption of a natural gas pipeline was taken to be the energy content of the fuel used to drive the pumps. Some $94 \%$ of the installed pumping horsepower was supplied by natural gas. The remaining $6 \%$ of the horse power was generated more efficiently, mostly by electric motors. The energy consumed by natural gas pipeline pumps that were electrically powered was not known. In order to estimate the electricity consumed, the Btu of natural gas pipeline fuel consumed was multiplied by a factor of 0.015 . From this computed value, electricity efficiency and generation loss must be taken into account. The electricity energy use in Btu must be converted to $\mathrm{kWhr}$, using the conversion factor $29.305 \times 10^{-5} \mathrm{kWhr} / \mathrm{Btu}$. Electricity generation and distribution efficiency was $29 \%$. When generation and distribution efficiency are taken into account, $1 \mathrm{kWhr}$ equals $11,765 \mathrm{Btu}$.

\section{Crude petroleum and petroleum product:}

J. N. Hooker, Oil Pipeline Enercy Consumption and Efficiency, ORNL-5697, ORNL, Oak Ridge, Tennessee, 1981. (Latest available data.) 


\section{A-11}

Coal shury and water:

W. F. Banks, Systems, Science and Software, Energy Consumption in the

Pipeline Industry, LaJolla, California, October 1977. (Latest available data.)

Rail

Total:

DOE, EIA, Fuel Oil and Kerosene Sales, 1990, p.42, annual. Adjusted sales of distillate fuel oil for railroad.

Freight:

Distillate fuel oil was obtained by subtracting total passenger fuel use from total distillate as reported by EIA.

Passenger.

Transit and Commuter - APTA, 1991 Transit Fact Book, October 1991, Washington, DC, p. 93, annual. Transit was defined as the sum of "heavy rail" and "all other."

Intercity - Sum of fuel used by Amtrak and Class I passenger trains. Source for Amtrak was personal communication with the Corporate Accounting Office of Amtrak, Washington, DC. Source for fuel use by Class I passenger trains was the AAR, Statistics of Class I Railroads 1990, July 1991, p. 157, annual. Fuel use for Class I passenger was derived as follows: fuel use for pass nnger locomotive, including weighted percent of fuel for yard switching. Diesel fuel consumer by work train was not included as it was considered to be indirect er.ergy. 
Table 2.12

Passenger Travel and Energy Use in the United States, 1990

\section{Highway}

\section{Automobiles}

Number of Vehicles - DOT, FHWA, Highway Statistics 1990, Table VM-1, p. 192.

Vmt - DOT, FHWA, Highway Statistics 1990, Table VM-1, p. 192.

Pmt - Calculated by ORNL (load factor times vmt).

Load Factor - DOT, FHWA, Office of Highway Information Management, 1990 NPTS, Public Use Tape, 1992.

Energy Use - Total gallons of fuel taken from DOT, FHWA, Highway Statistics 1990, Table VM-1, p. 192. These were distributed as follows: $98.8 \%$ gasoline and $1.2 \%$ diesel. Percentages were derived from the DOE, EIA, Office of Markets and End Use, Energy End Use Division, Household Vehicles Energy Consumption 1988, March 1990, p. 65.

\section{Personal Trucks}

Number of Vehicles - Based on the 1987 TIUS, $68.6 \%$ of total 2-axle, 4-tire trucks and $11.1 \%$ of tota! other trucks were for personal use. Therefore, $68.6 \%$ of total 2-axle, 4-tire trucks (as reported by DOT, FHWA in Highway Statistics 1990, Table VM-1, p. 192) and $11.1 \%$ of total other trucks were estimated to be for personal use.

$V m t-62.7 \%$ of total vehicle miles traveled by 2-axle, 4-tire trucks (as reported by DOT, FHWA in Highway Statistics 1990 , Table VM-1, p. 192) and $2.3 \%$ of total vehicle miles traveled by other trucks were for personal use. The percentages were derived by ORNL from the 1987 TIUS public use tape.

Pmt - Calculated by ORNL as vmt multiplied by load factor.

Load Factor - DOT, FHWA, Office of Highway Information Management, 1990 NPTS, Public Use Tape, 1992.

Energy Use - Assuming that there is no difference in fuel economy (measured in miles per gallon) between personal-use trucks and non-personal use trucks, $62.7 \%$ of total fuel consumption by 2-axle, 4-tire trucks (as reported by DOT, FHWA in Highway Statistics 1990 , Table VM-1, p. 192) and $2.3 \%$ of total other truck fuel consumption was for personal use. These percentages were derived by ORNL from the 1987 TIUS Public Use tape. Total truck energy use was the sum of light truck and other truck energy use.

Light Trucks: DOT, FHWA, Highway Statistics 1990, Table VM-1, p. 192, for single-unit, 2-axle, 4-tire trucks. $96.6 \%$ of fuel arsumed to be gasoline, $3.3 \%$ diesel, and $0.1 \% \mathrm{lpg}$; percentages were generated from the 1987 TIUS Public Use Tape. 
Other Trucks: DOT, FHWA, Highway Statistics 1990, Table VM-1, p. 192. Total gallons for other trucks was the difference between total and 2-axle, 4-tire trucks. These values were distributed based on data from the 1987 TIUS Public Use Tape: $19.4 \%$ of fuel assumed to be gasoline, $80.4 \%$ diesel, and $0.2 \% \mathrm{lpg}$.

\section{Motorcycles}

Number of Vehicles and Vmt - DOT, FHWA, Highway Statistics 1990, Table VM-1, p. 192.

Pmt - Calculated by ORNL as vmt multiplied by load factor.

Load Factor - DOT, FHWA, Office of Highway Information Management, 1990 NPTS, Publlic Use Tape, 1992.

Energy Use - DOT, FHWA, Highway Statistics 1990, Table VM-1, p. 192. For conversion purposes, fuel for all motorcycles was assumed to be gasoline.

Buses

Transit:

Number of Vehicles, Vmt, Pmt, and Energy Use - Motor bus only. APTA, 1991 Transit Fact Book, October 1991, Washington, DC, pp. 24-26.

Load Factor - Calculated by ORNL as pmt/vmt.

Intercity:

Number of Vehicles - Estimated by ORNL as $18 \%$ of commercial bus registrations, DOT, FHWA, Highway Statistics 1990, p. 20.

Pmt - Eno Transportation Foundation, Transportation in America, Tenth Edition, Washington, DC, 1992, p. 47.

Energy Use - Personal communication with Frank Smith, TPA, Washington, DC.

School:

Number of Vehicles - School and other nonrevenue as reported in DOT, FHWA, Highway Statistics 1990, p. 20.

Energy Use - Personal communication with Frank Smith, TPA, Washington, DC.

Load Factor - Calculated by ORNL as pmt/vmt.

Pmt - National Safety Council, Accident Facts, 1991 Edition, Chicago, IL, p. 70. 


\section{Non-Highway}

Air

Lange Certified Route Air Carriers:

Vmt - Revenue aircraft miles flown, DOT, FAA, FAA Statistical Handbook of Aviation Calendar Year 1990 p. 6-4.

Pmt - Revenue pmt of domestic operations, scheduled and unscheduled, DOT, FAA, FAA Statistical Handbook of Aviation Calendar Year 1990 , p. 6-4.

Load Factor - Calculated by ORNL as pmt/vmt.

Energy Use - DOT, Research and Special Programs Administration, Data Administration Division, "Fuel Cost and Consumption Tables;" annual figures were obtained by summing monthly totals. Because the data for international included fuel purchased abroad, the international total was divided by two to estimate domestic fuel purchases for international flights.

\section{General Aviation:}

Number of Vehicles, Vmt, Energy Use - DOT, FAA, General Aviation Activity and Avionics, Survey: Calendar Year 1990, pp. 2-8, 3-13, 5-6.

Pmt - Eno Transportation Foundation, Transportation in America, Tenth Edition, Washington, DC, 1992, p. 47.

Load Factor - Calculated by ORNL as pmt/vmt.

\section{Recreational Boating}

Number of Vehicles - Whitney Communications, Boating Industry Magazine, Annual Report, "The Boating Business 1990." The total was the sum of inboard, outboard, and inboard/outdrive boats.

Energy Use - Fuel use by recreational boating was calculated using the methodology developed by D. L. Greene in the report, OffHighway Use of Gasoline in the United States (DOT, FHWA, July 1986, p. 3-22). Results from Model 1 in the report indicated an average annual consumption of 205 gallons per boat. Total consumption in gallons was then calculated using the following equation: Total $=0.95$ (Gal/boat) (number of boats). An estimate of number of recreational boats in operation was found in Boating Industry Magazine, Annual Report, "The Boating Business 1990" (Communication Channels, Inc., Chicago, IL). The total was the sum of inboard, outboard and inboard/outdrive boats. 
Rail

Intercity:

Number of Vehicles, Vmt and Pmt - Personal communication with the Corporate Accounting Office of Amtrak, Washington, DC.

Load Factor - Calculated by ORNL as pmt/vmt.

Energy Use - Personal communication with the Accounting Division of Amtrak, Washington, DC.

\section{Transit and Commuter:}

Number of Vehicles, Vmt and Pmt - APTA, 1991 Transit Fact Book,

October 1991, Washington, DC, pp. 24-26.

Load Factor - Calculated by ORNL as pmt/vmt.

Enengy Use - APTA, 1991 Transit Fact Book, October 1991, Washington,

DC, p. 93. Transit was defined as the sum of "heavy rail" and "all other." 
Table 213

Energy Intensities of Passenger Modes, 1970-90

In reference to transportation, the energy intensity of a mode is the ratio of the energy inputs to a process to a measure of the useful outputs from that process; for example, Btu per pmt or Btu per ton-mile. The energy intensity ratios in Table 2.14 were calculated for each passenger mode using the following data sources:

\section{Highway}

\section{Automobiles}

Vmt - DOT, FHWA, Highway Statistics Summary to 1985, Table VM-201A, and Table VM-1 of the 1987-90 editions.

Pmt - vmt times load factor.

Energy Use - Total gallons of fuel for automobiles was taken from DOT, FHWA, Highway Statistics Summary to 1985, Table VM-201A; and Table VM-1 in the 1986-90 annual editions. Fuel for automobiles was distributed between fuel types for conversion into Btu's as follows:

$1970-80-94.7 \%$ gasoline, $5.3 \%$ diesel as reported in the DOE, EIA, Office of Energy Markets and End Use, Residential Energy Consumption Survey: Consumption Patterns of Household Vehicles, June 1979 to December 1980 , p. 10.

1981-82 - 94.1\% gasoline, 5.9\% diesel as reported in the DOE, EIA, Office of Energy Markets and End Use, Residential Energy Consumption Survey: Consumption Patterns of Household Vehicles, Supplement: January 1981 to September 1981, pp. 11, 13.

1983-84 - $97.5 \%$ gasoline, $2.5 \%$ diesel as reported in the DOE, EIA, Office of Markets and End Use, Energy End Use Division, Residential Transportation Energy Consumption Survey: Consumption Patterns of Household Vehicles, 1983, Jan., 1985, pp. 7, 9.

1985-87 - 98.5\% gasoline, $1.5 \%$ diesel as reported in the DOE, EIA, Office of Energy Markets and End Use, Residential Transportation Energy Consumption Survey: Consumption Patterns of Household Vehicles 1985, April 1987, pp. 25, 27.

$1988-90-98.8 \%$ gasoline and $1.2 \%$ diesel as reported in the DOE, EIA, Office of Markets and End Use, Energy End Use Division, Household Vehicles Energy Consumption 1988, March 1990, p. 65.

Buses

Transit:

Vmt and Pmt - APTA, 1991 Transit Fact Book, October 1991, Washington, DC, pp. 24-26 and annual.

Energy Use - Diesel: APTA, 1991 Transit Fact Book, October 1991, Washington, DC, p. 93, and annual. 
Gasoline: Total gallons of gasoline used by transit vehicles taken from APTA, 1991 Transit Fact Book, October 1991, Washington, DC, p. 93. According to APTA's Research and Statistics Department, motor bus accounts for approximately $5 \%$ of total transit gasoline use.

Intencity:

Pmt - 1970-84 - American Bus Association, Annual Report, Washington, DC, annual.

1985-90 - Eno Transportation Foundation, Transportation in America,

Tenth edition, Washington, DC, 1992, p. 47.

Energy Use - 1970-1984 - American Bus Association, Annual Report,

Washington, DC, annual.

1985-86 - Eno Transportation Foundation, Transportation in America,

Seventh edition, Washington, DC, p. 9.

1987-90 - Personal communication with Frank Smith, TPA, Washington,

DC.

School:

Vmt - 1970-84 - DOT, FHWA, Highway Statistics 1984, Washington, DC, Table VM-1, p. 175, and annual.

1985-87 - DOT, TSC, National Transportation Statistics, 1989, Figure 2, p. 7 , and annual.

1988-90 - National Safety Council, Accident Facts, 1991 Edition,

Chicago, IL, p. 71, and annual.

Enengy Use - 1970-1984 - DOT, FHWA, Highway Statistics 1984, Washington, DC, Table VM-1, and annual.

1985-86 - DOT, TSC, National Transportation Statistics, Figure 2, p. 5 , and annual.

1987-90 - Personal communication with Frank Smith, TPA, Washington, DC.

Non-Highway

Air

Certificated Air Carrien:

Pmt - DOT, FAA, FAA Statistical Handbook of Aviation, Calendar Year 1990 , Washington, DC, 1992, p. 6-4, and annual.

Energy Use - 1970-81 - DOT, Civil Aeronautics Board, Fuel Cost and Consumption, Washington, DC, annual.

1982-90 - DOT, Research and Special Programs Administration, Data Administration Division, "Fuel Cost and Consumption Tables;" annual figures were obtained by summing monthly totals. Because the data for international included fuel purchased abroad, the international total was divided in half to estimate domestic fuel purchases for international flights. 


\section{General Aviation.}

Pmt - Eno Transportation Foundation, Transportation In America, Tenth edition, Washingion, DC, 1992, p.47.

Energy Use - 1970-74 - DOT, TSC, National Transportation Statistics,Cambridge, MA, 1981.

1975-85 - DOT, FAA, FAA Aviation Forecasts, Washington, DC, annual. 1985-90 - DOT, FAA, General Aviation Activity and Avionics Survey: Calendar Year 1990, Table 5.1, p. 5-6. Jet fuel was converted from gallons to Btu using $135,000 \mathrm{Btu} / \mathrm{gallon}$ (kerosene-type jet fuel).

\section{Rail}

Passenger (Amtrak):

Pmt - 1971-83 - AAR, Statistics of Class I Railroads, Washington, DC, annual. 1984-88 - AAR, Railroad Facts, 1988 Edition, Washington, DC, December 1989, p. 61, and annual. 1989-90 - Personal communication with the Corporate Accounting Office of Amtrak.

Energy Use - Personal communication with the Corporate Accounting Office of Amtrak.

\section{Transit:}

Pmt - APTA, 1991 Transit Fact Book, October 1991, Washington, DC, p. 25.

Energy Use - Transit and Commuter - APTA, 1991 Transit Fact Book, October 1991, Washington, DC, p. 93, annual. Transit was defined as the sum of "heavy rail" and "all other." 
Table 214

Intercity Freight Movement and Energy Use in the

United States, 1990

\section{Highway}

\section{Trucks}

Vehicles - 7.5\% of total 2-axle, 4-tire trucks (as reported by DOT, FHWA in Highway Statistics 1990 . Table VM-1, p. 192) and 22.1\% of total other trucks were engaged in intercity freight movement. These percentages were derived by ORNL from the 1987 TIUS public use tape.

$V m t-13.7 \%$ of total vehicle miles traveled by 2-axle, 4-tire trucks (as reported by DOT, FHWA in Highway Statistics 1990, Table VM-1, p. 192) and 50.2\% of total vehicle miles traveled by other trucks were used in intercity freight movement. These percentages were derived by ORNL from the 1987 TIUS public use tape.

Ton Miles, Tons Shipped and Average Length of Haul - Eno Transportation Foundation, Transportation in America, Tenth Edition, Washington, DC, 1992 pp. 44, 46, 71.

Energy Intensity - Energy use divided by ton-miles.

Energy Use - 16\% of total fuel consumption by 2-axle, 4-tire trucks (as reported by DOT, FHWA in Highway Statistics 1990, Table VM-1, p. 192) and 53.2\% of total other truck fuel consumption were used in intercity freight movement. These percentages were derived by ORNL from the 1987 TIUS public use tape.

\section{Non-Highway}

\section{Waterborne Commerce}

Vehicles - U.S. Department of the Army, Army Corps of Engineers, Waterborne Transportation Lines of the United States, 1989, New Orleans, LA, 1991.

Ton Miles, Tons Shipped, and Average Length of Haul - U.S. Department of the

Army, Corps of Engineers, Waterborne Commerce of the United States,

Calendar Year 1989, Part 5: National Summaries, New Orleans, LA, 1990, p. 89.

Energy Intensity - Energy use divided by ton miles.

Energy Use - DOE, EIA, Fuel Oil and Kerosene Sales, 1990, p.42. Adjusted sales of distillate and residual fuel oil for vessel bunkering.

Domestic freight energy use was calculated as:

Distillate fuel $-77.5 \%$ domestic, $22.5 \%$ foreign

Residual fuel $-9.3 \%$ domestic, $90.7 \%$ foreign 
Percentages were derived from the DOC:, U.S. Forcign Trade, Bunker Fuels, "Oil and Coal Laden in the U.S. un Vessels Engaged in Foreign Trade," 1988. This report was discontinued in 1989.

\section{Pipeline}

Natural Gas:

Tons shipped - DOE, EIA, Natural Gas Annual 19\%(), Washington, DC, 1991, p. 20. Total natural gas disposition divided by $44,870 \mathrm{ft}^{3} / \mathrm{tun}$.

Enengy use - The amount of natural gas used to transport natural gas was defined as "pipeline fuel" as reported in DOE, EIA, Natural Gas Annual 1990. Table 1, p. 20. Cubic feet were converted to Btu using 1,031 $\mathrm{Btu} / \mathrm{ft}^{3}$. Electricity use was estimated using the following procedure as reported on p. 5-110 of J. N. Hooker et al., End Use Energy Consumption DataBase: Transportation Sector. The energy consumption of a natural gas pipeline was taken to be the energy content of the fucl used to drive the pumps. Some $94 \%$ of the installed pumping horsepower was supplied by natural gas. The remaining $6 \%$ of the horse power was generated more efficiently, mostly by electric motors. The energy consumed by natural gas pipeline pumps that were electrically powered was not known. In order to estimate the electricity consumed, the Btu of natural gas pipeline fuel consumed was multiplied by a factor of 0.015 . From this computed value, electricity efficiency and generation loss must be taken into account. The electricity energy use in Btu must be converted to $\mathrm{kWhr}$, using the conversion factor $29.305 \times 10^{-5}$ $\mathrm{kWhr} /$ Btu. Electricity generation and distribution efficiency was $29 \%$. When generation and distribution efficiency are taken into account, 1 kWhr equals 11,765 Btu.

\section{Crude Oil and Petroleum Product:}

Ton Miles and Tons Shipped - Eno Transportation Foundation, Transportation in America, Tenth Edition, Washington, DC, 1992, pp. 44, 46.

Coal Slurry - Ton Miles, Tons Shipped, and Average Length of Haul: DOT, Transport of Solid Commodities via Freight Pipelines, Freight Pipeline Technology, Vol. 11, Washington, DC, 1976, p. 6.

Energy Use - W. F. Banks, Systems, Science, and Software, Inc., Energy Consumption in the Pipeline Industry, LaJolla, CA, 1977. 
Rail

Vehicles, Vmt, Ton Miles, Tons Shipped, Average Length of Haul - AAR, Railroad Facts, 1991 Edition, Washington, DC, September 1991, pp. 27, 33, 34, 36, 48, 50.

Enengy Use - Distillate fuel oil was obtained by subtracting total passenger fuel use from total distillate as reported by EIA.

Total - DOE, EIA, Fuel Oil and Kerosene Sales, 1990, p. 42. Adjusted sales of distillate fuel oil for railroad.

Passenger - Transit and Commuter - APTA, 1991 Transit Fact Book October 1991, Washington, DC, p. 93. Transit was defined as the sum of "heavy rail" and "all other." Intercity - Sum of fuel used by Amtrak and Class I passenger trains. Source for Amtrak was personal communication with the Accounting Division of Amtrak, Washington, DC. Source for fuel use by Class I passenger trains was the AAR, Statistics of Class I Railroads 1990, July 1991, p. 157. Fuel use for Class I passenger was derived as follows: fuel use for passenger locomotive, including weighted percent of fuel for yard switching. Diesel fuel consumed by work train was not included as it was considered to be indirect energy. 
Table 215

Energy Intensities of Freight Modes, 1970-90

In reference to transportation, the energy intensity of a mode is the ratio of the energy inputs to a process to a measure of the useful outputs from that process; for example, Btu per pmt or Btu per ton-mile. The energ;' intensity ratios in Table 2.16 were calculated for each freight mode using the following data sources:

\section{Highway}

\section{Trucks}

Vmt - DOT, FHWA, Highway Statistics Summary to 1985, Table VM-201A, and Table VM-1 of the 1987-90 editions. Light trucks were defined as 2-axle, 4tire trucks. Other trucks were defined as the difference between total trucks and 2-axle, 4-tire trucks. See Table 3.15 for light truck vmt.

Energy Use - Light Trucks - Defined as 2-axle, 4-tire trucks. Total gallons of fuel was taken from DOT, FHWA, Highway Statistics Summary to 1985, Table VM-201A, and Table VM-1 of the 1986-90 annual editions. Based on data from the 1982 TIUS Public Use Tape, fuel use for 1970-1987 was distributed among fuel types as follows: $95.3 \%$ gasoline; 3.5\% diesel; and $1.2 \% \mathrm{lpg}$. Fuel use for 1988-90 was distributed based on the 1987 TIUS: $96.6 \%$ rdsoline; $3.3 \%$ diesel; and $0.1 \% \mathrm{lpg}$.

Other Trucks - Defined as the difference between total trucks and 2-axle, 4tire trucks. Total gallons of fuel was taken from DOT, FHWA, Highway Statistics Summary to 1985, Table VM-201A, and Table VM-1 of the 1986-90 annual editions. Based on data from the 1982 TIUS Public Use Tape, fuel use for 1970-1987 was distributed among fuel types as follows: $39.6 \%$ gasoline; $59.4 \%$ diesel; and $1.0 \% \mathrm{lpg}$. Fuel use for $1988-90$ was distributed based on the 1987 TIUS: $19.4 \%$ gasoline; $80.4 \%$ diesel; and $0.2 \%$ lpg.

\section{Non-Highway}

\section{Water}

Ton Miles - U.S. Department of the Army, Corps of Engineers, Waterborne Commerce of the United States, Calendar Year 1989, Part 5: National Summaries, New Orleans, LA, 1991, p. 89, and annual.

Energy Use - Calculated as the difference between total water freight energy use and foreign water freight energy use.

Total - DOE, EIA, Fuel Oil and Kerosene Sales, 1990, p. 42. Adjusted sales of distillate and residual fuel oil for vessel bunkering. 
Domestic and Foreign - 1970-88 - DOC, U.S. Foreign Trade, Bunker Fuels, "Oil and Coal Laden in the U.S. on Vessels Engaged in Foreign Trade," 1988, annual. In this were fuel oil (i.e., residual) and diesel oil laden in the U.S. on vessels engaged in foreign trade. The totals for residual and diesel used by foreign vessels and American vessels for foreign trade were subtracted from the EIA totals for residual and diesel deliveries to obtain the value for domestic trade.

1989-90 - Total freight energy use was distributed as follows:

Distillate fuel - $77.5 \%$ domestic, $22.5 \%$ foreign

Residual fuel - $9.3 \%$ domestic, $90.7 \%$ foreign

Percentages were derived from the DOC, U.S. Foreign Trade, Bunker

Fuels, "Oil and Coal Laden in the U.S. on Vessels Engaged in Foreign

Trade," 1988. This report was discontinued in 1989.

Rail

Freight Car Miles and Ton Miles - AAR, Railroad Facts, 1991 Edition, Washington, DC, September 1991, pp. 27, 36, and annual.

Energy Use - Distillate fuel oil was obtained by subtracting total passenger fuel use from total distillate as reported by ELA.

Total - DOE, EIA, Fuel Oil and Kerosene Sales, 1990, p. 42. Adjusted sales of distillate fuel onl for railroad.

Passenger - Transit and Commuter - APTA, 1991 Transit Fact Book, October 1991, Washington, DC, p. 93. Transit was defined as the sum of "heavy rail" and "all other." Intercity - Sum of fuel used by Amtrak and Class I passenger trains. Source for Amtrak was personal communication with the Accounting Division of Amtrak, Washington, DC. Source for fuel use by Class I passenger trains was the AAR, Statistics of Class I Railroads 1990, July 1991, p. 157. Fuel use for Class I passenger was derived as follows: fuel use for passenger locomotive, including weighted percent of fuel for yard switching. Diesel fuel consumed by work train was not included as it was considered to be indirect energy. 
Table 33

Vehicle Stock, New Sales and New Registrations

in the United States, 1990 Calendar Year

\section{Highway}

\section{Automobiles}

Vehicle Stock:

The number of vehicles in use by EPA size class were derived as follows: Market Shares by EPA size class for new car sales from 1970-1975 were taken from the DOT, NHTSA, Automotive Characteristics Historical DataBase, Washington, DC. Market shares for the years 1976-1990 were found in Linda S. Williams and Patricia S. Hu, Highway Vehicle MPG and Market Shares Report: Model Year 1990, ORNL-6672, April 1991, Table 7. These data were assumed to represent the number of cars registered in each size class for each year. These percentages were applied to the automobiles in operation for that year as reported by R. L. Polk and Company (FURTHER REPRODUCTION PROHIBITED) and summed to calculate the total mix for 1990 . This method assumed that all vehicles, large and small, were scrapped at the same rate.

Sales:

Domestic, import, and total sales were from MVMA, Facts and Figures '92, p. 15. The domestic sales were distributed by size class according to the following percentages: Two seater, $0.5 \%$; Minicompact, 0\%; Subcompact, 14.7\%; Compact 33.9\%; Midsize, 32.1\%; and Large, $18.8 \%$. The import sales were distributed by size class according to the following percentages: Twoseater, 5.8\%; Minicompact, 3.4\%; Subcompact, 41.9\%; Compact, 35.2\%; Midsize, $13.4 \%$; and Large, $0.4 \%$. These percentages were derived from the ORNL Light-Duty Vehicle Market Shares Data System. Domestic-sponsored imports (captive imports) were included in the import figure only.

\section{New Registrations:}

Domestic - The number of registrations for new automobiles was derived as follows: new car registrations by make (as reported in H. A. Stark (ed.), Ward's Communication, Inc., 1992 Ward's Automotive Yearbook, Detroit, MI, p. 241), were classified by ORNL into EPA size classes. Totals included Federal Government registrations. Van registrations were not included.

Import - Calculated by ORNL as the difference between total and domestic.

Total - MVMA, Facts and Figures '92, p. 21.

See Glossary for definition of Automobile Size Classifications. 
Fleet

Fleets of tes: or more:

Stock and Registrations - E. J. Bobit (ed.), Bobit Publishing Company, 1992 Automotive Fleet Fact Book, Redondo Beach, CA, 1992, pp. 16, 22. Vehicle stock was equal to the sum of business fleets 25 or more, business fleets 10-24, individually leased, and "other" fleets. This number did not include all cars in Federal Government fleets. Federal Government fleet data were from Federal Motor Vehicle Fleet Report, General Services Administration, Table 1 (all agencies - domestic sedans and station wagons.)

\section{Personal Autos:}

Stock and Registrations - Calculated by ORNL as the difference betvreen total auto and fleets.

\section{Motorcycles}

Stock - DOT, FHWA, Highway Statistics 1990, Table VM-1 p. 192.

Sales and Registrations - MIC, 1991 Motorcycle Statistical Annual, PP. 12 and 13. Domestic sales were assumed to equal U.S. production (p. 13), and included sales of motorcycles, scooters, and all-terrain vehicles for on- and off-highway use. Import was the difference between total sales (p. 12) and domestic.

\section{Recreational Vehicles}

Sales - Recreation Vehicle Industry Association, 1991... The Year in Review, p. 4, "Total Shipments."

\section{Truckss}

Stock - Vehicles in use by weight class were determined by applying the percentage in use by weight class as reported in DOC, Bureau of the Census, 1987 TIUS, (0-10,000 lbs, 91.9\%; 10,001-19,500 lbs, 2.3\%; 19,501-26,000 lbs, 1.7\%; 26,001 lbs and over, $4.1 \%$ ) to the total number of trucks in use as reported by R. L. Polk and Company (FURTHER REPRODUCTION PROHIBITED).

Sales - MVMA, Facts and Figures '92, p. 17.

Registrations - H. A. Stark (ed.), Ward's Communications, Inc., 1991 Ward's Automotive Yearbook, Detroit, MI, p. 250. 


\title{
APPENDIX B CONVERSIONS
}

\begin{abstract}
A Note About Heating Values
The heat content of a fuel is the quantity of energy released by burning a unit amount of that fuel. However, this value is not absolute and can vary according to several factors. For example, empirical formulae for determining the heating value of liquid fuels depend on the fuels' American Petroleum Institute (API) gravity. The API gravity varies depending on the percent by weight of the chemical constituents and impurities in the fuel, both of which are affected by the combination of raw materials used to produce the fuel and by the type of manufacturing process. Temperature and climatic conditions are also factors.
\end{abstract}

Because of these variations, the heating values in Table B.1 may differ from values in other publications. The figures in this report are representative or average values, not absolute ones. The gross heating values used here agree with those used by the Energy Information Administration (EIA).

Heating values fall into two categories, gross and net. If the products of fuel combustion are cooled back to the initial fuel-air or fuel-oxidizer mixture temperature and the water formed during combustion is condensed, the energy released by the process is the higher (gross) heating value. If the products of combustion are cooled to the initial fuel-air temperature, but the water is considered to remain as a vapor, the energy released by the process is lower (net) heating value. Usually the difference between the gross and net heating values for fuels used in transportation is around 5 to 8 percent; however, it is important to be consistent in their use. 
Table B.1

Approximate Heat Content for Various Fuels

Automotive gasoline

Diesel motor fuel

Methanol

Ethanol

Gasohol

Aviation gasoline

Propane

Butane

Jet fuel (naphtha)

Jet fuel (kerosene)

Lubricants

Wares

Asphalt and road oil

Petroleum coke

Natural gas

Wet

Dry

Liquid

Crude petroleum

Fuel Oils

Residual

Distillate
$125,000 \mathrm{Btu} / \mathrm{gal}($ gross $)=115,400 \mathrm{Btu} / \mathrm{gal}($ net $)$

$138,700 \mathrm{Btu} / \mathrm{gal}$ (gross) $=128,700 \mathrm{Btu} / \mathrm{gal}$ (net)

$64,600 \mathrm{Btu} / \mathrm{gal}$ (gross) $=56,560 \mathrm{Btu} / \mathrm{gal}$ (net)

$84,600 \mathrm{Btu} / \mathrm{gal}$ (gross) $=75,670 \mathrm{Btu} / \mathrm{gal}$ (net)

$120,900 \mathrm{Btu} / \mathrm{gal}$ (gross) $=112,417 \mathrm{Btu} / \mathrm{gal}$ (net)

$120,200 \mathrm{Btu} / \mathrm{gal}$ (gross) $=112,000 \mathrm{Btu} / \mathrm{gal}$ (net)

91,300 Btu/gal (gross) $=83,500 \mathrm{Btu} / \mathrm{gal}$ (net)

$103,000 \mathrm{Btu} / \mathrm{gal}$ (gross) $=93,000 \mathrm{Btu} / \mathrm{gal}$ (net)

$127,500 \mathrm{Btu} / \mathrm{gal}$ (gross) $=118,700 \mathrm{Btu} / \mathrm{gal}$ (net)

$135,000 \mathrm{Btu} / \mathrm{gal}$ (gross) $=128,100 \mathrm{Btu} / \mathrm{gal}$ (net)

$144,400 \mathrm{Btu} / \mathrm{gal}$ (gross) $=130,900 \mathrm{Btu} / \mathrm{gal}$ (net)

$131,800 \mathrm{Btu} / \mathrm{gal}$ (gross) $=120,200 \mathrm{Btu} / \mathrm{gal}$ (net)

$158,000 \mathrm{Btu} / \mathrm{gal}$ (gross) $=157,700 \mathrm{Btu} / \mathrm{gal}$ (net)

$143,400 \mathrm{Btu} / \mathrm{gal}$ (gross) $=168,300 \mathrm{Btu} / \mathrm{gal}$ (net)

$$
\begin{aligned}
& 1,112 \mathrm{Btu} / \mathrm{ft}^{3} \\
& 1,031 \mathrm{Btu} / \mathrm{ft}^{3} \\
& 90,800 \mathrm{Btu} / \mathrm{gal} \text { (gross) }=87,600 \mathrm{Btu} / \mathrm{gal} \text { (net) }
\end{aligned}
$$

$138,100 \mathrm{Btu} / \mathrm{gal}$ (gross) $=131,800 \mathrm{Btu} / \mathrm{gal}$ (net)

$149,700 \mathrm{Btu} / \mathrm{gal}$ (gross) $=138,400 \mathrm{Btu} / \mathrm{gal}$ (net) $138,700 \mathrm{Btu} / \mathrm{gal}$ (gross) $=131,800 \mathrm{Btu} / \mathrm{gal}$ (net)

Coal

Anthracite

Bituminous and lignite

Production average

Consumption average
$23.268 \times 10^{6} \mathrm{Btu} / \mathrm{short}$ ton $21.772 \times 10^{6} \mathrm{Btu} / \mathrm{short}$ ton $21.776 \times 10^{6} \mathrm{Btu} / \mathrm{short}$ ton $21.266 \times 10^{6} \mathrm{Btu} / \mathrm{short}$ ton 
Table B.2

Fuel Equivalents

1 million bbl/day crude oil

$=0.3650$ billion bblyear crude oil

$=5.800$ trillion Btu/day

$=2.117$ quadrillion Btu/year

$=90.09$ million short tons coal/year

$=2.074$ trillion $\mathrm{ft}^{3}$ natural gas/year

$=22.33 \times 10^{11}$ MJ/year

1 billion bbl/year crude oil $\quad=2.740$ million bbl/day crude oil

$=15.89$ trillion Btu/day

$=5.800$ quadrillion Btu/year

$=246.8$ million short ton coal/year

$=5.68$ trillion $\mathrm{ft}^{3} /$ year natural gas/day

$=61.19 \times 10^{11} \mathrm{MJ} /$ year

1 trillion Btu/day

$=172.4$ thousand bbl/day crude oil

$=62.93$ million bbl/year crude oil

$=0.3650$ quadrillion Btu/year

$=15.53$ million short tons coal/year

$=357.5$ billion $\mathrm{ft}^{3}$ natural gas/year

$=38.51 \times 10^{10} \mathrm{MJ} /$ year

1 quadrillion Btułyear

$=0.4724$ million bbl/day crude oil

$=172.4$ million bbl/year crude oil

$=2.740$ trillion Btu/day

$=\mathbf{4 2 . 5 5}$ million short tons coal/year

$=979.4$ billion $\mathrm{ft}^{3}$ natural gas/year

$=10.55 \times 10^{11} \mathrm{MJ} /$ year

1 billion short tons coal/year

$=11.10$ million bbl/day crude oil

$=4.052$ billion bbl/year crude oil

$=64.38$ trillion Btu/day

$=23.50$ quadrillion Btu/year

$=23.02$ trillion $\mathrm{ft}^{3}$ natural gas/year

$=24.79 \times 10^{12} \mathrm{MJ} / \mathrm{year}$

1 trillion $\mathrm{ft}^{3}$ natural gas/year $\quad=0.4823$ million bbl/day crude oil

$=0.1760$ billion bbl/year crude oil

$=2.797$ trillion Btu/day

$=1.021$ quadrillion Btu/year

$=43.45$ million short tons coal/year

$=10.77 \times 10^{11} \mathrm{MJ} /$ year

1 mega joule/year

$=44.78 \times 10^{-8} \mathrm{bbl} / \mathrm{day}$ crude oil

$=16.34 \times 10^{.5} \mathrm{bbl} / \mathrm{year}$ crude oil

$=2.597 \mathrm{Btu} / \mathrm{day}$

$=947.9 \mathrm{Btu} / \mathrm{year}$

$=4.034 \times 10^{-5}$ short tons coal/year

$=0.9285 \mathrm{ft}^{3}$ natural gas/year 
Table B.3

Energy Unit Conversions

\begin{tabular}{|c|c|c|c|}
\hline $1 \mathrm{Btu}$ & $=778.2 \mathrm{ft}-1 \mathrm{~b}$ & $1 \mathrm{kWhr}$ & $=3412 \mathrm{Btu}^{\circ}$ \\
\hline & $=107.6 \mathrm{~kg}-\mathrm{m}$ & & $=2.655 \times 10^{6} \mathrm{ft}-1 \mathrm{~b}$ \\
\hline & $=1055 \mathrm{~J}$ & & $=3.671 \times 10^{5} \mathrm{~kg}-\mathrm{m}$ \\
\hline & $=39.30 \times 10^{-5} \mathrm{hp}-\mathrm{h}$ & & $=3.600 \times 10^{6} \mathrm{~J}$ \\
\hline & $=39.85 \times 10^{-5}$ metric hp-h & & $=1.341 \mathrm{hp}-\mathrm{h}$ \\
\hline & $=29.31 \times 10^{-5} \mathrm{kWhr}$ & & $=1.360$ metric $\mathrm{hp}-\mathrm{h}$ \\
\hline $1 \mathrm{~kg}-\mathrm{m}$ & $=92.95 \times 10^{-4} \mathrm{Btu}$ & 1 Joule & $=94.78 \times 10^{.5} \mathrm{Btu}$ \\
\hline & $=7.233 \mathrm{ft}-\mathrm{lb}$ & & $=0.7376 \mathrm{ft}-\mathrm{lb}$ \\
\hline & $=9.806 \mathrm{~J}$ & & $=0.1020 \mathrm{~kg}-\mathrm{m}$ \\
\hline & $=36.53 \times 10^{-7} \mathrm{hp}-\mathrm{h}$ & & $=37.25 \times 10^{-8} \mathrm{hp}-\mathrm{h}$ \\
\hline & $=37.04 \times 10^{-7}$ metric hp-h & & $=37.77 \times 10^{-8}$ metric $\mathrm{hp}-\mathrm{h}$ \\
\hline & $=27.24 \times 10^{-7} \mathrm{kWhr}$ & & $=27.78 \times 10^{-8} \mathrm{kWhr}$ \\
\hline $1 \mathrm{hp}-\mathrm{h}$ & $=2544 \mathrm{Btu}$ & 1 metric hp-h & $=2510 \mathrm{Btu}$ \\
\hline & $=1.98 \times 10^{6} \mathrm{ft}-\mathrm{lb}$ & & $=1.953 \times 10^{6} \mathrm{ft}-1 \mathrm{~b}$ \\
\hline & $=2.738 \times 10^{6} \mathrm{kgm}$ & & $=27.00 \times 10^{4} \mathrm{~kg}-\mathrm{m}$ \\
\hline & $=2.685 \times 10^{6} \mathrm{~J}$ & & $=2.648 \times 10^{6} \mathrm{~J}$ \\
\hline & $=1.014$ metric $\mathrm{hp}-\mathrm{h}$ & & $=0.9863 \mathrm{hp}-\mathrm{h}$ \\
\hline & $=0.7475 \mathrm{kWhr}$ & & $=0.7355 \mathrm{kWhr}$ \\
\hline
\end{tabular}

This figure does not take into account the fact that electricity generation and distribution efficiency is approximately $29 \%$. If generation and distribution efficiency are taken into account, 1 $\mathrm{kWhr}=11,765 \mathrm{Btu}$ 


\begin{tabular}{rlrl}
\hline $1 \mathrm{in.}$ & $=83.33 \times 10^{-3} \mathrm{ft}$ & $1 \mathrm{ft}$ & $=12.0 \mathrm{in}$. \\
& $=27.78 \times 10^{-3} \mathrm{yd}$ & & $=0.33 \mathrm{yd}$ \\
& $=15.78 \times 10^{-6} \mathrm{mile}$ & & $=189.4 \times 10^{-3} \mathrm{mile}$ \\
& $=25.40 \times 10^{-3} \mathrm{~m}$ & & $=0.3048 \mathrm{~m}$ \\
& $=0.2540 \times 10^{-6} \mathrm{~km}$ & & $=0.3048 \times 10^{-3} \mathrm{~km}$ \\
& & & \\
$1 \mathrm{mile}$ & $=63360 \mathrm{in}$. & & $=39370 \mathrm{in}$. \\
& $=5280 \mathrm{ft}$ & & $=3281 \mathrm{ft}$ \\
& $=1760 \mathrm{yd}$ & & $=1093.6 \mathrm{yd}$ \\
& $=1609 \mathrm{~m}$ & & $=0.6214 \mathrm{mile}$ \\
& $=1.609 \mathrm{~km}$ & & $=1000 \mathrm{~m}$ \\
& $1 \mathrm{ft} / \mathrm{sec}=0.3048 \mathrm{~m} / \mathrm{s}=0.6818 \mathrm{mph}=1.0972 \mathrm{~km} / \mathrm{h}$ & \\
$1 \mathrm{~m} / \mathrm{sec}=3.281 \mathrm{ft} / \mathrm{s}=2.237 \mathrm{mph}=3.600 \mathrm{~km} / \mathrm{h}$ & \\
$1 \mathrm{~km} / \mathrm{h}=0.9114 \mathrm{ft} / \mathrm{s}=0.2778 \mathrm{~m} / \mathrm{s}=0.6214 \mathrm{mph}$ & \\
$1 \mathrm{mph}=1.467 \mathrm{ft} / \mathrm{s}=0.4469 \mathrm{~m} / \mathrm{s}=1.609 \mathrm{~km} / \mathrm{h}$ &
\end{tabular}


Table B.5

Volume and Flow Rate Conversions"

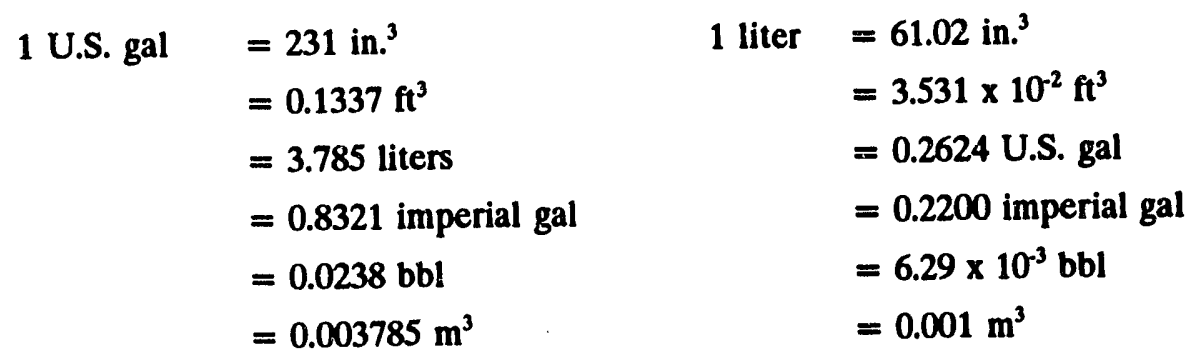

A U.S. gallon of gasoline weighs 6.2 pounds

$$
\begin{aligned}
& 1 \text { imperial gal }=277.4 \text { in. }^{3} \\
& 1 \mathrm{bbl}=9702 \text { in. }^{3} \\
& =0.1606 \mathrm{ft}^{3} \\
& =5.615 \mathrm{ft}^{3} \\
& =4.545 \text { liters } \\
& =158.97 \text { liters } \\
& =1.201 \text { U.S. gal } \\
& =42 \text { U.S. gal } \\
& =0.0286 \mathrm{bbl} \\
& =34.97 \text { imperial gal } \\
& =0.004546 \mathrm{~m}^{3} \\
& =0.15897 \mathrm{~m}^{3}
\end{aligned}
$$

For Imperial gallons, multiply above values by 1.201

$$
\begin{aligned}
1 \mathrm{liter} / \mathrm{hr} & =0.8474 \mathrm{ft}^{3} / \text { day } & & =309.3 \mathrm{ft}^{3} / \text { year } \\
& =6.298 \mathrm{U} . S . \text { gal/day } & & =2299 \mathrm{U} . \mathrm{S} . \text { gal/year } \\
& =5.28 \mathrm{imperial} \text { gal/day } & & =1927 \mathrm{imperial} \text { gal/year } \\
& =0.1510 \mathrm{bbl} / \text { day } & & =55.10 \mathrm{bbl} / \text { year } \\
1 \mathrm{bbl} / \mathrm{hr} & & & =49187 \mathrm{ft}^{3} \text { year } \\
& =137.8 \mathrm{ft}^{3} / \text { year } & & =3.679 \times 10^{5} \mathrm{U} . S . \text { gal/year } \\
& =839.3 \mathrm{imperial} \text { gal/day } & & =3.063 \times 10^{5} \text { imperial gal/year } \\
& =3815 \mathrm{liter} / \text { day } & & =1.393 \times 10^{6} \text { liter/day }
\end{aligned}
$$

The conversions for flow rates are identical to those for volume measures, if the time units are identical. 
B-7

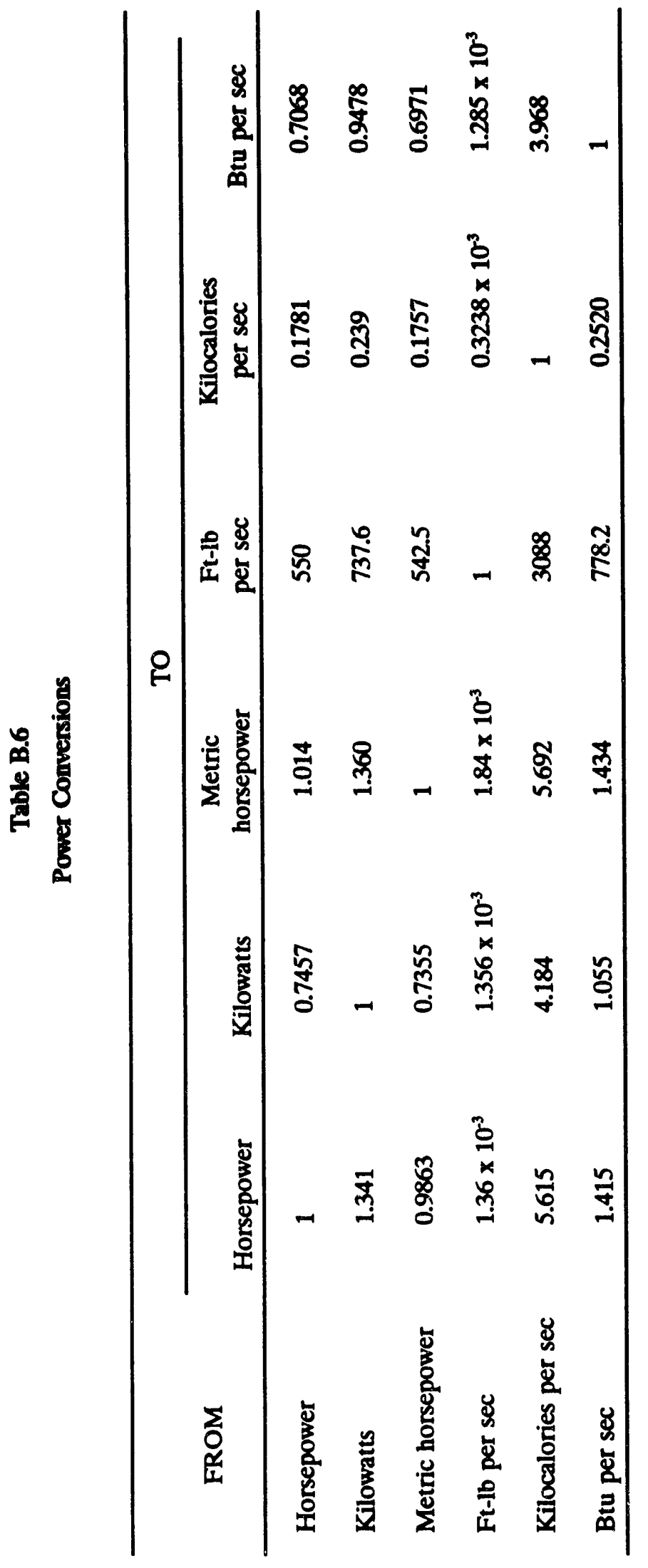




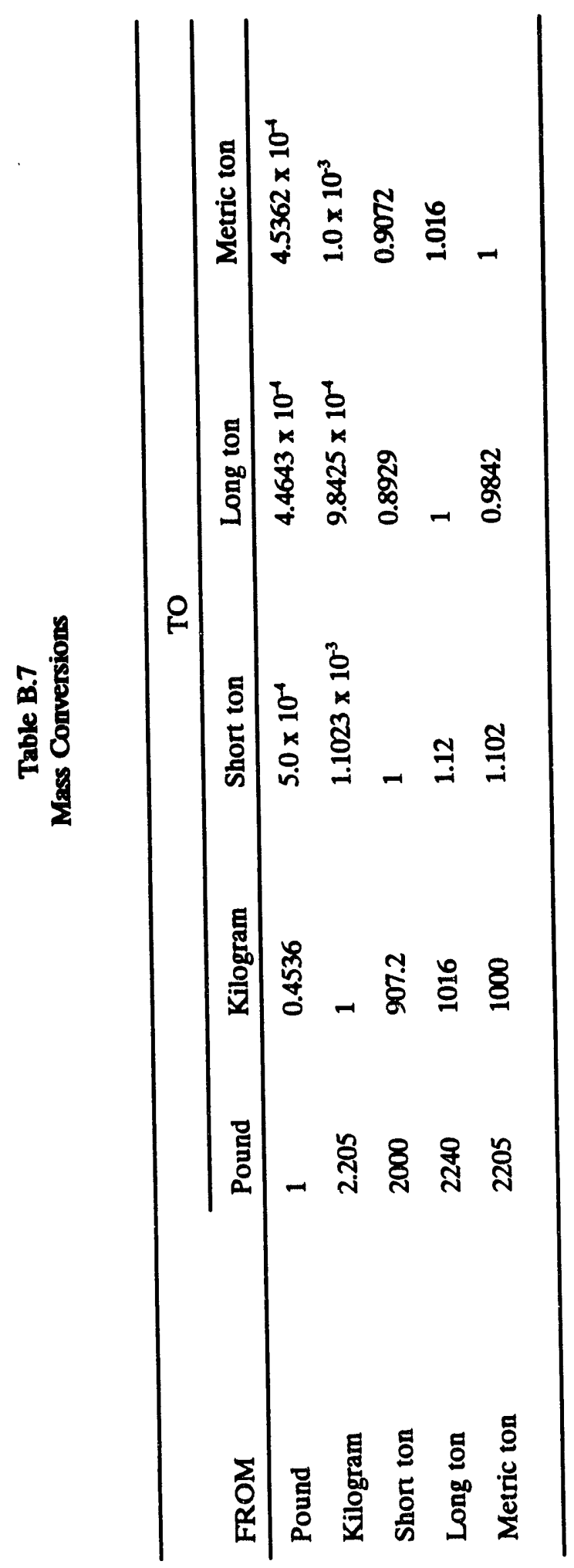


B-9

Table B.8

Fuel Eficieiency Conversionse

\begin{tabular}{lccc}
\hline MPG & Miles/iter & Kilometers $/ \mathrm{L}$ & L/100 kilometers \\
\hline 10 & 2.64 & 4.25 & 23.52 \\
15 & 3.96 & 6.38 & 15.68 \\
20 & 5.28 & 8.50 & 11.76 \\
25 & 6.60 & 10.63 & 9.41 \\
30 & 7.93 & 12.75 & 7.84 \\
35 & 9.25 & 14.88 & 6.72 \\
40 & 10.57 & 17.00 & 5.88 \\
45 & 11.89 & 19.13 & 5.23 \\
50 & 13.21 & 21.25 & 4.70 \\
55 & 14.53 & 23.38 & 4.28 \\
\end{tabular}

To convert fuel efficiency from miles per gallon (mpg) to liters per hundred kilometers, divide $\mathrm{mpg}$ into 235.24. 
B-10

Table B.9

SI Prefires and Their Values

\begin{tabular}{|c|c|c|c|}
\hline & Value & Prefix & Symbol \\
\hline $\begin{array}{l}\text { One million million millionth } \\
\text { One thousand million millionth } \\
\text { One million millionth } \\
\text { One thousand millionth } \\
\text { One millionth } \\
\text { One thousandth } \\
\text { One hundredth } \\
\text { One tenth } \\
\text { One } \\
\text { Ten } \\
\text { One hundred } \\
\text { One thousand } \\
\text { One million } \\
\text { One billion" } \\
\text { One trillion" } \\
\text { One quadrillion" } \\
\text { One quintillion" }\end{array}$ & $\begin{array}{l}10^{-18} \\
10^{-15} \\
10^{-12} \\
10^{9} \\
10^{6} \\
10^{-3} \\
10^{-2} \\
10^{-1} \\
10^{0} \\
10^{1} \\
10^{2} \\
10^{3} \\
10^{6} \\
10^{9} \\
10^{12} \\
10^{15} \\
10^{18}\end{array}$ & $\begin{array}{l}\text { atio } \\
\text { femto } \\
\text { pico } \\
\text { nano } \\
\text { micro } \\
\text { milli } \\
\text { centi } \\
\text { deci } \\
\text { deca } \\
\text { hecto } \\
\text { kilo } \\
\text { mega } \\
\text { giga } \\
\text { tera } \\
\text { peta } \\
\text { exa } \\
\end{array}$ & $\begin{array}{l}\mathbf{a} \\
\mathbf{f} \\
\mathbf{p} \\
\mathrm{n} \\
\mu \\
\mathrm{m} \\
\mathrm{c}\end{array}$ \\
\hline
\end{tabular}

"Care should be exercised in the use of this nomenclature, especially in foreign correspondence, as it is either unknown or carries a different value in other countries. A "billion," for example, signifies a value of $10^{12}$ in most other countries. 
Tablé B.10

Metric Units and Abbreviations

\begin{tabular}{|c|c|c|}
\hline Quantity & Unit name & Symbol \\
\hline $\begin{array}{l}\text { Energy } \\
\text { Specific energy } \\
\text { Specific energy consumption } \\
\text { Energy consumption } \\
\text { Energy oconomy } \\
\text { Power } \\
\text { Specific power } \\
\text { Power density } \\
\text { Speod } \\
\text { Acceleration } \\
\text { Range (distance) } \\
\text { Weight } \\
\text { Torque } \\
\text { Volume } \\
\text { Mass; payload } \\
\text { Length; width } \\
\text { Brake specific fuel consumption } \\
\text { Fuel oconomy (heat engine) } \\
\text { Air pressure }\end{array}$ & $\begin{array}{l}\text { joule } \\
\text { joule/kilogram } \\
\text { joule/kilogram-kilometer } \\
\text { joule/kilometer } \\
\text { kilomotor/kilojoule } \\
\text { kilowatt } \\
\text { watt/kilogram } \\
\text { watt/meter' } \\
\text { kilometer/hour } \\
\text { meter/second } \\
\text { kilometer } \\
\text { kilogram } \\
\text { newton॰meter } \\
\text { meter } \\
\text { kilogram } \\
\text { meter } \\
\text { kilogram/joule } \\
\text { liters/100 km }\end{array}$ & $\begin{array}{l}\mathrm{J} \\
\mathrm{J} / \mathrm{kg} \\
\mathrm{J} / \mathrm{kg} \cdot \mathrm{km}) \\
\mathrm{J} / \mathrm{km} \\
\mathrm{km} / \mathrm{kJ} \\
\mathrm{KW} \\
W / \mathrm{kg} \\
W / \mathrm{m}^{3} \\
\mathrm{~km} / \mathrm{h} \\
\mathrm{m} / \mathrm{s}^{2} \\
\mathrm{~km} \\
\mathrm{~kg} \\
\mathrm{~N} \cdot \mathrm{m} \\
\mathrm{m}^{3} \\
\mathbf{k g} \\
\mathrm{m} \\
\mathrm{kg} / \mathrm{J} \\
\mathrm{L} / 100 \mathrm{~km}\end{array}$ \\
\hline
\end{tabular}




\section{B-12}

\section{Conversion of Constant Dollar Values}

Many types of information in this data book are expressed in dollars. Generally, constant dollars are used--that is, dollars of a fixed value for a specific year, such as 1990 dollars. Converting current dollars to constant dollars, or converting constant dollars for one year to constant dollars for another year, requires conversion factors (Table B.11 and B.12). Table B.11 shows conversion factors using the Gross National Product inflation factors. Table B.12 shows conversion factors for the Consumer Price Index inflation factors. 


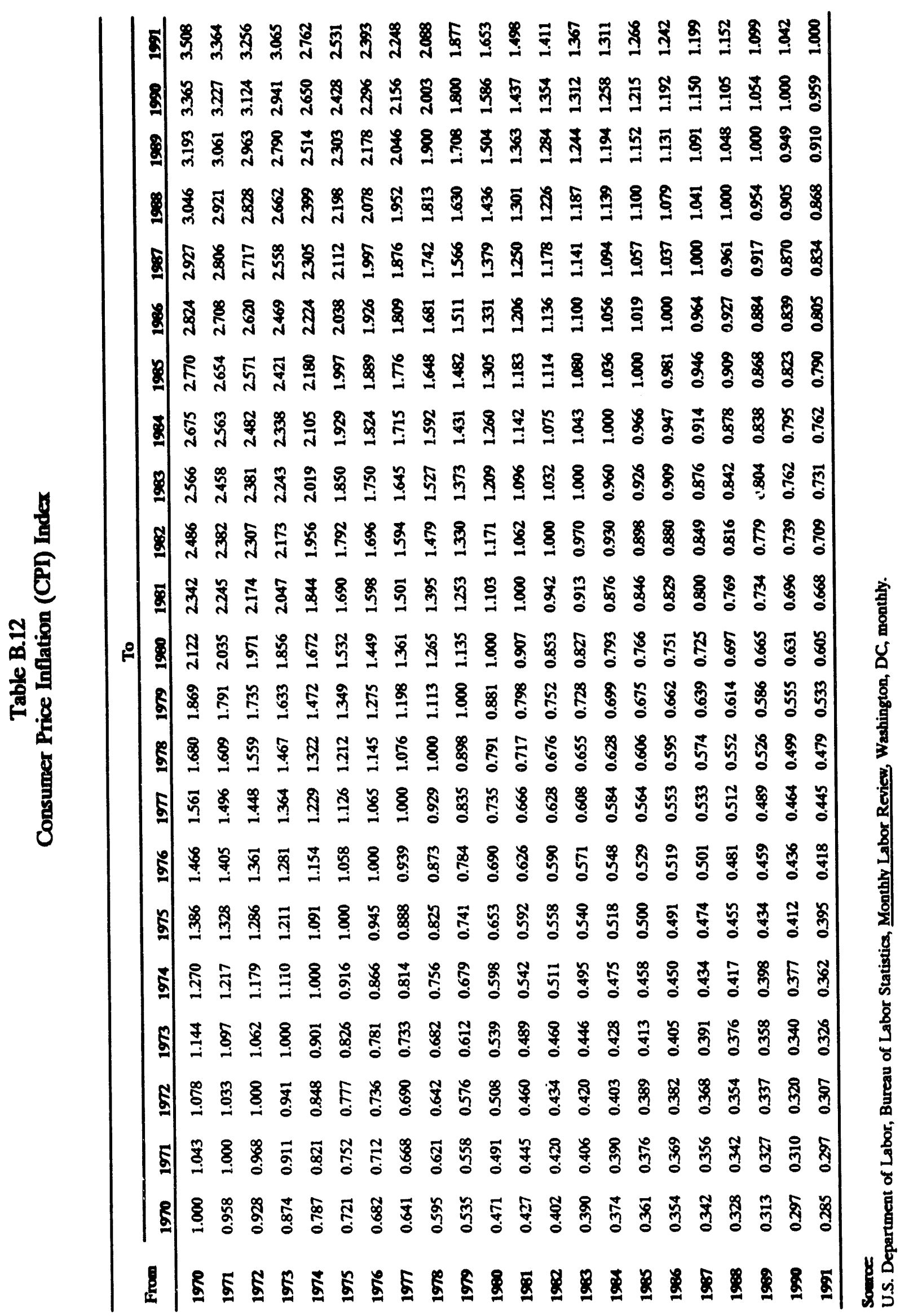




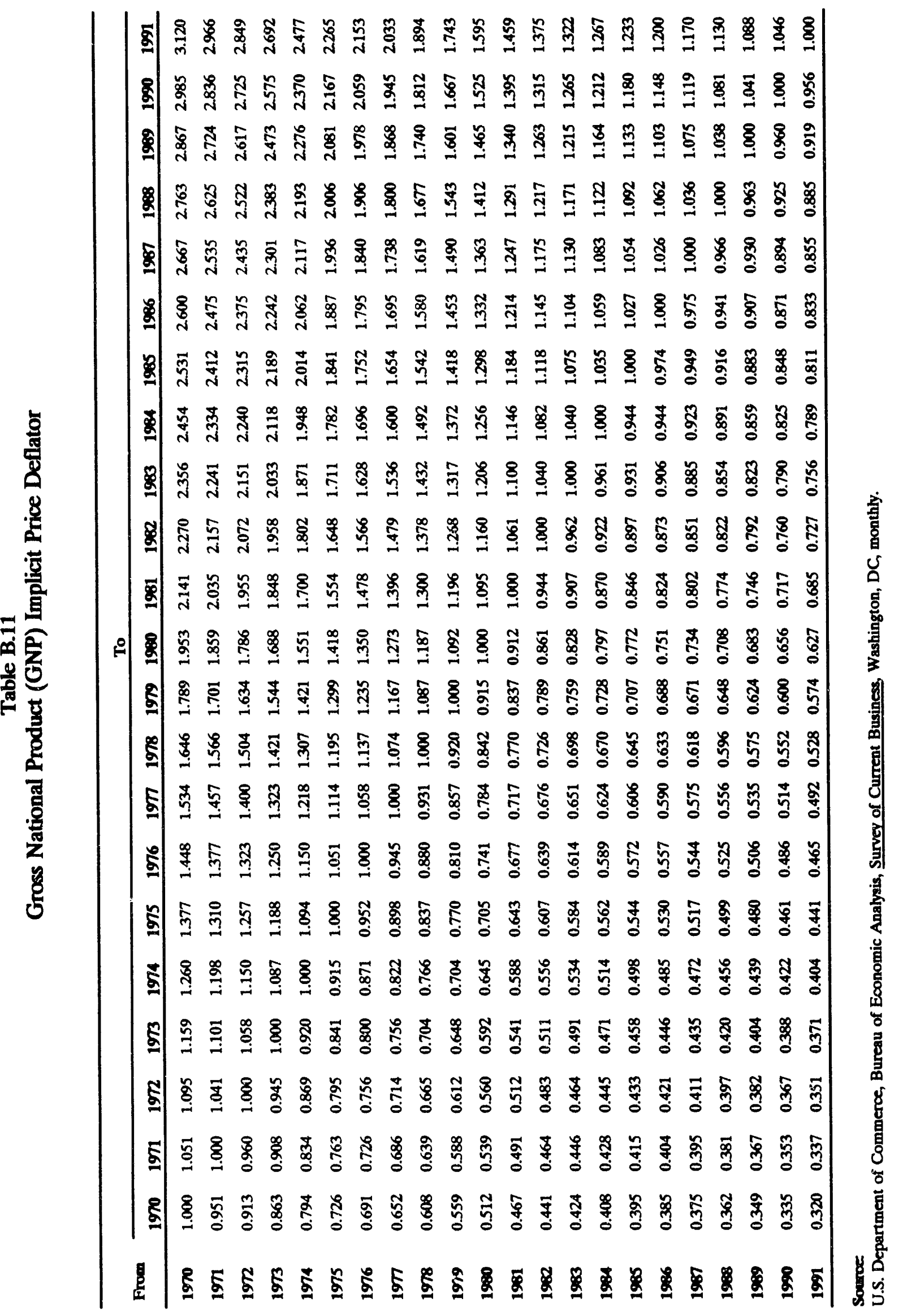




\section{GLOSSARY}

Acceleration power - Measured in kilowatts. Pulse power obtainable from a battery used to accelerate a vehicle. This is based on a constant current pulse for 30 seconds at no less than $2 / 3$ of the maximum open-circuit-voltage, at $80 \%$ depth-of-discharge relative to the battery's rated capacity and at $20^{\circ} \mathrm{C}$ ambient temperature.

Air Carrier - The commercial system of air transportation consisting of certificated air carriers, air taxis (including commuters), supplemental air carriers, commercial operators of large aircraft, and air travel clubs.

Certificated route air carrier: An air carrier holding a Certificate of Public Convenience and Necessity issued by the Department of Transportation to conduct scheduled interstate services. Nonscheduled or charter operations may also be conducted by these carriers. These carriers operate large aircraft (30 seats or more, or a maximum payload capacity of 7,500 pounds or more) in accordance with Federal Aviation Regulation part 121.

Domestic air operator: Commercial air transportation within and between the 50 States and the District of Columbia. Includes operations of certificated route air carriers, Pan American, local service, helicopter, intra-Alaska, intra-Hawaii, all-cargo carriers and other carriers. Also included are transborder operations conducted on the domestic route segments of U.S. air carriers. Domestic operators are classified based on their operating revenue as follows:

Majors - over $\$ 1$ billion

Nationals - $\$ 100-1,000$ million

Large Regionals - \$10-99.9 million

Medium Regionals - \$0-9.99 million

International air operator: Commercial air transportation outside the territory of the United States, including operations between the U.S. and foreign countries and between the U.S. and its territories and possessions.

Supplemental air carrier: A class of air carriers which hold certificates authorizing them to perform passenger and cargo charter services supplementing the scheduled service of the certificated route air carriers. Supplemental air carriers are often refcrred to as nonscheduled air carriers or "nonskeds". 
Amtrak - See Rail.

Automobile size classifications - Size classifications of automobiles are established by the Environmental Protection Agency (EPA) as follows:

Minicompact - less than 85 cubic feet of passenger and luggage volume.

Subcompact - between 85 to 100 cubic feet of passenger and luggage volume.

Compact - between 100 to 110 cubic feet of passenger and luggage volume.

Midsize - between 110 to 120 cubic feet of passenger and luggage volume.

Large - more than 120 cubic feet of passenger and luggage volume.

Two seater - automobiles designed primarily to seat only two aduits.

Station wagons are included with the size class for the sedan of the same name.

Aviation - See General aviation.

Aviation gasoline - All special grades of gasoline for use in aviation reciprocating engines, as given in the American Society for Testing and Materials (ASTM) Specification D 910. Includes all refinery products within the gasoline range that are to be marketed straight or in blends as aviation gasoline without further processing (any refinery operation except mechanical blending). Also included are finished components in the gasoline range which will be used for blending or compounding into aviation gasoline.

Barges - Shallow, nonself-propelled vessels used to carry bulk commodities on the rivers and the Great Lakes.

Battery efficiency - Measured in percentage. Net DC energy delivered on discharge, as a percentage of the total DC energy required to restore the initial state-of-charge. The efficiency value must include energy losses resulting from self-discharge, cell equalization, thermal loss compensation, and all battery-specific auxiliary equipment.

Btu - The amount of energy required to raise the temperature of 1 pound of water 1 degree Fahrenheit at or near 39.2 degrees Fahrenheit. An average Btu content of fuel is the heat value per quantity of fuel as determined from tests of fuel samples.

Bunker - A storage tank.

Bunkering fuels - Fuels stored in ship bunkers. 
Bus -

Intercity bus: A standard size bus equipped with front doors only, high backed seats, luggage compartments separate from the passenger compartment and usually with restroom facilities, for high-speed long distance service.

Motor bus: Rubber-tired, self-propelled, manually-steered bus with fuel supply on board the vehicle. Motor bus types include intercity, school, and transit.

School and other nonrevenue bus: Bus services for which passengers are not directly charged for transportation, either on a per passenger or per vehicle basis.

Transit bus: A bus designed for frequent stop service with front and center doors, normally with a rear-mounted diesel engine, low-back seating, and without luggage storage compartments or restroom facilities. Includes motor bus and trolley coach.

Trolley coach: Rubber-tired electric transit vehicle, manually-steered, propelled by a motor drawing current, normally through overhead wires, from a central power source not on boa the vehicle.

Calendar year - The period of time between January 1 and December 31 of any given year.

Captive imports - Products produced overseas specifically for domestic manufacturers.

Carbon dioxide $\left(\mathrm{CO}_{2}\right)$ - A colorless, odorless, non-poisonous gas that is a normal part of the ambient air. Carbon dioxide is a product of fossil fuel combustion.

Carbon monoxide (CO) - A colorless, odorless, highly toxic gas that is a normal by-product of incomplete fossil fuel combustion. Carbon monoxide, one of the major air pollutants, can be harmful in small amounts if breathed over a certain period of time.

Car-mile (railroad) - A single railroad car moved a distance of one mile.

Cargo ton-mile - See Ton-mile.

Certificated route air carriers - See Air carriers.

Class II freight railroad - See Rail.

Clean Fuel Vehicle - Vehicle meeting the clean fuel vheicle exhaust emissions standards with no restriction on fuel type. 
Coal slurry - Finely crushed coal mixed with sufficient water to form a fluid.

Combination trucks - Consist of a power unit (a truck tractor) and one or more trailing units (a semi-trailer or trailer). The most frequently used combination is popularly referred to as a "tractor-semitrailer" or "tractor trailer".

Commercial soctor - See Residential and Commercial sector.

Commuter railroad - See Rail.

Compact car - See Automobile size classifications.

Constant dollars - A series of figures is expressed in constant dollars when the effect of change in the purchasing power of the dollar has been removed. Usually the data are expressed in terms of dollars of a selected year or the average of a set of years.

Consumer Price Index (CPI) - An index issued by the U.S. Department of Labor, Bureau of Labor Statistics. The CPI is designed to measure changes in the prices of goods and services bought by wage earners and clerical workers in urban areas. It represents the cost of a typical consumption bundle at current prices as a ratio to its cost at a base year.

Continuous discharge capacity - Measured as percent of rated energy capacity. Energy delivered in a constant power discharge required by an electric vehicle for hill climbing and/or high-speed cruise, specified as the percent of its rated energy capacity delivered in a one hour constant-power discharge.

Corporate Average Fuel Economy (CAFE) standards - CAFE standards were originally established by Congress for new automobiles, and later for light trucks, in Title $\mathrm{V}$ of the Motor Vehicle Information and Cost Savings Act (15 U.S.C.1901, et seq.) with subsequent amendments. Under CAFE, automobile manufacturers are required by law to produce vehicle fleets with a composite sales-weighted fuel economy which cannot be lower than the CAFE standards in a given year, or for every vehicle which does not meet the standard, a fine of $\$ 5.00$ is paid for every one-tenth of a mpg below the standard.

Crude oil - A mixture of hydrocarbons that exists in the liquid phase in natural underground reservoirs and remains liquid at atmospheric pressure after passing through surface separating facilities. 
Crude oil imports - The volume of crude oil imported into the 50 States and the District of Columbia, including imports from U.S. territories, but excluding imports of crude oil into the Hawaiian Foreign Trade Zone.

Current dollars - Represents dollars current at the time designated or at the time of the transaction. In most contexts, the same meaning would be conveyed by the use of the term "dollars".

Disposable personal income - See Income.

Distillate fuel oil - The lighter fuel oils distilled off during the refining process. Included are products known as ASTM grades numbers 1 and 2 heating oils, diesel fuels, and number 4 fuel oil. The major uses of distillate fuel oils include heating, fuel for onand off-highway diesel engines, and railroad diesel fuel.

Domestic air operator - See Air carrier.

Domestic water transportation - See Internal water transportation.

Electric utilities sector - Consists of privately and publicly owned establishments which generate electricity primarily for resale.

Emission standards - Standards for the levels of pollutants emitted from automobiles and trucks. Congress established the first standards in the Clean Air Act of 1963. Currently, standards are set for four vehicle classes - automobiles, light trucks, heavyduty gasoline trucks, and heavy-duty diesel trucks.

Energy capacity - Measured in kilowatt hours. The energy delivered by the battery, when tested at $\mathrm{C} / 3$ discharge rate, up to termination of discharge specified by the battery manufacturer. The required acceleration power must be delivered by the battery at any point up to $80 \%$ of the battery's energy capacity rating.

Energy efficiency - In reference to transportation, the inverse of energy intensiveness: the ratio of outputs from a process to the energy inputs; for example, miles traveled per gallon of fuel (mpg).

Energy intensity - In reference to transportation, the ratio of energy inputs to a process to the useful outputs form that process; for example, gallons of fuel per passenger-mile or Btu per ton-mile. 
Fixed operating cost - See Operating cost.

\section{Fleet vehicles -}

Private fleet vehicles: Ideally, a vehicle could be classified as a member of a fleet if it is:

a) operated in mass by a corporation or institution,

b) operated under unified control, or

c) used for non-personal activities.

However, the definition of a fleet is not consistent throughout the fleet industry. Some companies make a distinction between cars that were bought in bulk rather than singularly, or whether they are operated in bulk, as well as the minimum number of vehicles that constitute a fleet (i.e. 4 or 10 ).

Government fleet vehicles: Includes vehicles owned by all federal (GSA), state, county, city, and metro units of government, including toll road operations.

Foreign freight - Movements between the United States and foreign countries and between Puerto Rico, the Virgin Islands, and foreign countries. Trade between U.S. territories and possessions (e.g. Guam, Wake, American Samoa) and foreign countries is excluded. Traffic to or from the Panama Canal Zone is included.

Gas Guzaler Tax - Originates from the 1978 Energy Tax Act (Public Law 95-618). A new car purchaser is required to pay the tax if the car purchased has a combined city/highway fuel economy rating that is below the standard for that year. For model years 1986 and later, the standard is $22.5 \mathrm{mpg}$.

Gasohol - A mixture of $10 \%$ anhydrous ethanol and $90 \%$ gasoline by volume. There are other fuels that contain methanol and gasoline, but these fuels are not referred to as gasohol.

Gasoline - See Motor gasoline.

General aviation - That portion of civil aviation which encompasses all facets of aviation except air carriers. It includes any air taxis, commuter air carriers, and air travel clubs which do not hold Certificates of Public Convenience and Necessity.

Gross National Product - A measure of monetary value of the goods and services becoming available to the nation from economic activity. Total value at market prices of all goods and services produced by the nation's economy. Calculated quarterly by the Department of Commerce, the Gross National Product is the broadest available measure of the level of economic activity. 
Gross vehicle weight (gvw) - The weight of the empty vehicle plus the maximum anticipated load weight.

Heavy-heavy truck - See Truck size classifications.

Houschold - Consists of all persons who occupy a housing unit, including the related family members and all unrelated persons, if any, who share the housing unit.

Housing unit - A house, apartment, a group of rooms, or a single room occupied or intended for occupancy as separate living quarters. Separate living quarters are those in which the occupants do not live and eat with any other persons in the structure and which have either (1) direct access from the outside of the building or through a common hallway intended to be used by the occupants of another unit or by the general public, or (2) complete kitchen facilities for the exclusive use of the occupants. The occupants may be a single family, one person living alone, two or more families living together, or any other group of related or unrelated persons who share living arrangements.

Hydrocarbon (HC) - A compound that contains only hydrogen and carbon. The simplest and lightest forms of hydrocarbon are gaseous. With greater molecular weights they are liquid, while the heaviest are solids.

Income -

Disposable personal income: Personal income less personal tax and non-tax payments.

National income - The aggregate earnings of labor and property which arise in the current production of goods and services by the nation's economy.

Personal income: The current income received by persons from all sources, net of contributions for social insurance.

Industrial sectur - Construction, manufacturing, agricultural and mining establishments.

Intercity bus - See Bus. 


\section{G-8}

Internal water transportation - Includes all local (intraport) traffic and traffic between ports or landings wherein the entire movement takes place on inland waterways. Also termed internal are movements involving carriage on both inland waterways and the water of the Great Lakes, and inland movements that cross short stretches of open water that link inland systems.

International air operator - See Air carrier.

International freight - See Foreign freight.

Jet fuel - Includes both naphtha-type and kerosene-type fuels meeting standards for use in aircraft turbine engines. Although most jet fuel is used in aircraft, some is used for other purposes such as generating electricity in gas turbines.

Kerosene-type jet fuel: A quality kerosene product with an average gravity of $\mathbf{4 0 . 7}$ degrees API and 10\% to $90 \%$ distillation temperatures of 217 and 261 degrees centigrade. Used primarily as fuel for commercial turbojet and turboprop aircraft engines. It is a relatively low freezing point distillate of the kerosene type.

Naphtha-type jet fuel: A fuel in the heavy naphtha boiling range with an average gravity of 52.8 degrees API and $10 \%$ to $90 \%$ distillation temperatures of 117 to 233 degrees centigrade used for turbojet and turboprop aircraft engines, primarily by the military. Excludes ramjet and petroleum.

Kerosene - A petroleum distillate in the 300 to 500 degrees Fahrenheit boiling range and generally having a flash point higher than 100 degrees Fahrenheit by the American Society of Testing and Material (ASTM) Method D56, a gravity range from 40 to 46 degrees API, and a burning point in the range of 150 to 175 degrees Fahrenheit. It is a clean-burning product suitable for use as an illuminant when burned in wick lamps. Includes grades of kerosene called range oil having properties similar to Number 1 fuel oil, but with a gravity of about 43 degrees API and an end point of 625 degrees Fahrenheit. Used in space heaters, cooking stoves, and water heaters.

Kerosene-type jet fuel - See Jet fuel.

Large car - See Automobile size classifications.

Light duty vehicles - Automobiles and light trucks combined. 
Light truck - Unless otherwise noted, light trucks are defined in this publication as twoaxle, four-tire trucks. The U.S. Bureau of Census classifies all trucks with a gross vehicle weight less than 10,000 pounds as light trucks (See Truck size classifications).

Light-heavy truck - See Truck size classifications.

Liquified petroleum gas (lpg) - Consists of propane and butane and is usually derived from natural gas. In locations where there is no natural gas and the gasoline consumption is low, naphtha is converted to lpg by catalytic reforming.

Load factor - A term relating the potential capacity of a system relative to its actual performance. Is often calculated as total passenger miles divided by total vehicle miles.

Low-emission vehicle - A clean fuel vehicle meeting the low-emission vehicle standards.

Medium truck - See Truck size classifications.

Midsize car - See Automobile size classifications.

Minicompact car - See Automobile size classifications.

Model year - In this publication, model year is referring to the "sales" model year, the period from October 1 to the next September 31.

Motor bus - See Bus.

Motor Gasoline - A mixture of volatile hydrocarbons suitable for operation of an internal combustion engine whose major components are hydrocarbons with boiling points ranging from 78 to 217 degrees centigrade and whose source is distillation of petroleum and cracking, polymerization, and other chemical reactions by which the naturally occurring petroleum hydrocarbons are converted into those that have superior fuel properties.

Naphtha-type jet fuel - See Jet fuel.

National income - See Income. 
Nationwide Personal Transportation Study (NPTS) - A nationwide home interview survey of households that provides information on the characteristics and personal travel patterns of the U.S. population. Surveys were conducted in 1969, 1977, 1983 and 1990 by the U.S. Bureau of Census for the U.S. Department of Transportation.

Natural gas - A mixture of hydrocarbon compounds and small quantities of various nonhydrocarbons existing in the gaseous phase or in solution with crude oil in natural underground reservoirs at reservoir conditions.

Nitrogen Oxides (NO $)$ - A product of combustion of fossil fuels whose production increases with the teinperature of the process. It can become an air pollutant if concentrations are excessive.

\section{Operating cost -}

Fixed operating cost: In reference to passenger car operating cost, refers to those expenditures that are independent of the amount of use of the car, such as insurance costs, fees for license and registration, depreciation and finance charges.

Variable operating cost: In reference to passenger car operating cost, expenditures which are dependent on the amount of use of the car, such as the cost of gas and oil, tires, and other maintenance.

Organization for Petroleum Exporting Countries (OPEC) - Includes Saudi Arabia, Iran, Venezuela, Libya, Indonesia, United Arab Emirates, Algeria, Nigeria, Ecuador, Gabon, Iraq, Kuwait, and Qatar. Data for Saudi Arabia and Kuwait include their shares from the Partitioned Zone (formerly the Neutral Zone).

Other single-unit truck - See Single-unit truck.

Particulates - Carbon particles formed by partial oxidation and reduction of the hydrocarbon fuel. Also included are trace quantities of metal oxides and nitrides, originating from engine wear, component degradation, and inorganic fuel additives. In the transportation sector, particulates are emitted mainly from diesel engines.

Passenger-miles traveled (PMT) - One person traveling the distance of one mile. Total passenger-miles traveled, thus, give the total mileage traveled by all persons.

Passenger rail - See Rail, "Amtrak" and "Transit Railroad". 
Personal Consumption Expenditures (PCE) - As used in the national accounts, the market value of purchases of goods and services by individuals and nonprofit institutions and the value of food, clothing, housing, and financial services received by them as income in kind. It includes the rental value of owner-occupied houses but excludes purchases of dwellings, which are classified as capital goods (investment).

Personal income - See Income.

Petroleum - A generic term applied to oil and oil products in all forms, such as crude oil, lease condensate, unfinished oil, refined petroleum products, natural gas plant liquids, and non-hydrocarbon compounds blended into finisted petroleum products.

Petroleum consumption - A calculated demand for petroleum products obtained by summing domestic production, imports of crude petroleum and natural gas liquids, imports of petroleum products, and the primary stocks at the beginning of the period and then subtracting the exports and the primary stocks at the end of the period.

Petroleum exports - Shipments of petroleum products from the 50 States and the District of Columbia to foreign countries, Puerto Rico, the Virgin Islands, and other U.S. possessions and territories.

Petroleum imports - All imports of crude petroleum, natural gas liquids, and petroleum products from foreign countries and receipts from Guam, Puerto Rico, the Virgin Islands, and the Hawaiian Trade Zone. The commodities included are crude oil, unfinished oils, plant condensate, and refined petroleum products.

Petroleum inventories - The amounts of crude oil, unfinished oil, petroleum products, and natural gas liquids held at refineries, at natural gas processing plants, in pipelines, at bulk terminals operated by refining and pipeline companies, and at independent bulk terminals. Crude oil held in storage on leases is also included; these stocks are know as primary stocks. Secondary stocks - those held by jobbers dealers, service station operators, and consumers -are excluded. Prior to 1975 , stock held at independent bulk terminals were classified as secondary stocks.

Petroleum products supplied - For each petroleum product, the amount supplied is calculated by summing production, crude oil burned directly, imports, and net withdrawals from primary stocks and subtracting exports.

Quad - Quadrillion, 10 15 . In this publication, a Quad refers to Quadrillion Btu. 
Rail -

Amtrak (American Railroad Tracks): Operated by the National Railroad Passenger Corporation of Washington, DC. This rail system was created by President Nixon in 1970, and was given the responsibility for the operation of intercity, as distinct from suburban, passenger trains between points designated by the Secretary of Transportation.

Class I freight railroad: Defined by the Interstate Commerce Commission each year based on annual operating revenue. For 1988, the threshold for Class I railroads was $\$ 87.9$ million. A railroad is dropped from the Class I list if it fails to meet the annual earnings threshold for three consecutive years.

Commuter railroad: Those portions of mainline railroad (not electric railway) transportation operations which encompass urban passenger train service for local travel between a central city and adjacent suburbs. Commuter railroad service - using both locomotive-hauled and self-propelled railroad passenger cars - is characterized by multi-trip tickets, specific station-to-station fares, and usually only one or two stations in the central business district. Also known as suburban railroad.

Transit railroad: Includes "heavy" and "light" transit rail. Heavy transit rail is characterized by exclusive rights-of-way, multi-car trains, high speed rapid acceleration, sophisticated signaling, and high platform loading. Also known as subway, elevated railway, or metropolitan railway (metro). Light transit rail may be on exclusive or shared rights-of-way, high or low platform loading, multi-car trains or single cars, automated or manually operated. In generic usage, light rail includes streetcars, trolley cars, and tramways.

Residential and Commercial sector - Consists of housing units, non-manufacturing business establishments (e.g., wholesale and retail businesses), health and educational institutions, and government offices.

Residential Transportation Energy Consumption Survey (RTECS) - This survey was designed by the Energy Information Administration of the Department of Energy to provide information on how energy is used by households for personal vehicles. It was conducted in 1983, 1985, and 1987. Data for the 1987 RTECS are not yet available. 
Residual fuel oil - The heavier oils that remain after the distillate fuel oils and lighter hydrocarbons are boiled off in refinery operations. Included are products know as ASTM grade numbers 5 and 6 oil, heavy diesel oil, Navy Special Fuel Oil, Bunker C oil, and acid sludge and pitch used as refinery fuels. Residual fuel oil is used for the production of electric power, for heating, and for various industrial purposes.

Rural - Usually refers to areas with population less than 5,000 .

Sales-weighted miles per gallon (mpg) - Calculation of a composite vehicle fuel economy based on the distribution of vehicle sales.

Scrappage rate - As applied to motor vehicles, it is usually expressed as the percentage of vehicles of a certain type in a given age class that are retired from use (lacking registration) in a given year.

School and other nonrevenue bus - See Bus.

Single unit truck - Includes two-axle, four-tire trucks and other single unit trucks.

Two-axle, four tire truck: A motor vehicle consisting primarily of a single motorized device with two axles and four tires.

Other single-unit truck: A motor vehicle consisting primarily of a single motorized device with more than two axles or more than four tires.

Special fuels - Consist primarily of diesel fuel with small amount of liquified petroleum gas, as defined by the Federal Highway Administration.

Specific acceleration power - Measured in watts per kilogram. Acceleration power divided by the battery system weight. Weight must include the total battery system.

Specific energy - Measured in watt hours per kilogram. The rated energy capacity of the battery divided by the total battery system weight.

Subcompact car - See Automobile size classifications.

Supplemental air carrier - See Air carrier. 
Ton-mile - The movement of one ton of freight the distance of one mile. Ton-miles are computed by multiplying the weight in tons of each shipment transported by the distance hauled.

Transmission types -

A3 - Automatic three speed

A4 - Automatic four speed

A5 - Automatic five speed

L4 - Automatic lockup four speed

M5 - Manual five speed

Transit bus - See Bus.

Transit railroad - See Rail.

Transportation sector - Consists of both private and public passenger and freight transportation, as well as government transportation, including military operations.

Truck Inventory and Use Survey (TIUS) - Survey designed to collect data on the characteristics and operational use of the nation's truck population. It is conducted every five years by the U.S. Bureau of the Census. Surveys were conducted in 1963, $1967,1972,1977,1982$, and 1987.

Trolley coach - See Bus.

Truck size classifications - U.S. Bureau of the Census has categorized trucks by gross vehicle weight (gvw) as follows:

Light - Less than 10,000 pounds gvw (Also see Light Truck.)

Medium - 10,001 to 20,000 pounds gvw

Light-heavy - 20,001 to 26,000 pounds gvw

Heavy-heavy - 26,001 pounds gvw or more.

Two-axde, four-tire truck - See Single-unit truck.

Two seater car - See Automobile size classifications. 
Ultra-low emission vehicle - A clean fuel vehicle meeting the more stringent Ultra-low emission standards.

Urban - Usually refers to areas with population of 5,000 or greater.

Variable operating cost - See Operating cost.

Vehicle-miles traveled (vmt) - One vehicle traveling the distance of one mile. Total vehicle miles, thus, is the total mileage traveled by all vehicles.

Zero-emission vehicle - A clean fuel vehicle meeting even more stringent zero-emission vehicle standards. 


\section{TITLE INDEX}

\section{Notations:}

indicates the end of the title

( ) indicates the page number 
Aduits

Average Annual Miles per Vehicle by Number of Adults in

Advanced

Advanced Battery Technology Goals of the U.S. Advanced Battery Consortium* (5-13)

Age

Average Age of Automobiles and Trucks in Use, 1970-1991* (3-10)

Automobile in Use by Age, 1970 and 1991* (3-20)

Automobiles in Operation ard Vehicle Travel by Age of Vehicle, $1991 *(3-22)$

Average Annual Miles Per Automobiles by Automobile Age* (3-24)

Trucks in Use by Age, 1970 and 1991* (3-35)

Trucks in Operation and Vehicle Travel by Age of Vehicle, $1991^{\star}(3-36)$

Distribution of Journey-to-Work Trips by Worker Age and Mode, 1990* (4-25)

Distribution of Vehicles by Age, 1969, 1977, 1983, and 1990

Series of the NPTS* $(4-27)$

Distribution of Annual Miles by Driver Age and Sex, 1969, 1977, Agency

1983, and 1990 Series of the NPTS* $(4-31)$

Air

Federal Government Vehicles by Agency, Fiscal Year 1988* (3-53)

California Air Resources Board Standards* (3-71)

Demographic Characteristics of Auto/Truck/Recreational Vehicle

(RV) and Air Travelers, 1988-90* (4-8)

Traffic Data for Large Certificated Route Air Carriers by

Carrier Group, Scheduled and Nonschedulec Services, 1982 and $1991 *(6-10)$

Summary Statistics for Domestic and International Certificated

Alcohol

Route Air Carriers (Combined Totals), 1970-90* (6-7)

Reid Vapor Pressure of Various Alcohol/Ether/Gasoline

Blends* $(5-15)$

Alternative

Number of Alternative Refuel Sites by State and Fuel Type,

AMFA

$1992 *(5-6)$

On-Road Fuel/Energy Economy Summary for the AMFA Federal

Amtrak

Vehicles, FY $1991^{*}(5-5)$

Summary Statistics for the National Railroad Passenger Annual

Corporation (Amtrak), 1971-91* (6-29)

Annual Miles Driven per Vehicle for Selected Countries, $1984-90 *(1-17)$

Annual Vehicle Miles Traveled by Personal Vehicles for Selected Countries, 1970-89* (1-19)

Average Annual Miles Per Automobiles by Automobile Age* (3-24)

Average Annual Miles per Bus By Type, 1970-90* (3-47)

Average Annual VMT, Vehicle Trips and Trip Length per Household for Selected Trip Furposes, 1969, 1977, 1983, and 1990 Series of the NPTS* $(4-17)$ 
Annual

Average Annual Miles per Vehicle by Number of Vehicles

Available, 1969, 1977, 1983, and 1990 Series of the NPTS* (4-29)

Average Annual Miles per Vehicle by Number of Adults in

Household, 1977, 1983, and 1990 Series of the NPTS* (4-30)

Distribution of Annual Miles by Driver Age and Sex, 1969, 1977, 1983, and 1990 Series of the NPTS* (4-31)

Average Annual Miles per Vehicle by Household Vehicle Ownership, $1990 *(4-32)$

Auto

Average Annual Expenditures of Households by Income, $1990^{*}(4-7)$

Demographic Characteristics of Auto/Truck/Recreational Vehicle

(RV) and Air Travelers, 1988-90* (4-8)

Automobile

Fuel Economy of the Gasoline Automobile Population for Selected Countries, 1970-89* (1-15)

Automobile Registrations for Selected Countries, 1950-90* (1-3)

Automobile Operating Costs, 1975-91* (2-40)

New Retail Automobile Sales in the United States,

$1970-91$ * (3-19)

Automobile in Use by Age, 1970 and 1991* (3-20)

Average Annual Miles Per Automobiles by Automobile Age* (3-24)

Average Material Consumption for a Domestic Automobile, 1978, 1984 , and $1992^{*}(3-25)$

Distribution of New Domestic Fleet Automobile Registrations by Size Class, $1975-91^{*}(3-50)$

Automobile Fleets by Use, $1970-91^{*}(3-51)$

Automobiles

Average Age of Automobiles and Trucks in Use, 1970-1991* (3-10)

Scrappace and Survival Rates for Automobiles, All Trucks, and

Light Trucks* (3-12)

Scrappage and Survival Rates for Automobiles* (3-14)

Automobiles in Operation and Vehicle Travel by Age of Vehicle, $1991 *(3-22)$

Average Annual Miles Per Automobiles by Automobile Age* (3-24)

Sales-Weighted Engine Size of Domestic and Import Automobiles by Size Class, Sales Periods 1976-1992* (3-26)

Sales-Weighted Curb Weight of Domestic and Import Automobiles by Size Class, Sales Periods 1976-1992* (3-27)

Sales-Weighted Interior Space of Domestic and Import Automobiles

by Size Class, Sales Periods 1976-1992* (3-28)

Period Sales, Market Shares, and Sales-Weighted Fuel Economies of New Domestic and Import Automobiles, Selected Sales Periods $1976-1992 *(3-30)$

Corporate Average Fuel Economy (CAFE) Standards Versus

Sales-Weighted Fuel Economy Estimates for Automobiles and Light Trucks, 1978-92* (3-55)

Federal Emission Control Requirements for Automobiles and Light

Trucks, 1976-94* (3-66)

Automobiles and Trucks in Use, 1979-1991* (3-9)

Available

Number of Households by Vehicles Available, 1969, 1977, 1983, and 1990 Series of the NPTS* $(4-15)$

Average Annual Miles per Vehicle by Number of Vehicles

Available, 1969, 1977, 1983, and 1990 Series of the NPTS* (4-29) 
Average

Average Price of a New Car, 1970-91* (2-39)

Average Age of Automobiles and Trucks in Use, 1970-1991* (3-10)

Average Annual Miles Per Automobiles by Automobile Age* (3-24)

Average Material Consumption for a Domestic Automobile, 1978, 1984 , and $1992^{\star}(3-25)$

Average Annual Miles per Bus By Type, 1970-90* (3-47)

Corporate Average Fuel Economy (CAFE) Standards Versus

Sales-Weighted Fuel Economy Estimates for Automobiles and Light

Trucks, 1978-92* (3-55)

Corporate Average Fuel Economy (CAFE) Fines Collected, $1983-91$ * $(3-57)$

Average Urban and Rural Interstate Speeds, 1970-90* (3-62)

Average Annual VMT, Vehicle Trips and Trip Length per Household for Selected Trip Purposes, 1969, 1977, 1983, and 1990 Series of the NPTS* (4-17)

Average Vehicle Occupancy for Selected Trip Purposes, 1969, 1977,1983 , and 1990 Series of the NPTS* (4-19)

Average Annual Miles per Vehicle by Number of Vehicles Available, 1969, 1977, 1983, and 1990 Series of the NPTS* (4-29) Average Annual Miles per Vehicle by Number of Adults in Household, 1977, 1983, and 1990 Series of the NPTS* (4-30)

Average Annual Miles per Vehicle by Household Vehicle Ownership, $1990 *(4-32)$

Aviation

Average Annual Expenditures of Households by Income, 1990* (4-7)

Axle

Summary Statistics for General Aviation, $1970-90 *(6-11)$

Barrel

Summary Statistics for Two-Axle, Four-Tire Trucks, $1970-90 *(3-38)$

Prices for a Barrel of Crude $0 i l$ and a Gallon of Gasoline, $1976-91^{*}(2-32)$

Refinery Yield of Petroleum Products from a Barrel of Crude $0 i 1$, Basic $1978-91^{*}(2-4)$

Battery

Basic Chemistry of Various Transportation Fuels* (5-14)

Advanced Battery Technology Goals of the U.S. Advanced Battery Blends Consortium* $(5-13)$

Reid Vapor Pressure of Various Alcohol/Ether/Gasoline

Board Blends* (5-15)

Breakdown

California Air Resources Board Standards* (3-71)

Breakdown of Domestic Marine Cargo by Commodity Class, $1989 *(6-18)$

Bus

Passenger Travel by Bus for Selected Countries, 1970-89* (1-22)

Energy Use by Bus for Selected Countries, 1970-89* (1-23)

Truck and Bus Registrations for Selected Countries, $1950-90 *(1-4)$

Passenger and Vehicie Travel by Bus Type, 1970-90* (3-46)

Average Annual Miles per Bus By Type, 1970-90* (3-47) 
Bus

Buses

Energy Consumption and Energy Intensities by Type of Bus, $1970-90 *(3-48)$

CAFE

Buses in Operation by Type, 1970-90* (3-45)

Corporate Average Fuel Economy (CAFE) Standards Versus

Sales-Weighted Fuel Economy Estimates for Automobiles and Light

Trucks, 1978-92* (3-55)

Corporate Average Fuel Economy (CAFE) Fines Collected,

Caiendar

$1983-91 *(3-57)$

Vehicle Stock and New Sales in United States 1990 Calendar

California

Year* $(3-8)$

Exhaust Emission Standards for Clean-Fuel Vehicles in the Capita

California Pilot Test Program* (3-70)

California Air Resources Board Standards* (3-71)

Car

Vehicles per Capita for Selected Countries, $1950-90 *(1-6)$

New Gasoline Car Fuel Economy for Selected Countries, $1973-89 *(1-13)$

Carbon

Average Price of a New Car, 1970-91* (2-39)

Contribution of Transportation Fuel Use to Total Carbon Emission Cargo

for Selected Countries* (3-73)

Breakdown of Domestic Marine Cargo by Commodity Class, $1989 *(6-18)$

Carloadings

Railroad Revenue Carloadings by Commodity Group, 1974 and

Carrier $1990 *(6-28)$

Traffic Data for Large Certificated Route Air Carriers by Carrier Group, Scheduled and Nonscheduled Services, 1982 and Carriers $1991 *(6-10)$

Traffic Data for Large Certificated Route Air Carriers by Carrier Group, Scheduled and Nonscheduled Services, 1982 and $1991 *(6-10)$

Summary Statistics for Domestic and International Certificated

Cars Route Air Carriers (Combined Totals), 1970-90* (6-7)

Census

Summary Statistics for Passenger Cars, 1970-90* (3-23)

The Gas Guzzler Tax on New Cars* (3-59)

Means of Transportation to Work for the United States: 1980 and Certificated

Traffic Data for Large Certificated Route Air Carriers by Carrier Group, Scheduled and Nonscheduled Services, 1982 and $1991 *(6-10)$

Summary Statistics for Domestic and International Certificated Route Air Carriers (Combined Totals), 1970-90* (6-7) 
Chemistry Class

Basic Chemistry of Various Transportation Fuels* (5-14)

Sales-Weighted Engine Size of Domestic and Import Automobiles by Size Class, Sales Periods 1976-1992* (3-26)

Sales-Weighted Curb Weight of Domestic and Import Automobiles by Size Class, Sales Periods 1976-1992* (3-27)

Sales-Weighted Interior Space of Domestic and Import Automobiles by Size Class, Sales Periods 1976-1992* (3-28)

Truck Fuel Economy by Size Class, 1977, 1982, and $1987^{*}(3-43)$

Percentage of Trucks by Size Class, 1977, 1982, and $1987^{*}(3-43)$

Distribution of New Domestic Fleet Automobile Registrations by

Size Class, $1975-91 *(3-50)$

Breakdown of Domestic Marine Cargo by Commodity Class, $1989 *(6-18)$

Class I Railroad Freight Systems in the United States Ranked by Revenue Ton-Miles, 1990* (6-25)

Summary Statistics for Class I Freight Railroads,

Clean $1970-90 *(6-26)$

Exhaust Emission Standards for Clean-Fuel Vehicles in the

California Pilot Test Program* (3-70)

Possible Fuel/Vehicles for Clean-Fuel Vehicles* (3-72)

Collected

Corporate Average Fuel Economy (CAFE) Fines Collected,

Commerce $1983-91 *(3-57)$

Tonnage Statistics for Domestic and International Waterborne Commerce, 1970-89* (6-15)

Summary Statistics for Domestic Waterborne Commerce,

Commodity $1970-89 *(6-16)$

Breakdown of Domestic Marine Cargo by Commodity Class, $1989 *(6-18)$

Railroad Revenue Carloadings by Commodity Group, 1974 and

Commuting $1990 *(6-28)$

Commuting Patterns of Journey-to-Work Trips by Mode 1969, 1977, 1983, and 1990 Series of the NPTS* $(4-22)$

Consortium

Advanced Battery Technology Goals of the U.S. Advanced Battery

Consortium* $(5-13)$

Consumption

Distribution of Energy Consumption by Source, 1981 and $1991 *(2-10)$

Consumption of Total Energy by End-Use Sector, 1970-91* (2-13)

Domestic Consumption of Transportation Energy by Mode and Fue 1

Type, $1990 *(2-14)$

Distribution of Domestic Consumption of Transportation Energy by

Mode and Fuel Type, 1990* (2-15)

Transportation Energy Consuniption by Mode, 1970-90* (2-18)

Personal Consumption Expenditures (PCE) as Related to

Transportation, 1970-91* (2-35)

United States Petroleum Production and Consumption, $1970-91^{*}(2-5)$ 
Consumption

Consumption of Petroleum by End-Use Sector, 1973-91* (2-7)

Average Material Consumption for a Domestic Automobile, 1978, 1984, and 1992* (3-25)

Energy Consumption and Energy Intensities by Type of Bus, $1970-90 *(3-48)$

Control

Gasohol Consumption by Reporting States, 1980-91*(5-18)

Federal Emission Control Requirements for Automobiles and Light

Trucks, 1976-94* (3-66)

Federal Emission Control Requirements for Heavy-Duty Gasoline

Trucks, 1976-94* (3-67)

Federal Emission Control Requirements for Heavy-Duty Diese 1

Trucks, 1976-94* (3-68)

Corporate

Corporate Average Fuel Economy (CAFE) Standards Versus

Sales-Weighted Fuel Economy Estimates for Automobiles and Light

Trucks, 1978-92* (3-55)

Corporate Average Fuel Economy (CAFE) Fines Collected,

$1983-91 *(3-57)$

Corporation

Summary Statistics for the National Railroad Passenger

Costs

Corporation (Amtrak), 1971-91* (6-29)

Countries

Automobile Operating Costs, 1975-91* (2-40)

Diesel Fuel Prices for Selected Countries, 1978-91* (1-11)

New Gasoline Car Fuel Economy for Selected Countries, $1973-89 *(1-13)$

Fuel Economy of the Gasoline Automobile Population for Selected Countries, 1970-89* (1-15)

Annual Miles Driven per Vehicle for Selected Countries, $1984-90 *(1-17)$

Inland Surface Transport of Goods for Selected Countries, $1985^{*}(1-18)$

Annual Vehicle Miles Traveled by Personal Vehicles for Selected Countries, 1970-89* (1-19)

Passenger Travel by Personal Vehicles for Selected Countries, $1970-89 *(1-20)$

Energy Use by Personal Vehicles for Selected Countries, $1970-89 *(1-21)$

Passenger Travel by Bus for Selected Countries, 1970-89* (1-22)

Energy Use by Bus for Selected Countries, 1970-89* (1-23)

Passenger Travel by Rail for Selected Countries, 1970-89* (1-24)

Energy Use by Rail for Selected Countries, 1970-89* (1-25)

Automobile Registrations for Selected Countries, 1950-90* (1-3)

Truck and Bus Registrations for Selected Countries, $1950-90^{*}(1-4)$

Vehicles per Capita for Selected Countries, 1950-90* (1-6)

Gasoline Prices for Selected Countries, 1978-91* (1-9)

Contribution of Transportation Fuel Use to Total Carbon Emission Crude

for Selected Countries* (3-73)

Prices for a Barrel of Crude $0 i 1$ and a Gallon of Gasoline, $1976-91 *(2-32)$ 
Crude

Refinery Yield of Petroleum Products from a Barrel of Crude $0 i 1$, $1978-91^{*}(2-4)$

Curb

Sales-Weighted Curb Weight of Domestic and Import Automobiles by Size Class, Sales Periods $1975-1992^{*}(3-27)$

Demographic

Summary Statistics on Demographic Characteristics and Total

Travel, 1969, 1977, 1983, and 1990 Series of the NPTS* (4-13)

Demographic Characteristics of Auto/Truck/Recreational Vehicle Diesel

(RV) and Air Travelers, 1988-90* (4-8)

Diesel Fuel Prices for Selected Countries, 1978-91* $(1-11)$

Federal Emission Control Requirements for Heavy-Duty Diesel

Trucks, $1976-94^{*}(3-68)$

Distance

Distribution of Journey-to-Work Trips by Trip Distance and Mode, 1990* (4-26)

Distribution of Trips for All Modes by Trip Purpose and

Round-Trip Distance, 1974, 1983, and 1990* (4-9)

Distribution

Distribution of Energy Consumption by Source, 1981 and

$1991 *(2-10)$

Distribution of Domestic Consumption of Transportation Energy by

Mode and Fuel Type, 1990* (2-15)

Distribution of New Domestic Fleet Automobile Registrations by

Size Class, $1975-91^{*}(3-50)$

Distribution of Journey-to-Work Trips by Usual Mode, 1969, 1977, 1983, and 1990 Series of the NPTS* (4-21)

Distribution of Journey-to-Work Trips by Household Income and Mode, 1990* (4-24)

Distribution of Journey-to-Work Trips by Worker Age and Mode, $1990 *(4-25)$

Distribution of Journey-to-Work Trips by Trip Distance and Mode, $1990 *(4-26)$

Distribution of Vehicles by Age, 1969, 1977, 1983, and 1990

Series of the NPTS* $(4-27)$

Distribution of Annual Miles by Driver Age and Sex, 1969, 1977, 1983, and 1990 Series of the NPTS* (4-31)

Distribution of Trips for All Modes by Trip Purpose and

Domestic

Round-Trip Distance, 1974, 1983, and 1990* (4-9)

Domestic Consumption of Transportation Energy by Mode and Fuel

Type, 1990* (2-14)

Distribution of Domestic Consumption of Transportation Energy by Mode and Fuel Type, 1390* (2-15)

Average Material Consumption for a Donestic Automobile, 1978, 1984 , and $1992^{*}(3-25)$

Sales-Weighted Engine Size of Domestic and Import Automobiles by Size Class, Sales Periods 1976-1992* (3-26)

Sales-Weighted Curb Weight of Domestic and Import Automobiles by Size Class, Sales Periods 1976-1992* (3-27)

Sales-Weighted Interior Space of Domestic and Import Automobiles by Size Class, Sales Periods 1976-1992* (3-28) 
Domestic

Period Sales, Market Shares, and Sales-Weighted Fuel Economies of New Domestic and Import Automobiles, Selected Sales Periods $1976-1992 *(3-30)$

New Retail Domestic Truck Sales by Gross Vehicle Weight, $1970-91 *(3-34)$

Period Sales, Market Shares, and Sales-Weighted Fuel Economies of New Domestic and Import Light Trucks, Selected Sales Periods $1976-92 *(3-37)$

Distribution of New Domestic Fleet Automobile Registrations by Size Class, $1975-91 *(3-50)$

Tonnage Statistics for Domestic and International Waterborne Commerce, $1970-89 *(6-15)$

Summary Statistics for Dumestic Waterborne Commerce, $1370-80 *(6-16)$

Breakdown of Domestic Marine Cargo by Commodity Class, $1.989 *(6-18)$

Summary Statistics for Domestic and International Certificated Driven Route Air Carriers (Combined Totals), 1970-30* (6-7)

Driver

Annual Miles Driven per Vehicle for Selected Countries, $1984-90 *(1-17)$

Distribution of Annual Miles by Driver Aye and Sex, 1969, 1977 , Duty

1983, and 1990 Series of the NPTS* $(4-31)$

Federal Emission Control Requirements for Heavy-Duty Gasoline

Trucks, 1976-94* (3-67)

Federal Emission Control Requirements for Heavy-Duty Diesel

Economies

Trucks, $1976-94^{\star}(3-68)$

Period Sales, Market Shares, and Sales-Weighted Fuel Economies of New Domestic and Import Automobiles, Selected Sales Periods 1976-1992* (3-30)

Period Sales, Market Shares, and Sales-Weighted Fuel Economies of New Domestic and Import Light Trucks, Selected Sales Periods Economy $1976-92^{\star}(3-37)$

New Gasoline Car Fuel Economy for Selected Countries, $1973-89 *(1-13)$

Fuel Economy of the Gasoline Automobile Population for Selected Countries, $1970-83^{*}(1-15)$

Truck Fuel Economy by Size Class, 1977, 1982, and 1987* (3-43)

Corporate Average Fuel Economy (CAFE) Standards Versus

Sales-Weighted Fuel Economy Estimates for Automobiles and Light Trucks, 1978-92* (3-55)

Corporate Average Fuel Economy (CAFE) Fines Collected, $1983-91 *(3-57)$

Fuel Eronomy by Speed, 1973 and $1924^{*}(3-60)$

On-Road Fuel/Energy Ecunumy Sumnary for the AMFA Federal

Electric Vehicles, FY $1991^{*}(5-5)$ Emission

Electric Utility Fnergy Input by Source, 1973-1991* (2-11)

Fecleral [mission control Requirements for Automobiles and l.ight Trusks, $1976-94^{*}(3-66)$ 


\section{I-10}

Emission

Federal Emission Control Requirements for Heavy-Duty Gasoline

Trucks, 1976-94* (3-67)

Federal Emission Control Requirements for Heavy-Duty Diesel

Trucks, $1976 \cdot 94 *(3-68)$

Exhaust Emission Standards for Clean-Fuel Vehicles in the

California Pilot Test Program* (3-70)

Contribution of Transportation Fuel Use to Total Carbon Emission

Emissions

for Selected Countries* (3-73) Energy

Transportation's Contribution to U.S. Emissions, 1978-90* (3-69)

Energy Use by Personal Vehicles for Selected Countries, $1970-89 *(1-21)$

Energy Use by Bus for Selected Countries, 1970-89* (1-23)

Energy Use by Rail for Selected Countries, 1970-89* (1-25)

Distribution of Energy Consumption by Source, 1581 and

$1991^{*}(2-10)$

Electric Utility Energy Input by Source, 1973-1991* (2-11)

Consumption of Total Energy by End-Use Sector, 1970-91* (2-13)

Domestic Consumption of Transportation Energy by Mode and Fue 1

Type, $1990 *(2-14)$

Distribution of Domestic Consumption of Transportation Energy by

Mode and Fuel Type, 1990* $(2-15)$

Transportation Energy Use by Mode, 1990* (2-17)

Transportation Energy Consumption by Mode, 1970-90* (2-18)

Passenger Travel and Energy Use in the United States,

$1990 *$ (2-22)

Energy Intensities of Passenger Modes, 1970-90* (2-24)

Intercity Freight Movement and Energy Use in the United States, $1990 *(2-25)$

Energy Intensities of Freight Modes, 1970-90* (2-27)

Highway Energy Use by Mode, 1970-90* (3-4)

Energy Consumption and Energy Intensities by Type of Bus, $1970-90 *(3-48)$

On-Road Fuel/Energy Economy Summary for the AMFA Federal

Vehicles, FY $1991^{*}(5-5)$

Nonhighway Energy Use by Mode, 1970-90* (6-2)

Engine

Pipeline Shipments of Energy, $1972-90 *(6-21)$

Sales-Weighted Engine Size of Domestic and Import Automobiles by

Estimates

Size Class, Sales Periods 1976-1992* $(3-26)$

Corporate Average Fuel Economy (CAFE) Standards Versus

Sales-Weighted Fuel Economy Estimates for Automobiles and Light Ethanol

Trucks, $1978-92^{\star}(3-55)$

Ether

U.S. Production of Methanol and Ethanol, 1978-1991* (5-16)

Reid Vapor Pressure of Various Alcohol/Ether/Gasoline

Exemptions

Blends* $(5-15)$

Exhaust

State Tax Exemptions for Gasohol, September $1992^{\star}(5-17)$

Exhaust Emission Standards for Clean-Fuel Vehicles in the

California Pilot Test Program* (3-70) 


\section{I-11}

Expenditures

Personal Consumption Expenditures (PCE) as Related to

Transportation, $1970-91^{*}(2-35)$

Federal

Average Annual Expenditures of Households by Income, 1990* (4-7)

Federal Government Vehicles by Agency, Fiscal Year 1988* (3-53)

Federal Emission Control Requirements for Automobiles and Light

Trucks, 1976-94* (3-66)

Federal Emission Control Requirements for Heavy-Duty Gasoline

Trucks, 1976-94* (3-67)

Federal Emission Control Requirements for Heavy-Duty Diesel

Trucks, 1976-94* (3-68)

On-Road Fuel/Energy Economy Summary for the AMFA Federal

Financial

Vehicles, FY $1991^{*}(5-5)$

Fines

Financial Profile of the Population, 1970-89* (4-5)

Corpcrate Average Fuel Economy (CAFE) Fines Collected, Fiscal $1983-91 *(3-57)$ Fleet

Federai Government Vehicles by Agency, Fiscal Year 1988* (3-53)

Distribution of New Domestic Fleet Automobile Registrations by Fleets

Size Class, $1975-91^{*}(3-50)$

Freight

Automobile Fleets by Use, $1970-91^{*}(3-51)$

Intercity Freight Movement and Energy Use in the United States, $1990 *(2-25)$

Energy Intensities of Freight Modes, 1970-90* (2-27)

Class I Railroad Freight Systems in the United States Ranked by

Revenue Ton-Miles, 1990* (6-25)

Summary Statistics for Class I Freight Railroads,

Fue 1 $1970-90 *(6-26)$

Diesel Fuel Prices for Selected Countries, 1978-91* (1-11)

New Gasoline Car Fuel Economy for Selected Countries, $1973-89 *(1-13)$

Fuel Economy of the Gasoline Automobile Population for Selected Countries, 1970-89* (1-15)

Domestic Consumption of Transportation Energy by Mode and Fuel Type, 1990* (2-14)

Distribution of Domestic Consumption of Transportation Energy by

Mode and Fuel Type, 1990* (2-15)

Retail Prices for Motor Fue 1, 1978-91* (2-29)

Period Sales, Market Shares, and Sales-Weighted Fuel Economies of New Domestic and Import Automobiles, Selected Sales Periods 1976-1992* (3-30)

Period Sales, Market Shares, and Sales-Weighted Fuel Economies of New Domestic and Import Light Trucks, Selected Sales Periods $1976-92^{*}(3-37)$

Truck Fuel Economy by Size Class, 1977, 1982, and 1987* (3-43)

Corporate Average Fuel Economy (CAFE) Standards Versus

Sales-Weighted Fuel Economy Estimates for Automobiles and Light

Trucks, $1978-92 *(3-55)$ 
Fue 1

Corporate Average Fuel Economy (CAFE) Fines Collected, $1983-91 *(3-57)$

Fuel Economy by Speed, 1973 and 1984* (3-60)

Exhaust Emission Standards for Clean-Fuel Vehicles in the

California Pilot Test Program* (3-70)

Possible Fuel/Vehicles for Clean-Fuel Vehicles* $(3-72)$

Contribution of Transportation Fuel Use to Total Carbon Emission

for Selected Countries* (3-73)

On-Road Fuel/Energy Economy Summary for the AMFA Federal

Vehicles, FY $1991^{*}(5-5)$

Number of Alternative Refuel Sites by State and Fuel Type, $1992^{*}(5-6)$

Fuels

Highway Usage of Gasoline and Special Fuels, 1973-90* $(2-20)$

Prices for Selected Transportation Fuels, 1978-91* $(2-30)$

Basic Chemistry of Various Transportation Fuels* (5-14)

FY

On-Road Fuel/Energy Economy Summary for the AMFA Federal

Vehicles, FY $1991^{*}(5-5)$

Gallon

Prices for a Barrel of Crude $0 i 1$ and a Gallon of Gasoline,

$1976-91 *(2-32)$

Gas

Tax Receipts from the Sale of Gas Guzzlers, 1980-91* (3-57)

Gasohol

The Gas Guzzler Tax on New Cars* (3-59)

State Tax Exemptions for Gasohol, September $1992^{\star}(5-17)$

Gasohol Consumption by Reporting States, $1980-91^{*}(5-18)$

Gasoline

New Gasoline Car Fuel Economy for Selected Countries,

$1973-89 *(1-13)$

Fuel Economy of the Gasoline Automobile Population for Selected

Countries, $1970-89 *(1-15)$

Gasoline Prices for Selected Countries, $1978-91^{*}(1-9)$

Highway Usage of Gasoline and Special Fuels, 1973-90* (2-20)

Prices for a Barrel of Crude $0 i 1$ and a Gallon of Gasoline,

$1976-91 *(2-32)$

Federal Emission Control Requirements for Heavy-Duty Gasoline

Trucks, 1976-94* (3-67)

Reid Vapor Pressure of Various Alcohol/Ether/Gasoline

Blends* $(5-15)$

GNP

Gross National Product (GNP) as Related to Transportation, $1970-91^{\star}(2-34)$

Goals

Advanced Battery Technology Goals of the U.S. Advanced Battery Consortium* $(5-13)$

Goods

Inland Surface Transport of Goods for Selected Countries, $1985 *(1-18)$

Government

Federal Government Vehicles by Agency, Fiscal Year 1988* (3-53) Gross

Gross National Product (GNP) as Related to Transportation, $1970-91 *(2-34)$ 


\section{I-13}

Gross

New Retail Domestic Truck Sales by Gross Vehicle Weight,

Guzzler $1970-91 *(3-34)$

Guzzlers

The Gas Guzzler Tax on New Cars* (3-59)

Heavy

Tax Receipts from the Sale of Gas Guzzlers, $1980-91^{*}(3-57)$

Federal Emission Control Requirements for Heavy-Duty Gasoline

Trucks, 1976-94* (3-67)

Federal Emission Control Requirements for Heavy-Duty Diesel

Highway

Trucks, 1976-94* (3-68)

Highway Usage of Gasoline and Special Fueis, 1973-90* (2-20)

Highway Energy Use by Mode, 1970-90* (3-4)

Household

Highway Vehicle Miles Traveled by Mode, 1979-90* (3-6)

Average Annual VMT, Vehicle Trips and Trip Length per Household

for Selected Trip Purposes, 1969, 1977, 1983, and 1590 Series of the NPTS* $(4-17)$

Distribution of Journey-to-Work Trips by Household Income and Mode, 1990* (4-24)

Average Annual Miles per Vehicle by Number of Adults in

Household, 1977, 1983, and 1990 Series of the NPTS* (4-30)

Average Annual Miles per Vehicle by Household Vehicle Ownership,

Houseriolds $1990 *(4-32)$

Number of Households by Vehicles Available, 1969, 1977, 1983, and 1990 Series of the NPTS* (4-15) Import

Average Annual Expenditures of Households by Income, 1990* (4-7)

Sales-Weighted Engine Size of Domestic and Import Automobiles by

Size Class, Sales Periods 1976-1992* (3-26)

Sales-Weighted Curb Weight of Domestic and Import Automobiles by Size Class, Sales Periods 1976-1992* (3-27)

Sales-Weighted Interior Space of Domestic and Import Automobiles

by Size Class, Sales Periods 1976-1992* (3-28)

Period Sales, Market Shares, and Sales-Weighted Fuel Economies

of New Domestic and Import Automobiles, Selected Sales Periods

$1976-1992^{*}(3-30)$

Period Sales, Market Shares, and Sales-Weighted Fuel Economies

of New Domestic and Import Light Trucks, Selected Sales Periods $1976-92 *(3-37)$

Income

Distribution of Journey-to-Work Trips by Household Income and

Mode, $1990 *(4-24)$

Indices

Average Annual Expenditures of Households by Income, 1990* (4-7)

Statistical Indices as Related to Transportation,

Inland

$1970-91 *(2-36)$

Inland Surface Transport of Goods for Selected Countries, $1985^{\star}(1-18)$

Input

Electric Utility Energy Input by Source, 1973-1991* (2-11) 


\section{I-14}

Intensities

Energy Intensities of Passenger Modes, 1970-90* (2-24)

Energy Intensities of Freight Modes, 1970-90* (2-27)

Energy Consumption and Energy Intensities by Type of Bus, $1970-90 *(3-48)$

Intercity

Intercity Freight Movement and Energy Use in the United States, $1990 *(2-25)$

Interior

Sales-Weighted Interior Space of Domestic and Import Automobiles

by Size Class, Sales Periods $1976-1992^{\star}(3-28)$

International

Tonnage Statistics for Domestic and International Waterborne

Commerce, 1970-89* (6-15)

Summary Statistics for Domestic and International Certificated

Interstate

Route Air Carriers (Combined Totals), 1970-90* (6-7) Journey

Average Urban and Rural Interstate Speeds, 1970-90* (3-62)

Distribution of Journey-to-Work Trips by Usual Mode, 1969, 1977, 1983, and 1990 Series of the NPTS* $(4-21)$

Commuting Patterns of Journey-to-Work Trips by Mode 1969, 1977, 1983, and 1990 Series of the NPTS* $(4-22)$

Distribution of Journey-to-Work Trips by Household Income and Mode, 1990* (4-24)

Distribution of Journey-to-Work Trips by Worker Age and Mode, $1990 *(4-25)$

Distribution of Journey-to-Work Trips by Trip Distance and Mode, $1990 *(4-26)$

Lanes Length

Miles of High-Occupancy Vehicle Lanes, 1969-90* (3-75)

Average Annual VMT, Vehicle Trips and Trip Length per Household for Selected Trip Purposes, 1969, 1977, 1983, and 1990 Series of Light the NPTS* $(4-17)$

Scrappage and Survival Rates for Automobiles, All liucks, and Light Trucks* (3-12)

New Retail Sales of Light Trucks in the United States, $1970-91^{*}(3-32)$

Period Sales, Market Shares, and Sales-Weighted Fuel Economies of New Domestic and Import Light Trucks, Selected Sales Periods $1976-92^{*}(3-37)$

Corporate Average Fuel Economy (CAFE) Standards Versus

Sales-Weighted Fuel Economy Estimates for Automobiles and Light Trucks, $1978-92 *(3-55)$

Federal Emission Control Requirements for Automobiles and Light Marine Trucks, 1976-94* (3-66)

Breakdown of Domestic Marine Cargo by Commodity Class, Market $1989 *(6-18)$

Period Sales, Market Shares, and Sales-Weighted Fuel Economies of New Domestic and Import Automobiles, Selected Sales Periods $1976-1992^{*}(3-30)$ 
Market

Period Sales. Market Shares, and Sales-Weighted Fuel Economies of New Domestic and Import Light Trucks, Selected Sales Periods

Material $1976-92 *(3-37)$

Average Material Consumption for a Domestic Automobile, 1978, Methanol Miles 1984, and $1992^{\star}(3-25)$

U.S. Production of Methanol and Ethanol, 1978-1991* (5-16)

Annual Miles Driven per Vehicle for Selected Countries, $1984-90 *(1-17)$

Annual Vehicle Miles Traveled by Personal Vehicles for Selected Countries, 1970-89* (1-19)

Average Annual Miles Per Automobiles by Autonobile Age* (3-24)

Average Annual Miles per Bus By Type, 1970-90* (3-47)

Highway Vehicle Miles Traveled by Mode, 1979-90* (3-6)

Miles of High-Occupancy Vehicle Lanes, 1969-90* (3-75)

Average Annual Miles per Vehicle by Number of Vehicles

Available, 1969, 1977, 1983, and 1990 Series of the NPTS* (4-29)

Average Annual Miles per Vehicle by Number of Adults in

Household, 1977, 1983, and 1990 Series of the NPTS* (4-30)

Distribution of Annual Miles by Driver Age and Sex, 1969, 1977, 1983, and 1990 Series of the NPTS* (4-31)

Average Annual Miles per Vehicle by Household Vehicle Ownership, $1990 *$ (4-32)

Class I Railroad Freight Systems in the United States Ranked by

Mode

Revenue Ton-Miles, 1990* (6-25)

Domestic Consumption of Transportation Energy by Mode and Fuel

Type, $1990 *(2-14)$

Distribution of Domestic Consumption of Transportation Energy by Mode and Fuel Type, 1990* (2-15)

Transportation Energy Use by Mode, 1990* (2-17)

Transportation Energy Consumption by Mode, 1970-90* (2-18)

Highway Energy Use by Mode, 1970-90* (3-4)

Highway Vehicle Miles Traveled by Mode, 1979-90* (3-6)

Mode of Trave 1 by Trip Purpose, 1990* (4-11)

Distribution of Journey-to-Work Trips by Usual Mode, 1969, 1977, 1983, and 1990 Series of the NPTS* (4-21)

Commuting Patterns of Journey-to-Work Trips by Mode 1969, 1977, 1983, and 1990 Series of the NPTS* (4-22)

Distribution of Journey-to-Work Trips by Household Income and

Mode, $1990 *(4-24)$

Distribution of Journey-to-Work Trips by Worker Age and Mode, $1990 *(4-25)$

Distribution of Journey-to-Work Trips by Trip Distance and Mode, 1990* (4-26)

Modes

Nonhighway Energy Use by Mode, 1970-90* (6-2)

Energy Intensities of Passenger Modes, 1970-90* (2-24)

Energy Intensities of Freight Modes, 1970-90* (2-27)

Distribution of Trips for All Modes by Trip Purpose and

Motor

Round-Trip Distance, 1974, 1983, and 1990* (4-9)

Retail Prices for Motor Fue1, 1978-91* (2-29) 
Movement

Intercity Freight Movement and Energy Use in the United States, National $1990 *(2-25)$

Gross National Product (GNP) as Related to Transportation, $1970-91 *(2-34)$

Summary Statistics for the National Railroad Passenger

Nonhighway

Corporation (Amtrak), 1971-91* (6-29)

Nonscheduled

Nonhighway Energy Use by Mode, $1970-90^{*}(6-2)$

Traffic Data for Large Certificated Route Air Carriers by

Carrier Group, Scheduled and Nonscheduled Services, 1982 and

NPTS $1991^{\star}(6-10)$

Summary Statistics on Demographic Characteristics and Total

Trave1, 1969, 1977, 1983, and 1990 Series of the NPTS* (4-13)

Number of Households by Vehicles Available, 1969, 1977, 1983,

and 1990 Series of the NPTS* (4-15)

Average Annual VMT, Vehicle Trips and Trip Length per Household

for Selected Trip Purposes, 1969, 1977, 1983, and 1990 Series of the NPTS* $(4-17)$

Average Vehicle Occupancy for Selected Trip Purposes, 1969, 1977,1983 , and 1990 Series of the NPTS* $(4-19)$

Distribution of Journey-to-Work Trips by Usual Mode, 1969, 1977, 1983, and 1990 Series of the NPTS* (4-21)

Commuting Patterns of Journey-to-Work Trips by Mode 1969, 1977,

1983, and 1990 Series of the NPTS* (4-22)

Distribution of Vehicles by Age, 1969, 1977, 1983, and 1990

Series of the NPTS* $(4-27)$

Average Annual Miles per Vehicle by Number of Vehicles

Available, 1969, 1977, 1983, and 1990 Series of the NPTS* (4-29)

Average Annual Miles per Vehicle by Number of Adults in

Household, 1977, 1983, and 1990 Series of the NPTS* (4-30)

Distribution of Annual Miles by Driver Age and Sex, 1969, 1977, 1983, and 1990 Series of the NPTS* $(4-31)$

Occupancy

Miles of High-Occupancy Vehicle Lanes, 1969-90* (3-75)

Average Vehicle Occupancy for Selected Trip Purposes, 1969,

$0 i 1$

1977,1983 , and 1990 Series of the NPTS* $(4-19)$

Prices for a Barrel of Crude $0 i l$ and a Gallon of Gasoline, $1976-91 *(2-32)$

Refinery Yield of Petroleum Products from a Barrel of Crude $0 i 1$, Operating $1978-91^{*}(2-4)$

Operation

Automobile Operating Costs, $1975-91^{*}(2-40)$

Automobiles in Operation and Vehicle Travel by Age of Vehicle,

$1991^{*}(3-22)$

Trucks in Operation and Vehicle Travel by Age of Vehicle,

$1991 *(3-36)$

Operations

Buses in Operation by Type, $1970-90 *(3-45)$

Summary Statistics for Rail Transmit Operations, $1970-90^{*}(6-31)$ 


\section{I-17}

Ownership

Average Annual Miles per Vehicle by Household Vehicle Ownership, $1990 *(4-32)$

Passenger

Passenger Travel by Personal Vehicles for Selected Countries, 1970-89* (1-20)

Passenger Travel by Bus for Selected Countries, 1970-89* $(1-22)$

Passenger Travel by Rail for Selected Countries, 1970-89* $(1-24)$

Passenger Travel and Energy Use in the United States, $1990 *$ ( 2-22)

Energy Intensities of Passenger Modes, $1970-90^{*}(2-24)$

Summary Statistics for Passenger Cars, 1970-90* (3-23)

Passenger and Vehicle Travel by Bus Type, 1970-90* (3-46)

Summary Statistics for the National Railroad Passenger

Patterns

Corporation (Amtrak), 1971-91* (6-29)

Commuting Patterns of Journey-to-Work Trips by Mode 1969, 1977,

PCE

1983, and 1990 Series of the NPTS* (4-22)

Personal Consumption Expenditures (PCE) as Related to

Transportation, $1970-91 *(2-35)$

Percentage

Periods

Percentage of Trucks by Size Class, 1977, 1982, and 1987* (3-43)

Sales-Weighted Engine Size of Domestic and Import Automobiles by

Size Class, Sales Periods 1976-1992* (3-26)

Sales-Weighted Curb Weight of Domestic and Import Automobiles by

Size Class, Sales Periods 1976-1992* (3-27)

Sales-Weighted Interior Space of Domestic and Import Automobiles

by Size Class, Sales Periods 1976-1992* (3-28)

Period Sales, Market Shares, and Sales-Weighted Fuel Economies

of New Domestic and Import Automobiles, Selected Sales Periods

$1976-1992 *(3-30)$

Period Sales, Market Shares, and Sales-Weighted Fuel Economies

of New Domestic and Import Light Trucks, Selected Sales Periods

Personal

$1976-92 *(3-37)$

Annual Vehicle Miles Traveled by Personal Vehicles for Selected

Countries, 1970-89* (1-19)

Passenger Travel by Personal Vehicles for Selected Countries, $1970-89 *(1-20)$

Energy Use by Personal Vehicles for Selected Countries, $1970-89 *(1-21)$

Personal Consumption Expenditures (PCE) as Related to

Petroleum

Transportation, $1970-91^{*}(2-35)$

Refinery Yield of Petroleum Products from a Barrel of Crude $0 i 1$, $1978-91^{*}(2-4)$

United States Petroleum Production and Consumption,

$1970-91$ * $(2-5)$

Pilot

Consumption of Petroleum by End-Use Sector, 1973-91* (2-7)

Exhaust Emission Standards for Clean-Fuel Vehicles in the

California Pilot Test Program* (3-70) 


\section{I-18}

Pipeline

Pipeline Shipments of Energy, $1972-90^{*}(6-21)$

Population

Fuel Economy of the Gasoline Automobile Population for Selected Countries, $1970-89 *(1-15)$

Population and Vehicle Profile, 1950-90* (4-3)

Pressure

Financial Profile of the Population, 1970-89* (4-5)

Reid Vapor Pressure of Various Alcohol/Ether/Gasoline

Price

Blends* $(5-15)$

Prices

Average Price of a New Car, 1970-91* (2-39)

Diesel Fuel Prices for Selected Countries, 1978-91* (1-11)

Gasoline Prices for Selected Countries, 1978-91* (1-9)

Retail Prices for Motor Fuel, 1978-91* (2-29)

Prices for Selected Transportation Fuels, 1978-91* (2-30)

Prices for a Barrel of Crude $0 i 1$ and a Gallon of Gasoline, $1976-91 *(2-32)$

Products

Refinery Yield of Petroleum Products from a Barrel of Crude $0 i 1$, Profile $1978-91^{*}(2-4)$

Population and Vehicle Profile, 1950-90* (4-3)

Purpose

Financial Profile of the Population, $1970-89 *(4-5)$

Mode of Travel by Trip Purpose, 1990* (4-11)

Distribution of Trips for All Modes by Trip Purpose and

Purposes

Round-Trip Distance, 1974, 1983, and 1990* (4-9)

Average Annual VMT, Vehicle Trips and Trip Length per Household for Selected Trip Purposes, 1969, 1977, 1983, and 1990 Series of the NPTS* $(4-17)$

Average Vehicle Occupancy for Selected Trip Purposes, 1969, 1977,1983 , and 1990 Series of the NPTS* (4-19)

Rail

Passenger Travel by Rail for Selected Countries, 1970-89* (1-24)

Energy Use by Rail for Selected Countries, 1970-89* (1-25)

Summary Statistics for Rail Transmit Operations, 1970-90* (6-31) Railroad

Class I Railroad Freight Systems in the United States Ranked by Revenue Ton-Miles, 1990* (6-25)

Railroad Revenue Carloadings by Commodity Group, 1974 and $1990 *(6-28)$

Summary Statistics for the National Railroad Passenger

Corporation (Amtrak), 1971-91* (6-29)

Railroads

Summary Statistics for Class I Freight Railroads,

Ranked $1970-90 *(6-26)$

Class I Railroad Freight Systems in the United States Ranked by Rates

Revenue Ton-Miles, 1990* (6-25)

Scrappage and Survival Rates for Automobiles, A11 Trucks, and Light Trucks* $(3-12)$ 
Rates

Receipts

Scrappage and Survival Rates for Automobiles* (3-14)

Scrappage and Survival Rates for All Trucks* (3-16)

Recreational

Tax Receipts from the Sale of Gas Guzzlers, $1980-91$ * (3-57)

Refinery

Demographic Characteristics of Auto/Truck/Recreational Vehicle

(RV) and Air Travelers, 1988-90* (4-8)

Refue 1

Refinery Yield of Petroleum Products from a Barrel of Crude $0 i 1$, $1978-91 *(2-4)$

Number of Alternative Refuel Sites by State and Fuel Type, $1992^{*}(5-6)$

Registrations

Automobile Registrations for Selected Countries, 1950-90* (1-3)

Truck and Bus Registrations for Selected Countries, $1950-90 *(1-4)$

Distribution of New Domestic Fleet Automobile Registrations by

Reid

Size Class, $1975-91^{*}(3-50)$

Reid Vapor Pressure of Various Alcohol/Ether/Gasoline

Reporting

Blends* $(5-15)$

Resources

Gasohol Consumption by Reporting States, 1980-91*(5-18)

Retail

California Air Resources Board Standards* (3-71)

Retail Prices for Motor Fuel, 1978-91* (2-29)

New Retail Automobile Sales in the United States, $1970-91 *(3-19)$

New Retail Sales of Light Trucks in the United States,

$1970-91 *(3-32)$

New Retail Domestic Truck Sales by Gross Vehicle Weight, Revenue

$1970-91 *(3-34)$

Class I Railroad Freight Systems in the United States Ranked by

Revenue Ton-Miles, 1990* (6-25)

Railroad Revenue Carloadings by Commodity Group, 1974 and $1990 *(6-28)$

Road

On-Road Fuel/Energy Economy Summary for the AMFA Federal

Round

Vehicles, FY $1991^{\star}(5-5)$

Distribution of Trips for All Modes by Trip Purpose and Route

Round-Trip Distance, 1974, 1983, and 1990* (4-9)

Traffic Data for Large Certificated Route Air Carriers by

Carrier Group, Scheduled and Nonscheduled Services, 1982 and $1991 *(6-10)$

Summary Statistics for Domestic and International Certificated Rural Route Air Carriers (Combined Totals), 1970-90* (6-7)

Average Urban and Rural Interstate Speeds, 1970-90* (3-62) 
RV

lemographic Characteristics of Auto/Truck/Recreational Vehicle

(liv) and Air Travelers, 1's\&8-94* (1--8)

Sale

Tax Recoipts from the Sale of Gis Guzklers, 1980-91* (3-57)

sales

New Rutail Automobile Sales in the United States,

$1970-91 *(3-19)$

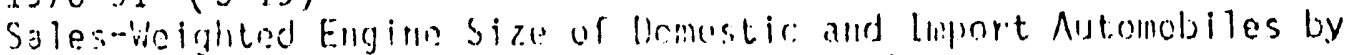

Size Class, Sales reriois $1976 \cdot 1902^{*}(3-26)$

Sales-Weighted Curb Weight of Domestic and Inport Automobiles by

Size Class, Sales Periods 1976-1992* (3-27)

Sales-Weighted Interior Space of Domestic and Import Automobiles

by Size Class, Sales Periods 1976-1992* (3-28)

Period Sales, Market Shares, and Sales-Weighted Fuel Economies

of New Domestic and Import Automobiles, Selected Sales Periods

1976-1992* (3-30)

New Retail Sales of Light Trucks in the United States,

$1970-91 *(3-32)$

New Retail Domestic Truck Sales by Gross Vehicle Weight, $1970-91 *(3-34)$

Period Sales, Market Shares, and Sales-Weighted Fuel Economies

of New Domestic and Import Light Trucks, Selected Sales Periods

$1976-92^{\star}(3-37)$

Corporate Average Fuel Economy (CAFE) Standards Versus

Sales-Weighted Fuel Economy Estimates for Automobiles and Light

Trucks, 1978-92* (3-55)

Vehicle Stock and New Sales in United States 1990 Calendar

Year* $(3-8)$

Scheduled

Traffic Data for Large Certificated Route Air Carriers by

Carrier Group, Scheduled and Nonscheduled Services, 1982 and $1991^{\star}(6-10)$

Scrappage

Scrappage and Survival Rates for Automobiles, All Trucks, and

Light Trucks* (3-12)

Scrappage and Survival Rates for Automobiles* (3-14)

Sector

Scrappage and Survival Rates for All Trucks* (3-16)

Consumption of Total Energy by End-Use Sector, 1970-91* (2-13)

Selected

Consumption of Petroleum by End-Use Sector, 1973-91* (2-7)

Diesel Fuel Prices for Selected Countries, 1978-91* (1-11)

New Gasoline Car Fuel Economy for Selected Countries, $1973-89 *(1-13)$

Fuel Economy of the Gasoline Automobile Population for Selected Countries, 1970-89* $(1-15)$

Annual Miles Driven per Vehicle for Selected Countries, $1984-90 *(1-17)$

Inland Surface Transport of Goods for Selected Countries, $1985^{*}(1-18)$

Annual Vehicle Miles Traveled by Personal Vehicles for Selected Countries, 1970-89* (1-19)

Passenger Travel by Persorial Vehicles for Selected Countries, $1970-89^{*}(1-20)$ 


\section{I-21}

Selected

Enorgy Use by Personal Vehicles for Selected Countries, $19 ; 0-83^{*}(1-2.1)$

Passenger Travel by lius for Selected Countries, 1970-83* (1-22)

Energy Use by Dus for Selected Countiries, 1970-89. $(1-23)$

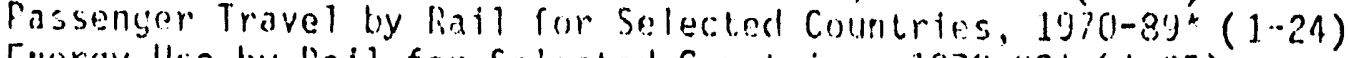

[nersy Use by liail for Selocted Couitrias, $197\left(1-89^{\star}(1-25)\right.$

Automobile: Registrations for Selected Countries, $1959-90 *(1-3)$

Truck and Bus Registralions for Selected Countries,

$1950-90 *(1-4)$

Vehicles per Capita for Selected Countries, $19501-9\left(1^{*}(1-6)\right.$

Gasoline Prices for Scolected Counlries, $1918-1 j 1^{*}(1-9)$

Prices for Sulectod Transportation Funls, 19/8-91* (2*30)

Period Salos, Market Shares, and Sales-Welatitco Fuel Ecrinomies of Nery Donest lic and Import Automobiles, Selected Sales Periods $19 / 6-1932^{\star}(3-30)$

Period Sales, Market Shares, and Sales-Weighted Fuel Economies of New Domestic and Import Light Trucks, Selected Sales Periods $1976-92^{\star}(3-37)$

Contribution of Transportation Fuel Use to Total Carbon Emission for Selected Countries* (3-73)

Average Annual VMT, Vehicle Trips and Trip Length per Household for Selected Trip Purposes, 1969, 1977, 1983, and 1990 Series of the NPTS* $(4-17)$

Average Vehicle Occupancy for Selected Trip Purposes, 1969, Series 1977, 1983, and 1990 Series of the NPTS* $(4-19)$

Summary Statistics on Demographic Characteristics and Total

Travel, 1969, 1977, 1983, and 1990 Series of the NPTS* (4-13)

Number of Households by Vehicles Available, 1969, 1977, 1983, and 1990 Series of the NPTS* (4-15)

Average Annual VMT, Vehicle Trips and Trip Length per Household for Selected Trip Purposes, 1969, 1977, 1983, and 1990 Series of the NPTS* $(4-17)$

Average Vehicle Occupancy for Selected Trip Purposes, 1969, 1977, 1983, and 1990 Series of the NPTS* (4-19)

Distribution of Journey-to-Work Trips by Usual Mode, 1969, 1977, 1983, and 1990 Series of the NPTS* $(4-21)$

Commuting Patterns of Journey-to-Work Trips by Mode 1969, 1977, 1983, and 1990 Series of the NPTS* $(4-22)$

Distribution of Vehicles by Age, 1969, 1977, 1983, and 1990

Series of the NPTS* (4-27)

Average Annual Miles per Vehicle by Number of Vehicles

Available, 1969, 1977, 1983, and 1990 Series of the NPTS* (4-29)

Average Annual Miles per Vehicle by Number of Adults in

Household, 1977, 1983, and 1990 Series of the NPTS* (4-30)

Distribution of Annual Miles by Driver Age and Sex, 1969, 1977 , Services 1983, and 1990 Series of the NPTS* $(4-31)$

Traffic Data for Large Certificated Route Air Carriers by Carrier Group, Scheduled and Nonscheduled Services, 1982 and $1991^{\star}(6-10)$ 
Sex

Distribution of Annual Miles by Driver Age and Sex, 1969, 1977, Shares

1983, and 1990 Series of the NPTS* $(4-31)$

Period Sales, Market Shares, and Sales-Weighted Fuel Economies

of New Domestic and Import Automobiles, Selected Sales Periods

$1976-1992^{*}(3-30)$

Period Sales, Market Shares, and Sales-Weighted Fuel Economies

of New Domestic and Import Light Trucks, Selected Sales Periods

Shipments

$1976-92^{*}(3-37)$

Single

Pipeline Shipments of Energy, $1972-90 *(6-21)$ Sites

Summary Statistics for Other Single-Unit Trucks, 1970-90* (3-40)

Number of Alternative Refuel Sites by State and Fuel Type,

Source $1992^{*}(5-6)$

Distribution of Energy Consumption by Source, 1981 and $1991 *(2-10)$ Space

Electric Utility Energy Input by Source, 1973-1991* (2-11)

Sales-Weighted Interior Space of Domestic and Import Automobiles Speed

by Size Class, Sales Periods 1976-1992* (3-28)

Speeds

Fuel Economy by Speed, 1973 and 1984* (3-60) Standards

Average Urban and Rural Interstate Speeds, 1970-90* (3-62)

Corporate Average Fuel Economy (CAFE) Standards Versus

Sales-Weighted Fuel Economy Estinates for Automobiles and Light.

Trucks, 1978-92* (3-55)

Exhaust Emission Standards for Clean-Fuel Vehicles in the

California Pilot Test Program* (3-70)

California Air Resources Board Standards* (3-71)

Statistical

Statistical Indices as Related to Transportation,

Statistics

$1970-91 *(2-36)$

Summary Statistics for Passenger Cars, 1970-90* (3-23)

Summary Statistics for Two-Axle, Four-Tire Trucks, $1970-90 *(3-38)$

Summary Statistics for Other Single-Unit Trucks, 1970-90* (3-40)

Summary Statistics for Combination Trucks, 1970-90* (3-42)

Summary Statistics on Demographic Characteristics and Total

Trave 1, 1969, 1977, 1983, and 1990 Series of the NPTS* (4-13)

Summary Statistics for General Aviation, $1970-90^{*}(6-11)$

Tonnage Statistics for Domestic and International Waterborne

Commerce, $1970-89 *(6-15)$

Summary Statistics for Domestic Waterborne Commerce, $1970-89 *(6-16)$

Summary Statistics for Class I Freight Rallroads, $1970-90 *(6-26)$

Summary Statistics for the National Railroad Passenger

Corporation (Amtrak), 1971-91* (6-29) 
Statistics

Summary Statistics for Rail Transmit Operations, 1970-90* (6-31)

Summary Statistics for Domestic and International Certificated Stock

Route Air Carriers (Combined Totals), 1970-90* (6-7)

Vehicle Stock and New Sales in United States 1990 Calendar

Summary

Year* $(3-8)$

Summary Statistics for Passenger Cars, 1970-90* (3-23)

Summary Statistics for. Two-Axle, Four-Tire Trucks, $1970-90 *(3-38)$

Summary Statistics for Other Single-Unit Trucks, 1970-90* (3-40)

Summary Statistics for Combination Trucks, 1970-90* (3-42)

Summary Statistics on Demographic Characteristics and Total

Trave 1, 1969, 1977, 1983, and 1990 Series of the NPTS* (4-13)

On-Road Fuel/Energy Economy Summary for the AMFA Federal

Vehicles, FY 1991* (5-5)

Summary Statistics for General Aviation, 1970-90* (6-11)

Summary Statistics for Domestic Waterborne Commerce,

$1970-89 *(6-16)$

Summary Statistics for Class I Freight Railroads, $1970-90 *(6-26)$

Summary Statistics for the National Railroad Passenger

Corporation (Amtrak), 1971-91* (6-29)

Summary Statistics for Rail Transmit Operations, $1970-90^{*}(6-31)$

Summary Statistics for Domestic and International Certificated

Surface

Rcute Air Carriers (Combined Totals), 1970-90* (6-7)

Inland Surface Transport of Goods for Selected Countries,

Survival $1985^{\star}(1-18)$

Scrappage and Survival Rates for Automobiles, All Trucks, and Light Trucks* (3-12)

Scrappage and Survival Rates for Automobiles* (3-14)

Systems

Scrappage and Survival Rates for All Trucks* (3-16)

Class I Railroad Freight Systems in the United States Ranked by

$\operatorname{Tax}$

Revenue Ton-Miles, 1990* (6-25)

Tax Receipts from the Sale of Gas Guzzlers, 1980-91* (3-57)

The Gas Guzzler Tax on New Cars* (3-59)

State Tax Exemptions for Gasohol, September 1992* (5-17)

Technology

Advanced Battery Technology Goals of the U.S. Advanced Battery

Tire

Consortium* $(5-13)$

Summary Statistics for Two-Axle, Four-Tire Trucks,

Ton $1970-90 *(3-38)$

Class I Railroad Freight Systems in the United States Ranked by Tonnage

Revenue Ton-Miles, 1990* (6-25)

Tonnage Statistics for Domestic and International Waterborne Commerce, $1970-89 *(6-15)$ 


\section{I-24}

Totals

Traffic

Summary Statistics for Domestic and International Certificated Route Air Carriers (Combined Totals), 1970-90* (6-7)

Traffic Data for Large Certificated Route Air Carriers by

Carrier Group, Scheduled and Nonscheduled Services, 1982 and

Transmit $1991 *(6-10)$

Transport

Summary Statistics for Rail Transmit Operations, 1970-90* (6-31)

Inland Surface Transport of Goods for Selected Countries, $1985^{*}(1-18)$

Transportation

Domestic Consumption of Transportation Energy by Mode and Fue 1

Type, 1990* (2-14)

Distribution of Domestic Consumption of Transportation Energy by

Mode and Fuel Type, 1990* (2-15)

Transportation Energy Use by Mode, 1990* (2-17)

Transportation Energy Consumption by Mode, 1970-90* (2-18)

Prices for Selected Transportation Fuels, 1978-91* (2-30)

Gross National Product (GNP) as Related to Transportation, $1970-91$ * $(2-34)$

Personal Consumption Expenditures (PCE) as Related to

Transportation, $1970-91^{*}(2-35)$

Statistical Indices as Related to Transportation, $1970-91^{*}(2-36)$

Transportation's Contribution to U.S. Emissions, 1978-90* (3-69)

Contribution of Transportation Fuel Use to Total Carbon Emission for Selected Countries* (3-73)

Means of Transportation to Work for the United States: 1980 and 1990 Census* (4-12)

Travel

Basic Chemistry of Various Transportation Fuels* (5-14)

Passenger Travel by Personal Vehicles for Selected Countries, $1970-89 *(1-20)$

Passenger Travel by Bus for Selected Countries, 1970-89* (1-22)

Passenger Travel by Rail for Selected Countries, 1970-89* (1-24)

Passenger Travel and Energy Use in the United States, $1990 *(2-22)$

Automobiles in Operation and Vehicle Travel by Age of Vehicle, $1991^{\star}(3-22)$

Trucks in Operation and Vehicle Travel by Age of Vehicle, $1991^{*}(3-36)$

Passenger and Vehicle Travel by Bus Type, 1970-90* (3-46)

Mode of Travel by Trip Purpose, 1990* (4-11)

Summary Statistics on Demographic Characteristics and Total

Traveled

Travel, 1969, 1977, 1983, and 1990 Series -of the NPTS* $(4-13)$

Annual Vehicle Miles Traveled by Personal Vehicles for Selected Countries, 1970-89* (1-19)

Travelers

Highway Vehicle Miles Traveled by Mode, 1979-90* (3-6)

Demographic Characteristics of Auto/Truck/Recreational Vehicle

(RV) and Air Travelers, 1988-90* (4-8) 
Trip

Mode of Travel by Trip Purpose, 1990* (4-11)

Average Annual VMT, Vehicle Trips and Trip Length per Household for Selected Trip Purposes, 1969, 1977, 1983, and 1990 Series of t'ie NPTS* $(4-17)$

Average Vehicle Occupancy for Selected Trip Purposes, 1969, 1977,1983 , and 1990 Series of the NPTS* $(4-19)$

Distribution of Journey-to-Work Trips by Trip Distance and Mode, $1990 *(4-26)$

Distribution of Trips for All Modes by Trip Purpose and Trips

Round-Trip Distance, 2.974, 1983, and 1990* (4-9)

Average Annual VMT, Vehicle Trips and Trip Length per Household for Selected Trip Purposes, 1969, 1977, 1983, and 1990 Series of the NPTS* (4-17)

nistribution of Journey-to-Work Trips by Usual Mode, 1969, 1977, 1983, and 1990 Series of the NPTS* (4-21)

Commuting Patterns of Journey-to-Work Trips by Mode 1969, 1977, 1983 , and 1990 Series of thic NPTS* (4-22)

Distribution of Journey-to-Work Trips by Household Income and Mode, 1990* (4-24)

Distribution of Journey-to-Work Trips by Worker Age and Mode, 1990 * (4-25)

Distribution of Journey-to-Work Trips by Trip Distance and Mode, 1990* (4-26)

Distribution of Trips for All Modes by Trip Purpose aild Truck

Round-Trip Distance, 1974, 1983, and 1990* (4-9)

Truck and Bus Registrations for Selected Countries, $1950-90 *(1-4)$

New Retail Domestic Truck Sales by Gross Vehicle Weight, $1970-91 *(3-34)$

Truck Fuel Economy by Size Class, 1977, 1982, and 1987* (3-43)

Demographic Characteristics of Auto/Truck/Recreational Vehicle Trucks

(RV) and Air Travelers, $1988-90^{*}(4-8)$

Average Age of Automobiles and Trucks in Use, 1970-1991* (3-10)

Scrappage and Survival Rates for Automobiles, A11 Trucks, and

Light Trucks* (3-12)

Scrappage and Survival Rates for A11 Trucks* (3-16)

New Retail Sales of Light irucks in the United States, $1970-91 *(3-32)$

Trucks in Use by Age, 1970 and 1991* (3-35)

Trucks in Operation and Vehicle Travel by Age of Vehicle, $1991^{*}(3-36)$

Period Sales, Market Shares, and Sales-Weighted Fuel Economies of New Domestic and Import Light Trucks, Selected Sales Periods $1976-92^{*}(3-37)$

Summary Statistics for Two-Axle, Four-Tire Trucks, $1970-90 *(3-38)$

Summary Statistics for Other Single-Unit Trurks, 1970-90* (3-40)

Summary Statistics for Combination Trucks, 1970-90* $(3-42)$

Percentage of Trucks by Size Class, 1977, 1982, and $1987^{*}(3-43)$ 


\section{I-26}

Trucks

Corporate Average Fuel Economy (CAFE) Standards Versus

Sales-Weighted Fuel Economy Estimates for Automobiles and Light Trucks, 1978-92* (3-55)

Federal Emission Control Requirements for Automobiles and Light Trucks, 1976-94* (3-66)

Federal Emission Control Requirements for Heavy-Duty Gasoline

Trucks, 1976-34* (3-67)

Federal Emission Control Requirements for Heavy-Duty Diesel

Trucks, 1976-94* (3-68)

Unit

Automobiles and Trucks in Use, $1979-1991^{*}(3-9)$ United

Summary Statistics for Other Single-Unit Trucks, 1970-90* (3-40)

Passenger Travel and Energy Use in the United States,

$1990 *(2-22)$

Intercity Freight Movement and Energy Use in the United States, $1990 *(2-25)$

United States Petroleum Production and Consumption, $1970-91 *(2-5)$

New Retail Automobile Sales in the United States, $1970-91$ * (3-19)

New Retail Sales of Light Trucks in the United States, $1970-91 *(3-32)$

Vehicle Stock and New Sales in United States 1990 Calendar Year* (3-8)

Means of Transportation to Work for the United States: 1980 and 1990 Census* (4-12)

Class I Railroad Freight Systems in the United States Ranked by Urban

Revenue Ton-Miles, $1990^{*}(6-25)$ Usual 1

Average Urban and Rural Interstate Speeds, 1970-90* (3-62)

Distribution of Journey-to-Work Trips by Usual Mode, 1969, 1977, Utility 1983, and 1990 Series of the NPTS* $(4-21)$ Vapor

Electric Utility Energy Input by Source, 1973-1991* (2-11)

Reid Vapor Pressi're of Various Alcohol/Ether/Gasoline

Vehicle Blends* $(5-15)$

Annual Miles Driven per Vehicle for Selected Countries, $1984-90 *(1-17)$

Annual Vehicle Miles Traveled by Personal Vehicles for Selected Countries, $1970-89 *(1-19)$

Automobiles in Operation and Vehicle Travel by Age of Vehicle, $1991 *(3-22)$

New Retail Domestic Truck Sales by Gross Vehicle Weight, $1970-91$ * $(3-34)$

Trucks in Operaition and Vehicle Travel by Age of Vehic ${ }^{1} e$, $1991^{*}(3-36)$

Passenger and Vehicie Travel by Bus Type, 1970-90* (3-46)

Highway Vehicle Miles Traveled by Mode, 1979-90* (3-6)

Miles of High-Occupancy Vehicle Lanes, 1969-90* (3-75)

Vehicle Stock and New Sales in United States 1990 Calendar Year* $(3-8)$ 
Vehicle

Av rage Annual VMT, Vehicle Trips and Trip Length per Household for Selected Trip Purposes, 1969, 1977, 1983, and 1990 Series of the NPTS* $(4-17)$

Average Vehicle Occupancy for Selected Trip Purposes, 1969, 1977,1983 , and 1990 Series of the NPTS* (4-19)

Average Annual Miles per Vehicle by Number of Vehicles Available, 1969, 1977, 1983, and 1990 Series of the NPTS* (4-29) Population and Vehicle Profile, 1950-90* (4-3)

Average Annual Miles per Vehicle by Number of Adults in Household, 1977, 1983, and 1990 Series of the NPTS* (4-30)

Average Annual Miles per Vehicle by Household Vehicle Ownership, $1990 *(4-32)$

Demographic Characteristics of Auto/Truck/Recreational Vehicle

(RV) and Air Travelers, 1988-90* (4-8)

Vehicles

Annual Vehicle Miles Traveled by Personal Vehicles for Selected

Countries, 1970-89* (1-19)

Passenger Travel by Personal Vehicles for Selected Countries, $1970-89 *(1-20)$

Energy Use by Personal Vehicles for Selected Countries, $1970-89 *(1-21)$.

Vehicles per Capita for Selected Countries, 1950-90* (1-6)

Federal Government Vehicles by Agency, Fiscal Year 1988* (3-53)

Exhaust Emission Standards for Clean-Fuel Vehicles in the

California Pilot Test Program* (3-70)

Possible Fuel/Vehicles for Clean-Fuel Vehicles* (3-72)

Number of Households by Vehicles Available, 1969, 1977, 1983, and 1990 Series of the NPTS* (4-15)

Distribution of Vehicles by Age, 1969, 1977, 1983, and 1990

Series of the NPTS* (4-27)

Average Annual Miles per Vehicle by Number of Vehicles

Available, 1969, 1977, 1983, and 1990 Series of the NPTS* (4-29)

On-Road Fuel/Energy Economy Summary for the AMFA Federal

VMT Vehicles, FY $1991^{*}(5-5)$

Average Annual VMT, Vehicle Trips and Trip Length per Household for Selected Trip Purposes, 1969, 1977, 1983, and 1990 Series of the NPTS* $(4-17)$

Waterborne

Tonnage Statistics for Domestic and International Waterborne

Commerce, 1970-89* (6-15)

Summary Statistics for Domestic Waterborne Commerce,

Weight $1970-89 *(6-16)$

Sales-Weighted Curb Weight of Domestic and Import Automobiles by Size Class, Sales Periods 1976-1992* (3-27)

New Retail Domestic Truck Sales by Gross Vehicle Weight,

Weighted $1970-91 *(3-34)$

Sales-Weighted Engine Size of Domestic and Import Automobiles by Size Class, Sales Periods 1976-1992* (3-26)

Sales-Weighted Curb Weight of Domestic and Import Automobiles by Size Class, Sales Periods 1976-1992* (3-27)

Sales-Weighted Interior Space of Domestic and Import Automobiles

by Size Class, Sales Periods 1976-1992* (3-28) 
Weighted

Period Sales, Market Shares, and Sales-Weighted Fuel Economies of New Domestic and Import Automobiles, Selected Sales Periods 1976-1992* (3-30)

Period Sales, Market Shares, and Sales-Weighted Fuel Economies of New Domestic and Import Light Trucks, Selected Sales Periods 1976-92* (3-37)

Corporate Average Fuel Economy (CAFE) Standards Versus

Sales-Weighted Fuel Economy Estimates for Automobiles and Light Work Trucks, $1978-92^{*}(3-55)$

Means of Transportation to Work for the United States: 1980 and 1990 Census* (4-12)

Distribution of Journey-to-Work Trips by Usual Mode, 1969, 1977, 1983 , and 1990 Series of the NPTS* (4-21)

Commuting Patterns of Journey-to-Work Trips by Mode 1969, 1977, 1983, and 1990 Series of the NPTS* $(4-22)$

Distribution of Journey-to-Work Trips by Household Income and Mode, 1990* (4-24)

Distribution of Journey-to-Work Trips by Worker Age and Mode, $1990 *(4-25)$

Distribution of Journey-to-Work Trips by Trip Distance and Mode, Worker 1990* (4-26)

Distribution of Journey-to-Work Trips by Worker Age and Mode, $1990 *(4-25)$

Yield

Refinery Yield of Petroleum Products from a Barrel of Crude $0 i 1$, $1978-91^{*}(2-4)$ 


\section{INTERNAL DISTRIBUTION}

$\begin{aligned} \text { 1. } & \text { V. D. Baxter } \\ 2 . & \text { T. J. Blasing } \\ 3 . & \text { M. S. Bronzini } \\ \text { 4. } & \text { J. B. Cannon } \\ \text { 5. } & \text { R. S. Carlsmith } \\ 6 . & \text { F. A. Creswick } \\ 7 . & \text { T. R. Curlee } \\ 8 . & \text { S. C. Davis } \\ 9 . & \text { S. K. Fischer } \\ \text { 10-11. } & \text { D. L. Greene } \\ 12 . & \text { L. J. Hill } \\ 13 . & \text { E. L. Hillsman } \\ \text { 14. } & \text { P. S. Hu } \\ 15 . & \text { M. A. Kuliasha } \\ 16 . & \text { P. N. Leiby }\end{aligned}$

17. S. P. Miaou

18. R. B. Shelton

19. B. Sorensen

20-21. F. Southworth

22. S. G. Strang

23. J. J. Tomlinson

24. L. F. Truett

25. A. F. Turhollow

26. D. P. Vogt

27. T. J. Wilbanks

28. ORNL Patent Office

29-30. Central Research Library

31. Document Reference Section

32-33. Laboratory Records

34. Laboratory Records--RC

\section{EXTERNAL DISTRIBUTION}

35. H. M. Ingram, Director, Udal Center for Studies in Public Policy, The University of Arizona, 803/811 East First Street, Tucson, Arizona 85719

36. C. D. MacCracken, President, Calmac Manufacturing Corporation, P.O. Box 710, Englewood, New Jersey 07631

37. J. B. Shrago, Director, Office of Technology Transfer, 405 Kirkland Hall, Vanderbilt University, Nashville, Tennessee 37240

38-997. Center for Transportation Analysis, Energy Division, 5500A, Room A217

998-999. OSTI, U.S. Department of Energy, P.O. Box 62, Oak Ridge, TN 37831

1000. Office of Assistant Manager of Energy Research and Development, DOE/ORO, P.O. Box 2001, Oak Ridge, TN 37831-8600 

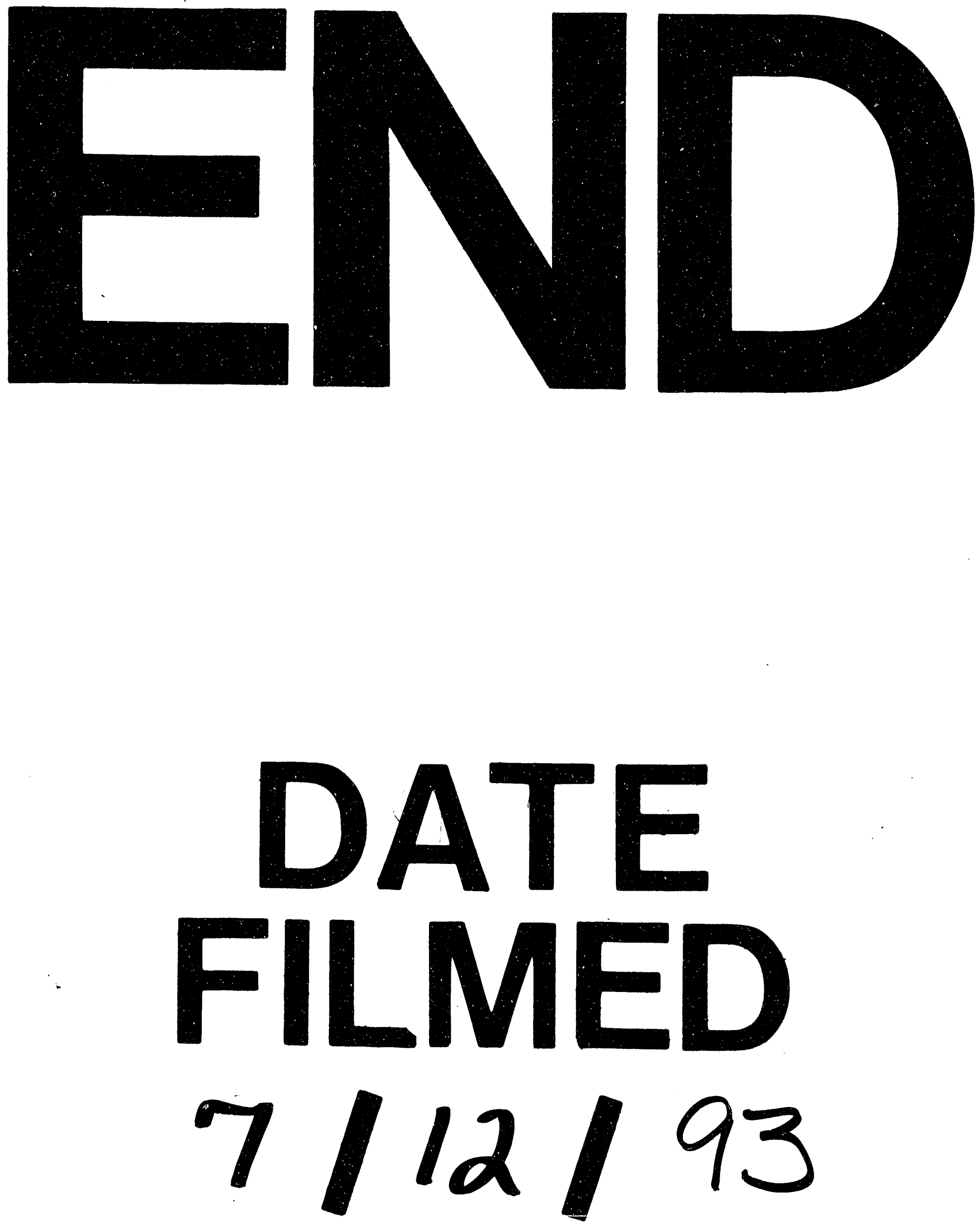

1 
